6-1992

\title{
Data Recovery at Justiceburg Reservior (Lake Alan Henry), Garza and Kent Counties, Texas: Phase III, Season 1
}

Douglas K. Boyd

Prewitt and Associates, Inc.

Steve A. Tomka

Raba Kistner

C. Britt Bousman

Department of Anthropology, Texas State University

Karen M. Gardner

Prewitt and Associates, Inc.

Martha Doty Freeman

Prewitt and Associates, Inc.

Follow this and additional works at: https://scholarworks.sfasu.edu/ita

Part of the American Material Culture Commons, Archaeological Anthropology Commons, Environmental Studies Commons, Other American Studies Commons, Other Arts and Humanities Commons, Other History of Art, Architecture, and Archaeology Commons, and the United States History Commons

Tell us how this article helped you.

This Article is brought to you for free and open access by the Center for Regional Heritage Research at SFA ScholarWorks. It has been accepted for inclusion in Index of Texas Archaeology: Open Access Gray Literature from the Lone Star State by an authorized editor of SFA ScholarWorks. For more information, please contact cdsscholarworks@sfasu.edu. 


\section{Data Recovery at Justiceburg Reservior (Lake Alan Henry), Garza and Kent Counties, Texas: Phase III, Season 1}

\section{Creative Commons License}

\section{c) (1)@ $\Theta$}

This work is licensed under a Creative Commons Attribution-NonCommercial-No Derivative Works 4.0 International License. 


\section{DATA RECOVERY AT JUSTICEBURG RESER VOIR (LAKE ALAN HENRY), \\ GARZA AND KENT COUNTIES, TEXAS: PHASE III, SEASON 1}

Prewitt and Associates, Inc. Consulting Archeologists 7701 N. Lamar, Suite 104 Austin, Texas 78752 (512) $459-3349$

by

Douglas K. Boyd

Steve A. Tomka

C. Britt Bousman

Karen M. Gardner

and

Martha Doty Freeman

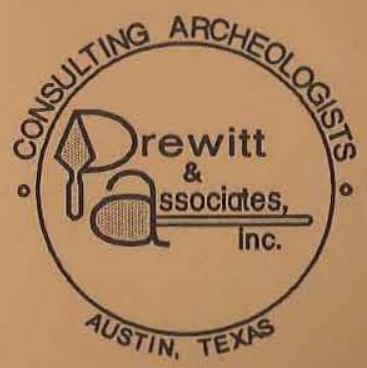




\title{
DATA RECOVERY AT JUSTICEBURG RESERVOIR (LAKE ALAN HENRY), GARZA AND KENT COUNTIES, TEXAS: \\ PHASE III, SEASON 1
}

by

\author{
Douglas K. Boyd \\ Steve A. Tomka \\ C. Britt Bousman \\ Karen M. Gardner \\ and \\ Martha Doty Freeman \\ with Contributions by \\ Vaughn M. Bryant, Jr. \\ Phil Dering \\ Raymond W. Neck \\ and \\ David G. Robinson
}

Co-Principal Investigators: Elton R. Prewitt and C. Britt Bousman

REPORTS OF INVESTIGATIONS, NUMBER 84

Prewitt and Associates, Inc.

Consulting Archeologists

Austin, Texas

June 1992 
Prewitt and Associates, Inc.

Consulting Archeologists

7701 N. Lamar, Suite 104

Austin, Texas 78752-1012

(512) 459-3349

Lake Alan Henry (Justiceburg Reservoir) Reports

Phase I Cultural Resources Investigations at Justiceburg Reservoir on the Double Mountain Fork of the Brazos River, Garza and Kent Counties, Texas, by Douglas K. Boyd, Martha Doty Freeman, Michael D. Blum, Elton R. Prewitt, and J. Michael Quigg. 2 vols. Reports of Investigations No. 66.1989 (xiv + 643 pp., maps, illus., appendixes).

Phase II Investigations at Prehistoric and Rock Art Sites, Justiceburg Reservoir, Garza and Kent Counties, Texas, by Douglas K. Boyd, James T. Abbott, William A. Bryan, Colin M. Garvey, Steve A. Tomka, and Ross C. Fields. 2 vols. Reports of Investigations No. 71 . 1990 (xiv +571 pp., maps, illus., appendixes).

Phase II Historical Investigations at Justiceburg Reservoir, Garza and Kent Counties, Texas, by Martha Doty Freeman and Douglas K. Boyd. Reports of Investigations No. 72.1990 (ix + 156 pp., maps, illus., appendix).

Archeological Survey of Wildlife Mitigation Lands, Justiceburg Reservoir, Garza County, Texas, by Douglas K. Boyd, C. Britt Bousman, and Martha Doty Freeman. Reports of Investigations No. 79.1991 (vii + 75 pp., maps, illus., appendix).

Data Recovery at Justiceburg Reservoir (Lake Alan Henry), Garza and Kent Counties, Texas: Phase III, Season 1, by Douglas K. Boyd, Steve A. Tomka, C. Britt Bousman, Karen M. Gardner, and Martha Doty Freeman. Reports of Investigations No. 84. 1992 (xii + 256 pp., maps, illus., appendixes).

Series Technical Editor: Linda Nance Foster 


\section{TABLE OF CONTENTS}

ABSTRACT $\ldots \ldots \ldots \ldots \ldots \ldots \ldots \ldots \ldots \ldots \ldots \ldots \ldots \ldots \ldots \ldots \ldots \ldots \ldots \ldots \ldots \ldots \ldots \ldots \ldots \ldots \ldots$

ACKNOWLEDGMENTS $\ldots \ldots \ldots \ldots \ldots \ldots \ldots \ldots \ldots \ldots \ldots \ldots \ldots \ldots \ldots \ldots \ldots \ldots \ldots \ldots \ldots \ldots \ldots$

CHAPTER 1: INTRODUCTION

Douglas K. Boyd $\ldots \ldots \ldots \ldots \ldots \ldots \ldots \ldots \ldots \ldots \ldots \ldots \ldots \ldots \ldots \ldots \ldots \ldots \ldots \ldots \ldots \ldots$

CHAPTER 2: BACKGROUND AND RESEARCH ORIENTATION

Douglas K. Boyd, Steve A. Tomka, and Martha Doty Freeman $\ldots \ldots \ldots \ldots \ldots \quad 5$

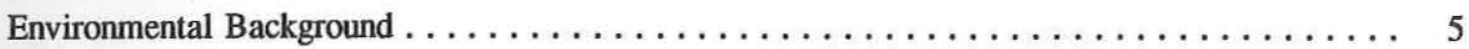

Archeological Background $\ldots \ldots \ldots \ldots \ldots \ldots \ldots \ldots \ldots \ldots \ldots \ldots \ldots \ldots$

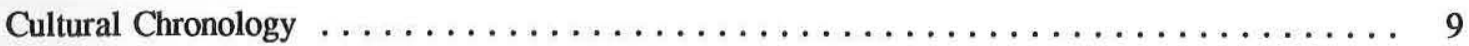

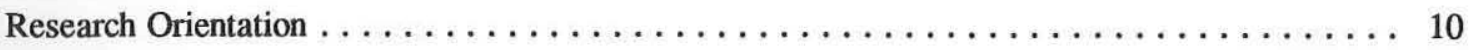

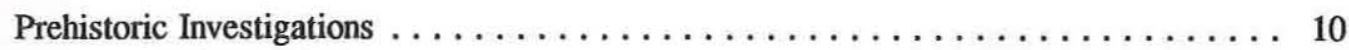

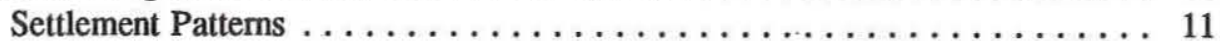

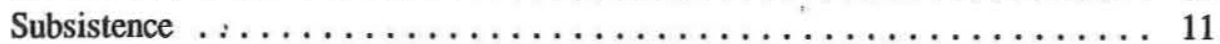

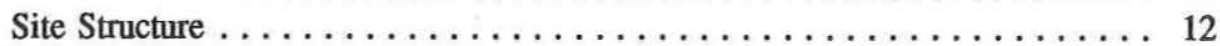

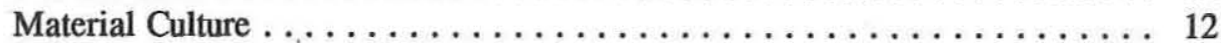

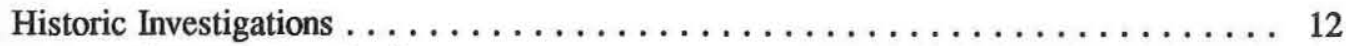

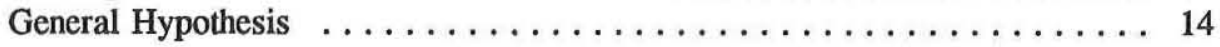

Addressing the Research Design . . . . . . . . . . . . . . . . . 14

CHAPTER 3: OBJECTIVES AND METHODS

Douglas K. Boyd, Steve A. Tomka, and C. Britt Bousman . . . . . . . . . 15

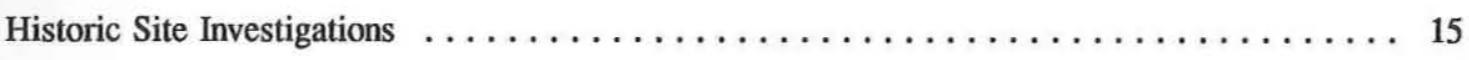

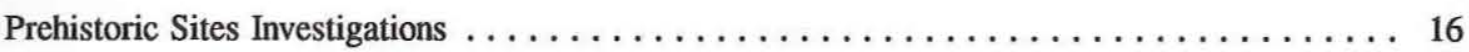

Excavation and Collection Procedures $\ldots \ldots \ldots \ldots \ldots \ldots \ldots \ldots \ldots \ldots \ldots \ldots \ldots \ldots \ldots \ldots$

Laboratory and Analytical Procedures . . . . . . . . . . . . . . . . 17

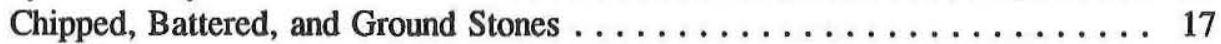

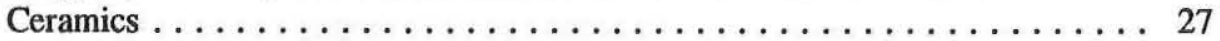

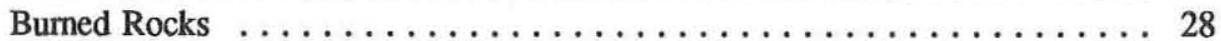

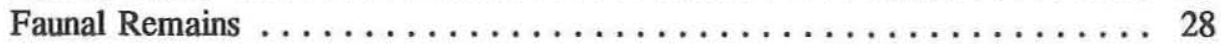

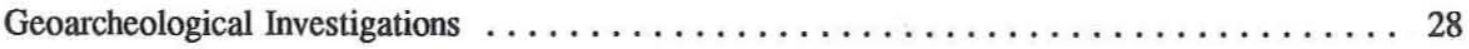

CHAPTER 4: DATA RECOVERY AT THE ED SCOTT CABIN, 41KT42

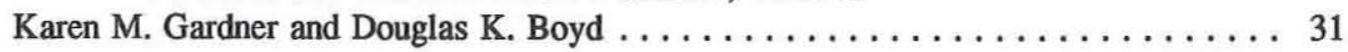

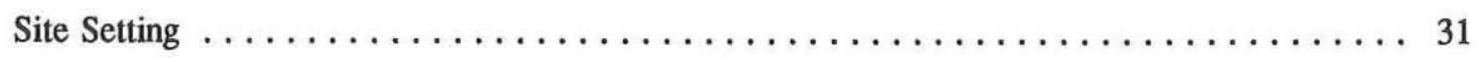

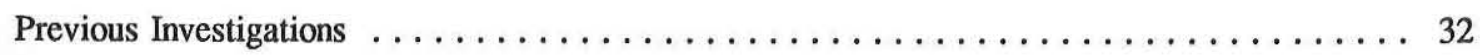

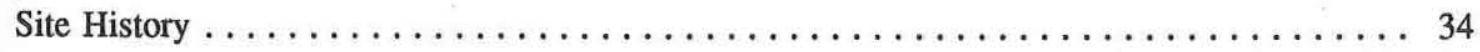

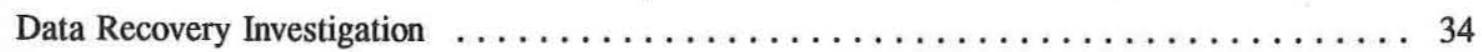

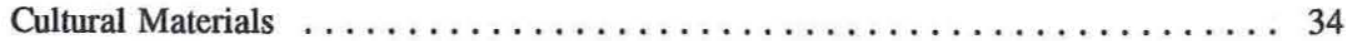

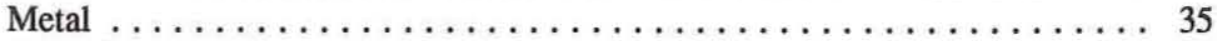

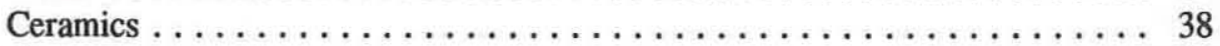

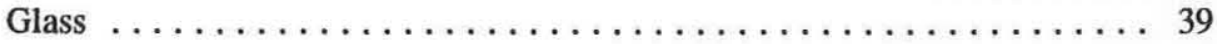




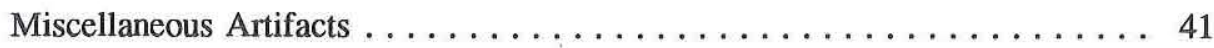

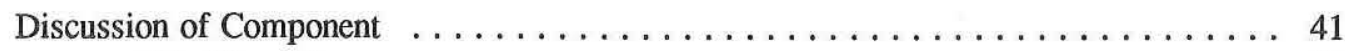

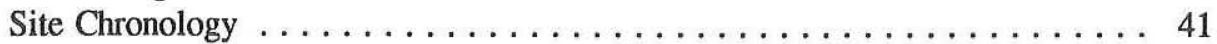

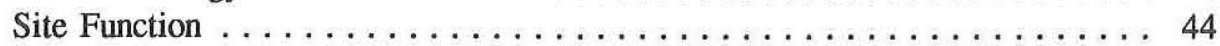

Socioeconomic Indicators $\ldots \ldots \ldots \ldots \ldots \ldots \ldots \ldots \ldots \ldots$

Intrasite Activity Patterning $\ldots \ldots \ldots \ldots \ldots \ldots \ldots \ldots \ldots$

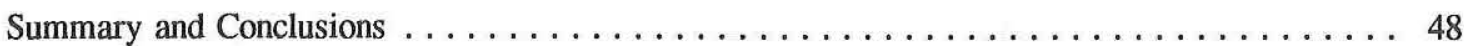

CHAPTER 5: DATA RECOVERY AT THE GOBBLER CREEK BRIDGE SITE, 41GR383

Douglas K. Boyd, Steve A. Tomka, and C. Britt Bousman . . . . . . . . . 51

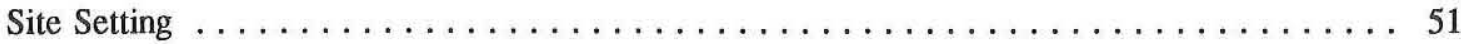

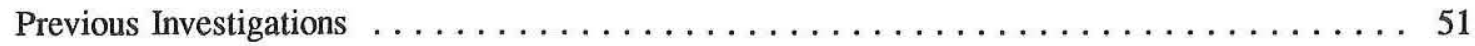

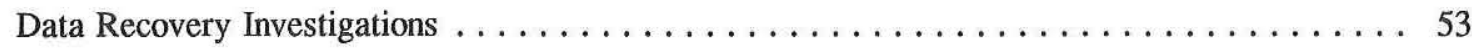

Sediments and Stratigraphy $\ldots \ldots \ldots \ldots \ldots \ldots \ldots \ldots \ldots \ldots \ldots \ldots \ldots \ldots \ldots \ldots \ldots \ldots \ldots$

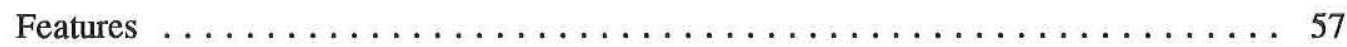

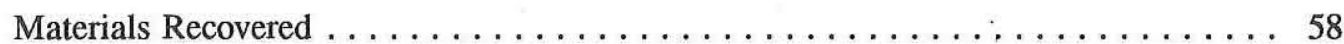

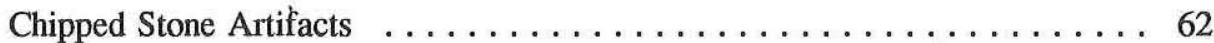

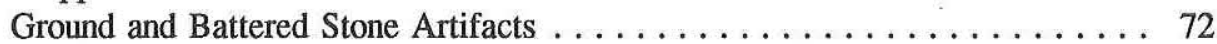

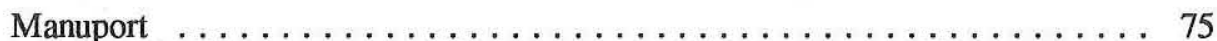

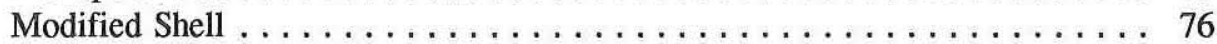

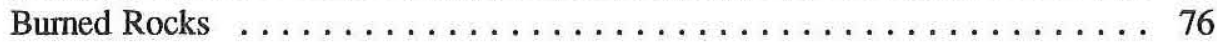

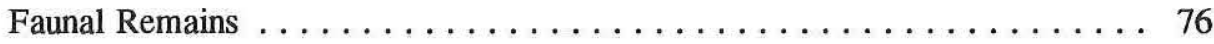

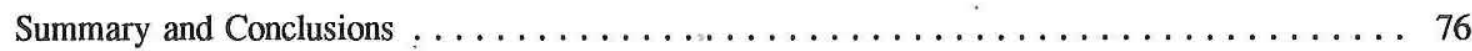

Site Chronology and Definition of Component $\ldots \ldots \ldots \ldots \ldots \ldots \ldots \ldots$

Intrasite Patterning and Site Function $\ldots \ldots \ldots \ldots \ldots \ldots \ldots \ldots \ldots$

Cultural Assessment of Component $\ldots \ldots \ldots \ldots \ldots \ldots \ldots \ldots \ldots \ldots \ldots$

CHAPTER 6: DATA RECOVERY AT THE GRAPE CREEK BENCH SITE, 41GR484

Douglas K. Boyd, Steve A. Tomka, and C. Britt Bousman . . . . . . . . . . 81

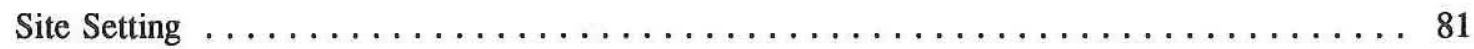

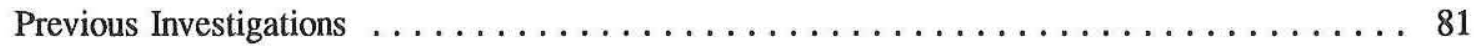

Data Recovery Investigations $\ldots \ldots \ldots \ldots \ldots \ldots \ldots \ldots \ldots \ldots \ldots \ldots \ldots \ldots \ldots$

Sediments and Stratigraphy $\ldots \ldots \ldots \ldots \ldots \ldots \ldots \ldots \ldots \ldots \ldots \ldots \ldots$

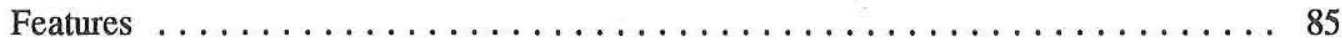

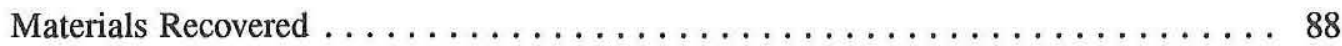

Chipped Stone Artifacts $\ldots \ldots \ldots \ldots \ldots \ldots \ldots \ldots \ldots \ldots \ldots$

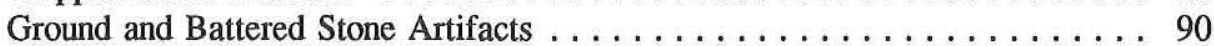

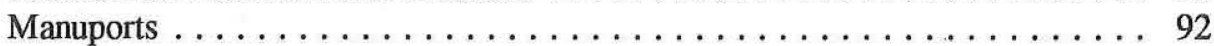

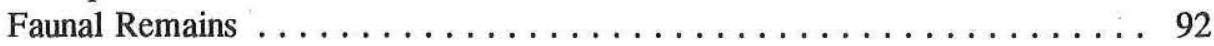

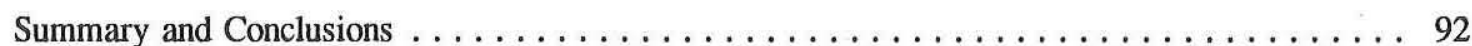

CHAPTER 7: DATA RECOVERY AT THE SOUTH SAGE CREEK SITE, 41KT33

Douglas K. Boyd, Steve A. Tomka, and C. Britt Bousman . . . . . . . . . . . 95

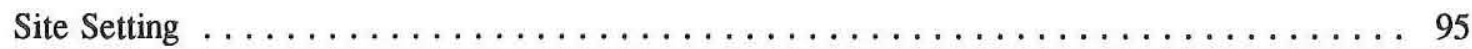




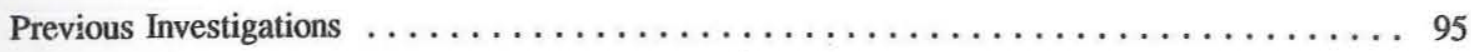

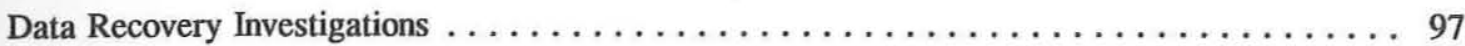

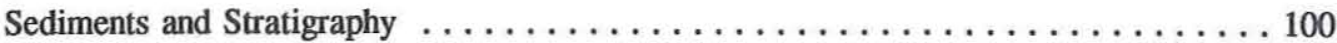

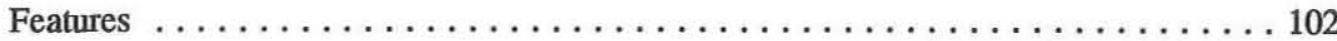

Materials Recovered . . . . . . . . . . . . . . . . . . . . . . 103

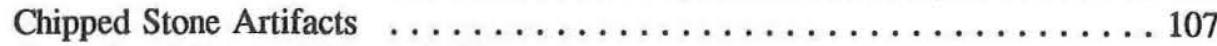

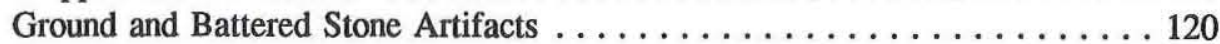

Ceramics . . . . . . . . . . . . . . . . . . . . . . . 123

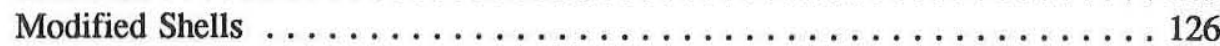

Burned Rocks . . . . . . . . . . . . . . . . . . . . . . 127

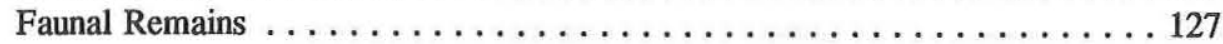

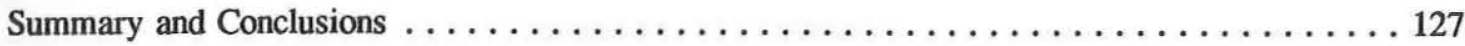

Site Chronology and Definition of Component $\ldots \ldots \ldots \ldots \ldots \ldots \ldots \ldots \ldots \ldots \ldots$

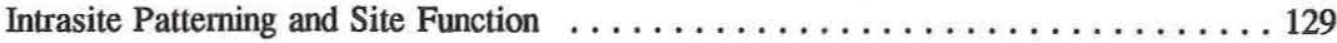

Cultural Assessment of Component $\ldots \ldots \ldots \ldots \ldots \ldots \ldots \ldots \ldots \ldots \ldots \ldots \ldots \ldots \ldots \ldots \ldots$

CHAPTER 8: OFF-SITE GEOLOGICAL INVESTIGATIONS

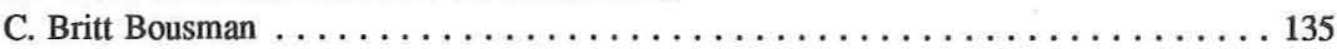

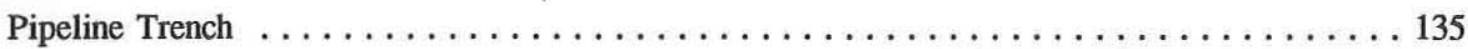

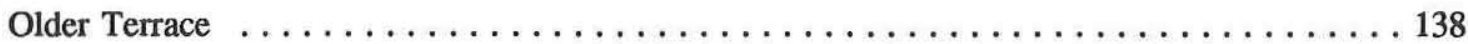

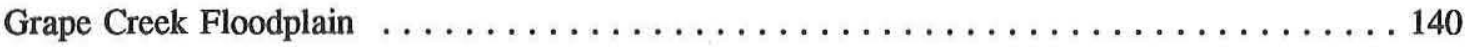

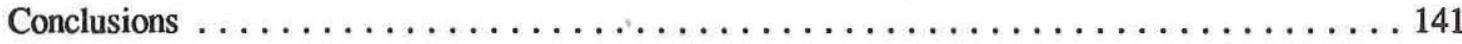

CHAPTER 9: SUMMARY AND CONCLUSIONS

Douglas K. Boyd, Steve A. Tomka, and C. Britt Bousman . . . . . . . . . . . 143

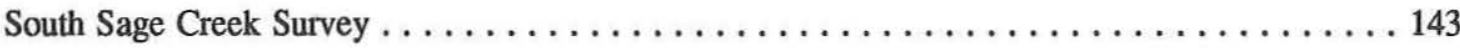

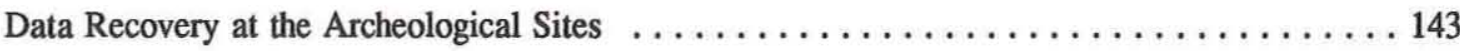

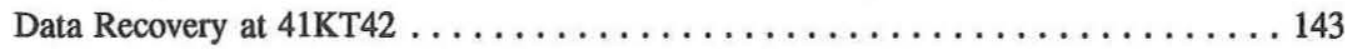

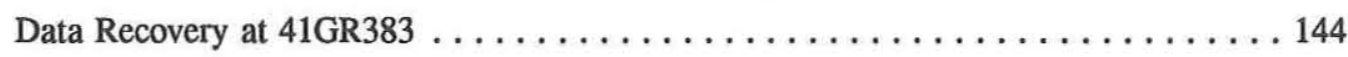

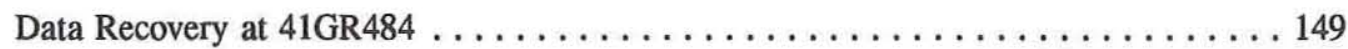

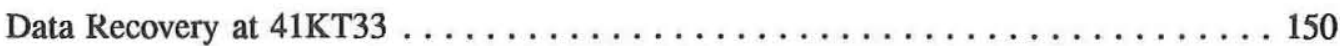

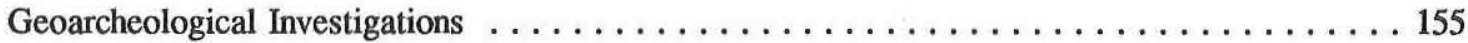

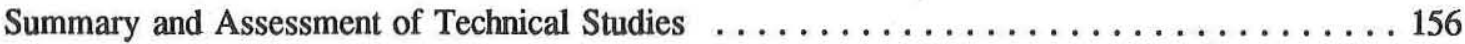

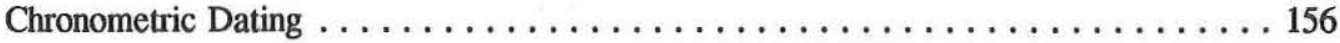

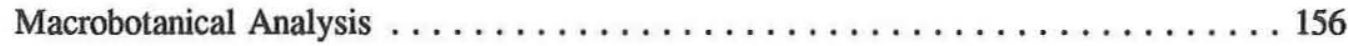

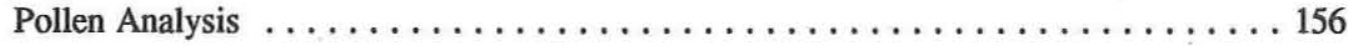

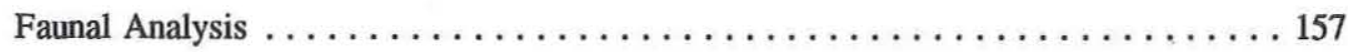

Petrographic Analysis . . . . . . . . . . . . . . . . . . . 157

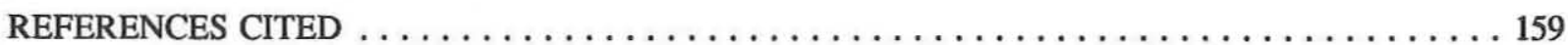


APPENDIX A: ARCHEOLOGICAL SURVEY OF SOUTH SAGE CREEK, KENT COUNTY, TEXAS

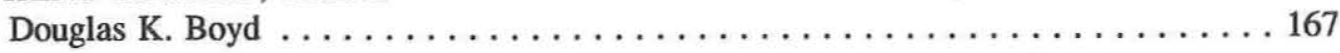

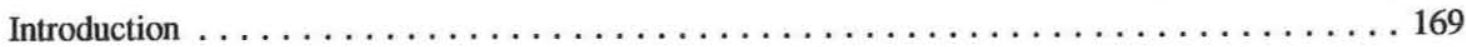

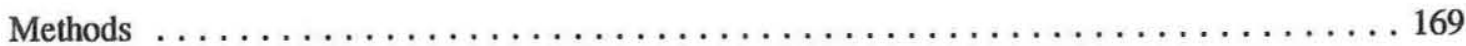

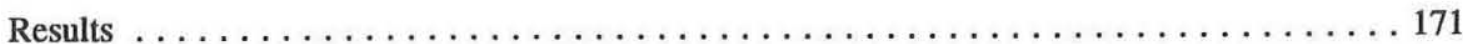

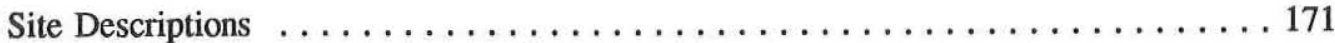

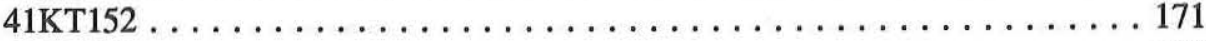

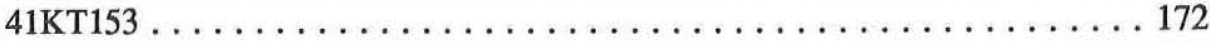

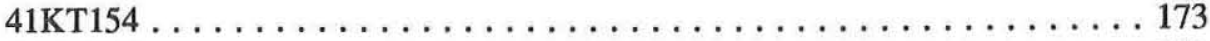

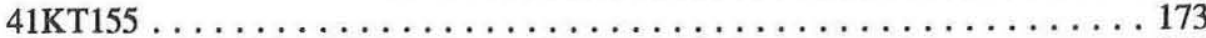

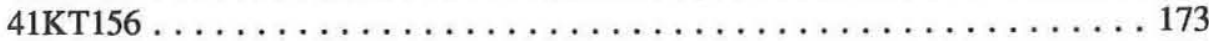

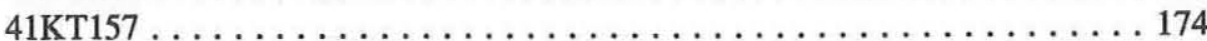

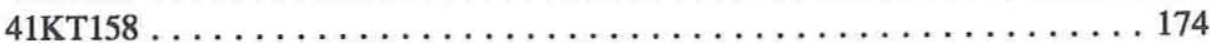

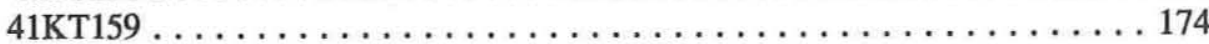

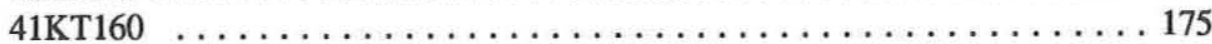

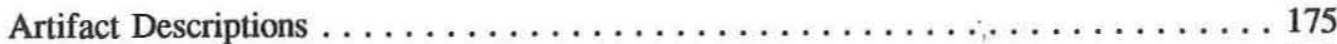

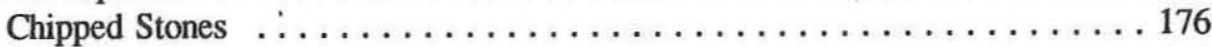

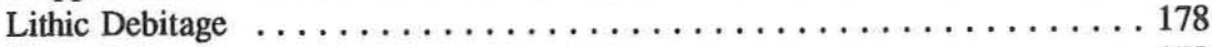

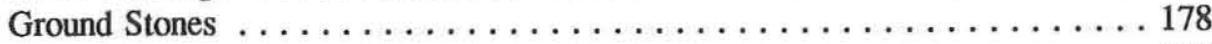

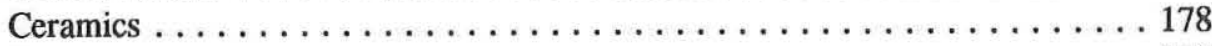

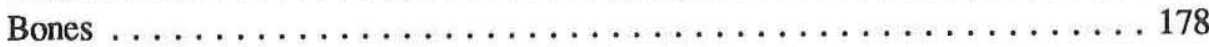

Summary, Assessments, and Recommendations $\ldots \ldots \ldots \ldots \ldots \ldots \ldots \ldots \ldots \ldots \ldots \ldots \ldots \ldots \ldots \ldots$

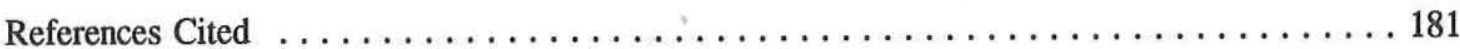

APPENDIX B: ARTIFACT PROVENIENCE, PREHISTORIC SITES $\ldots \ldots \ldots \ldots \ldots \ldots \ldots \ldots 183$

APPENDIX C: FAUNAL REMAINS FROM THE PREHISTORIC SITES
Raymond $W$. Neck and Douglas $K$. Boyd $\ldots \ldots \ldots \ldots \ldots \ldots \ldots \ldots \ldots \ldots \ldots \ldots \ldots$

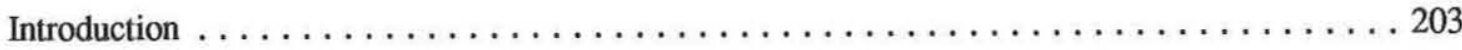

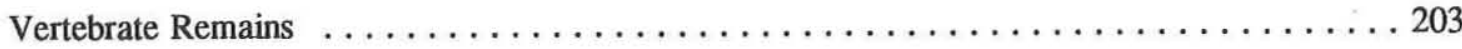

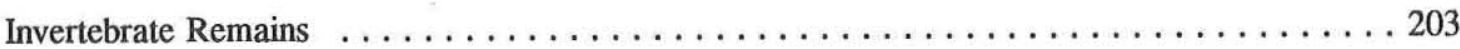

APPENDIX D: MACROBOTANICAL ANALYSIS OF THREE FLOTATION SAMPLES

FROM JUSTICEBURG RESERVOIR

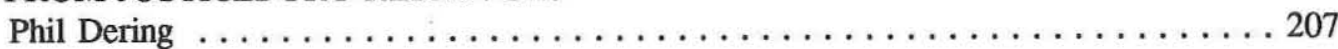

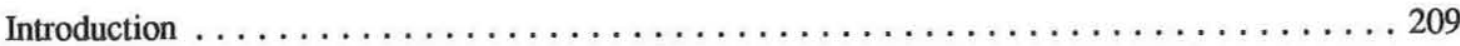

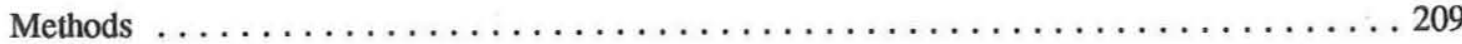

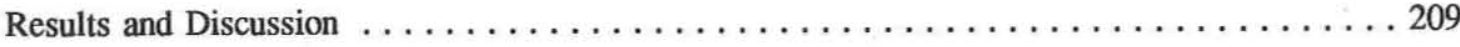

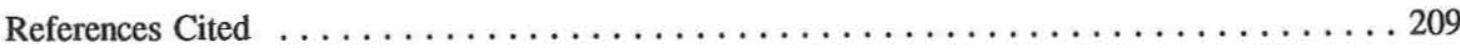




\section{APPENDIX E: POLLEN ANALYSIS OF ARCHEOLOGICAL SEDIMENTS}

FROM JUSTICEBURG RESERVOIR

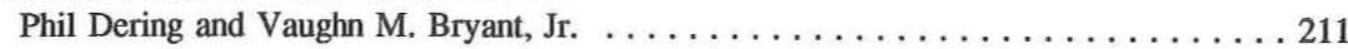

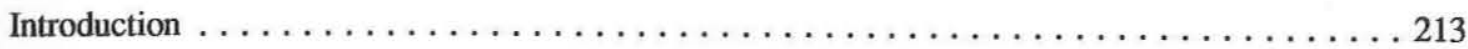

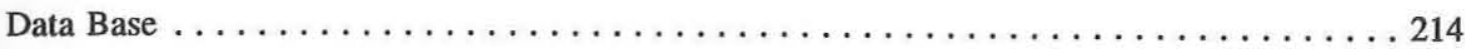

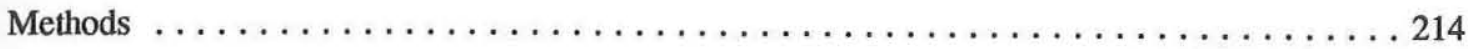

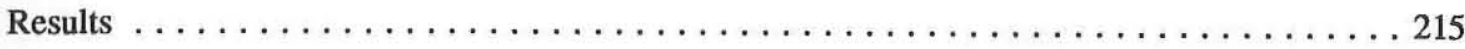

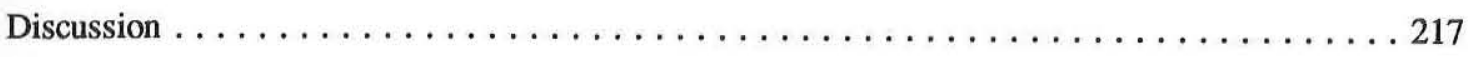

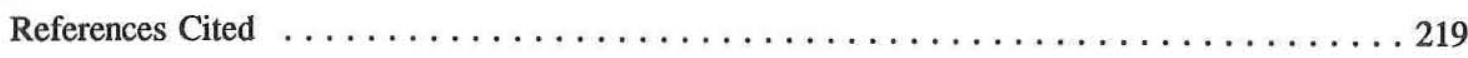

APPENDIX F: PETROGRAPHIC ANALYSIS OF NONLOCAL PLAINWARES

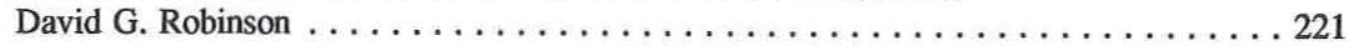

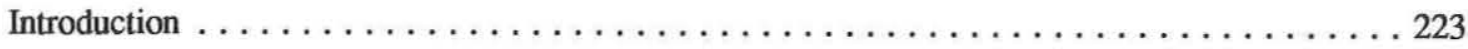

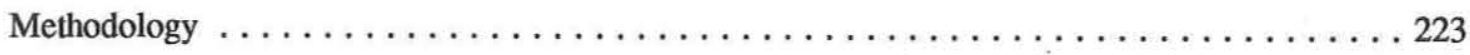

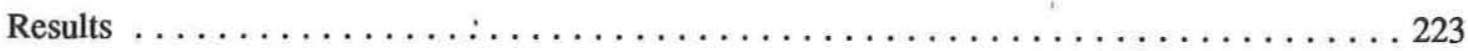

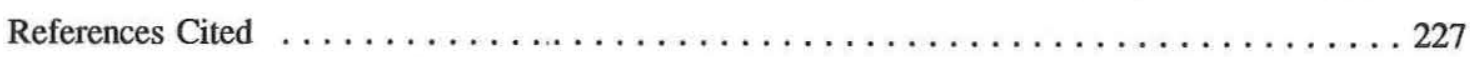

APPENDIX G: ABSOLUTE CHRONOLOGY RESULTS

C. Britt Bousman . . . . . . . . . . . . . . . . . . . . . . . . . . . . . . 229

APPENDIX H: GEOMORPHIC PROFILE DESCRIPTIONS

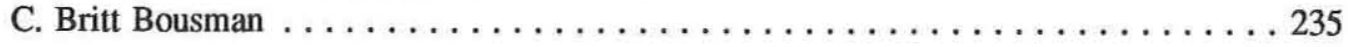

APPENDIX I: TEXTURAL AND CHEMICAL ANALYSIS OF SEDIMENT SAMPLES

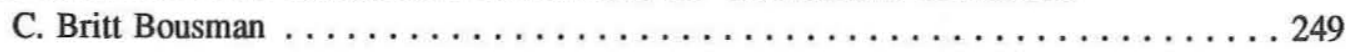




\section{LIST OF FIGURES}

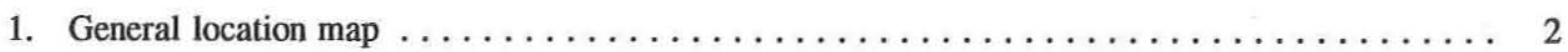

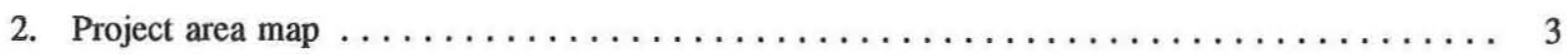

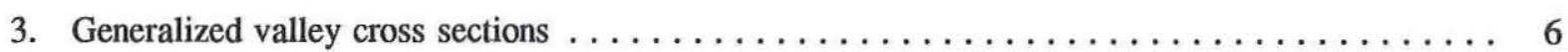

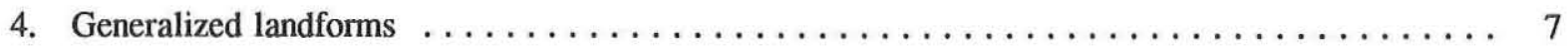

5. Map showing project area and locations of regional lithic material

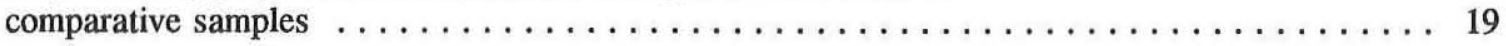

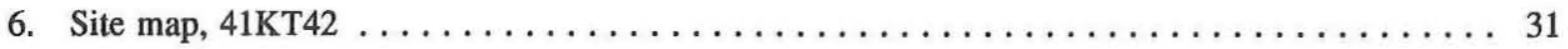

7. Map of the house foundation and 1988 test excavations, $41 \mathrm{KTT} 42 \ldots \ldots \ldots \ldots \ldots \ldots \ldots \ldots$

8. Distribution of surface-collected artifacts by material type, $41 \mathrm{KT} 42 \ldots \ldots \ldots \ldots \ldots \ldots \ldots$

9. Distribution of surface-collected artifacts by functional categories, $41 \mathrm{KT} 42 \ldots \ldots \ldots \ldots$

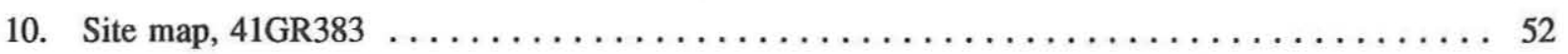

11. Detailed map of the excavation block area, 41GR383 $\ldots \ldots \ldots \ldots \ldots \ldots \ldots \ldots \ldots \ldots$

12. Photograph of the completed excavation block at $41 \mathrm{GR} 383 \ldots \ldots \ldots \ldots \ldots \ldots \ldots \ldots \ldots$

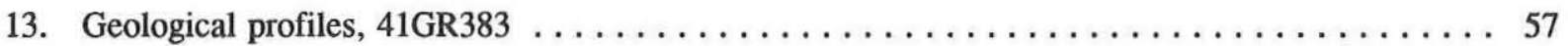

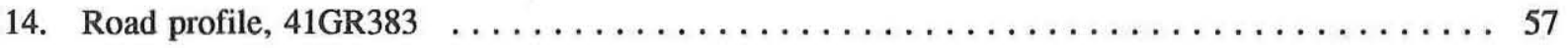

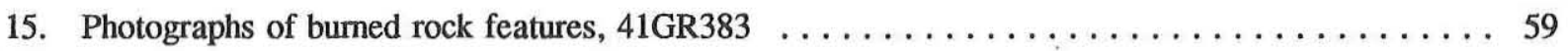

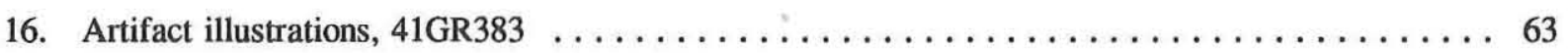

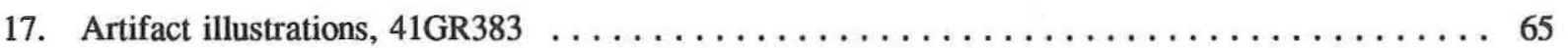

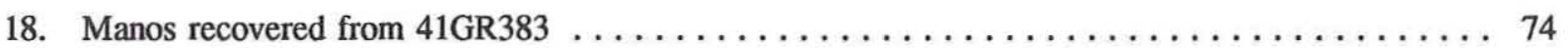

19. Moderately battered hammerstone recovered from 41 GR $383 \ldots \ldots \ldots \ldots \ldots \ldots \ldots \ldots$

20. Horizontal artifact distributions, $41 \mathrm{GR} 383 \ldots \ldots \ldots \ldots \ldots \ldots \ldots \ldots \ldots \ldots \ldots \ldots \ldots$

21. Horizontal artifact distributions, 41 GR $383 \ldots \ldots \ldots \ldots \ldots \ldots \ldots \ldots \ldots \ldots \ldots \ldots$

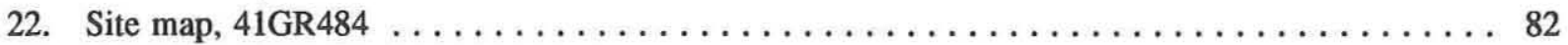

23. Excavation block surface topography and unit designations, $41 \mathrm{GR} 484 \ldots \ldots \ldots \ldots \ldots \ldots$

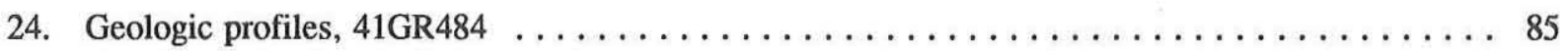

25. Detailed plan and profile views of Features 1 and 3,41 GR484 $\ldots \ldots \ldots \ldots \ldots \ldots \ldots$

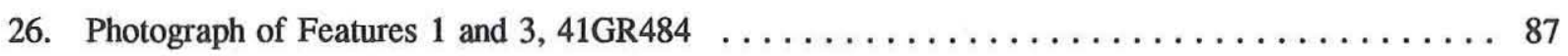

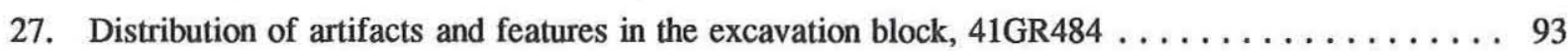

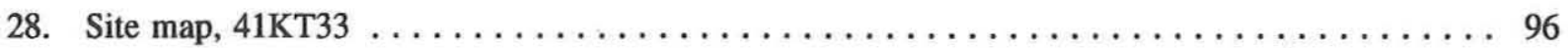

29. Detailed map of the eastern portion of site 41KT33 showing locations of random sample units and the excavation block $\ldots \ldots \ldots \ldots \ldots \ldots \ldots \ldots \ldots \ldots \ldots \ldots \ldots \ldots \ldots$

30. Photograph of completed excavation block at $41 \mathrm{KT} 33 \ldots \ldots \ldots \ldots \ldots \ldots \ldots \ldots \ldots$

31. Excavation block surface topography and unit designations, $41 \mathrm{KT} 33 \ldots \ldots \ldots \ldots \ldots \ldots \ldots$

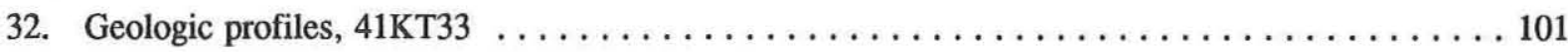




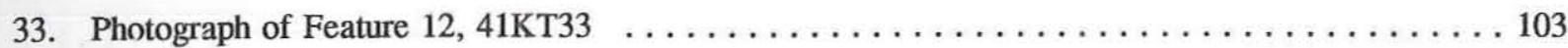

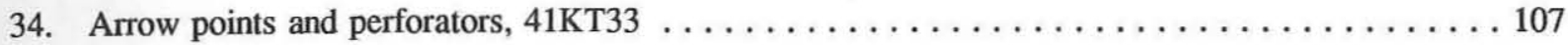

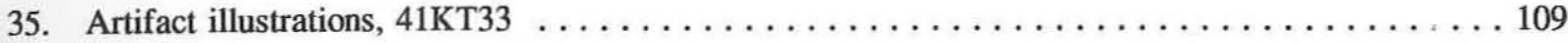

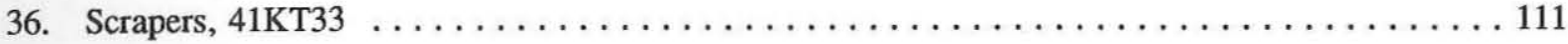

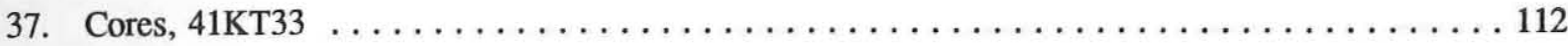

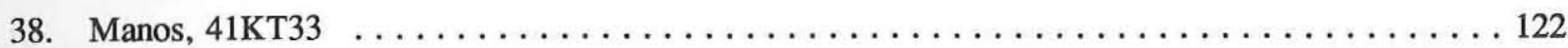

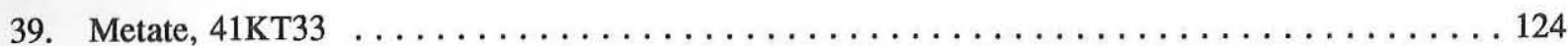

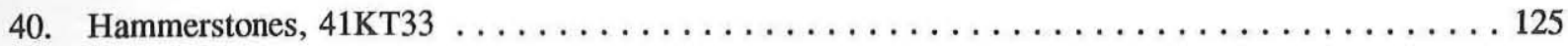

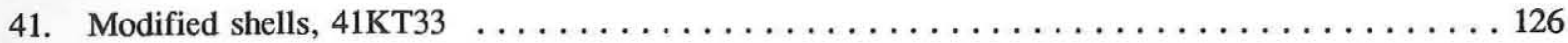

42. Distribution of artifacts and features in the excavation block, $41 \mathrm{KT} 33 \ldots \ldots \ldots \ldots \ldots \ldots \ldots$

43. Distribution of artifacts in the excavation block, $41 \mathrm{KT} 33 \ldots \ldots \ldots \ldots \ldots \ldots \ldots \ldots \ldots \ldots \ldots \ldots$

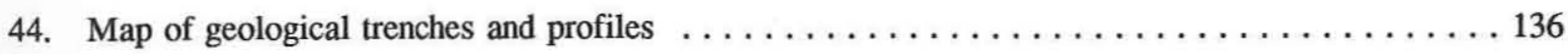

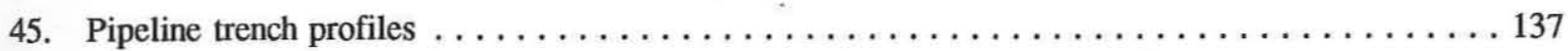

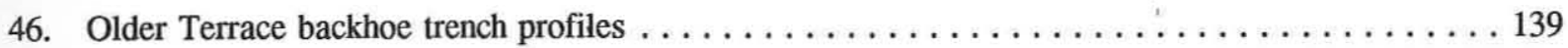

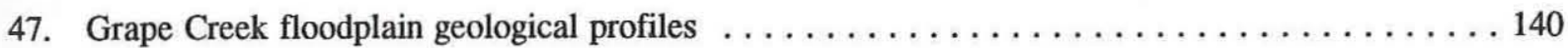

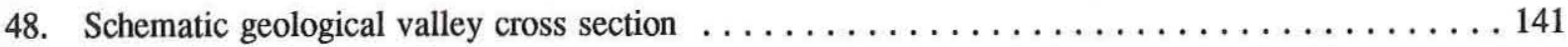

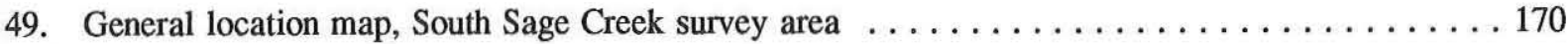

50. Artifacts from South Sage Creek survey $\ldots \ldots \ldots \ldots \ldots \ldots \ldots \ldots \ldots \ldots \ldots \ldots \ldots \ldots \ldots \ldots \ldots$ 


\section{LIST OF TABLES}

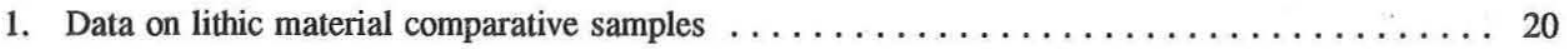

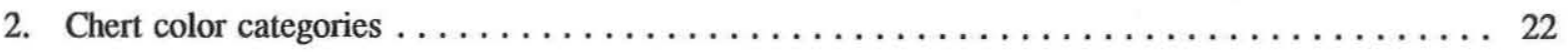

3. Artifacts recovered during 1987 survey and 1988 testing, 41 KT42 $4 \ldots \ldots \ldots \ldots \ldots \ldots$

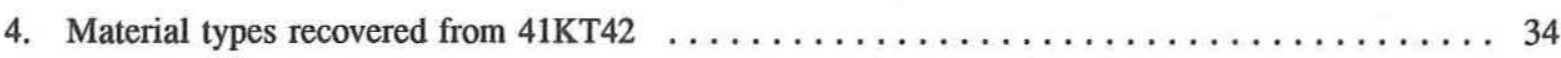

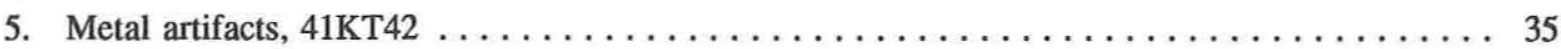

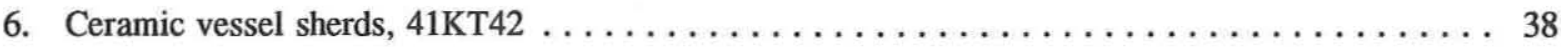

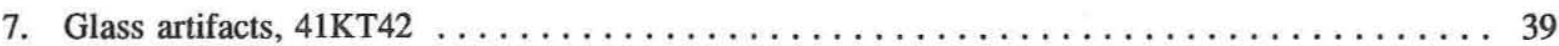

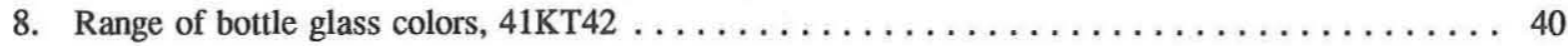

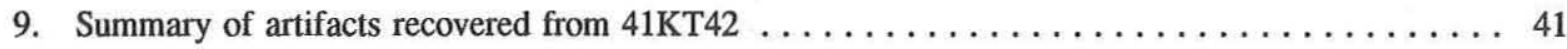

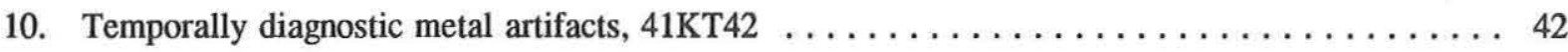

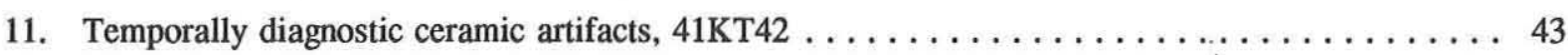

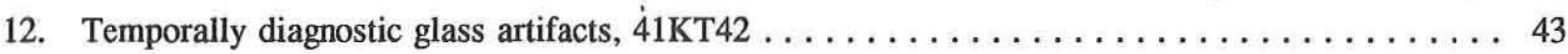

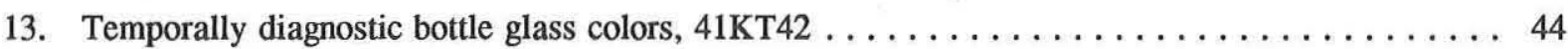

14. Functional classification of artifacts by material, $41 \mathrm{KT} 42 \ldots \ldots \ldots \ldots \ldots \ldots \ldots \ldots$

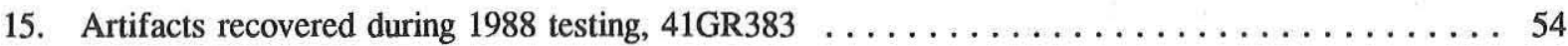

16. Artifacts recovered during 1990 data recovery, 41 GR383 $\ldots \ldots \ldots \ldots \ldots \ldots \ldots \ldots \ldots 60$

17. Core attributes by raw material type, 41 GR $383 \ldots \ldots \ldots \ldots \ldots \ldots \ldots \ldots \ldots \ldots \ldots \ldots \ldots \ldots \ldots \ldots \ldots$

18. Edge-modified flake attributes by raw material type, 41 GR $383 \ldots \ldots \ldots \ldots \ldots \ldots \ldots$

19. Unmodified lithic debitage attributes by raw material type, $41 \mathrm{GR} 383 \ldots \ldots \ldots \ldots \ldots \ldots$

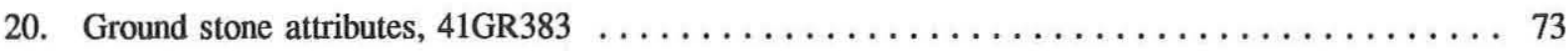

21. Vertical distribution of chipped, ground, and battered stones, 41GR383 $\ldots \ldots \ldots \ldots \ldots \ldots 77$

22. Artifacts recovered during 1988 testing, 41GR484 $\ldots \ldots \ldots \ldots \ldots \ldots \ldots \ldots \ldots \ldots$

23. Artifacts recovered during 1990 data recovery, $41 \mathrm{GR} 484 \ldots \ldots \ldots \ldots \ldots \ldots \ldots \ldots$

24. Unmodified lithic debitage attributes by raw material type, 41GR484 $\ldots \ldots \ldots \ldots \ldots \ldots$

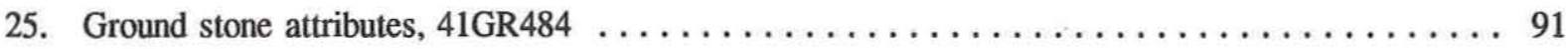

26. Artifacts recovered during 1988 testing, $41 \mathrm{KT} 33 \ldots \ldots \ldots \ldots \ldots \ldots \ldots \ldots \ldots \ldots \ldots \ldots \ldots \ldots \ldots \ldots$

27. Artifacts recovered during 1990 data recovery, $41 \mathrm{KT} 33 \ldots \ldots \ldots \ldots \ldots \ldots \ldots \ldots \ldots$

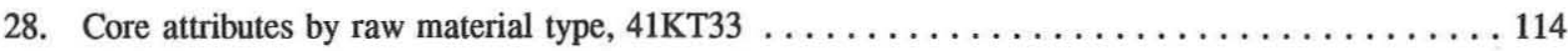

29. Edge-modified flake attributes by raw material type, $41 \mathrm{KT} 33 \ldots \ldots \ldots \ldots \ldots \ldots \ldots \ldots$

30. Unmodified lithic debitage attributes by raw material type, $41 \mathrm{KT} 33 \ldots \ldots \ldots \ldots \ldots \ldots$

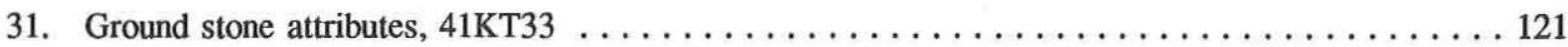

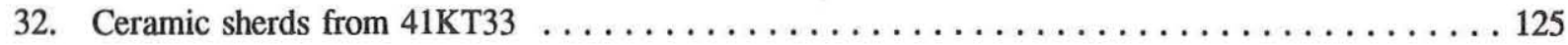

33. Vertical distribution of chipped, ground, and battered stones, $41 \mathrm{KT} 33 \ldots \ldots \ldots \ldots \ldots \ldots 128$ 


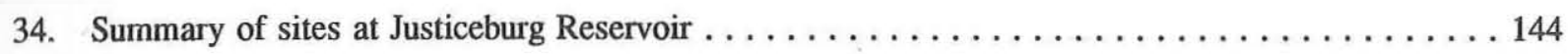

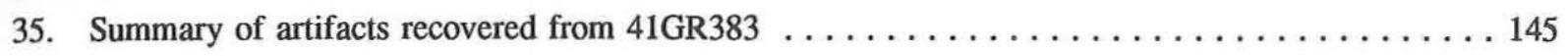

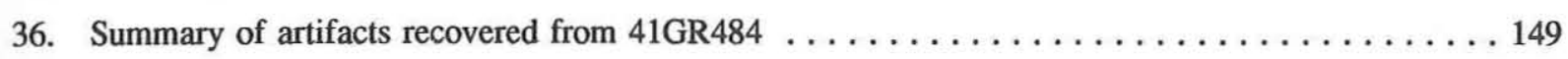

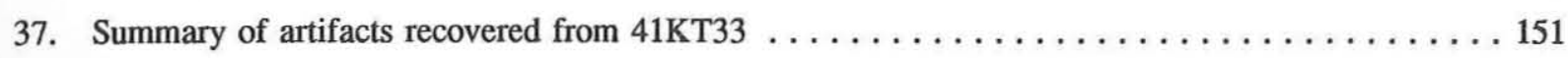

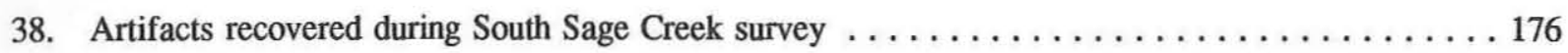

39. Metric data for dart points, South Sage Creek survey $\ldots \ldots \ldots \ldots \ldots \ldots \ldots \ldots \ldots \ldots \ldots \ldots \ldots \ldots \ldots \ldots$

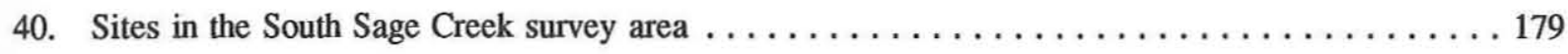

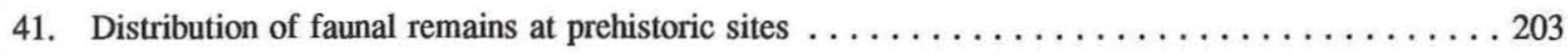

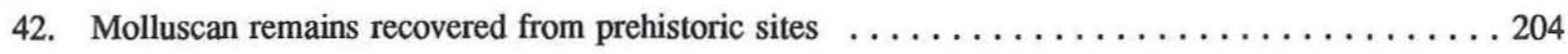

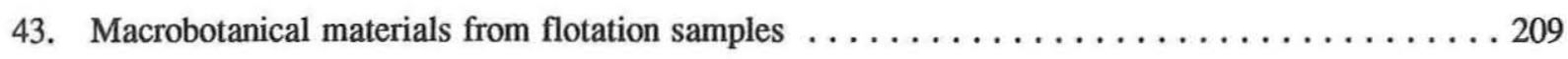

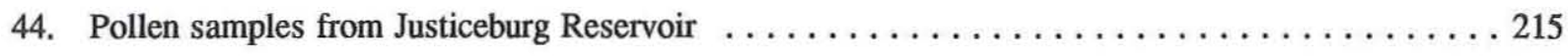

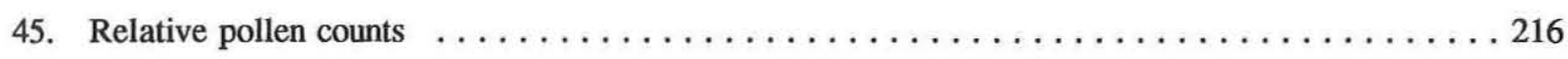

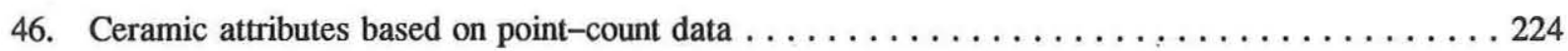

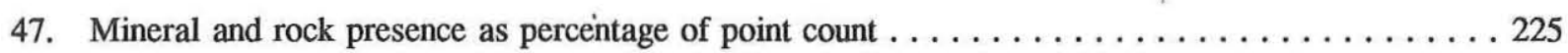

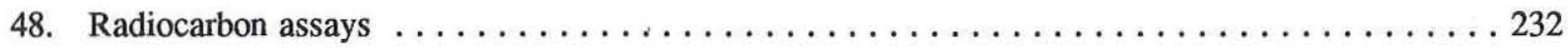


Phase III data recovery investigations at one historic and three prehistoric sites, augmented by additional survey and off-site geological investigations, were conducted at Lake Alan Henry (formerly Justiceburg Reservoir) on the Double Mountain Fork of the Brazos River in Garza and Kent counties, Texas, during the fall and winter of 1990-1991. Descriptive data from this first of three field seasons of data recovery are presented here in anticipation of a final synthetic report that will relate all the investigations to a series of research design hypotheses.

Analysis of surface distributions at $41 \mathrm{KT} 42$, a late nineteenth- to early twentieth-century ranch line camp known locally as the Ed Scott Cabin, groups the artifacts into material and functional categories that demonstrate primary and secondary refuse accumulations adjacent to the cabin. The distribution of primary refuse shows kitchen artifacts are spatially distinct from other types that include architectural, firearm, ranching, clothing, and personal items. The primary discard pattern is obfuscated by redistribution attributed to secondary refuse discard.

The uppermost of two superimposed hearths at 41GR484, the Grape Creek Bench Site, is radiocarbon dated to 260 B.P. and yielded charcoal identified as Carya sp. Excavations were halted at this Late Prehistoric II site because of extremely low artifact recovery. Geoarcheological investigations demonstrate that most of the site has been destroyed by cutbank erosion associated with the meanderings of Grape Creek.

At 41KT33, the Late Prehistoric I South Sage Creek Site, stone-lined hearth features dated to 1005 B.P. are surrounded by clusters of artifacts. Petrographic analysis of brownware ceramics suggests affiliations with the local Palo Duro Complex and nonlocally with the Pecos River valley. The Gobbler Creek Bridge Site, 41GR383, spans the late Archaic and Late Prehistoric I periods. Intact and dispersed stone-lined hearths radiocarbon dated to $1865-1215$ B.P. are surrounded by artifact clusters. Both of the sites appear to have been multifunctional campsites, and repeated occupations are likely. Dense concentrations of fire-cracked rocks at these sites may represent secondary refuse disposal. Lithic analysis indicates extensive use of nonlocal materials derived from Cretaceous formations that occur in the Callahan Divide and Edwards Plateau to the south. Freshwater mussels are the only faunal remains recovered from either of these sites. The meat is presumed to have been consumed as food, while the shells sometimes were made into ornaments.

An additional 440 acres of land were surveyed for cultural resources; 360 of these acres were subsequently acquired by the City of Lubbock for use as wildlife mitigation lands. Nine prehistoric archeological sites and one isolated find were documented and evaluated for their eligibility for listing on the National Register of Historic Places. Five of these sites are considered to be ineligible for listing on the National Register, and five are potentially eligible for listing. Avoidance is recommended at these five sites, with testing recommended to determine their National Register eligibility if avoidance is not possible.

Geological investigations provide information about depositional environments in and near the archeological sites. Two soils buried in the Double Mountain Fork floodplain are radiocarbon dated to 860-600 B.P. and 1700-1300 B.P.; fluvial sediments extend as much as $15 \mathrm{~m}$ below these soils in portions of the floodplain. An older terrace previously was identified $18 \mathrm{~m}$ above the modern river channel. Current work obtained a terminal date of 8690 B.P. from a buried soil that caps this older terrace. Another radiocarbon date of 3320 B.P. was obtained from fill in a gully that is eroded into the older terrace. These dates bracket an erosional episode when the older terrace was heavily dissected. The erosion coincides with the Altithermal, a period believed to have been characterized by a hot and dry climatic regime. 


\section{ACKNOWLEDGMENTS}

Thanks are extended to the numerous individuals and institutions who assisted during the investigations reported herein. Foremost is the City of Lubbock which is funding these studies. Dan A. Hawkins, Director of Water Utilities, and Mike Gilleland, Engineering Assistant, provided crucial liaison with the City and helped with field logistics. Barbara A. Nickerson of Freese and Nichols, Inc., Technical Representative for the City, gave administrative assistance and provided liaison with regulatory authorities. Helpful comments regarding the field efforts were made by Robert F. Scott of the Fort Worth District, Corps of Engineers; James E. Bruseth of the Texas Historical Commission; and Richard Wilshusen of the Advisory Council on Historic Preservation, Denver.

The initial field crew consisted of Wayne Chesser, Rolando Garza, and Gene Longcrier. Crewmembers added for the Gobbler Creek Bridge Site include Annette Carver, Doug Drake, Tom Dureka, Dan Lauterbur, Ann Mesrobian, and Richard Walter. Their perseverance through cold windy weather and the high quality of data collection testifies to their professionalism and dedication to duty. The Great Western Inn in Snyder was a warm comfortable haven following the cold days in the field; the motel management graciously provided us with a room to store gear and equipment during weekend breaks.

Numerous student volunteers from the Department of Anthropology at Texas Tech University, working under the direction of Grant D. Hall, assisted in excavations at the South Sage Creek and Gobbler Creek Bridge sites. Special thanks are extended to Dr. Hall and the students who volunteered repeatedly for fieldwork: Todd Reynolds, Chad Williams, Mark Willis, Jason Hodges, Laura Lochner, Brent Scott, and Doug Burns. Local avocational archeologists who aided us in numerous ways include Zoe Kirkpatrick, Frank Runkles, and Emmett Shedd. Emmett was also instrumental in gaining access to properties during our explorations of regional lithic sources. A survey crew from the district office of the Texas Department of Highways and Public Transportation assisted in the mapping of the Gobber Creek Bridge Site.

Brett Cruse of EMANCO, Inc., Houston, and Billy R. Harrison of the Panhandle-Plains Historical Museum in Canyon loaned comparative ceramic samples for petrographic analysis from the Kent Creek Site and Deadman's Shelter, respectively. Independent ceramic identifications were made by Regge Wiseman of the Laboratory of Anthropology, Santa Fe, and Jack Hedrick of El Paso. The ceramic thin sections used in the petrographic analysis were prepared by Clifton Neely of the Bureau of Economic Geology, The University of Texas at Austin. J. Michael Quigg of Mariah Associates, Inc. in Austin assisted with the vertebrate faunal identifications.

The staff at Prewitt and Associates, Inc. provided professional assistance through all phases of these investigations. Linda N. Foster undertook the technical editing and produced a much more readable report. Sandra L. Hannum and Karen M. Gardner ably drafted the maps and produced the figures, while E. Ellen Atha skillfully prepared the artifact illustrations. Laboratory processing was efficiently directed by Jeanine McDonald and Gardner. During all stages of the project, Elton R. Prewitt gave sound advice that is interwoven through this report. Ross C. Fields provided his usual sage counsel that would only be obvious by its omission. 


\section{INTRODUCTION}

Douglas K. Boyd

Since 1987, intensive archeological, geoarcheological, and historical investigations have been conducted at Justiceburg Reservoir, now being constructed on the Double Mountain Fork of the Brazos River in Garza and Kent counties, Texas (Figs. 1 and 2). The reservoir, which will be called Lake Alan Henry upon completion, is sponsored and financed by the City of Lubbock, Texas. The cultural resources have been inventoried (Phase I), and National Register of Historic Places evaluations (Phase II) have been completed for a sample of archeological sites that will be directly impacted by the project (Boyd et al. 1989, 1990; Freeman and Boyd 1990). The Phase I and Phase II cultural resources investigations were conducted for the City of Lubbock by Prewitt and Associates, Inc. of Austin, Texas. The cultural resources study moved into the final stage, Phase III data recovery, in the fall of 1990. This final phase of work is designed to mitigate the reservoir's destructive impacts to the cultural resources through an integrated program of interdisciplinary studies to be conducted over a period of approximately 4 years. This work is guided by a Memorandum of Agreement among the Corps of Engineers, the State Historic Preservation Officer, and the Advisory Council on Historic Preservation, with the concurrence of the City of Lubbock. A comprehensive research design and data recovery plan developed by Prewitt and Associates, Inc. to guide the Phase III investigations was subsequently reviewed and approved by cultural resource personnel of the City of Lubbock's Technical Representative (Freese and Nichols, Inc. of Fort Worth, Texas) and the signatories to the Memorandum of Agreement. The City of Lubbock then contracted with Prewitt and Associates, Inc. to conduct the Phase III cultural resources investigations, and fieldwork began in November 1990.

The Phase III data recovery plan specifies which sites are to be investigated and establishes the level of effort for each site. Any significant changes to the data recovery plan must be reviewed and approved by the managing agencies. The data recovery plan also specifies that the cultural resources investigations are to be conducted in three separate seasons of fieldwork. The work tasks in each season are prioritized according to the reservoir construction and inundation schedule. Each field season is to be followed by a period of laboratory/analytical research and will result in a descriptive report of investigations that will cover only those investigations undertaken during that season. Upon completion of the third and final field season and its descriptive report, a period of comparative laboratory/analytical research will follow, resulting in a final synthetic/interpretive report of investigations. This final report will summarize all of the data recovery investigations, place the work within a regional perspective, and address the specific and general research questions proposed in the research design. Project completion is currently scheduled for the fall of 1994 .

This report documents the first field season of the Phase III data recovery investigations at Justiceburg Reservoir. It includes descriptive reports of the data recovery work completed at one 


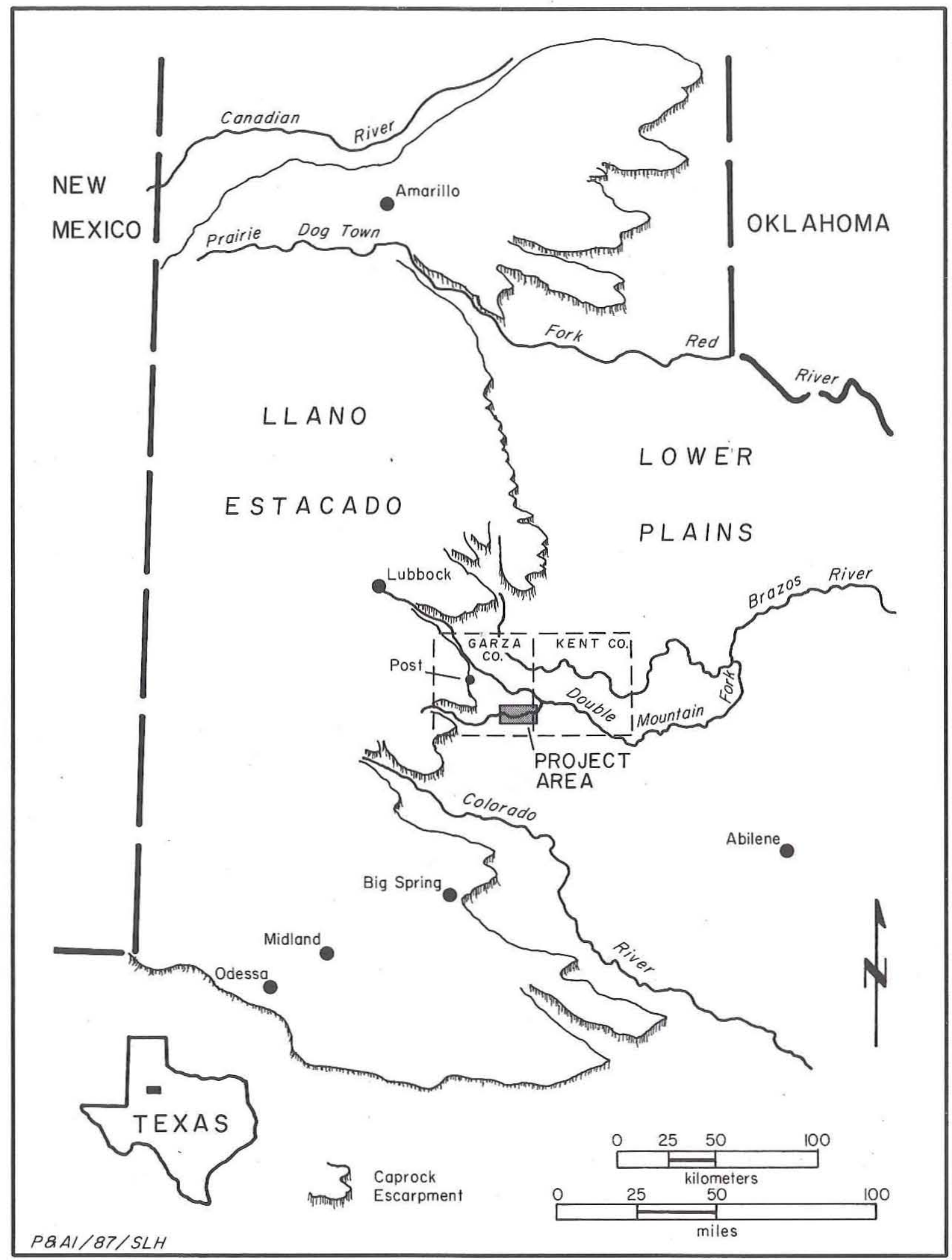

Figure 1. General location map. 


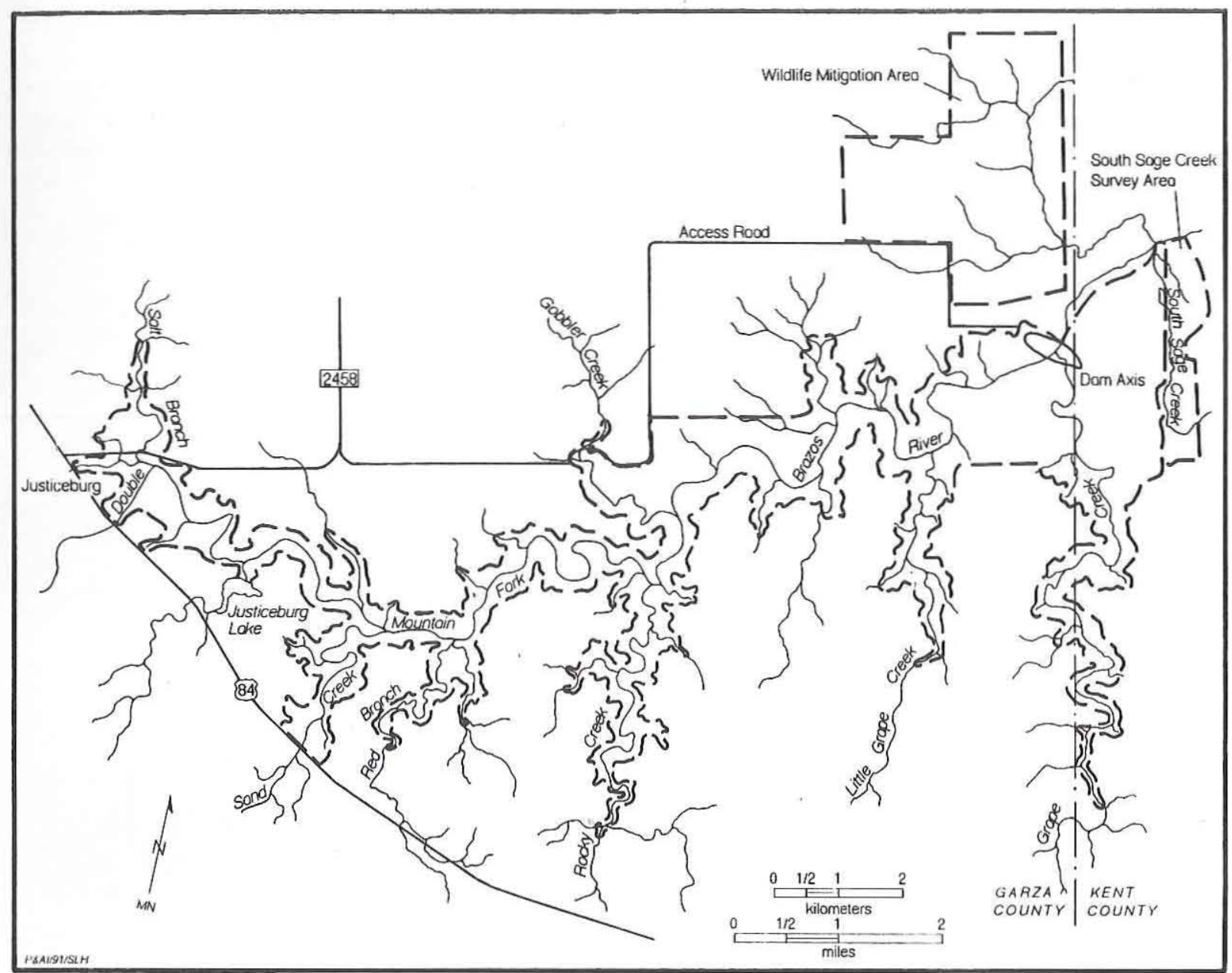

Figure 2. Project area map.

historic (41KT42) and three prehistoric (41GR383, 41GR484, and 41KT33) archeological sites. All of these sites are threatened by immediate construction impacts. Historic site 41KT42 and prehistoric site 41GR484 are located in the dam construction zone, prehistoric site $41 \mathrm{KT} 33$ is located in a secondary borrow area, and prehistoric site 41GR383 is within the construction right-of-way of a planned Texas Department of Highways and Public Transportation road (FM 3519) that will provide public access to the reservoir. Limited nonsite paleoenvironmental investigations during Season 1 are also reported. In addition, the City of Lubbock is acquiring a tract of land on South Sage Creek downstream from the reservoir and requested that it be inventoried. The cultural resources survey of this tract was conducted during Season 1 and is reported as an appendix to this volume.
This report is divided into nine chapters and nine appendixes. Chapter 2 presents the environmental and archeological background, including a summary of pertinent portions of the research design. Chapter 3 contains the specific objectives that helped guide these investigations as well as the methodologies used to achieve the results reported here; Chapter 3 also includes a description of regional lithic raw materials. Chapter 4 presents the results of investigations, focusing on the horizontal distribution of artifacts, at $41 \mathrm{KT} 42$, an historic ranching line camp. Excavations at late Archaic/early Late Prehistoric site 41GR383 are reported in Chapter 5. Chapter 6 presents the limited excavation results from the Late Prehistoric II occupation at 41GR484, and Chapter 7 consists of a discussion of excavations at Late Prehistoric site 41KT33. Results from off-site geoarcheological investigations are provided in Chapter 8 , and the 
summary and conclusions comprise Chapter 9. Appendix A presents the findings from the South Sage Creek survey. Prehistoric artifact proveniences and the analysis of faunal remains are listed in Appendixes B and C, respectively. Macrobotanical analysis from flotation samples is provided in Appendix D, while the results of the pollen analysis are in Appendix E. Appendix F consists of the ceramic petrographic analysis. Onsite and off-site geologic profile descriptions are provided in Appendix H, and associated texture and chemical data are listed in Appendix I. 


\section{BACKGROUND AND RESEARCH ORIENTATION}

Douglas K. Boyd, Steve A. Tomka, and Martha Doty Freeman

This chapter is a brief synopsis of background information necessary for understanding the archeological and geoarcheological investigations reported below. Both environmental and archeological discussions are presented, including a summary of local prehistoric culture history, and these lead to a review of pertinent topics in the research design which guide the Phase III investigations. The information presented in this chapter is largely taken from previous reports of investigations (Boyd et al. 1990, 1991), with some modifications.

\section{ENVIRONMENTAL BACKGROUND}

Justiceburg Reservoir is located within the Lower Plains region of Texas (Brown et al. 1982), also referred to as the Rolling Plains (Lobeck 1948). The Lower Plains region is bordered on the north by the Canadian River in Oklahoma, on the east by the Western Cross Timbers region, on the south by the Edwards Plateau of Central Texas, and on the west by the Llano Estacado, the southernmost extension of the High Plains. The Llano Estacado, or High Plains, is the dominant physiographic feature, and the Caprock Escarpment clearly marks the boundary between the Lower Plains and the High Plains. The project area is several kilometers east of the Caprock Escarpment.

The flat, featureless plain of the Llano Estacado provides a stark contrast to the undulating, eroded badland topography of the Lower Plains. The rolling landscape is the result of the erosion and retreat of the High Plains. During the last several hundred thousand years, the Caprock Escarpment has been retreating westward, exposing to erosion the underlying Triassic and Permian beds. The region is further dissected by wellentrenched rivers and tributary drainages which head on the Llano Estacado or at the Caprock Escarpment. Three river systems, the Red, Brazos, and Colorado, flow generally eastward through the Lower Plains region. The surface waters originate as rainfall or spring seeps from groundwater aquifers.

The Justiceburg Reservoir project area lies mostly within Triassic exposures consisting of alternating layers of mudstones, conglomerates, and sandstones. Where the Double Mountain Fork has cut down through the erosion-resistant sandstone layers, the topography is quite rugged. This segment of the valley, in the mid portion of the reservoir from the mouth of Sand Creek to just below the mouth of Little Grape Creek (see Fig. 2), is a steep-sided, narrow-valley canyon (Fig. 3, cross section $\left.\mathrm{A}-\mathrm{A}^{\prime}\right)$. The canyon rim and lower erosional remnants are capped by sandstone strata. The valley slope is nearly vertical in places, and the canyon local relief varies from $18.3-30.5 \mathrm{~m} \mathrm{(60-}$ $100 \mathrm{ft}$ ). The narrow canyon is less than $200 \mathrm{~m}$ wide at the bottom, and the river meanders back and forth within the valley, leaving only thin strips of alluvial floodplain between the canyon wall and stream.

The topography differs upstream and downstream from this canyon-confined segment of the river. The eastern end of the reservoir, near the 
A

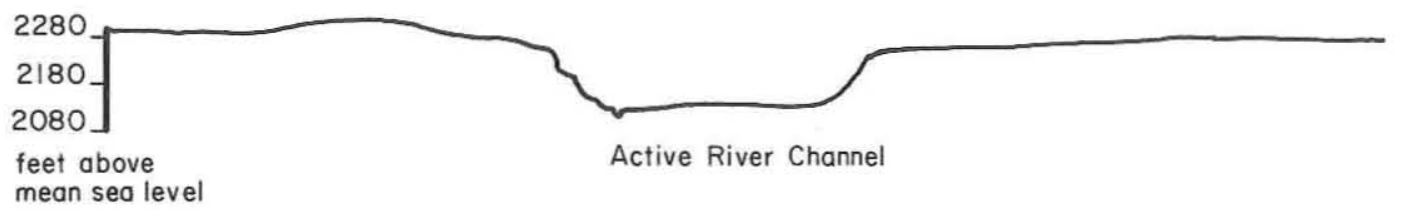

B

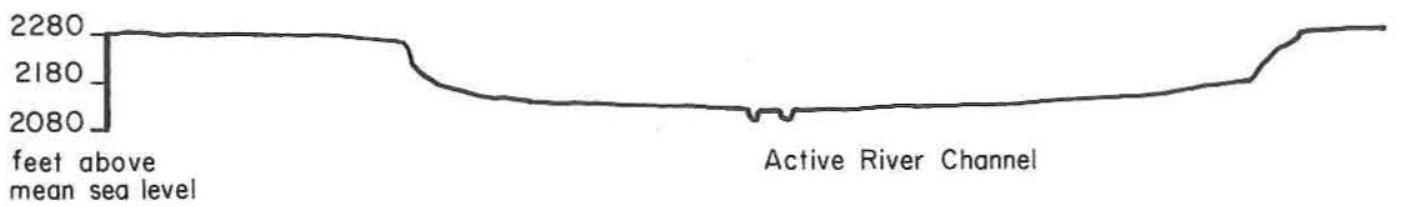

C

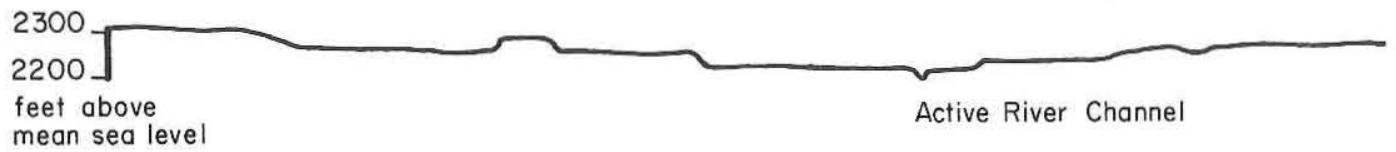

mean sea leve
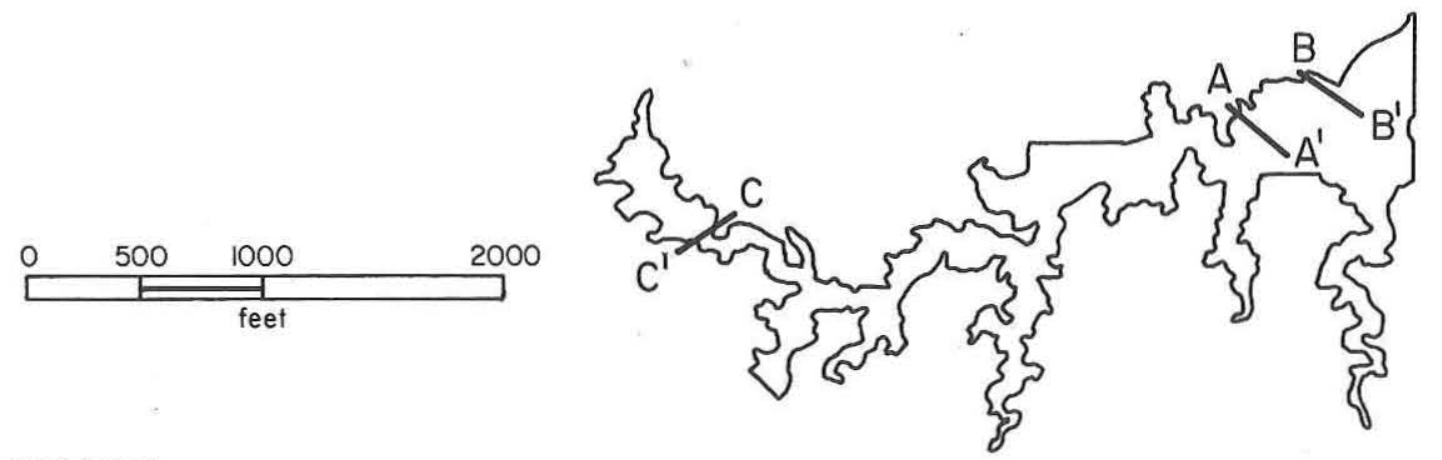

$P Q A I / 87 / S L H$

Figure 3. Generalized valley cross sections.

mouth of Grape Creek, is also a steep-sided canyon, but the valley widens out considerably with an alluvial floodplain over $1 \mathrm{~km}$ wide at this point (Fig. 3, cross section B-B'). In the western upstream end of the reservoir near the community of Justiceburg, canyon cutting is not pronounced because the river has not cut down through the erosion-resistant sandstone strata. The river channel is within a wide shallow valley which slopes gradually into the eroded upland (Fig. 3, cross section C-C').

The rugged topography in the project area is characterized by a range of distinctive landforms (Fig. 4). The upland and upland margin settings are found all along the canyon rim. In some areas, the flat upland ends abruptly at the canyon rim with little or no eroded upland margin. In other areas, the eroding upland margin extends hundreds of meters back from the canyon rim. Abrupt canyon rims are marked by erosion-resistant sandstone ledges which usually form a bluff several meters high. Erosion along the bluff has created numerous overhangs and shelters throughout the project area. The valley wall, the area between the upper bluff 

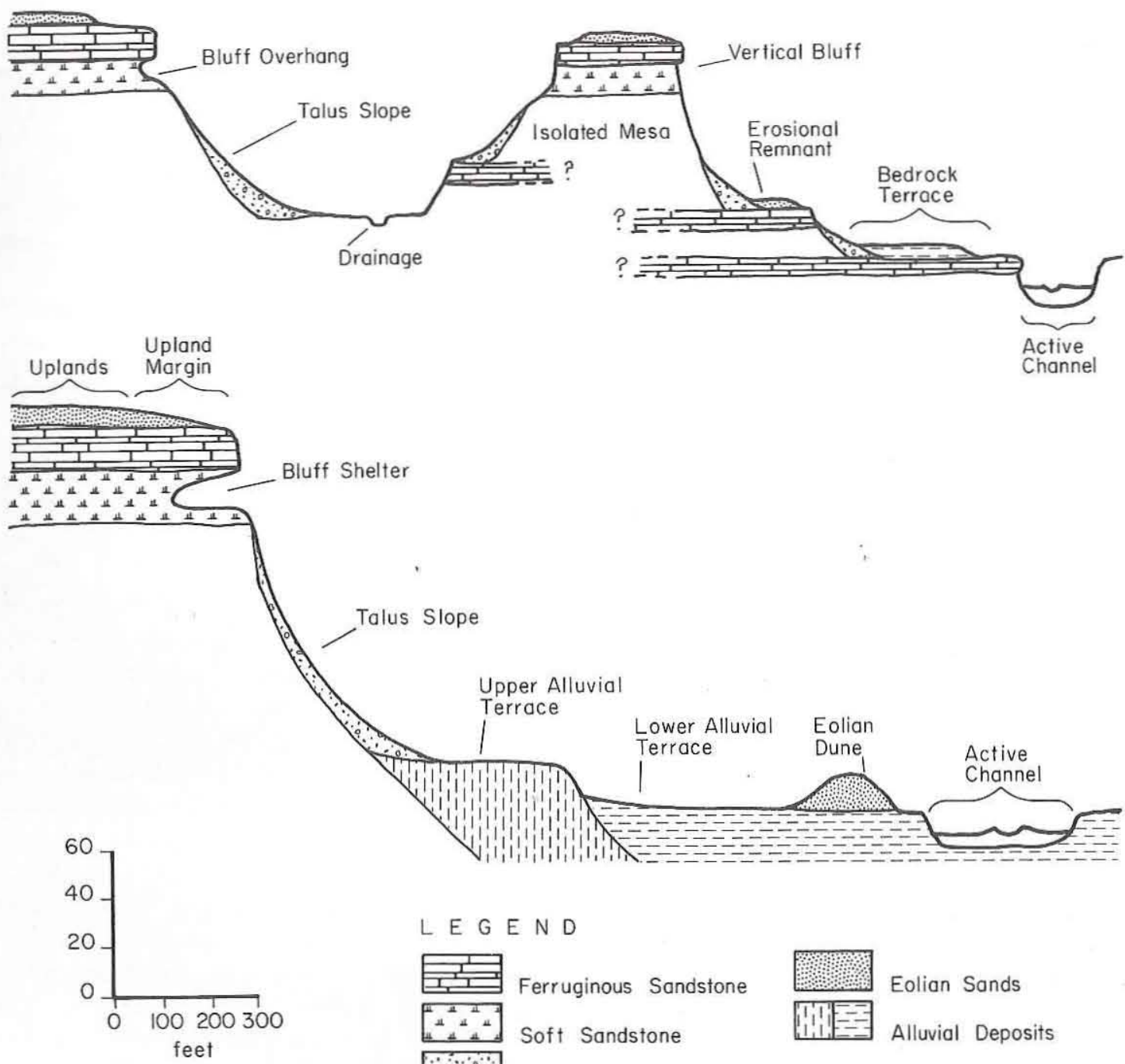

Talus Slope

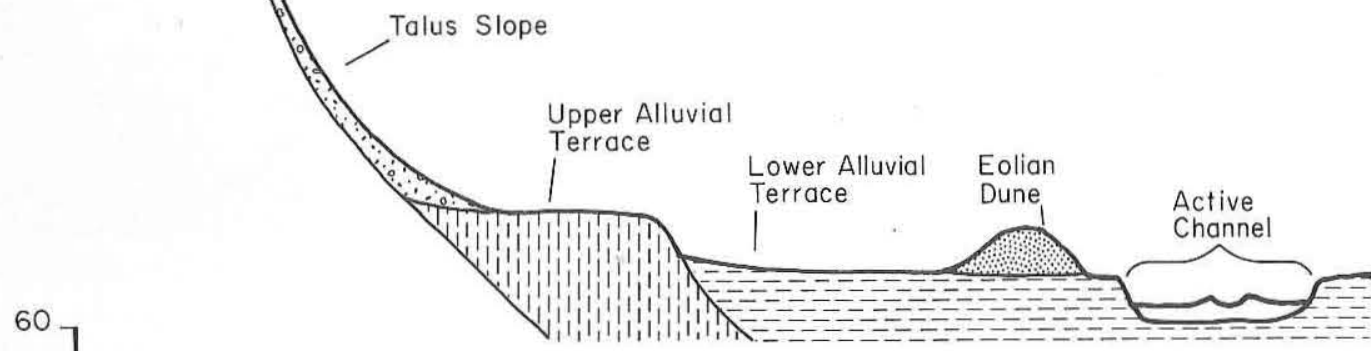

L E G E N D

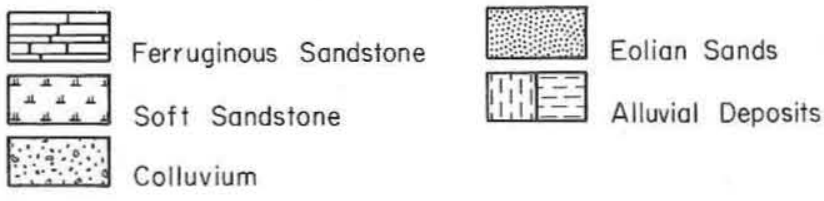

$P \& A / / 87 / S L H$

Figure 4. Generalized landforms.

and the valley floor, consists of talus slopes, isolated mesas, erosional remnants, bedrock benches, or any combination of these landforms. Talus slopes are composed of softer and more easily eroded mudstones and siltstones and are characteristically very steep. Talus slopes may be $20-30 \mathrm{~m}$ high, extending from the canyon rim to the valley floor, or they may cover only a few meters between exposed ledges of sandstone. In heavily eroded areas with numerous layers of erosion-resistant sandstone, the valley wall stairsteps, forming projecting erosional remnants, bedrock terraces, and isolated mesas. The valley wall landforms constitute a considerable portion of the project area, and the surface distance between the canyon rim and the valley floor may be hundreds of meters. The valley floor consists of the meandering channel of the Double Mountain Fork or its tributaries and alluvial terraces. It varies from a few meters to over $1,000 \mathrm{~m}$ wide. In the lower portion of the reservoir, upper and lower alluvial terraces sometimes can be distinguished, but in the remainder usually only a single terrace is evident. A few eolian sand dunes have formed on the alluvial terraces at the 
upper end of the reservoir, and occasional levees are evident along the river and stream channel margins.

The modern climate in the project area (from Scurry County data in Pass 1981:122) is mild, with short periods of extreme heat or cold. The mean minimum temperature in January is $-2^{\circ} \mathrm{C}\left(28^{\circ} \mathrm{F}\right)$, and the mean maximum in July is $35.5^{\circ} \mathrm{C}\left(96^{\circ} \mathrm{F}\right)$, but extremes range from $-23.3{ }^{\circ} \mathrm{C}\left(-10{ }^{\circ} \mathrm{F}\right)$ to $46.1{ }^{\circ} \mathrm{C}\left(115^{\circ} \mathrm{F}\right)$. The growing season averages 214 days. The average yearly rainfall is $48.3 \mathrm{~cm}$ (19.32 inches), with most occurring during the spring and summer months. Windspeed at Lubbock averages $20.5 \mathrm{kph}(12.8 \mathrm{mph})$, but a maximum windspeed of $142.4 \mathrm{kph}(89 \mathrm{mph})$ has been recorded (Pass 1981:111). The prevailing winds come from the south and southwest. Severe weather conditions, i.e., blizzards, droughts, and thunderstorms, are not uncommon.

The project area is within the Mesquite Plains district of the Kansan biotic province (Blair 1950). Vegetation in the region can be categorized generally into three floral assemblages occupying different topographic settings: (1) the juniper-mesquite/ upland slope assemblage; (2) the mesquite-oldfield/ terrace-floodplain assemblage; and (3) the saltcedar/riparian floral assemblage (Kenmotsu 1981:343-346). Lists of flora found in the region are presented in Etchieson et al. (1979:25-32), Kenmotsu (1981:343-346), Wulfkuhle (1986:4044), and Boyd et al. (1989:19-20). Recent modification to plant and animal communities is apparent throughout the region, but little effort has been made to identify native species, particularly those that are no longer extant. Portions of the project area have undergone severe alterations, but some locations appear to be relatively undisturbed.

\section{ARCHEOLOGICAL BACKGROUND}

The history of archeological investigations in the Justiceburg Reservoir area and the development of the region's cultural sequence are long and complex stories. A comprehensive archeological background is presented in Boyd et al. (1989:23-59), and only a brief synopsis is presented here.

Archeological interest in the Justiceburg area began in the 1950s as members of the South Plains Archeological Society began documenting and investigating sites in Garza County. Professional archeological investigations, however, did not begin until Justiceburg Reservoir was in the early planning stages in the 1970s. The initial archeological work was a survey of the proposed reservoir area funded by the South Plains Association of Governments (SPAG). This work, conducted in 19741975 , produced an inventory of archeological sites and resulted in a series of reports (Campbell 1975, 1977; Campbell and Judd 1977a, 1977b; Judd 1977), but these reports made very minimal recommendations for treatment of the resources. A second archeological investigation (Alexander 1982) documented selected sites in order to evaluate the results of the SPAG survey and their recommendations. Alexander (1982:3-4) concluded that the cultural resources were not adequately recorded and that their true significance had been underestimated. A complete resurvey of the proposed Justiceburg Reservoir area and a reevaluation of its cultural resources was recommended.

The proposed Justiceburg Reservoir area, including the construction zones, the flood pool, and a shoreline easement around the reservoir (ca. 8,600 acres), was intensively resurveyed by Prewitt and Associates, Inc. in 1987. This Phase I investigation included a detailed regional historic overview, subsurface geoarcheological testing, and an intensive pedestrian survey (Boyd et al. 1989). The survey resulted in the documentation of 330 sites (excluding 45 isolated finds), and site significance was reevaluated. Sites were assessed relative to very specific prehistoric and historic research problems identified for the Lower Plains region of Texas. Most of the sites $(n=238)$ were considered to be potentially eligible for listing on the National Register of Historic Places because of their integrity and potential to provide data relevant to addressing regional research problems. It was recommended that a sample of the various site types be tested to determine their National Register significance.

Phase II testing of a sample of the cultural resources conducted by Prewitt and Associates, Inc. in 1988 included various levels of archeological testing and documentation at 67 sites (Boyd et al. 1990). Intensive geoarcheological investigations were undertaken as well as the development of two regional historic contexts and a prehistoric research design to provide the framework for National Register assessments of the historic and prehistoric resources. Based on these contextual models, 17 prehistoric and rock art sites and 7 historic sites were recommended as eligible for listing on the 
National Register of Historic Places.

The next cultural resources investigation at Justiceburg was an archeological survey of ca. 2,440 acres in Garza County immediately north of the dam site. The City of Lubbock was considering the purchase of this land to serve as wildlife habitat to mitigate the destruction of similar habitat in the reservoir. The wildlife mitigation lands survey (Boyd et al. 1991), conducted in August and September of 1990 , documented 1 historic and 32 prehistoric archeological sites where none had been previously recorded. Nine of these sites were evaluated as being significant or potentially significant, and appropriate recommendations were made to protect the sites from impact during development of the wildlife area.

The final step in the Justiceburg Reservoir cultural resources program is the Phase III data recovery effort, which was initiated in the fall of 1990. The Phase III effort will encompass three separate seasons of fieldwork and include archeological investigations of prehistoric, historic, and rock art sites as well as additional geomorphic and paleoenvironmental studies. This report documents the first of the three planned seasons of data recovery at Justiceburg Reservoir.

\section{CULTURAL CHRONOLOGY}

The Lower Plains of Texas were inhabited by man for at least the last ca. 12,000 years, but the archeological studies at Justiceburg suggest that the region's archeological record is extremely biased. Severe erosion of the landscape over thousands of years has removed a considerable amount of the late Pleistocene and early/middle Holocene sediments and landforms. The result is an archeological record dominated by late Holocene (i.e., late Archaic, Late Prehistoric, and Historic) sites. This phenomenon has been noted in the past but only now is beginning to be understood. A growing body of paleoenvironmental, archeological, and geomorphic evidence for the Southern Plains strongly suggests that a long period of severe aridity during the mid Holocene, called the Altithermal period, is responsible for the accelerated erosion and removal of earlier sediments. While the evidence is far from conclusive, this phenomenon is evident in the geomorphic record at Justiceburg Reservoir.

The Paleoindian and early/middle Archaic periods (ca. 11,000-4500 B.P.) are not well repre- sented in the Lower Plains. Diagnostic projectile points dating to these periods are sometimes found, but intact cultural deposits of this age are rare. In the Justiceburg Reservoir area, no intact components firmly dated to these time periods have been found, and only a few possible candidates exist in disturbed contexts. In the canyonland environment in and around the reservoir, it appears that erosion and retreat of the canyon rim and valley walls occurs very rapidly, and it is doubtful if evidence of any early human occupations along the upland margin would be preserved. Likewise, the Double Mountain Fork of the Brazos River and its major tributaries are dynamic fluvial systems that apparently have stripped away all of the early sediments except for a few isolated remnants. Thus, it appears that the potential for Paleoindian and early/ middle Archaic occupations now exists only in the uplands, and such occupations most likely would be found near large playa lakes or on high rises within a few hundred meters of the canyon rim.

The prehistoric archeological record at Justiceburg Reservoir dates almost entirely to the late Archaic (ca. 4500-2000 B.P.) and Late Prehistoric (ca. 2000 B.P. to European contact) periods, and sites from both periods are preserved along the eroding upland margin, on lower bedrock benches, and in the stream valley alluvial terraces. No late Archaic cultural phases or complexes have been adequately defined for the region, but late Archaic sites are very common. The Summers Complex proposed for southwestern Oklahoma (Leonhardy 1966) may be a valid cultural unit in the Texas Lower Plains, but this remains to be demonstrated. Leonhardy (1966:32) noted similarities in the cultural materials between the Summers Complex and late Archaic materials in Central Texas and in the Texas Panhandle.

The region's Late Prehistoric period is only somewhat better understood. Ceramics and arrow points appear early in the first millenium A.D., and the Texas Panhandle-Plains sites show influence from two different areas. The Late Prehistoric I period (ca. 2000-1000 B.P.) in the northern Panhandle-Plains is characterized by occupations with demonstrated Woodland influence (e.g., cordmarked pottery), while contemporaneous occupations in the southern Panhandle-Plains show strong cultural ties with the Southwest. The Palo Duro Complex defined for the southern Lower Plains (Willey and Hughes 1978) is characterized by 
Mogollon-style pithouse architecture and imported Jornada brownware pottery. Several sites in the Justiceburg Reservoir area have been recognized as belonging to the Palo Duro Complex.

The Late Prehistoric II (ca. 1000 B.P. to European contact) and Protohistoric/Historic aboriginal (European contact to ca. A.D. 1875) periods include the Garza Complex and historic Plains Indian occupations. The Garza Complex, defined in the vicinity of Justiceburg (Runkles 1964), dates to ca. 550-250 B.P. (A.D. 1400-1700) and is characterized as a bison-hunting nomadic lifestyle that may be associated with an influx of bison back into the Southem Plains after a period of relative scarcity. Only a few sites associated with the Garza Complex have been archeologically investigated, however, and the complex remains poorly defined and understood. Many sites in the Justiceburg Reservoir area date to the Late Prehistoric II time period, and it is likely that at least some belong to the Garza Complex, even though no Garza or Lott arrow points characteristic of the complex have been found. Campsites containing protohistoric or historic aboriginal materials have not been identified in the Justiceburg Reservoir area, even though use of the area by protohistoric/ historic Plains Indian groups is evidenced in historic records and by the numerous rock art sites that contain historic Plains Biographic Style motifs.

\section{RESEARCH ORIENTATION}

Archeological research in the southern Lower Plains has not been extensive, and the Justiceburg Reservoir studies constitute the region's largest single archeological data base. In conjunction with the Phase II investigations at Justiceburg, detailed prehistoric and historic research designs were developed to provide the necessary foundation for assessing site significance relative to regional research problems.

\section{Prehistoric Investigations}

A model of late Holocene human adaptation was proposed for the prehistoric archeological investigations (Boyd and Tomka 1990). The model, based on work by Binford (1980), Kelly (1980, 1983), and Hayden (1986, 1987), suggests that human subsistence strategies and settlement patterns are controlled in large part by resource distribution and that human social groups exploit resources using some combination of two different resourceacquisition patterns, i.e., as logistically oriented collectors or residentially mobile foragers. In a nutshell, collector strategies move food resources to less-mobile residential camps through the employment of special task groups, while foragers move people to resources through frequent residential camp moves.

More specifically, the model proposes that a single resource, bison, is the main factor conditioning the selection of subsistence strategies and landuse patterns in the Lower Plains. The model suggests that climatic changes caused bison populations to fluctuate through time and that it was the abundance or scarcity of bison that controlled human subsistence strategy selection. Bison are viewed as the only sufficiently stable bulk resource in the Lower Plains that feasibly could be exploited by humans under a logistically oriented collector strategy. During times of bison abundance, such as proposed for the late Archaic and Late Prehistoric II periods, human populations would act as logistical collectors to exploit the bison but would also exploit a wide range of other resources as foragers. In times of bison scarcity, such as proposed for the Late Prehistoric I period, human populations would operate exclusively as foragers and exploit a wide range of less-abundant and less-dependable resources. This is not to say that a single group always practiced either a forager or a collector strategy; in contrast, human groups are dynamic and flexible in their resource procurement, and it is expected that subsistence strategies were shifted to accommodate a fluctuating resource base (e.g., seasonal availability of resources). It is suggested, however, that the subsistence strategy practiced by a single human group at any given point in time does, in fact, fit somewhere in the collector-forager continuum.

The practical utility of this model lies in the fact that different types of sites, both quantitatively and qualitatively, are generated under these different resource-acquisition patterns. For example, only two site types (residential base camps and locations) are generated by a forager system, while several different site types (residential base camps, field camps, locations, stations, and caches) would be generated within a collector-oriented strategy. In addition, the residential base camps and locations generated under different strategies should be 
substantially different. Furthermore, these differences should be archeologically recognizable. Thus, the immediate goal of the Justiceburg archeological research is to determine how individual sites fit within the collector-forager continuum, and the long-range goal is ultimately to identify, through intersite studies, the relationship between resource structure and land-use patterns through time and space.

The model summarized above provides the theoretical framework for evaluating the prehistoric sites recorded during the overall Justiceburg Reservoir project. However, two additional factors that must be considered are site integrity and a site's potential for contributing data useful for addressing the general hypotheses and specific research questions generated by the model. Four major research topics pertinent to assessing the model have been defined: settlement patterns, subsistence, site structure, and material culture. Within each of these topics, a series of general hypotheses and specific research topics were proposed in the research design.

The general hypotheses are directly related to the theoretical model of late Holocene human adaptation and deal with a regional level of interpretation. Within each research topic, two general hypotheses are proposed; the first describes archeological expectations under a collector-oriented resource procurement strategy, and the second describes the expectations under a residentially mobile forager system. All of the general hypotheses proposed in the research design are repeated in their original form below.

\section{Settlement Patterns}

\section{GENERAL HYPOTHESIS 1a}

Residential base camps within collector systems may be either single-season camps oriented toward procurement and processing of bison or multiseasonal base camps that were bison oriented on a seasonal basis but geared toward foraging for supplemental plant and animal resources during other parts of the year. In either case, lengthy site occupations and/or yearly reoccupations are likely, and low residential mobility and relatively high populations should be evident by site size, overall frequency of cultural materials and features, and intensity of site use. The presence of a relatively high percentage of nonlocal lithic materials and other exotic trade items may indicate large territory exploitation and participation in interregional exchange networks.

Logistically oriented collector systems may also include residential base camps that were season specific and oriented toward foraging for specific resources. Within the overall context of a collector-dominated system, some residential base camps may have been solely foraging oriented and hence would appear no different archeologically than those described below.

\section{GENERAL HYPOTHESIS $1 \mathrm{~b}$}

Residential base camps within an exclusively forager system should exhibit archeological evidence of highly mobile, relatively short term, season-specific occupations, although reoccupation on a seasonal basis is also likely. The sites served as base camps for daily foraging activities exploiting specific resource patches. It is possible that a single site may have been oriented toward a single resource, although it is more likely that multiple resources were exploited from a single base camp. Exclusive foragers exploited a relatively small overall territory that should be evident archeologically by low percentages of nonlocal lithic materials and few exotic trade items.

\section{Subsistence}

\section{GENERAL HYPOTHESIS 2a}

Residential base camps that operated within a logistically oriented collector system will exhibit multiple lines of evidence of bulk procurement and processing of bison, a high-yield, large-biomass resource. Exploitation of other plant and animal resources probably will be evident in the flora and fauna recovered. The overall faunal assemblages, however, will be dominated by bison and will be biased toward high-meat-yield body parts (e.g., ribs, scapulas, and femurs) that were selectively transported from kill sites back to the camps. Food storage of bulk resources is characteristic of collector systems but is not likely to include storage pits at bison-oriented sites. Meat drying and/or salting for storage probably were important activities at bison-oriented collector sites but may be difficult to recognize archeologically (e.g., post 
molds indicating drying racks).

\section{GENERAL HYPOTHESIS $2 b$}

Residential base camps generated by a forager system will exhibit evidence of exploitation of a diverse range of relatively low yield (small biomass) resources. Faunal assemblages will be diverse and may include deer, numerous small mammals such as rabbits and rodents, turtle, fish, etc. A low percentage of bison may be represented, but the overall faunal assemblage will not be dominated by any one resource. Macrobotanical and pollen remains will represent a diverse range of plant foods.

\section{Site Structure}

\section{GENERAL HYPOTHESIS 3a}

Bison-oriented collector base camps will have well-defined site structure with spatially discrete activity areas and special-function features related to bison processing. Specific activity areas might include hide processing stations with evidence of unifacial scraping tool rejuvenation, tool manufacturing areas where the final stages of lithic reduction occurred, secondary butchering areas where selected cuts were further processed, bone grease manufacturing areas, and cooking areas where bison and/or other resources were prepared. Activity areas will be identifiable as high-frequency clusters of artifacts and/or faunal and floral remains. Horizontal patterning of activity areas may even provide evidence of community-level organization (i.e., habitation areas or structures). Due to the increased length of occupation, more-frequent site maintenance activities may have generated welldefined midden areas at these sites.

\section{GENERAL HYPOTHESIS 3b}

Residential base camps generated within an exclusively forager system will be characterized by multifunctional and overlapping features and activity areas representing exploitation of a single resource or contemporaneous exploitation of multiple resources. Site reoccupation for exploiting different resources at different times is also likely. Although individual base camps may exhibit various degrees of specialization, overall these sites will appear unspecialized due to the similarities in the procurement and processing strategies and material culture for exploiting various low-yield plant and animal resources.

\section{Material Culture}

\section{GENERAL HYPOTHESIS 4a}

Material culture assemblages at bison-oriented collector residential base camps will include specialized tools reflecting the importance of bison hunting (projectile points), meat processing (cutting tools such as beveled knives), and hide processing (scraping tools such as end scrapers). Manufacture and rejuvenation of these tools will be important activities represented in the lithic debitage and in staged preforms. It is expected that hide processing may be particularly well represented in campsites, and resharpening of unifacial hide-scraping tools should be evident. Lithic debitage should reflect a strategy of nonlocal material procurement and transportation of early-stage tools to base camps for the final stages of tool manufacture. Specifically, the debitage should exhibit a high percentage of nonlocal materials and a disproportionately high frequency of decorticate flakes.

\section{GENERAL HYPOTHESIS $4 \mathrm{~b}$}

Forager residential base camps will be characterized by a generalized stone tool assemblage and dominance of local material use. Chipped stone tools will be dominated by multifunctional and expedient tools, i.e., various types of bifacial and unifacial cutting and/or scraping tools exhibiting considerable morphological variability. Lithic debitage will be dominated by local materials, and all stages of lithic manufacture will be evident by the presence of cores and complementary percentages of corticate and decorticate flakes.

\section{Historic Investigations}

For the historic resources, two comprehensive regional historic contexts were developed as part of the Phase II investigations at Justiceburg Reservoir. One of the historic contexts, "Buffalo Hunting on the Rolling Plains, 1874-1879" (Freeman 1990a), falls within a general theme suggested by the Texas Historical Commission entitled "Natural Resources 
Exploitation and Development." This context, however, is not applicable to the Phase III historic sites and is not considered further here. The second context, "Ranching on the Western Rolling Plains, 1877-1945" (Freeman 1990b), falls within another Commission-generated thematic context, "Agriculture in Texas," and does relate to the Phase III historic sites.

Ranching in the western Rolling Plains area began in the late 1870 s at a time when hostile Indians and large buffalo herds were disappearing. Utilization of the area accelerated during the early 1880 s as numerous ranchers from the Cross Timbers region moved their cattle herds westward to take advantage of the abundant grasses and springs and of the canyons that afforded shelter to their animals. While cattle were the most frequently raised animals, a few ranchers brought sheep with them; however, the occurrence and distribution of sheep ranching in the region is poorly documented.

Favorable markets and weather resulted in a florescence of ranching on the western Rolling Plains between 1879 and 1885 . For the most part, ranching was carried on by a combination of individually and company-owned outfits that grazed animals on sections leased from railroad companies and the State of Texas. In a few cases, ranchers filed claims to sections along major water courses such as Grape Creek, but leases sufficed for the most part. Some ranchers brought their families with them; more commonly, headquarters were occupied by single males who hired other young men to work as hands on the range where they lived in shelters such as dugouts.

Goods and materials were acquired during the early years from Fort Griffin, Weatherford, and Fort Worth, and the few small stores in the region that were a legacy of the 1870 s buffalo hunting trade. By 1881, however, most supplies came from Colorado City, a community that was established in anticipation of the construction of the Texas and Pacific Railroad from Fort Worth and eventually had the greatest impact on Rolling Plains ranching. Between 1881 when the first train arrived at the townsite and the mid 1880s when unfavorable weather and competition from other towns triggered an economic collapse, Colorado City was the shipping and supply headquarters for West Texas, serving ranches in a 27-county region. The nearest trade competitors were Dodge City, Kansas; Springer, New Mexico; and Trinidad, Colorado, which supplied the northern Texas Panhandle (Jones and Cline 1940:33, 36, 38, 40, 43, 47, 49, 51, 59; Hendrix 1941:35, 36; Jones and Richardson 1943: 39).

The connection between Colorado City and the western Rolling Plains was strong, with individuals such as "Uncle Pete" Snyder, who had built a store on Deep Creek in Scurry County to supply buffalo hunters, later moving to Colorado City; and other Rolling Plains ranchers either making their permanent homes in the town or visiting there frequently. However, boom tumed to bust by the late 1880s following a period of blizzard and drought, and the economic situation worsened after the national panic of 1893 . Colorado City never regained its prominence.

Just as weather and economic issues affected the Rolling Plains, so also legal issues affected the ranching industry there. In 1895, the State Legislature passed the Four-Section Act. Designed to encourage permanent settlement and the acquisition of homestead tracts from the State, the Act forced open-range ranchers who had leased land for grazing to develop innovative methods of controlling sections that were sure to be purchased by new homesteaders from outside the immediate area. Many ranchers and ranching companies managed to retain their ranges for several years by encouraging employees to file on four sections. Assistance was provided to the employee when the ranch owner made the yearly payments required by the State and paid county taxes on the parcel as well. For their part, the employees agreed to allow the ranch owner to run his cattle on the sections. In addition, some hands agreed to allow the rancher or ranch company the privilege of first refusal should the hand decide to sell the sections. Hands who filed homesteads under such agreements usually remained employees of the larger ranch but were obligated to fulfill the terms of their agreement with the State by building improvements on the homestead section and occupying that section for three years.

A variety of property types were associated with ranching on the Western Rolling Plains from 1877 to 1945 . During the open-range period, ranch headquarters and line camps were the most prominent property types. During the closed-range ranching period, the homestead/ranch headquarters was the common property type, and quite frequently a single property may have been occupied and in 
use during both periods.

Specific kinds of structures and features characterize the ranching period sites in the Rolling Plains. The dugout was by far the most common structure associated with the ranching period, followed by above-ground homes. During the openrange period, dugouts frequently functioned as line camps and often served as temporary ranch headquarters until a more permanent structure, usually a wood frame or rock house, could be constructed. The dugout also was a common structure associated with closed-range ranching since almost all new homesteaders constructed at least temporary dugouts before building permanent homes. Other features associated with ranching properties in the region included fences and corrals for horses and cattle; wells, windmills, water tanks, and stock ponds to provide water for home or livestock use; and outbuildings such as tack rooms for equipment storage and covered sheds for protecting livestock from severe weather.

This historic context is intended to place the ranching sites in the Justiceburg Reservoir area within the context of the broader historic patterns that created them and to establish the identity and extent of other comparable cultural properties. The context is also essential for outlining the property types included within the region in general and the project area specifically. For the Phase III investigations, a general hypothesis was prepared for each historic site to be investigated, and a series of specific research questions relative to the ranching context were formulated.

\section{General Hypothesis}

The general hypothesis proposed for $41 \mathrm{KT} 42$ is that the site is a unique example of a pre-1900, open-range line camp since it was apparently a well-constructed wood frame structure at a time when virtually all line camps were simple, functional dugouts. The structure may have been built and used by former buffalo hunters H. T. Cornelius and J. Wright Mooar and probably was occupied later by OS Ranch cowboys. The history of the construction, use, and abandonment of this site is not clear from archival records, thus strengthening the importance of the archeological remains. The house was built on a substantial rock foundation with a large rock fireplace and chimney and represents a considerable investment of labor for a simple line camp. It is possible that the structure was built as a ranching headquarters prior to its use as a line camp in the 1880 s, thereby adding to its unusual nature. The site apparently was in use from the 1880 s to the early 1900 s, and the surviving architectural remains and associated artifacts are representative of this critical time period in ranching history.

\section{Addressing the $\mathbb{R e s e a r c h}$ Desigm}

This report is the first in a series of Justiceburg reports, the primary function of which is to present excavation results from the final phase of investigations. No attempt is made to address the research design hypotheses in these reports. Rather, research design assessment is saved until all site excavations, artifact analyses, and special studies are complete because proper assessment of the research design involves the comparison of archeological data from multiple sites. In fact, the final report in the Justiceburg series will be dedicated solely to assessing the research design and testing its hypotheses and research questions. It would be premature and grossly inefficient to begin this process in incremental steps at this time. Thus, while this and subsequent descriptive reports may appear to lack analytical and interpretative depth, substantive attention to the issues presented in the research design will be the focus of the final synthetic report. The research design is presented in part to provide the guiding research questions as background information and in part to provide information necessary for justifying the specific methods and approaches used in the excavations and analyses. 


\section{OBJECTIVES AND METHODS}

Douglas K. Boyd, Steve A. Tomka, and C. Britt Bousman

The preceding chapter describes the theoretical research orientation of the cultural resources investigations at Justiceburg Reservoir. This chapter bridges the gap between theoretical orientation and practical application by describing the objectives and methods for the Season 1 data recovery. The objectives and methods are directly related to the data needs of the research design and were formulated with the ultimate goal of addressing the regional problems outlined by the applicable historic context and the prehistoric model.

Four archeological sites (one historic and three prehistoric) were investigated during the Season 1 data recovery efforts. The historic site investigation has, of necessity, a different set of objectives and methods than do the prehistoric site investigations.

\section{HISTORIC SITE INVESTIGATIONS}

The significance of site $41 \mathrm{KT} 42$ is related to the historic context "Ranching on the Western Rolling Plains, 1877-1945" (Freeman 1990b). It was generally hypothesized that $41 \mathrm{KT} 42$ is a unique example of a pre-1900, open-range line camp that continued to be used into the closedrange period. It's uniqueness is derived from the fact that the well-constructed wood frame structure at the site was unusual for its time, location, and function. Archival and informant research provided substantial information but failed to answer many crucial questions concerning the history of its construction, use, and abandonment. Thus, the archeological remains at this site are of considerable importance for their potential to address unanswered research questions.

The primary objective of the data recovery investigation at $41 \mathrm{KT} 42$ was to obtain data that could address questions proposed in the research design. Cultural evidence of the historic occupation is limited to surface artifacts and features. The main structure and other related features had been virtually destroyed since site abandonment, and only the rock foundation and part of the chimney firebox remained intact. These features were already adequately recorded and possessed no further research potential. Hence, only the associated scattered artifacts were considered to hold additional research value. The specific objective at $41 \mathrm{KT} 42$ was to obtain a sample of material culture that would be adequate to support interpretations of the age and duration of occupation, site function, intrasite activity patterning, sociocultural status of the occupants, and regional patterns of acquisition. It was decided that the appropriate investigative methodology was a controlled, intensive surface collection of artifacts and additional site mapping. The specific details of these field methods and explanation of the collection strategy are presented in the site chapter (Chapter 4). Laboratory procedures for the historic artifacts were the same as for the prehistoric materials (see discussion below). Historic artifacts were then sorted into material categories (e.g., metal, glass, ceramics) and analyzed by functional classification as described in Chapter 4. 


\section{PREHISTORIC SITES INVESTIGATIONS}

The significance of the three prehistoric sites is related to the Model of Late Holocene Human Adaptation (Boyd and Tomka 1990). The ultimate goal of the prehistoric research is to understand the broad patterns of human cultural systems; in order to accomplish this, a wide range of site types (i.e., location and function), temporal periods, and cultural affiliations must be sampled. Hence, all sites slated for data recovery fill a particular niche in the spatial/temporal/cultural continuum. Each of the three sites investigated offered the potential to provide data relative to the general research topics of settlement pattern, subsistence, site structure, and material culture; but more importantly, each site was considered unique in its potential to fill a particular spatial/temporal/cultural niche within the overall model of human adaptation.

It was originally proposed that all three prehistoric sites functioned as residential base camps generated by a logistically oriented collector system of resource procurement (i.e., bison) but that different time periods were represented. Although no cultural affiliations could be assigned, sites 41GR383 and 41KT33 were thought to be late Archaic occupations located in different topographic settings, while 41 GR 484 was considered to date to the Late Prehistoric II period. It was subsequently discovered that the investigated portion of $41 \mathrm{KT} 33$ had a single component that dates to the Late Prehistoric I (or transitional Late Prehistoric I/II) period. This change necessitated a reevaluation of the site while fieldwork was in progress, but it was demonstrated that $41 \mathrm{KT} 33$ filled a unique tempo$\mathrm{ral} / \mathrm{spatial}$ niche in the research design and might possibly represent a unique cultural niche as well.

The prehistoric site investigations are related to the research design in that the primary objective is to obtain data necessary for addressing its specific research questions. For each of the three prehistoric sites investigated during Season 1 data recovery, additional, more-specific objectives were to obtain (1) artifactual evidence to support interpretations of cultural affiliation and intercultural relationships in the Southern Plains; (2) an adequate sample (i.e., large enough to be statistically valid) of artifacts and features to support interpretations on subsistence strategies, occupation intensity, site function, and local land-use patterns; (3) temporally diagnostic artifacts and datable samples (e.g., organic materials) to support interpretations of site age and duration of occupation; and (4) paleoenvironmental data to support climatic reconstructions and relate human subsistence pattems to the changing resource base. All of these objectives require archeological or paleoenvironmental samples from good geological contexts and high stratigraphic integrity.

The field methods employed in investigating the prehistoric sites varied only slightly from site to site. Such minor variations in methodology are discussed in the respective chapters on site investigations, but the overall methodology is described here.

\section{Excavation and Collection Procedures}

At many sites, the approach considered most appropriate for obtaining an interpretable sample of artifacts and activities is a single block excavation of contiguous units, i.e., sampling one large area with a block excavation as opposed to sampling several areas with smaller block excavations. For open campsites, contiguous excavation blocks allow more-reliable correlations of archeological assemblages and thus lead to more-reliable assessments of artifact and feature relationships and spatial patterns. The size of the excavation blocks at each site was determined by the predicted artifact density (estimate based on the 1988 testing results) and the need to obtain a sufficiently large lithic tool sample to permit interpretation. Thus, a minimumsize block excavation was established for each site, with a $10 \%$ flexibility allowance for the overall field effort. The minimum excavation block sizes established for the three prehistoric sites were $30 \mathrm{~m}^{2}$ at $41 \mathrm{GR} 383,64 \mathrm{~m}^{2}$ at $41 \mathrm{GR} 484$, and $55 \mathrm{~m}^{2}$ at $41 \mathrm{KT} 33$. When it became necessary to adjust the total field effort by more than the $10 \%$ flexibility factor (i.e., the total number of excavation units increased or decreased by more than $10 \%$ ), these changes were coordinated through the City of Lubbock's Technical Representative and approved by the Corps of Engineers.

The archeological excavations were conducted entirely by hand. Horizontal and vertical control was maintained using $1 \times 1-\mathrm{m}$ units and $10-\mathrm{cm}$ levels. Most units, dispersed or in blocks, were designated as Excavation Units; however, at 41KT33 isolated units for specific sampling purposes were designated as Sample Units. Site maps 
were prepared with the aid of a transit and stadia, and excavation units were laid out in a grid from one of the site datum points established during the 1988 testing. Each site had a primary datum point that had been assigned an arbitrary elevation of $100.00 \mathrm{~m}$. Elevations of secondary datum points, all other grid points, and excavation levels are relative to the primary datum point. Arbitrary levels were set at even $10-\mathrm{cm}$ increments. For example, an excavation unit might start at $97.58 \mathrm{~m}$ (elevation of the surface at the highest corner of the unit), and Level 1 would be from 97.58 to $97.50 \mathrm{~m}$. All additional levels were in even $10-\mathrm{cm}$ increments: Level 2 from 97.50 to $97.40 \mathrm{~m}$, Level 3 from $97.40-97.30 \mathrm{~m}$, and so on. Within a unit, excavation levels were measured using a transit and stadia or by depth below a level string line set at a known elevation.

All excavated fill was dry screened through 1/4-inch-mesh hardware cloth, and all artifacts were bagged by unit and level provenience. Excavation Record Forms were completed for each level, and when a feature was encountered, it was recorded on a separate Feature Record Form. Additional feature documentation consisted of drawing plan and profile views, taking black-andwhite and color-slide photographs, and collecting special samples. In situ artifacts and features were mapped on grid paper, and elevations were shot by transit or taken from a line level. For small artifacts, only one elevation was recorded, but for larger artifacts or features, top and bottom elevations were recorded.

Special samples include bulk sediment for flotation/macrobotanical analysis or radiocarbon dating, smaller sediment samples for pollen/phytolith analysis, and charcoal or other organic materials for radiocarbon dating. Special procedures, such as cleaning trowels with distilled water and immediate sealing of samples in zip-lock plastic bags, were used for taking the pollen/phytolith samples to prevent contamination. In addition, all bones, shells, and charcoal fragments as well as fragile or unique artifacts were carefully collected in aluminum foil to prevent contamination or damage to the specimen.

\section{Laboratory and Analytical Procedures}

The materials and data recovered during the Season 1 investigations were processed in three stages: (1) laboratory preparation; (2) analysis of artifacts and samples; and (3) report preparation. Laboratory preparation consisted of cleaning and cataloguing all cultural materials according to provenience. Each specimen was labeled (or bagged with a label if it could not be labeled) with the site number and a lot number assigned to its particular provenience. Lot numbers were assigned to every excavation level from which materials were recovered, to special proveniences associated with features, and to individually mapped specimens. A running specimen inventory by lot number was maintained as the numbers were assigned. All nonartifact samples (e.g., sediment and charcoal) were assigned a sequential sample number in the field and indexed by provenience.

After being catalogued, the cultural materials were classified for analysis. Artifacts were sorted according to material types: chipped, ground, battered, and other modified stones; unmodified manuports; ceramics; burned rocks; modified shells; and unmodified faunal remains. The analysis of each material class varied according to the nature of the material and the kinds of data necessary for addressing different research problems.

The stone tools were analyzed and described by Tomka; burned rocks, ceramics, and modified shells were analyzed and described by Boyd. The objectives and methods for these analyses are described below, and the results are presented in the chapters on prehistoric site investigations (Chapters 5-7). All unmodified faunal materials are described separately in Appendix C.

Various special studies were conducted on samples and artifacts, and some specialized technical analyses (e.g., macrobotanical and pollen analyses, petrographic analysis of ceramics, and radiocarbon assays) were performed by independent consultants. The methods and results of the special studies are reported in separate appendixes.

\section{Chipped, Battered, and Ground Stones}

The objectives of the chipped, battered, and ground stone artifact analysis were to (1) characterize the collection in technological and morphological terms, (2) define site use and function, if possible, and (3) relate patterns noted in the organization of technology to patterns of hunter-gatherer mobility defined in the research design. To achieve the first objective, a number of attributes were 
recorded for the various artifact categories. These attributes were chosen to describe the artifacts in morphological terms and help define the stage of reduction of the particular artifact.

It was hoped that the analysis of the lithic tools and debitage from each site could provide clues to aid in understanding the use of the sites and their functions within the regional settlement pattern. However, due to differential preservation of material remains and curation of tools, not all activities carried out at particular sites will be represented in the archeologically recovered assemblages. Site function, the role of a particular site in the overall land-use system, cannot be directly derived from artifacts recovered at a single site. Rather, a knowledge of the entire settlement/subsistence pattem can provide information pertinent to the role (function) of specific sites within the overall system. As a result, a comprehensive reconstruction or exploration of site function(s) for particular sites is deferred until a more complete picture of regional and site variability can be obtained. These questions will be addressed in the final synthetic report.

The chipped stone artifacts were classified into 10 categories: (1) arrow point; (2) dart point; (3) perforator; (4) gouge; (5) biface; (6) cobble tool; (7) uniface; (8) core; (9) edge-modified flake; and (10) unmodified debitage. Battered and ground stones were classified into four categories: (1) mano; (2) metate; (3) anvil; and (4) hammerstone.

The attributes recorded for the chipped, battered, and ground stone artifacts can be grouped under 14 headings: (1) raw material; (2) core characteristics; (3) nature of the core; (4) tool morphology; (5) cause of fracture; (6) size; (7) cortex characteristics; (8) working-edge characteristics; (9) base, stem, and blade treatment; (10) reworking category; (11) platform characteristics; (12) flake type; (13) wear type; and (14) weight. Each of these groups consists of individual attributes. Brief descriptions of attribute definitions, the states that each attribute can assume, and the class of artifacts on which the attribute was recorded are given below. To retain consistency, the majority of the attributes used in this analysis are the same as those employed during the Phase II analysis of lithic materials from Justiceburg Reservoir (Boyd et al. 1990); however, not all of the Phase II investigation attributes were used in the present study because the interpretive potential of some proved to be rather limited and others could not be recorded with sufficient consistency.

\section{RAW MATERIAL}

Fifteen raw material types were defined following a preliminary inspection of the lithic artifacts from the project area. These are (1) finegrained chert; (2) coarse-grained chert; (3) finegrained Potter chert; (4) coarse-grained Potter chert; (5) fine-grained quartzite; (6) coarse-grained quartzite; (7) chalcedony; (8) silicified wood; (9) Tecovas jasper; (10) Alibates agate; (11) opalized caliche; (12) silicified caliche; (13) obsidian; (14) sandstone; and (15) other.

\section{Fine-Grained Cherts}

To characterize the fine-grained cherts from the project area proper and contrast them with finegrained cherts found in the immediate region as well as those from more-distant areas, a systematic collection of materials at natural occurrences and characterization of raw materials was undertaken. Fine-grained cherts were collected from the project area proper, from the upstream drainage of the Double Mountain Fork of the Brazos River, and from the Cretaceous limestones of the Edwards Plateau and the Callahan Divide, a northern outlier of the Edwards Plateau, located between 97 to $161 \mathrm{~km}$ (60 to 100 miles) south-southeast of the project area in a long linear outcrop (Fig. 5). Consistent differences were noted in colors and textures among the specimens from the project area and the Double Mountain Fork drainage versus the cherts from the Edwards Plateau and Callahan Divide. These color and texture differences can aid in the definition of lithic raw material procurement practices, especially when contrasting the procurement of local versus distant nonlocal raw materials (Tomka and Fields 1990).

Twenty-two chert and Ogallala quartzite gravel samples were collected (Table 1). Eight of these are from within the Justiceburg Reservoir project area proper, seven are from upstream of the project area in the Double Mountain Fork drainage, and one is from southwest of the project area in the Colorado drainage. Six samples of Cretaceous cherts were collected from the Callahan Divide and adjacent portions of the Edwards Plateau. Two of these are from the northwestern corner of the 


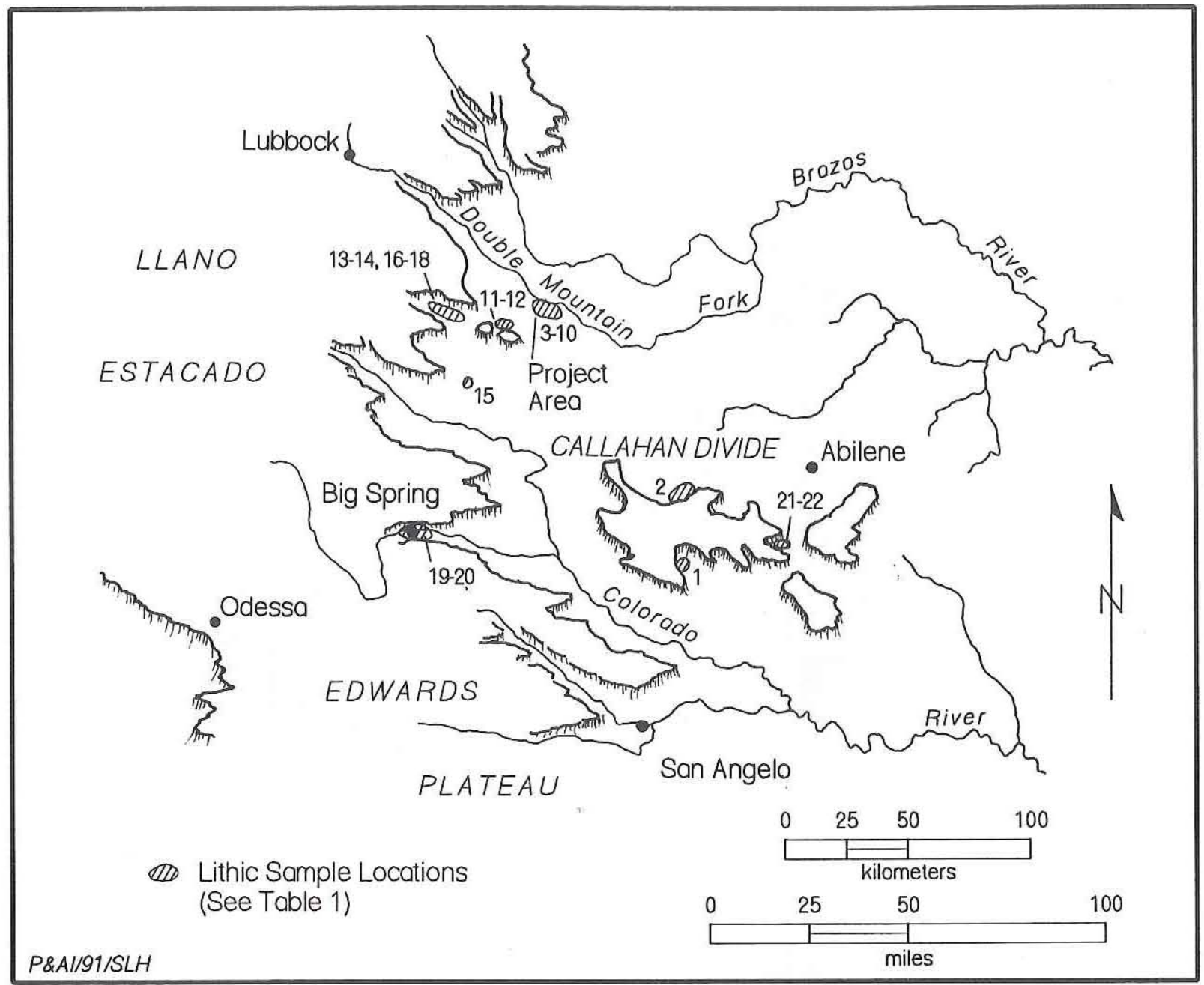

Figure 5. Map showing project area and locations of collection of regional lithic material comparative samples (adapted from Raisz 1957).

Edwards Plateau at Big Spring in Howard County, two others are from the western portion of the Callahan Divide just south of Sweetwater in Nolan County, and the last two are from the eastern edge of the divide near Buffalo Gap in Taylor County.

To investigate lithic procurement patterns, flakes were removed from each collected chert nodule, labeled by locality and nodule, and then sorted into distinct color categories (Table 2). Fifty color categories were defined. Thirty-seven of these are local chert specimens, and 13 are from nonlocal sources. Three additional color categories were employed: local indeterminate, nonlocal indeterminate, and indeterminate.

All archeological fine-grained chert specimens were compared to these samples, and arche- ological specimens that visually appear to be exact matches to the modern collected specimens are assumed to have originated from the documented local or nonlocal source; however, the main purpose of this exercise was to distinguish between local and nonlocal fine-grained cherts rather than to identify specific individual sources. Those artifacts with colors that are similar in range and character to the local samples but do not have an exact match in the raw materials collected from the project area were classified as local indeterminate. Those archeological cherts that are similar to nonlocal specimens in terms of color and texture but have no exact match in the comparative color chart were classified as nonlocal indeterminate.

Finally, specimens that are so small or so 


\begin{tabular}{|c|c|c|c|}
\hline \multicolumn{4}{|c|}{ TABLE 1} \\
\hline $\begin{array}{l}\text { Sample } \\
\text { Locality } \\
\text { No. }\end{array}$ & Sample Description & Color(s) (see Table 2) & Sample Location (see Fig. 5) \\
\hline 1 & Primary(?) Cretaceous & $40,41,42,47,50$ & $\begin{array}{l}\text { Nolan County; north of Oak Creek } \\
\text { Reservoir }\end{array}$ \\
\hline 2 & $\begin{array}{l}\text { Secondary Cretaceous; } \\
\text { Quatemary alluvium }\end{array}$ & 45,51 & Nolan County; south of Sweetwater \\
\hline 3 & Secondary Lingos gravels & $16,18,19,25,30,34$ & Garza County; Justiceburg project area \\
\hline 4 & Secondary Lingos gravels & 12,22 & Garza County; Justiceburg project area \\
\hline 5 & $\begin{array}{l}\text { Primary Lingos gravels; } \\
\text { gravel pit }\end{array}$ & $5,7,12,14,15,21,28,31,36,37$ & Garza County; Justiceburg project area \\
\hline 6 & Secondary Lingos gravels & $2,9,28,31,37$ & Garza County; Justiceburg project area \\
\hline 7 & Secondary Lingos gravels & $13,17,25,27,29$ & Garza County; Justiceburg project area \\
\hline 8 & Secondary Lingos gravels & $2,3,4,6,7,26,28,35,37$ & Garza County; Justiceburg project area \\
\hline 9 & Secondary Lingos gravels & $4,6,11,20,27,28,30,35,37$ & Kent County; Justiceburg project area \\
\hline 10 & Secondary Lingos gravels & $5,6,7,12,26,33,35$ & Kent County; Justiceburg project area \\
\hline 11 & Stream gravels; mixed & no fine-grained cherts in sample & $\begin{array}{l}\text { Garza County; Double Mountain Fork } \\
\text { at Highway } 84\end{array}$ \\
\hline 12 & Stream gravels; mixed & $1,3,18$ & $\begin{array}{l}\text { Garza County; Sand Creek at Highway } \\
84\end{array}$ \\
\hline 13 & Stream gravels; mixed & $3,10,11,24,27,29,32$ & $\begin{array}{l}\text { Garza County; Double Mountain Fork } \\
\text { at FM } 669\end{array}$ \\
\hline 14 & Stream gravels; mixed & $4,5,6,8,10,12,22,29,31,36$ & Garza County; creek at FM 669 \\
\hline 15 & Stream gravels; Cretaceous & $6,14,27,28$ & Borden County; creek north of Gail \\
\hline 16 & Stream gravels; mixed & $5,8,9,10,12,15,24,29$ & Garza County; creek on Macy Ranch \\
\hline 17 & Stream gravels; mixed & $6,12,22,23,30,31$ & $\begin{array}{l}\text { Garza County; Double Mountain Fork } \\
\text { on Macy Ranch }\end{array}$ \\
\hline 18 & Stream gravels; mixed & $4,8,11,24,28,35,36$ & $\begin{array}{l}\text { Garza County; Double Mountain Fork } \\
\text { on Macy Ranch }\end{array}$ \\
\hline 19 & $\begin{array}{l}\text { Secondary Cretaceous; } \\
\text { colluvial slope }\end{array}$ & 43,44 & Howard County; south of Big Spring \\
\hline 20 & $\begin{array}{l}\text { Primary Cretaceous gravels; } \\
\text { gravel pit }\end{array}$ & 43,44 & Howard County; south of Big Spring \\
\hline 21 & Stream gravels; Cretaceous & $40,41,42,46,48,49,52$ & $\begin{array}{l}\text { Taylor County; Buffalo Gap/Lake } \\
\text { Abilene }\end{array}$ \\
\hline 22 & $\begin{array}{l}\text { Primary Cretaceous gravels; } \\
\text { gravel pit }\end{array}$ & $40,42,46,52$ & $\begin{array}{l}\text { Taylor County; Buffalo Gap/Lake } \\
\text { Abilene }\end{array}$ \\
\hline
\end{tabular}


heavily burned that the true color could not be discerned with certainty were classified as indeterminate. In classifying individual chert flakes into the available color categories, it was assumed that heat treatment (not burning) would not have changed the original color of the raw material from one color category to another and that the before-heattreatment color can be identified with certainty. In support of this assertion, limited heat treatment experiments conducted on some chert specimens showed no substantial color changes in the cherts.

Although none of the comparative specimens of chert collected from the project area developed patina from exposure to air, a number of the nonlocal cherts collected from the Callahan Divide began patinating almost immediately after removal from the core. This process, which is most likely dehydration, resulted in a light blue to bluish gray tint acquired by at least two of the nonlocal color categories (Colors 43 and 44) that were originally dark to light brown. The rapid rate of alteration suggests that most archeological specimens from these cherts would be light blue to bluish gray. Because none of the local specimens are of this color or patinated to this color, it is assumed that most archeological light blue to bluish gray flakes are of a nonlocal origin matching Color 43 in character.

The local cherts range in color from light gray to yellowish brown and darker gray, with all specimens encountered containing a variety of bands of lighter and darker colors. These fine-grained specimens occur in the form of angular fragments and small to medium-sized rounded or lenticular pebbles. One specimen collected from the project area in Garza County is $14 \mathrm{~cm}$ long, although most specimens tend not to exceed $6 \mathrm{~cm}$ in maximum size. The large amount of swirling and banding, together with the smaller size and the lack of extremely fine grained, highly silicified, and translucent materials, sets these specimens apart from the nonlocal Cretaceous cherts collected from the Edwards Plateau and Callahan Divide. The latter are more highly silicified, are generally larger, and lack the swirling and narrow banding noted in the specimens collected from the project area. Also, the nonlocal Cretaceous cherts contain dark brown, dark gray, and bluish gray colors that are not represented in specimens collected from within the project area.

Other nonlocal fine-grained materials are documented archeologically, and these include Alibates agate and Tecovas jasper. Alibates agate is mottled, multicolored, silicified dolomite originating in the Alibates Dolomite Lentil of the Quartermaster Formation of Permian age. It occurs northeast of Amarillo and has a relatively limited, localized distribution. Tecovas jasper is somewhat similar to Alibates agate in broad visual characteristics. It originates from the Tecovas Formation of Triassic age. It is encountered in outcrops along the eastern escarpment from Quitaque to Palo Duro Canyon and northwest of Amarillo (Peterson 1988: 90). A single outcrop of moderate-quality Tecovas jasper may be present in the project area (Emmett Shedd, personal communication 1991), and future investigations will target this source for complete documentation and material collection. Small tabular chunks of Tecovas jasper were also recovered from the main channel of the Devil's Mountain Fork of the Brazos as well as a number of its tributaries; however, the majority of these specimens as well as those from the primary outcrop do not appear to be of workable quality.

\section{Other Lithic Materials}

A number of other lithic resources of varying quality are abundant in Quaternary gravel deposits found on the uplands, canyon rims, and erosional remnants of the project area (Boyd 1989:Figure 23). The most abundant include quartzites and Potter chert. A large portion of these gravels are composed of pink, purple, and red quartzites derived from the Ogallala Formation. These materials range from small spherical pebbles to large elongated, and even flat biconvex, nodules. The small to medium-sized pebbles are ideal for hammerstones and occur in the immediate vicinity of most sites. The larger specimens which could serve as blanks for ground stone manos are not common, however, and their procurement would involve greater search times. An additional type of quartzite, a conglomerate, was identified in the archeological lithic collections from Phase II. It appears to have formed from the metamorphosis of large quartzite crystals and has a highly lustrous appearance.

Also contained in the Quaternary gravels are Potter chert nodules varying in diameter from ca. 8 to $20 \mathrm{~cm}$ or more. This material ranges in quality from extremely coarse nodules that can be split 


\begin{tabular}{|c|c|c|}
\hline & & $\begin{array}{c}\text { TABLE } 2 \\
\text { CHERT COLOR CATEGORIES }\end{array}$ \\
\hline Color No. & Sample Locality Nos. & Description \\
\hline 1 & 12 & flat white with gray-brown translucent mottles \\
\hline 2 & 6,8 & light yellowish gray with gray specks \\
\hline 3 & $8,12,13$ & light gray with brown mottles, fossiliferous \\
\hline 4 & $8,9,14,18$ & light yellow-brown with light gray mottles, fossiliferous \\
\hline 5 & $5,10,14,16,23$ & yellow-brown with white and brown mottles \\
\hline 6 & $8,9,10,14,15,17$ & light brownish gray with white mottles or specks \\
\hline 7 & $5,8,10$ & light gray to white translucent \\
\hline 8 & $14,16,18$ & $\begin{array}{l}\text { blue-gray with black, brown, blue specks, mottles and veins, fossiliferous, } \\
\text { translucent }\end{array}$ \\
\hline 9 & 6,16 & blue-gray with gray and white mottling \\
\hline 10 & $13,14,16$ & gray with white mottling or banding \\
\hline 11 & $9,13,18$ & light gray \\
\hline 12 & $4,5,10,14,16,17$ & gray \\
\hline 13 & 7 & brownish gray, coarse \\
\hline 14 & 5,15 & brownish gray with brown or white specks \\
\hline 15 & 5,16 & brownish gray with large light gray mottles \\
\hline 16 & 3 & light yellow-red \\
\hline 17 & 7 & light to dark greenish brown with dark blue specks \\
\hline 18 & 3,12 & black with milky quartz veins \\
\hline 19 & 3 & dark gray, coarse \\
\hline 20 & 9 & black \\
\hline 21 & 5 & light olive-brown with dark blue and red specks \\
\hline 22 & $4,14,17$ & $\begin{array}{l}\text { dark gray mottled with light gray and black; central core is reddish yellow to } \\
\text { light red }\end{array}$ \\
\hline 23 & 17 & dark gray mottled with red, yellowish red, light gray, fossiliferous \\
\hline 24 & $13,16,18$ & light to dark olive-brown mottled with red \\
\hline 25 & 3,7 & red, can have black, yellow, light gray mottles, coarse \\
\hline 26 & 8,10 & milky white with reddish yellow tint, translucent \\
\hline 27 & $7,9,13,15$ & brown-gray with red specks \\
\hline 28 & $5,6,8,9,15,18$ & brownish yellow with light gray mottles, can be translucent \\
\hline
\end{tabular}




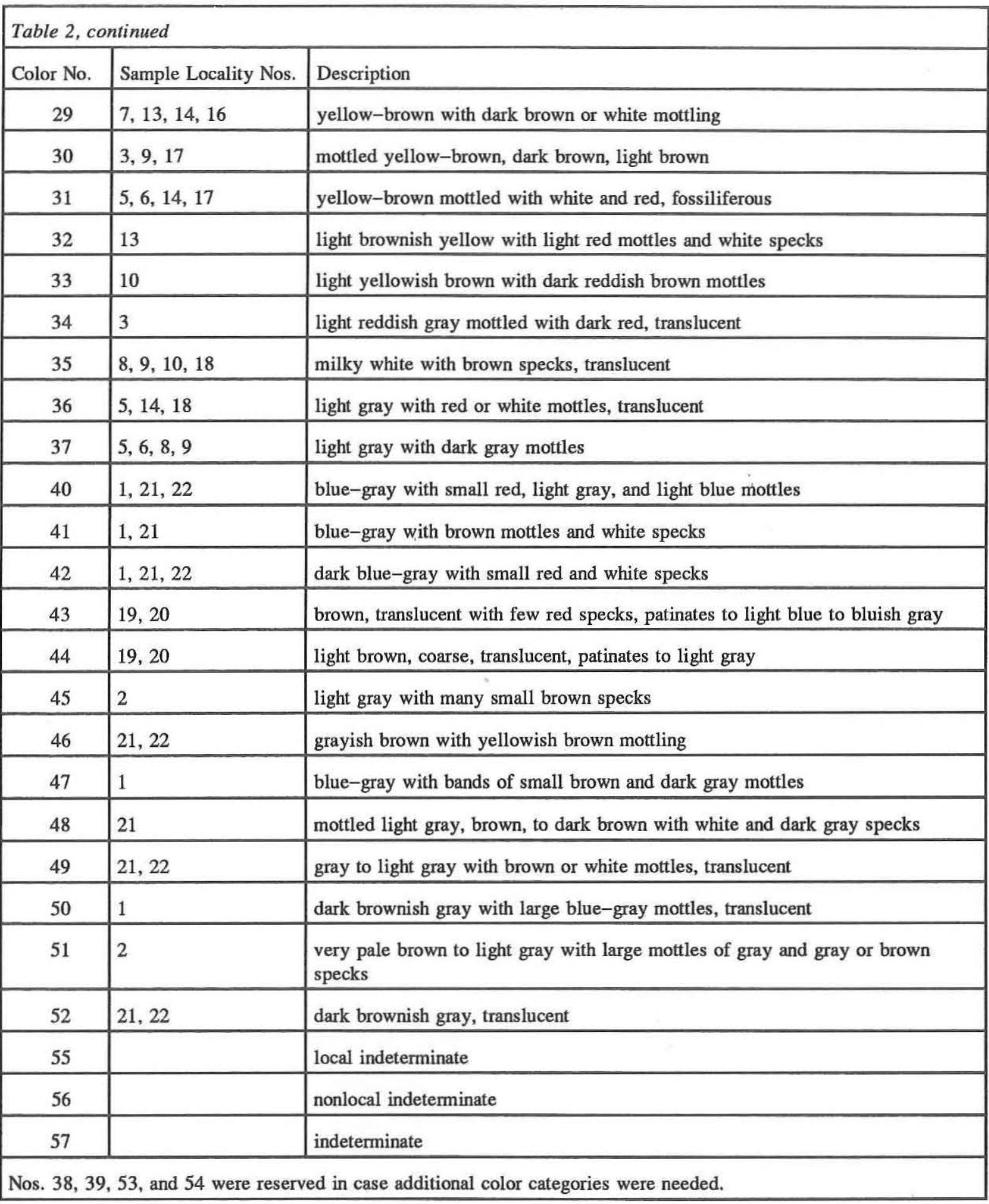

only with extreme force to very fine grained pieces that fracture relatively easily and predictably. Heat treatment improves the fracture quality of both types, but more improvement is seen in the fine- grained Potter chert.

Less-frequent lithic raw materials in the Quaternary gravels in the project area are silicified wood, opalized caliche, and silicified caliche. 
The silicified wood specimens are relatively coarse to fine grained, small $(3-5 \mathrm{~cm})$ to medium-sized $(8-12 \mathrm{~cm})$ tabular chunks. Chalcedony specimens varying in size from 2 to $20 \mathrm{~cm}$ have been recovered from gravel bars of the Double Mountain Fork of the Brazos and its tributary creeks. The chalcedony specimens have a barklike corticate surface that is reminiscent of silicified wood. They range in quality from very fine grained and translucent specimens to coarse-grained and internally fractured chunks. Opalized and silicified caliche occur relatively frequently in the project area and its vicinity. While the finer quality opalized caliche is less frequent, some single chunks can contain portions which grade from silicified to opalized in quality.

The less-frequent raw materials encountered range in size from small angular nodules to specimens greater than $20 \mathrm{~cm}$ in maximum dimension. The coarse-grained cherts occur in the form of small $(5-7 \mathrm{~cm})$ lenticular nodules and range in color from dark gray to white or red. Their small size and internal fracture planes and lines make them an inferior raw material compared to the locally occurring fine-grained cherts.

Sandstone, a widely utilized raw material in the project area, occurs in abundance and forms the bluff edges in most of the reservoir area. Triassicage sandstones extend through a large portion of the region, including Palo Duro Canyon (Matthews 1969:23) and Mackenzie Reservoir (Hughes and Willey 1978:21). Tabular pieces of sandstone, together with lenticular and oval nodules formed as resistant concretions in softer limestone, occur often on solid sandstone bedrock. Although their distribution may be patchy, they occur throughout the project area. A dark gray to black, relatively coarse material is tentatively identified as basalt. Finally, any materials not falling within these types were grouped into a miscellaneous material category.

\section{Local and Nonlocal Lithic Materials}

Based on the geomorphic history and the comparative collections of lithic raw materials from the project area, the following raw material types are considered to be local: (1) fine-grained Potter chert; (2) coarse-grained Potter chert; (3) finegrained quartzite; (4) coarse-grained quartzite; (5) a variety of fine-grained cherts; (6) coarse-grained chert; (7) silicified wood; (8) opalized caliche; (9) silicified caliche; and (10) sandstone. The origins of the following material types are uncertain: (1) conglomerate quartzite; (2) basalt; (3) unidentified quartzite; and (4) miscellaneous materials. Referring to the regional collection of raw materials and other raw material studies, the following presently are presumed to be nonlocal: (1) Alibates agate; (2) Tecovas jasper; and (3) a variety of finegrained cherts.

\section{CORE CHARACTERISTICS}

Three attributes are included in this group: (1) core type; (2) removal directionality; and (3) number of flake removals. These attributes were recorded only on cores. Core type refers to the products of core reduction (flake, blade, multipurpose, or indeterminate). Flake removal directionality (unidirectional, bidirectional, opposed bidirectional, multidirectional, or indeterminate) was recorded to gauge the degree of systematic core reduction practiced by the prehistoric knappers. The number of flake removals consists of the count of flake scars not resulting from platform crushing. Platform preparation scars $1-10 \mathrm{~mm}$ in length were excluded.

\section{NATURE OF TOOL BLANK}

This attribute refers to the initial nature or condition of the raw material used in the manufacture of tools such as projectile points, perforators, gouges, bifaces, and unifaces. Four possible blank types were defined: (1) cobble/pebble; (2) flake; (3) other tool; and (4) indeterminate. The presence of cortex on both faces of a biface or on unreduced corticate margins was considered indicative of cobble/pebble blanks. Smaller bifaces with unreduced platform remnants and/or unreduced flake ventral surfaces as remnants are assumed to have been made from flake blanks. Tools manufactured by reworking other artifact categories were classified into the third category. Numerous bifacial artifacts that are substantially reduced and show none of the characteristics described were classified as indeterminate blank types.

\section{TOOL MORPHOLOGY}

Four attributes are used to characterize tool 
morphology: (1) completeness; (2) outline shape; (3) transverse cross section; and (4) morphofunctional category. Completeness is used to differentiate fragments from complete artifacts. In addition to complete specimens, projectile point, perforator, biface, and uniface fragments were classified into one of the following fragment categories: proximal, medial, distal, and longitudinal fragments; triangular wedges; edges; and barbs. Completeness for cobble tools, cores, edge-modified flakes, hammerstones, and ground stone artifacts was recorded as complete or fragmentary. Outline shape was recorded for ground stone artifacts. It assumes the following categories: (1) rounded; (2) oval; (3) angular; (4) spherical; (5) rectangular; and (6) indeterminate. This characteristic could be determined with certainty when only a small portion of the artifact was missing, and thus most fragments were classified as having indeterminate shapes. Transverse cross section categories include the following: (1) lenticular; (2) biconvex; (3) biconcave; (4) planoconvex; (5) planoconcave; (6) beveled; (7) tabular; (8) biconvex or planoconvex with medial ridge; and (9) indeterminate. Transverse cross sections were recorded only on projectile points, perforators, gouges, bifaces, and ground stone artifacts. Morphofunctional categories were employed in the classification of perforators, bifaces, gouges, unifaces, cobble tools, and ground stones. The categories designate specific functional categories established primarily on the basis of morphological characteristics; they are subgroupings within specific tool types. Two categories of perforators were distinguished: (1) drills; and (2) reamers. Drills are assumed to have been utilized to perforate materials, while reamers are used to enlarge already-existing holes. Bifaces are grouped into five morphological categories: (1) unutilized bifaces; (2) bifacial knives; (3) twobeveled bifacial knives; (4) four-beveled bifacial knives; and (5) indeterminate fragments. Six morphofunctional categories of gouges are distinguished: (1) unifacial triangular (Clear Fork); (2) bifacial triangular (Clear Fork); (3) unifacial ovate; (4) bifacial ovate; (5) unifacial rectangular; and (6) bifacial rectangular. Unifaces are classified into the following morphofunctional categories: (1) end scrapers; (2) side scrapers; (3) combination end/ side scrapers; and (4) indeterminate-function edge fragments. It is recognized that some unifacial gouges probably were utilized in scraping as op- posed to planing tasks (see Hester et al. 1973 and Shiner 1975). Although these specimens most correctly should be incorporated with end scrapers, the lack of microwear analysis restricts their classification strictly on morphological characteristics. Two groups of cobble tools were distinguished based on size and assumed manner of use: (1) chopping tools; and (2) wedges. In general, wedges are smaller than choppers and exhibit less ridge rounding generated from heavy contact with the worked material. Occasionally, the portion of the tool opposite the working edge may exhibit crushing or battering.

Ground stone artifacts were subdivided into the following morphofunctional analytical categories: (1) mano; (2) metate; (3) hammerstone; (4) unknown/indeterminate; and (5) anvil. The presence/absence of grinding wear was established based on examination with a binocular microscope under $40 \mathrm{x}$ magnification. Specimens exhibiting macro- or microscopic striations; polish; flat surfaces; beveled, planoconcave, or ridged transverse cross sections; or evidence of workingsurface rejuvenation (i.e., pecking) were classified as ground. These characteristics were readily observable on quartzite specimens. On sandstone specimens, striations and polish could not be observed at 40x magnification. Rather, specimens with characteristic flat surfaces and either diagnostic cross-sectional configurations or surface rejuvenation were classified as ground stones. Many ground stone tools were extensively weathered, and this results in a conservative classification of ground stone tools.

\section{CAUSE OF FRACTURE}

This attribute identifies the cause of fracture of incomplete projectile points, perforators, gouges, bifaces, and unifaces. Four types were distinguished: (1) use; (2) manufacture; (3) postdepositional; and (4) indeterminate. Some use-generated breaks and a large variety of manufacturing breaks have been reproduced experimentally (Tomka 1986). Others are taken from studies of manufacture and use- generated tool failures (e.g., Muto 1971; Crabtree 1972; Callahan 1979; Johnson 1979, 1981; Odell and Cowan 1986). The diagnostic morphologies defined from these replications are the comparative bases used in identifying fracture causes on the archeological specimens. Break 
morphologies that share characteristics of more than one cause of fracture or that were not experimentally replicated were assigned to an indeterminate category.

\section{SIZE}

Eleven size measurements are included under this attribute: (1) maximum length; (2) working surface maximum length; (3) maximum width; (4) working surface maximum width; (5) maximum thickness; (6) maximum dimension category; (7) blade length; (8) blade width; (9) base width; (10) neck width; and (11) stem/haft length. Maximum length, maximum width, and maximum thickness were measured on complete specimens and fragments with appropriate intact portions. Blade length, blade width, base width, neck width, and haft length were measured only when the appropriate portion of the artifact was complete. Maximum dimension categories consist of 10-mm-increment size classes ranging from $1-10$ to $61 \mathrm{~mm}$ and greater. Edge-modified flakes and unmodified debitage are grouped into dimension categories. In all of the artifact categories, only measurements taken on complete specimens are used in the statistical manipulation of the data. Working surface length and width measurements were taken on complete ground stone specimens to calculate working surface area since differences exist between overall measurements and the extent of the working surface.

\section{CORTEX CHARACTERISTICS}

Four attributes were used to characterize the nature of cortex on lithic artifacts: (1) cortex category; (2) cortex amount; (3) cortex presence/ absence; and (4) cortex backing. Cortex category was recorded as either primary, secondary, or tertiary. Cortex amount was recorded in $25 \%$ increments from $0 \%$ to $100 \%$. Cortex amount was recorded on unmodified debitage flakes, proximal fragments, and chips, while cortex category was recorded only on perforators, gouges, unifaces, and edge-modified flakes. Cortex presence/absence is self-explanatory. Only cortex presence/absence was recorded on chunks or angular debris. The cortex backing attribute is an indication of the character of the surface of the tool opposite the working edge. It was recorded on cobble tools.

\section{WORKING-EDGE CHARACTERISTICS}

This group consists of two attributes recorded on edge-modified flakes: (1) number of modified edges; and (2) inferred manner of use. The first attribute identifies the number of modified edges. The inferred manner of use, on the majority of the specimens, was determined by comparison with replicated use-wear on experimental tools in conjunction with diagnostic wear patterns described in the literature (Tringham et al. 1974; Keeley 1980; Yerkes 1987). The following use categories were identified: (1) cut/saw; (2) scrape; (3) engrave; (4) bore; (5) saw/scrape; (6) scrape/engrave; (7) saw/engrave; (8) scrape/saw/engrave; and (9) other combination.

\section{BASE, STEM, AND BLADE TREATMENT}

This attribute was recorded on projectile points. It has five states: (1) stem smoothing; (2) base smoothing; (3) blade beveling; (4) stem beveling; and (5) blade serrating. These values were recorded as present or absent.

\section{REWORKING CATEGORY}

This analytical category consists of two attributes: (1) resharpening; and (2) reuse. Resharpening, recorded on projectile points and bifaces as present/absent, gauges the occurrence of artifact maintenance. Two criteria were used to establish the presence of reworking on a specimen: (1) morphological asymmetry along the longitudinal or transverse cross section; and (2) changes in flake removal patterns along the length of the projectile point. Reuse identifies the utilization of a given artifact following reworking and/or breakage for a function other than that for which it was initially manufactured (e.g., projectile point reworked to a drill, broken projectile point used as a burin).

\section{PLATFORM CHARACTERISTICS}

Three attributes were recorded to characterize striking platforms on unmodified lithic debitage: (1) cortex; (2) grinding; and (3) faceting. Platform cortex and grinding were recorded as either present or absent, while faceting refers to the number of platform facets. 
FLAKE TYPE

Four flake types were distinguished: complete; (2) proximal; (3) chip; and (4) chunk. Complete flakes retain both a striking platform and a feathered and/or hinged termination. Proximal fragments have only a platform. All medial and distal fragments were classified as chips. Angular debris lacking clear flake features was placed in the chunk category. Flake type was identified for edge-modified flakes and unmodified debitage.

\section{WEAR TYPE}

The attributes in this group identify the presence/absence of wear on selected bifacial, unifacial, and ground stone artifacts and the type and degree of wear on ground stones, hammerstones, and cobble tools. The attributes are (1) use-wear, (2) haft wear, (3) degree of battering, (4) pecking, (5) step fracturing, and (6) edge rounding. The first attribute identifies the presence/absence of use-wear on ground stone artifacts. It is recorded as either unifacial, bifacial, or indeterminate. The presence of haft wear was recorded on perforators, gouges, nonprojectile-point bifaces, and unifaces. Haft wear was observed under $10 x$ to $40 x$ magnification. It consisted of ventral and/or dorsal face polish and flake ridge rounding and/or lateral edge rounding. The degree of battering was recorded on hammerstones and manos. It consists of the following values: (1) slight; (2) moderate; (3) extensive; and (4) absent. The first category consists of battering covering an area of only $1 \mathrm{~cm}^{2}$. Battering covering between $1-3 \mathrm{~cm}^{2}$ was included in the second category, while battering over more than $3 \mathrm{~cm}^{2}$ was considered extensive. Pecking had the following values: (1) unifacial; (2) bifacial; (3) absent; and (4) indeterminate. It was recorded on ground stone artifacts. Step fracturing is recorded on cobble tools and is indicative of the degree of working edge use in conjunction with the hardness of the worked material. It was recorded as a presence/absence attribute. Finally, edge rounding, also recorded only on cobble tools, is indicative of the degree of working-edge wear. While some edge rounding similar to use-wear may result from platform preparation (i.e., of a core), the wear noted on these tool edges extends onto the two faces of the working edge. This distribution should not occur in the case of core platform preparation.

\section{WEIGHT}

Weight was recorded to the nearest gram with an O'Hause Triple Beam Balance scale. Weight was measured for complete cobble tools, hammerstones, and ground stone artifacts.

\section{Ceramics}

Ceramics were recovered from only one site, $41 \mathrm{KT} 33$, during the Season 1 investigations. The small sample of sherds consists entirely of undecorated brownwares which, based on temper characteristics, were considered likely to have been manufactured somewhere in the Jornada Mogollon culture area of southern New Mexico or western Texas. Defining the variability and origins of these imported brownwares is crucial to understanding Late Prehistoric cultural interactions in the Texas South Plains. Thus, the primary goal of the analysis was to address the problem of ceramic origins. Specific objectives of the analysis were to (1) characterize and describe the physical properties of the ceramic sample, (2) identify ceramic technology, (3) identify the ceramic "types" represented and the source(s) of components, and (4) compare the ceramic sample from 41KT33 to similar imported ceramic types in the Texas South Plains. Unfortunately, the small size of both the ceramic sample and the individual sherds precluded many aspects of ceramic analysis. Specifically, no determinations of vessel form could be made, and none of the sherds is large enough to yield a reliable thermoluminescence date.

The sherds were first studied in detail, including a low-power (10x to 40x) examination, and the ceramic attributes (e.g., paste, temper, and surface finish) were described. They were then sent to two ceramic specialists who independently provided visual identifications and descriptions. The results of these studies are detailed in Chapter 7.

To more fully exploit the potential of the ceramic sample from $41 \mathrm{KT} 33$, a comparative petrographic analysis was also undertaken. The goal of this analysis was to compare a sample of imported brownware sherds from three roughly contemporaneous sites in the Texas South Plains. The two additional sites were selected because they yielded brownware ceramics from dated archeological components which are likely to be related to 
the cultural occupation at 41KT33. A small sample $(n=12)$ of brownware sherds from these three sites was thin sectioned by the Thin Section Laboratory at the Bureau of Economic Geology, The University of Texas at Austin, and submitted for petrographic study to David G. Robinson, Texas Archeological Research Laboratory, The University of Texas at Austin. The methods and results of this analysis are presented in Appendix F.

\section{Burned Rocks}

Prehistoric burned rocks at Justiceburg are generally of two types. Sandstone slabs, and occasionally limestone nodules, constitute the largest category. The sandstone does not crack as a result of intensive heating, and the limestone nodules only rarely are fire cracked. Thus, evidence of heating is mainly limited to interior discoloration (blackening or reddening).

The second category of burned rocks is the fire-cracked siliceous rocks, which are almost exclusively dominated by Potter chert and coarsegrained Ogallala quartzites. Evidence of heating of these materials is primarily the distinctive and generally easily recognizable angular, blocky fracturing. When these materials are intensively heated, their internal crystalline structures are altered, they often fracture immediately if cooled rapidly, and afterward they easily fracture upon low impact. The quartzites rarely exhibit discoloration since they are generally very dark colored (such as the red and maroon Ogallala materials). Heated Potter chert, on the other hand, almost always exhibits significant reddening or darkening of the outer rind or cortex.

The distribution and frequency of burned sandstone and fire-cracked rocks (both scattered and as feature clusters) within an excavation area has many implications for the length and intensity of occupations and site function. Sophisticated and costly technical analyses of burned rocks were not attempted as they rarely produced interpretable results in previous investigations at Justiceburg Reservoir (see assessments of thermoluminescence dating and pollen/phytolith studies of burned rocks in Boyd et al. 1990:246-248, 251-252). Thus, the goal of the burned rock analysis was limited to characterizing the burned rocks and their distributions.

Burned rocks were encountered in two con- texts within the prehistoric site excavations: randomly scattered; or (2) clustered into distinct features. Burned rocks were ubiquitous and constitute the greatest single category of cultural material recovered. They were weighed and discarded in the field or brought back to the laboratory where they were weighed and discarded. Samples of burned rocks, however, were taken for permanent curation.

\section{Faunal Remains}

Unmodified vertebrate and invertebrate faunal remains are analyzed and described in Appendix C. A few modified mussel shells were recovered from 41KT33; these artifacts are described in Chapter 7.

\section{GEOARCHEOLOGICAL INVESTIGATIONS}

The geoarcheological investigations conducted during the first season of Phase III data recovery had five interrelated objectives. The first was to assess the geological context of archeological materials at each prehistoric site. This objective is crucial for establishing site integrity as discussed in the Research Orientation section in Chapter 2. The second and closely dependent objective was to establish the chronological sequence of deposition at the archeological sites. The third, establishing the nature of the sedimentary and pedogenic processes active in site formation and their influence on the archeological record, required the identification of depositional and postdepositional environments reflected by stratigraphy, sediments, and soil chemistry. These results also provide information on site integrity. A fourth objective was to continue and expand upon the late Pleistocene and Holocene geological record established for Justiceburg Reservoir by Blum (1989a) and Abbott (1990) with the aim of better understanding the unequal temporal and spatial distributions of sites in the reservoir area due to dynamic changes in the geological landscape. The last objective was to supplement the still limited paleoenvironmental record for the reservoir area. This will be a major focus in future seasons, but in this season of geoarcheological investigations the primary source of paleoenvironmental data was from stable carbon isotopes measured in buried, radiocarbon-dated sediment samples.

In order to accomplish these objectives, a 
number of methods and techniques were employed. At each prehistoric site, a series of profiles were described using the methods described by Soil Survey Staff (1975) and Birkeland (1984). These sediment descriptions provide field observations on color, texture, soil structure, horizon boundaries and inclusions such as $\mathrm{CaCO}^{3}$ and manganese for each sediment horizon in each profile. The detailed profile descriptions provide the framework and elemental data on which the contexts of the archeological remains are assessed. These as well as all other detailed profile descriptions are presented in Appendix H. Sediments from these profiles were sampled for texture and chemical analyses, and these data are presented in Appendix I. Additionally, all profiles were sampled for radiocarbon analysis. When possible charcoal samples were used for radiocarbon assays; otherwise, bulk carbon from organic-rich sediment samples was selected.

A series of off-site backhoe trenches was excavated, described, and sampled by the same methods as those used in the archeological site profiles. These provide additional information on late Pleistocene and Holocene landscape evolution. This effort focused on the dam construction area, and in most cases the geomorphic backhoe trenches were placed on or near the investigated prehistoric sites. Thus, they provide general information on landscape change, as well as more specific data that contribute to a fuller understanding of the geological contexts of prehistoric archeological sites. 

Karen M. Gardner and Douglas K. Boyd

Site 41KT42 was recorded during the 1987 survey (Boyd et al. 1989), and National Register testing and archival/informant research related to the site's history were completed in 1988 (Freeman and Boyd 1990). It is known locally as the Ed Scott Cabin. The structure at $41 \mathrm{KT} 42$ was probably a frame cabin associated with the father-son cowboys Ed Scott, Sr., and Ed Scott, Jr.; both were long-time ranch hands in the Justiceburg area, but neither ever owned the property or lived there for very long. Ed Scott, Jr., is especially well remembered since he lived in the area all his life, from 1873-1971. Even though it is misconceived, the name is retained since it has historical precedent. As a result of the testing, the Ed Scott Cabin was assessed as being eligible for listing on the National Register of Historic Places, and further work was recommended. It is located immediately upstream of the Justiceburg dam and will be inundated.

\section{SITE SETTING}

The Ed Scott Cabin is situated on a colluvial peneplain sloping down to Grape Creek ca. $0.5 \mathrm{~km}$ upstream from its confluence with the Double Mountain Fork of the Brazos River (Fig. 6). The topography slopes westward from the base of the canyon wall at an elevation of $2170 \mathrm{ft} \mathrm{msl}$ to the creek at ca. $2140 \mathrm{ft} \mathrm{msl}$. The main structure foundation is located ca. $150 \mathrm{~m}$ east of the springfed creek and is within $50 \mathrm{~m}$ of the base of the canyon wall. The site is somewhat protected from

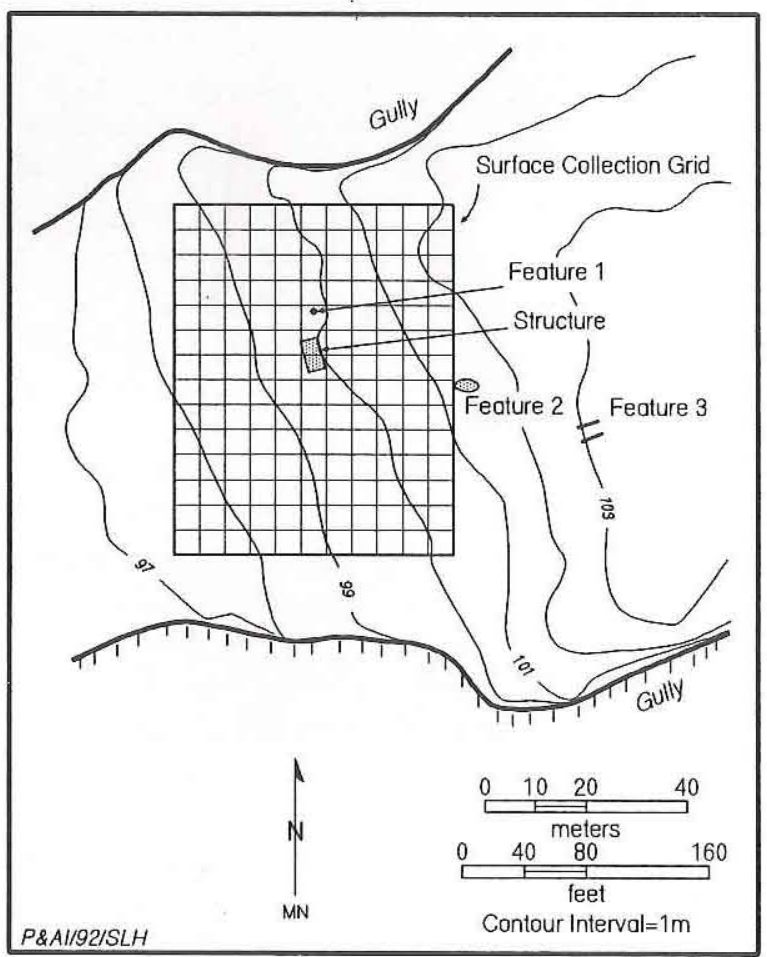

Figure 6. Site map, $41 \mathrm{KT} 42$.

the elements on the north where the canyon wall projects westward. Erosional gullies delimit the north and south boundaries of the $130 \times 130-\mathrm{m}$ site area. Vegetation cover is moderate to heavy except along the base of the talus slope and along the gullies. Vegetation noted in the vicinity includes grasses, mesquite, yucca, sunflowers, and various shrubs, but no non-native plants were identified. 
Some vegetation clearing apparently has occurred, and as the site has long been a popular picnic spot, some surface relic collecting undoubtedly has taken place.

\section{PREVIOUS INVESTIGATIONS}

The 1987 survey documented a multicomponent, surficial late Archaic/Late Prehistoric occupation in addition to the historic occupation (Boyd et al. 1989:552-553). A Fresno arrow point and an Ensor dart point were collected from the surface. In addition, possible bedrock mortars were observed in a sandstone rock used in the structure foundation. The historic component (Boyd et al. 1989:361-362, 633-634) consisted of an artifact scatter, a rock chimney base, and the foundation of the main house. Four metallic cartridge cases (one .38-caliber and two .44-caliber Winchester centerfire and one .32-caliber Winchester rim-fire) were collected from the surface. Archival and informant research revealed that the historic occupation probably dated to the 1880 s and that it continued well into the twentieth century. The structure most likely was built as a ranching line camp.

The 1988 testing (Freeman and Boyd 1990: $106-110,130-131)$ was aimed only at the historic component. Additional archival and informant research was conducted, and archeological investigations consisted of intensive surface inspection, site mapping and detailed mapping of the structure, and excavation of four $1 \times 1-\mathrm{m}$ test units on the south side of the structure foundation (Fig. 7). In addition to the main structure, three features of unknown function were recorded. Sixty artifacts were recovered from the test excavations (Table 3 ), including a .44- or .45-caliber center-fire cartridge case that has no headstamp and a hand-finished bottle mouth fragment. The latter was probably manufactured prior to 1903 (Lorrain 1968:44).

The house structure consists of a rectangular $4.4 \times 6.2-\mathrm{m}(14 \times 20-\mathrm{ft})$ foundation of dry-laid sandstone slabs with an intact chimney base at the north end. It is oriented north-south, and the entrance was probably on the south end. The chimney collapsed southward, leaving a pile of rock rubble on top of the foundation. The test units revealed that the foundation is a solid course of unworked sandstone slabs which rests directly on the ground surface. The chimney base is $2.3 \mathrm{~m}$ ( $7 \mathrm{ft}, 3$ inches) wide and $46 \mathrm{~cm}$ (1 ft, 6 inches deep;

\begin{tabular}{|c|c|c|}
\hline \multicolumn{3}{|c|}{$\begin{array}{c}\text { TABLE } 3 \\
\text { ARTIFACTS RECOVERED DURING 1987 SURVEY } \\
\text { AND 1988 TESTING, 41KT42 }\end{array}$} \\
\hline $\begin{array}{l}\text { Material } \\
\text { Class }\end{array}$ & Descriptions & Totals \\
\hline Metal & $\begin{array}{l}\text { Unidentifiable fragments } \\
\text { Wire staples } \\
\text { Machine-cut square nails } \\
\text { Container lid } \\
\text { Brass cartridge cases } \\
\end{array}$ & $\begin{array}{r}2 \\
18 \\
9 \\
1 \\
5\end{array}$ \\
\hline Ceramic & $\begin{array}{l}\text { Coarse earthenware jar frag- } \\
\text { ments (Albany slip/salt glaze) }\end{array}$ & 7 \\
\hline Glass & $\begin{array}{l}\text { Unidentifiable fragments } \\
\text { clear } \\
\text { purple } \\
\text { Bottle base fragment, clear } \\
\text { Bottle mouth fragment, purple }\end{array}$ & $\begin{array}{l}8 \\
1 \\
1 \\
1\end{array}$ \\
\hline Hard Rubber & Comb handle fragment & 1 \\
\hline Leather & Unidentifiable fragment & 1 \\
\hline Bone & $\begin{array}{l}\text { Unidentifiable fragment } \\
\text { Unidentifiable fragment, } \\
\text { bumed } \\
\text { Bovid rib fragments } \\
\end{array}$ & $\begin{array}{l}1 \\
1 \\
4\end{array}$ \\
\hline Wood & Unidentifiable fragments & 3 \\
\hline Total: & & 64 \\
\hline
\end{tabular}

the remaining portion is $1.2 \mathrm{~m}(4 \mathrm{ft})$ high. Although some informants thought it was a log structure, it was most likely a wood-frame (board and batten) house.

Feature 1 is a small (1-m-diameter) surface cluster of fist-sized sandstone rocks located $3 \mathrm{~m}$ north of the chimney base. Its function is unknown. Feature 2 is a $5 \times 5-m$ surface concentration of unpatterned sandstone slabs located $30 \mathrm{~m}$ southeast of the house. It definitely appears to be unnatural, but it is uncertain whether it represents an associated feature (possibly the remains of a smaller structure foundation) or is the result of vegetation clearing. Feature 3 is a $3 \times 3-m$ crude double alignment of surficial and shallowly buried sandstone slabs. There are two parallel rows of rocks, each ca. $1 \mathrm{~m}$ wide, $3 \mathrm{~m}$ long, and ca. $1 \mathrm{~m}$ apart. The rows are oriented northeast-southwest, and the patterned nature of the rocks indicates that this feature may be a foundation for a small wood 


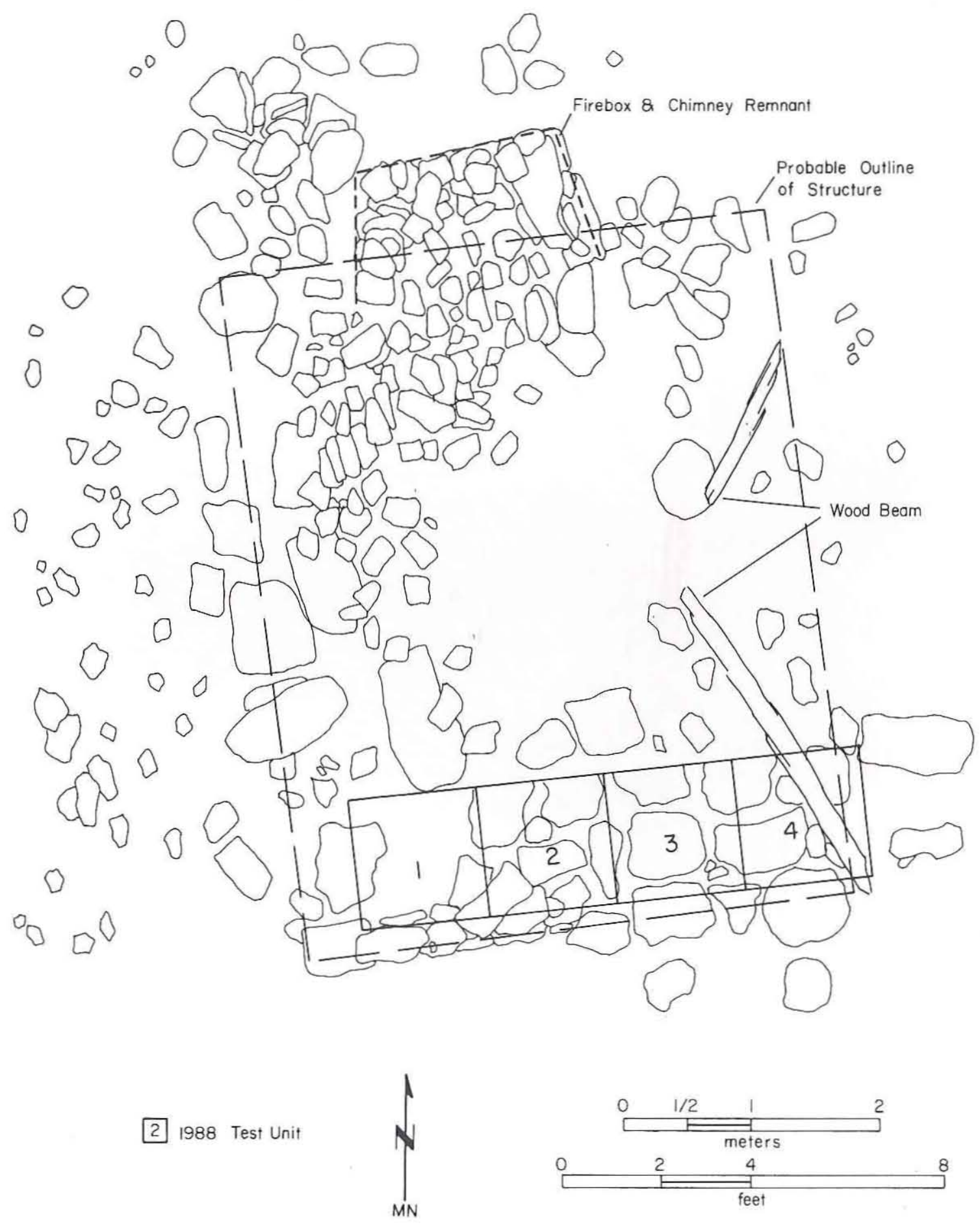

P\&AI/91/SLH

Figure 7. Map of the house foundation and 1988 test excavations, $41 \mathrm{KT} 42$. 
frame structure. No artifacts were associated with any of these three features. Perhaps Features 2 and 3 represent small barns or storage buildings associated with the line camp, but there is no evidence of such structures at other line camps in the region (Freeman 1990b) nor is there any archival or oral history documenting the functions of outbuildings at 41KT42.

\section{SITE HISTORY}

The history of the property containing the Ed Scott Cabin (Section 56, Block 5) is well documented, but the history of the construction, use, and abandonment of the site remains quite vague. The following information is summarized from Boyd et al. (1989:633-634) and Freeman and Boyd (1990: 83, 94-97, 110). Sometime between 1878 and 1882, H. T. "Tuck" Cornelius and former buffalo hunter J. Wright Mooar purchased several sections of land, including Section 56, from the State of Texas. Cornelius had operated a trading post on Deep Creek (now located in Snyder) from 18761878 and undoubtedly knew Mooar from his involvement with the buffalo-hunting trade. In 1878, Cornelius sold the trading post to Pete Snyder and went into the ranching business with Mooar.

Cornelius owned Section 56 until 1886, when he sold it to ranchers Andy and Frank Long of Nolan County. The Longs bought out and operated the OS (Overall \& Street) Ranch, of which Section 56 was only a small part. They then sold the OS Ranch, including Section 56, to the partnership of Connell, Clark, and Scharbauer in 1901. Connell bought out Scharbauer's and Clark's share of the partnership in 1901 and 1913, respectively, leaving him as the sole owner of Section 56 and the OS Ranch. The Connell land was split among his heirs in 1954, and Blanche Connell acquired the tract containing Section 56. This tract was then sold to Billy Huddleston in 1970. Huddleston remained the owner until 1988 when the City of Lubbock purchased Section 56 as part of its Justiceburg Reservoir project.

\section{DATA RECOVERY INVESTIGATION}

The data recovery investigation at the Ed Scott Cabin was limited to controlled collection of the surface artifacts. A reinspection of the site area confirmed the surficial nature of the cultural re- mains, and no further investigations of the structure and features were made. The 1988 site datum (ca. $5 \mathrm{~m}$ northeast of the house foundation) was relocated, and a site grid was established. Northsouth and east-west grid lines were established, then the site area was sectioned into $1545 \times 5-m$ surface collection units within a $55 \times 75-\mathrm{m}$ block around the structure (see Fig. 6). The size and location of the surface collection grid was determined by the areal extent of the cultural materials. As expected, the artifact frequency decreased away from the house foundation, and very few artifacts were observed beyond the gridded area.

Each $5 \times 5-m$ collection unit was intensively searched for surface artifacts. The units were scoured on hands and knees, moving or cutting vegetation if necessary to expose the ground surface. An average of 12 minutes was spent on each collection unit, but the actual time varied greatly since bare units could be collected quickly while heavily vegetated units required more time. All cultural items were collected and bagged by the unit's grid coordinates (e.g., N10-15/E5-10).

\section{Cultural Materials}

A total of 570 artifacts was collected from the $1545 \times 5-m$ units at $41 \mathrm{KT} 42$. Fifty-nine units yielded artifacts. As would be expected at an historic site, the majority of these are metal, ceramics, and glass (Table 4). These artifacts are described by material class.

\begin{tabular}{|l|r|r|}
\hline \multicolumn{3}{|c|}{ TABLE 4 } \\
MATERIAL TYPES RECOVERED FROM \\
41KT42 \\
\hline Material & No. of & \\
Classification & Artifacts & Percent \\
\hline Metal & 224 & 39 \\
Ceramic & 81 & 14 \\
Glass & 252 & 44 \\
Bone & 10 & 2 \\
Shell & 1 & $<1$ \\
Rubber & 1 & $<1$ \\
Stone & 1 & $<1$ \\
\hline Total: & 570 & 100 \\
\hline
\end{tabular}




\section{Metal}

Of the artifacts recovered from $41 \mathrm{KT} 42,224$ are of metal. The majority are containers and utensils; quantities of structural and fencing materials also are present, and the other functional categories are minimally represented (Table 5).

Most of the containers are food related, with the majority being can fragments. Few complete cans were found, but many of the partial cans and fragments fall into three temporally diagnostic groups. Most common is the lap side-seam can with a stamped or flanged seal at one end and either a hole-in-cap or hole-in-top seal at the other. The lap seam was the dominant type of side seam until 1888, while the stamped can end was developed in 1847 and further improved on in 1849 . The hole-in-cap seal came into use by 1820 , while hole-in-top seals were not common until after 1900. Also collected were cans with double, or

\begin{tabular}{|c|c|c|}
\hline \multicolumn{3}{|c|}{$\begin{array}{c}\text { TABLE } 5 \\
\text { METAL ARTIFACTS, } 41 \mathrm{KT} 42\end{array}$} \\
\hline Functional Category & Artifact Description & No. of Specimens \\
\hline Containers and Utensils & $\begin{array}{l}\text { Lap-seam cans } \\
\text { Double-seam cans } \\
\text { Hole-in-top can lids } \\
\text { Hole-in-cap can lids } \\
\text { Flat oblong (sardine-type) can } \\
\text { Unidentified cans } \\
\text { Can fragments } \\
\text { Unidentified cap } \\
\text { Lard can } \\
\text { Buckets } \\
\text { Handle ear } \\
\text { Cup fragments } \\
\text { Domed, hinged lid } \\
\text { Cast-iron plate } \\
\text { Unidentified }\end{array}$ & $\begin{array}{r}5 \\
2 \\
3 \\
2 \\
1 \\
2 \\
94 \\
1 \\
1 \\
2 \\
1 \\
4 \\
1 \\
1 \\
1\end{array}$ \\
\hline Structural & $\begin{array}{l}\text { Cut nails } \\
\text { Wire nails } \\
\text { Miscellaneous hardware }\end{array}$ & $\begin{array}{r}17 \\
3 \\
18\end{array}$ \\
\hline Fencing & $\begin{array}{l}\text { Wire staples } \\
\text { Burnell's Four-Point barbed wire } \\
\text { Miscellaneous wire lengths }\end{array}$ & $\begin{array}{r}12 \\
4 \\
18\end{array}$ \\
\hline Firearms & $\begin{array}{l}.32 \text {-caliber cartridge } \\
.38 \text {-caliber cartridges } \\
.44 \text {-caliber cartridges } \\
.45 \text {-caliber cartridges } \\
\text { Grooved bullet base } \\
\text { Lead shot }\end{array}$ & $\begin{array}{l}1 \\
2 \\
5 \\
2 \\
1 \\
1\end{array}$ \\
\hline Clothing & $\begin{array}{l}\text { Buttons } \\
\text { Rivet }\end{array}$ & $\begin{array}{l}2 \\
1 \\
\end{array}$ \\
\hline Personal & Watch cog & 1 \\
\hline Other & $\begin{array}{l}\text { Horseshoe nail } \\
\text { Unidentified metal fragments }\end{array}$ & $\begin{array}{r}1 \\
14\end{array}$ \\
\hline Total: & & 224 \\
\hline
\end{tabular}


locked, side seams, which by 1888 began to replace the lap as the preferred side seam (Busch 1981:9697; Rock 1984:100-102). None of the cans collected with a double seam have intact end seals, but it is assumed that they are otherwise similar to the lap-seam cans. The third form identified is a flat, oblong (sardine) can with a lap side seam. Cans with a key-wind opening mechanism were developed in 1866 (Rock 1984:100).

Isolated can lids are present and are fairly evenly divided between the hole-in-cap and holein-top types. One unidentified can cap also was found. It is a small circular cap with straight sides.

The only product-identifiable can collected is a fragmentary lard can or pail. Part of the stamped design is either missing or illegible, with about half of the design remaining. Enough is present to identify it as most likely being labeled "Pure Refined Family Lard" produced by "N.K. Fairbank \& Co., St. Louis." This product was apparently fairly common, with the company also having manufacturing locations in Chicago, New York, and Omaha (Herskovitz 1978:75).

One lap-seam can has evidence of secondary use. The top has been removed, and the bottom is punctured with two concentric rings of holes along the outer perimeter and then a random hole pattern on the center ring. Altogether, 22 holes are punched in the bottom, 18 from the outside in and the remaining 4 from the inside out. It may have been used as some form of drain or sifter.

Two nonfood containers were found; one is the base of a bucket, and the other is a partially complete bucket with an internal double seam, a rolled rim, and one handle ear. Stamped on the bottom is "The Acme" made by "Walsh \& Co." with several patent dates and other illegible information. The bucket also apparently was used for target practice, having several bullet holes in the bottom. The bucket base is circular and probably had a stamped bottom seam. It has no markings of any kind. An isolated handle ear similar to the one on the bucket was found, but it is not possible to tell if it is from this bucket or some other container.

Other identifiable metal utensils include a domed and hinged lid from a small tea or coffee pot, four cup fragments, and a small portion of a cast-iron plate or shallow pan. All of these are similar to items illustrated in the 1897 Sears Roebuck Catalog (Israel 1976).

One metal container cannot be identified but is unusual enough to warrant description. It is roughly V-shaped with a gusset at one end, while the other end is open. One edge has a thick band with a pair of rivet holes at each end, with one rivet and burr, while the other side and the gusset have a narrow band. Its purpose is unknown, but it may have been modified from another object, such as a bucket, for a specific purpose.

The structural category consists of nails and miscellaneous hardware. Twenty nails, all of which are machinemade, were found; 17 are cut nails, and 3 are wire nails. Cut nails made completely by machine began to be produced in the late 1830s and are almost indistinguishable from the cut nails produced today. Machinemade wire nails were developed in the 1850s and were being produced in larger sizes and greater quantities by ca. 1890 (Nelson 1968; Moncure 1984:126). Cut nails have greater holding power, but by the 1890 s, wire nails began to replace them as the more common nail because of their relative cheapness, ease of handling, and greater variety of sizes. Nelson (1968) generalized that the presence of wire nails indicates maintenance and repairs or alterations no earlier than the late nineteenth century. The dominance of cut nails in this sample suggests that most of the construction was done with cut nails because wire nails either were not available or only became available after most of the original construction was completed. Other miscellaneous hardware includes two bolts, a lining or decorative nail, and an assortment of unidentified metal bands and fragments.

Fencing materials also are a substantial component of this sample. Twelve 1-1/4-inch staples were found, along with various lengths of wire. The staples are identical to those advertised as fencing staples in the 1897 Sears Roebuck Catalog (Israel 1976). The four pieces of barbed wire recovered are all Burnell's Four-Point which was patented by Arthur S. Burnell of Marshalltown, Iowa, on June 19, 1877 . Burnell's Patent No. 192225 was on a double wire strand with a fourpoint barb (Clifton 1970:150). This was one of the most successful of the four-point, double-strand varieties and has been found in Kansas, Missouri, Colorado, and Texas. This type of barbed wire is also typical of the period from 1867-1880 when most of the new barbed wire invented was classified as "vicious" because of the damage done to livestock coming into contact with it (McCallum and McCallum 1965:251-252). The remaining wire 
fragments are various lengths of fencing and gate wire.

In the category of firearms, 10 cartridges, 1 grooved bullet base, and 1 lead shot fragment were found. The cartridges represent four different calibers and several different manufacturers. There are two major classifications of cartridges: rimfire and center-fire. Rim-fire cartridges are fired by the priming compound distributed around the inside of the rim's outer diameter, while center-fire cartridges are fired by a primer located in the center of the casehead (Barnes 1989:9). Most of the cartridges have headstamps, i.e., markings on the cartridge case head, and attempts were made to identify each cartridge as fully as possible. In some cases, especially where no headstamp is present, the cartridge dimensions were used to aid identification.

One .32-caliber rim-fire cartridge was collected. It's only marking is the headstamp "U," which identifies it as a product of the Union Metallic Cartridge Company founded in 1867. This company merged with Remington Arms in 1911 to become the Remington Arms-Union Metallic Cartridge Company, which in 1921 became the Remington Arms Company, Incorporated, by which name it is still known (White and Munhall 1977: 31 ). The cartridge measures closest to a .32 Long, which was originally a revolver caliber but was also used extensively in various rifles. It was introduced in 1861 for the Smith \& Wesson New Model \#2 revolver and was soon being produced by a variety of manufacturers. The Colt New Line revolvers, made from ca. 1873 to 1884 , also used this caliber. The .32 Long was listed in catalogs around 1930 but is no longer produced in the United States (Flayderman 1980:97; Bames 1989:364, 373).

Two cartridges with headstamps of "WRA Co 38 WCF" are .38-caliber Winchester center-fire cartridges made by the Winchester Repeating Arms Company. The initials "WRA Co" have been used since 1866 to represent the Winchester Repeating Arms Company and its successors, based in New Haven, Conneticut (White and Munhall 1977:156). These could be either pistol or rifle cartridges, but it is not possible to be more specific since exact measurements could not be made.

Five .44-caliber center-fire cartridges were found, four of which have headstamps. Three of these were made by the Winchester Repeating Arms
Company, with two stamped "WRA Co 44 WCF" and the other "WRA Co 44 CFW" (White and Munhall 1977:156). These were all produced by the same company, but the difference between a cartridge stamped WCF (Winchester center-fire) and one stamped CFW (center-fire Winchester) is unclear. It may simply be an indication of a different time period of manufacture. The fourth cartridge has a headstamp of "UMC 44 CFW." It was made by the Union Metallic Cartridge Company of Bridgeport, Connecticut. As previously mentioned, this company was founded in 1867 and in 1911 merged to become the Remington ArmsUnion Metallic Cartridge Company, at which time the initials REM-UMC were used (White and Munhall 1977:148). Therefore, this particular cartridge dates between 1867 and 1911. The last cartridge of this caliber does not have a headstamp, but its dimensions are closest to a .44-caliber Colt (Barnes 1989:246, 256), which was introduced in 1871. The dimensions of the other cartridges failed to provide enough information to be more specific about the type of firearm represented.

The remaining two cartridges are both $.45-$ caliber center-fire specimens, only one of which has a headstamp. This cartridge is stamped "D.C. Co. 45 Colt" and was made by a Canadian company, the Dominion Cartridge Company, that was founded in 1886 and later became the Dominion Ammunition Division of Canadian Industries Limited. This particular headstamp was used from 1886 until at least 1913 (Mueller and Olson 1968: White and Munhall 1977:62). The other cartridge does not have a headstamp and is also missing its primer but measures closest to a .45 Colt. The .45 Colt was introduced in 1873 and was the favorite handgun caliber until 1892 (Barnes 1989:250, 256).

Parenthetically, it is worth noting that the four cartridges recovered during the survey phase include one .32-caliber rim-fire, one .38-caliber centerfire, and two .44-caliber center-fires. The .32caliber rim-fire cartridge has an " $\mathrm{H}$ " as a headstamp, which belongs to the Winchester Repeating Arms Company (White and Munhall 1977:23). This cartridge measures closest to an Extra Short cartridge which was used in pistols and was available ca. 1880-1920 (Barnes 1989:363). All of the center-fire cartridges were made by the Winchester Repeating Arms Company, with headstamps of "WRA Co 38 WCF" and "WRA Co 44 WCF" (White and Munhall 1977:148). These date from 
1866 to 1911.

Only three clothing-related artifacts were found. This includes two 2-hole, sew-through buttons; both are corroded, but one has a faint crosshatch pattern on the surface. The other clothing article is a rivet with a five-point star stamped on its surface. The only personal item found is a small cog, probably from a pocket watch or clock. All of the remaining metal artifacts recovered have been classified as other; most of these are objects with no identifiable purpose, but one horseshoe nail is included.

\section{Ceramics}

A total of 81 ceramic items was recovered from $41 \mathrm{KT} 42$ during data recovery (Table 6). The majority of these are coarse earthenware vessel fragments, but a small amount of whiteware and ironstone also was found. Two bisque doll parts and one pipe bowl fragment complete the ceramic inventory.

Of the sherds recovered, 52 are coarse earthenwares representing at least five different vessels. Most are body sherds, but base sherds and several rim fragments also are included, along with two handles (each from a different vessel).

Various glazing styles are the only form of decoration on the recovered earthenware. Most common is a cream to light gray salt glaze on the exterior of the vessel, while the interior is coated with an Albany slip glaze. The second variation is an Albany slip glaze on both the exterior and interior. The final variation is a salt glaze on the exterior and interior.

The use of a salt glaze to enhance the appearance and durability of a pot was first developed during the fifteenth century in Germany and has since been a standard treatment for earthenware. Salt glazing was the most commonly used utilitarian glaze throughout the nineteenth century and only began to diminish in popularity at the start of the twentieth century (Greer 1981:180-181). Prior to 1850 , vessels often had little or no salt glazing on the interior, due to the way pots were stacked in kilns. After 1850, it became the custom in the United States to pour a glaze solution into the interior to ensure a proper glaze (Greer 1981: 192). Only one vessel from $41 \mathrm{KT} 42$ has a salt glaze on both the exterior and interior and therefore probably was made after.1850. The salt glazes on all sherds have the creamy beige or gray color typical of salt glazes, as well as the characteristic orange-peel texture.

By the beginning of the nineteenth century, the Albany slip glaze was being utilized. During the last quarter of that century and the early twentieth century, Albany slip glaze became the most popular glaze of the slip type. These natural clay glazes were the second most common glaze used on utilitarian earthenware. The original clay used for this glaze was from Albany, New York, and was transported by railroad all over the United States. The complication with the term "Albany" slip glaze is that even when local clays were used for the glaze, rather than those actually from Albany, the glaze

\begin{tabular}{|l|l|l|c|c|}
\hline \multicolumn{5}{|c|}{ TABLE 6 } \\
\hline & & Vessel Form & $\begin{array}{l}\text { No. of } \\
\text { Sherds }\end{array}$ & $\begin{array}{l}\text { Minimum No. } \\
\text { of Vessels }\end{array}$ \\
\hline Ware & Decoration & large jar & 30 & 2 \\
\hline Coarse earthenware & Salt glaze/Albany slip & jar, small jug & 20 & 2 \\
& Albany slip & jar & 2 & 1 \\
\hline Whiteware & Salt glaze & plate, saucer & 11 & 3 \\
& Undecorated & teacup & 13 & 4 \\
\hline Ironstone & Undecorated & plate & 2 & 1 \\
\hline Totals: & \multicolumn{3}{|l|}{} \\
\hline NOTE: Two bisque doll parts and one clay pipe bowl fragment also were recovered. & 78 & 13 \\
\hline
\end{tabular}


was still called Albany. Therefore, unless the clay source is actually known, slip glazes of this type are commonly referred to as an Albany slip glaze. The use of a slip glaze on the interior of a vessel with a salt glaze on the exterior became essentially a standard practice with potters after 1850 (Greer 1981:179-197). The vessel fragments with this glaze are probably most typical of those produced after 1850. Slip glazes were used on the exterior of pots if the clays available to the potter did not take a salt glaze well (Greer 1981:197). Around 1875 , the use of a slip glaze on the interior and exterior became popular. The colors represented by the sherds range from the dark glossy brown most typical of Albany slip glazes to the ruddy browns which are also common.

A minimum of five vessels is probably represented by the earthenware sherds. These are mainly large straight-sided jars, but at least one small jug is represented. The jug has a small mouth with a lid ledge on the interior. It also has two small holes pierced through the rim, possibly for a carrying strap or thin handle.

Whiteware forms the second most common type of ceramic found. None of the 24 sherds recovered have any form of decoration. At least seven vessels are represented by several plate fragments, at least one saucer, and what appear to be the remains of four teacups. Whiteware does not have a definitive date of introduction but is known to have developed out of pearlware in the 1820 s. After the 1820 s, undecorated vessels tend to be kitchen wares, such as plates and bowls, along with other items such as chamberpots (Miller 1980:2-3).

Only two ironstone sherds were found. One is a body sherd, and the other is the base of a plate with a fragmentary hallmark on the bottom that includes the hindquarters of a lion with the letters "IR. .." (probably "IRONSTONE CHINA") above the design and the letter "J. .." below. This hallmark was registered to J. and G. Meakin of Eastwood Works, Hanley, England. This group of potters was founded in 1851 and continues to operate today (Wetherbee 1985:22,133). Like the whiteware, these sherds have no decoration other than the plain white glaze. Plain white ironstone came into popularity in the mid 1850s (Miller 1980: 29). White ironstone which was made in England and sold in the United States was popular during the 30 -year period from 1840 to 1870 but declined in popularity after 1900 (Wetherbee 1985:6).

Nonvessel ceramics include two toy pieces and one pipe bowl fragment. Both toy pieces are doll parts made of white bisque and of a solid composition with mold marks at the seams. One is a hand and wrist fragment, with the fingers roughly delineated, while the other is part of a leg, most likely the calf.

Only a very small rim fragment of a pipe bowl was recovered. It is made of a fine brown paste and has a band running parallel to the rim. Additional bands extend perpendicular to this first band. It may also have a brown glaze, slightly darker than the paste. There is very little discoloration on the interior, so the pipe probably was not used heavily prior to breaking. The fragment is too small for any estimates on bowl shape, bore diameter, or other diagnostic characteristics.

\section{Glass}

Glass is the largest category of artifacts found at $41 \mathrm{KT} 42$, with 252 fragments recovered. The majority of these are unidentified bottle fragments, but several diagnostic partial bottles are present. With the exception of two pieces of flat window glass, all of the glass falls into the functional category of containers (Table 7).

\begin{tabular}{|l|l|r|r|}
\hline \multicolumn{4}{|c|}{ TABLE 7 } \\
\hline Functional & & No. of & \\
Category & Artifact Category & Specimens & Percent \\
\hline Containers & Unidentified & & \\
& fragments & 228 & 90 \\
& Base fragments & 7 & 3 \\
& Neck fragments & 8 & 3 \\
& Pressed glass & 7 & 3 \\
\hline fragments & Window glass & 2 & 1 \\
\hline Totals: & & 252 & 100 \\
\hline
\end{tabular}

Ninety percent of all the glass collected could be identified only to the level of bottle glass fragments. The colors of the bottle glass range from clear to amber (Table 8). A distinction was made between green and dark green glass as well as 


\begin{tabular}{|l|c|c|}
\hline \multicolumn{3}{|c|}{ TABLE 8} \\
\hline \multicolumn{2}{|c|}{ RANGE OF BOTTLE GLASS COLORS, 41KT42 } \\
\hline Color & No. of & \\
\hline Clear & Specimens & Percent \\
Green & 66 & 26 \\
Dark green & 24 & 10 \\
Blue & 33 & 13 \\
Aqua & 7 & 3 \\
Purple & 2 & 1 \\
Brown & 78 & 31 \\
Opaque (milk glass) & 23 & 9 \\
Amber & 1 & $<1$ \\
\hline Total: & 16 & 6 \\
\hline
\end{tabular}

between brown and amber glass. Purple glass, also called lavender or amethyst, is the dominant color group $(31 \%)$. This high percentage is most likely due to the fact that these artifacts were collected from the surface, and the purple tint is a result of the manganese present in clear glass being exposed to sunlight (ultraviolet rays).

Color is not generally indicative of time periods or use, but it is possible to make certain generalizations based on color. Clear glass was widely used for a variety of bottles and was especially common after 1875 . Green and dark green glass also had a variety of uses, including as containers for wine and mineral water, from around 1865. Blue glass was used from the 1890 s to the 1960 s, typically for medicines, soda water, and cosmetics. Aqua glass was very common and used for nearly any product. Brown and amber glass was widely used after 1860 , especially for alcoholic beverages. Opaque glass, or milk glass, was used for medicines, cosmetics, and food from the 1890 s to the 1960s (Fike 1987:13). While it is not possible to identify the function of a bottle fragment based on its color, it is possible to recognize that certain glass colors were often used for specific products.

No complete bottles were found, but both bottle necks and bases were collected. Of the eight necks collected, two are complete and six are fragments. Both of the complete necks have handtooled lips and therefore probably date prior to the turn of the twentieth century when machinemade bottles became popular (Lorrain 1968:38). One of these is of purple glass and has a patent, or extract, neck finish, while the other is aqua glass with a bead neck finish (Herskovitz 1978:5). One of the neck fragments is clear glass with a bead neck finish. It appears to be hand tooled and possibly was burned or subjected to high temperatures. The remains of two snuff jars are also present. One is clear glass, and the other is brown; both appear to have the rounded lip and squarish body typical of snuff bottles (Herskovitz 1978:4). The other fragments can be identified no further than belonging to bottle necks.

Seven base fragments, three rectangular and four circular, were recovered. The first of the rectangular bases is of purple glass with a Blake (Variant 1) base profile (Fike 1987:10). This is a small bottle with indented panels, probably on all four sides, and was most likely a medicine bottle. The other two rectangular bases are fragmentary; one is purple glass with at least one indented panel, and the other is a thick, clear glass.

The other four bases are circular and incomplete. Three are of dark green glass, and one is purple glass. Two of the dark green fragments fit together; thus, while there are three dark green base fragments, only two different bottles are represented. The two that fit together are a heavily patinated thick glass, with a portion of a deep kick-up remaining. The other dark green base fragment is also thick but has a shallow kick-up. The purple base represents a small bottle with a slightly beveled edge at the base.

Seven pressed glass fragments were recovered, some with simple band designs and others with lettering. Square or rectangular bottles with indented panels containing lettering first appeared around 1867. The raised lettering on these bottles usually gave the contents and often the city and state of the manufacturer of the product. These bottles are most commonly found in connection with patent medicines (Lorrain 1968:40; Wilson 1981: 39-61). Four panels with lettering were collected, all of which are a thick clear glass. Two of these panels fit together to spell ". . ARSA ...," which is probably a portion of the word sarsaparilla, a common ingredient in many medicinal products (Fike 1987:214-221). The remaining two panels are too fragmentary to be able to identify anything other than isolated letters. One panel has the letter " $L "$ which appears at the end of a word, followed by another word beginning with "M." The last 
panel is heavily patinated and has at least one word, beginning with an "S." The remaining pressed glass pieces are decorative; two have a pattern of rings around the neck, and the last fragment has a line along the body.

Only two fragments of flat glass were recovered. Both are window glass and are too small to determine anything about method of manufacture.

\section{Miscellaneous Artifacts}

The remaining artifacts recovered from $41 \mathrm{KT} 42$ are all isolated materials which do not fit into one of the larger material groups. These include shell, stone, rubber, and bone. The shell artifact is a small circular button that is broken but appears to be a 4-hole sew-through type. One pumice stone was recovered. It is a small rectangular slab with rounded edges. One end has been worn down at an angle in comparison to the other end, which is a flat surface. The rubber fragment is very small and is not identifiable other than to material type. Ten fragments of bone were found, all of which are burned. These are all small fragments and are not species identifiable, but some definitely represent large mammals (cf. Bos or Bison).

\section{Discussion of Component}

The goal of the data recovery investigations at $41 \mathrm{KT} 42$ was to provide additional information to complement and enhance the site's history and place it within a regional context. The history of the construction, use, and abandonment of the site is not well documented by the archival and informant evidence, thus strengthening the importance of the archeological remains.

The total number of artifacts recovered to date is 634 , with 4 specimens from the survey phase, 60 from the testing phase, and 570 from the data recovery phase (Table 9). Of these, the vast majority are glass $(41.5 \%)$, metal $(40.9 \%)$, and ceramics $(13.9 \%)$, with only minor amounts of bone $(2.5 \%)$ and other materials (1.3\%) represented.

This section considers the artifacts from a number of view points: (1) what each material category indicates in terms of site chronology, site function, and socioeconomic indicators; and (2) what the distribution of artifacts by functional classes indicates about intersite activity patteming. Through these interpretations of the cultural materials, an attempt is made to complement and expand what is known about the site.

\section{Site Chronology}

Of the 574 surface artifacts recovered from $41 \mathrm{KT} 42,558(97 \%)$ are functionally identifiable. The majority of these are identifiable only in general terms, e.g., can fragments and bottle glass fragments, but many also have characteristics and attributes that are temporally diagnostic. The temporal designations are most easily presented in terms of material and are further subdivided by functional class.

\section{METAL}

A variety of the metal artifacts can be related

\begin{tabular}{|l|c|r|r|r|r|}
\hline \multicolumn{7}{|c|}{ TABLE 9 } \\
\hline Material & & & & & \\
Classification & 1987 Survey & 1988 Testing & Data Recovery & Total & Percent \\
\hline Metal & 4 & 31 & 224 & 259 & 40.9 \\
Ceramic & - & 7 & 81 & 88 & 13.9 \\
Glass & - & 11 & 252 & 263 & 41.5 \\
Bone & - & 6 & 10 & 16 & 2.5 \\
Other* & - & 5 & 3 & 8 & 1.3 \\
\hline Totals: & 4 & 60 & 570 & 634 & 100.1 \\
\hline *Includes rubber, leather, wood, shell, and stone & & & \\
\hline
\end{tabular}


to a specific time period, including cans, nails, barbed wire, and ammunition cartridges (Table 10). The most common can is the lap-seam, stampedend type that was not produced until 1847. This was improved on in 1888 by the double-seam, stamped-end can, which in turn was replaced by the sanitary can ca. 1904 (Rock 1984:100-102). Holein-cap can ends were being produced in the 1820 s, but at $41 \mathrm{KT} 42$ they are found in association with lap-seam, stamped-end cans that again indicate manufacture after 1847. Hole-in-top can ends were not developed until the turn of the twentieth century, while the flat, oblong, sardine-type can was common after 1866. The characteristics of the cans indicate that their earliest availability was ca. 1850 lasting up to the turn of the century. Sanitary cans, the predominant type after 1904, were not found, providing a definitive time limit for the can age range.

Two types of nails were found at $41 \mathrm{KT} 42$, both of which are machinemade. The most common is the cut nail, which was being manufactured by the late 1830s. Machinemade wire nails were developed in the $1850 \mathrm{~s}$, but the technology to produce them in large quantities was not available until 1890 (Nelson 1968). The small number of wire nails recovered suggests that construction probably occurred prior to 1890 .

All of the identifiable barbed wire is of a variety known as Bumell's Four-Point which was patented in 1877 (Clifton 1970:150). This was one of the most popular forms of double-strand barbed wire in the period from 1877-1880 (McCallum and
McCallum 1965:251-252).

The ammunition cartridges are temporally diagnostic because in most cases it is possible to place them in time periods based on the companies manufacturing the ammunition or the firearms themselves. Among the 13 cartridges, at least three different companies are known to be represented, based on the headstamps. The Union Metallic Cartridge Company headstamp was used from 1867-1911, the Winchester Repeating Arms Company headstamp was first used in 1866 , while the Dominion Cartridge Company headstamp was probably used ca. 1886-1913 (Mueller and Olson 1968; White and Munhall 1977:31, 62, 156). Based on this information, it appears that the earliest any of these cartridges were made was in 1866 and that they were common into the early 1900 s.

\section{CERAMICS}

Like the metal artifacts, certain characteristics of the ceramics are also temporally diagnostic. The majority of the ceramics recovered are vessel fragments (Table 11). These ceramics in general are typical of a broad time range, but the glazes and combination of glazes also are characteristic of more-specific time periods.

The only decorations found on the coarse earthenware sherds are various combinations of glazes: a salt glaze on the exterior with an Albany slip glaze coating the interior, an Albany slip glaze on both the exterior and interior, and a salt glaze on both the interior and exterior. The combination of

\begin{tabular}{|l|l|l|l|c|}
\hline \multicolumn{5}{|c|}{ TEMPORALLY DIAGNOSTIC METAL ARTIFACTS, 41KT42 } \\
\hline $\begin{array}{l}|c| \\
\text { Functional }\end{array}$ & & Initial Date of & General Period of & No. of \\
Category & Artifact Characteristic/Type & Manufacture & Availability & Specimens \\
\hline \multirow{2}{*}{ Containers } & Lap-seam cans, stamped end & 1847 & $1847-1888$ & 5 \\
& Double-seam cans, stamped end & 1888 & 1888 -ca. 1904 & 2 \\
& Hole-in-cap ends & ca. 1820 & 1820 -ca. 1900 & 2 \\
& Hole-in-top ends & 1866 & $1900-?$ & 3 \\
& Flat (sardine) can & 1900 & $1866-?$ & 1 \\
\hline \multirow{2}{*}{ Structural } & Cut nails & 1850 s & 1830 s-1890 & 17 \\
& Wire nails & 1877 & $1890-$ modern & 3 \\
\hline Fencing & Barbed wire & $1866-1886$ & $1877-?$ & 4 \\
\hline Firearms & Cartridges & $1866-1913$ & 13 \\
\hline
\end{tabular}




\begin{tabular}{|c|c|c|c|}
\hline \multicolumn{4}{|c|}{$\begin{array}{c}\text { TABLE } 11 \\
\text { TEMPORALLY DIAGNOSTIC CERAMIC } \\
\text { ARTIFACTS, 41KT42 }\end{array}$} \\
\hline Ware & Decoration & $\begin{array}{l}\text { Minimum } \\
\text { No. of } \\
\text { Vessels }\end{array}$ & $\begin{array}{l}\text { Characteristic } \\
\text { Time Period }\end{array}$ \\
\hline $\begin{array}{l}\text { Coarse } \\
\text { earthenware }\end{array}$ & $\begin{array}{l}\text { Salt glaze/ } \\
\text { Albany slip } \\
\text { Albany slip } \\
\text { Salt glaze }\end{array}$ & $\begin{array}{l}2 \\
2 \\
1\end{array}$ & $\begin{array}{l}\text { after } 1850 \\
\text { after ca. } 1875 \\
\text { after } 1850\end{array}$ \\
\hline Whiteware & Undecorated & 7 & after $1820 \mathrm{~s}$ \\
\hline Ironstone & Undecorated & 1 & after 1850 \\
\hline
\end{tabular}

a salt glaze on the exterior and an Albany slip on the interior, and the use of a salt glaze on both the interior and exterior, are typical of the period after 1850. The use of an Albany slip glaze on both the exterior and the interior was not a common practice with potters until the mid 1870s (Greer 1981:179197).

Whiteware was available sometime after the $1820 \mathrm{~s}$, but since it is undecorated, it is difficult to assign the sherds to a more definitive period (Miller 1980:2-3). Only two small fragments of ironstone were found, one of which has the only hallmark found in the ceramic assemblage. The hallmark was registered to a company of English potters, J. and G. Meakin, and was used from 1851 onward (Wetherbee 1985:22,133). Plain white ironstone was popular in the United States from 1840 to 1870 but declined in popularity by the turn of the century (Wetherbee 1985:6).

Unfortunately, the pipe bowl fragment and the doll parts are too small to be temporally diagnostic, other than in a very broad, general sense. Clay pipes were a common fixture from before colonial times, but the bowl fragment recovered is too small to be identified further in terms of shape, bore diameter, or any other temporally diagnostic characteristic. Likewise, the doll fragments are also typical of a broad time span beginning as early as the 1800s. Dolls and doll parts were made by numerous manufacturers, in varying quantities and qualities (Hume 1969:319). Both the hand fragment and the leg fragment are too small to be indicative of any specific time period.
GLASS

Ninety-nine percent of the glass recovered is bottle glass; the remaining $1 \%$ is flat window glass. Of the bottle glass, $91 \%$ is identifiable only to the level of fragments, with the remainder being diagnostic bottle parts.

No complete bottles were found, but some of the bases and necks recovered have attributes that are temporally diagnostic (Table 12). The necks with lips remaining are all hand tooled, indicating manufacture prior to 1900 when completely machinemade bottles came into popularity (Lorrain 1968:38). Other datable bottle characteristics include pressed glass with examples of square or rectangular bottles with indented panels, often with lettering, which first appeared ca. 1867 (Wilson 1981:39-61).

\begin{tabular}{|c|c|c|c|}
\hline \multicolumn{4}{|c|}{$\begin{array}{l}\text { TEMPORALLY DIAGNOSTIC GLASS } \\
\text { ARTIFACTS, } 41 \mathrm{KT} 42\end{array}$} \\
\hline $\begin{array}{l}\text { Artifact } \\
\text { Type }\end{array}$ & $\begin{array}{l}\text { No. of } \\
\text { Specimens }\end{array}$ & $\begin{array}{l}\text { Diagnostic } \\
\text { Characteristics }\end{array}$ & Time Period \\
\hline $\begin{array}{l}\text { Base } \\
\text { Base } \\
\text { Lip } \\
\text { Body }\end{array}$ & $\begin{array}{l}1 \\
1 \\
3 \\
7\end{array}$ & $\begin{array}{l}\text { Rectangular, } \\
\text { indented panels } \\
\text { Indented panel } \\
\text { Hand tooled } \\
\text { Pressed glass }\end{array}$ & $\begin{array}{l}\text { after } 1867 \\
\text { after } 1867 \\
\text { before } 1900 \\
\text { after ca. } 1867\end{array}$ \\
\hline
\end{tabular}

Fragments constitute the remainder of the bottle glass, with color being the only other readily distinguishable characteristic. It is possible to use the color of the fragments, with caution, to indicate general periods when certain colors were more common than others (Table 13). This should not be used as a primary time reference for glass but does give additional circumstantial information that may support other temporal assessments. The lavender glass is not separated but is included with the clear glass since the purple tint is usually the result of the manganese in the glass being exposed to ultraviolet rays. As seen, the colors represented are all characteristic of the mid to late 1800 s and agree with the time ranges of the other bottle characteristics. The high percentage of clear glass may reflect an increased demand by 1880 for clear glass containers, primarily for food (Fike 1987:17). 


\begin{tabular}{|l|c|r|l|}
\hline \multicolumn{4}{|c|}{ TABLE 13 } \\
\hline \multicolumn{4}{|c|}{ TEMPORALLY DIAGNOSTIC BOTTLE } \\
GLASS COLORS, 41KT42 \\
\hline & No. of & & \\
Color & Specimens & Percent & Time Period \\
\hline Clear & 144 & 57.6 & after 1875 \\
Green & 57 & 22.8 & after ca. 1865 \\
Blue & 7 & 2.8 & $1890-1960$ \\
Aqua & 2 & 0.8 & common since 1800s \\
Brown & 39 & 15.6 & after 1860 \\
Opaque & 1 & 0.4 & $1890-1960$ \\
\hline Total: & 250 & 100.0 & \\
\hline Derived from Fike (1987:13-17) \\
\hline \multicolumn{4}{|c|}{} \\
\hline
\end{tabular}

\section{CHRONOLOGICAL SUMMARY}

From the artifacts collected at $41 \mathrm{KT} 42$, it is possible to reach conclusions about the period of occupation at the site. All of the diagnostic artifacts generally date after 1850 but are not characteristic of the twentieth century. It would appear that this site was most actively occupied from the 1850 s until 1900 , and in fact several of the artifacts were manufactured no earlier than the $1860 \mathrm{~s}$, 1870 s, and 1880 s. The lack of artifacts diagnostic of the early 1900s suggests that the site was not as active at this time.

It should be pointed out that no apparently modern materials are present, although they might be expected since the area is currently a favorite public spot. This may also account for the low number of more-intact diagnostic artifacts, such as complete bottles, which may have been collected as souvenirs.

\section{Site Function}

Based on the previous investigations, the presumed function of $41 \mathrm{KT} 42$ was as a cattle company line camp (Freeman and Boyd 1990:106). The kinds of artifacts expected to occur on this type of site would include structural items, kitchenwares, ranching paraphernalia, and firearms, and these are the types of artifacts that were found.

The structural items recovered, such as the nails, window glass, and other miscellaneous hardware, are typically found at historic house structures. It is surprising that more items of these types were not found; however, since this area is a popular picnic spot, many surface artifacts may have been collected through the years since abandonment of the site.

The recovered kitchenware items include ceramics, glass, and metal. The coarse earthenwares are containers and jars of various sizes and of the types that would be used to prepare and store food products. The other kitchenware ceramics, whitewares and ironstones, are examples of items that were readily available during the nineteenth century. Undecorated plates, bowls, and cups were the most common and generally most inexpensive forms of tableware (Miller 1980:3-4).

Except for the two pieces of window glass, all of the other glass fragments belong to containers. These include beverage bottles, such as for wine and beer, patent medicine bottles, snuff bottles, and other generic glass containers. These are the types of utilitarian and personal glassware that would be used on a daily basis.

The large number of metal can fragments and cans is not unusual. Canned food was available from the early 1800 s and by mid century was a common staple.

Being a line camp, it also is not surprising to find an assortment of fencing materials, including barbed wire, fencing staples, and fencing and gate wire. The single horseshoe nail found also indicates the presence of horses.

All of the cartridges recovered are of the common calibers used in pistols, revolvers, and rifles that are typical of the mid to late $1800 \mathrm{~s}$. The cartridge made by the Dominion Cartridge Company, based in Canada, is the only unusual occurrence.

Few personal and clothing items were collected, and those that were are not out of the ordinary. They include buttons, a pipe fragment, a cog possibly from a pocket watch, and a clothing rivet. Less common is the pumice stone.

The only artifacts found that are surprising are the two doll parts. Given that this was a line camp, presumably principally occupied by men, the presence of a doll is unusual. It may have been intended as a gift, or possibly a family was there at some period.

All of the artifacts at $41 \mathrm{KT} 42$, with the exception of the doll parts, are typical of what would be expected at a line camp. They are all 
functional and utilitarian items representing domestic (household) or ranching (livestock-related) activities.

\section{Socioeconomic Indicators}

As demonstrated in the preceding section, most of the artifacts are typical of what would be expected at a line camp. All of the materials are utilitarian and functional and used for specific purposes in daily existence.

The metal artifact group consists primarily of cans and can fragments, nails, fencing materials, and cartridges. All of these are typical of the mid 1800 s on, and all are items that would have been used on a daily basis. Both the ceramics and glass are likewise typical of this period and are representative of daily activities. The ceramics, including the whitewares and ironstones, are examples of the less-expensive utilitarian wares available (Miller 1980). The identifiable glass is representative of the types and forms of bottles commonly available, such as wine and liquor bottles and patent medicines. The clothing and personal items are also examples of functional objects that were commonly available.

In terms of socioeconomic status, all indications support the concept of a line camp. Most of the artifacts can be classified as utilitarian and served practical rather than nonutilitarian purposes. All are representative of the types of goods readily available through the late 1800 s and early 1900 s.

\section{Intrasite Activity Patterning}

This section discusses the distribution of artifacts by material and functional class to reveal information about activities at $41 \mathrm{KT} 42$. Only those artifacts collected from the surface in the collection grids were used in this analysis. None of the artifacts excavated during the testing phase are included because differing recovery methods would bias the spatial patterning exhibited by the surface artifact distributions. Artifacts were classified by material and by functional group (Table 14). The material classes are metal, ceramics, glass, bone (not included in Table 14), and miscellaneous, while the functional groups are kitchen minus bone, architecture, firearms, clothing, personal, ranching, and unknown. These functional classes are modified from South (1977:95-96).

The distribution of all artifacts composed of the four materials and the seven functional groups shows that two large oblong concentrations occur near the northwest and southeast comers of the structure (Fig. 8a). Three additional small concentrations occur northeast, southwest, and south of the structure.

By materials, the greatest number of metal and ceramic artifacts occur in the two large oblong artifact clusters (Fig. $8 \mathrm{~b}$ and c). Most of the glass also occurs in these two large oblong clusters, but it comprises most of the artifacts in the three small artifact concentrations recorded in the total artifact distribution patterns (Fig. 8d). Bone only occurs in

\begin{tabular}{|l|r|r|r|r|r|r|}
\hline \multicolumn{7}{|c|}{ TABLE 14 } \\
\multicolumn{7}{|c|}{ FUNCTIONAL CLASSIFICATION OF SURFACE-COLLECTED ARTIFACTS } \\
BY MATERIAL, 41KT42 \\
Functional & & & & & & \\
Classification & Metal & Ceramics & Glass & Miscellaneous & Totals & Percent \\
\hline Kitchen & 121 & 78 & 250 & - & 449 & 79.8 \\
Architecture & 20 & - & 2 & - & 22 & 3.9 \\
Firearms* & 15 & - & - & - & 15 & 2.7 \\
Clothing & 3 & - & - & 1 & 4 & 0.7 \\
Personal & 1 & 1 & - & 1 & 3 & 0.5 \\
Ranching & 54 & 2 & - & - & 56 & 9.9 \\
Unknown & 13 & - & - & 1 & 14 & 2.5 \\
\hline & 227 & 81 & 252 & 3 & 563 & 100.0 \\
\hline Totals: & 25 & & & & \\
\hline
\end{tabular}




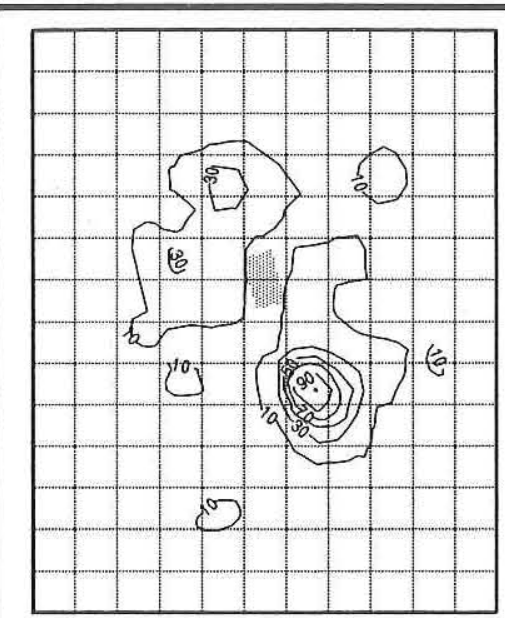

a) All Artifacts; Contour Interval=20

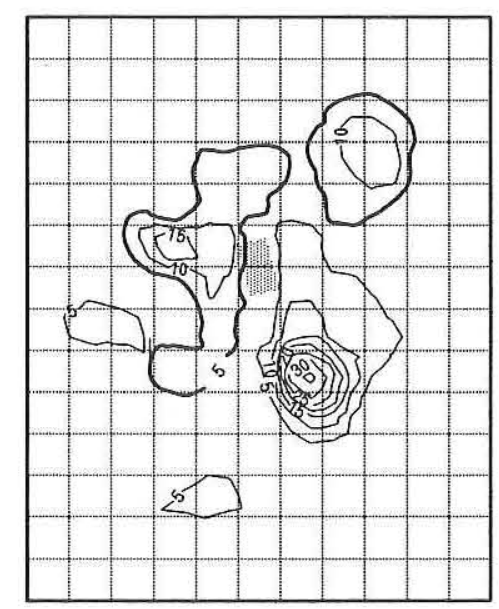

d) Glass; Contour Interval=5

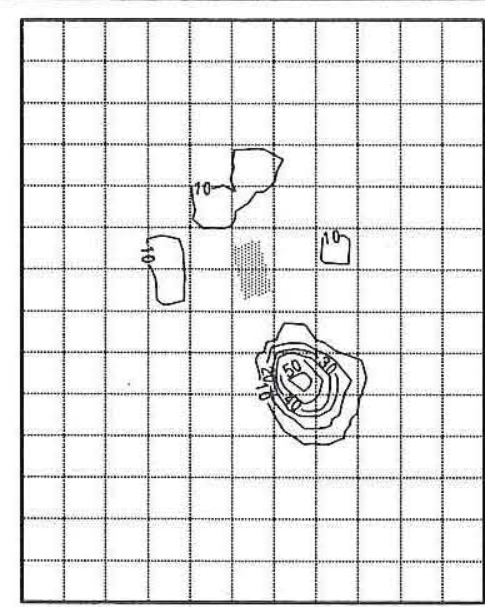

b) Metal; Contour Interval=10

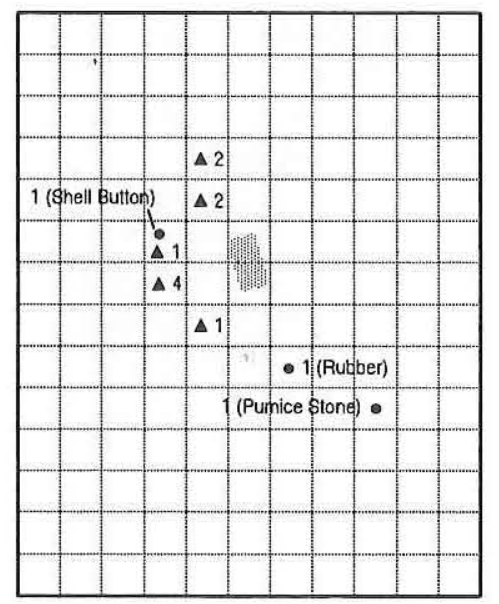

e) Other Artifacts; Bone $=\Delta$

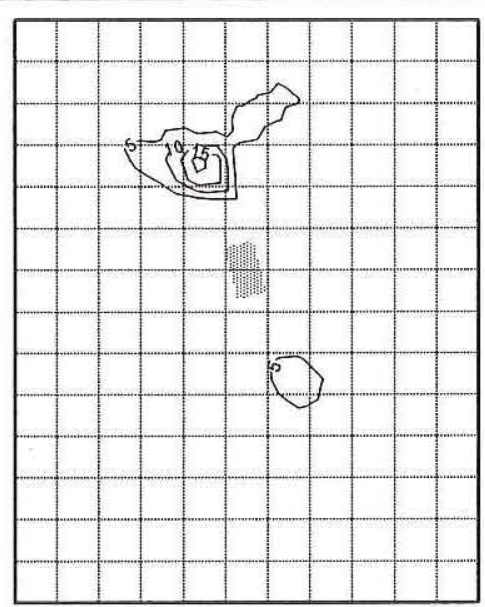

c) Ceramics; Contour Interval=5

Figure 8. Distribution of surface-collected artifacts by material type, 41KT42. Shaded area denotes the house foundation.

the northwestern large oblong cluster (Fig. 8e), and the miscellaneous artifacts are too infrequent to show any interpretable patterning. The southeastern oblong cluster is mainly composed of metal and glass, while the northwestern oblong cluster can be subdivided into two separate subclusters. The subcluster north of the structure is dominated by ceramics and metal, and the subcluster west of the structure is dominated by glass and metal.

The distribution of artifacts by functional categories also can be compared to the total artifact distributions shown in Figure 8a. The kitchen artifact group is associated with the preparation, consumption, and storage of food and consists of appropriate ceramic (ironstone and whiteware tablewares), glass (bottle necks and other fragments), and metal containers (cans and buckets). The faunal remains found on the site consisted of small fragments, and they are not included in the kitchen group because their occurrence may be due to nonhuman activities. The distribution of kitchen artifacts strongly mirrors the total artifact distribution patterns, and this is expected as they comprise the majority (80\%) of all artifacts (Fig. 9a). The two large oblong clusters as well as the three small clusters are represented by the distribution of kitchen-related artifacts. The distribution of metal cans was plotted separately, and their densest concentration is in the far south portion of the southeastern oblong cluster (Fig. 9b). This, along 


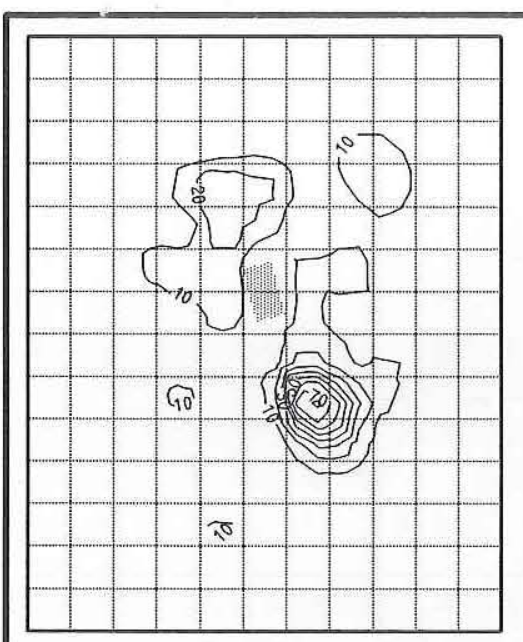

a) Kitchen Artifacts; Contour Interval=20

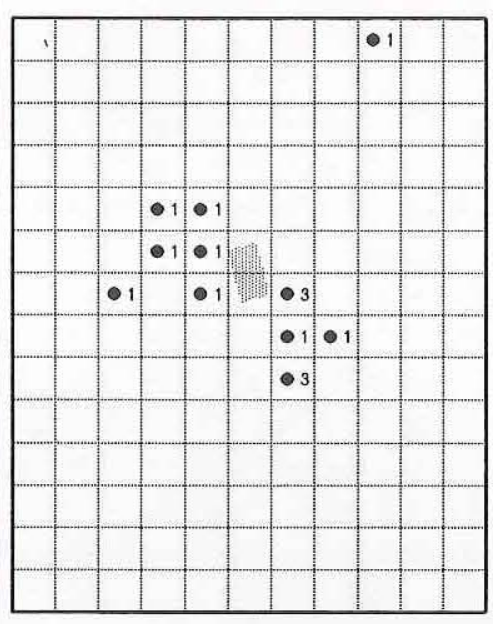

d) Firearms

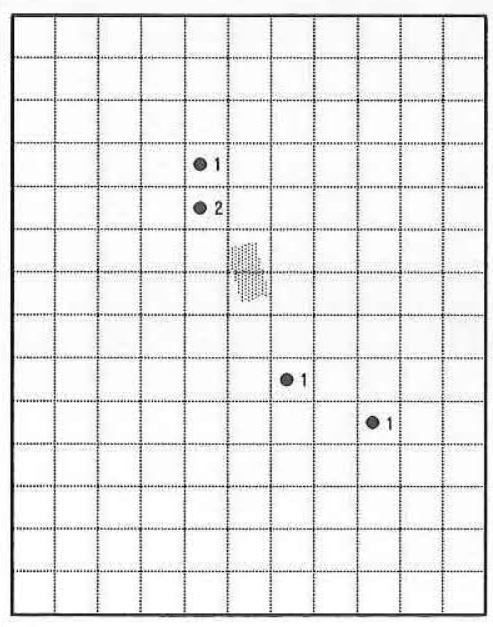

g) Personal Artifacts

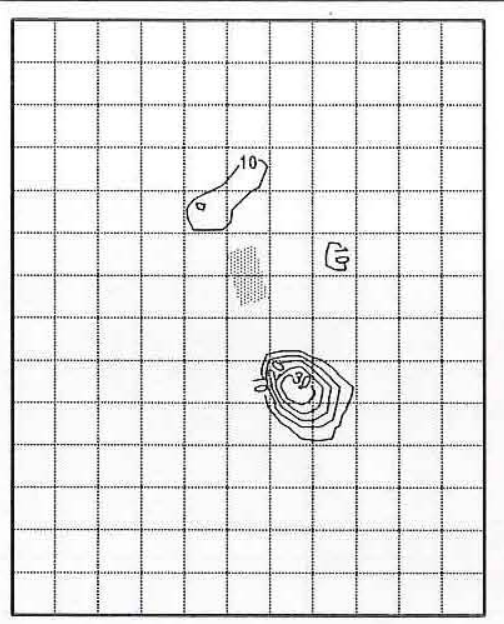

b) Can Frogments; Contour Interval=5

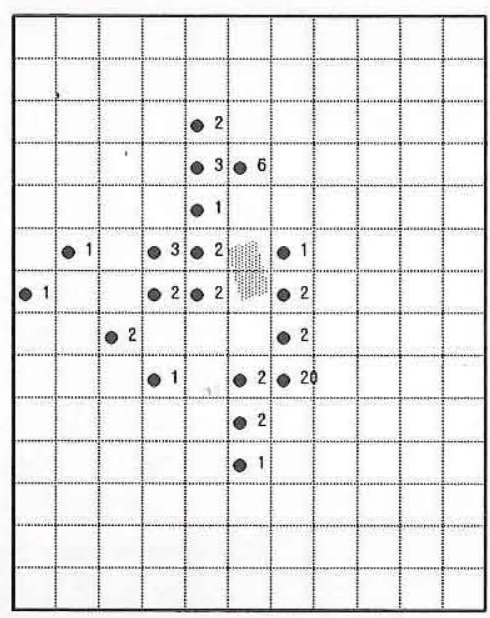

e) Ranching-related Artifacts

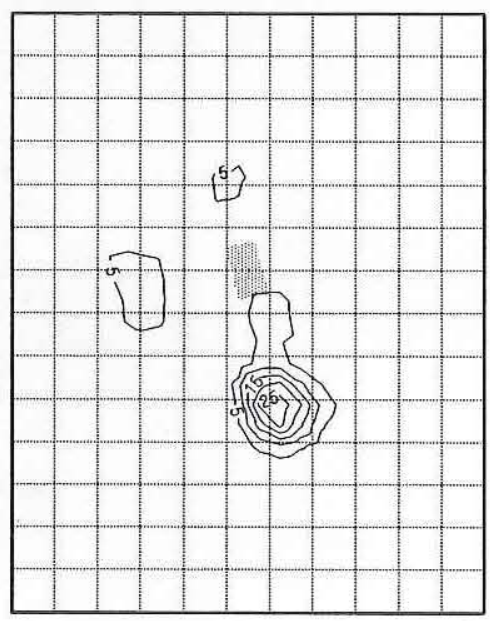

h) Nonkitchen Artifacts; Contour Interval=5

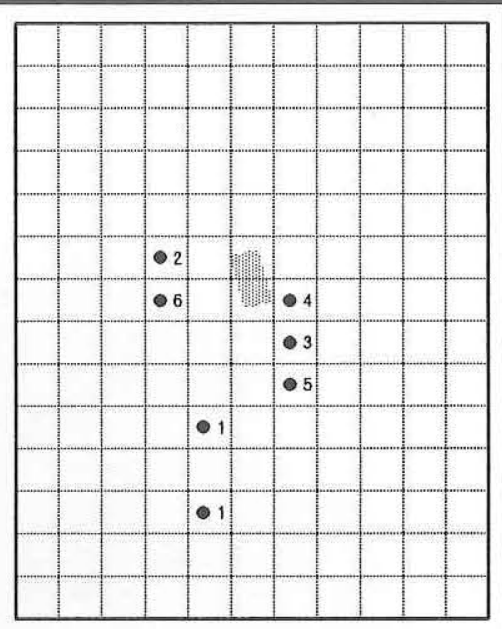

c) Architecural Artifacts

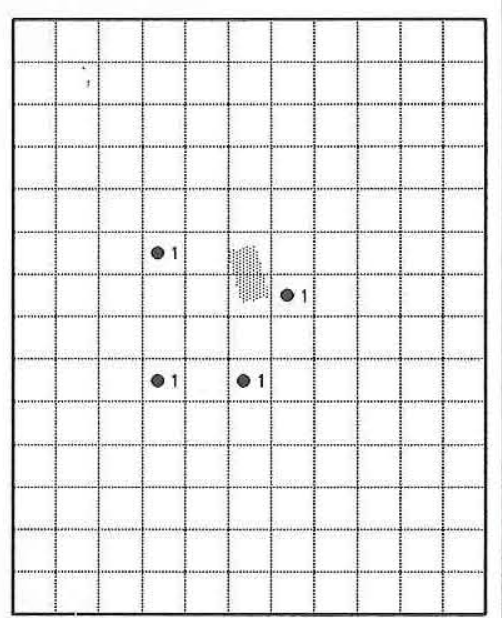

f) Clothing Artifacts

Figure 9. Distribution of surface-collected artifacts by functional categories, 41KT42. Shaded area denotes the house foundation. 
with the glass distributions (see Fig. 8d), can be used to suggest that a dump or secondary refuse concentration occurs on the south side of the structure. Ignoring this possible dump, the greatest concentration of kitchen artifacts is on the northern side of the structure, and this to a certain degree is caused by the occurrence of 23 earthenware sherds in a single collection grid. It is possible that a second less-intensively used or possibly temporary refuse dump was north of the structure, but this interpretation is not firm. Alternatively, it is possible that food preparation activities occurred more frequently on the northern portion of the site than in other areas and that kitchen-related artifacts in this area represent primary discard rather than secondary refuse dumping.

The architectural artifact group consists of wire and cut nails and window glass. Structural materials such as stone features are omitted. These artifacts are restricted to the southern portion of the site (Fig. 9c). All the wire nails were recovered west of the structure, but the cut nails enjoyed a wider distribution, and five were in the southern dump.

Thirteen spent cartridges, one lead shot fragment, and a grooved bullet base make up the firearms group. Most of these artifacts are either on the northwest or the southeast side of the structure in the two oblong artifact clusters (Fig. 9d). Three cartridges occur in the southern dump, and these are $.44, .38$, and .32 calibers. A single lead shot recovered from ca. $50 \mathrm{~m}$ northeast of the structure may not be associated.

The ranching group includes miscellaneous hardware, stable- and barn-related artifacts, and fencing and other ranching-associated artifacts. These artifacts are more or less evenly distributed across the site, except for a concentration of fencing materials (barbed wire, staples, and wire gate latches) and hardware in the southern dump (Fig. 9e).

The clothing group consists of buttons and a single rivet, and these are scattered in the southem portion of the site (Fig. 9f). The personal artifacts consist of a watch cog, a pumice stone, a pipe fragment, and doll fragments. These artifacts exhibit no concentrations and do not appear to be discarded in the dump (Fig. 9g).

Looking at material types and functional classes, there is a hazy distribution for many artifact groupings because of low frequencies.
Nevertheless, a dense concentration of a variety of artifacts occurs south-southeast of the structure, and this can be identified reliably as a secondary refuse accumulation, better known as a garbage dump. Ignoring the artifacts in this dump and using functional categories, a concentration of kitchenrelated artifacts occurs north of the structure, and the other types of artifacts were displaced slightly away from the kitchen concentration to the west, east, and south of the structure (Fig. 9h). These distributions suggest a dichotomy between different types of primary discard. Kitchen-related discard patterns (perhaps activities) seem to be spatially disjunct from primary discard patterns related to other activities. Secondary refuse discard is a third pattern that obscures and perhaps distorts the primary discard patterns.

\section{SUMMARY AND CONCLUSIONS}

There is no conclusive archival or archeological evidence regarding the construction and use of the structure at $41 \mathrm{KT} 42$. It might have been built as early as ca. 1880, when Cornelius and Mooar began ranching in Garza and Kent counties. If it is associated with Cornelius, then its construction would date sometime between 1878-1886. Informants claim that it was used as a line camp by the Longs and Connell, which would indicate that it was built by at least 1886-1901. Regardless of who was responsible, the structure probably was built prior to 1900 , and it almost certainly was originally intended to serve as a line camp. It does appear, however, to have been a rather substantial line camp compared to the numerous pre-1900 dugouts which normally functioned as line camps. Informants state that the structure was used by OS Ranch cowboys O. B. Kelley, Oliver Curtis, Ed Scott, Sr. (beginning in 1884), and Ed Scott, Jr., who came to Garza County in 1889 and worked for the ranch for more than 60 years.

The Ed Scott Cabin apparently was used as a ranching line camp into the twentieth century, but it is not clear how and when the wooden superstructure disappeared. Some claim that it was in ruins by World War I, while others think that it was still largely intact until recent years. The artifacts, however, are very characteristic of the turn of the century and suggest little or no occupation or use of the site after ca. 1920. The structure itself was 
most likely a wood frame house, and the rock (native sandstone) foundation and chimney indicate that a substantial amount of labor was invested in its construction. This type of structure was unusual for early ranching line camps, which more com- monly were simple dugouts. The surface artifact distributions suggest that much of the original site structure remained intact and that the activities and distribution of these activities is consistent with the historically defined use of the site. 


\title{
DATA RECOVERY AT THE GOBBLER CREEK BRIDGE SITE, 41GR383
}

\author{
Douglas K. Boyd, Steve A. Tomka, and C. Britt Bousman
}

Site 41GR383 was discovered in 1987 (Boyd et al. 1989) and tested in 1988 (Boyd et al. 1990); based on the results of these investigations, it was interpreted as a multicomponent (or transitional) late Archaic/Late Prehistoric open campsite. It was assessed as being eligible for listing on the National Register of Historic Places and slated for Phase III data recovery. The site is located within the right-of-way of the Texas State Department of Highways and Public Transportation's planned Farm-to-Market Road 3519, immediately adjacent to Gobbler Creek where a bridge is currently under construction.

\section{SITE SETTING}

This large $(150 \times 200-\mathrm{m})$ site is on an upland slope (el. 2240-2280 ft msl) west of Gobbler Creek and approximately $1.5 \mathrm{~km}$ upstream from the confluence of Gobbler Creek and the Double Mountain Fork of the Brazos River (Fig. 10). A county road bisects the site into north and south segments. The northem portion of the site is heavily deflated and eroded by slopewash leading to a small gully that flows to Gobbler Creek. The southern portion of the site is on an upland slope with a sequence of small exposed bedrock benches which act to retain colluvial sediments on their upslope margins; the slope tilts moderately to the east down to a bedrock bluff overlooking Gobbler Creek. The excavation block was placed between this bluff and an upslope bedrock bench. In addition to the road, other artificial disturbances include drainage ditches and barbed wire fencelines on both sides of the road, a parallel overhead electrical power line, and two petroleum pipelines, one buried and one on the surface (both cross the site from northeast to southwest). Also, extensive surface collection by avocational archeologists and relic hunters has occurred. Vegetation, consisting of grasses, junipers, mesquites, Mormon tea, hackberry, yucca, and various shrubs, is sparse in the eroded northern area but fairly dense in the southern area where sediments are intact.

\section{PREVIOUS INVESTIGATIONS}

The 1987 survey (Boyd et al. 1989:116-117, 482-483) documented a high density of surface artifacts in the northern portion of the site and intact sediments with buried cultural materials in the southern area. The roadcut provided an excellent cross section of the site sediments, revealing an extensive pavement of burned rocks and artifacts in the southern area. It was thought that this relatively dense concentration of rocks might represent a small burned rock midden. A gouge and a planar tool were collected, and grinding stones and an arrow point tip were observed. A cluster of seven manos on the surface undoubtedly represented a relic hunter's cull pile. Based on the single diagnostic artifact, site age was tentatively interpreted as Late Prehistoric.

The 1988 testing at 41GR383 (Boyd et al. 1990:85-91, 236-239, 393-394, 396-397) consisted of site mapping, controlled surface collection of 


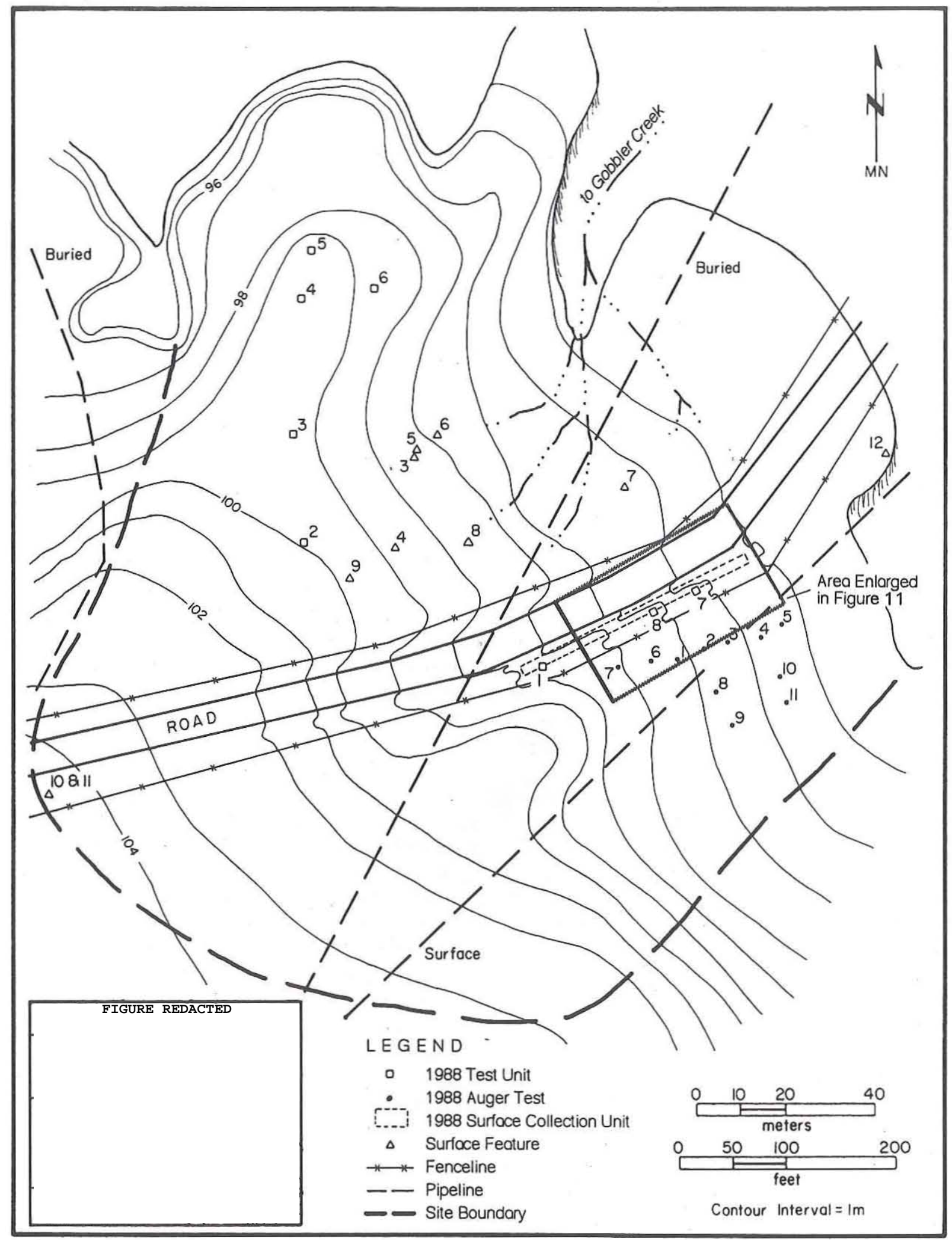

Figure 10. Site map, 41GR383. 
diagnostic artifacts, a surface collection unit (linear transect of 1-m collection units along the roadcut), mechanical excavation of 11 auger tests, and hand excavation of 8 test units. A total of 341 artifacts was recovered (Table 15), including 4 untyped dart points ( 2 are expanding-stem specimens) and a Granbury arrow point. All of the projectile points were surface finds but indicated a probable multicomponent occupation for the site. Other artifacts recovered in the excavations include chipped and ground stone tools. Freshwater mussel shell fragments also were recovered, and 12 features were recorded ( 7 surface burned rock clusters, 2 burned rock clusters encountered in test pits, and 3 bedrock mortars [Features 10-12]).

Cultural materials in the southern portion of the site were found throughout the sediment, which varied in thickness from $40-90 \mathrm{~cm}$, ending on bedrock. No cultural or natural stratification was evident, but it was considered likely that two or more components might be present and that they might be vertically separable.

Site 41GR383 was assessed as having a high research potential and was recommended for further work. Based on the artifact densities in the southern half of the site, it was estimated that a $30-\mathrm{m}^{2}$ excavation block would yield an interpretable sample of artifacts.

\section{DATA RECOVERY INVESTIGATIONS}

The Phase III investigation at the Gobbler Creek Bridge Site consisted of additional site mapping and excavation of fifty-three $1 \times 1-\mathrm{m}$ units (Fig. 11). Site mapping included a detailed topographic map of the excavation block and surrounding area. A Texas State Department of Highways and Public Transportation survey crew assisted in the topographic mapping and tied the site map into nearby TSDHPT brass markers. As the greatest artifact densities were observed in Test Units 7 and 8 and Auger Tests 1, 2, 3, and 6 dug in 1988, the area between them was selected as the most profitable for an excavation block. This block was to be confined mainly within the right-of-way but with landowner permission could extend beyond if necessary. The excavation grid was established using the southern right-of-way as the east-west grid line, with the TSDHPT brass caps (nos. 255 and 281) serving as datum points on either end of the line. Hence, grid north is perpendicular to the right-of-way and $22.5^{\circ}$ west of true north. For discussion purposes in this chapter, directions always refer to grid directions unless otherwise specified. All elevations are metric and are relative to an arbitrary $100.00-\mathrm{m}$ point established in 1988. The brass caps were assigned metric elevations relative to the 1988 site datum points, and all site elevations were then shot relative to the brass caps.

The original excavation block was laid out as a 3x8-m block (twenty-four 1x1-m units) extending north of the right-of-way to the existing barbed wire fence along the road. As excavation progressed, the block was expanded several meters to the west and north. One row of units also was excavated south of the right-of-way line. Excavations included forty-nine 1x1-m units in a contiguous block, with two additional units immediately adjacent to the block on the west end (Fig. 12). These units were assigned sequential numbers and are designated as Excavation Units (EUs). The two dispersed units (Eus 52 and 53), located $7 \mathrm{~m}$ west of the block units, were excavated to provide geomorphic data and test a potential buried gully which was visible as a dip in the bedrock exposed along the roadcut.

\section{Sediments and Stratigraphy}

Six profiles are presented from 41GR383 (Fig. 13). Four are from the excavation block, one is from EU 52 west of the block, and one is from a geological exposure in the roadcut north of the block. Detailed sediment descriptions of these profiles are provided in Appendix H. Bedrock at the site consists of Triassic Dockum Group sandstones (Barnes 1967). The bedrock has a stairstepped topography with resistant sandstone slabs capping soft friable sandstone layers. This soft sandstone is easily eroded and obviously an important source for colluvial sediments that contain archeological remains.

Sedimentary sequences differ slightly between excavation units in the excavation block, but all of the profiles demonstrate the accumulation of a thin mantle of sediments over bedrock. In a number of profiles (e.g., EU 33 and EU 12), the lowest soil zone above bedrock is a $\mathrm{C}$ horizon that is partially composed of decomposing bedrock. This $\mathrm{Cr}$ horizon does not show up in the two downslope profiles (EU 25 and EU 22), but it is present in other 
TABLE 15

ARTIFACTS RECOVERED DURING 1988 TESTING, 41GR383

\begin{tabular}{|c|c|c|c|c|c|c|c|c|c|c|c|c|}
\hline \multicolumn{13}{|c|}{$\begin{array}{l}\text { TABLE } 15 \\
\text { ARTIFACTS RECOVERED DURING } 1988 \text { TESTING, 41GR383 }\end{array}$} \\
\hline Provenience & $\begin{array}{l}\text { Arrow } \\
\text { Point } \\
\end{array}$ & $\begin{array}{l}\text { Dart } \\
\text { Points } \\
\end{array}$ & $\begin{array}{l}\text { Other } \\
\text { Bifaces }\end{array}$ & $\begin{array}{l}\text { Cobble } \\
\text { Tools } \\
\end{array}$ & Unifaces & Cores & $\begin{array}{l}\text { Edge- } \\
\text { modified } \\
\text { Debitage } \\
\end{array}$ & $\begin{array}{l}\text { Unmodified } \\
\text { Debitage }\end{array}$ & Manos & Metate & $\begin{array}{l}\text { Ground } \\
\text { Stones }\end{array}$ & Hammerstone \\
\hline Surface & 1 & 3 & 7 & 5 & $26^{*}$ & 1 & 4 & 21 & 5 & - & 2 & 1 \\
\hline $\begin{array}{l}\text { Surface } \\
\text { Collection Unit }\end{array}$ & - & 1 & - & - & 3 & - & 4 & 18 & 1 & - & 2 & - \\
\hline $\begin{array}{l}\text { Auger Test } 1 \\
\text { Auger Test } 2 \\
\text { Auger Test } 3 \\
\text { Auger Test } 4 \\
\text { Auger Test } 5 \\
\text { Auger Test } 6 \\
\text { Auger Test } 7 \\
\text { Auger Test } 8 \\
\text { Auger Test } 10 \\
\text { Auger Test } 11\end{array}$ & $\begin{array}{l}- \\
- \\
- \\
- \\
- \\
- \\
- \\
- \\
- \\
-\end{array}$ & $\begin{array}{l}- \\
- \\
- \\
- \\
- \\
- \\
- \\
- \\
-\end{array}$ & $\begin{array}{l}- \\
- \\
\overline{1} \\
- \\
- \\
- \\
- \\
- \\
-\end{array}$ & $\begin{array}{l}- \\
- \\
- \\
- \\
- \\
- \\
- \\
- \\
-\end{array}$ & $\begin{array}{l}1 \\
- \\
- \\
- \\
- \\
- \\
- \\
- \\
- \\
-\end{array}$ & $\begin{array}{l}- \\
- \\
- \\
- \\
- \\
- \\
- \\
- \\
-\end{array}$ & $\begin{array}{l}- \\
- \\
- \\
- \\
- \\
- \\
- \\
- \\
-\end{array}$ & $\begin{array}{r}3 \\
4 \\
2 \\
2 \\
5 \\
3 \\
3 \\
2 \\
2 \\
1 \\
1 \\
2 \\
\end{array}$ & $\begin{array}{l}- \\
- \\
- \\
- \\
- \\
- \\
- \\
- \\
-\end{array}$ & $\begin{array}{l}- \\
- \\
- \\
- \\
- \\
- \\
- \\
- \\
-\end{array}$ & $\begin{array}{l}- \\
- \\
- \\
- \\
- \\
- \\
- \\
- \\
1\end{array}$ & $\begin{array}{l}- \\
- \\
- \\
- \\
- \\
- \\
- \\
- \\
-\end{array}$ \\
\hline $\begin{array}{l}\text { Test Unit } 2 \\
\text { Test Unit } 3 \\
\text { Test Unit } 4 \\
\text { Test Unit } 5 \\
\text { Test Unit } 6 \\
\text { Test Unit } 7 \\
\text { Test Unit } 8\end{array}$ & $\begin{array}{l}- \\
- \\
- \\
- \\
- \\
-\end{array}$ & $\begin{array}{l}- \\
- \\
- \\
- \\
- \\
- \\
-\end{array}$ & $\begin{array}{l}- \\
- \\
- \\
- \\
- \\
- \\
-\end{array}$ & $\begin{array}{l}- \\
\overline{1} \\
- \\
\overline{-} \\
1 \\
2\end{array}$ & $\begin{array}{l}\overline{2} \\
- \\
- \\
- \\
- \\
-\end{array}$ & $\begin{array}{l}- \\
\overline{-} \\
\overline{1} \\
- \\
\overline{1} \\
\end{array}$ & $\begin{array}{l}1 \\
\overline{1} \\
1 \\
4 \\
\overline{7} \\
\end{array}$ & $\begin{array}{r}31 \\
14 \\
20 \\
1 \\
17 \\
17 \\
25 \\
74 \\
\end{array}$ & $\begin{array}{l}- \\
- \\
- \\
- \\
- \\
- \\
-\end{array}$ & $\begin{array}{l}- \\
- \\
- \\
- \\
- \\
\overline{1}\end{array}$ & $\begin{array}{l}\overline{1} \\
- \\
- \\
- \\
\overline{1}\end{array}$ & $\begin{array}{l}- \\
- \\
- \\
- \\
- \\
-\end{array}$ \\
\hline Totals: & 1 & 4 & 8 & 9 & 32 & 3 & 22 & 247 & 6 & 1 & 7 & 1 \\
\hline
\end{tabular}




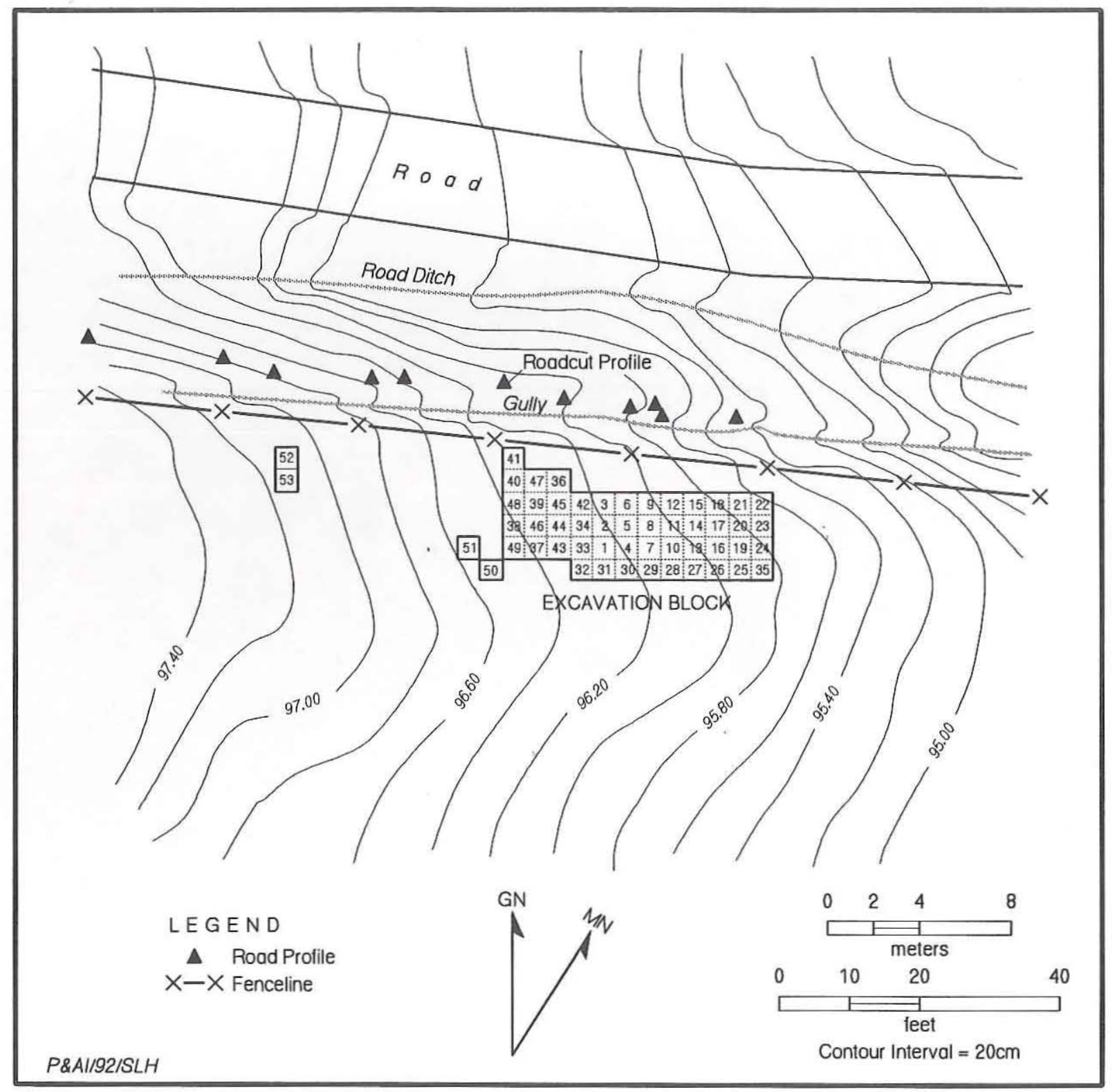

Figure 11. Detailed map of the excavation block area, 41GR383.

nearby profiles in the excavation block that were not described. The apparent greater soil horizon differentiation in some excavation block profiles (EU 33 and EU 12) and other upslope profiles (EU 52 and Roadcut Profile) could be due to slightly thicker sediment accumulations upslope immediately below a bedrock outcrop and compressed sedimentary sequences downslope, greater introduction of organic matter by prehistoric occupants in the lower portion of the block, or a mix of these factors.
During the course of excavation and geoarcheological investigations at 41GR383, it became clear that the sediment thicknesses observed in the roadcut were significantly greater than those documented in most of the excavation block. A profile showing the present ground surface and the bedrock surface along the roadcut demonstrates the occurrence of a fluted gully transected by the road (Fig. 14). Sandy sediments (sandy loam to loamy sand) overlying discontinuous basal gravels (in the flutes) fill this gully. Burned rocks were documented in at 


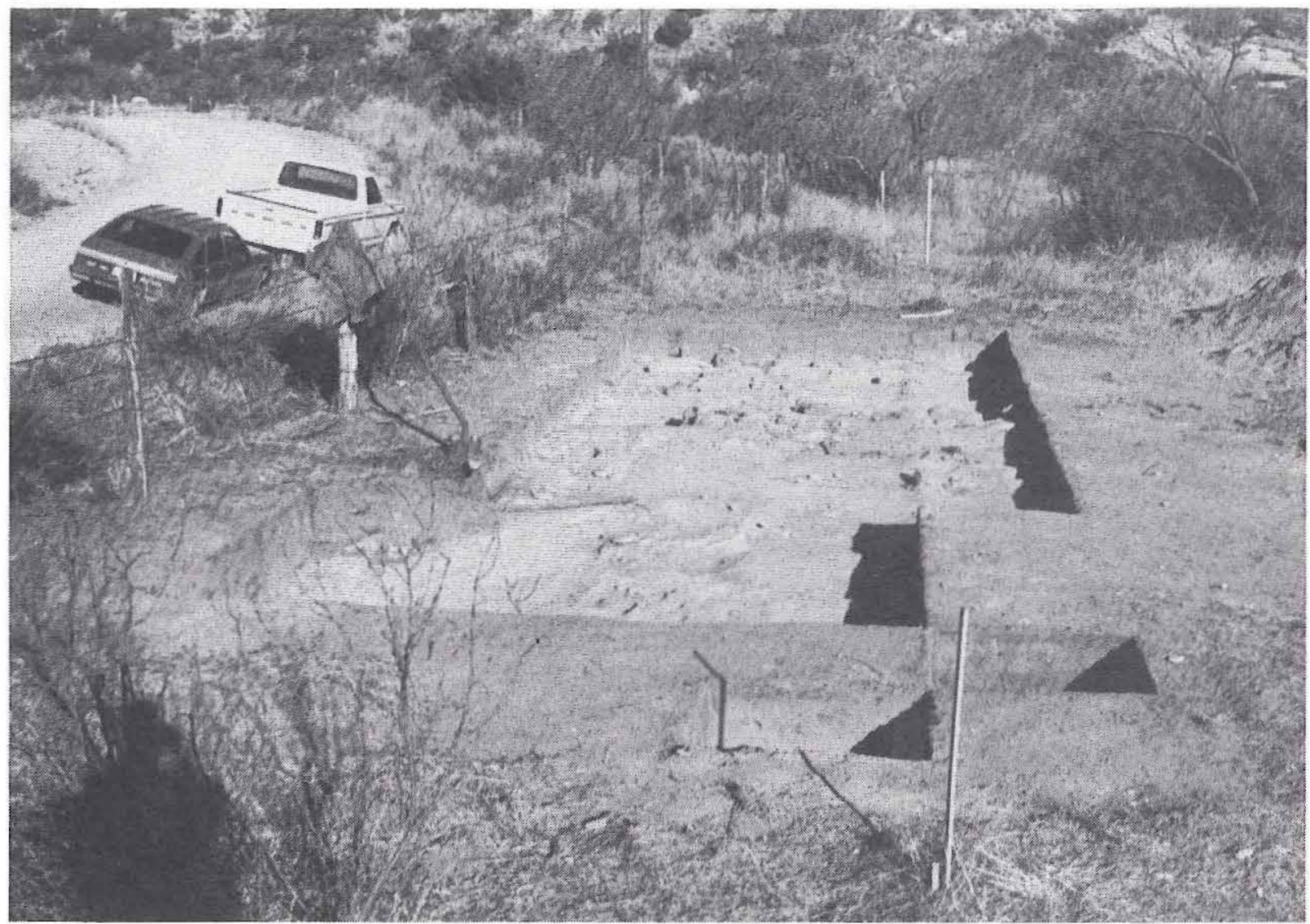

Figure 12. Photograph of the completed excavation block at 41GR383. View is grid east down the highway right-of-way line.

least two vertically distinct zones. A detailed profile was described in this roadcut, and in this profile an upper sandy loam C horizon covers a buried $\mathrm{A}$ soil horizon and two $\mathrm{Ck}$ horizons below (see Fig. 13). The $2 \mathrm{Ab}$ and $2 \mathrm{Ck} 1$ horizons had evidence of prehistoric occupations.

Additional evidence on the nature of this gully is provided by the EU 52 profile (see Fig. 13). Again, an A horizon with burned rocks is buried by more-recent sediments, but most importantly, the bedrock steadily climbs toward the bedrock outcrops exposed to the southwest. Although not presented here, a similar profile was uncovered in EU 41. Buried A horizons are documented in all profiles in or adjacent to the filled gully, and this suggests more-recent sedimentation after the formation of this soil. Combined, these profiles show that the edge of the gully was immediately adjacent to the road and that most of the sediments in the gully were disturbed by road and borrow ditch construction and erosion induced by this construction. The prehistoric occupation occurred on the bedrock outcrop (now buried) and in the gully, but little undisturbed sediments remain in the gully.

Four $\delta^{13} \mathrm{C}$-corrected sediment dates associated with the cultural zone were obtained (see Appendix G). An assay on sediment from $35-45 \mathrm{~cm}$ below the surface in EU 48 produced an age of $1865 \pm 140$ B.P. (GX-16515) with a tree-ringcalibrated (cal.) age of 1824 B.P., while sediment from $35-45 \mathrm{~cm}$ in EU 52 produced an age of $450 \pm$ 125 B.P. (GX-16512), cal. 510 B.P. The latter date is suspect and may be much too young due to contamination of recent carbon released from decaying organic matter leaching from the surface. The presence of leaching in EU 52 is indicated by increasing carbonate percentages down-profile (see Appendix I). Two radiocarbon dates are available from Feature 13. A sediment sample from 


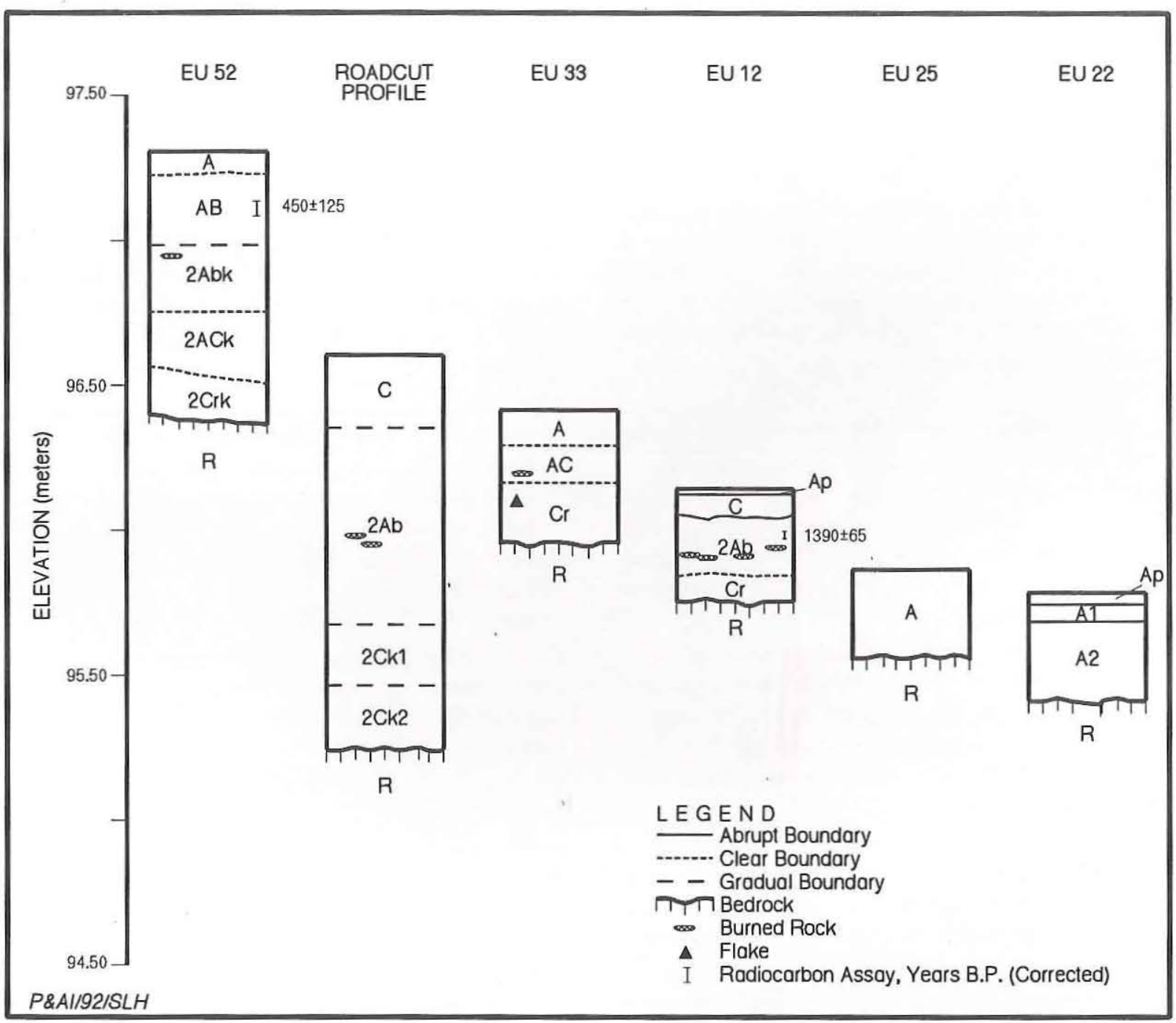

Figure 13. Geological profiles, 41GR383.

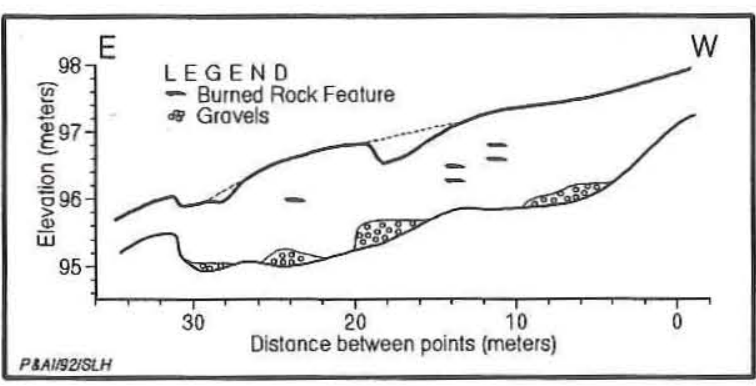

Figure 14. Road profile, 41GR383.

$32-38 \mathrm{~cm}$ below the surface was collected below feature rocks in EU 15; the age is $1215 \pm 140$ B.P. (GX-16626), cal. 1163 B.P. with a single standard deviation range of $970-1290$ B.P. A charcoal sample from $25 \mathrm{~cm}$ below the surface was collected from EU 12 in Feature 13. This sample was too small for conventional radiocarbon dating but within the range of AMS radiocarbon techniques. The AMS assay resulted in an age estimate of $1390 \pm$ 65 B.P. (GX-16627-AMS), cal. 1299 B.P. Using a t-test, the probability of contemporaneity between the two uncalibrated dates is $12.8 \%$ (Long and Rippeteau 1974), but the overlap in the calibrated one standard deviation age ranges is between 12791290 B.P., and this is considered a reasonable age estimate for Feature 13.

\section{Features}

Fifteen features have been found at this site; 
12 of these were documented during the testing phase: 7 surface burned rock clusters, 2 burned rock clusters encountered in test units, and 3 bedrock mortars (Boyd et al. 1990:89). Three burned rock clusters (Features 13-15) were encountered in the excavation block during data recovery. These latter three features were lying directly on undulating, weathered sandstone bedrock, and it was difficult at times to determine where the feature rocks ended and bedrock began.

Feature 13 is a large, irregular-shaped cluster of burned rocks encountered from ca. 10-30 cm below the surface in EUs 9, 11, 12, 14, and 15. It measures $206 \mathrm{~cm}$ east-west and $165 \mathrm{~cm}$ northsouth but was only partially excavated since it continued into the north wall of the excavation block. It consists of ca. 132 rocks that weigh $74.4 \mathrm{~kg}$. They are all slabs and fragments of local sandstone, and most exhibit pronounced 'interior discoloration from intensive heating. Feature 13 is interpreted as a series of disturbed hearths on an intensively utilized living surface. Charcoal and organic-stained sediment were virtually absent, although some charcoal flecks were collected from under one burned rock; these, as well as a bulk sediment sample, were submitted for radiocarbon assay (see above and Appendix G). Six pollen taxa were identified in a sediment sample from Feature 13 , but due to the high degree of pollen degradation, no interpretations are offered (see Appendix E).

Two radiocarbon dates associated with Feature 13 were obtained. Sediment from below the feature rocks produced an age of $1215 \pm$ 140 B.P., cal. 1163 B.P., and a small charcoal fragment preserved under a feature rock produced an age of $1390 \pm 65$ B.P., cal. 1299 B.P., using the AMS technique.

Feature 14 (Fig. 15a) is a large $(155 \times 195-\mathrm{cm})$, roughly ovate pile of ca. 65 burned sandstone slabs and fragments that weigh $129.5 \mathrm{~kg}$. It is a dense concentration of rocks encountered at ca. 10-25 cm below the surface in EUs 1, 2, 4, and 5 and is stacked two to three rocks deep in places. The rocks are jumbled, and there is no apparent patterning to their arrangement. No charcoal or organic-stained soil was observed, although all of the rocks appear to be intensively burned. Feature 14 is interpreted as a disturbed series of hearths or a single large hearth on an intensively utilized surface. Eight taxa were identified in a pollen sample from Feature 14 sediment, but due to the high degree of pollen degradation, interpretations are unreliable (see Appendix E). Flotation of a sediment sample yielded no macrobotanical remains (see Appendix D).

Feature 15 (Fig. 15b) is a 90x130-cm cluster of burned rocks from ca. 11-38 $\mathrm{cm}$ below the surface; the majority is in EUs 34 and 42, but it extends slightly into EUs 2 and 3 . The ovate cluster is oriented with its long axis north-south, and its base lies directly on bedrock. The feature consists of neatly patterned rocks and appears undisturbed relative to the condition of Features 13 and 14. The rocks $(58.7 \mathrm{~kg})$ in Feature 15 are almost exclusively sandstone slabs and fragments but also include a few limestone nodules; all appear to have been heated. They are neatly arranged into a slab-lined basin with a domed pile of rocks centered on top. No charcoal or organic-stained sediment were observed. While the exact nature of this feature is unclear, it is tentatively interpreted as a collapsed roasting or baking pit. It apparently had a shallow, slab-lined bottom and may have had slab-lined walls which collapsed inward, forming the pile on top of the basin. If the pit was cleaned out after its last use, a lengthy exposure could account for the total absence of charcoal and the collapse of its walls. Six taxa were identified in a sediment pollen sample from Feature 15, but again poor preservation precludes useful interpretations (see Appendix E).

In addition to the feature samples, two control samples from the cultural zone in EU 52 (one at $37-42 \mathrm{~cm}$ below the surface and the other at $85-90 \mathrm{~cm}$ below the surface) were submitted for pollen analysis. Four taxa were identified in these samples, but the data are not considered to be interpretable by the palynologists (see Appendix E).

\section{Materials Recovered}

This section discusses the 2,103 chipped stone artifacts, 55 ground and battered stone specimens, 1 manuport, and 1 worked shell specimen (Table 16). In addition, burned sandstone, fire-cracked siliceous rocks, and faunal remains are also discussed. The majority of the artifacts ( $n=2,094$, 97\%) came from contiguous excavation units that form a single block. A few artifacts $(n=66,3 \%)$ are from two dispersed excavation units located $7 \mathrm{~m}$ west of the block. All of the specimens were 


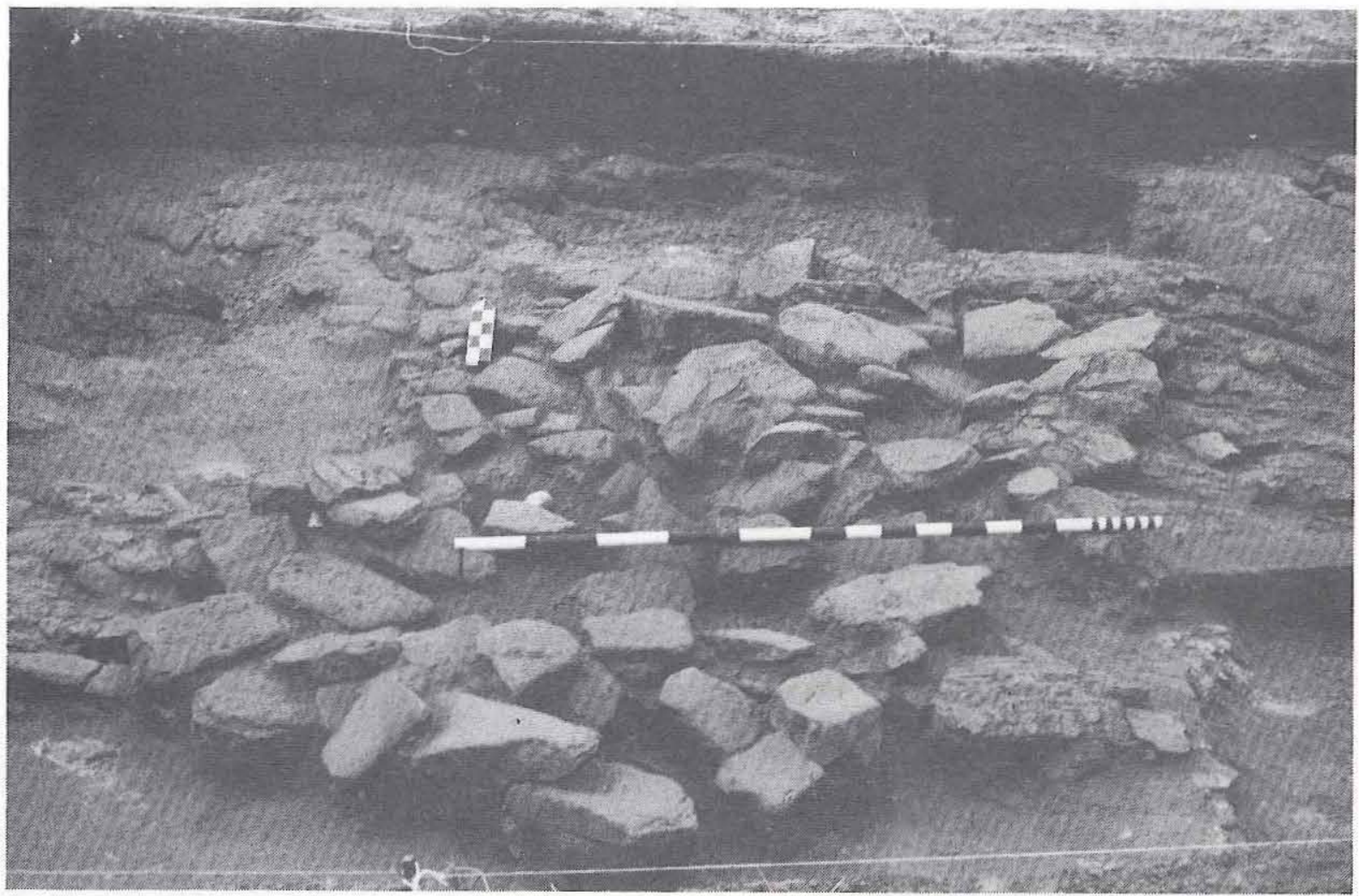

\section{a}

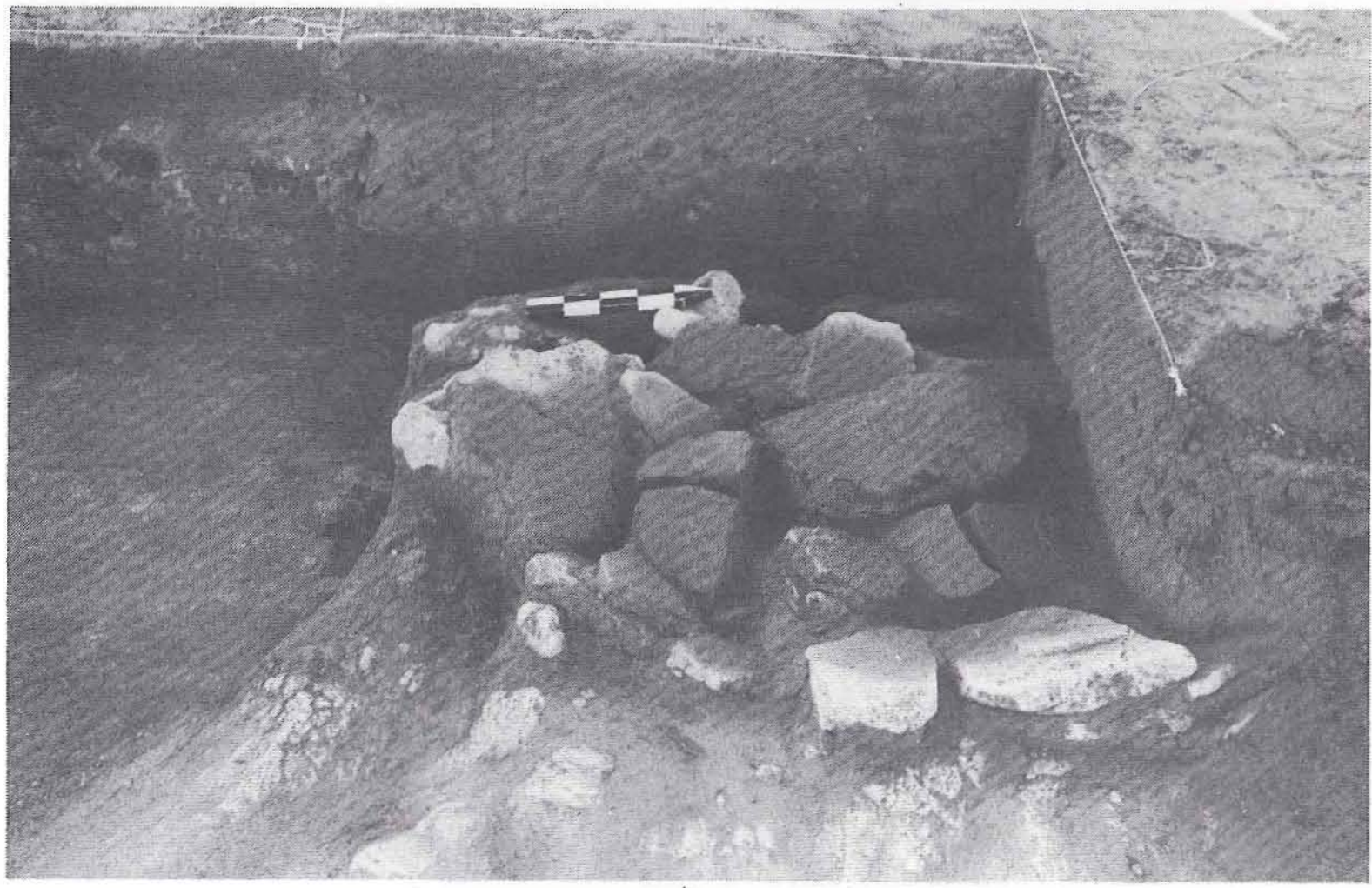

b

Figure 15. Photographs of burned rock features, 41GR383. (a) View to north of Feature 14 with surrounding area exposed to bedrock; (b) view to west of partially exposed Feature 15. 
TABLE 16

ARTIFACTS RECOVERED DURING 1990 DATA RECOVERY, 41GR383

\begin{tabular}{|c|c|c|c|c|c|c|c|c|c|c|c|c|c|c|}
\hline $\begin{array}{l}\text { Unit and } \\
\text { Maximum Depth }\end{array}$ & $\begin{array}{l}\text { Arrow } \\
\text { Point }\end{array}$ & $\begin{array}{l}\text { Dart } \\
\text { Point }\end{array}$ & Gouges & $\begin{array}{l}\text { Other } \\
\text { Bifaces }\end{array}$ & $\begin{array}{l}\text { Cobble } \\
\text { Tools }\end{array}$ & Unifaces & Cores & $\begin{array}{l}\text { Edge- } \\
\text { modified } \\
\text { Flakes }\end{array}$ & $\begin{array}{l}\text { Unmodified } \\
\text { Debitage }\end{array}$ & $\begin{array}{l}\text { Ground } \\
\text { Stone } \\
\text { Tools }\end{array}$ & $\begin{array}{l}\text { Hammer- } \\
\text { stones }\end{array}$ & Manuport & $\begin{array}{l}\text { Modified } \\
\text { Shell }\end{array}$ & Totals \\
\hline \multicolumn{15}{|l|}{$\begin{array}{l}\text { Excavation } \\
\text { Block }\end{array}$} \\
\hline EU $1,35 \mathrm{~cm}$ & - & - & - & - & - & - & 2 & 2 & 35 & - & - & - & - & 39 \\
\hline EU 2, $37 \mathrm{~cm}$ & - & - & - & 1 & 1 & - & - & 2 & 23 & 2 & - & - & - & 29 \\
\hline EU $3,41 \mathrm{~cm}$ & - & - & - & 1 & - & - & - & 5 & 30 & 1 & - & - & - & 37 \\
\hline $\mathrm{EU} \mathrm{4,} 36 \mathrm{~cm}$ & - & - & - & - & 1 & - & 1 & 1 & 26 & - & - & - & - & 29 \\
\hline EU $5,31 \mathrm{~cm}$ & - & - & - & - & - & - & - & - & 25 & 4 & - & - & - & 29 \\
\hline $\mathrm{EU} 6,43 \mathrm{~cm}$ & - & - & - & - & - & - & 1 & 3 & 31 & - & - & - & - & 35 \\
\hline EU $7,35 \mathrm{~cm}$ & - & - & - & - & - & - & - & 2 & 41 & - & - & - & - & 43 \\
\hline $\mathrm{EU} 8,20 \mathrm{~cm}$ & - & - & - & - & - & - & - & 1 & 36 & - & - & - & - & 37 \\
\hline $\mathrm{EU} 9,46 \mathrm{~cm}$ & - & - & - & 1 & - & 1 & - & 1 & 28 & 1 & - & - & - & 32 \\
\hline EU $10,24 \mathrm{~cm}$ & - & - & - & - & - & - & 1 & 1 & 20 & - & - & - & - & 22 \\
\hline EU $11,35 \mathrm{~cm}$ & - & - & - & - & - & 2 & - & 2 & 31 & - & - & - & - & 35 \\
\hline EU $12,45 \mathrm{~cm}$ & - & - & - & - & - & - & 1 & 2 & 54 & 2 & - & - & - & 59 \\
\hline $\mathrm{EU} 13,40 \mathrm{~cm}$ & - & - & - & - & - & - & 1 & - & 30 & - & - & - & - & 31 \\
\hline EU $14,47 \mathrm{~cm}$ & - & - & - & 1 & - & - & - & 3 & 37 & - & - & - & - & 41 \\
\hline EU $15,47 \mathrm{~cm}$ & - & - & - & - & - & - & 1 & - & 46 & 2 & - & - & - & 49 \\
\hline EU $16,40 \mathrm{~cm}$ & - & - & 1 & 1 & - & - & 1 & 5 & 29 & - & - & - & - & 37 \\
\hline $\mathrm{EU} 17,40 \mathrm{~cm}$ & - & - & - & - & - & - & - & - & 38 & - & - & - & - & 38 \\
\hline EU $18,38 \mathrm{~cm}$ & - & - & - & - & - & - & - & - & 14 & - & - & - & - & 14 \\
\hline EU $19,48 \mathrm{~cm}$ & - & - & - & - & - & - & - & - & 37 & 1 & - & - & - & 38 \\
\hline EU 20, $44 \mathrm{~cm}$ & - & - & - & 1 & - & 1 & 2 & 2 & $28^{-}$ & 1 & - & - & - & 35 \\
\hline $\mathrm{EU} 21,42 \mathrm{~cm}$ & - & - & - & 1 & - & - & - & 1 & 28 & - & - & - & - & 30 \\
\hline EU $22,55 \mathrm{~cm}$ & - & - & - & 1 & - & - & - & 1 & 25 & - & 2 & - & - & 29 \\
\hline EU $23,44 \mathrm{~cm}$ & - & - & - & - & - & - & - & - & 18 & - & - & - & - & 18 \\
\hline EU 24, $54 \mathrm{~cm}$ & - & - & 1 & 1 & - & - & 2 & - & 39 & 1 & - & - & - & 44 \\
\hline EU $25,43 \mathrm{~cm}$ & - & - & - & - & - & - & - & - & 38 & - & - & - & - & 38 \\
\hline EU $26,53 \mathrm{~cm}$ & - & - & - & - & - & - & - & - & 30 & - & - & - & - & 30 \\
\hline EU 27, $39 \mathrm{~cm}$ & - & - & - & - & - & - & - & 1 & 27 & - & - & - & - & 28 \\
\hline EU $28,33 \mathrm{~cm}$ & - & - & - & - & - & - & - & 1 & 25 & - & - & - & - & 26 \\
\hline
\end{tabular}


Table 16, continued

\begin{tabular}{|c|c|c|c|c|c|c|c|c|c|c|c|c|c|c|}
\hline $\begin{array}{l}\text { Unit and } \\
\text { Maximum Depth }\end{array}$ & \begin{tabular}{|l} 
Arrow \\
Point \\
\end{tabular} & \begin{tabular}{|l} 
Dart \\
Point \\
\end{tabular} & Gouges & $\begin{array}{l}\text { Other } \\
\text { Bifaces }\end{array}$ & $\begin{array}{l}\text { Cobble } \\
\text { Tools } \\
\end{array}$ & Unifaces & Cores & $\begin{array}{l}\text { Edge- } \\
\text { modified } \\
\text { Flakes } \\
\end{array}$ & $\begin{array}{l}\text { Unmodified } \\
\text { Debitage }\end{array}$ & $\begin{array}{l}\text { Ground } \\
\text { Stone } \\
\text { Tools } \\
\end{array}$ & $\begin{array}{l}\text { Hammer- } \\
\text { stones }\end{array}$ & Manuport & $\begin{array}{l}\text { Modified } \\
\text { Shell }\end{array}$ & Totals \\
\hline EU $29,35 \mathrm{~cm}$ & - & - & - & 1 & - & - & 1 & 1 & 14 & - & - & _ & - & 17 \\
\hline EU $30,33 \mathrm{~cm}$ & - & - & - & - & - & - & - & 1 & 42 & 3 & - & - & - & 46 \\
\hline EU $31,31 \mathrm{~cm}$ & - & - & - & 1 & 2 & - & - & - & 48 & 1 & - & - & - & 52 \\
\hline $\mathrm{EU} 32,38 \mathrm{~cm}$ & - & - & - & - & - & - & - & - & 30 & 1 & 1 & - & - & 32 \\
\hline EU $33,42 \mathrm{~cm}$ & - & - & - & - & 1 & 1 & - & 1 & 46 & - & - & - & - & 49 \\
\hline EU $34,44 \mathrm{~cm}$ & - & - & - & 1 & - & - & - & - & 37 & 3 & - & - & - & 41 \\
\hline EU $35,42 \mathrm{~cm}$ & - & - & - & 2 & - & - & - & - & 21 & 1 & - & - & - & 24 \\
\hline EU $36,56 \mathrm{~cm}$ & - & - & - & 1 & - & - & 1 & 1 & 40 & 1 & - & - & - & 44 \\
\hline EU $37,43 \mathrm{~cm}$ & - & - & - & 1 & - & 1 & - & 1 & 41 & 3 & - & - & - & 47 \\
\hline EU $38,51 \mathrm{~cm}$ & - & - & - & - & - & 2 & 1 & 2 & 40 & 1 & 1 & - & - & 47 \\
\hline EU $39,67 \mathrm{~cm}$ & - & - & - & - & 1 & - & 1 & 1 & 93 & 4 & - & - & - & 100 \\
\hline EU $40,73 \mathrm{~cm}$ & - & - & - & 1 & - & 1 & - & - & 45 & 1 & - & - & - & 48 \\
\hline EU 41, $96 \mathrm{~cm}$ & 1 & - & - & - & - & - & - & 3 & 48 & - & - & - & - & 52 \\
\hline $\mathrm{EU} 42,50 \mathrm{~cm}$ & - & - & - & - & - & - & - & - & 33 & - & - & - & - & 33 \\
\hline $\mathrm{EU} 43,39 \mathrm{~cm}$ & - & - & - & - & 1 & - & - & 1 & 30 & 1 & - & - & - & 33 \\
\hline EU $44,38 \mathrm{~cm}$ & - & - & - & 1 & - & 1 & 3 & - & 55 & 3 & - & - & - & 63 \\
\hline EU $45,50 \mathrm{~cm}$ & - & - & - & - & - & - & - & 2 & 49 & - & - & - & - & 51 \\
\hline $\mathrm{EU} 46,47 \mathrm{~cm}$ & - & - & - & 1 & - & - & 2 & 1 & 33 & 2 & - & 1 & - & 40 \\
\hline $\mathrm{EU} 47,77 \mathrm{~cm}$ & - & - & - & 3 & 2 & - & 3 & 1 & 82 & 2 & - & - & - & 93 \\
\hline EU $48,66 \mathrm{~cm}$ & - & 1 & - & - & - & - & - & 1 & 82 & - & - & - & - & 84 \\
\hline EU $49,49 \mathrm{~cm}$ & - & - & - & 1 & - & - & 1 & - & 45 & 2 & - & - & - & 49 \\
\hline EU $50,40 \mathrm{~cm}$ & - & - & - & - & - & - & 1 & - & 36 & - & 1 & - & - & 38 \\
\hline EU $51,56 \mathrm{~cm}$ & - & - & - & 1 & - & 1 & - & 2 & 51 & 4 & - & - & - & 59 \\
\hline \multicolumn{15}{|l|}{ Dispersed Units } \\
\hline EU $52,112 \mathrm{~cm}$ & - & - & - & 1 & 1 & - & 1 & 1 & 41 & 1 & - & - & - & 46 \\
\hline EU $53,84 \mathrm{~cm}$ & - & - & - & - & - & - & 1 & - & 17 & 1 & - & - & 1 & 20 \\
\hline TOTALS: & 1 & 1 & 2 & 25 & 10 & 11 & 29 & 56 & 1,968 & 50 & 5 & 1 & 1 & 2,160 \\
\hline
\end{tabular}


recovered from the subsurface. The items recovered from within the block and the two dispersed units are considered as part of a single, coherent assemblage. This descriptive section discusses all of the artifacts recovered from the site.

\section{Chipped Stone Artifacts}

One arrow point, 1 dart point, 2 gouges, 25 bifaces, 10 cobble tools, 11 unifaces, 29 cores, 56 edge-modified flakes, and 1,968 pieces of unmodified debitage were recovered. Sixty-three $(3 \%)$ of these chipped stone artifacts, consisting of 1 biface, 1 cobble tool, 2 cores, 1 edge-modified flake, and 58 pieces of unmodified lithic debitage, are from dispersed excavation units (EUs 52 and 53). The remaining artifacts are from the excavation block units.

\section{ARROW POINT}

The single arrow point recovered is a proximal fragment consisting only of the stem portion of an expanding-stem, concave-base specimen similar to Scallorn points (Jelks 1962:Fig. 13); however, its fragmentary nature precludes its assignment to this type. Stem and base smoothing are absent, and the specimen is use broken. The nature of the blank used in its manufacture cannot be determined. It is made of nonlocal fine-grained chert (Color 51). The proximal fragment has a 13-mm-wide and 1-mm-deep base. The specimen is too fragmentary for any other meaningful measurements.

\section{DART POINT}

Only one bifacially flaked distal fragment can be classified as a dart point with confidence. One face of the tip retains impact fracture scars, and the blade break morphology is characteristic of usegenerated snap fractures. Its blade edges are straight, and the distal impact fracture has been rejuvenated. The fragment has a lenticular transverse cross section and is made of Alibates agate. None of its metric measurements are complete, and the point cannot be assigned to a specific type.

\section{GOUGES}

Two complete gouges were recovered. Both are manufactured on small, locally available, fine- grained chert (Colors 17 and 18) pebbles and retain only limited retouch. Unifacial retouch occurs only on the distal end of one of the gouges (Fig. 16a). Haft wear could not be discerned at $40 \mathrm{x}$ magnification on its proximal end. The concave working edge is slightly rounded, and its ventral and dorsal surfaces exhibit limited step fracturing. The specimen is $51 \mathrm{~mm}$ long, $32 \mathrm{~mm}$ wide, and $19 \mathrm{~mm}$ thick. The second gouge (Fig. 16b) is somewhat more extensively retouched. In addition to the slightly concave working edge, one of its lateral margins was shaped unifacially. Haft wear in the form of light polish extends for $24 \mathrm{~mm}$ along the proximal portion of the tool. The working edge is moderately rounded and retains use-related polish. This gouge is $48 \mathrm{~mm}$ long, $35 \mathrm{~mm}$ wide, and $14 \mathrm{~mm}$ thick.

\section{OTHER BIFACES}

Of the 25 bifaces recovered, 3 are complete, 4 are proximal, 2 are medial, and 4 are distal fragments. The remaining fragments consist of 10 indeterminate biface edges and 2 wedges. The largest of the three complete bifaces is a small fine-grained Potter chert nodule with minimal shaping retouch (Fig. 16c). Only seven flake scars are present on alternate faces of one lateral edge of the nodule. Based on the minimal retouch, it appears to be an early-reduction-stage biface. The specimen is $82 \mathrm{~mm}$ long, $50 \mathrm{~mm}$ wide, and $20 \mathrm{~mm}$ thick. The second complete biface is made on a small locally available fine-grained chert (Color 16) pebble with minimal retouch along its two lateral edges. The specimen may represent an aborted projectile point preform. The minimal shaping suggests that it was discarded in the early stage of reduction. The biface is $23 \mathrm{~mm}$ long, $13 \mathrm{~mm}$ wide, and $6 \mathrm{~mm}$ thick. The third complete biface is a triangular specimen with a convex base (Fig. 16d). Judging from its size, shape, and degree of reduction, it is possible that the specimen is an arrow point preform. On the other hand, the longitudinal asymmetry and the reworked remnant of a distal end break indicate that the specimen may have been utilized. This break may have resulted from the specimen's use as a projectile point or a bifacial knife. As a finished projectile point, it is similar to Granbury specimens (Jelks 1962:35-36) recovered from other sites in the project area, as well as Type 1-B arrow points or preforms recov- 


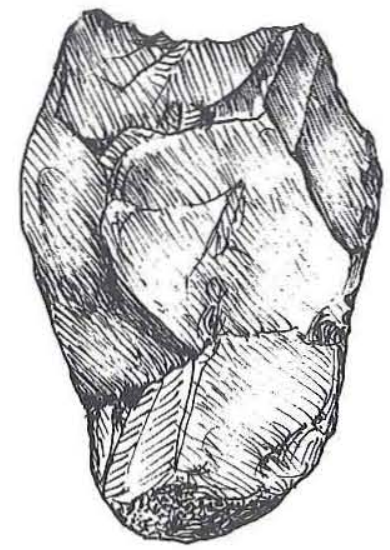

a

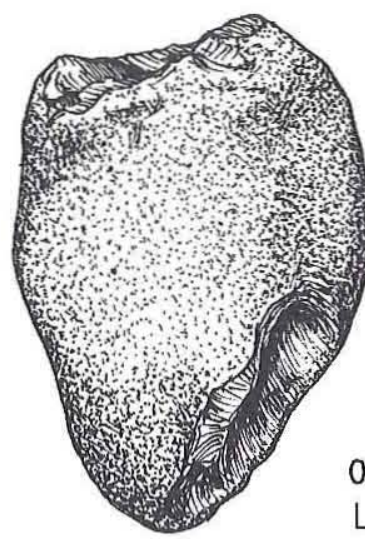

b

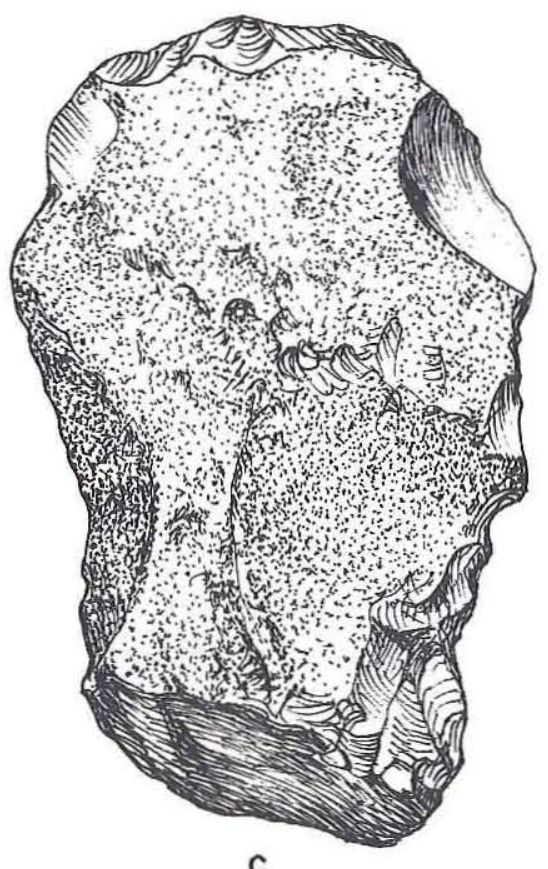

c
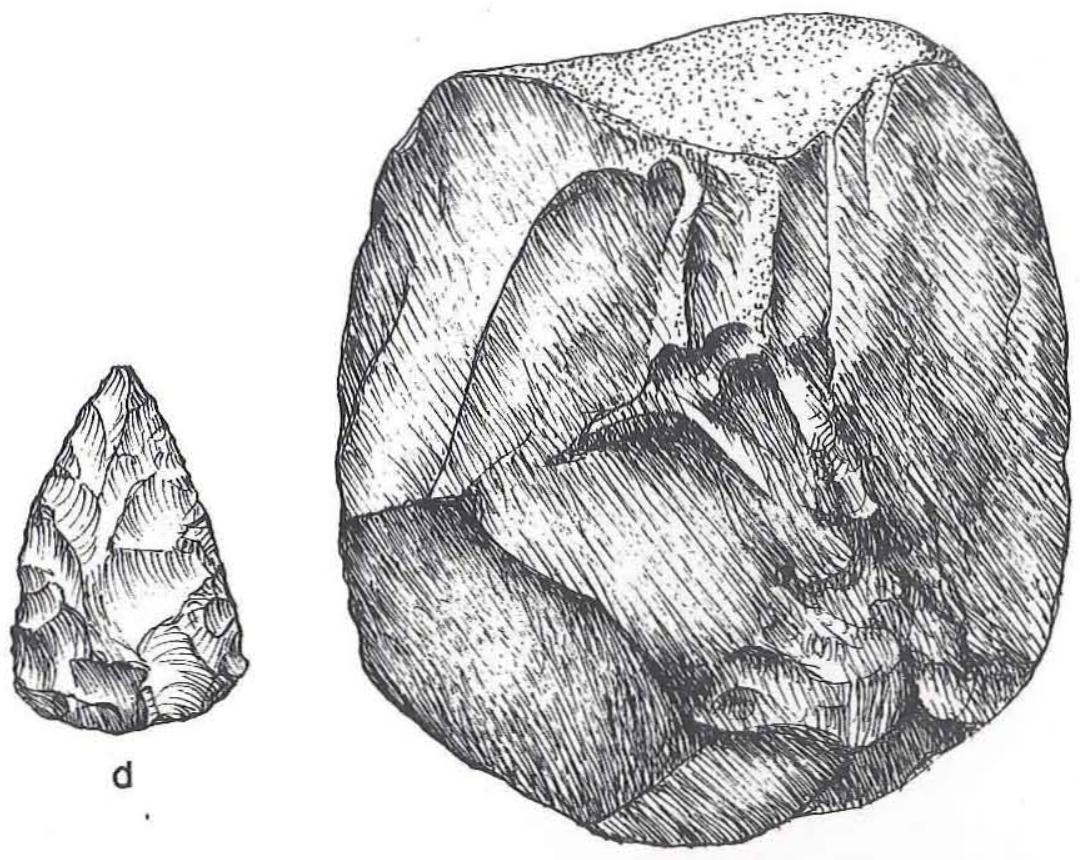

e

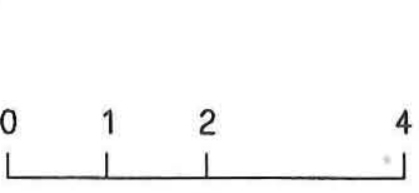

$\mathrm{cm}$
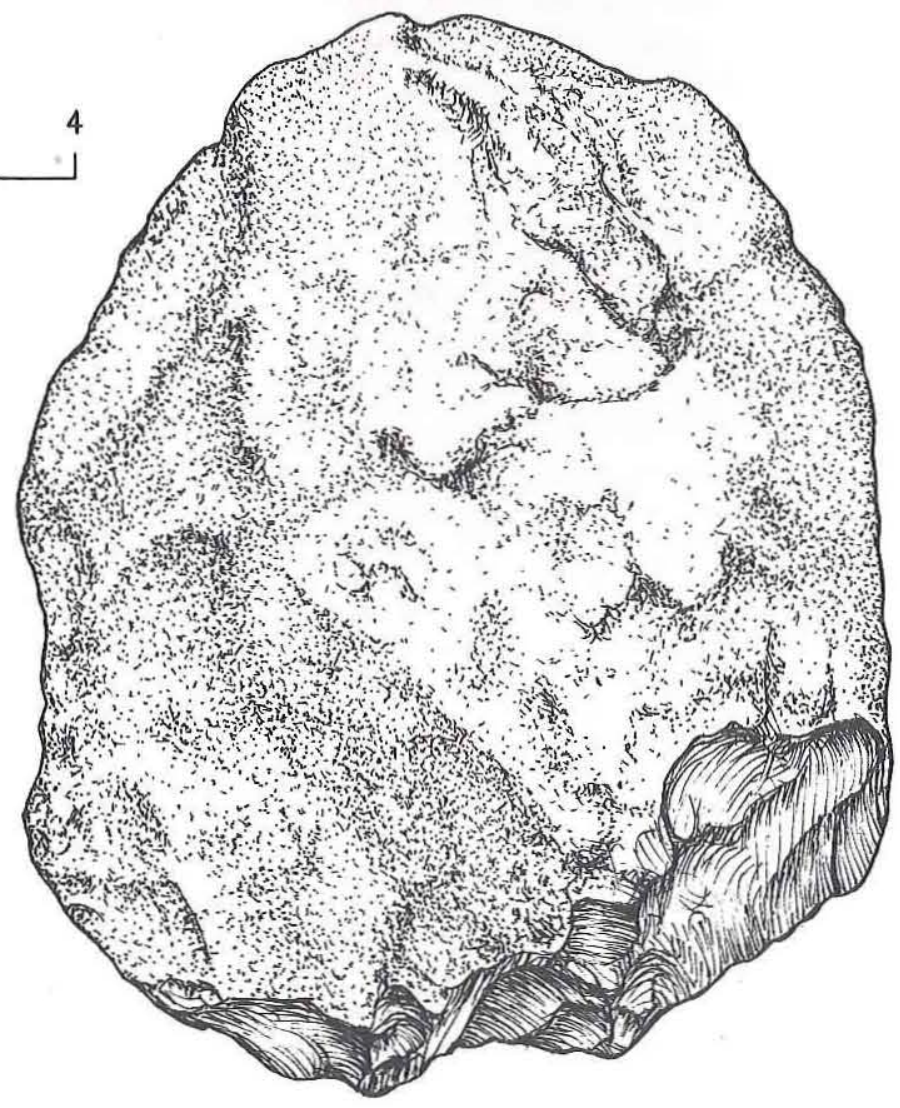

1

Figure 16. Artifact illustrations, 41GR383. (a-b) Gouges; (c) early-reduction-stage biface; (d) late-reduction-stage biface or projectile point preform; (e-f) cobble tools. 
ered from southeastern New Mexico and adjacent areas of Texas and Mexico (Leslie 1978:93). The biface is made of nonlocal fine-grained chert (Color 43). It is $36 \mathrm{~mm}$ long, $23 \mathrm{~mm}$ wide, and $6 \mathrm{~mm}$ thick.

Of the four proximal fragments, two are triangular specimens with straight to slightly convex bases and straight to recurved blade edges. Their morphology and systematic flaking suggest that they are late-reduction-stage projectile point preforms. The larger of the fragments has a $20-\mathrm{mm}$-wide base and is $5 \mathrm{~mm}$ thick. It was broken in manufacture. The second of these fragments has a $20-\mathrm{mm}$-wide base, but no other metric attributes are complete. The cause of breakage could not be established on this specimen. One of the two remaining proximal fragments also has a triangular shape and a convex base. It is a marginally retouched flake broken in biface manufacture. It represents an early-reduction-stage projectile point blank. It has an $18-\mathrm{mm}$-wide base and is $4 \mathrm{~mm}$ thick. The last proximal fragment is a narrow $(34 \mathrm{~mm})$ and thick $(22 \mathrm{~mm})$ specimen with sinuous edges. The manufacture break and rather rough morphology suggest that it was broken in the early stage of reduction. Burinlike flake scars removed from the break face and paralleling the longitudinal axis suggest that this biface fragment was reused as an engraver and subsequently rejuvenated. No use-wear is noted (40x) on this edge. Two of the proximal fragments are of fine-grained Potter chert, and the third is of opalized caliche. The remaining specimen is indeterminate nonlocal fine-grained chert.

The two medial fragments are use-broken bifacial knives. Both appear to be beveled as a result of resharpening. The larger fragment is made of nonlocal fine-grained chert (Color 49); the other is Alibates agate. They are 8 and $10 \mathrm{~mm}$ thick, respectively. The other metric attributes are incomplete.

Three of the four distal biface fragments are either projectile point or finished bifacial knife fragments. All three are use broken and exhibit well-patterned regular flaking. The three fragments are made of nonlocal fine-grained chert (Colors 41, 51, and 55). The fourth fragment is a small middle-reduction-stage specimen made of conglomerate quartzite. None of its metric attributes are complete.

Stages of reduction cannot be assigned to the
2 wedges and 10 indeterminate edge fragments. Eleven of the 12 are made of fine-grained chert; the remaining fragment is of Tecovas jasper. The majority of the cherts are of nonlocal origin $(\mathrm{n}=7$, $64 \%$; Colors $41[n=3], 42,43$, and $56[n=2])$, with only three $(27 \%$; Colors $6[n=2]$ and 12$)$ being locally available. The origin of the last finegrained chert fragment could not be determined.

\section{COBBLE TOOLS}

Six complete and four fragmentary cobble tools were recovered. All were used as choppers. They exhibit heavy step fracturing and rounding on their working edges (Fig. 16e, f). The six complete tools are cortex backed. Cortex backing could not be determined on the four distal fragments. Two of the 10 cobble tools were reused as cores following their initial use as choppers. One of the complete specimens has two working edges, and another exhibits chopping wear on four distinct edges. Of the 10 chopping tools, 6 are made of fine-grained and 1 of coarse-grained Potter chert. One specimen each is of fine-grained quartzite and silicified wood. The six complete chopping tools have a mean length of $91.0 \mathrm{~mm}(\sigma=18.6, \mathrm{~min} .=70$, $\max$. $=107)$, a mean width of $90.8 \mathrm{~mm}(\sigma=13.1$, min. $=74, \max .=114)$, and a mean thickness of $62.3 \mathrm{~mm}(\sigma=14.7, \min .=38, \max .=79)$. The six specimens have a mean weight of $579 \mathrm{~g}$, ranging from 276 to $1,069 \mathrm{~g}(\sigma=271.9)$. No metric attributes could be recorded on the chopping tool fragments.

\section{UNIFACES}

Eleven unifaces were recovered. Of these, the largest morphofunctional category consists of four end scrapers, followed by three side scrapers and two combination end and side scrapers. The remaining two specimens are indeterminate uniface edges.

The four end scrapers are complete tools made on secondary flake blanks. Two are made of fine-grained Potter chert (Fig. 17a), and one is of fine-grained chert. All are minimally shaped. The final fine-grained chert end scraper is more extensively retouched (Fig. 17b). None of the end scrapers appear to have been hafted. The end scrapers have a mean length of $45.5 \mathrm{~mm}(\sigma=9.0$, min. $=37, \max .=56)$, a mean maximum width of 


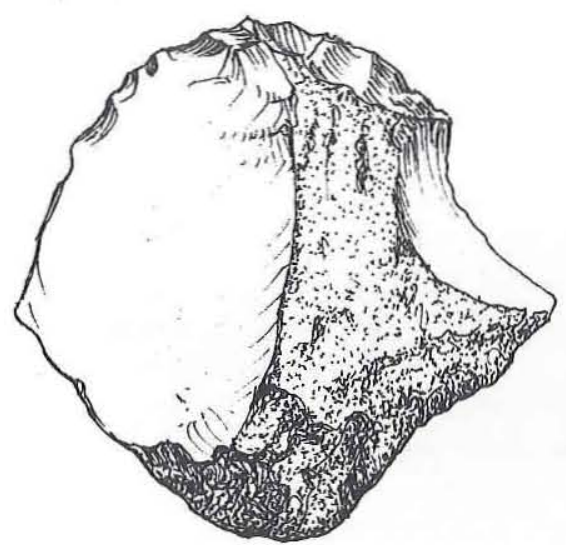

a

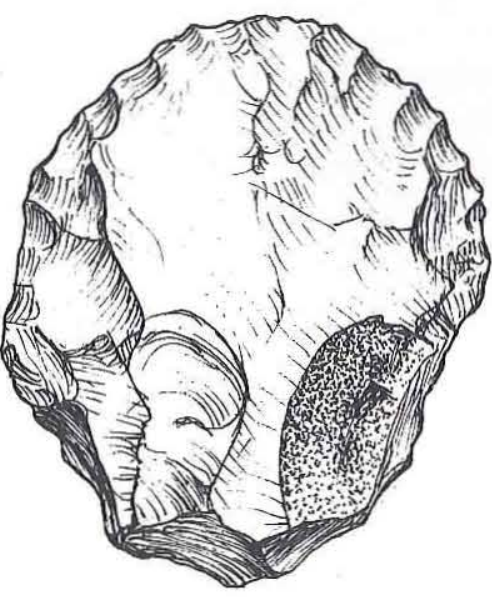

b

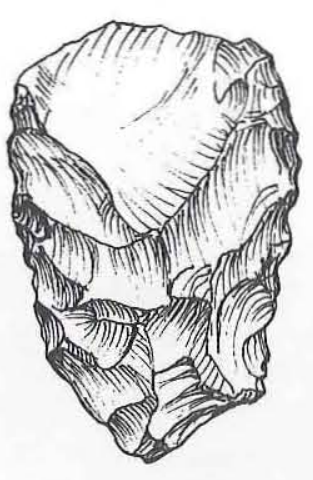

d
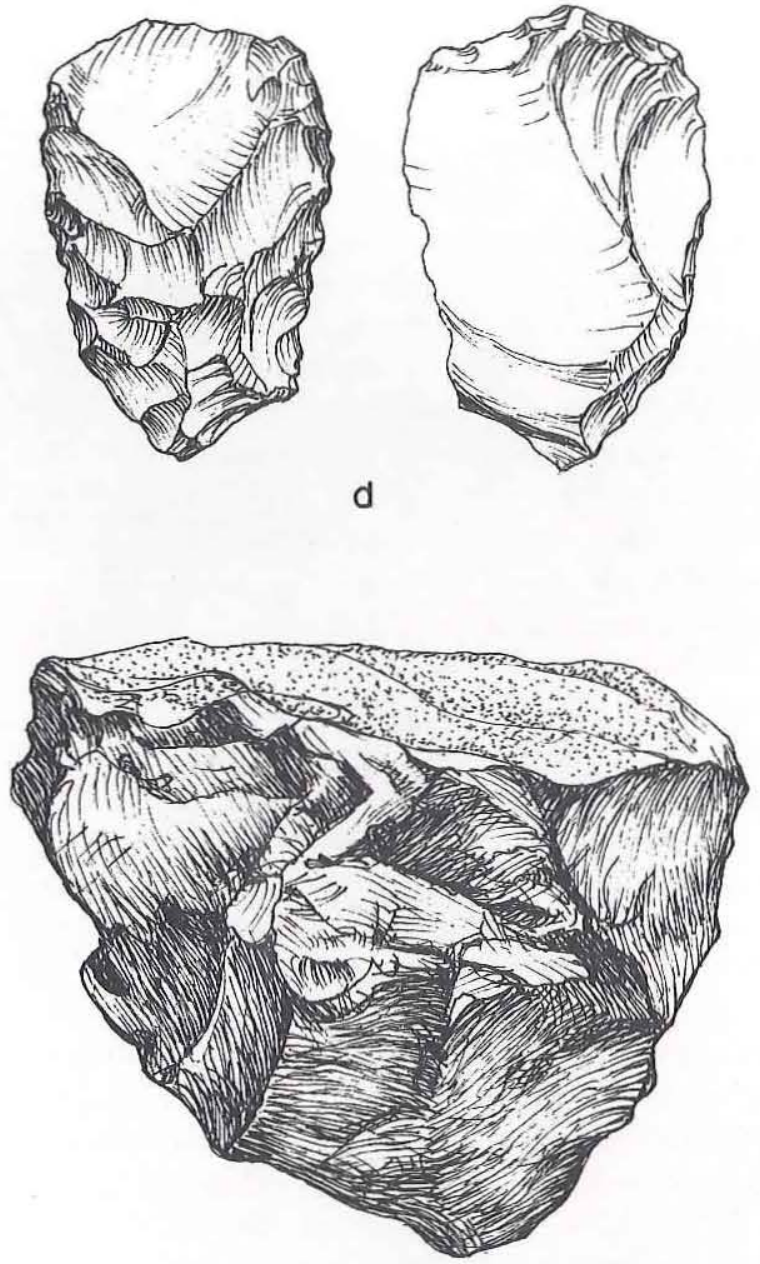

e
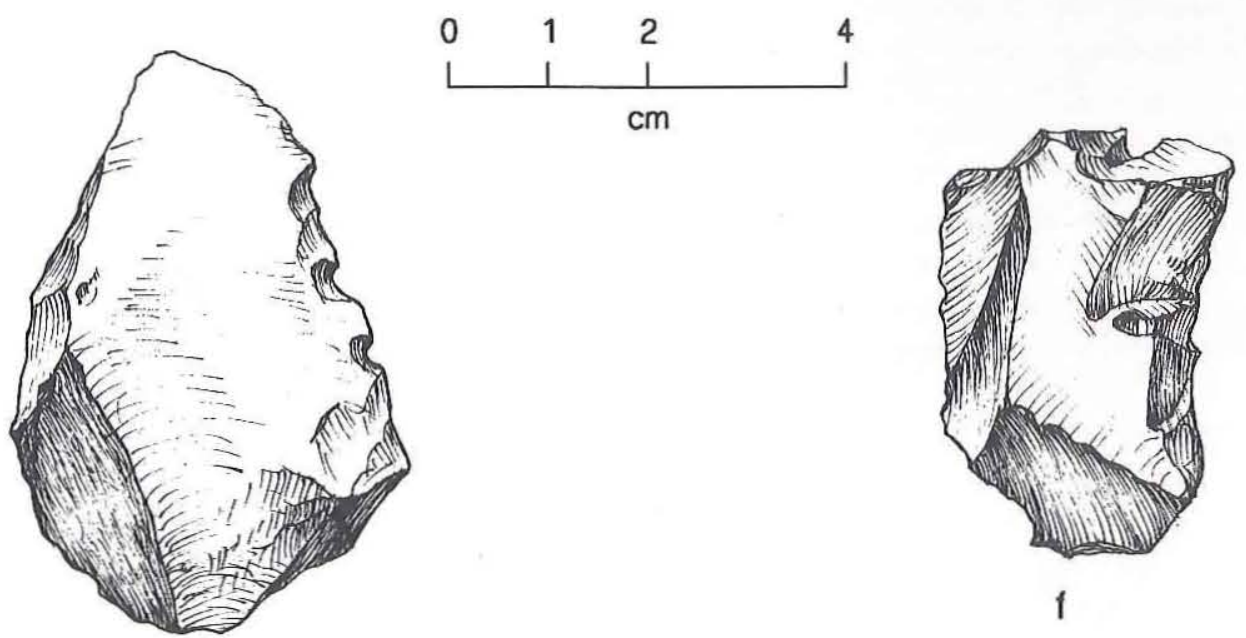

C

Figure 17. Artifact illustrations, 41GR383. (a-b) End scrapers; (c) side scraper; (d) combination end and side scraper; (e) unidirectional core; (f) multidirectional core. 
$47.8 \mathrm{~mm}(\sigma=13.8, \min .=28, \max .=52)$, and a mean thickness of $14.5 \mathrm{~mm}(\sigma=4.9, \mathrm{~min} .=9.0$, $\max .=20)$. One of the fine-grained chert end scrapers was made of locally available material (Color 6); the origin of the other specimen could not be determined.

Two of the three side scrapers are complete; the third is a longitudinal fragment. One is made on a tertiary flake blank (Fig. 17c), one is a secondary flake, and one is a primary flake fragment. All three tools have minimally retouched single utilized edges. The cause of the longitudinal break could not be determined, although it is possible that a broken flake was used as a blank. The primary flake blank is $12 \mathrm{~mm}$ thick; the other measurements are incomplete. The side scraper manufactured on the secondary flake blank measures $47 \times 60 \times 24 \mathrm{~mm}$, while the specimen made on the tertiary flake measures $57 \times 36 \times 17 \mathrm{~mm}$. All three side scrapers are made of fine-grained Potter chert.

Both of the combination end and side scrapers are complete. The larger $(50 \times 37 \times 11 \mathrm{~mm})$ is made on a secondary flake. Only minimal retouch is evident on one lateral edge and the distal end. The second tool (Fig. 17d) is made on a tertiary flake blank and measures $44 \times 29 \times 11 \mathrm{~mm}$. It has three working edges, with the distal working edge located on the face opposite from the two lateral working edges. Both tools are made of fine-grained chert; the larger is of locally available chert (Color 6), and the other is a nonlocal chert (Color 51).

The two unifacial tool edges cannot be assigned to morphofunctional categories. Both appear to represent flake blanks. Due to their small size, the cortex category cannot be determined on these fragments. One of the fragments was broken in use; the cause of break could not be determined on the other fragment. Both specimens are of fine-grained chert; one is nonlocal (Color 43 ), and the other is of indeterminate origin.

\section{CORES}

Twenty-nine cores and core fragments, representing seven raw material types were recovered (Table 17). Fine-grained chert cores dominate the collection $(\mathrm{n}=8,28 \%)$, followed by finegrained Potter chert $(\mathrm{n}=7,24 \%)$ and coarsegrained chert and coarse-grained quartzite in equal numbers $(n=4,14 \%)$. Tecovas Jasper $(n=2,7 \%)$ and coarse-grained Potter chert $(\mathrm{n}=1,3 \%)$ speci- mens occur in low frequencies.

Complete cores dominate the overall collection. The four coarse-grained quartzite cores are complete, as are a majority of the coarse-grained chert $(\mathrm{n}=3,75 \%)$ and fine-grained Potter chert $(\mathrm{n}=5,71 \%)$ cores. The finer-grained raw materials, such as fine-grained chert and quartzite and Tecovas jasper, have smaller percentages of complete cores. All 29 specimens are flake cores. The fine-grained Potter chert cores have the highest mean number of flake removals, followed by the Tecovas jasper and fine-grained chert cores. The lowest mean number of flake removals occurs on the coarse-grained quartzite cores. All three of the fine-grained quartzite cores are unidirectional (Fig. 17e). Unidirectional cores are also frequent among the fine-grained chert and the coarse-grained quartzite, comprising $75 \%$ of each material. Bidirectional and multidirectional cores (Fig. 17f) are infrequent but occur in a wider range of raw material types. None of the 29 cores have been reused. The metric attributes indicate that the fine- and coarse-grained chert cores are the smallest. The fine-grained Potter chert and fine-grained quartzite cores are the largest specimens in the collection.

Seven of the eight fine-grained chert cores are of local origin (Colors 16, 26, 28, 37, and 55 $[n=3])$. The origin of one specimen could not be determined with certainty.

\section{EDGE-MODIFIED FLAKES}

A total of 56 edge-modified flakes was recovered (Table 18). The majority of these are fine-grained cherts $(80 \%)$, with fine-grained Potter chert specimens being the next most frequent (14\%). The remaining three specimens are of Tecovas jasper, coarse-grained Potter chert, and a black basaltic material. Sixty-seven percent $(n=30)$ of the fine-grained chert tools are fragmentary specimens. Edge-modified flake tool fragments also outnumber complete tools among the fine-grained Potter cherts. The three specimens of other raw materials are also flake fragments. The breakdown of flake types by raw material indicates that chips outnumber other flake types among the fine-grained chert and fine-grained Potter chert edge-modified flakes. Only six of the complete fine-grained chert expedient tools are flake fragments. This indicates that complete flakes were the most frequently selected flake types used as expedient tools. 
TABLE 17

CORE ATTRIBUTES BY RAW MATERIAL TYPE, 41GR383

\begin{tabular}{|c|c|c|c|c|c|c|c|c|}
\hline Attributes & \begin{tabular}{|l} 
Fine- \\
Grained \\
Chert
\end{tabular} & $\begin{array}{l}\text { Coarse- } \\
\text { Grained } \\
\text { Chert }\end{array}$ & $\begin{array}{l}\text { Fine- } \\
\text { Grained } \\
\text { Quartzite }\end{array}$ & $\begin{array}{l}\text { Coarse- } \\
\text { Grained } \\
\text { Quartzite }\end{array}$ & $\begin{array}{l}\text { Fine- } \\
\text { Grained } \\
\text { Potter } \\
\text { Chert }\end{array}$ & \begin{tabular}{|l} 
Coarse- \\
Grained \\
Potter \\
Chert
\end{tabular} & $\begin{array}{l}\text { Tecovas } \\
\text { Jasper }\end{array}$ & Totals \\
\hline \multicolumn{9}{|l|}{ Completeness } \\
\hline Complete & 4 & 3 & 2 & 4 & 5 & - & 1 & 19 \\
\hline Fragment & 4 & $\underline{1}$ & 1 & $=$ & $\underline{2}$ & $\underline{1}$ & $\underline{1}$ & 10 \\
\hline Totals: & 8 & 4 & 3 & 4 & 7 & 1 & 2 & 29 \\
\hline \multicolumn{9}{|l|}{ Number of Removals } \\
\hline Mean & 5.3 & 3.0 & 4.0 & 1.5 & 7.0 & 5.0 & 6.0 & \\
\hline Standard Deviation & 5.6 & 2.2 & 5.2 & 0.6 & 5.5 & & 5.7 & \\
\hline Minimum & 1 & 1 & 1 & 1 & 2 & & 2 & \\
\hline Maximum & 17 & .6 & 10 & 2 & 15 & & 10 & \\
\hline \multicolumn{9}{|l|}{ Removal Direction } \\
\hline Unidirectional & 6 & 2 & 3 & 3 & 4 & - & - & 18 \\
\hline Bidirectional & - & 1 & - & 1 & 3 & - & 1 & 6 \\
\hline Opposed Bidirectional & - & - & - & - & - & - & - & - \\
\hline Multidirectional & $\underline{2}$ & 1 & $=$ & $=$ & $=$ & $\underline{1}$ & $\underline{1}$ & 5 \\
\hline Totals: & 8 & 4 & 3 & 4 & 7 & $\overline{1}$ & 2 & 29 \\
\hline \multicolumn{9}{|l|}{ Maximum Length } \\
\hline Mean & 33.1 & 40.5 & 62.7 & 42.3 & 81.4 & 88.0 & 58.5 & \\
\hline Standard Deviation & 7.3 & 16.1 & 20.8 & 9.9 & 34.4 & & 14.8 & \\
\hline Minimum & 22 & 17 & 39 & 33 & 29 & & 48 & \\
\hline Maximum & 42 & 53 & 78 & 56 & 146 & & 69 & \\
\hline \multicolumn{9}{|l|}{ Maximum Width } \\
\hline Mean & 28.3 & 28.5 & 56.3 & 27.5 & 55.0 & 46.0 & 29.5 & \\
\hline Standard Deviation & 9.6 & 14.2 & 19.4 & 3.9 & 16.8 & & 4.9 & \\
\hline Minimum & 13 & 15 & 34 & 24 & 24 & & 26 & \\
\hline Maximum & 41 & 46 & 69 & 33 & 73 & & 33 & \\
\hline \multicolumn{9}{|l|}{ Maximum Thickness } \\
\hline Mean & 16.9 & 14.8 & 31.7 & 25.3 & 42.3 & 29.0 & 26.5 & \\
\hline Standard Deviation & 6.6 & 8.8 & 4.9 & 2.9 & 15.9 & & 9.2 & \\
\hline Minimum & 8 & 5 & 26 & 22 & 16 & & 20 & \\
\hline Maximum & 28 & 24 & 35 & 29 & 60 & & 33 & \\
\hline
\end{tabular}

Tertiary and secondary flakes dominate the edgemodified specimens among the two more frequently used raw materials. Primary flakes occur only among the fine-grained cherts. The majority of the fine-grained chert specimens are in the 21-30-mm and 11-20-mm size classes. A slightly higher number of fine-grained Potter chert edge-modified flakes fall in the 11-20 mm size class compared to larger size classes. Nonetheless, the majority (63\%) of the fine-grained Potter chert flakes are 


\begin{tabular}{|c|c|c|c|c|c|c|}
\hline \multicolumn{7}{|c|}{$\begin{array}{l}\text { TABLE } 18 \\
\text { EDGE-MODIFIED FLAKE ATTRIBUTES BY RAW MATERIAL TYPE, 41GR383 }\end{array}$} \\
\hline Attributes & $\begin{array}{l}\text { Fine-Grained } \\
\text { Chert }\end{array}$ & $\begin{array}{c}\text { Fine-Grained } \\
\text { Potter Chert }\end{array}$ & $\begin{array}{l}\text { Coarse-Grained } \\
\text { Potter Chert }\end{array}$ & $\begin{array}{c}\text { Tecovas } \\
\text { Jasper }\end{array}$ & Other & Totals \\
\hline \multicolumn{7}{|l|}{ Completeness } \\
\hline Complete & 21 & 2 & - & - & - & 23 \\
\hline Fragment & $\underline{24}$ & $\underline{6}$ & $\underline{1}$ & $\underline{1}$ & 1 & $\underline{33}$ \\
\hline Totals: & $\overline{45}$ & 8 & 1 & $\overline{1}$ & $\overline{1}$ & 56 \\
\hline \multicolumn{7}{|l|}{ Flake Type } \\
\hline Complete & 15 & 2 & - & - & - & 17 \\
\hline Proximal & 8 & 2 & 1 & 1 & 1 & 13 \\
\hline Chip & $\underline{22}$ & $\underline{4}$ & $=$ & $=$ & $=$ & $\underline{26}$ \\
\hline Totals: & 45 & 8 & 1 & 1 & 1 & 56 \\
\hline \multicolumn{7}{|l|}{ Cortex Category } \\
\hline Primary & 2 & - & - & - & - & 2 \\
\hline Secondary & 12 & 3 & - & 1 & - & 16 \\
\hline Tertiary & $\underline{31}$ & $\underline{5}$ & $\underline{1}$ & $=$ & $\underline{1}$ & $\underline{38}$ \\
\hline Totals: & 45 & 8 & $\overline{1}$ & $\overline{1}$ & $\overline{1}$ & 56 \\
\hline \multicolumn{7}{|c|}{ Maximum Dimension } \\
\hline $1-10 \mathrm{~mm}$ & 1 & - & - & - & - & 1 \\
\hline $11-20 \mathrm{~mm}$ & 15 & 3 & - & - & - & 18 \\
\hline $21-30 \mathrm{~mm}$ & 20 & 2 & 1 & 1 & 1 & 25 \\
\hline $31-40 \mathrm{~mm}$ & 8 & 2 & - & - & - & 10 \\
\hline $41-50 \mathrm{~mm}$ & 1 & $\underline{1}$ & $=$ & $=$ & $=$ & 2 \\
\hline Totals: & $\overline{45}$ & $\overline{8}$ & $\overline{1}$ & $\overline{1}$ & 1 & 56 \\
\hline \multicolumn{7}{|c|}{ No. of Modified Edges } \\
\hline & 36 & 7 & 1 & 1 & 1 & 46 \\
\hline Two & 9 & $\underline{1}$ & $=$ & $=$ & $=$ & 10 \\
\hline Totals: & 45 & 8 & $\overline{1}$ & $\overline{1}$ & $\overline{1}$ & 56 \\
\hline \multicolumn{7}{|l|}{ Inferred Use } \\
\hline Sawing/Cutting & 2 & 1 & - & 1 & - & 4 \\
\hline Scraping & 37 & 6 & 1 & - & 1 & 45 \\
\hline Sawing/Scraping & 5 & 1 & - & - & - & 6 \\
\hline Sawing/Engraving & 1 & $=$ & $=$ & $=$ & $=$ & 1 \\
\hline Totals: & $\overline{45}$ & $\overline{8}$ & $\overline{1}$ & $\overline{1}$ & $\overline{1}$ & $\overline{56}$ \\
\hline
\end{tabular}

greater than $20 \mathrm{~mm}$. Among the fine-grained chert edge-modified flakes, specimens with single working edges $(n=36)$ outnumber those with two utilized edges $(n=9)$. The same pattern is noted among the fine-grained Potter cherts expediency tools. Edges utilized in scraping tasks are most frequent in the fine-grained chert edge-modified flake collection (82\%) and among the fine-grained Potter cherts (75\%). Among the fine-grained cherts, working edges used in the performance of multiple tasks (e.g., sawing/scraping, etc.) are more frequent than sawing/cutting edges. The small 
sample of edge-modified flakes in most material types does not allow the evaluation of differential use of certain materials. It is evident, however, that the fine-grained materials such as fine-grained chert and fine-grained Potter chert have a higher likelihood of being used as expediency tools than the coarse-grained materials.

Of the 45 fine-grained chert specimens, $60 \%$ are of local origin, $38 \%$ are nonlocal, and $2 \%$ are of indeterminate origin. Colors $6(n=13)$ and 7 $(n=3)$ constitute the largest number of local finegrained cherts. Five additional specimens are also classified as locally available, although they do not match specific chert colors represented in the comparative collection. Of the nonlocal finegrained cherts, Color 41 contains the largest number $(n=5)$, followed by Colors $42(n=3)$ and 43 $(n=3)$. Three others are classified as indeterminate nonlocal specimens.

\section{UNMODIFIED DEBITAGE}

Table 19 presents the unmodified lithic debitage attributes by raw material type. Of the 1,968 pieces of debitage, $63 \%$ are fine-grained chert, $21 \%$ are fine-grained Potter chert, and $5 \%$ are fine-grained quartzites. Coarse-grained chert, quartzite, and Potter chert occur in lower frequencies $(2 \%, 2 \%$, and $4 \%$, respectively). Of the other material types, Tecovas jasper is the most frequent, followed by silicified caliche, Alibates agate, chalcedony, and silicified wood. Debitage of miscellaneous raw materials is relatively frequent.

With the exception of the coarse-grained Potter chert debitage, chips represent the most frequent flake type category in each of the other raw material types with large debitage samples. Fine-grained cherts have somewhat higher percentages of chips than the other raw material types $(55 \%)$. The percentages of chips in the finegrained quartzites $(45 \%)$ and fine-grained Potter cherts $(47 \%)$ are relatively similar. Among the less frequently occurring material types, chips tend to outnumber other flake types in all but the opalized caliche and chalcedony debitage. Chunks appear to be most frequent among the coarse-grained Potter chert. Among the fine-grained materials, they are relatively frequent in the cherts, quartzites, and Potter cherts.

Decorticate debitage is most frequent in the fine-grained cherts $(81 \%)$, followed by the fine- grained Potter cherts (65\%). Lower percentages of decorticate debitage are found in the coarse-grained Potter chert (49\%) and fine-grained quartzite (49\%) collections. Among the less frequently occurring material types, Tecovas jasper and Alibates agate have the highest percentages of entirely decorticate debitage ( $93 \%$ and $88 \%$, respectively). The lowest percentage of entirely cortex-covered debitage occurs in the fine-grained cherts $(2 \%)$ and finegrained $(9 \%)$ and coarse-grained $(11 \%)$ Potter cherts. Fine- and coarse-grained quartzites have significantly higher percentages of entirely corticate debitage (23\% and $44 \%$, respectively). Among the less frequently occurring raw material types, Alibates agate, Tecovas jasper, opalized caliche, and coarse-grained chert contain no entirely cortexcovered debitage. The breakdown of cortex percentages by raw material type tends to follow similar trends among the chunks.

The examination of platform cortex on complete flakes and proximal fragments indicates that decorticate platforms are most frequent among the fine-grained cherts $(87 \%)$, with lower percentages occurring among the fine-grained Potter cherts $(71 \%)$ and the coarse-grained cherts $(65 \%)$. The lowest percentages are found among the coarsegrained Potter chert debitage (49\%). Among the less frequent material types, debitage with decorticate platforms is common among all but the coarse-grained quartzite specimens.

Among the raw material types with large samples, platform grinding is most frequent in the fine-grained chert debitage $(42 \%)$. Ground platforms are less frequent in the fine-grained Potter cherts (13\%). With the exception of five of the nine specimens of Tecovas jasper debitage, platform grinding occurs in low frequencies or is entirely absent among the other raw materials.

Single-facet striking platforms are most frequent among the coarse-grained Potter chert $(90 \%)$ and fine-grained quartzite $(85 \%)$ complete flakes and proximal fragments. Somewhat lower percentages occur among the coarse-grained chert (71\%) and fine-grained Potter chert $(70 \%)$ debitage. The lowest percentage of single-facet platforms is found among the fine-grained chert debitage $(48 \%)$. Single-facet specimens are relatively frequent in the other raw material types. Platforms with three or more facets on complete flakes and proximal fragments are most frequent in the finegrained chert debitage and the coarse-grained cherts 


\begin{tabular}{|c|c|c|c|c|c|c|c|c|c|c|c|c|c|c|}
\hline \multicolumn{15}{|c|}{$\begin{array}{c}\text { TABLE } 19 \\
\text { UNMODIFIED LITHIC DEBITAGE ATTRIBUTES BY RAW MATERIAL TYPE, } 41 \text { GR383 }\end{array}$} \\
\hline Attributes & $\begin{array}{l}\text { Fine- } \\
\text { Grained } \\
\text { Chert }\end{array}$ & $\begin{array}{l}\text { Coarse- } \\
\text { Grained } \\
\text { Chert }\end{array}$ & $\begin{array}{l}\text { Fine- } \\
\text { Grained } \\
\text { Quartzite }\end{array}$ & $\begin{array}{l}\text { Coarse- } \\
\text { Grained } \\
\text { Quartzite }\end{array}$ & \begin{tabular}{|l} 
Fine- \\
Grained \\
Potter \\
Chert \\
\end{tabular} & \begin{tabular}{|l} 
Coarse- \\
Grained \\
Potter \\
Chert \\
\end{tabular} & $\begin{array}{l}\text { Opalized } \\
\text { Caliche } \\
\end{array}$ & $\begin{array}{l}\text { Silicified } \\
\text { Caliche } \\
\end{array}$ & \begin{tabular}{|l} 
Silicified \\
Wood
\end{tabular} & Chalcedony & \begin{tabular}{|l}
$\begin{array}{l}\text { Tecovas } \\
\text { Jasper }\end{array}$ \\
\end{tabular} & \begin{tabular}{|l} 
Alibates \\
Agate
\end{tabular} & Other & Totals \\
\hline \multicolumn{15}{|l|}{$\begin{array}{l}\text { Flake } \\
\text { Type }\end{array}$} \\
\hline Complete & 274 & 17 & 27 & 7 & 110 & 35 & 2 & 4 & 1 & 3 & 3 & 1 & 1 & 485 \\
\hline Proximal & 239 & - & 12 & 1 & 66 & 4 & - & 3 & - & - & 6 & 2 & 3 & 336 \\
\hline Chip & 679 & 19 & 41 & 10 & 197 & 22 & 1 & 6 & 2 & 3 & 6 & 5 & 13 & 1004 \\
\hline Chunk & 51 & $\underline{2}$ & 11 & 16 & 45 & 10 & $=$ & $=$ & $=$ & $\underline{4}$ & $=$ & $\underline{3}$ & 1 & 143 \\
\hline $\begin{array}{l}\text { Totals: } \\
\end{array}$ & 1243 & 38 & 91 & 34 & 418 & 71 & 3 & 13 & 3 & 10 & 15 & 11 & 18 & 1968 \\
\hline \multicolumn{15}{|l|}{$\begin{array}{l}\text { Chunk } \\
\text { Cortex }\end{array}$} \\
\hline Present & 36 & 2 & 8 & 15 & 33 & 4 & - & - & - & - & - & 3 & 1 & 102 \\
\hline Absent & 15 & $=$ & $\underline{3}$ & 1 & 12 & 6 & $=$ & $=$ & $=$ & 4 & $=$ & $=$ & $=$ & 41 \\
\hline Totals: & 51 & $\overline{2}$ & $\overline{11}$ & 16 & 45 & 10 & $\overline{0}$ & 0 & $\overline{0}$ & 4 & $\overline{0}$ & $\overline{3}$ & $\overline{1}$ & $\overline{143}$ \\
\hline \multicolumn{15}{|l|}{$\begin{array}{l}\text { Dorsal } \\
\text { Cortex } \\
\text { Percent }\end{array}$} \\
\hline 0 & 960 & 26 & 39 & 3 & 242 & 30 & 2 & 10 & 2 & 4 & 14 & 7 & 12 & 1351 \\
\hline $1-50$ & 148 & 8 & 16 & 3 & 63 & 13 & - & 1 & - & - & - & 1 & 3 & 256 \\
\hline 51-99 & 64 & 2 & 7 & 4 & 36 & 11 & 1 & - &. & 1 & 1 & - & - & 127 \\
\hline 100 & 20 & $=$ & 18 & 8 & 32 & 7 & $=$ & $\underline{2}$ & 1 & 1 & $=$ & $=$ & 2 & 91 \\
\hline Totals: & 1192 & 36 & 80 & 18 & 373 & 61 & 3 & 13 & 3 & 6 & 15 & 8 & 17 & 1825 \\
\hline \multicolumn{15}{|l|}{$\begin{array}{l}\text { Platform } \\
\text { Cortex }\end{array}$} \\
\hline Present & 69 & 6 & 16 & 5 & 51 & 20 & - & 2 & - & 1 & - & 1 & 1 & 172 \\
\hline Absent & 444 & 11 & $\underline{23}$ & 3 & 125 & 19 & $\underline{2}$ & 5 & $\underline{1}$ & $\underline{2}$ & 2 & $\underline{2}$ & $\underline{3}$ & 649 \\
\hline Totals: & 513 & 17 & 39 & 8 & 176 & 39 & 2 & 7 & 1 & 3 & 9 & 3 & 4 & 821 \\
\hline
\end{tabular}


Table 19, continued

\begin{tabular}{|c|c|c|c|c|c|c|c|c|c|c|c|c|c|c|}
\hline Attributes & $\begin{array}{l}\text { Fine- } \\
\text { Grained } \\
\text { Chert }\end{array}$ & $\begin{array}{l}\text { Coarse- } \\
\text { Grained } \\
\text { Chert }\end{array}$ & $\begin{array}{l}\text { Fine- } \\
\text { Grained } \\
\text { Quartzite }\end{array}$ & $\begin{array}{l}\text { Coarse- } \\
\text { Grained } \\
\text { Quartzite }\end{array}$ & $\begin{array}{l}\text { Fine- } \\
\text { Grained } \\
\text { Potter } \\
\text { Chert } \\
\end{array}$ & $\begin{array}{l}\text { Coarse- } \\
\text { Grained } \\
\text { Potter } \\
\text { Chert } \\
\end{array}$ & $\begin{array}{l}\text { Opalized } \\
\text { Caliche }\end{array}$ & $\begin{array}{l}\text { Silicified } \\
\text { Caliche }\end{array}$ & $\begin{array}{l}\text { Silicified } \\
\text { Wood }\end{array}$ & Chalcedony & $\begin{array}{l}\text { Tecovas } \\
\text { Jasper }\end{array}$ & $\begin{array}{l}\text { Alibates } \\
\text { Agate }\end{array}$ & Other & Totals \\
\hline \multicolumn{15}{|l|}{$\begin{array}{l}\text { Platform } \\
\text { Grinding }\end{array}$} \\
\hline Present & 213 & 4 & 1 & - & 22 & - & - & 1 & - & - & 5 & - & 1 & 247 \\
\hline Absent & 300 & 13 & 38 & $\underline{8}$ & 154 & 39 & $\underline{2}$ & $\underline{6}$ & 1 & $\underline{3}$ & 4 & 3 & 3 & 574 \\
\hline Totals: & $\overline{513}$ & 17 & 39 & 8 & 176 & 39 & 2 & 7 & 1 & 3 & 9 & 3 & 4 & 821 \\
\hline \multicolumn{15}{|l|}{$\begin{array}{l}\text { Platform } \\
\text { Faceting }\end{array}$} \\
\hline 1 facet & 248 & 12 & 33 & 8 & 123 & 35 & 1 & 4 & 1 & 2 & 4 & 2 & 3 & 476 \\
\hline 2 facets & 114 & - & 5 & - & 26 & 2 & 1 & 1 & - & - & 1 & 1 & 1 & 152 \\
\hline$\geq 3$ facets & 151 & 5 & 1 & $=$ & 27 & 2 & $=$ & 2 & $=$ & 1 & 4 & $=$ & $=$ & 193 \\
\hline Totals: & 513 & 17 & 39 & 8 & 176 & 39 & 2 & 7 & 1 & 3 & $\overline{9}$ & 3 & $\overline{4}$ & 821 \\
\hline \multicolumn{15}{|l|}{$\begin{array}{l}\text { Maximum } \\
\text { Dimension }\end{array}$} \\
\hline $1-10 \mathrm{~mm}$ & 184 & 6 & 9 & 1 & 45 & 2 & - & 2 & - & 2 & 1 & 1 & - & 253 \\
\hline $11-20 \mathrm{~mm}$ & 933 & 23 & 45 & 24 & 258 & 34 & 1 & 7 & 3 & 6 & 11 & 7 & 12 & 1364 \\
\hline $21-30 \mathrm{~mm}$ & 108 & 6 & 14 & 7 & 74 & 10 & 1. & 2 & - & - & 3 & 1 & 5 & 231 \\
\hline $31-40 \mathrm{~mm}$ & 15 & 2 & 10 & 1 & 25 & 13 & - & 1 & - & 1 & - & 2 & 1 & 71 \\
\hline $41-50 \mathrm{~mm}$ & 3 & 1 & 6 & 1 & 7 & 7 & - & 1 & - & - & - & - & - & 26 \\
\hline $51-60 \mathrm{~mm}$ & - & - & 6 & - & 4 & 2 & - & - & - & - & - & - & - & 12 \\
\hline$\geq 61 \mathrm{~mm}$ & - & $=$ & 1 & $=$ & 5 & 3 & 1 & $=$ & $=$ & 1 & $=$ & $=$ & $=$ & 11 \\
\hline Totals: & $\overline{1243}$ & 38 & 91 & 34 & 418 & 71 & 3 & 13 & 3 & 10 & 15 & 11 & $\overline{18}$ & 1968 \\
\hline
\end{tabular}


( $29 \%$ each), followed by the fine-grained Potter chert specimens $(15 \%)$. With the exception of the small sample of coarse-grained cherts, the other coarse-grained raw materials in general have relatively low percentages of flakes and proximal fragments with three or more striking platform facets. Among the raw material types with low sample sizes, the Tecovas jasper debitage has the highest frequency of specimens with three or more facets (4 of 9).

The majority of the debitage of all the material types $(69 \%)$ measures between $11-20 \mathrm{~mm}$ in maximum dimension. In addition, among the material types with large debitage samples, the fine-grained chert has the largest percentage of flakes in the smallest size category (15\%), followed by the fine-grained Potter chert $(11 \%)$ and finegrained quartzite $(10 \%)$. Coarse-grained Potter chert $(35 \%)$ and fine-grained quartzite $(25 \%)$ have the largest percentages of debitage greater than $30 \mathrm{~mm}$, followed by the fine-grained Potter chert $(10 \%)$. The trends in the size distribution of the debitage among the raw material types with large samples appear to parallel the size range of naturally occurring raw materials in the project area (see Chapter 3, Raw Material).

Of the 1,243 fine-grained chert unmodified debitage, $66 \%$ are of nonlocal origin, $30 \%$ are of local origin, and the origin of $4 \%$ cannot be determined. Among the nonlocal fine-grained cherts, Color $51(n=252,20 \%)$ contains the largest percentage of debitage, followed by Colors 43 $(n=213,17 \%)$ and $41(n=159,12 \%)$. The indeterminate local color category contains the largest percentage of specimens $(n=57,5 \%)$ among the local specimens. Colors $29(\mathrm{n}=36,3 \%)$ and 5 $(n=34,3 \%)$ contain the next highest percentage of locally available fine-grained cherts. The dominance of the nonlocal fine-grained chert debitage is significant, especially in light of the $41 \mathrm{KT} 33$ debitage collection that is composed primarily of locally available cherts (see Chapter 7). The fact that neither Alibates agate nor Tecovas jasper occur in significant quantities suggests that raw material procurement was directed south-southeast of the Double Mountain Fork of the Brazos. This pattern may reflect the greater distances involved in procuring jasper and agate compared to the finegrained cherts occurring along the Callahan Divide. Additionally or conversely, it may also represent the existence of cultural and/or territorial bound- aries that prevented or reduced access to Tecovas jasper or Alibates agate sources.

\section{Ground and Battered Stone Artifacts}

A total of 55 ground and battered stone artifacts was recovered. Two of these came from isolated excavation units; the others are from the excavation units located within the block. Five of the 55 specimens were associated with Feature 13, 5 were associated with Feature 14, and 2 others were associated with Feature 15 . Of the 55 specimens, 15 are manos and mano fragments, 35 are metates and metate fragments, and 5 are hammerstones. Table 20 presents the ground stone artifact attributes by morphofunctional category.

\section{MANOS}

Of the 15 manos, 6 are quartzite and 9 are sandstone. Of the five complete manos, one is quartzite, and the others are sandstone. Only 10 of the specimens are complete enough to record their shape; nine are oval, and one is rectangular. Eight specimens have biconvex transverse cross sections; three of these are quartzite, and five are sandstone. Two other mano fragments are sandstone and have biconvex cross sections with medial ridges. Of the remaining five manos, two have beveled cross sections, one is planoconvex, and two others are too fragmentary to determine their cross sections. Seven of the 15 manos have bifacial use-wear (Fig. 18a, b); two of these are quartzite, and the others are sandstone. Use-wear is unifacially distributed on the remaining three quartzite and five sandstone specimens (Fig. 18c). Pecking, resulting from working-surface rejuvenation, is unifacially distributed on eight manos; three of these are fine-grained quartzite, and five are sandstone. Bifacially distributed pecking occurs on three manos; one is finegrained quartzite and two are sandstone. Pecking is absent on the remaining four manos; two are fine-grained quartzite, and two are sandstone. Moderate battering is present only on one finegrained quartzite mano fragment. It is distributed on acute edges formed by original unbroken and break faces. The battering consists of bifacial crushing and may be the result of the tool's reuse as a hammerstone or chopper. Battering is indeterminate on three small quartzite and two sandstone mano fragments and is absent on the two fine- 


\begin{tabular}{|c|c|c|c|c|}
\hline \multicolumn{5}{|c|}{$\begin{array}{c}\text { TABLE } 20 \\
\text { GROUND STONE ATTRIBUTES, 41GR383 }\end{array}$} \\
\hline Attribute & Category & Manos & Metates & Totals \\
\hline Raw Material & $\begin{array}{l}\text { Sandstone } \\
\text { Quartzite } \\
\text { Totals: } \\
\end{array}$ & $\begin{array}{r}9 \\
\frac{6}{15}\end{array}$ & $\frac{35}{35}$ & $\begin{array}{l}44 \\
\frac{6}{50}\end{array}$ \\
\hline Completeness & $\begin{array}{l}\text { Complete } \\
\text { Fragment } \\
\text { Totals: }\end{array}$ & $\begin{array}{r}5 \\
\frac{10}{15}\end{array}$ & $\frac{-\overline{35}}{35}$ & $\begin{array}{r}5 \\
45 \\
50\end{array}$ \\
\hline Shape & \begin{tabular}{l} 
Rounded \\
Oval \\
Angular \\
Rectangular \\
Indeterminate \\
\multicolumn{1}{c}{ Totals: }
\end{tabular} & $\begin{array}{l}- \\
9 \\
- \\
1 \\
\frac{5}{15}\end{array}$ & $\begin{array}{r}2 \\
1 \\
16 \\
16 \\
- \\
35\end{array}$ & $\begin{array}{r}2 \\
10 \\
16 \\
17 \\
5 \\
50\end{array}$ \\
\hline Transverse Cross Section & $\begin{array}{l}\text { Biconvex } \\
\text { Planoconvex } \\
\text { Planoconcave } \\
\text { Beveled } \\
\text { Tabular } \\
\text { Biconvex with medial ridge } \\
\text { Indeterminate } \\
\text { Totals: }\end{array}$ & $\begin{array}{l}8 \\
1 \\
- \\
2 \\
\overline{2} \\
\underline{2} \\
15\end{array}$ & $\begin{array}{r}3 \\
3 \\
6 \\
8 \\
15 \\
- \\
- \\
35\end{array}$ & $\begin{array}{r}11 \\
4 \\
6 \\
10 \\
15 \\
2 \\
2 \\
50\end{array}$ \\
\hline Use-Wear & $\begin{array}{l}\text { Unifacial } \\
\text { Bifacial } \\
\text { Totals: }\end{array}$ & $\begin{array}{l}8 \\
\frac{7}{15}\end{array}$ & $\begin{array}{r}30 \\
\frac{5}{35}\end{array}$ & $\begin{array}{l}39 \\
\frac{11}{50}\end{array}$ \\
\hline Pecking & $\begin{array}{l}\text { Unifacial } \\
\text { Bifacial } \\
\text { Absent } \\
\text { Totals: }\end{array}$ & $\begin{array}{r}8 \\
3 \\
4 \\
15 \\
\end{array}$ & $\begin{array}{r}29 \\
5 \\
\frac{1}{35} \\
\end{array}$ & $\begin{array}{r}37 \\
8 \\
5 \\
50 \\
\end{array}$ \\
\hline Battering & $\begin{array}{l}\text { Moderate } \\
\text { Absent } \\
\text { Indeterminate } \\
\text { Totals: } \\
\end{array}$ & $\begin{array}{r}1 \\
9 \\
\underline{5} \\
15\end{array}$ & $\begin{array}{l}- \\
35 \\
\overline{35}\end{array}$ & $\begin{array}{r}1 \\
44 \\
5 \\
50\end{array}$ \\
\hline Reuse & $\begin{array}{l}\text { Present } \\
\text { Absent } \\
\text { Totals: }\end{array}$ & $\begin{array}{r}2 \\
\frac{13}{15}\end{array}$ & $\begin{array}{l}13 \\
\frac{22}{35}\end{array}$ & $\begin{array}{l}15 \\
\frac{35}{50}\end{array}$ \\
\hline
\end{tabular}

grained quartzite and seven sandstone mano fragments. In addition to the fine-grained quartzite mano reused as a hammerstone or chopper, an additional sandstone mano recovered from Feature 14 appears to have been reused as a hearthstone.

\section{METATES}

The 35 metates recovered are sandstone fragments. Sixteen are rectangular, 16 are angular, two are rounded, and one is oval. The majority are tabular fragments, followed by beveled and planoconcave specimens. The remaining six consist of three biconvex and three planoconvex specimens. Use-wear is unifacially distributed on 30 metate fragments and occurs on both faces of 5 specimens. Twenty-nine of the 30 metate fragments with unifacial use-wear also exhibit pecking. Only one 

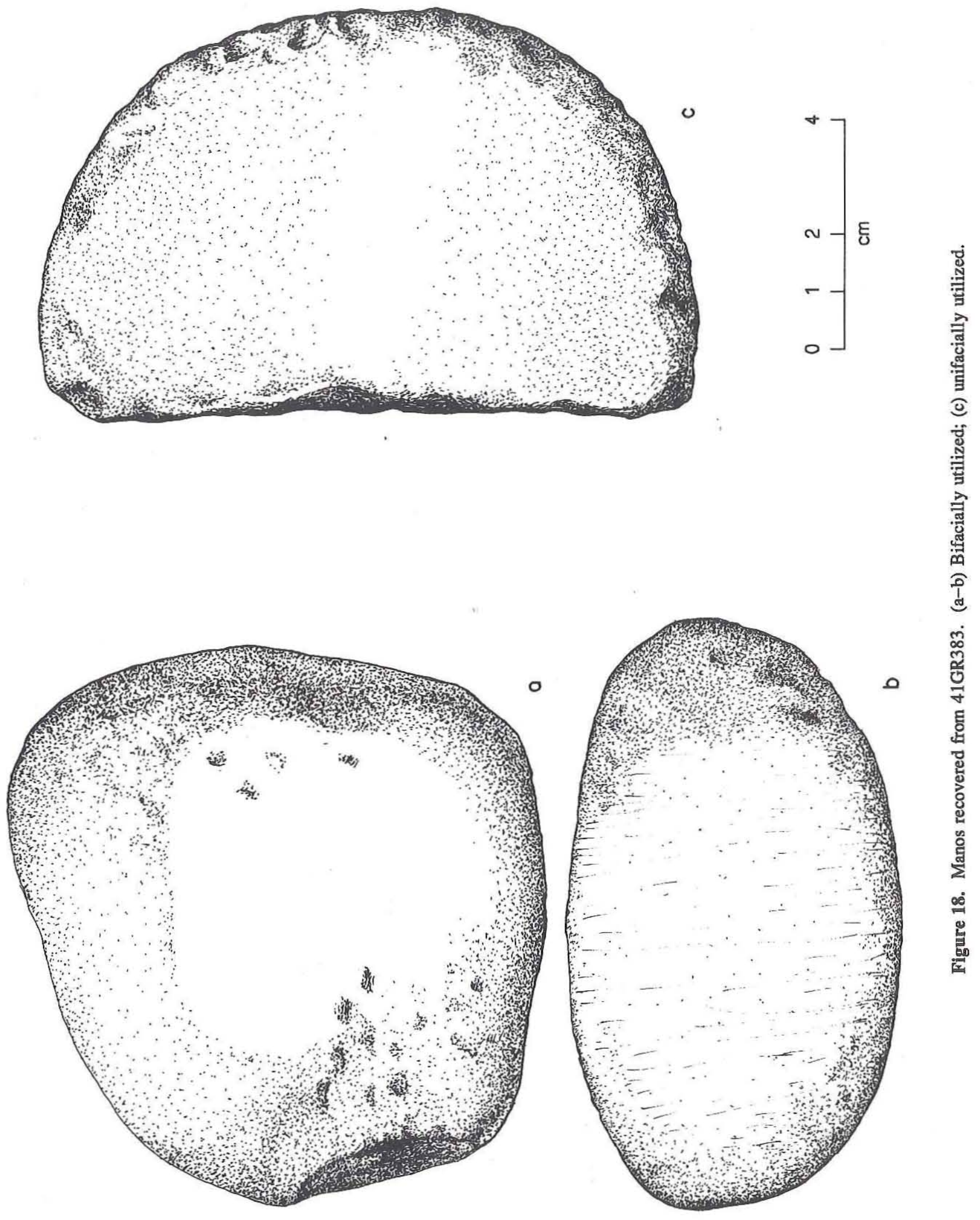
of these 30 specimens retains no traces of pecking. The five metate fragments with bifacial use-wear also exhibit bifacial pecking. Battering is absent on all of the metate fragments. Signs of reuse are absent on 22 of the metate fragments. Twelve of the remaining 13 fragments were recovered from burned rock features, suggesting that they were reutilized as building blocks of these features. The remaining specimen is a fire-cracked metate fragment probably reused as a hearthstone but not recovered in association with a burned rock feature.

\section{HAMMERSTONES}

Of the five hammerstones recovered, four are complete and one is fragmentary. Three of the complete specimens have only a slight degree of battering on their naturally rounded edges. The fourth complete hammerstone (Fig. 19), as well as the fragment, exhibit moderate battering. Evidence of reuse is absent on the four complete specimens. The hammerstone fragment appears to have been reused as a core and subsequently was fire cracked. Three of the five hammerstones are of coarsegrained quartzite, the other two are of fine-grained quartzite. The largest specimen measures $106 \times 73 \times 50 \mathrm{~mm}$ and weighs $561 \mathrm{~g}$. The three remaining specimens are medium sized and have a mean length of $68.0 \mathrm{~mm}(\sigma=5.0, \mathrm{~min} .=63$, $\max$. $=73)$, a mean width of $54 \mathrm{~mm}(\sigma=4.0, \mathrm{~min} .=50$, max. $=58)$, a mean thickness of $29 \mathrm{~mm}(\sigma=7.0$, min. $=21$, max. $=38$, and a mean weight of $159.7 \mathrm{~g}(\sigma=35.9, \min .=137, \max .=201)$.

\section{Manuport}

One artifact exhibits no conclusive evidence of use as a tool, but the specimen is a fine-grained reddish sandstone that does not occur naturally in the vicinity of the site. The material is probably a Permian sandstone from the project area, but it is distinctively different from the Triassic sandstones that crop out at the site. The manuport is a thin, enlongated, oval-shaped fragment which measures $260 \times 87 \times 25 \mathrm{~mm}$. One end is straight, while the other is convex to rounded. The edges exhibit some flake scars that may have been the result of either intentional shaping or natural causes, but they are mostly obliterated by subsequent weathering and/or edge wear. One large refit flake was recovered in situ in its negative flake scar, perhaps indicating postdepositional damage to the specimen. The function of this manuport is unknown, although based on its shape it may have been used as a pestle with the narrow oval bedrock mortars, three of which are found at the site.

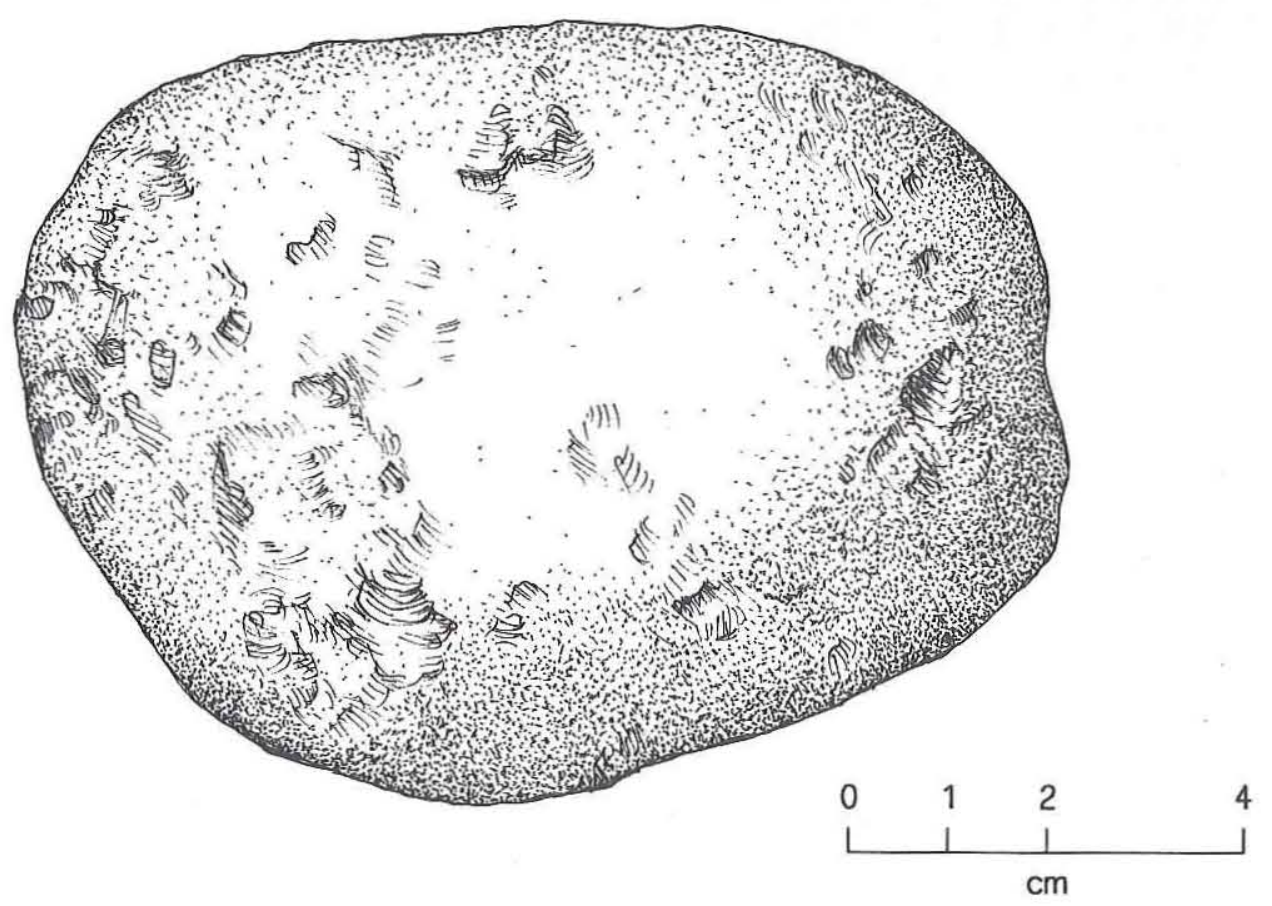

Figure 19. Moderately battered hammerstone recovered from 41GR383. 


\section{Modified Shell}

A single freshwater mussel shell fragment (from EU 53, Level 3) exhibits evidence of intentional modification. The $17 \times 20-\mathrm{mm}$ fragment is less than $1 \mathrm{~mm}$ thick. All edges are broken, and a portion of a possible drill hole ( $<1 \mathrm{~mm}$ diameter) is present along one edge. The fragment appears to have been drilled from the exterior. The fragment may have been intended as an ornament (e.g., pendant), but its small size and the incompleteness of the drill hole make this suggestion tentative.

\section{Burned Rocks}

Burned rocks at $41 \mathrm{GR} 383$ consisted of burned sandstone and fire-cracked rocks. A total of $820 \mathrm{~kg}$ of burned sandstone was documented, accounting for $99.5 \%$ of all burned rocks. The burned sandstone was too ubiquitous to be collected, but it was weighed and examined in the field. One mano and 12 metate fragments were found among the burned rocks and apparently were recycled as hearthstones. The sandstones are dominantly Triassic grayish green, micaceous sandstones but also include some conglomerate (probably Triassic) sandstones and some red sandstones of probable Permian origin.

A total of ca. $4 \mathrm{~kg}$ of fire-cracked rocks (ca. $0.5 \%$ of all burned rocks) were encountered in the excavation block. They apparently were scattered randomly throughout the block, and no features were observed. The majority of the fire-cracked rocks in the excavation block were Potter chert at $79.0 \%(3.2 \mathrm{~kg})$, followed by $18.9 \%$ quartzite, $1.7 \%$ limestone, and $0.4 \%$ chert at $<1 \mathrm{~kg}$ each. All of these materials are of local origin and are intensively heat fractured. Heat treating of lithic materials does not appear to have been intended, and the few fire-cracked chert specimens and one hammerstone were probably burned incidentally.

\section{Faunal Remains}

The faunal remains from 41GR383 consist of bones and shells which are identified and discussed in Appendix C. The vertebrate faunal remains consist of five noncultural bone fragments. Small, medium, and possibly large mammals are represented, but the only identified species are cottontail and jack rabbit.
The invertebrate remains include three terrestrial snails and ca. $24 \mathrm{~g}$ of freshwater mussel shell fragments. The terrestrial snails are likely to be natural, but the freshwater mussel shells are thought to be cultural in origin. Although no complete bivalve halves were found, fragments were abundant throughout the excavations.

\section{SUMMARY AND CONCLUSIONS}

The Phase III data recovery investigations at 41GR383 yielded evidence of a late Archaic/Late Prehistoric I cultural component. Three burned rock features were encountered, and 2,160 artifacts were recovered.

\section{Site Chronology and Definition of Component}

Four radiocarbon dates (three conventional sediment assays and one AMS charcoal assay) were obtained from the cultural deposits at 41GR383. One sediment date ( $450 \pm 125$ B.P., cal. 510 B.P.) appears to be too young due to contamination, but the others are more consistent. A sediment date of $1865 \pm 140$ B.P., cal. 1824 B.P., is the oldest, while two dates from below Feature 13 provide ages of $1215 \pm 140$ B.P. (sediment) and $1390 \pm 65$ B.P. (charcoal), cal. 1163 B.P. and 1299 B.P., respectively. These three dates span the period from A.D. 85 to 735 (cal. A.D. 126-787) and suggest that the site occupations are late Archaic into Late Prehistoric I. This assessment is consistent with the artifactual evidence but is hampered by the paucity of diagnostic artifacts. Only two specimens could definitely be classed as projectile points, although neither could be typed; one is a dart point tip, and the other is a cornernotched arrow point base. Several bifaces appear to be projectile point preforms, most likely for dart points, but they could also be preforms for large, early arrow point styles. Thus, the handful of diagnostics also represent the transitional period from late Archaic into Late Prehistoric I.

Because of the absence of natural stratigraphy and the lack of cultural stratification, the cultural materials recovered from 41GR383 are analyzed as a single component representing multiple occupations over an unknown period of time. As used here, the term component simply refers to the most discrete and definable temporal unit within a site. 
The vertical distribution of the chipped, ground, and battered stone artifacts (Table 21) indicates that the cultural zone includes all sediment above bedrock. All of the units ended on bedrock, either hard sandstone or mottled decomposing sandstone. Most units ended at $40-50 \mathrm{~cm}$ below the surface, but others were excavated to $50-90 \mathrm{~cm}$ before reaching bedrock, and one of the isolated units (EU 52) was excavated to $110 \mathrm{~cm}$ before encountering bedrock in its lowest corner. Artifacts were recovered throughout the excavation block, but the average number of artifacts per level was generally higher in the upper levels, with less than $10 \%$ (using the average artifacts per level) recovered from Levels 7 and 8. Where sediments are deepest $(>50 \mathrm{~cm})$, the cultural zone is more dispersed and appears to be compressed in the shallower units. Even in the two dispersed units (EUs 52 and 53) where sediments are as deep as $110 \mathrm{~cm}$, artifacts were recovered from Levels 2 through 9, but less than $10 \%$ (using the average artifacts per level) were recovered from Levels 8 and 9. It is clear that the artifacts at 41GR383 are vertically dispersed or compressed, depending upon sediment thickness, but even the deeper units exhibit no apparent stratigraphic break in the distributions. Lacking any obvious stratigraphic separation of the cultural materials or diagnostic artifacts from distinct time periods, it is most appropriate to consider the artifact assemblage as a single component.

\section{Intrasite Patterning and Site Function}

Cultural materials from 41GR383 were analyzed as a single unit. As multiple occupations are likely, there is some degree of inherent disturbance to the intrasite patterning, and this is probably compounded by bioturbation. Nevertheless, spatial patterning is evident in the distribution of

TABLE 21

VERTICAL DISTRIBUTION OF CHIPPED, GROUND, AND BATTERED STONES, 41GR383

\begin{tabular}{|c|c|c|c|c|}
\hline Level & $\begin{array}{c}\text { No. of Units } \\
\text { Excavated }\end{array}$ & $\begin{array}{c}\text { No, of Artifacts } \\
\text { Recovered }\end{array}$ & $\begin{array}{c}\text { Average No. } \\
\text { of Artifacts }\end{array}$ & $\begin{array}{c}\% \text { of Average No. } \\
\text { of Artifacts }\end{array}$ \\
\hline \multicolumn{5}{|c|}{ Excavation Block } \\
\hline 1 & 51 & 319 & 6.3 & 11.0 \\
\hline 2 & 51 & 837 & 16.4 & 28.6 \\
\hline 3 & 49 & 556 & 11.3 & 19.7 \\
\hline 4 & 39 & 238 & 6.1 & 10.6 \\
\hline 5 & 15 & 84 & 5.6 & 9.8 \\
\hline 6 & 7 & 43 & 6.1 & 10.6 \\
\hline 7 & 4 & 10 & 2.5 & 4.4 \\
\hline 8 & 2 & 6 & 3.0 & 5.2 \\
\hline 9 & 1 & - & 0.0 & 0.0 \\
\hline & 219 & 2093 & 57.3 & \\
\hline \multicolumn{5}{|c|}{ Dispersed Units } \\
\hline 1 & 2 & - & 0.0 & 0.0 \\
\hline 2 & 2 & 6 & 3.0 & 9.2 \\
\hline 3 & 2 & 12 & 6.0 & 18.5 \\
\hline 4 & 2 & 8 & 4.0 & 12.3 \\
\hline 5 & 2 & 9 & 4.5 & 13.8 \\
\hline 6 & 2 & 15 & 7.5 & 23.1 \\
\hline 7 & 2 & 9 & 4.5 & 13.8 \\
\hline 8 & 2 & 4 & 2.0 & 6.2 \\
\hline 9 & 1 & 2 & 1.0 & 3.1 \\
\hline 10 & 1 & - & 0.0 & 0.0 \\
\hline \multirow[t]{2}{*}{11} & 1 & - & 0.0 & 0.0 \\
\hline & 19 & 65 & 32.5 & \\
\hline
\end{tabular}


artifacts and features in the excavation block. These distributions likely reflect real cultural patterns in spite of the disturbances (Gregg et al. 1991).

Assuming that the intact hearths were the main focal point of activities within the block (and this assumption is well supported by numerous ethnoarcheological studies of hunter-gatherers, e.g. Yellen 1977; Binford 1978; O'Connell 1987; Bartram et al. 1991; Gargett and Hayden 1991; O'Connell et al. 1991), the distributions of the various artifact classes were compared to the features, and there appears to be activity patterning relative to these features. Burned sandstone was so ubiquitous that it was weighed and discarded in the field (Fig. 20a). The largest concentrations of burned rocks correspond with the locations of the three archeologically recognizable clusters described as Features 13, 14, and 15 (Fig. 20b). A fourth concentration located north of Feature 15 in EU 36 may represent the edge of a feature which extends north and east into unexcavated units. The fire-cracked rocks (mainly Potter chert and quartzites) show a distinctly different distribution, with the largest concentration being in the southwest comer of the excavation block away from the features (Fig. 20c), and even though close to the primary area of use, i.e., the hearths, this concentration could represent a secondary refuse concentration (Schiffer 1987:58-64).

In general, all classes of chipped, ground, and battered stone artifacts occur in greater frequencies toward the west end of the block. The average artifact density for the block is 41 artifacts per $\mathrm{m}^{2}$, and the density per unit increases from east to west from an average density of $32.5 / \mathrm{m}^{2}$ in the eastern 24 units to an average of $44.6 / \mathrm{m}^{2}$ in the western 27 units (Fig. 20d). Artifact density is greatest in the

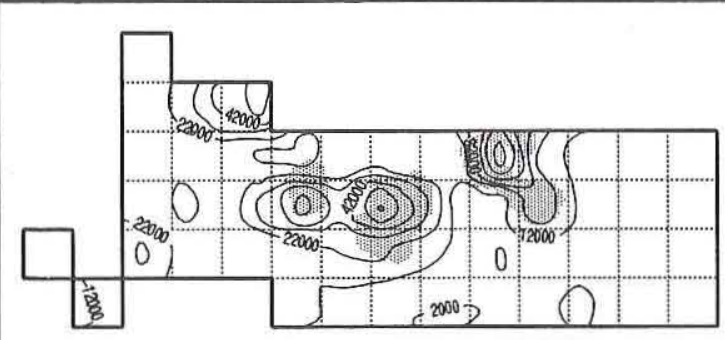

a) Burned Sandstone; Contour Interval $=10,000 \mathrm{~g}$ Minimum Contour $=2000 \mathrm{~g}$

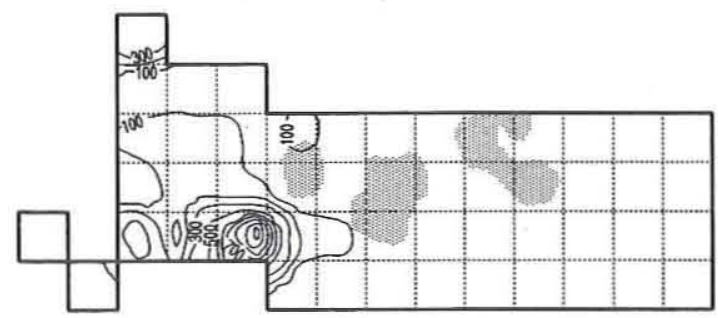

c) Fire-cracked Rock; Contour Interval=100g

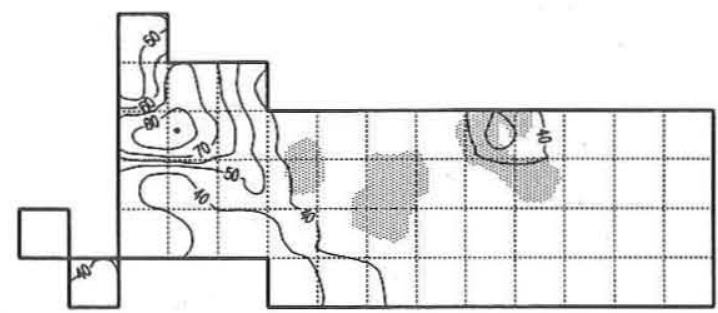

e) Unmodified Debitage; Contour Interval=10 artifacts Minimum Contour $=40$ artitocts

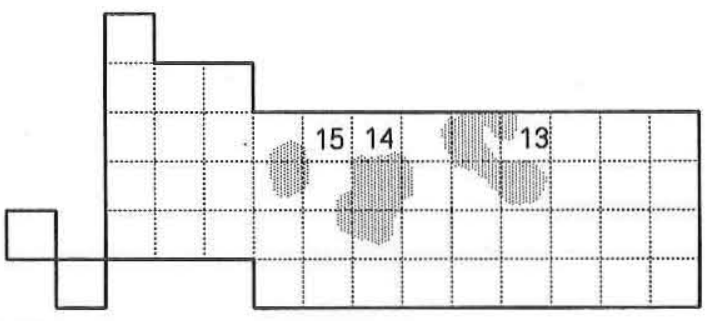

b) Features

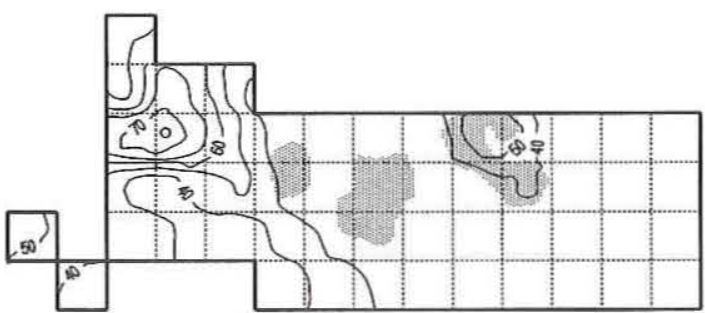

d) Total Number of Artifacts/unit; Contour Interval=10 artifacts Minimum Contour $=40$ artifacts

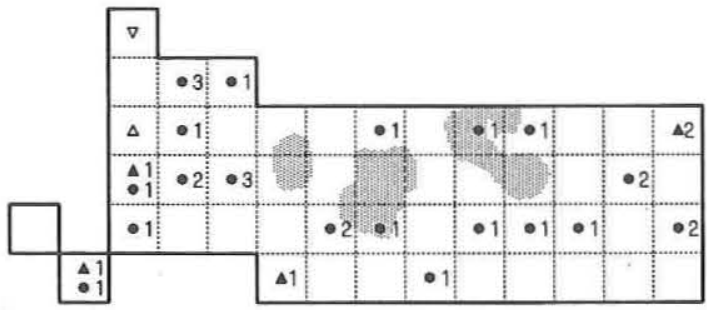

f) Hammerstones $=\Delta$; Cores $=0$; Arrow Point $=\nabla ;$ Dart Point $=\Delta$

Figure 20. Distribution of artifacts and features, 41GR383. Shaded areas denote burned rock features. 
northwest corner of the block, with three units yielding more than $80 / \mathrm{m}^{2}$, and a minor concentration occurs adjacent to Feature 13. Artifact density in the isolated excavation units (46 specimens from EU 52 and 20 specimens from EU 53) is $33 / \mathrm{m}^{2}$ compared to the $41 / \mathrm{m}^{2}$ average for the block. This suggests that the artifact frequency peaks in or near the western end of the block and then decreases farther west.

Unmodified debitage is clustered at Feature 13 and in the area west of Feature 14 north of the fire-cracked rock concentration (Fig. 20e). These distributions suggest that there is spatial separation of activities within the excavation block. The unmodified debitage can be used to define at least one lithic reduction activity area in the northwest comer of the block. In general, the presence of cores and hammerstones in the site helps support this interpretation (Fig. 20f); however, the distribu- tion of cores shows no strong association with unmodified debitage, while hammerstones are associated weakly, at best, with unmodified debitage. A single arrow point base and a dart point tip found in the western portion of the site may be related to the lithic reduction activity.

Distributions of the remaining artifacts and cultural materials (i.e., bifaces, unifaces, edgemodified flakes, cobble tools, gouges, ground stones, and mussel shells) are difficult to interpret, mostly because of low frequencies. Bifaces and unifaces are scattered but slightly more frequent in the western portion of the block (Fig. 21a). Edgemodified flakes display weak concentrations, one southeast of Feature 13 and the other in the area between Features 14 and 15 (Fig. 21b). This distribution suggests additional activity areas adjacent to the features. The cobble tools are all in the western end of the block, while the two gouges

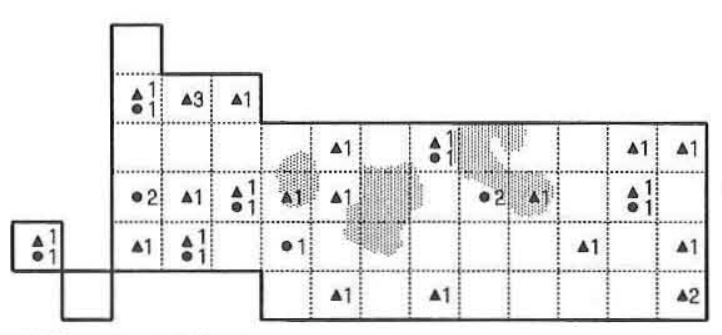

a) Bifaces $=\Delta$; Unilaces $=\bullet$

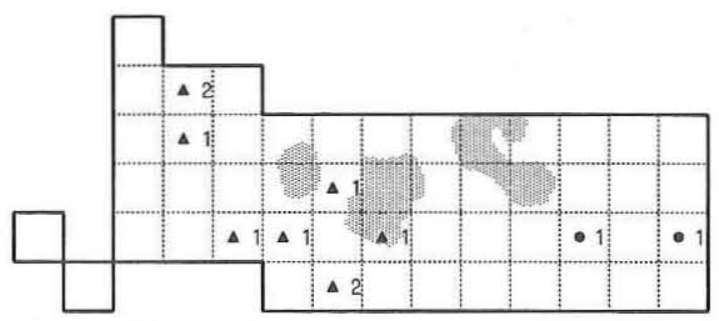

c) Cobble Tools $=\Delta$; Gouges $=0$

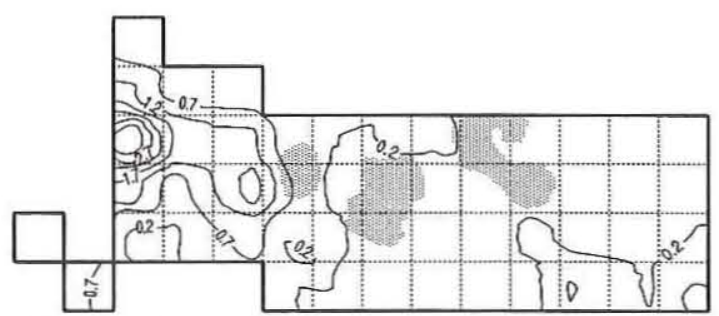

e) Mussel Shells; Contour Interval $=0.5 \mathrm{~g}$ Minimum Contour $=0.2 \mathrm{~g}$

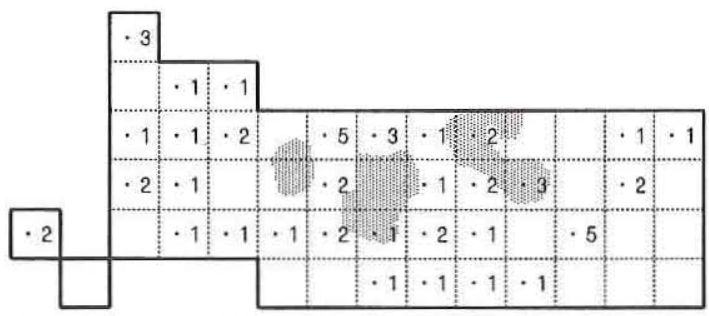

b) Total Number of Edge-Modified Flakes

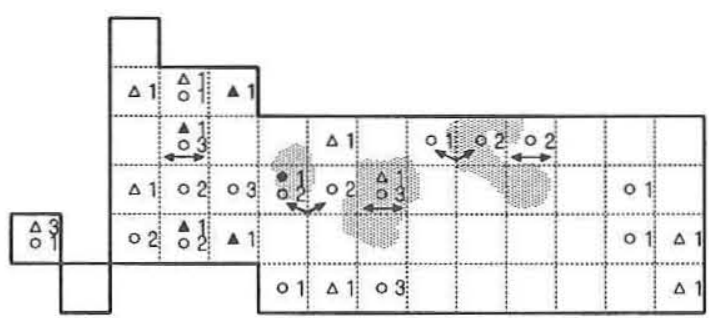

d) $M a n o=\Delta ;$ Mano Fragment $=\Delta$; Metate $=0$; Metate Fragment $=0 ; \quad \leftrightarrow \quad=$ Refit Fragments

Figure 21. Distribution of artifacts, 41 GR383. Shaded areas denote bumed rock features. 
were found in the eastern half (Fig. 21c). The ground stone artifacts consist mainly of unusable fragments, many of which were recycled as hearthstones. The numerous fragments are scattered around the block and in the features, but the few complete ground stone tools are clustered in the western end of the block (Fig. 21d). Although mussel shell fragments were frequent throughout the block, they are concentrated in the western portion (Fig. 21e). The only possibly modified shell fragment was found west of the block in EU 52. The total absence of bones could be a cultural phenomenon (i.e., related to site function) but more likely is due to poor preservation.

Functionally, the excavated portion of site 41GR383 (and the site as a whole) is interpreted as a multifunctional campsite. The variety of tool types represented indicates a correspondingly wide range of activities, including manufacture and maintenance of lithic tools and animal and plant food processing and procurement. Lithic artifacts and debitage indicate that tool rejuvenation was a primary activity but that manufacture of new tools was limited. Hunting is indicated by the presence of projectile points and by unifacial scraping and cutting tools which may have been used on animal hides and meat. The chopper tools may also have functioned as bone-crushing tools. Mussel shells from the site probably represent an overall minor food resource, but mussels may have gained importance as a food source when plant foods were limited during winter and early spring (Hackenberger and Bousman 1978).

Plant processing is perhaps the best-represented activity at the site. The relatively high frequency of ground stone tools and the presence of numerous ground stones recycled as hearthstones is interpreted as evidence of plant food preparation. In addition, the presence of a possible pestle (described as a manuport) and three bedrock mortars (mapped at the extreme east and west boundaries of the site) may be additional evidence of plant processing. Mortars in the Southwest were frequently used in the processing of mesquite beans which served as a staple food resource for many cultural groups (Bell and Castetter 1937), although there is no definite functional evidence for the Justiceburg mortars.

\section{Cultural Assessment of Component}

The site occupations apparently span the transition from late Archaic into Late Prehistoric I, but the lack of diagnostic artifacts and the limited size of the artifact sample preclude any definite statements about cultural affiliation. Archaic cultural units remain poorly defined in the region, and there is no hint that these remains are associated with the late Archaic bison hunters of the Lower Plains. Likewise, there is no indication of a connection with any Late Prehistoric I manifestations such as Plains Woodland or the Palo Duro Complex. Nevertheless, it is perhaps useful to reiterate that the Palo Duro Complex has both arrow and dart points in clear association dating to the first millenium A.D. so the occurrence of both forms at 41 GR383 does not necessarily indicate multiple occupations, and their co-occurrence at the site is consistent with its age. At present, however, interpretations regarding cultural associations should not be offered and cannot be supported, but future comparative analyses may aid in a morecomplete understanding of the Gobbler Creek Bridge Site. 


\section{DATA RECOVERY AT THE GRAPE CREEK BENCH SITE, 41GR484}

Douglas K. Boyd, Steve A. Tomka, and C. Britt Bousman

Site 41GR484 was discovered during the 1987 reservoir survey (Boyd et al. 1989) and was investigated further during the 1988 testing phase (Boyd et al. 1990). It is located within the footprint of the proposed dam for Justiceburg Reservoir. It was defined as a single-component Late Prehistoric II campsite and was assessed as eligible for listing on the National Register of Historic Places; thus, further work was recommended.

\section{SITE SETTING}

The Grape Creek Bench Site is an open site immediately southeast of the confluence of the Double Mountain Fork of the Brazos River and Grape Creek (Fig. 22). It is situated on an alluvial terrace of the Double Mountain Fork and a sloping erosional bedrock peneplain that make up the valley floor in this stretch of the river. Grape Creek is actively eroding a 4-8-m-high vertical cutbank that now forms the southern boundary of the site. This cutbank exposes 1-2 $\mathrm{m}$ of colluvial deposits which unconformably overlie bedrock (Triassic Tecovas Formation) for most of the 200-m-long cutbank. The peneplain surface tilts down to the northwest from the valley wall to the river and is generally flat, although some evidence of root plow disturbance was noted. Sediments apparently are undisturbed for several lateral meters along the cutbank edge, but an undulating, hummocky surface away from the edge is the result of vegetation clearing.
Vegetation is sparse along the cutbank edge, consisting of grasses, a few small mesquites, and shrubs, but becomes quite dense in the disturbed areas where sunflowers are dominant. The site is at an elevation of $2130-2150 \mathrm{ft} \mathrm{msl}$ and covers an estimated area of $50 \mathrm{~m}$ north-south by $200 \mathrm{~m}$ eastwest.

\section{PREVIOUS INVESTIGATIONS}

The initial investigation in 1987 (Boyd et al. $1989: 88,386,394,517-518$ ) consisted of a surface examination, excavation of a backhoe trench (BHT 1987-14) from which bone fragments (at $40 \mathrm{~cm}$ below the surface) and sediment samples were recovered, and removal of a charcoal sample from a sandstone slab-lined hearth (Feature 1) exposed along the cutbank. Radiocarbon assays were obtained on the charcoal and two sediment samples. The charcoal from the hearth yielded a date of 260 \pm 70 B.P., cal. 302 B.P., for the cultural component (Boyd et al. 1989:Table 6). Bulk carbon in sediments from BHT 1987-14 yielded two radiocarbon dates of $1160 \pm 60$ B.P., cal. 1064 B.P. $(100 \mathrm{~cm}$ below the surface) and $1830 \pm 70$ B.P., cal. 18041760 B.P. (150 cm below the surface). However, these samples were taken from alluvial sediments near the Double Mountain Fork channel, and they are not correlated with slope sediments on 41GR484 (Blum 1989a).

National Register testing in 1988 (Boyd et al. 


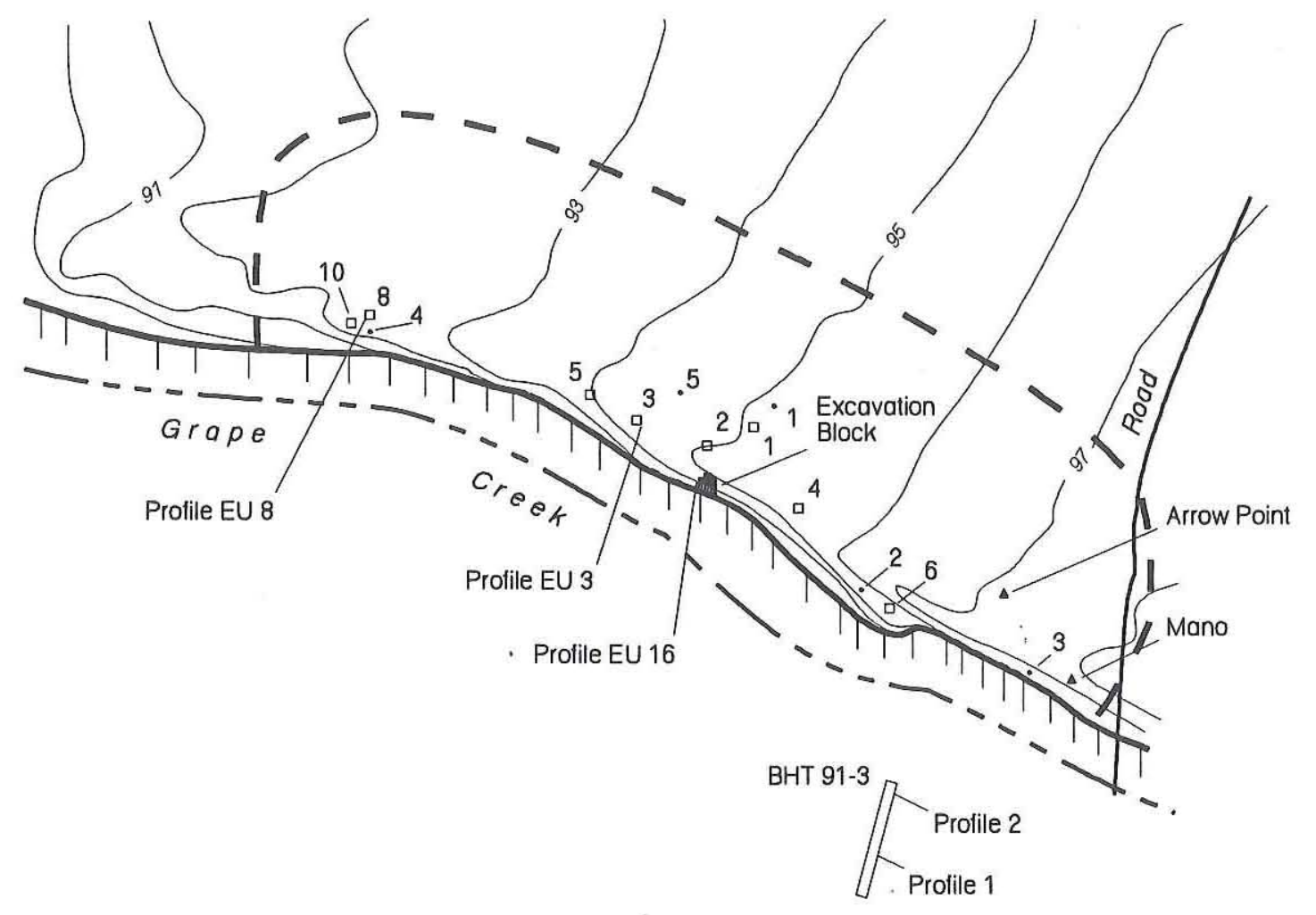

$$
\begin{gathered}
\text { L E G E N D } \\
=- \text { Site Boundary } \\
\text { - } \quad \text { Excavation Unit } \\
\text { - } \quad 1988 \text { Test Unit } \\
\Delta \quad \text { Surface Artifact }
\end{gathered}
$$

P\&AI/92/SLH

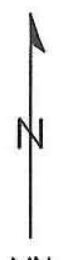

$\mathrm{MN}$

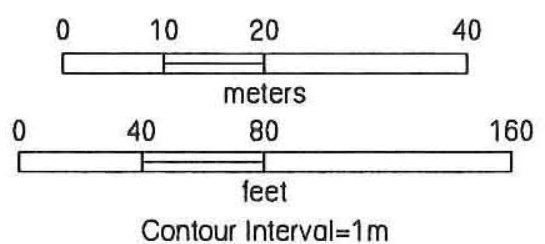

Contour Interval $=1 \mathrm{~m}$

Figure 22. Site map, 41GR484.

1990:189-193, 337, 561) included a backhoe trench (BHT 1988-67) excavated to obtain geomorphic data, which yielded bone fragments and a biface from the upper $40 \mathrm{~cm}$. Five $1 \times 1-\mathrm{m}$ test units were then excavated, and a surface collection was made. A total of 65 artifacts was recovered during testing (Table 22). Cultural materials were found on the surface at the upper end of the site and were buried downslope. A $15 \times 15-m$ surface collection unit in the east end of the site yielded 31 artifacts, including an untyped arrow point, two cobble tools, two cores, an edge-modified flake, and two manos. The test units yielded 32 artifacts, including a uniface, 2 edge-modified flakes, a hammerstone, and a metate fragment. The test units were scattered along the cutbank edge and revealed that the cultural zone is shallowly buried (to ca. $30 \mathrm{~cm}$ ) in the east end of the site and becomes progressively deeper downslope toward the Double Mountain Fork (to ca. $70 \mathrm{~cm}$ at the lower end of the site).

Two features also were investigated in 1988. A sample of burned sandstone was obtained from Feature 1 (the hearth discovered in 1987), but only a small area was excavated to obtain the sample. The burned rock was analyzed chemically for organic residue, but no interpretable remains were present. Feature 2 was observed eroding out of the Grape Creek cutbank and was exposed in Test Unit 


\begin{tabular}{|c|c|c|c|c|c|c|c|c|c|}
\hline \multicolumn{10}{|c|}{$\begin{array}{l}\text { TABLE } 22 \\
\text { ARTIFACTS RECOVERED DURING } 1988 \text { TESTING, 41GR484 }\end{array}$} \\
\hline Provenience & \begin{tabular}{|l} 
Arrow \\
Point
\end{tabular} & Biface & \begin{tabular}{|l} 
Cobble \\
Tools \\
\end{tabular} & Uniface & Cores & \begin{tabular}{|l} 
Edge- \\
modified \\
Debitage \\
\end{tabular} & $\begin{array}{l}\text { Unmodified } \\
\text { Debitage }\end{array}$ & $\begin{array}{l}\text { Ground } \\
\text { Stones }\end{array}$ & Hammerstone \\
\hline Surface & - & - & - & - & - & - & 1 & - & - \\
\hline $\begin{array}{l}\text { Surface } \\
\text { Collection } \\
\text { Unit }\end{array}$ & 1 & - & 2 & - & 2 & 1 & 23 & 2 & - \\
\hline $\begin{array}{l}\text { Backhoe } \\
\text { Trench } 67\end{array}$ & - & 1 & - & - & - & - & - & - & - \\
\hline $\begin{array}{l}\text { Test Unit } 2 \\
\text { Test Unit } 3 \\
\text { Test Unit 4* }\end{array}$ & $\begin{array}{l}- \\
-\end{array}$ & $\begin{array}{l}- \\
-\end{array}$ & $\begin{array}{l}- \\
-\end{array}$ & $\begin{array}{l}- \\
1 \\
-\end{array}$ & - & $\begin{array}{l}- \\
2 \\
-\end{array}$ & $\begin{array}{r}8 \\
18 \\
1\end{array}$ & $\begin{array}{l}- \\
\overline{1}\end{array}$ & $\begin{array}{l}- \\
1\end{array}$ \\
\hline Totals: & 1 & 1 & 2 & 1 & 2 & 3 & 51 & 3 & 1 \\
\hline
\end{tabular}

4. It consisted of approximately one-half of a circular (50-70-cm-diameter), sandstone slablined hearth at $58-70 \mathrm{~cm}$ below the ground surface. A quartzite hammerstone and a sandstone metate fragment were associated with the feature. A thermoluminescence assay was attempted on a hearthstone from Feature 2, but it was found to be unsuitable for dating.

Following the 1988 test excavations, the site again was assessed as eligible for listing on the National Register of Historic Places and was selected for data recovery. It was acknowledged, however, that the limited testing was not adequate to fully define the nature and extent of the cultural deposits and that the artifact density was expected to be very low. It was apparent that additional dispersed excavation units were needed to isolate the most productive portion of the site before selecting a location for an excavation block. A maximum of 10 excavation units were specified as dispersed units. It was estimated that a $64-\mathrm{m}^{2}$ excavation block would be the minimum size needed to obtain an interpretable artifact sample.

\section{DATA RECOVERY INVESTIGATIONS}

Data recovery at the Grape Creek Bench Site consisted of additional detailed topographic mapping of the area, surface collection of an arrow point and a mano, and excavation of eight dispersed units and nine contiguous units (see Fig. 22). All site elevations were shot relative to an arbitrary elevation of $95.00 \mathrm{~m}$. All previous test units and backhoe trenches were re-located and mapped, with the exception of Backhoe Trench 1987-14 which could not be found.

The artifact density was extremely low in the dispersed excavation units, and it was considered most productive to begin the excavation block along the cutbank edge to expose Feature 1 and the surrounding area. As the block excavations progressed, it became increasingly obvious that the artifact density was far too low to yield an interpretable assemblage without a substantial increase in effort. It was determined, in consultation with the City of Lubbock's Technical Representative Freese and Nichols, Inc. and the Fort Worth District of the U.S. Army Corps of Engineers, that such an increase was not warranted. Work at the site was terminated with only $14 \%$ ( 9 units) of the targeted excavation block (64 units) completed (Fig. 23). The nine excavated units completely exposed two overlapping hearths, Features 1 and 3.

\section{Sediments and Stratigraphy}

Three profiles from the block and dispersed excavation units at $41 \mathrm{GR} 484$ are discussed here, 


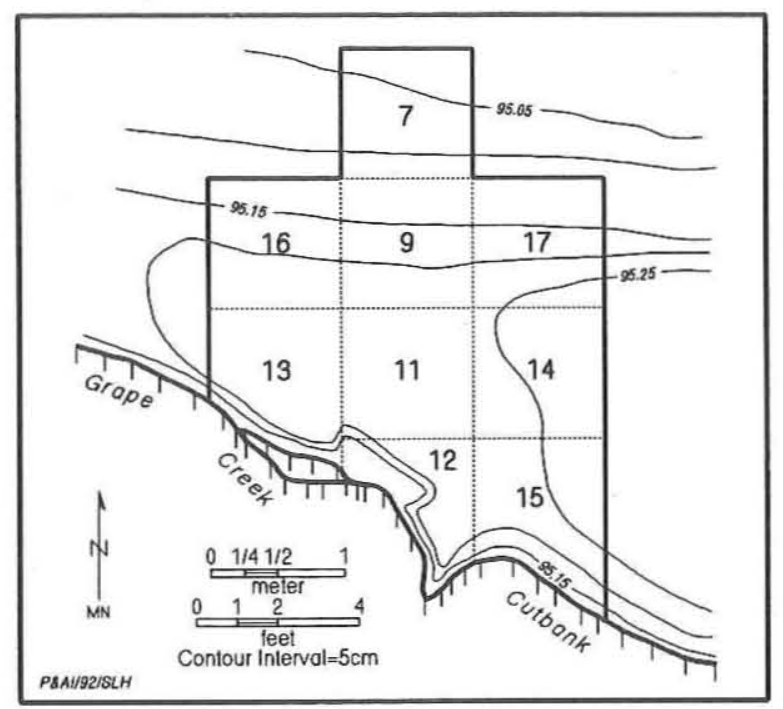

Figure 23. Excavation block surface topography and unit designations, 41GR484.

and another two profiles from an off-site backhoe trench (BHT 1991-3) cut into the Grape Creek floodplain are discussed in detail in Chapter 8. Detailed profile descriptions are provided in Appendix $\mathrm{H}$, and the locations of these profiles are shown on Figure 22.

As stated above, 41GR484 lies on a small eroded bedrock peneplain that gently slopes down toward the Double Mountain Fork to the north. Grape Creek is actively eroding this bedrock feature and by this process forming a low bluff overlooking the creek (see Fig. 22). The higher canyon rim overlooking the site is mapped as Trujillo Formation (Triassic) sediments, and these consist of sandstones and well-cemented conglomerates (Mason Johnston and Associates, Inc. n.d.). On-site bedrock is mapped as the Tecovas Formation (Triassic) and consists of well-stratified red mudstones interbedded with thin light gray sandy shales (Mason Johnston and Associates, Inc. n.d.).

The bedrock surface of the peneplain was unevenly eroded, and a flat sloping sheet of colluvial deposits now covers most of this undulating bedrock surface. Profile descriptions from Excavation Unit (EU) 3 and EU 16 (in the block) characterize this colluvium predominantly as slightly gravelly sandy loam to sandy loam and loam. Prehistoric features and artifacts are found within this colluvial sheet and exposed by cutbank erosion along Grape Creek. A radiocarbon assay on charcoal from Feature $1(20-30 \mathrm{~cm})$ produced a date of
$260 \pm 70$ B.P., cal. 302 B.P.

In the northwestern portion of the site, Blum (1989a:94, 1989b:394) documents a sedimentary sequence in BHT 1987-14 that, according to his fieldnotes, represents an alluvial inset fill deposited by the Double Mountain Fork. Unfortunately, the exact location of Blum's BHT 1987-14 is not known, but it is clearly downslope and northwest of EU 8. Three sediment zones were recognized by Blum, and the lower zone had two bulk organic carbon radiocarbon assays of $1160 \pm 60$ B.P. and $1830 \pm 70$ B.P., cal. 1064 B.P. and 18041760 B.P., respectively. The middle zone in Blum's BHT 1987-14 is described as massive to weak, medium blocky dark brown sandy muds, and while Blum did not characterize this as a buried soil, the observed blocky structure suggests that it might be one. Again according to Blum's fieldnotes, he suggests that the uppermost zone, massive to laminated reddish brown muddy sands with siliceous pebbles, interfingers with the colluvial sediments documented upslope at 41GR484; however, such an interpretation requires a long continuous profile, and this was not obtained. It is possible that the upper zone in BHT 1987-14 does not interfinger with the colluvial sediments and that it too represents a younger alluvial inset fill deposit.

The sedimentary sequence documented in EU 8 also has a buried soil, reddish brown loam to slightly gravelly loam with weak coarse subangular blocky structure, between $51-77 \mathrm{~cm}$ (Fig. 24), and it is likely that this correlates with Blum's middle sedimentary zone in his BHT 1987-14. This does not imply that the lower two zones at EU 8 are alluvium, however, and it is thought that these sediments are colluvial in origin with a weakly developed soil on their upper surface (i.e., Zone 3). The overlying two sedimentary zones at EU 8 are identified as colluvium, and these probably correspond to sediments documented in the excavation block at EU 16 and the sediments containing Feature 1 dated to ca. 260 B.P., cal. 302 B.P. If the upper two zones in BHT 1987-14 are inset fill and stratigraphically separate from the lower zones in that profile, then it seems likely that they are younger than most of the colluvial sediments on 41GR484.

The sediment profile (see Appendix $\mathrm{H}$ ) and radiocarbon dates (see Appendix G) from BHT 1991-3, immediately southwest of Grape Creek, demonstrate the late Holocene lateral migration of 


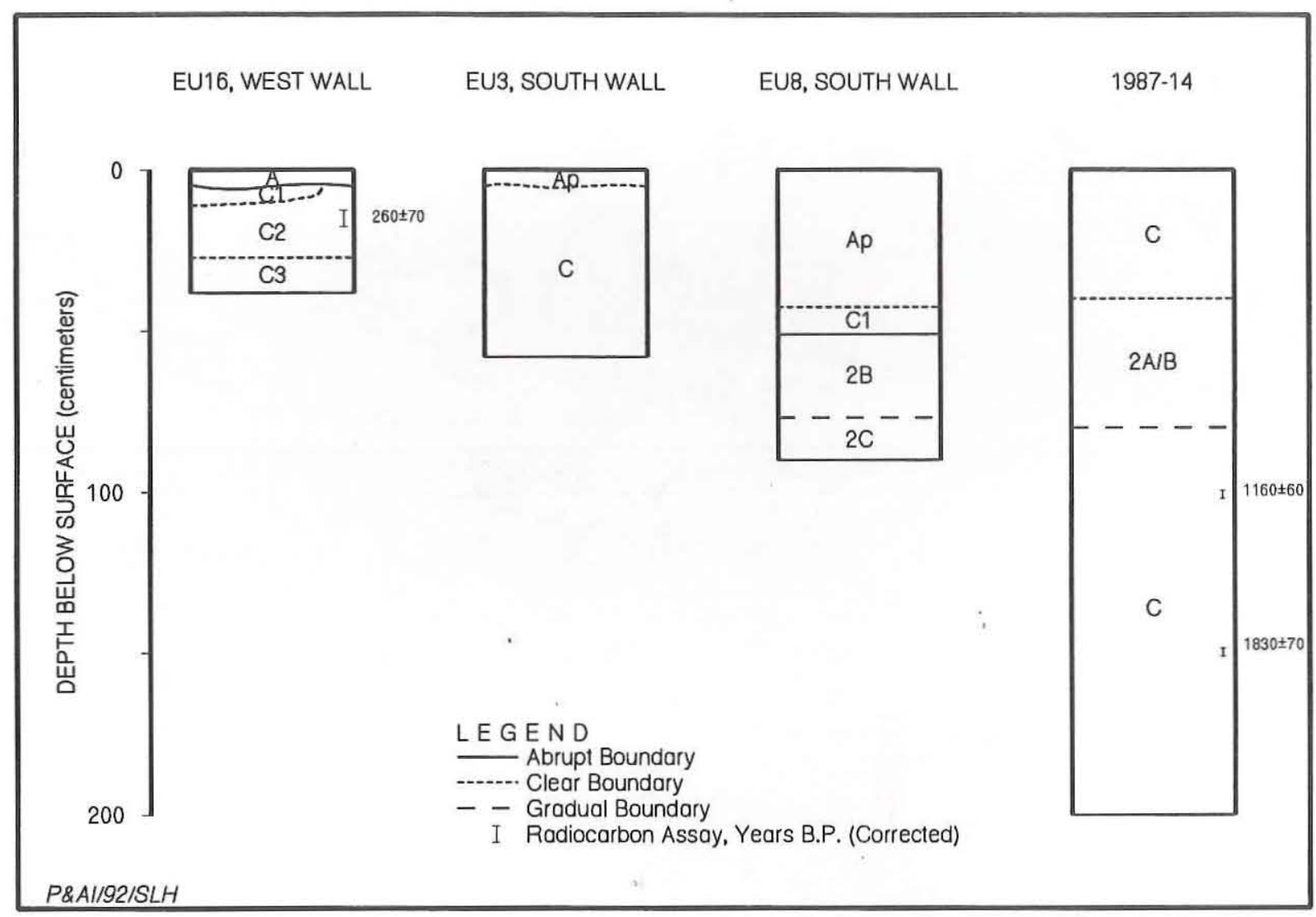

Figure 24. Geologic profiles, 41GR484.

Grape Creek to the east. This meandering formed the cutbank on the southwest side of 41GR484 and destroyed an unknown portion of the prehistoric site in the process. Radiocarbon assays show the destruction of $41 \mathrm{GR} 484$ took place in the last 200 300 years.

\section{Features}

Three sandstone slab-lined hearths have been investigated at 41GR484, and no other features are known. Feature 1 was exposed in the Grape Creek cutbank and discovered during the Phase I survey. A small portion of the hearth was excavated to obtain a charcoal sample that was subsequently radiocarbon dated. During the Phase II testing, a small area was excavated in Feature 1 to obtain burned rock samples for residue analysis; however, the results were inconclusive (Boyd et al. 1990: 191).

In the current data recovery phase, the excavation block was located specifically to expose
Feature 1, and in the process Feature 3 was discovered and exposed (Figs. 25 and 26). Complete excavation of Feature 1 revealed an ovate, $135 \times 150-\mathrm{cm}$ cluster of in situ tabular sandstone slabs that comprise a single horizontal layer which dips very slightly toward the center. An estimated $20 \%$ of the feature itself was lost to stream erosion, and the uppermost portion apparently has been disturbed, possibly by root plowing or some other form of vegetation clearing. Damage to the feature was minimal, however, and a 2-4-cm-thick layer of intensively burned, reddened earth below the main horizontal layer of rocks indicated that most of Feature 1 was in situ. A considerable amount of charred wood was preserved between and immediately above the rocks. The identification of this charcoal is discussed below.

Feature 1 was ca. $10 \mathrm{~cm}$ thick from 25 to 35 $\mathrm{cm}$ below the surface, and a metate slab was found lying directly on top of the hearth along its north edge at 19 to $27 \mathrm{~cm}$ below the surface. A few other burned rocks, including a metate fragment and 


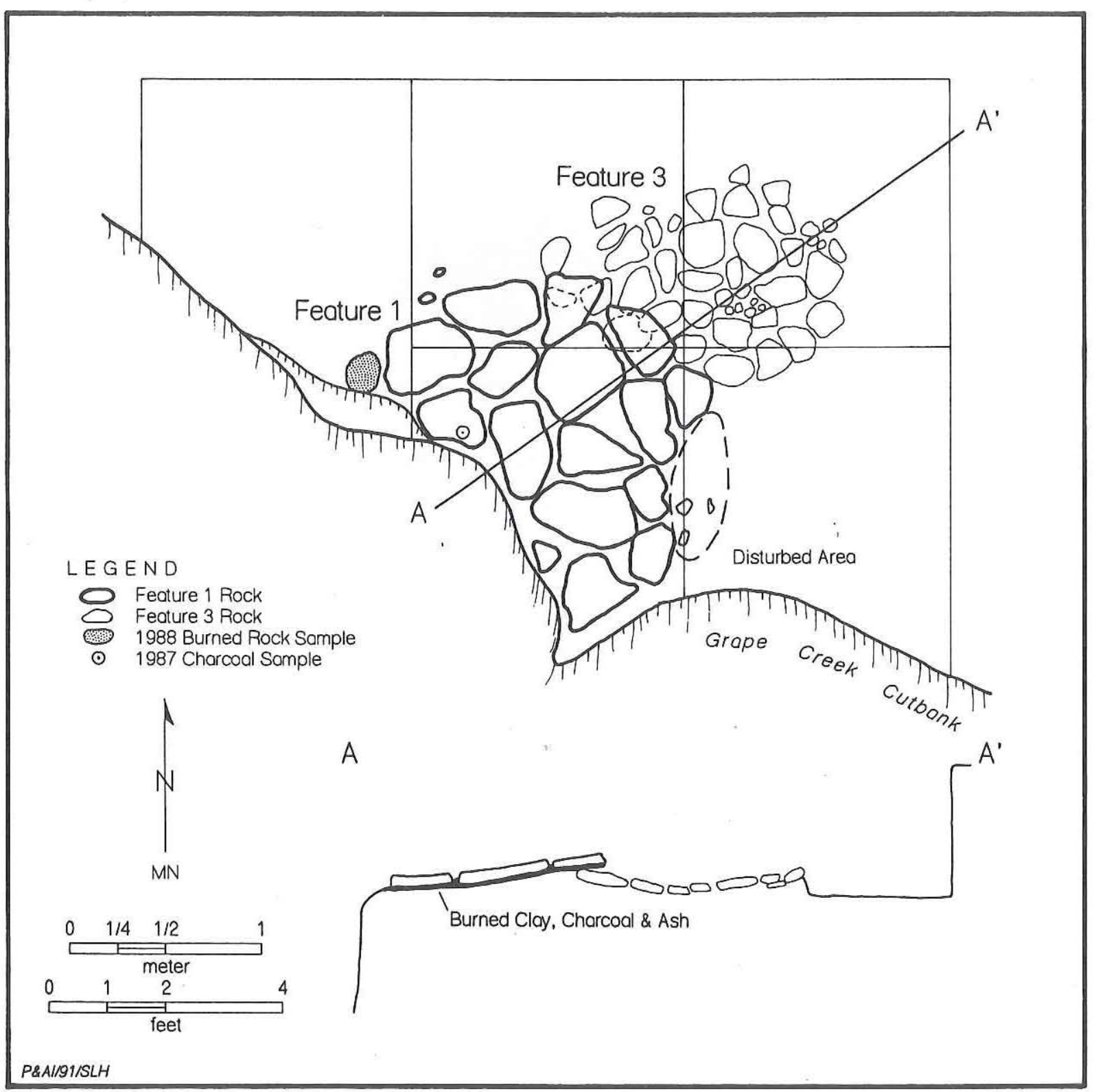

Figure 25. Detailed plan and profile views of Features 1 and 3, 41GR484.

two large rocks that probably functioned as anvils, were found from 9 to $20 \mathrm{~cm}$ below the surface. These upper rocks were apparently in a disturbed context above the intact portion of the feature, but they are undoubtedly part of the feature and may have been recycled as hearthstones. Three other ground stone artifacts found north of the feature at the same level ( 28 to $36 \mathrm{~cm}$ below the surface) may be associated. An unmodified, $67 \times 43 \times 20-\mathrm{mm}$ ovate sandstone pebble found just above the feature in EU 11 is apparently a manuport, but its function is unknown. The metate was definitely associated with the hearth and possibly indicates plantprocessing activities.

Pollen analysis of two sediment samples from Feature 1 identified seven taxa, but due to the high degree of pollen degradation, no interpretations are offered (see Appendix E). Flotation of two sediment samples from the feature produced charred Carya sp. wood (see Appendix D) that could be either hickory or pecan, neither of which is native to the area today; however, based on the modern 


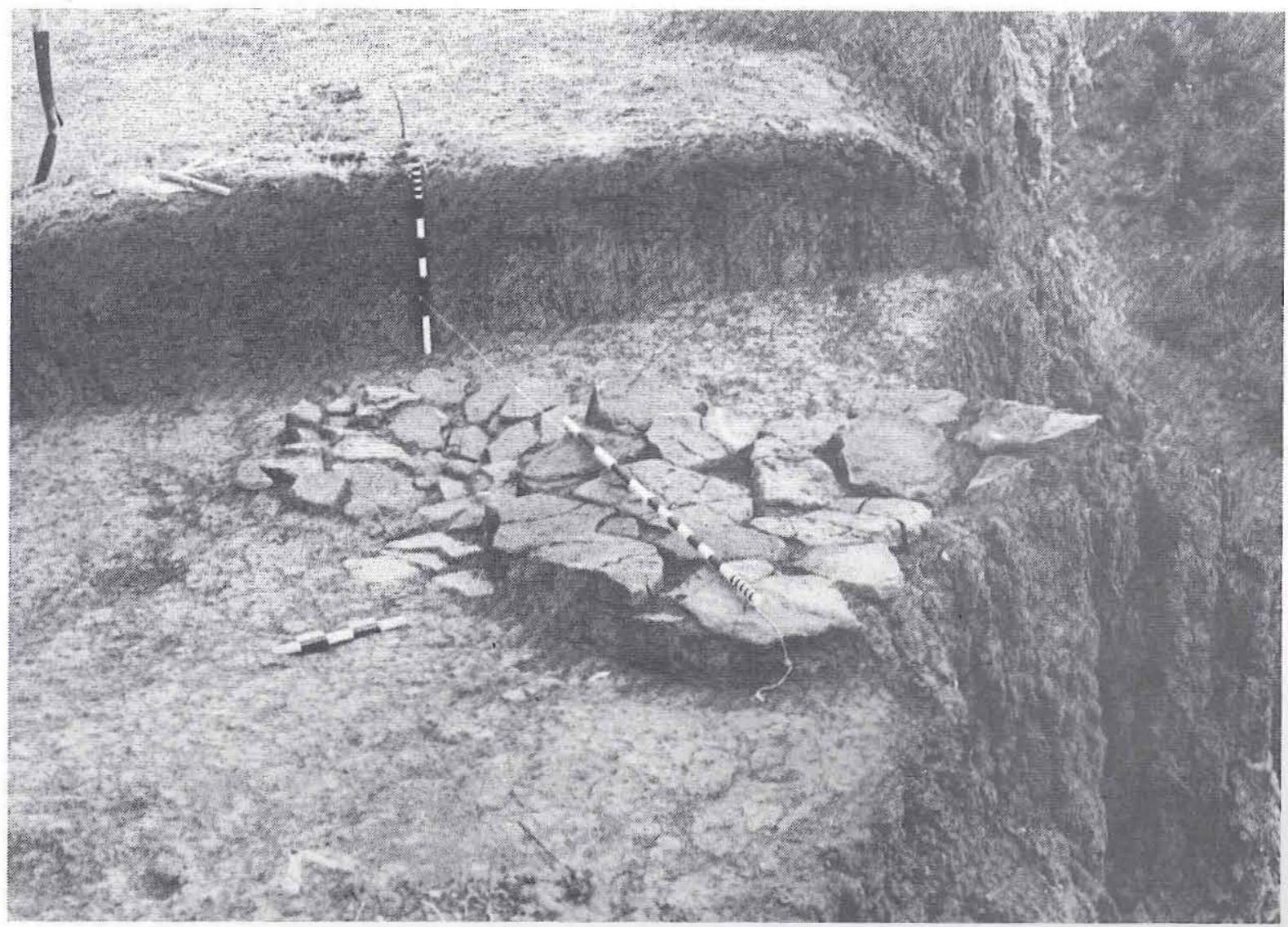

Figure 26. Photograph of Features 1 and 3, 41GR484. View is east-southeast; Feature 1 is in foreground along the edge of the Grape Creek cutbank.

distribution of these trees, it most likely is pecan. The presence of possible pecan wood in Feature 1, along with the corresponding radiocarbon date of $260 \pm 70$ B.P. from charcoal in the same feature, has some interesting implications. Pecan is a riparian species that is not found today in Garza County because of the relatively dry conditions. Its possible presence here at ca. A.D. 1690 suggests that slightly more mesic conditions may have existed at that time.

Feature 2, in the western end of the site, was also visible in the Grape Creek cutbank. Test Unit 4, excavated in 1988, exposed Feature 2 at 58-70 $\mathrm{cm}$ below the surface (Boyd et al. 1990:191). It consisted of approximately one-half of a 70-cmdiameter cluster of tabular sandstone slabs lying horizontally in a single layer. Some charcoal flecks were preserved under the rocks, but there was no discoloration in the surrounding sediment. A sandstone metate fragment and a quartzite hammer- stone were found adjacent to the feature at the same level. No additional work was undertaken on Feature 2 during the data recovery, and two nearby excavation units (EUs 8 and 10) produced only a single flake in the zone associated with the feature.

Feature 3 is a single horizontal layer of sandstone slabs forming an $80 \times 110-\mathrm{cm}$ ovate hearth at $30-40 \mathrm{~cm}$ below the surface. The southwest portion of Feature 3 is stratified below the northeast corner of Feature 1, and they are separated by $2-3 \mathrm{~cm}$ of orange oxidized sediment. The rocks are smaller than those of Feature 1, but they form a slightly more prominent basin shape (see Fig. 25). One of the hearthstones is a recycled metate fragment, and a metate fragment found $25 \mathrm{~cm}$ east of the hearth at 24 to $27 \mathrm{~cm}$ below the surface may be associated. No charcoal, ashy soil, or burned earth was observed in or under Feature 3. Feature 3 is clearly the older of the two, and it may have been covered with a thin veneer of sediment by the time 
Feature 1 was constructed and used. Four taxa were identified in a pollen sample from Feature 3, but due to the high degree of degradation, no interpretations are offered (see Appendix E).

In addition to the feature samples, one control sediment sample from the cultural zone in EU 14 (28-38 $\mathrm{cm}$ below the surface) was submitted for pollen analysis. Four taxa were identified in the sample, but again the data are not considered interpretable (see Appendix E).

\section{Materials Recovered}

Seventeen chipped stone artifacts, nine ground stone specimens, and three unmodified manuports were recovered (Table 23). Because no evidence of a mixed component was found at the site and due to the small size of the collection, the two artifacts recovered from the surface and all subsurface specimens are discussed together.

\section{Chipped Stone Artifacts}

One arrow point fragment and 16 pieces of unmodified debitage were recovered. The arrow point fragment is a surface find. The 16 pieces of unmodified debitage came from 12 of the excavation units.

\section{ARROW POINT}

The single specimen recovered is a distal fragment broken during manufacture and thus can be considered as a preform/blank (Bradley 1975). It retains a large portion of the parent flake's unretouched ventral surface. Judging from the orientation of the ripples, the reduction proceeded from the flake's platform and bulb of percussion to the tip of the projectile point. Although the small pressure flake scars are well patterned on one face, the edges of the preform/blank are relatively sinuous.

\begin{tabular}{|c|c|c|c|c|c|}
\hline \multicolumn{6}{|c|}{$\begin{array}{c}\text { TABLE } 23 \\
\text { ARTIFACTS RECOVERED DURING } 1990 \text { DATA RECOVERY, 41GR484 }\end{array}$} \\
\hline $\begin{array}{l}\text { Unit and } \\
\text { Maximum Depth }\end{array}$ & Arrow Point & $\begin{array}{l}\text { Unmodified } \\
\text { Debitage } \\
\end{array}$ & Manuports & $\begin{array}{l}\text { Ground Stone } \\
\text { (Quartzite) }\end{array}$ & $\begin{array}{l}\text { Ground Stone } \\
\text { (Sandstone) }\end{array}$ \\
\hline Surface & 1 & - & - & - & 1 \\
\hline \multicolumn{6}{|l|}{ Dispersed } \\
\hline $1,59 \mathrm{~cm}$ & - & - & - & - & - \\
\hline $2,65 \mathrm{~cm}$ & - & 1 & - & - & - \\
\hline $3,61 \mathrm{~cm}$ & - & 2 & - & - & - \\
\hline $4,50 \mathrm{~cm}$ & - & 1 & - & - & - \\
\hline $5,46 \mathrm{~cm}$ & - & 2 & - & - & - \\
\hline $6,40 \mathrm{~cm}$ & - & 1 & - & 1 & - \\
\hline $8,97 \mathrm{~cm}$ & - & 1 & - & - & - \\
\hline $10,92 \mathrm{~cm}$ & - & 1 & - & - & - \\
\hline \multicolumn{6}{|l|}{ Excavation Block } \\
\hline $7,42 \mathrm{~cm}$ & - & 1 & - & - & - \\
\hline $9,44 \mathrm{~cm}$ & - & - & - & - & - \\
\hline $11,44 \mathrm{~cm}$ & - & 1 & 3 & - & 5 \\
\hline $12,40 \mathrm{~cm}$ & - & - & - & - & 1 \\
\hline $13,40 \mathrm{~cm}$ & - & - & - & - & - \\
\hline $14,48 \mathrm{~cm}$ & - & - & - & - & 1 \\
\hline $15,48 \mathrm{~cm}$ & - & 1 & - & - & - \\
\hline $16,40 \mathrm{~cm}$ & - & 2 & - & - & - \\
\hline $17,44 \mathrm{~cm}$ & - & 2 & - & - & - \\
\hline Totals: & 1 & 16 & 3 & 1 & 8 \\
\hline
\end{tabular}


The sinuous edge and the flake core's ventral surface suggest that the specimen was broken relatively early in the reduction sequence. It is manufactured of a fine-grained nonlocal chert (Color 41).

\section{UNMODIFIED DEBITAGE}

Table 24 presents the unmodified lithic debitage attributes by raw material type. Of the 16 pieces of debitage, $69 \%$ are fine-grained chert, $19 \%$ are Tecovas jasper, and $13 \%$ are Alibates agate. The majority of the fine-grained chert and all of the Tecovas jasper debitage measure between $11-20 \mathrm{~mm}$ in maximum dimension. With the exception of the two complete Alibates agate flakes, flake fragments (chips and proximal fragments) of the other raw materials tend to be more frequent than complete specimens. The majority of the debitage $(75 \%)$ in the three material categories

\begin{tabular}{|c|c|c|c|c|}
\hline & IC DEBITAGE ATT & $\begin{array}{l}\text { LE } 24 \\
\text { UTES BY RAW }\end{array}$ & TERIAL TYPE, & \\
\hline Attributes & Fine-Grained Chert & Tecovas Jasper & Alibates Agate & Totals \\
\hline Flake Typ & & & & \\
\hline Complete & 4. & - & 2 & 6 \\
\hline Proximal & 2 & 3 & - & 2 \\
\hline Chip & $\underline{5}$ & $=$ & $=$ & $\underline{8}$ \\
\hline Totals: & 11 & 3 & 2 & 16 \\
\hline Dorsal Cor & & & & \\
\hline 0 & 8 & 2 & 2 & 12 \\
\hline $1-50$ & 1 & - & - & 1 \\
\hline $51-99$ & 1 & - & - & 1 \\
\hline 100 & 1 & $\underline{1}$ & $=$ & $\underline{2}$ \\
\hline Totals: & 11 & 3 & $\overline{2}$ & $\overline{16}$ \\
\hline Platform C & & & & \\
\hline Present & 1 & - & - & 1 \\
\hline Absent & $\underline{5}$ & $=$ & $\underline{2}$ & $\underline{7}$ \\
\hline Totals: & 6 & 0 & 2 & 8 \\
\hline Platform C & & & & \\
\hline Present & 2 & - & 2 & 4 \\
\hline Absent & 4 & $=$ & $=$ & $\underline{4}$ \\
\hline Totals: & $\overrightarrow{6}$ & $\overline{0}$ & 2 & 8 \\
\hline Platform F & & & & \\
\hline 1 facet & 2 & - & - & 2 \\
\hline$\geq 3$ facets & 4 & $=$ & $\underline{2}$ & $\underline{6}$ \\
\hline Totals: & $\overline{6}$ & $\overline{0}$ & 2 & 8 \\
\hline Maximum & & & & \\
\hline $1-10 \mathrm{~mm}$ & 1 & - & - & 1 \\
\hline $11-20 \mathrm{~mm}$ & 9 & 3 & 1 & 13 \\
\hline $21-30 \mathrm{~mm}$ & $\underline{1}$ & $=$ & $\underline{1}$ & $\underline{2}$ \\
\hline Totals: & $\overline{11}$ & 3 & 2 & $\overline{16}$ \\
\hline
\end{tabular}


is entirely decorticate. Platform cortex is present on a single fine-grained chert flake. Platform grinding is evident on both of the Alibates agate flakes and on two of the fine-grained chert flakes (one complete and one proximal). Single-facet platforms occur only in the fine-grained chert debitage, although multiple-facet platforms outnumber them two to one. A closer look at the frequency of platform multifaceting and grinding by raw material indicates that both of the Alibates agate specimens are multifaceted and ground. This, in conjunction with their size range and decorticate nature, suggests that they were removed from bifaces either during the late stages of reduction or during resharpening. Two of the fine-grained chert specimens have single-facet platforms that are not ground; apparently they were flaked from unifacial artifacts either during manufacture or resharpening. Two other flake platforms are multifaceted and ground. Their size (1-10 and 11-20 mm) and decorticate nature suggest that they were detached from bifacial artifacts either during late-stage manufacture or, more probably, during edge rejuvenation.

Overall, the scant lithic debitage collection appears to represent either the later stages of reduction or, more probably, biface and uniface rejuvenation. This conclusion is reinforced by the fact that of the 11 fine-grained chert specimens, 8 $(73 \%)$ are of nonlocal origin. In addition, the two Alibates agate specimens are also obviously nonlocal, as potentially are the three Tecovas jasper pieces. This indicates that $81 \%$ of the unmodified debitage may be of nonlocal origin and probably was removed from finished artifacts brought to the site. On-site manufacture of some lithic tools is represented by three corticate fine-grained chert flakes that appear to represent the early reduction stages of small, locally available chert nodules.

\section{Ground and Battered Stone Artifacts}

Nine ground stone artifacts were recovered. One of these is from the surface, five are associated with Features 1 and 3, two came from the excavation block in close proximity to the features, and one came from a nearby dispersed excavation unit. Of the nine specimens, two are mano fragments, five are metate fragments, and two are anvils. Table 25 presents the ground stone artifact attributes by morphofunctional category.

\section{MANOS}

One of the two manos (fine-grained quartzite) came from an isolated excavation unit located away from the main excavation block; the other specimen (sandstone) was a surface find. Both are fragmentary. The larger of the two is an oval sandstone mano with unifacial use-wear and a welldeveloped medial ridge on the utilized face. The utilized face has been pecked, and the margins and faces do not exhibit battering wear. This specimen is $119 \mathrm{~mm}$ wide and $38 \mathrm{~mm}$ thick. The second mano is an angular fine-grained quartzite nodule fragment. It retains only one face of the original artifact. The small working surface fragment exhibits pecking. It is not possible to determine whether the mano was a unifacial or bifacial specimen. No complete measurements could be recorded.

\section{METATES}

The five metates recovered exhibit morphological characteristics (i.e., beveled and planoconcave cross sections) of ground stone artifacts and evidence of grinding-surface rejuvenation (i.e., pecking). Two are associated with Feature 1, one is part of Feature 3, and two were recovered in close proximity to the two hearths.

A large bifacially used metate fragment was sitting immediately above the northern edge of Feature 1; both working surfaces of the angular fragment exhibit pecking. It has a beveled transverse cross section indicative of more-extensive use on one face than on the other. The cross section and wear distribution suggest that the artifact initially was used unifacially, then broken, and subsequently used on the opposite face. This specimen measures $388 \times 256 \times 62 \mathrm{~mm}$; its working surface is $293 \mathrm{~mm}$ long and $206 \mathrm{~mm}$ wide. The second specimen, a unifacially used angular fragment, was recovered above Feature 1 and immediately adjacent to its disturbed edge. It may have been reused as a hearthstone. It exhibits pecking on the utilized face and has a beveled transverse cross section. This fragment is $35 \mathrm{~mm}$ thick. The unifacially used metate fragment from Feature 3 was part of the hearth configuration. It exhibits pecking on its utilized face. The fragment is roughly ovate in shape and has a planoconcave, 37-mm-thick transverse cross section. 


\begin{tabular}{|c|c|c|c|c|c|}
\hline \multicolumn{6}{|c|}{$\begin{array}{c}\text { TABLE } 25 \\
\text { GROUND STONE ATTRIBUTES, 41GR484 }\end{array}$} \\
\hline Attribute & Category & Anvils & Manos & Metates & Totals \\
\hline Raw Material & $\begin{array}{l}\text { Sandstone } \\
\text { Quartzite } \\
\text { Totals: }\end{array}$ & $\begin{array}{l}2 \\
\overline{2}\end{array}$ & $\begin{array}{l}1 \\
\frac{1}{2}\end{array}$ & $\begin{array}{l}5 \\
\overline{5}\end{array}$ & $\begin{array}{l}8 \\
\frac{1}{9}\end{array}$ \\
\hline Completeness & $\begin{array}{l}\text { Complete } \\
\text { Fragment } \\
\text { Totals: }\end{array}$ & $\begin{array}{l}1 \\
\frac{1}{2}\end{array}$ & $\overline{2}$ & $\overline{5}$ & $\begin{array}{l}1 \\
\frac{8}{9}\end{array}$ \\
\hline Shape & \begin{tabular}{l} 
Oval \\
Angular \\
Rectangular \\
Indeterminate \\
\multicolumn{1}{c}{ Totals: } \\
\end{tabular} & $\begin{array}{l}1 \\
\overline{1} \\
\overline{2}\end{array}$ & $\begin{array}{l}1 \\
- \\
\overline{1} \\
2\end{array}$ & $\begin{array}{l}2 \\
3 \\
- \\
= \\
5\end{array}$ & $\begin{array}{l}4 \\
3 \\
1 \\
1 \\
9\end{array}$ \\
\hline Transverse Cross Section & $\begin{array}{l}\text { Biconcave } \\
\text { Planoconcave } \\
\text { Beveled } \\
\text { Tabular } \\
\text { Biconvex with medial ridge } \\
\text { Indeterminate } \\
\text { Totals: } \\
\end{array}$ & $\begin{array}{l}- \\
\overline{-} \\
\overline{2} \\
\bar{z} \\
\overline{2}\end{array}$ & $\begin{array}{l}- \\
\overline{-} \\
\overline{1} \\
1 \\
\frac{1}{2}\end{array}$ & $\begin{array}{l}1 \\
1 \\
3 \\
- \\
- \\
\overline{5}\end{array}$ & $\begin{array}{l}1 \\
1 \\
3 \\
2 \\
1 \\
1 \\
\frac{1}{9}\end{array}$ \\
\hline Pecking & \begin{tabular}{l} 
Unifacial \\
Bifacial \\
Absent \\
Indeterminate \\
\multicolumn{1}{c}{ Totals: }
\end{tabular} & $\begin{array}{l}\overline{-} \\
\overline{2} \\
\overline{2}\end{array}$ & $\begin{array}{l}1 \\
- \\
\overline{1} \\
\frac{1}{2}\end{array}$ & $\begin{array}{l}3 \\
1 \\
- \\
\frac{1}{5}\end{array}$ & $\begin{array}{l}5 \\
1 \\
2 \\
1 \\
9\end{array}$ \\
\hline Battering & $\begin{array}{l}\text { Absent } \\
\text { Indeterminate } \\
\text { Totals: }\end{array}$ & $\begin{array}{l}2 \\
\frac{2}{2}\end{array}$ & $\begin{array}{l}1 \\
\frac{1}{2}\end{array}$ & $\begin{array}{l}4 \\
\frac{1}{5}\end{array}$ & $\begin{array}{l}7 \\
\frac{2}{9}\end{array}$ \\
\hline
\end{tabular}

Of the two metate fragments not associated directly with the features, one was located approximately $60 \mathrm{~cm}$ north of Feature 1 and $60 \mathrm{~cm}$ northwest of Feature 3. It is an ovate fragment with a biconcave transverse cross section. Pecking, derived from the rejuvenation of the working surfaces, is evident on both faces. The specimen is $28 \mathrm{~mm}$ thick; none of its other measurements are complete. The second fragment was located about $35 \mathrm{~cm}$ east of Feature 3. It is a unifacially used rectangular metate fragment. Pecking is evident on one of its faces, and its transverse cross section is beveled, indicating substantial unifacial wear. The specimen is $31 \mathrm{~mm}$ thick; other complete measurements cannot be recorded.

\section{ANVILS}

Both anvils were recovered immediately above and adjacent to a disturbed portion of Feature 1, a slab-lined hearth, and they may have been reused as hearthstones. One of the specimens is heat fractured, probably as a result of this reuse; the other is complete. Both are made of tabular sandstone; one is oval, and one is rectangular. Pecking and battering wear is absent, but both of the utilized faces exhibit irregular striations probably derived from chopping or cutting. The complete specimen is $250 \mathrm{~mm}$ long, $175 \mathrm{~mm}$ wide, and $46 \mathrm{~mm}$ thick; the working surface is $236 \mathrm{~mm}$ long and $165 \mathrm{~mm}$ wide. The incomplete specimen is 
$168 \mathrm{~mm}$ wide and $68 \mathrm{~mm}$ thick; its length and working-surface dimensions are not complete.

\section{Manuports}

Three artifacts are classified as manuports, but they lack any definite evidence of modification and their functions are unknown. One is a flat (20-mm-thick), ovate ( $43 \times 67-\mathrm{mm})$, stream-rolled limestone pebble. It was recovered from EU 11 just above Feature 1. It has one smooth face and could have functioned as a mano, but if so then it would have had a very small grinding surface.

The other two are sandstone specimens found immediately north of and level with Feature 1. One is a long ovate specimen $(253 \times 76 \times 42 \mathrm{~mm})$, while the other is an irregular angular fragment $(160 \times 83 \times 25 \mathrm{~mm})$. These two specimens are definitely not hearthstones, and they appear to be associated with other isolated ground stones. These specimens were originally thought to be ground stones, and pollen washes from both were analyzed, but no pollen was identified.

\section{Faunal Remains}

The faunal remains recovered from 41GR484 consist entirely of two shell fragments from EU 6 (see Appendix C). Both are unmodified fragments of freshwater mussel shells and may be cultural.

\section{SUMMARY AND CONCLUSIONS}

The Phase III data recovery at 41GR484 yielded evidence of a Late Prehistoric II/Protohistoric cultural component. Three burned rock features have been investigated, and 29 artifacts were recovered. The Grape Creek Bench Site consists of a single cultural zone that is shallowly buried in the eastern end of the site and more deeply buried in the central and western portions. In the excavation block area, cultural materials are present from ca. $20-40 \mathrm{~cm}$ below the surface, but they are exposed at ca. $50-70 \mathrm{~cm}$ below the surface in the vicinity of Test Unit 4. The cultural zone appears generally to follow the modern slope. Dispersed excavation units across the site failed to produce any evidence of a significant buried cultural zone, and the excavation block produced evidence of only limited activity. All of the features and artifacts at the site are treated as a single component for analysis purposes. Although multiple occupations are indicated by the superposition of hearths in the excavation block, the cultural deposits across the site cannot be separated. The age of the component, considered to be terminal Late Prehistoric II/Protohistoric, is based on surface-collected arrow points and a charcoal radiocarbon date from Feature 1, but the total time span represented by the occupations is unknown.

The cultural zone exposed in the excavation block is a ca. 20-cm-thick deposit consisting of two overlapping features (1 and 3), seven ground stone artifacts, and seven unmodified flakes. Features 1 and 3 are interpreted as a slab-lined hearths. Feature 1, radiocarbon dated to ca. 260 B.P., cal. 302 B.P., is obviously the younger of the two since it was stratified over Feature 3; however, the question of how much older Feature 3 is than Feature 1 remains unanswered. The excellent preservation of charcoal in Feature 1 and its total absence in Feature 3 could be interpreted in at least three ways. First, this discrepancy might indicate that Feature 3 is considerably older than Feature 1 and that the lack of charcoal in Feature 3 is due to this age difference and preservation bias. Alternatively, the difference in charcoal occurrence could be related primarily to different postdepositional histories of the features and less so to their ages. Perhaps Feature 3 was exposed to the elements, i.e., wind and rain, for a period of time (not necessarily a long period; Longacre and Ayers 1968:158) before burial, while Feature 1 could have been buried relatively quickly, thus sealing and preserving the charcoal in the sediment. In that case, the time span between the construction and use of these features might be comparatively short. The third, but least likely, explanation is that there was a behavioral difference in the way the hearths were used and maintained rather than a preservational difference between the features. The Feature 3 rocks exhibit pronounced evidence of thermal alteration (i.e., interior discoloration), suggesting the presence of an intense fire, but the ash and charcoal may have been removed and used for hide tanning (Wallace and Hoebel 1952:93). In all probability, a combination of the first two factors, age and depositional history, accounts for the observed differences.

The sparse cultural materials recovered throughout the site and in the excavation block in particular include no temporally diagnostic speci- 
mens and provide only minimal functional information (see Table 23). The ground stone artifacts dominate the assemblage and almost certainly are associated with the feature activities (Fig. 27), but their numerical domination may result from curation of other tool types. The sparse lithic debris suggests that limited lithic tool production or repair occurred, probably, but not necessarily, contemporaneous with the features. Manufacture and/or maintenance of chipped stone tools appears to have been only a minor activity at 41GR484. The low density of chipped stone debris might be explained in part by the presence of metal tools in Protohistoric times, thus alleviating the need for most stone tools. However, the tree-ring-calibrated date from the Feature 1 hearth is 302 B.P. (A.D. 1648), and this is too early for intensive utilization and abundant occurrence of metal artifacts in the Southern Plains. A second alternative explanation, related to site function, is that the excavation block was placed in an area where specialized processing activities occurred, possibly at the edge of a camp, and chipped stone tools and debris were not discarded in large numbers or that artifacts may have been intensively curated. A third interpretation is that the total length of the occupations was extremely short. The second and third alternatives are the most plausible interpretations for the low artifact density.

All of the archeological and geomorphic evidence indicates that the outlying cultural materials are probably associated with the same occupations represented in the excavation block area. The arrow point collected from the surface and the Alibates agate flakes support a single-component interpretation for the site. Artifact density appears to be extremely low across the site.

The ground stone tools are obviously clustered around the features, and other artifact

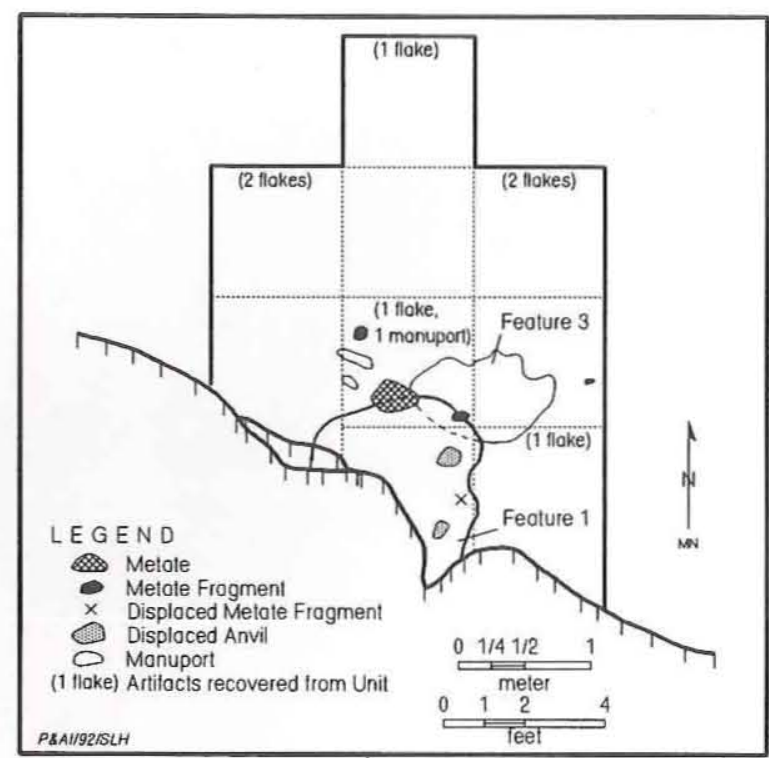

Figure 27. Distribution of artifacts and features in the excavation block, 41GR484.

frequencies decrease dramatically away from the features, thus indicating that the features were the focal point of activities at the site. The overall low density of lithic artifacts suggests either an ephemeral occupation or that the area sampled was peripheral to the core site area. It is likely that the main occupation area was to the south and that lateral movement of Grape Creek during the last 200-300 years removed the greatest portion of the site. At any rate, the portion of the site that remains is characterized by a very low artifact density with sporadic, localized, feature-oriented activities. Construction of the hearths, particularly Feature 1 with its large, neatly arranged slabs, represents a substantial labor effort. This fact, along with the dominance of ground stone tools, suggests that food (probably plant) processing was the major activity. 


\section{DATA RECOVERY AT THE SOUTH SAGE CREEK SITE, 41KT33}

Douglas K. Boyd, Steve A. Tomka, and C. Britt Bousman

Site 41KT33 was discovered in 1987 (Boyd et al. 1989) and tested in 1988 (Boyd et al. 1990). It is ca. $1.5 \mathrm{~km}$ downstream from the construction site of the Justiceburg dam on the Double Mountain Fork of the Brazos River in a secondary borrow area. The site was defined as a probable late Archaic period campsite. It was assessed as being eligible for listing on the National Register of Historic Places, and further work was recommended.

\section{SITE SETTING}

The South Sage Creek Site is an open site on an alluvial terrace in the broad lower reaches of the Double Mountain Fork valley (Fig. 28). The site is ca. $400 \mathrm{~m}$ south of the river on an elevated terrace that forms a flat, wide, sloping ridge between the Double Mountain Fork and South Sage Creek. Abbott (1990:44-51) identifies this as the Older Terrace, and it is perched $12-15 \mathrm{~m}$ above the active Double Mountain Fork floodplain at an elevation of 2150-2170 ft msl. Colluvial and eolian deposits cap the terrace, and its relatively flat, gently northeast-sloping top drops off sharply into the river floodplain on its north side and gradually slopes down to South Sage Creek on its east side. Vegetation is mainly grasses but also includes prickly pears and various shrubs. There may have been limited vegetation clearing in some portions of the site, but the majority appears undisturbed. Two unimproved roads, one abandoned and one currently in use, cross the site from north to south.

\section{PREVIOUS INVESTIGATIONS}

The 1987 survey (Boyd et al. 1989:379, 548549) encountered sporadic surface features and artifacts over this large open campsite. Shovel tests and roadcut exposures indicated that buried cultural deposits were present in the upper $40 \mathrm{~cm}$ of sediment in some areas. The site was assessed as having an excellent research potential, and further work was recommended.

During the 1988 testing phase (Boyd et al. 1990:194-199, 333-334), three geomorphic backhoe trenches were excavated in the site, and clear cultural evidence was encountered in one (BHT 1988-55). Based on these results, six test units (four $1 \times 1 \mathrm{~m}$, one $1 \times 1.5 \mathrm{~m}$, and one $1 \times 2 \mathrm{~m}$ ) were excavated in various parts of the site (see Fig. 28). In addition, the entire $240-\mathrm{m}$ north-south by $380-\mathrm{m}$ east-west site area was mapped, diagnostic surface artifacts were collected, and all cultural materials were collected from a 10-m-diameter surface collection unit. Two untyped expanding-stem dart points were recovered. A large metate was recorded but not collected since it was thought to be associated with a possible feature that was not tested due to time constraints. A total of 220 artifacts was recovered during testing (Table 26).

Ten surface features were reported. Feature 


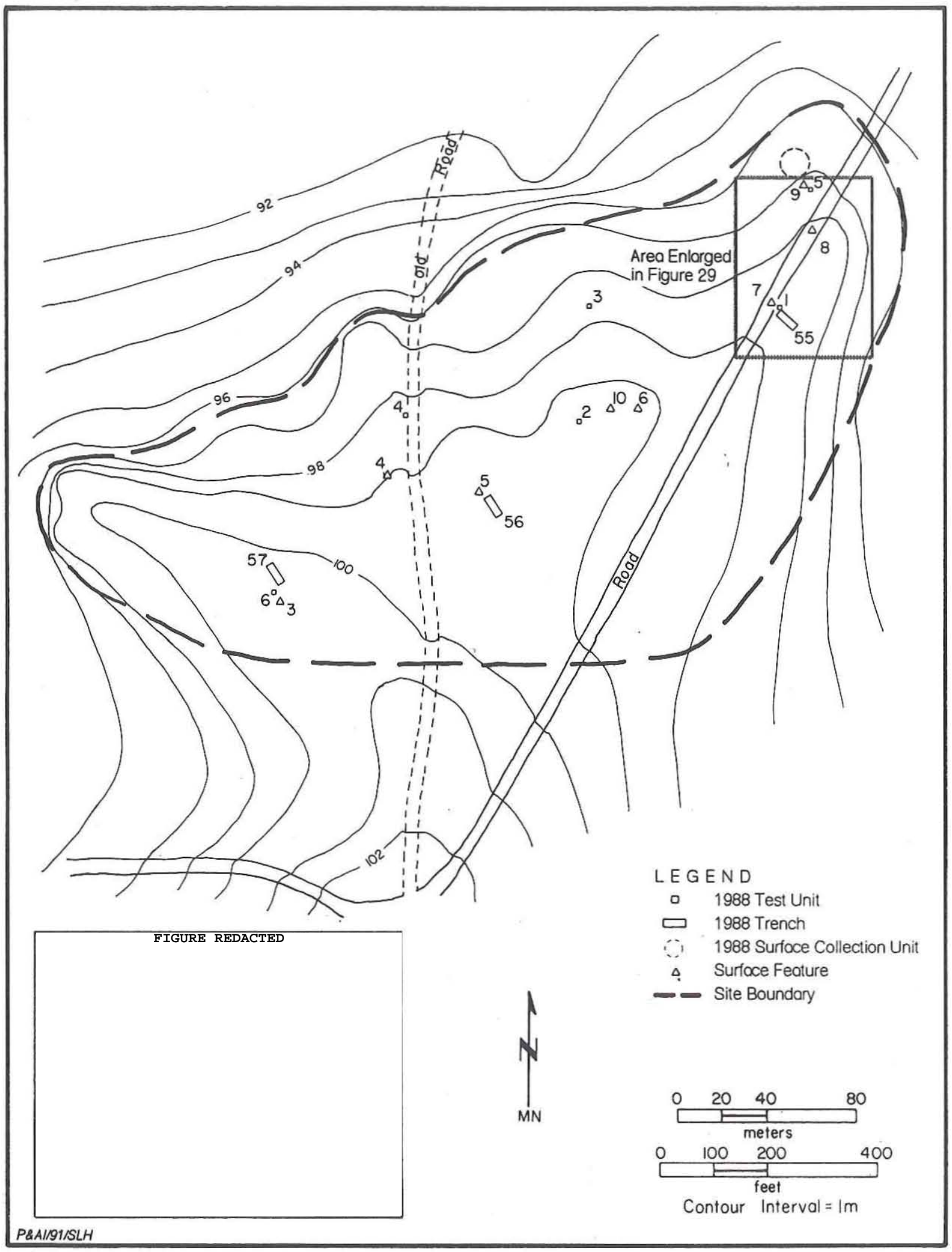

Figure 28. Site map, $41 \mathrm{KT} 33$. 
TABLE 26

ARTIFACTS RECOVERED DURING 1988 TESTING, 41KT33

\begin{tabular}{|c|c|c|c|c|c|c|c|c|c|}
\hline Provenience & \begin{tabular}{|l} 
Dart \\
Points
\end{tabular} & Bifaces & \begin{tabular}{|l} 
Cobble \\
Tools
\end{tabular} & Unifaces & Cores & $\begin{array}{l}\text { Edge- } \\
\text { modified } \\
\text { Debitage }\end{array}$ & $\begin{array}{l}\text { Unmodified } \\
\text { Debitage }\end{array}$ & \begin{tabular}{|l} 
Ground \\
Stones
\end{tabular} & Hammerstones \\
\hline Surface & 1 & 2 & 3 & $5 *$ & - & - & - & 4 & 3 \\
\hline \begin{tabular}{|l} 
Surface \\
Collection \\
Unit
\end{tabular} & - & - & 1 & 1 & - & 3 & 41 & - & 1 \\
\hline \begin{tabular}{|l} 
BHT \\
$1988-55$
\end{tabular} & - & - & 1 & - & - & - & 12 & 1 & - \\
\hline \begin{tabular}{|l} 
Test Unit 1 \\
Test Unit 3 \\
Test Unit 4 \\
Test Unit 5 \\
Test Unit 6 \\
\end{tabular} & $\begin{array}{l}- \\
1 \\
- \\
- \\
-\end{array}$ & $\begin{array}{l}- \\
- \\
- \\
- \\
\end{array}$ & $\begin{array}{l}- \\
- \\
- \\
- \\
\end{array}$ & $\begin{array}{l}- \\
- \\
1 \\
- \\
-\end{array}$ & $\begin{array}{l}- \\
- \\
- \\
1 \\
3\end{array}$ & $\begin{array}{l}2 \\
- \\
- \\
2 \\
4\end{array}$ & $\begin{array}{r}27 \\
9 \\
11 \\
28 \\
50 \\
\end{array}$ & $\begin{array}{l}- \\
- \\
\overline{-} \\
-\end{array}$ & $\begin{array}{l}- \\
- \\
- \\
-\end{array}$ \\
\hline Totals: & 2 & 2 & 7 & 7 & 4 & 11 & 178 & 5 & 4 \\
\hline
\end{tabular}

1 was investigated by Test Unit 4 and proved to be a large $(100 \times 120-\mathrm{cm})$ pile of fire-cracked Potter chert, limestone, and quartzite cobbles and burned sandstone fragments. It was interpreted as a burned rock dump, possibly residue from cleaning out some type of roasting pit. The other nine features were small (less than 100-cm-diameter) burned rock concentrations or slab-lined hearths, and one of these (Feature 2) was investigated by Test Unit 6 . As datable quantities of charcoal were not present, thermoluminescence assays were attempted on burned rocks from Features 1 and 2; a date of 4425 \pm 895 B.P. was obtained on sandstone from Feature 1 , and the limestone sample from Feature 2 could not be dated.

Testing confirmed that intact buried cultural deposits were present, and a second untyped expanding-stem dart point was recovered. While Test Units 5 and 6 yielded the greatest number of artifacts, these materials were shallowly buried and the depositional contexts were questionable. Materials recovered in Test Unit 1, however, were concentrated in a discrete cultural zone from ca. 5$20 \mathrm{~cm}$ below the surface in undisturbed sediment and were interpreted as representing a probable single-component late Archaic occupation of unknown duration. Site 41KT33 again was assessed as having an excellent research potential and subsequently was selected for data recovery. It was estimated that a $55-\mathrm{m}^{2}$ excavation block in the vicinity of Test Unit 1 would yield an interpretable artifact assemblage.

\section{DATA RECOVERY INVESTIGATIONS}

Data recovery at the South Sage Creek Site consisted of detailed mapping of the eastern portion of the site, excavation of 7 random sample units, and excavation of 62 contiguous units in a block (Fig. 29) near the 1988 excavations (Test Unit 1 and BHT 1988-55). One surface artifact, the large metate observed in 1988, also was collected. Shovel scraping in the vicinity indicated that the metate was not associated with any feature as had been suspected but that the area was most likely disturbed by vegetation clearing.

The random sample units were excavated with two goals in mind. The first was to initiate a systematic sampling program on a trial basis in order to assess the interpretive utility of this strategy for future use at Justiceburg. The second goal was to define further the buried archeological deposits in the eastern portion of the site for the purpose of selecting the best location for the excavation block.

The decision to implement a systematic 


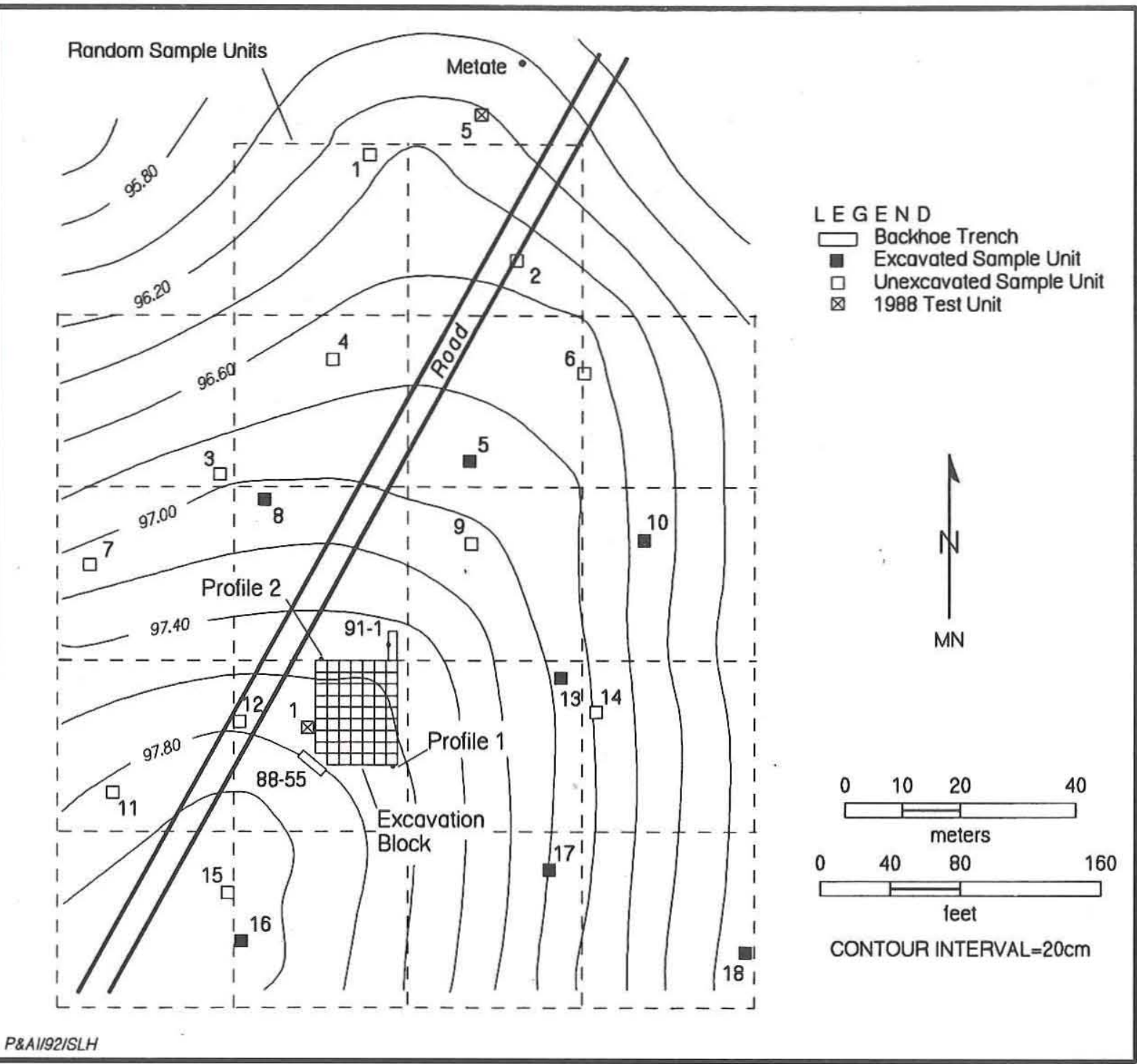

Figure 29. Detailed map of the eastern portion of site $41 \mathrm{KT} 33$ showing locations of random sample units and the excavation block.

unaligned (i.e., random) sampling program was made in consultation with the Advisory Council on Historic Preservation (ACHP). The ACHP felt that such a sampling strategy would enhance the interpretability of the archeological data by sampling a larger site area, hence revealing more activities and site structure than would be revealed by a block excavation alone. This method has been utilized successfully for sampling complex sedentary village sites in the Southwest, such as in the Dolores Archeological Program in Colorado (Kane and Robinson 1988), but its usefulness for investigating pre-village Plains open sites has not been demon- strated. These types of open hunter-gatherer sites such as $41 \mathrm{KT} 33$ present a much more difficult problem because without clear stratigraphic separation of occupations or components, it is not possible to reliably correlate materials from widely dispersed excavation units.

Surface artifact distributions and topography were used to estimate the sampling universe in the eastern portion of the site. This area was subdivided into 18 sample blocks (see Fig. 29), each being $15 \times 15 \mathrm{~m}$ and containing $2251 \times 1-\mathrm{m}$ units. All site mapping was tied into the previous site datum points and the arbitrary $100.00-\mathrm{m}$ elevation of the 
prime datum. A secondary site datum, designated as grid point $0-0$, was established in the southwestern corner of the sampling universe, and the area was gridded off at $15-\mathrm{m}$ intervals. The 18 sample blocks were numbered consecutively from west to east, beginning in the north. Within each block, a randomly generated number indicated which 1x1-m sample unit was selected for excavation.

Location and excavation of the random sample units (designated SUs) was done on a priority basis to further define subsurface deposits as an aid in selecting the location for the excavation block. Since the vicinity of 1988 Test Unit 1 and BHT 1988-55 was already defined as a productive target area for block excavation, the sample units closest to this area were excavated first. Upon completing seven of the sample units (SUs 5, 8, 10, $13,16,17$, and 18), the subsurface artifact density was defined sufficiently to allow judicious selection of the excavation block location. Based on the sample unit artifact frequencies and surface topog- raphy, the area east of the 1988 test excavations was determined to be the most productive location.

The center of the excavation block was placed ca. $4 \mathrm{~m}$ east of Test Unit 1 and was expanded in all four directions according to the artifact and feature distributions until sixty-two 1x1-m excavation units (designated EUs and assigned sequential numbers 1-62) were completed (Fig. 30). The artifact counts in each unit were close to the predicted frequency, and the $62-\mathrm{m}^{2}$ block was within the specified size range for obtaining an interpretable artifact assemblage. However, diagnostic artifacts from the block excavation revealed that the site was not solely a late Archaic occupation as had been expected based on artifact recovery in the widely scattered test units. The presence of ceramics and arrow points and the absence of dart points in the block excavation indicate a Late Prehistoric occupation.

As the block progressed, it became obvious that systematic excavation of dispersed random units would not yield interpretable data at $41 \mathrm{KT} 33$

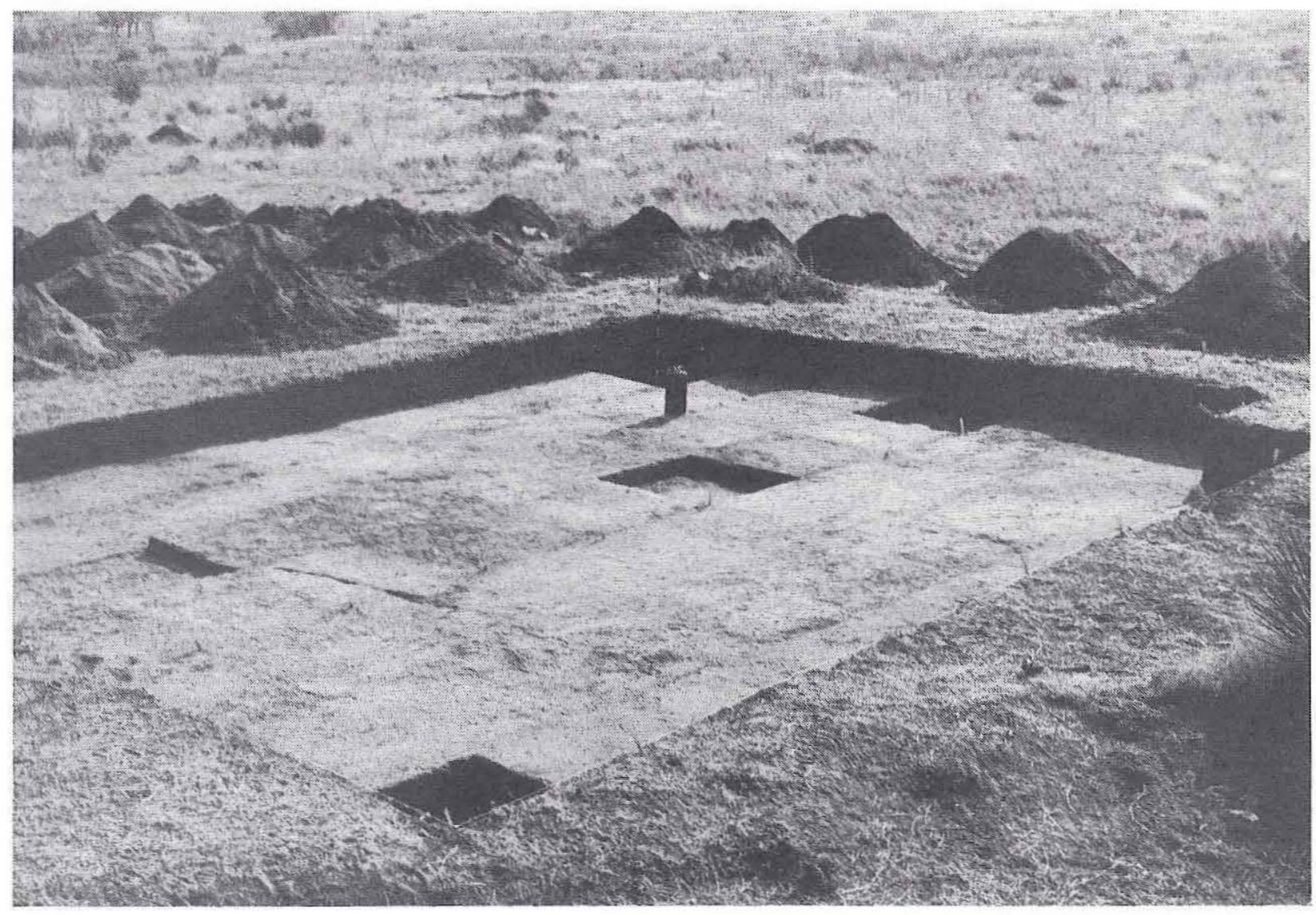

Figure 30. Photograph of completed excavation block at 41KT33. View is to the south. 
because of the distance between the sample units, the inability to relate them to the block excavation, and the likelihood of mixing components of different ages. The absence of well-defined cultural or natural stratigraphy makes it impossible to determine if materials recovered in the outlying sample units are from the same occupation, component, or even gross time period. In simplest terms, it is not clear exactly what universe is being sampled when dealing with large open campsites where multiple overlapping and interfingering occupations or components are likely to occur. Only within a contiguous block excavation is it remotely possible to feel relatively certain about component integrity, and then only with reservations. Because of these problems, it was decided in consultation with the Corps of Engineers that the random sampling program should be terminated, and all further effort was focused on the excavation block. Singleoccupation or single-component sites or sites with unusually clear stratigraphy may not suffer from the same limitations, and thus this sampling strategy might work on some open sites.

Excavation proceeded in $10-\mathrm{cm}$ arbitrary levels using elevations relative to the site datum. The ground surface in the block area was flat and gently sloping to the north and east, ranging from elevation $97.88 \mathrm{~m}$ (southwest comer) to $97.58 \mathrm{~m}$ (northeast corner) (Fig. 31). A depression, probably due to vegetation removal, was noted in the central portion of the block, and disturbed sediments were subsequently observed in those excavation units. All units were excavated to ca. 30$40 \mathrm{~cm}$ below the ground surface where a truncated soil was encountered. Cultural materials were encountered from just below the surface to a depth of ca. $40 \mathrm{~cm}$, but the main cultural zone was from ca. $10-30 \mathrm{~cm}$. Since this zone generally followed the surface slope, it was always the same relative to the ground surface. Two opposite corner units were excavated an additional $20-30 \mathrm{~cm}$ below the cultural zone. Excavation Unit 6 in the southeast comer of the block was excavated to $63 \mathrm{~cm}$ below the surface, and EU 60 in the northwest comer was excavated to $53 \mathrm{~cm}$ below the surface.

Excavation and backfilling of BHT 1988-55 had scattered a thin layer of sediment over the surface surrounding the trench. A few centimeters of disturbed sediment was observed on the surface of several units closest to the trench, but the trench fill was easily detected due to color differences.

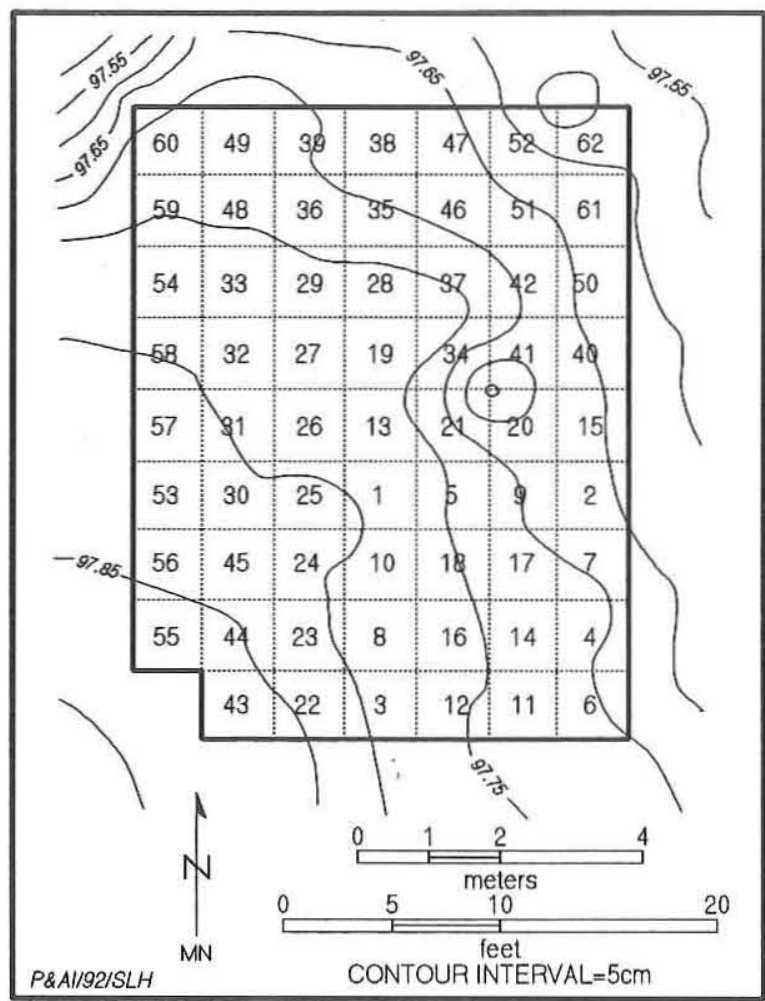

Figure 31. Excavation block surface topography and unit designations, 41KT33.

All upper disturbed sediment was removed from these units prior to excavation.

\section{Sediments and Statigraphy}

Three new profiles were described at the 41KT33 excavation block, and three previous profiles, BHTs 1988-55 through 1988-57, were available from previous investigations (Abbott 1990:44-51). Two profiles are from the excavation block (the west wall of EU 6 near the southeast corner of the block and the north wall of EU 60 near the northwest corner of the block), one profile is from the west wall of BHT 1991-1 immediately north of EU 62 (near the northeast corner of the excavation block), and the BHT $1988-55$ profile is near the southwest corner of the block (see Fig. 29). Detailed profile descriptions of the 1991 profiles are provided in Appendix $\mathrm{H}$, and these are illustrated in Figure 32 along with the BHT 1988-55 profile. As stated above, $41 \mathrm{KT} 33$ is on an elevated alluvial terrace, known as the Older Terrace, that forms a ridge between the Double Mountain Fork 


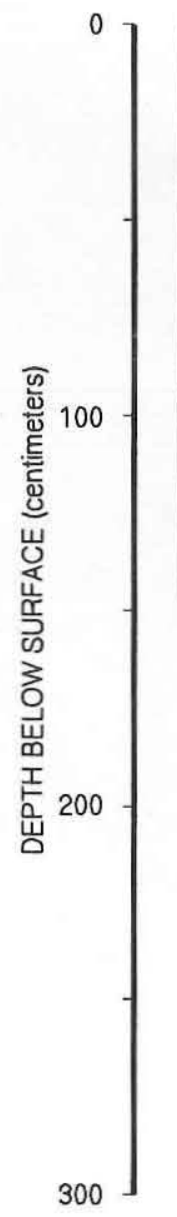

BHT 88-55

EU 60, NORTH WALL

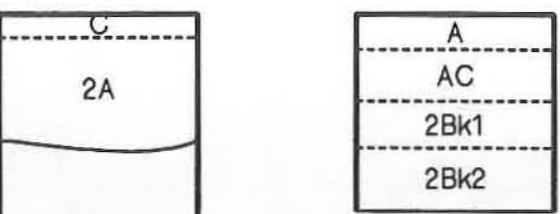

3Bk

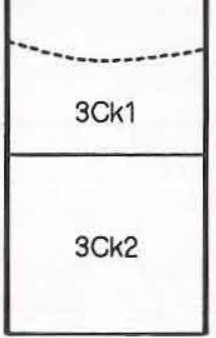

P\&AI/92/SLH

BHT 91-1

EU 6, WEST WALL

LEGEND

Abrupt Boundary

Clear Boundary

- - Gradual Boundary

TTाT Bedrock

I Radiocarbon Assay, Years B.P. (Corrected)

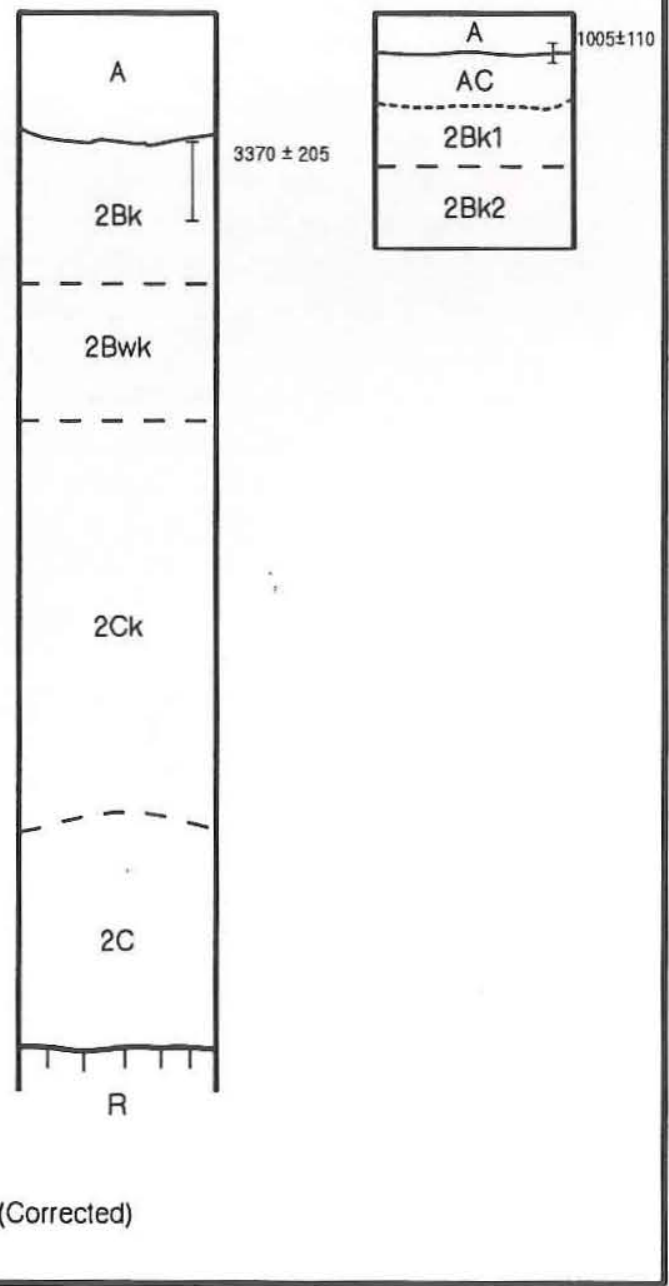

Figure 32. Geologic profiles, $41 \mathrm{KT} 33$.

and South Sage Creek. Some upstream portions of this terrace are protected by bedrock outcrops, and it appears that their position helped preserve this terrace from erosion.

The profile from BHT 1991-1 exposed $265 \mathrm{~cm}$ of unconsolidated sediments that sit directly on bedrock. Yellowish red loam with very weak medium subangular blocky structure was observed in the upper $32 \mathrm{~cm}$. These sediments represent mainly colluvial deposits with a possible eolian contribution. These sediments have been slightly altered by pedogenesis to form a weak A horizon soil. This colluvium sits unconformably on a thick truncated soil (2Bk and $2 \mathrm{Bwk}$ horizons) between $32-105 \mathrm{~cm}$ which itself grades down to a series of well-bedded fluvial sand and gravel deposits between $105-265 \mathrm{~cm}$ ( $2 \mathrm{Ck}$ and $2 \mathrm{C}$ horizons). This entire sequence sits directly on sandstone and shale bedrock. Bedrock is exposed also on the surface at low promontories that jut into the floodplain at the north-central and northwest portions of the site (9$9.5 \mathrm{~m}$ above bankfull stage of the Double Mountain Fork). This suggests that an intermediate bedrock bench occurs on the south valley wall, and clearly the Older Terrace sits on top of this bench.

The BHT 1988-55 profile (Abbott 1990) is 
fairly similar to the BHT $1991-1$ profile with the additions of a thin surface colluvial layer in the upper $7 \mathrm{~cm}$ of BHT $1988-55$ and a thinner Bk horizon below the unconformity. Abbott did not extend his backhoe trench deep enough to observe the gravel beds resting on bedrock.

The profiles from EU 6 and EU 60 are similar as well. Both have a reddish brown to dark reddish brown sandy loam A horizon overlying a reddish brown to dark reddish brown sandy loam $\mathrm{AC}$ horizon. In both profiles, the $\mathrm{AC}$ horizons are separated by an unconformity from the underlying $2 \mathrm{Bk}$ horizons. These $2 \mathrm{Bk}$ horizons are the upper portion of the Older Terrace, and the unconformity between them and the overlying soil horizons is used to correlate the profiles at $41 \mathrm{KT} 33$.

The in situ archeological remains occur mostly in the 25-35-cm-thick colluvial sediments that cap the Older Terrace. Within this colluvium, two very small charcoal samples from Feature 12 were combined for a single radiocarbon date (see Appendix G). The corrected age is $1005 \pm$ 110 B.P. (GX-16513/16514), cal. 933 B.P. At $41 \mathrm{KT} 33$, the upper surface of the Older Terrace is marked by a truncated, well-developed soil (2BK horizon in BHT 1991-1). A single radiocarbon assay of $3370 \pm 205$ B.P. (GX-16508), cal. 3630 B.P., is available from this soil horizon in the Older Terrace (see Fig. 32). A more complete expression of this soil (ca. $225 \mathrm{~cm}$ thick) is recorded in the BHT 1991-2 profile (350 m southwest of the excavation block), which also produced a more reliable radiocarbon age estimate, $8690 \pm 305$ B.P. (GX-16509), cal. 9595 B.P. (see Chapter 8). This assay from BHT 1991-2 can be used to imply that the $41 \mathrm{KT} 33$ date suffers from contamination by younger carbon, probably through leaching and bioturbation down-profile. As discussed more fully in Chapter 8, the implications of these radiocarbon determinations are that the soil capping the Older Terrace at $41 \mathrm{KT} 33$ was severely beveled by erosion during the mid Holocene. After erosion of the Older Terrace ceased, colluvial and eolian sediments began to accumulate and late Archaic through Late Prehistoric hunter-gatherers occupied the site.

\section{Features}

Scattered burned sandstone slabs were recovered throughout the cultural zone in the excavation block, but only two concentrations were recognized as features. Feature numbers 1-10 were assigned during the testing phase and are described in Boyd et al. (1990:197-198); the two features exposed in the excavation block were designated as Features 11 and 12. Both are close together near the center of the excavation block and may be closely coeval. The burned rocks throughout the rest of the block appear to represent scattered rocks lying within a cultural zone. The cultural zone, however, is poorly defined due to a lack of stratigraphy, but the scattered burned rocks are generally at the same depths as the features and the main concentration of artifacts.

Feature 11 is a small $(30 \times 35-\mathrm{cm})$ discrete cluster of 10 sandstone fragments found from 16$25 \mathrm{~cm}$ below the surface in EUs 1 and 10 . The rocks are all intensively burned angular fragments generally lying horizontal but not neatly patterned as would be expected in a slab-lined hearth. No discolored soil was observed, and only a few flecks of charcoal were noted. One fire-cracked Potter chert fragment also was found in the cluster. Randomly scattered burned sandstone fragments lying just beyond the perimeter of the feature suggest that it is not intact. Feature 11 is interpreted as a displaced hearth that was disturbed by subsequent occupations or a secondary deposit (i.e., dump) of burned rocks.

Feature 12 (Fig. 33) is a larger $(120 \times 160-\mathrm{cm})$ concentration of 213 burned rocks weighing $55.9 \mathrm{~kg}$. It is interpreted as a circular hearth that was displaced by subsequent occupations and then subjected to recent partial disturbance. The feature is at 13-27 cm below the surface in EUs 5, 9, 20, and 21 and extends slightly into EUs 2 and 15. It consists entirely of burned sandstone slabs with a chert flake, a uniface, and some fire-cracked Potter chert fragments in close proximity. A radiocarbon determination on charcoal from Feature 12 produced an age estimate of $1005 \pm 110$ B.P., cal. 933 B.P.

The western half of the feature appears intact, with the rocks being generally horizontal and forming an abrupt curved edge on the south and west. Although tightly clustered, there is no recognizable patterning such as a basin shape in this portion of the feature. No organic-stained sediment was observed, but some charcoal fragments were present between and under the rocks.

The eastern half of Feature 12 appears to be disturbed and corresponds with a prominent surface 


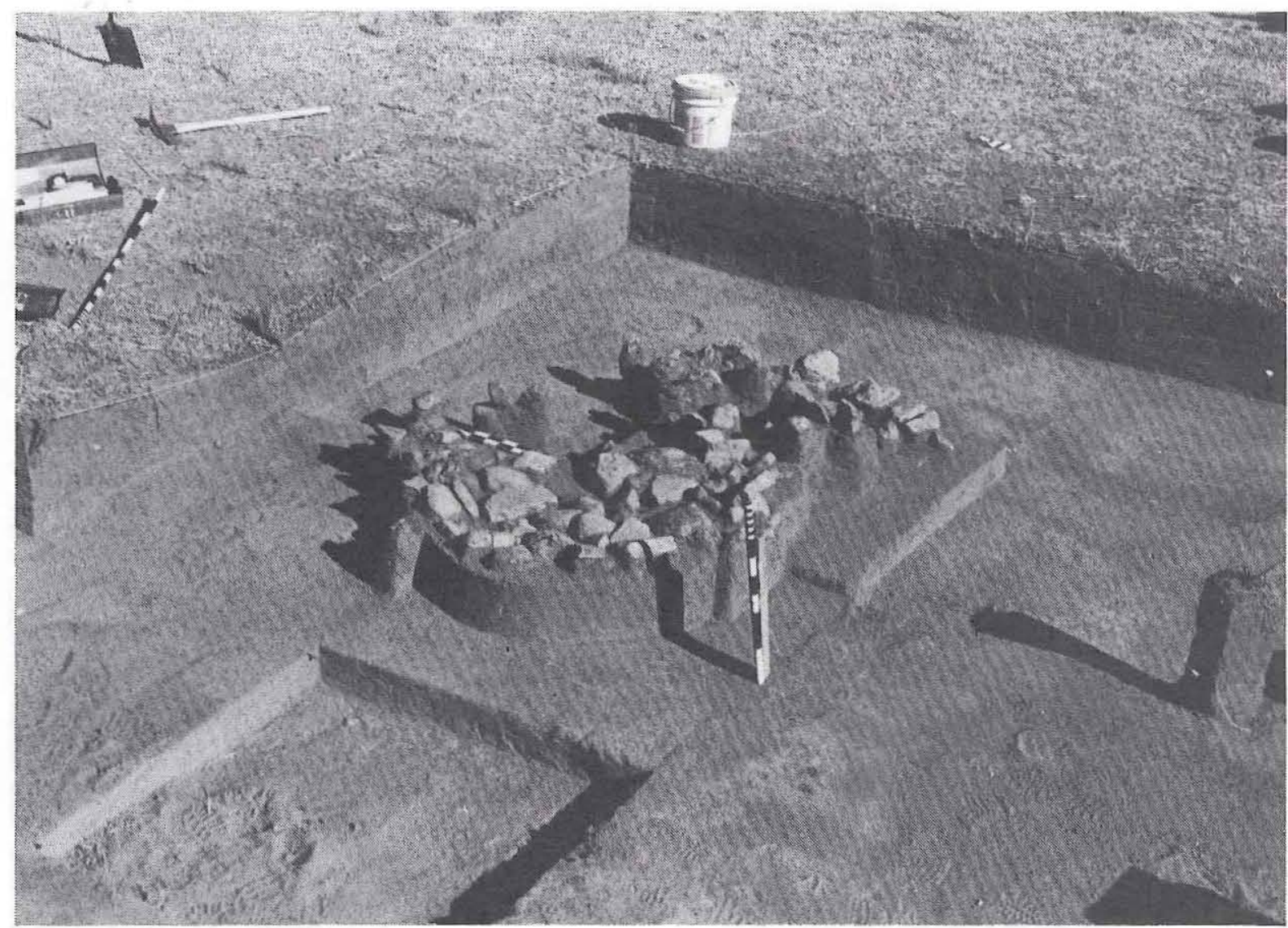

Figure 33. Photograph of Feature 12, 41KT33. View is northeast; undisturbed portion of feature is in foreground. Note surface depression (north wall of EUs 20 and 21) in left center of photo.

depression centered at grid location N26/E27 (see Fig. 33). The burned rocks in this area are not tightly packed, and they are oriented at various angles, including some standing vertically. The surface depression and feature disturbance most likely are due to vegetation clearing, such as a tree uprooted by chaining.

Two sediment samples from Feature 12 and a control sample from the cultural zone in EU 60 (10-15 cm below the surface) were analyzed for pollen (see Appendix E). Eight taxa were identified in the feature samples, and seven taxa were identified in the control sample. Due to the high degree of degradation, however, no interpretations of the pollen evidence are warranted. Two samples of feature sediment and a control sample from the cultural zone in EU 1 were floated to recover macrobotanical remains. One feature sample and the control sample yielded no macrobotanical remains; the other feature sample produced macro- botanical remains that were submitted for identification, but none was identifiable (see Appendix D).

\section{Materials Recovered}

This section discusses the 2,062 chipped stone artifacts, 42 ground and battered stones, 6 ceramic sherds, and 2 shell artifacts (Table 27). The burned rocks and faunal specimens also are discussed. The majority $(n=2,055,97 \%)$ of the artifacts are from the excavation block. A few artifacts $(n=56,3 \%)$ are from random sample units located away from the block. In addition, one artifact was recovered from the surface. Because the random sample units could not be tied stratigraphically to the excavation block, and because dart points were recovered from the surface and a test unit but not from the excavation block, it is necessary to assume that only the artifacts recovered from within the block are part of a coherent assemblage. This descriptive section 


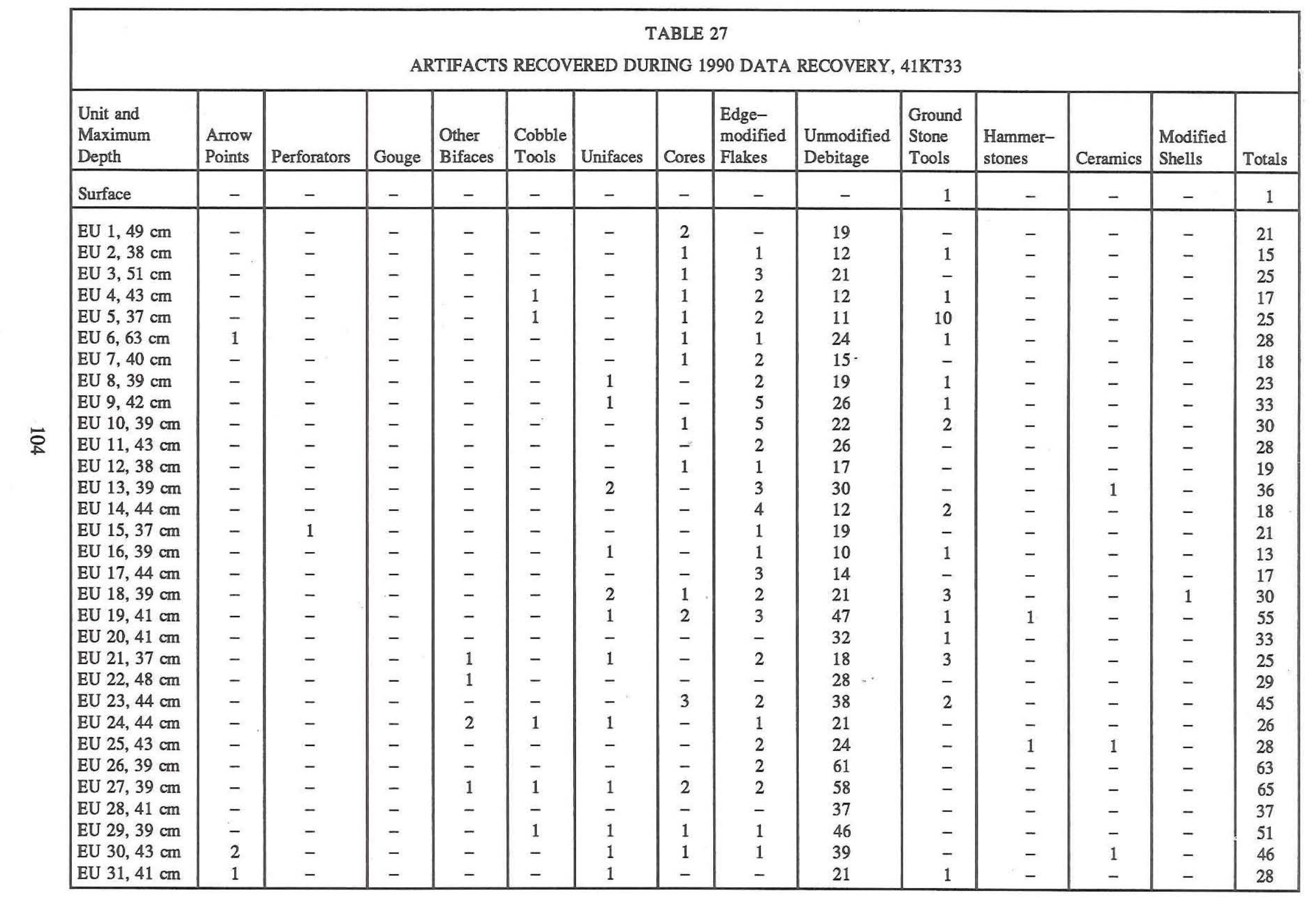


Table 27, continued

\begin{tabular}{|c|c|c|c|c|c|c|c|c|c|c|c|c|c|c|}
\hline $\begin{array}{l}\text { Unit and } \\
\text { Maximum } \\
\text { Depth }\end{array}$ & $\begin{array}{l}\text { Arrow } \\
\text { Points }\end{array}$ & Perforators & Gouge & $\begin{array}{l}\text { Other } \\
\text { Bifaces }\end{array}$ & $\begin{array}{l}\text { Cobble } \\
\text { Tools }\end{array}$ & Unifaces & Cores & $\begin{array}{l}\text { Edge- } \\
\text { modified } \\
\text { Flakes } \\
\end{array}$ & $\begin{array}{l}\text { Unmodified } \\
\text { Debitage }\end{array}$ & $\begin{array}{l}\text { Ground } \\
\text { Stone } \\
\text { Tools }\end{array}$ & $\begin{array}{l}\text { Hammer- } \\
\text { stones }\end{array}$ & Ceramics & $\begin{array}{l}\text { Modified } \\
\text { Shells }\end{array}$ & Totals \\
\hline EU $32,40 \mathrm{~cm}$ & - & - & - & - & - & - & 2 & 2 & 61 & - & - & - & - & 64 \\
\hline EU $33,39 \mathrm{~cm}$ & - & - & - & - & - & 1 & - & - & 24 & - & - & - & - & 25 \\
\hline EU $34,41 \mathrm{~cm}$ & - & - & - & - & 1 & - & - & 2 & 15 & - & 2 & - & - & 20 \\
\hline EU $35,34 \mathrm{~cm}$ & - & - & - & - & - & - & - & 1 & 25 & - & - & - & - & 26 \\
\hline EU $36,36 \mathrm{~cm}$ & - & - & - & - & - & - & 1 & - & 32 & - & - & - & - & 33 \\
\hline EU $37,41 \mathrm{~cm}$ & - & - & - & - & - & - & - & 3 & 49 & - & - & - & - & 52 \\
\hline EU $38,34 \mathrm{~cm}$ & 1 & - & - & - & - & 1 & 2 & 5 & 26 & - & - & - & - & 35 \\
\hline EU $39,36 \mathrm{~cm}$ & 1 & - & - & - & - & - & - & 2 & 24 & - & - & - & - & 27 \\
\hline EU $40,37 \mathrm{~cm}$ & - & - & - & - & - & 2 & 2 & 5 & 27 & - & - & - & - & 36 \\
\hline EU $41,44 \mathrm{~cm}$ & - & - & - & - & - & - & - & - & 26. & - & - & - & - & 26 \\
\hline $\mathrm{EU} 42,44 \mathrm{~cm}$ & - & - & - & - & - & - & 1 & 2 & 34 & - & - & - & - & 37 \\
\hline $\mathrm{EU} 43,48 \mathrm{~cm}$ & - & - & - & - & - & - & - & 1 & 22 & 1 & - & - & - & 24 \\
\hline EU $44,47 \mathrm{~cm}$ & - & - & - & - & - & 2 & - & 4 & 20 & - & - & 1 & - & 27 \\
\hline EU $45,45 \mathrm{~cm}$ & - & - & - & - & - & - & - & 1 & 31 & - & - & - & - & 32 \\
\hline $\mathrm{EU} 46,42 \mathrm{~cm}$ & - & - & - & - & - & - & - & 8 & 44 & - & - & - & - & 52 \\
\hline EU $47,38 \mathrm{~cm}$ & - & - & - & - & - & - & 1 & 2 & 34 & - & - & 1 & - & 38 \\
\hline EU $48,36 \mathrm{~cm}$ & - & - & - & - & - & - & 3 & 4 & 33 & - & - & - & - & 40 \\
\hline EU $49,33 \mathrm{~cm}$ & 1 & 1 & - & - & - & - & - & 2 & 27 & 1 & - & - & - & 31 \\
\hline EU $50,36 \mathrm{~cm}$ & - & - & - & - & - & - & - & 3 & 18 & - & - & - & - & 21 \\
\hline EU $51,39 \mathrm{~cm}$ & - & - & - & - & 1 & - & 2 & 1 & 35 & - & - & - & - & 39 \\
\hline EU $52,35 \mathrm{~cm}$ & - & - & - & - & - & - & - & 3 & 34 & - & - & - & - & 37 \\
\hline EU $53,43 \mathrm{~cm}$ & - & - & - & - & 1 & - & 1 & 2 & 47 & 1 & - & - & - & 52 \\
\hline EU $54,39 \mathrm{~cm}$ & - & - & - & - & - & 1 & - & 1 & 30 & 1 & - & - & - & 33 \\
\hline EU $55,48 \mathrm{~cm}$ & - & - & - & 1 & - & 1 & - & 1 & 44 & - & - & - & - & 47 \\
\hline EU $56,46 \mathrm{~cm}$ & 1 & - & - & - & - & 1 & 1 & 3 & 35 & - & - & - & - & 41 \\
\hline EU $57,42 \mathrm{~cm}$ & - & - & - & - & - & 1 & 1 & 3 & 31 & 1 & - & - & 1 & 38 \\
\hline EU $58,41 \mathrm{~cm}$ & - & - & - & - & - & 1 & 2 & 2 & 37 & - & - & - & - & 42 \\
\hline EU $59,36 \mathrm{~cm}$ & 2 & - & - & - & - & 1 & - & 3 & 32 & - & - & 1 & - & 40 \\
\hline $\mathrm{EU} 60,53 \mathrm{~cm}$ & - & - & - & - & - & 1 & - & 3 & 31 & - & - & - & - & 35 \\
\hline EU $61,35 \mathrm{~cm}$ & - & - & - & - & - & - & - & 1 & 24 & - & - & - & - & 25 \\
\hline $\mathrm{EU} 62,33 \mathrm{~cm}$ & - & - & - & - & 2 & - & 1 & 6 & 23 & - & - & - & - & 32 \\
\hline
\end{tabular}


Table 27, continued

\begin{tabular}{|c|c|c|c|c|c|c|c|c|c|c|c|c|c|c|}
\hline $\begin{array}{l}\text { Unit and } \\
\text { Maximum } \\
\text { Depth }\end{array}$ & $\begin{array}{l}\text { Arrow } \\
\text { Points }\end{array}$ & Perforators & Gouge & $\begin{array}{l}\text { Other } \\
\text { Bifaces }\end{array}$ & $\begin{array}{l}\text { Cobble } \\
\text { Tools } \\
\end{array}$ & Unifaces & Cores & $\begin{array}{l}\text { Edge- } \\
\text { modified } \\
\text { Flakes }\end{array}$ & $\begin{array}{l}\text { Unmodified } \\
\text { Debitage }\end{array}$ & $\begin{array}{l}\text { Ground } \\
\text { Stone } \\
\text { Tools }\end{array}$ & $\begin{array}{l}\text { Hammer- } \\
\text { stones }\end{array}$ & Ceramics & $\begin{array}{l}\text { Modified } \\
\text { Shells }\end{array}$ & Totals \\
\hline $\begin{array}{l}\text { SU } 5,50 \mathrm{~cm} \\
\text { SU } 8,50 \mathrm{~cm} \\
\text { SU } 10,60 \mathrm{~cm} \\
\text { SU } 13,50 \mathrm{~cm} \\
\text { SU } 16,50 \mathrm{~cm} \\
\text { SU } 17,50 \mathrm{~cm} \\
\text { SU } 18,50 \mathrm{~cm}\end{array}$ & $\begin{array}{l}1 \\
- \\
- \\
- \\
- \\
- \\
-\end{array}$ & $\begin{array}{l}- \\
- \\
- \\
- \\
- \\
- \\
-\end{array}$ & $\begin{array}{l}1 \\
- \\
- \\
- \\
- \\
- \\
-\end{array}$ & $\begin{array}{l}- \\
- \\
- \\
- \\
- \\
-\end{array}$ & $\begin{array}{l}- \\
- \\
- \\
- \\
- \\
-\end{array}$ & $\begin{array}{l}1 \\
- \\
- \\
- \\
- \\
- \\
-\end{array}$ & $\begin{array}{l}- \\
- \\
- \\
- \\
- \\
-\end{array}$ & $\begin{array}{l}- \\
- \\
- \\
- \\
- \\
-\end{array}$ & $\begin{array}{r}24 \\
7 \\
2 \\
10 \\
4 \\
4 \\
1\end{array}$ & $\begin{array}{l}1 \\
- \\
- \\
- \\
- \\
- \\
-\end{array}$ & $\begin{array}{l}- \\
- \\
- \\
- \\
- \\
- \\
-\end{array}$ & $\begin{array}{l}- \\
- \\
- \\
- \\
- \\
-\end{array}$ & $\begin{array}{l}- \\
- \\
- \\
- \\
- \\
-\end{array}$ & $\begin{array}{r}28 \\
7 \\
2 \\
10 \\
4 \\
4 \\
1\end{array}$ \\
\hline Totals: & 11 & 2 & 1 & 6 & 10 & 28 & 40 & 137 & 1827 & 38 & 4 & 6 & 2 & 2112 \\
\hline
\end{tabular}


discusses all of the artifacts recovered from the random sample units and the excavation units comprising the block.

\section{Chipped Stone Artifacts}

A total of 11 arrow points and fragments, 2 perforators, 1 gouge, 6 bifaces, 10 cobble tools, 28 unifaces, 40 cores, 137 edge-modified flakes, and 1,827 pieces of unmodified debitage was recovered. Of these, only 1 arrow point, 1 gouge, 1 uniface, and 52 pieces of unmodified lithic debitage are from random sample units. The remaining chipped stone artifacts are from the excavation block.

\section{ARROW POINTS}

Of the 11 arrow points recovered, 2 are complete, 5 are proximal fragments, and 4 are distal fragments. Ten are made of fine-grained chert, and one is of coarse-grained chert. Three are typed as Scallorn, one is typed as Harrell, two do not resemble known types, and the remaining five are too fragmented for accurate classification.

Scallorn

One complete point (Fig. 34a) and two proximal fragments (Fig. 34b and c) are included in this type (Jelks 1962:Fig. 13). All three are corner notched; two have convex bases, and one has a straight base. The complete point has straight blade edges and downward-curving barbs. The two barbs and one ear appear to have been broken in use and subsequently reworked. The two proximal fragments are broken across their necks. One point fragment is use broken, but break cause could not be determined on the other specimen. Stem and base smoothing are absent on all three points, and the blade edges are not serrated on the single complete point. The nature of the cores used in the manufacture of the three points cannot be determined. All three are made of fine-grained chert; the two proximal fragments are nonlocal cherts (Color 41s and 43), and the complete specimen is a locally available chert (Color 27). The complete point has an overall length of $21 \mathrm{~mm}$, its blade measures $16 \mathrm{~mm}$, and its stem is $5 \mathrm{~mm}$ long. Its reworked base is $6 \mathrm{~mm}$ wide, and the point is $3 \mathrm{~mm}$ thick. One of the two proximal fragments has an 11-mm-wide base and an 8-mm-wide neck; the

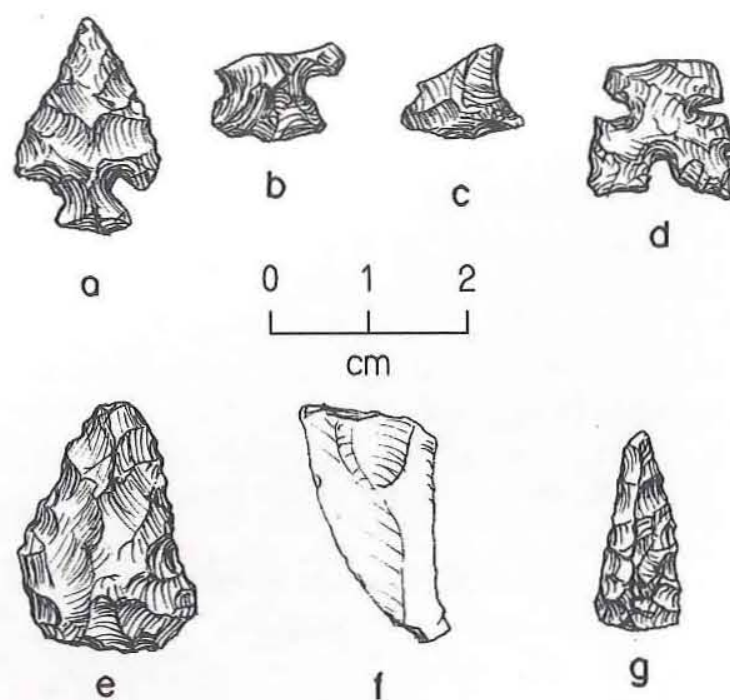

Figure 34. Arrow points and perforators, 41KT33. (a-c) Scallorn arrow points; (d) Harrell arrow point; (e) untyped arrow point; (f-g) perforators.

other has a base with of $12 \mathrm{~mm}$ and a neck width of $7 \mathrm{~mm}$. Other measurements could not be recorded on the fragments.

Harrell

One proximal fragment is classified as a Harrell (Fig. 34d) (Bell 1958). The specimen is characterized by a triangular outline, relatively deep and narrow side notches, and a concave base with a deep central notch. An additional shallow notch is found on one margin of the stem, located midway between the base corner and the side notch. Base and stem smoothing and beveling are absent, and it is not possible to determine the presence and/or type of blade treatment on the small blade section remaining. Resharpening and reuse cannot be determined. The blade break appears to have been the result of use. Judging from the small portion of the original ventral surface remaining on one face and the planoconvex cross section, the point was made on a small flake. It is made of nonlocal fine-grained chert (Color 41). The maximum width of the blade is $11 \mathrm{~mm}$, the base is $15 \mathrm{~mm}$ wide, and the neck is $6 \mathrm{~mm}$ wide. The haft is $9 \mathrm{~mm}$ long, and the point is $2 \mathrm{~mm}$ thick.

\section{Untyped}

One complete arrow point (Fig. 34e) and one proximal fragment are included in this class. These 
specimens are similar to Granbury arrow points (Jelks 1962) and to triangular preforms in the Eastern Jomada region (Leslie 1978). Both are triangular in outline and are characterized by straight to convex bases, rounded stem/base corners, and slightly recurved blade edges. Neither exhibits stem and/or base smoothing. Both have been resharpened. The complete point still retains a small portion of the parent flake's ventral surface indicative of the use of a flake for point manufacture. The specimen has a planoconvex cross section. The broken blade on the proximal fragment exhibits a perverse fracture morphology, suggesting that it was broken in an attempted flake removal. The heavily resharpened blade edges suggest that the break may have occurred during this rejuvenation episode. The nature of the blank cannot be determined on the proximal fragment. It has a lenticular transverse cross section.' Both points are made of nonlocal fine-grained chert (Colors 41 and 43). The complete point is $25 \mathrm{~mm}$ long; the blade is $15 \mathrm{~mm}$ long, the stem is $10 \mathrm{~mm}$ long, the maximum width of the blade at the shoulder is $15 \mathrm{~mm}$, the base is $16 \mathrm{~mm}$ wide, and the specimen is $5 \mathrm{~mm}$ thick. The proximal fragment has a 9-mm-long stem, the blade is $11 \mathrm{~mm}$ wide at the shoulder, the base is $13 \mathrm{~mm}$ wide, and the maximum thickness is $3 \mathrm{~mm}$.

\section{Untyped Fragments}

One proximal and four distal arrow point fragments cannot be typed. Three of the specimens were broken in manufacture, but break cause cannot be determined for the other two. The proximal fragment is also broken longitudinally so that only a corner of the stem remains. Three of the five fragments have lenticular transverse cross sections. The nature of the blank used in their manufacture is not immediately evident on these specimens. The other two have planoconvex cross sections and still retain portions of the parent flakes' ventral surfaces. They are made on flakes. Resharpening is evident on a single specimen, is absent on two others, and could not be determined on the remaining two fragments due to their small size. The proximal fragment exhibits no base and/or stem smoothing, and none of the distal specimens have serrated or beveled blade edges. Four of the five specimens are made of fine-grained chert; one is a coarsegrained specimen. One of the fine-grained pieces is of nonlocal origin (Color 42); the others are locally available cherts (Colors 2, 14, and 27).

\section{PERFORATORS}

Two perforators were recovered. One is a proximal fragment (Fig. 34f), and the other is a narrow blade fragment (Fig. $34 \mathrm{~g}$ ). The proximal specimen appears to have been an unretouched secondary complete flake with a pointed distal end used as a drill. It is possible that the distal break was caused by use, but this could not be determined with certainty. Use-related microflaking extends $5 \mathrm{~mm}$ from the break face and is distributed on alternate faces of the edges. The proximal fragment exhibits no haft wear, and the lack of shaping suggests that it represents an expediency tool. The stem is $18 \mathrm{~mm}$ long and $13 \mathrm{~mm}$ wide at its maximum. The blade is $6 \mathrm{~mm}$ wide at its junction with the stem, and the flake is $7 \mathrm{~mm}$ thick. The distal fragment is a narrow bifacially flaked blade segment with use-wear distributed on altemate faces of its edges. The break morphology is characteristic of use failure. Given the heavily retouched biconvex transverse cross section, it is not possible to determine the nature of the blank used in its manufacture. Both perforator fragments are made of fine-grained chert, one of which is locally available (Color 32). The origin of the second specimen, the expediency tool, could not be determined based on its color. Its expedient nature suggests, however, that this is also a locally available chert.

\section{GOUGE}

One complete unifacial gouge was recovered from Sample Unit 5 (Fig. 35a). It has a planoconvex transverse cross section and a triangular shape. It is made on a large secondary finegrained Potter chert flake. The working edge is straight to slightly convex and exhibits five rejuvenation flake scars. Edge wear is not visible microscopically (40x magification) on the irregular edge, suggesting perhaps that the tool was discarded soon after the removal of the rejuvenation flakes. Haft wear extends for $28 \mathrm{~mm}$ along the proximal edges of the tool; its overall length is $58 \mathrm{~mm}$. If the extent of haft wear is correctly identified, the difference between the extent of haft wear and overall tool length suggests that exhaustion was not 

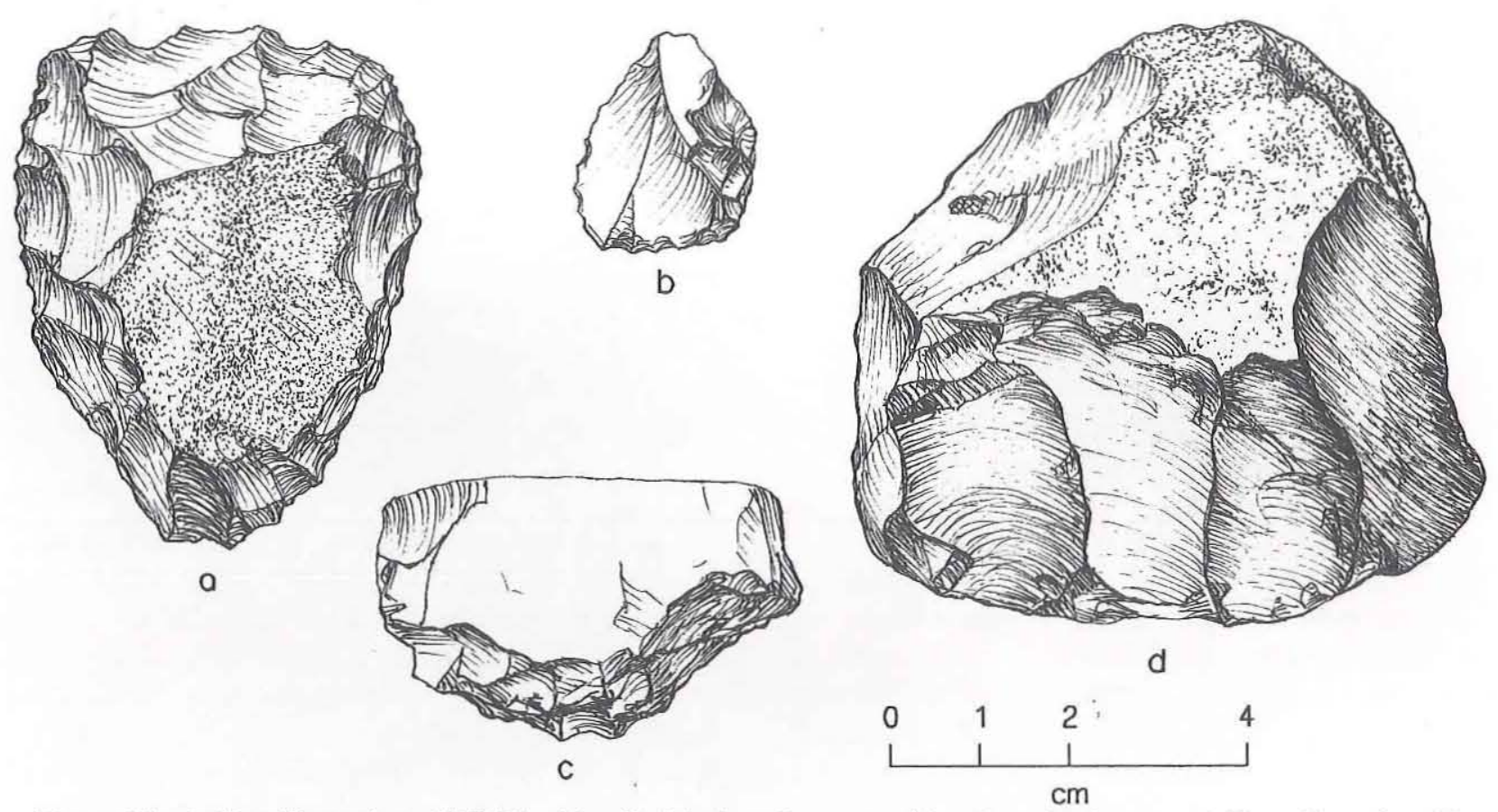

Figure 35. Artifact illustrations, 41KT33. (a) unifacial triangular gouge; (b) early-reduction-stage biface; (c) wedge; (d) chopper.

the reason for tool discard. The gouge is $45 \mathrm{~mm}$ wide and $22 \mathrm{~mm}$ thick.

\section{OTHER BIFACES}

One complete (Fig. 35b) and five biface fragments were recovered. Three of the fragments are indeterminate biface edges; the other two are proximal specimens. The complete biface is a small tertiary flake with minimal shaping retouch. The only flake scars on its ventral surface represent attempts to reduce its rather prominent bulb of percussion. Based on the minimal retouch, it appears to be an early-reduction-stage biface. Judging from its shape and the nature of the blank, it is possible that the specimen is an arrow point blank or preform. The specimen is $23 \mathrm{~mm}$ long, $19 \mathrm{~mm}$ wide, and $6 \mathrm{~mm}$ thick.

One of the two proximal fragments is made on a thin tertiary flake. The fragment has a rounded base defined by regularly patterned flake removals. The perverse break morphology suggests that it was broken during manufacture. Although it cannot be classified into a reduction stage based on metric attributes, its degree of reduction suggests a middle-reduction-stage biface. The length, width, and thickness of the specimen are incomplete. The second proximal fragment is a relatively thick $(14 \mathrm{~mm})$ specimen with highly sinuous bifacial edges. It has a convex to rounded base. The break morphology suggests that it was broken as a result of a failed longitudinal thinning attempt. Judging from the three burin scars removed from one lateral edge, the biface fragment may have been reused as an engraver. The thickness of the specimen and its sinuous edges suggest that it is a middle-reductionstage biface.

The three indeterminate biface edges are small fragments for which the stage of reduction cannot be determined. Two of the specimens appear to have been broken postdepositionally; the third has a break morphology characteristic of manufacture failures.

All of the bifaces are made of fine-grained chert. The complete specimen and one of the edge fragments are made of locally available cherts (Colors 27 and 31); the other fragments are of nonlocal cherts (Colors 41, 49, 51, and 52).

\section{COBBLE TOOLS}

Six complete and four fragmentary cobble tools were recovered. Two of the complete cobble tools are classified as wedges (Fig. 35c). The 
remaining four complete tools and the four fragments are choppers (Fig. 35d). The eight choppers exhibit heavy step fracturing on their working edges, and seven of the eight also have heavily rounded working edges. Two of the four complete tools are cortex backed. Cortex backing could not be determined on the three distal fragments. The fourth chopping tool fragment, a longitudinally broken specimen, is cortex backed. Two of the four complete chopping tools have been reused; based on the randomness of the flake removals, these were multidirectional cores utilized as chopping tools. Three of the complete specimens have two working edges each, and the fourth complete chopper has a single working edge. Of the eight chopping tools, six are made of fine-grained Potter chert and two are of fine-grained quartzite. The four complete chopping tools have a mean length of $72.0 \mathrm{~mm}$ $(\sigma=13.6, \min .=53, \max .=84)$, a mean width of $64.3 \mathrm{~mm}(\sigma=7.1, \min .=54, \max .=70)$, and a mean thickness of $45.3 \mathrm{~mm}(\sigma=8.3, \mathrm{~min} .=36$, max. = 56). The four specimens have a mean weight of $250 \mathrm{~g}$, ranging from 160 to $389 \mathrm{~g}$ $(\sigma=97.7)$. Only two metric attributes could be recorded on the longitudinally broken chopping tool; it is $73 \mathrm{~mm}$ long and $30 \mathrm{~mm}$ wide.

Both of the cobble tools used as wedges are complete. One is a large secondary flake with a corticate striking platform; the other is a small cortex-backed pebble. Neither of the two working edges exhibit edge rounding, but they both have light step fracturing. One of the two is of finegrained quartzite, and the other is an indeterminate local fine-grained chert specimen. The quartzite tool is $53 \mathrm{~mm}$ long, $42 \mathrm{~mm}$ wide, $29 \mathrm{~mm}$ thick, and weighs $69 \mathrm{~g}$. The chert specimen is $28 \mathrm{~mm}$ long, $46 \mathrm{~mm}$ wide, $16 \mathrm{~mm}$ thick, and weighs only $24 \mathrm{~g}$.

\section{UNIFACES}

Of the 28 unifaces recovered, the largest morphofunctional category consists of 13 indeterminate edges; six are end scrapers, six are combination end and side scrapers, two are combination scrapers and gravers, and one is a side scraper. In addition to indeterminate unifacial tool edges, the remainder of the collection consists of nine complete tools, four distal ends, and two proximal fragments.

The six end scrapers consist of four complete tools and two distal fragments. One of the com- plete scrapers and one of the distal fragments are made on tertiary flake blanks (Fig. 36a). Two of the other complete end scrapers and the second distal fragment (Fig. 36b) are made on secondary flakes. The fourth complete end scraper is made on a small corticate pebble core (Fig. 36c). The two distal end scraper fragments and the specimen made on the pebble core have been extensively shaped. The other end scrapers have a relatively expediently manufactured appearance with only minimal marginal retouch. The two distal fragments were broken in use or during working-edge rejuvenation. Hafting could not be determined on these fragments; the four complete end scrapers were not hafted. The complete specimens have a mean length of $33.3 \mathrm{~mm}(\sigma=9.4, \mathrm{~min} .=22, \max .=42)$; the five specimens with maximum width and thickness dimensions have a mean width of $38.3 \mathrm{~mm}$ $(\sigma=18.6$, min. $=19.0$, max. $=62)$, and a mean thickness of $14.4 \mathrm{~mm}(\sigma=5.8, \min .=6.0, \max .=$ 20 ). Four of the six are fine-grained chert, one is chalcedony, and the remaining specimen is a coarse-grained Potter chert. Two of the finegrained chert end scrapers are made from locally available sources (Colors 3 and 37), one is a nonlocal chert (Color 42), and the last specimen is an indeterminate nonlocal chert (Color 56).

The single side scraper is a fragmentary tool. It was made on a primary flake (Fig. 36d). The tool has a single utilized edge, and the distal break appears to be use related. None of the metric measurements are complete. It is made of a finegrained chert that probably is available locally, although the particular color does not occur in our comparative samples (Color 55).

The six combination end and side scrapers consist of four complete tools, one proximal fragment, and one distal specimen. Three of the four complete specimens are made on tertiary flakes. The fourth complete scraper is made on a primary flake. The proximal fragment is made on a small pebble, and the distal specimen is a secondary flake fragment. Only two complete combination end and side scrapers are extensively shaped (Fig. 36e); the other specimens are only marginally retouched (Fig. $36 \mathrm{f}$ ). The proximal and distal fragments are use broken. Only one complete end and side scraper appears to have been hafted; it is $91 \mathrm{~mm}$ long, $37 \mathrm{~mm}$ wide, and $19 \mathrm{~mm}$ thick (see Fig. 36e). Haft wear is evident on $42 \mathrm{~mm}$ of the proximal end. The four complete combination end and side 

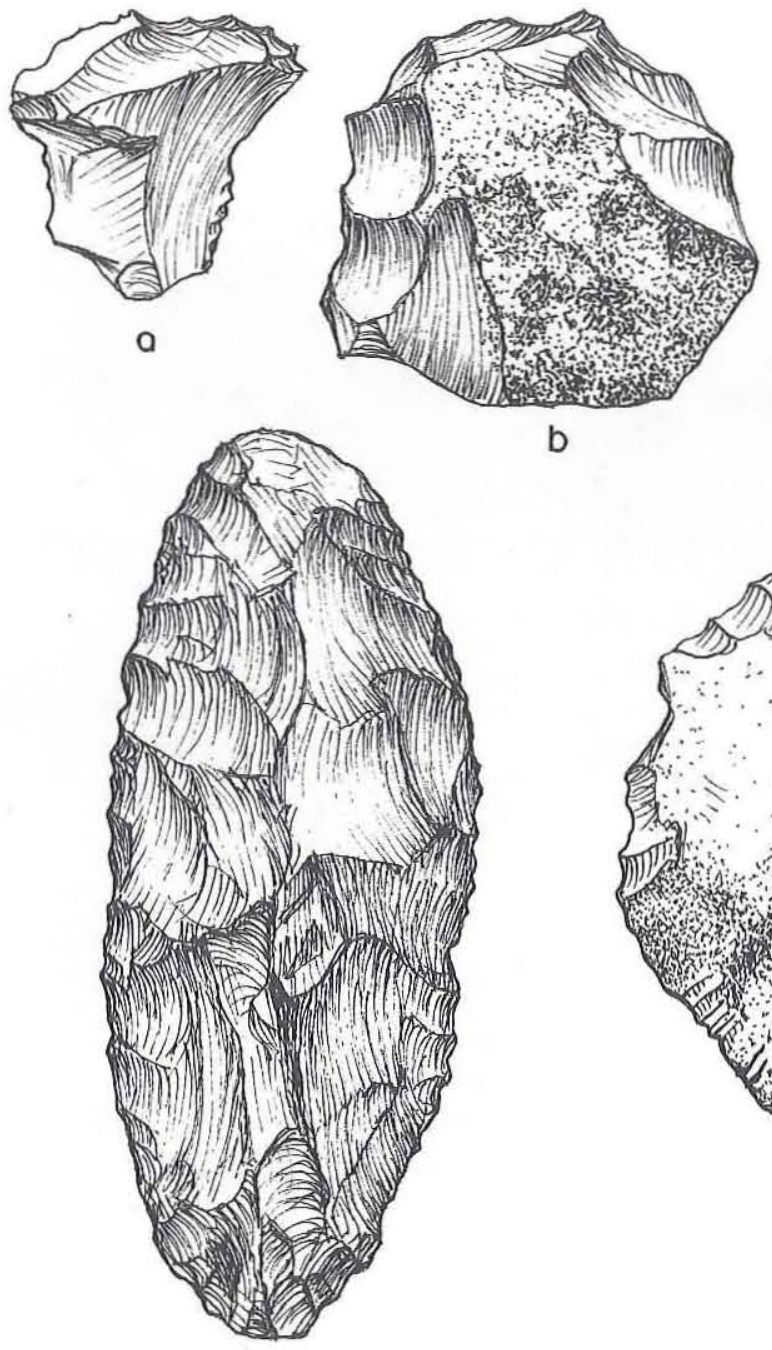

e
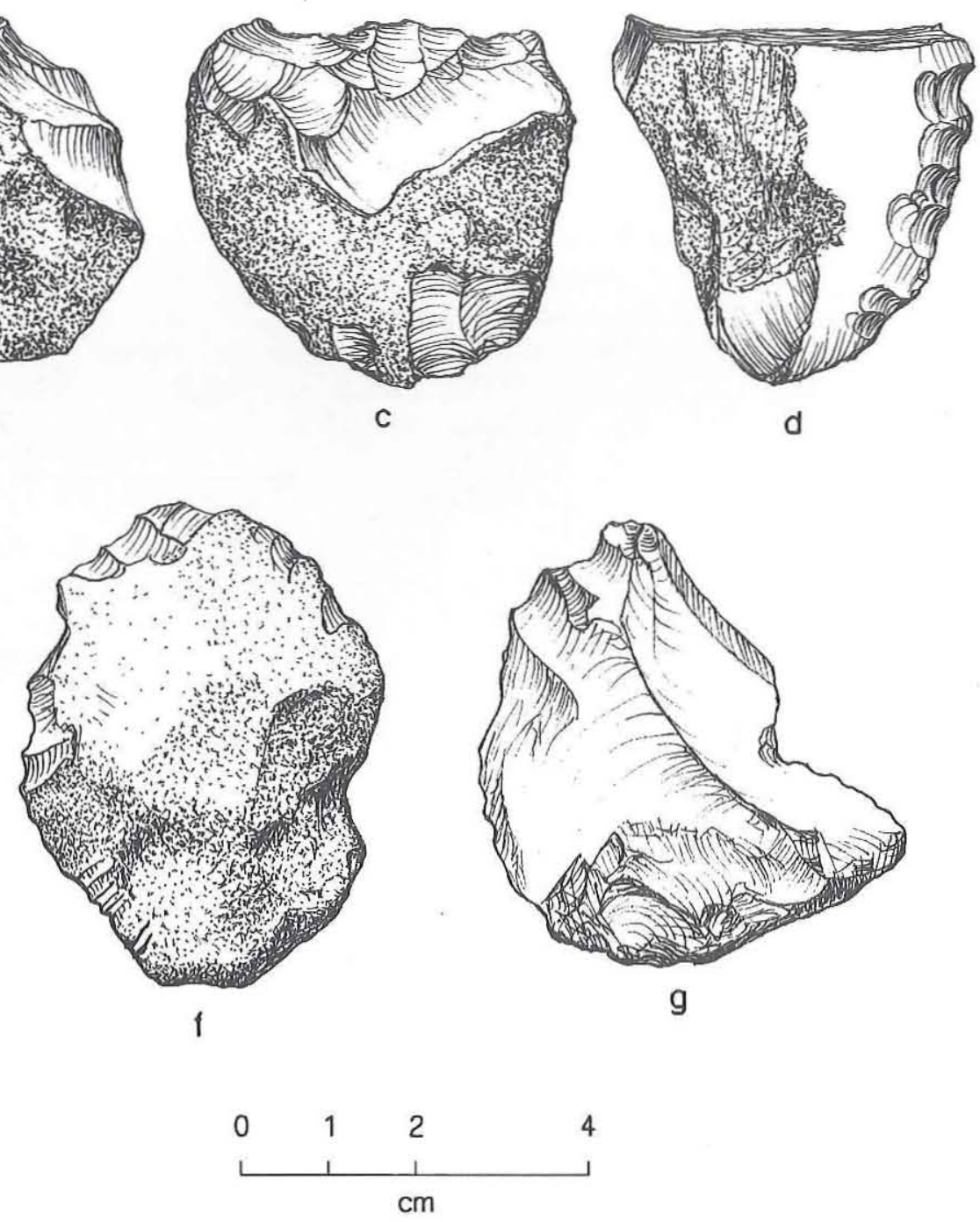

Figure 36. Scrapers, 41KT33. (a-c) end scrapers; (d) side scraper; (e-f) combination end and side scrapers; (g) combination scraper/graver.

scrapers have a mean length of $51.3 \mathrm{~mm}(\sigma=29.7$, min. $=22$, $\max .=91)$. Maximum width and thickness were recorded on all six items, they have a mean width of $33.0 \mathrm{~mm}(\sigma=6.7, \min .=22$, $\max$. $=40)$ and a mean thickness of $13.2 \mathrm{~mm}(\sigma=3.7$, $\min .=9, \max .=19)$. Four of the tools are of fine-grained chert, and two are of fine-grained quartzite. Of the fine-grained cherts, two are of locally represented colors (Colors 3 and 27), and one is an indeterminate but probably locally available chert (Color 55). The fourth tool is made of a nonlocal fine-grained chert (Color 41).

One of the two combination scraper/graver tools is complete; the other is a medial fragment with a broken proximal end and a missing graver tip. The complete tool has two retouched and utilized lateral edges adjacent to the rather blunt distal graving tip (Fig. 36g). The incomplete specimen has a single retouched and used lateral edge adjacent to the partial distal graver tip. The complete specimen is made on a complete secondary flake, and the medial fragment is made on a tertiary flake. The complete scraper/graver measures $55 \times 40 \times 15 \mathrm{~mm}$. None of the dimensions are complete on the fragmentary specimen. One of the tools is made of fine-grained quartzite; the other is of nonlocal fine-grained chert (Color 41).

The 13 unifacial tool edges cannot be assigned to morphofunctional categories. Twelve of the indeterminate edges represent flake blanks; the 
other is a tabular pebble fragment. Three of the 13 may have been primary flake blanks, 4 may have been secondary flake blanks, and 5 may represent tertiary flakes; the tabular pebble fragment also retains cortex. The cause of breakage could not be determined on any of these fragments. Nine of the specimens are of fine-grained chert, one is translucent silicified wood, another is Tecovas jasper, one is opalized caliche, and the final fragment is a black basaltic material with large white crystalline inclusions. Six of the fine-grained chert tool fragments are of locally available materials (Colors $3,4,9,8[\mathrm{n}=2]$, and 27), two are of nonlocal cherts (Colors 42 and 47), and the final specimen is of a probable nonlocal chert.

\section{CORES}

Forty cores and core fragments representing eight different raw material types were recovered (Table 28). Fine-grained chert cores dominate the collection $(n=26)$, followed by three Tecovas jasper and three fine-grained Potter chert specimens. Coarse-grained chert, fine-grained quartzite, and coarse-grained Potter chert cores are represented by two specimens each. The remaining two cores are chalcedony and opalized caliche.

Core fragments dominate the collection $(60 \%)$. Thirteen of the 16 complete cores are finegrained chert, 2 are Tecovas jasper, and 1 is finegrained Potter chert. The remaining cores of other raw material types are fragmentary. With the exception of two fine-grained chert blade cores (Fig. 37a), the remaining 38 (95\%) are flake cores (Fig. 37b). The fine-grained Potter chert cores have the highest mean number of flake removals, followed by the fine-grained chert, opalized caliche, and Tecovas jasper cores. The lowest mean number of flake removals occurs on the coarse-grained Potter chert cores. Only two raw material types, coarse-grained Potter chert and fine-grained chert, contain unidirectional cores. Bidirectional cores occur in a wider range of raw material types. The single opposed bidirectional core is a fine-grained chert specimen. Sixty-five percent of the cores are multidirectional; they are more frequent among the fine-grained chert, Tecovas jasper, and fine-grained Potter chert than other categories. Three cores, one each of fine-grained quartzite, fine-grained Potter chert, and coarsegrained Potter chert, are fire-cracked rocks subse-

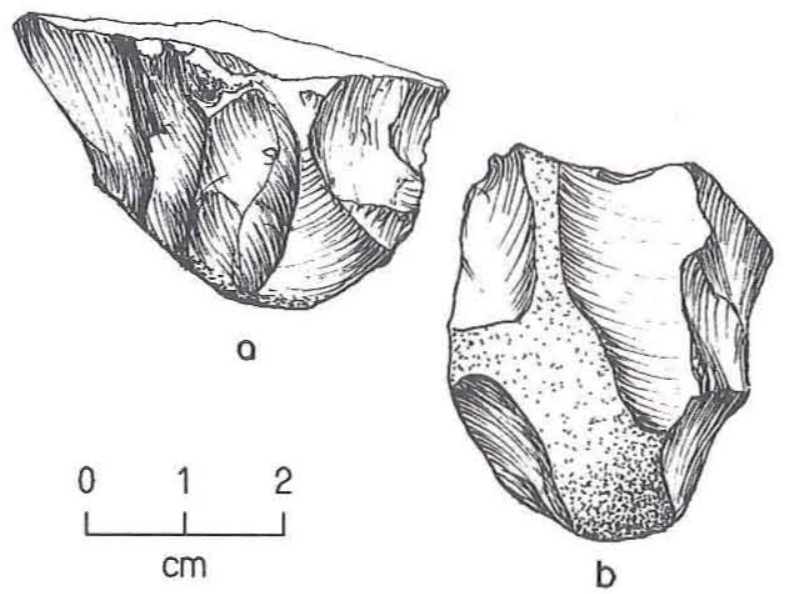

Figure 37. Cores, 41KT33.

quently utilized as cores and may represent heattreated cores, heat-treatment failures, or the impromptu use of heated materials. The metric attributes indicate that, with the exception of the opalized caliche and chalcedony specimens, finegrained chert and Tecovas jasper are the smallest cores. The fine-grained quartzite and fine-grained Potter chert cores are the largest specimens in the collection.

Of the 26 fine-grained chert cores, $22(85 \%)$ are of local origin: Colors $3(n=2) ; 4(n=3) ; 5$ $(\mathrm{n}=2) ; 6(\mathrm{n}=3) ; 7(\mathrm{n}=1) ; 8(\mathrm{n}=1) ; 12(\mathrm{n}=2)$; $24(\mathrm{n}=2) ; 28(\mathrm{n}=1) ; 31(\mathrm{n}=1) ; 37(\mathrm{n}=1)$; and $55(n=3)$. Only three $(11.5 \%)$ of the fine-grained chert cores are of nonlocal origin (Colors 43, 49, and 51), and the origin of one specimen could not be determined with certainty.

\section{EDGE-MODIFIED FLAKES}

A total of 137 edge-modified flakes was recovered (Table 29). The majority of these are fine-grained cherts (75\%), with Tecovas jasper and fine-grained Potter chert specimens being the next most frequent ( $5 \%$ each). Edge-modified flakes of other raw materials are infrequent. The majority of the fine-grained chert tools are complete specimens (64\%). Complete edge-modified flakes are also abundant among the Tecovas jasper and silicified caliche specimens, although sample sizes are extremely small. The breakdown of flake types by raw material indicates that complete flakes were not necessarily selected for use as expediency 
tools. The majority of the edge-modified flakes are chips (medial and distal fragments) and proximal specimens. Secondary and tertiary flakes dominate the edge-modified specimens. The two grades of Potter chert, and the fine-grained chert have higher percentages of tertiary edge-modified flakes. Secondary specimens dominate the other raw material categories. Primary flakes are most frequent among the fine-grained chert specimens. Although two fine-grained chert specimens do occur in the smallest size class, the majority of the edgemodified flakes made of fine-grained materials are found in the 11-20-mm and 21-30-mm size classes. The fine-grained cherts, quartzites, and Potter chert materials also have sizable numbers of edge-modified flakes greater than $30 \mathrm{~mm}$. Among raw material types with considerable sample sizes, expediency tools with single working edges greatly outnumber specimens with two utilized edges. Edges utilized in scraping tasks are the most frequent $(80 \%)$, followed by working edges used in sawing/cutting tasks (12\%). Working edges used in the performance of other multiple tasks (i.e., sawing/scraping, sawing/engraving, and sawing/ scraping/engraving) are infrequent, occurring only in the fine- and coarse-grained chert and fine-grained Potter chert material types. The small sample of edge-modified flakes in most material types does not allow the evaluation of differential use of certain materials. It is evident, however, that the fine-grained materials such as fine-grained chert, Tecovas jasper, and fine-grained Potter chert have a higher likelihood of being used as expediency tools than the coarse-grained materials.

Of the 102 fine-grained chert specimens, 50 are of local origin, 48 are nonlocal, and 4 are indeterminate origin. Of the 50 local specimens, Colors $6(n=6), 5(n=5), 14(n=4)$, and 27 $(n=4)$ occur in the highest frequency. Five locally available colors not represented in our comparative collections were also recovered. Among the nonlocal cherts, Colors $41(n=13)$ and $51(n=12)$ are the most numerous. Seven specimens believed to be nonlocal in origin are not matched by any colors in the nonlocal comparative collections.

\section{UNMODIFIED DEBITAGE}

Table 30 presents the unmodified lithic debitage attributes by raw material type. Of the 1,827 specimens, $59 \%$ are fine-grained chert, $22 \%$ are fine-grained Potter chert, and $6 \%$ are finegrained quartzite. Coarse-grained varieties of these raw material types occur in lower frequencies. Of the other material types, Tecovas jasper is the most frequent, followed by opalized caliche, chalcedony, silicified caliche, Alibates agate, and silicified wood. A single obsidian flake was also recovered from the site; it was submitted for $\mathrm{x}$-ray florescence trace element analysis but was lost by the laboratory before the analysis could be done.

Chips represent the most frequent flake type category in each of the raw material types with sufficient debitage sample sizes. Fine- and coarse-grained quartzites have significantly higher percentages of chips than the other raw material types ( $56 \%$ and $55 \%$, respectively). The percentage of chips in the fine- and coarse-grained cherts (39\% and 38\%, respectively) and fine- and coarsegrained Potter cherts ( $40 \%$ and $34 \%$, respectively) are relatively similar. The higher percentages of chips in the quartzites may be due to the lesscrystalline and more-grainy structure of the quartzites compared to the other material types. Among the less frequently occurring material types, complete flakes tend to outnumber or be similar in frequency to chips. Chunks are most frequent among the coarse-grained Potter cherts and coarsegrained quartzites.

Decorticate debitage is most frequent in the fine-grained chert and fine-grained quartzite categories ( $58 \%$ each), followed by coarse-grained chert $(51 \%)$ and fine-grained Potter chert $(50 \%)$. Significantly lower percentages of decorticate debitage are found in the coarse-grained Potter chert $(41 \%)$ and coarse-grained quartzite $(24 \%)$ categories. The lowest percentage of entirely cortex-covered debitage occurs in the fine- $(6 \%)$ and coarse-grained ( $8 \%$ ) cherts; the two grades of quartzite (18\% each) and the fine-grained Potter chert (15\%) have similar percentages, while coarsegrained Potter chert has a significantly higher occurrence of entirely corticate debitage (23\%). The breakdown of cortex percentages by raw material type tends to follow similar trends among the chunks.

The examination of platform cortex on complete flakes and proximal fragments indicates that decorticate platforms are most frequent among the fine-grained quartzite $(80 \%)$ and the finegrained chert $(73 \%)$. The coarse-grained varieties of these materials have somewhat lower percentages 


\begin{tabular}{|c|c|c|c|c|c|c|c|c|c|}
\hline & & CORE ATTRIBU & $\begin{array}{r}\text { TABLE } \\
\text { TES BY RAW }\end{array}$ & $\begin{array}{l}28 \\
\text { MATERIAL TY }\end{array}$ & $\mathrm{PE}, 41 \mathrm{KT} 33$ & & & & \\
\hline Attributes & $\begin{array}{c}\text { Fine-Grained } \\
\text { Chert }\end{array}$ & $\begin{array}{l}\text { Coarse-Grained } \\
\text { Chert }\end{array}$ & $\begin{array}{c}\text { Fine-Grained } \\
\text { Quartzite }\end{array}$ & $\begin{array}{c}\text { Fine-Grained } \\
\text { Potter Chert }\end{array}$ & \begin{tabular}{|c|}
$\begin{array}{c}\text { Coarse-Grained } \\
\text { Potter Chert }\end{array}$ \\
\end{tabular} & $\begin{array}{l}\text { Opalized } \\
\text { Caliche }\end{array}$ & Chalcedony & \begin{tabular}{|l} 
Tecovas \\
Jasper
\end{tabular} & Totals \\
\hline $\begin{array}{l}\text { Core Type } \\
\text { Flake } \\
\text { Blade } \\
\text { Totals: } \\
\end{array}$ & $\begin{array}{r}24 \\
\underline{2} \\
26 \\
\end{array}$ & $\begin{array}{l}2 \\
\overline{2}\end{array}$ & $\begin{array}{l}2 \\
\overline{2}\end{array}$ & $\begin{array}{l}3 \\
= \\
3\end{array}$ & $\begin{array}{l}2 \\
\overline{2} \\
\end{array}$ & $\begin{array}{l}1 \\
\overline{1}\end{array}$ & $\begin{array}{l}1 \\
= \\
1\end{array}$ & $\begin{array}{l}3 \\
\overline{3}\end{array}$ & $\begin{array}{r}38 \\
\underline{2} \\
40 \\
\end{array}$ \\
\hline $\begin{array}{l}\text { Completeness } \\
\text { Complete } \\
\text { Fragment } \\
\text { Totals: } \\
\end{array}$ & $\begin{array}{l}13 \\
\underline{13} \\
26 \\
\end{array}$ & $\frac{\overline{2}}{2}$ & $\frac{-}{2}$ & $\begin{array}{l}1 \\
\frac{2}{3} \\
\end{array}$ & - $\frac{-}{2}$ & $\begin{array}{l}- \\
1 \\
1\end{array}$ & $\begin{array}{l}- \\
1 \\
\end{array}$ & $\begin{array}{l}2 \\
\frac{1}{3} \\
\end{array}$ & $\begin{array}{l}16 \\
\underline{24} \\
40\end{array}$ \\
\hline $\begin{array}{l}\text { Number of Removals } \\
\text { Mean } \\
\text { Standard Deviation } \\
\text { Minimum } \\
\text { Maximum }\end{array}$ & $\begin{array}{c}7.1 \\
3.2 \\
1 \\
15 \\
\end{array}$ & $\begin{array}{c}5.0 \\
1.4 \\
4 \\
6 \\
\end{array}$ & $\begin{array}{c}3.0 \\
0.0 \\
3 \\
3 \\
\end{array}$ & $\begin{array}{c}7.7 \\
6.0 \\
2 \\
14 \\
\end{array}$ & $\begin{array}{c}1.5 \\
0.7 \\
1 \\
2 \\
\end{array}$ & 7.0 & 5.0 & $\begin{array}{c}7.0 \\
1.7 \\
5 \\
8 \\
\end{array}$ & \\
\hline $\begin{array}{l}\text { Removal Direction } \\
\text { Unidirectional } \\
\text { Bidirectional } \\
\text { Opposed Bidirectional } \\
\text { Multidirectional } \\
\text { Totals: } \\
\end{array}$ & $\begin{array}{r}5 \\
3 \\
1 \\
17 \\
26 \\
\end{array}$ & $\begin{array}{l}\overline{1} \\
\overline{1} \\
\frac{1}{2} \\
\end{array}$ & $\begin{array}{l}\overline{1} \\
\overline{1} \\
\frac{1}{2} \\
\end{array}$ & $\begin{array}{l}\overline{1} \\
\overline{2} \\
\frac{2}{3} \\
\end{array}$ & $\begin{array}{l}2 \\
- \\
- \\
= \\
2\end{array}$ & $\begin{array}{l}- \\
- \\
\overline{1} \\
1 \\
\end{array}$ & $\begin{array}{l}- \\
- \\
\overline{1} \\
1 \\
1\end{array}$ & $\begin{array}{l}- \\
\overline{-} \\
\overline{3}\end{array}$ & $\begin{array}{r}7 \\
6 \\
1 \\
\underline{26} \\
40 \\
\end{array}$ \\
\hline $\begin{array}{l}\text { Reuse } \\
\text { Present } \\
\text { Absent } \\
\text { Indeterminate } \\
\text { Totals: }\end{array}$ & $\begin{array}{r}- \\
13 \\
\frac{13}{26}\end{array}$ & $\begin{array}{l}- \\
\overline{2} \\
\overline{2}\end{array}$ & $\begin{array}{l}1 \\
1 \\
\overline{2}\end{array}$ & $\begin{array}{l}1 \\
2 \\
= \\
3\end{array}$ & $\begin{array}{l}\frac{1}{1} \\
\frac{1}{2}\end{array}$ & $\begin{array}{l}\overline{1} \\
\overline{\overline{1}}\end{array}$ & $\begin{array}{l}\overline{1} \\
\overline{1}\end{array}$ & $\begin{array}{l}\overline{3} \\
\overline{3}\end{array}$ & $\begin{array}{r}3 \\
23 \\
\frac{14}{40}\end{array}$ \\
\hline
\end{tabular}


Table 28 , continued

\begin{tabular}{|c|c|c|c|c|c|c|c|c|c|}
\hline Attributes & $\begin{array}{c}\text { Fine-Grained } \\
\text { Chert }\end{array}$ & $\begin{array}{l}\text { Coarse-Grained } \\
\text { Chert }\end{array}$ & $\begin{array}{c}\text { Fine-Grained } \\
\text { Quartzite }\end{array}$ & $\begin{array}{c}\text { Fine-Grained } \\
\text { Potter Chert }\end{array}$ & $\begin{array}{c}\text { Coarse-Grained } \\
\text { Potter Chert }\end{array}$ & $\begin{array}{l}\text { Opalized } \\
\text { Caliche }\end{array}$ & Chalcedony & $\begin{array}{l}\text { Tecovas } \\
\text { Jasper }\end{array}$ & Totals \\
\hline $\begin{array}{l}\text { Maximum Length } \\
\text { Mean } \\
\text { Standard Deviation } \\
\text { Minimum } \\
\text { Maximum }\end{array}$ & $\begin{array}{c}33.2 \\
9.4 \\
19 \\
54\end{array}$ & $\begin{array}{c}39.5 \\
31.8 \\
17 \\
62\end{array}$ & $\begin{array}{c}86.5 \\
16.3 \\
75 \\
98\end{array}$ & $\begin{array}{c}59.7 \\
22.2 \\
35 \\
61\end{array}$ & $\begin{array}{c}41.0 \\
7.1 \\
36 \\
46\end{array}$ & 19.0 & 31.0 & $\begin{array}{c}36.3 \\
10.6 \\
32 \\
44\end{array}$ & \\
\hline $\begin{array}{l}\text { Maximum Width } \\
\text { Mean } \\
\text { Standard Deviation } \\
\text { Minimum } \\
\text { Maximum }\end{array}$ & $\begin{array}{c}26.8 \\
7.0 \\
17 \\
42\end{array}$ & $\begin{array}{c}37.0 \\
32.5 \\
14 \\
60\end{array}$ & $\begin{array}{c}53.0 \\
12.8 \\
44 \\
62 \\
\end{array}$ & $\begin{array}{c}48.3 \\
16.3 \\
30 \\
61 \\
\end{array}$ & $\begin{array}{c}36.0 \\
5.7 \\
32 \\
40 \\
\end{array}$ & 15.0 & 20.0 & $\begin{array}{c}28.7 \\
10.6 \\
19 \\
40\end{array}$ & \\
\hline $\begin{array}{l}\text { Maximum Thicknes } \\
\text { Mean } \\
\text { Standard Deviation } \\
\text { Minimum } \\
\text { Maximum }\end{array}$ & $\begin{array}{c}18.8 \\
5.4 \\
11 \\
31\end{array}$ & $\begin{array}{c}19.0 \\
14.1 \\
9 \\
29\end{array}$ & $\begin{array}{c}43.0 \\
4.2 \\
40 \\
46\end{array}$ & $\begin{array}{c}38.0 \\
19.1 \\
21 \\
59\end{array}$ & $\begin{array}{c}26.5 \\
4.9 \\
23 \\
30\end{array}$ & 14.0 & 15.0 & $\begin{array}{c}24.0 \\
9.8 \\
13 \\
32\end{array}$ & \\
\hline
\end{tabular}




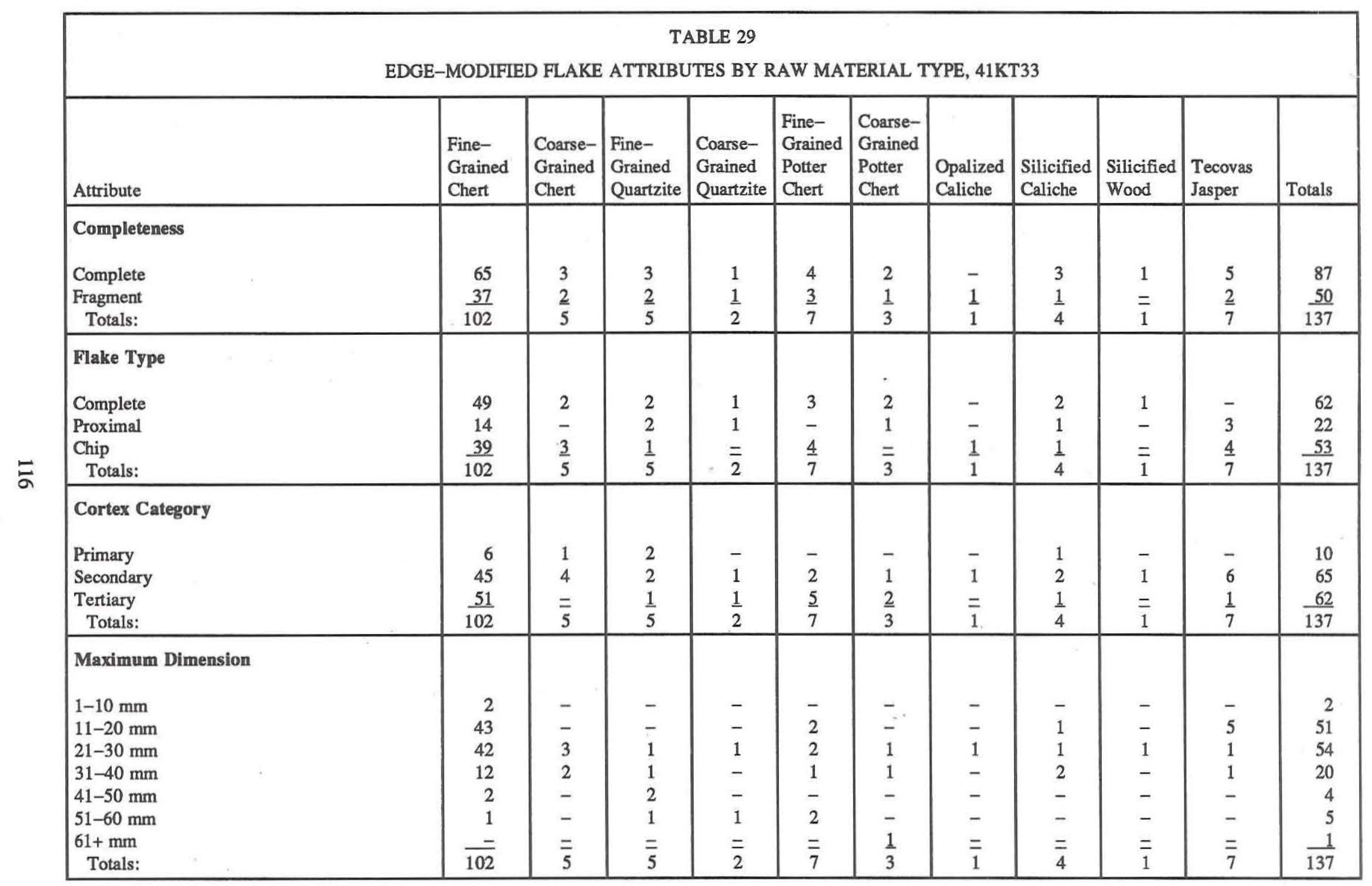


Table 29, continued

\begin{tabular}{|c|c|c|c|c|c|c|c|c|c|c|c|}
\hline Attribute & $\begin{array}{l}\text { Fine- } \\
\text { Grained } \\
\text { Chert }\end{array}$ & $\begin{array}{l}\text { Coarse- } \\
\text { Grained } \\
\text { Chert } \\
\end{array}$ & $\begin{array}{l}\text { Fine- } \\
\text { Grained } \\
\text { Quartzite }\end{array}$ & $\begin{array}{l}\text { Coarse- } \\
\text { Grained } \\
\text { Quartzite }\end{array}$ & $\begin{array}{l}\text { Fine- } \\
\text { Grained } \\
\text { Potter } \\
\text { Chert } \\
\end{array}$ & $\begin{array}{l}\text { Coarse- } \\
\text { Grained } \\
\text { Potter } \\
\text { Chert } \\
\end{array}$ & $\begin{array}{l}\text { Opalized } \\
\text { Caliche }\end{array}$ & \begin{tabular}{|l} 
Silicified \\
Caliche
\end{tabular} & $\begin{array}{l}\text { Silicified } \\
\text { Wood }\end{array}$ & $\begin{array}{l}\text { Tecovas } \\
\text { Jasper }\end{array}$ & Totals \\
\hline \multicolumn{12}{|l|}{ Number of Modified Edges } \\
\hline One & 91 & 4 & 5 & 1 & 4 & 2 & 1 & 1 & 1 & 7 & 117 \\
\hline Two & 11 & $\underline{1}$ & $=$ & $\underline{1}$ & $\underline{3}$ & 1 & $=$ & $=$ & $=$ & $=$ & 17 \\
\hline Totals: & 102 & 5 & 5 & 2 & 7 & 3 & 1 & 1 & 1 & 7 & 134 \\
\hline \multicolumn{12}{|l|}{ Inferred Use } \\
\hline Sawing/Cutting & 10 & 1 & 2 & 1 & 1 & 1 & - & - & - & 1 & 17 \\
\hline Scraping & 85 & 3 & 3 & 1 & 4 & 2 & 1 & 4 & 1 & 6 & 110 \\
\hline Engraving & 2 & - & - & - & - & - & - & - & - & - & 2 \\
\hline Sawing/Scraping & 1 & 1 & - & - & 1 & - & - & - & - & - & 3 \\
\hline Sawing/Engraving & 4 & - & - & - & - & - & - & - & - & - & 4 \\
\hline Sawing/Scraping/Engraving & $=$ & $=$ & $=$ & $=$ & 1 & $=$ & $=$ & $=$ & $=$ & $=$ & 1 \\
\hline Totals: & 102 & 5 & 5 & 2 & 7 & 3 & 1 & 4 & 1 & 7 & 137 \\
\hline
\end{tabular}




\begin{tabular}{|c|c|c|c|c|c|c|c|c|c|c|c|c|c|c|}
\hline \multicolumn{15}{|c|}{$\begin{array}{l}\text { TABLE } 30 \\
\text { UNMODIFIED LITHIC DEBITAGE ATTRIBUTES BY RAW MATERIAL TYPE, 41KT33 }\end{array}$} \\
\hline Attributes & \begin{tabular}{l|} 
Fine- \\
Grained \\
Chert
\end{tabular} & $\begin{array}{l}\text { Coarse- } \\
\text { Grained } \\
\text { Chert }\end{array}$ & $\begin{array}{l}\text { Fine- } \\
\text { Grained } \\
\text { Quartzite }\end{array}$ & $\begin{array}{l}\text { Coarse- } \\
\text { Grained } \\
\text { Quartzite } \\
\end{array}$ & \begin{tabular}{|l|} 
Fine- \\
Grained \\
Potter \\
Chert \\
\end{tabular} & \begin{tabular}{|l} 
Coarse- \\
Grained \\
Potter \\
Chert \\
\end{tabular} & $\begin{array}{l}\text { Opalized } \\
\text { Caliche } \\
\end{array}$ & \begin{tabular}{|l} 
Silicified \\
Caliche
\end{tabular} & \begin{tabular}{|l} 
Silicified \\
Wood
\end{tabular} & Chalcedony & \begin{tabular}{|l} 
Tecovas \\
Jasper
\end{tabular} & $\begin{array}{l}\text { Alibates } \\
\text { Agate }\end{array}$ & Obsidian & Totals \\
\hline \multicolumn{15}{|l|}{$\begin{array}{l}\text { Flake } \\
\text { Type }\end{array}$} \\
\hline Complete & 358 & 23 & 27 & 5 & 127 & 24 & 6 & 5 & - & 4 & 13 & 3 & - & 595 \\
\hline Proximal & 181 & 14 & 13 & 1 & 72 & 10 & 2 & - & - & - & 3 & 1 & - & 297 \\
\hline Chip & 414 & 28 & 65 & 11 & 163 & 27 & 2 & 2 & 1 & 5 & 11 & - & 1 & 730 \\
\hline Chunk & 118 & 9 & 12 & 3 & 43 & 18 & 1 & $=$ & $=$ & 1 & $=$ & $=$ & $=$ & 205 \\
\hline Totals: & 1071 & 74 & 117 & 20 & $\overline{405}$ & 79 & $\overline{11}$ & $\overline{7}$ & $\overline{1}$ & 10 & $\overline{27}$ & $\overline{4}$ & $\overline{1}$ & 1827 \\
\hline \multicolumn{15}{|l|}{$\begin{array}{l}\text { Dorsal } \\
\text { Cortex } \\
\text { Percent }\end{array}$} \\
\hline 0 & 548 & 33 & 61 & 4 & 196 & 25 & 6 & 5 & 1 & 3 & 15 & 1 & 1 & 899 \\
\hline $1-50$ & 250 & 18 & 17 & 8 & 79 & 13 & 2 & 2 & - & 3 & 9 & 1 & - & 402 \\
\hline $51-99$ & 103 & 9 & 8 & 2 & 32 & 9 & 2 & - & - & 2 & 2 & 2 & - & 171 \\
\hline 100 & 52 & 5 & 19 & $\underline{3}$ & 55 & 14 & $=$ & $=$ & $=$ & 1 & 1 & $=$ & $=$ & 150 \\
\hline Totals: & $\overline{953}$ & $\overline{65}$ & $\overline{105}$ & $\overline{17}$ & $\overline{362}$ & $\overline{61}$ & $\overline{10}$ & $\overline{7}$ & $\overline{1}$ & 9 & 27 & $\overline{4}$ & $\overline{1}$ & 1622 \\
\hline \multicolumn{15}{|l|}{$\begin{array}{l}\text { Chunk } \\
\text { Cortex }\end{array}$} \\
\hline Present & 76 & 5 & 8 & 2 & 27 & 13 & - & - & $=$ & 1 & - & - & - & 132 \\
\hline Absent & 42 & 4 & 4 & 1 & $\underline{16}$ & $\underline{5}$ & 1 & $=$ & $=$ & $=$ & $=$ & $=$ & $=$ & 73 \\
\hline Totals: & $\overline{118}$ & $\overline{9}$ & $\overline{12}$ & 3 & $\overline{43}$ & $\overline{18}$ & $\overline{1}$ & 0 & $\overline{0}$ & $\overline{1}$ & $\overline{0}$ & $\overline{0}$ & $\overline{0}$ & 205 \\
\hline \multicolumn{15}{|l|}{$\begin{array}{l}\text { Platform } \\
\text { Cortex }\end{array}$} \\
\hline Present & 144 & 13 & 8 & 2 & 78 & 18 & - & - & - & 1 & 6 & 1 & - & 271 \\
\hline Absent & $\underline{395}$ & $\underline{24}$ & $\underline{32}$ & 4 & $\underline{121}$ & $\underline{16}$ & $\underline{8}$ & $\underline{5}$ & $=$ & $\underline{3}$ & 10 & $\underline{3}$ & $=$ & $\underline{621}$ \\
\hline Totals: & 539 & $\overline{37}$ & 40 & 6 & 199 & 34 & 8 & 5 & $\overline{0}$ & $\overline{4}$ & 16 & $\overline{4}$ & $\overline{0}$ & $\overline{892}$ \\
\hline
\end{tabular}




\begin{tabular}{|c|c|c|c|c|c|c|c|c|c|c|c|c|c|c|}
\hline Attributes & \begin{tabular}{|l|}
$\begin{array}{l}\text { Fine- } \\
\text { Grained } \\
\text { Chert }\end{array}$ \\
\end{tabular} & \begin{tabular}{|l} 
Coarse- \\
Grained \\
Chert \\
\end{tabular} & $\begin{array}{l}\text { Fine- } \\
\text { Grained } \\
\text { Quartzite } \\
\end{array}$ & $\begin{array}{l}\text { Coarse- } \\
\text { Grained } \\
\text { Quartzite } \\
\end{array}$ & \begin{tabular}{|l|} 
Fine- \\
Grained \\
Potter \\
Chert \\
\end{tabular} & \begin{tabular}{|l} 
Coarse- \\
Grained \\
Potter \\
Chert \\
\end{tabular} & $\begin{array}{l}\text { Opalized } \\
\text { Caliche }\end{array}$ & \begin{tabular}{|l} 
Silicified \\
Caliche
\end{tabular} & $\begin{array}{l}\text { Silicified } \\
\text { Wood }\end{array}$ & Chalcedony & $\begin{array}{l}\text { Tecovas } \\
\text { Jasper }\end{array}$ & \begin{tabular}{|l} 
Alibates \\
Agate
\end{tabular} & Obsidian & Totals \\
\hline \multicolumn{15}{|l|}{$\begin{array}{l}\text { Platform } \\
\text { Grinding }\end{array}$} \\
\hline Present & 107 & 5 & 6 & - & 40 & 1 & - & - & - & 1 & 6 & - & - & 166 \\
\hline Absent & 432 & $\underline{32}$ & $\underline{34}$ & $\underline{6}$ & $\underline{159}$ & $\underline{33}$ & $\underline{8}$ & $\underline{5}$ & $=$ & $\underline{3}$ & $\underline{10}$ & 4 & $=$ & $\underline{726}$ \\
\hline Totals: & 539 & 37 & 40 & 6 & 199 & 34 & 8 & 5 & 0 & 4 & 16 & 4 & 0 & 892 \\
\hline \multicolumn{15}{|l|}{$\begin{array}{l}\text { Platform } \\
\text { Faceting }\end{array}$} \\
\hline 1 facet & 318 & 28 & 25 & 4 & 136 & 28 & 3 & 2 & - & 3 & 9 & 2 & - & 558 \\
\hline 2 facets & 102 & 7 & 11 & 2 & 43 & 5 & 4 & 3 & - & 1 & 3 & 2 & - & 183 \\
\hline$\geq 3$ facets & $\underline{119}$ & 2 & $\underline{4}$ & $=$ & 20 & 1 & 1 & $=$ & $=$ & $=$ & 4 & $=$ & $=$ & $\underline{151}$ \\
\hline Totals: & 539 & 37 & 40 & 6 & 199 & 34 & 8 & 5 & 0 & 4 & 16 & 4 & 0 & 892 \\
\hline \multicolumn{15}{|l|}{$\begin{array}{l}\text { Maximum } \\
\text { Dimension }\end{array}$} \\
\hline $1-10 \mathrm{~mm}$ & 99 & 4 & 8 & 1 & 22 & 2 & - & - & - & 1 & 1 & - & - & 138 \\
\hline $11-20 \mathrm{~mm}$ & 810 & 50 & 76 & 14 & 267 & 42 & 10 & 7 & 1 & 9 & 24 & 2 & 1 & 1313 \\
\hline $21-30 \mathrm{~mm}$ & 141 & 16 & 22 & 2 & 68 & 14 & 1 & - & - & - & 1 & 2 & - & 267 \\
\hline $31-40 \mathrm{~mm}$ & 20 & 4 & 5 & 1 & 34 & 10 & - & - & - & - & 1 & - & - & 75 \\
\hline $41-50 \mathrm{~mm}$ & 1 & - & 5 & - & 6 & 5 & - & - & - & - & - & - & - & 17 \\
\hline $51-60 \mathrm{~mm}$ & - & - & 1 & - & 2 & 3 & - & - & - & - & - & - & - & 6 \\
\hline $60+\mathrm{mm}$ & $=$ & $=$ & $=$ & 2 & 6 & 3 & $=$ & $=$ & $=$ & $=$ & $=$ & $=$ & $=$ & 11 \\
\hline Totals: & $\mid 1071$ & 74 & 117 & 20 & 405 & 79 & 11 & 7 & 1 & 10 & 27 & 4 & 1 & 1827 \\
\hline
\end{tabular}


of decorticate platforms $(67 \%$ and $65 \%$, respectively), although the lowest percentage is among the coarse-grained Potter chert debitage (47\%). Debitage with decorticate platforms is common among the less frequent material types.

Among the raw material types with large samples, platform grinding is most frequent in the fine-grained chert and fine-grained Potter chert debitage (20\% each). Ground platforms are less frequent but similar in relative frequency in the coarse-grained chert (14\%) and fine-grained quartzite $(15 \%)$ specimens. With the exception of the Tecovas jasper debitage (38\%), platform grinding occurs in low frequencies or is entirely absent among the other raw materials.

Single-facet striking platforms are most frequent among the coarse-grained Potter chert $(82 \%)$ and coarse-grained chert $(76 \%)$ complete flakes and proximal fragments. Somewhat lower percentages occur among the fine-grained Potter chert $(68 \%)$ and coarse-grained quartzite $(67 \%)$ debitage, while the lowest percentages of singlefacet platforms are found among the fine-grained quartzite $(63 \%)$ and fine-grained chert $(59 \%)$. Platforms with three or more facets on complete flakes and proximal fragments are most frequent in the fine-grained chert debitage ( $22 \%$ ), followed by the fine-grained quartzite and fine-grained Potter chert specimens $(10 \%$ each). The coarse-grained raw materials, in general, have relatively low percentages of flakes and proximal fragments with three or more striking platform facets. Among the raw material types with low sample sizes, the Tecovas jasper debitage has the highest percentage $(25 \%)$ of specimens with three or more facets.

The majority of the debitage of all the material types measures between 11-20 mm in maximum dimension. In addition, among the material types with large debitage samples, the fine-grained chert has the largest percentage of flakes in the smallest size category followed by the other finegrained materials. Coarse- and fine-grained Potter cherts have the largest percentages of debitage greater than $30 \mathrm{~mm}$, followed by the fine-grained quartzite debitage. These trends in the size distribution of the debitage among the raw material types with large samples appear to parallel the size range of naturally occurring raw materials in the project area (see Chapter 3, Raw Materials).

Of the 1,071 fine-grained chert unmodified debitage, $60 \%$ are of local origin, $34 \%$ are of nonlocal origin, and the origin of $6 \%$ cannot be determined. Among the local cherts, Colors 5 $(n=85), 6(n=53)$, and $42(n=47)$ occur in greatest frequency. In addition, 64 locally available specimens not represented in our local comparative collections also were recovered. Among the nonlocal specimens, Colors $51(n=85), 41(n=68)$, and $43(n=65)$ occur in greatest frequency. Fortytwo (4\%) pieces of fine-grained chert debitage do not match colors represented in our regional nonlocal chert collections; nevertheless, these are believed to be from nonlocal sources.

\section{Ground and Battered Stone Artifacts}

Forty-two ground and battered stone artifacts were recovered. One is from the surface, another was recovered in a sample unit, and the remaining 40 are from the excavation block; 12 are manos and mano fragments, 26 are metates and metate fragments, and 4 are hammerstones. Fifteen of the 38 ground stones are associated with Feature 12, and two are associated with Feature 11. Table 31 presents the ground stone artifact attributes by morphofunctional category.

\section{MANOS}

Of the 12 manos, 8 are quartzite and 4 are sandstone. Only three are complete; one is quartzite (Fig. 38a), and the other two are sandstone. A pollen wash from the complete sandstone mano from EU 4 (Fig. 38b) was analyzed, but the only pollen identified represents modern grass, and its presence is considered to be the result of contamination (see Appendix E).

Only six specimens are complete enough to record their shape; four are oval, one is rounded, and one is rectangular. Five specimens have biconvex transverse cross sections; all are quartzite. Three other sandstone mano fragments have biconvex cross sections with medial ridges, and a single sandstone mano has a planoconvex cross section. The remaining three specimens are too fragmentary to determine their cross sections. Seven of the 12 manos have bifacial use-wear; 4 are quartzite, and 3 are sandstone. Use-wear is unifacially distributed on the remaining four quartzite and one sandstone specimens. Pecking resulting from workingsurface rejuvenation is unifacially distributed on two manos, one of fine-grained quartzite and one 


\begin{tabular}{|c|c|c|c|c|}
\hline \multicolumn{5}{|c|}{$\begin{array}{c}\text { TABLE } 31 \\
\text { GROUND STONE ATTRIBUTES, 41KT33 }\end{array}$} \\
\hline Attribute & Category & Manos & Metates & Totals \\
\hline Raw Material & $\begin{array}{l}\text { Sandstone } \\
\text { Quartzite } \\
\text { Totals: }\end{array}$ & $\begin{array}{r}4 \\
\frac{8}{12} \\
\end{array}$ & $\frac{26}{26}$ & $\begin{array}{r}30 \\
\frac{8}{38} \\
\end{array}$ \\
\hline Completeness & $\begin{array}{l}\text { Complete } \\
\text { Fragment } \\
\text { Totals: }\end{array}$ & $\begin{array}{r}3 \\
\frac{9}{12}\end{array}$ & $\begin{array}{r}2 \\
24 \\
26\end{array}$ & $\begin{array}{r}5 \\
\frac{33}{38} \\
\end{array}$ \\
\hline Shape & \begin{tabular}{l} 
Rounded \\
Oval \\
Angular \\
Rectangular \\
Indeterminate \\
\multicolumn{1}{c}{ Totals: } \\
\end{tabular} & $\begin{array}{c}1 \\
4 \\
- \\
1 \\
\frac{6}{12} \\
\end{array}$ & $\begin{array}{r}1 \\
1 \\
9 \\
15 \\
\overline{26} \\
\end{array}$ & $\begin{array}{r}2 \\
5 \\
9 \\
16 \\
6 \\
38 \\
\end{array}$ \\
\hline Transverse Cross Section & $\begin{array}{l}\text { Biconvex } \\
\text { Biconcave } \\
\text { Planoconvex } \\
\text { Planoconcave } \\
\text { Beveled } \\
\text { Tabular } \\
\text { Biconvex with medial ridge } \\
\text { Indeterminate } \\
\quad \text { Totals: }\end{array}$ & $\begin{array}{l}5 \\
- \\
1 \\
- \\
- \\
- \\
3 \\
\frac{3}{12}\end{array}$ & $\begin{array}{r}\overline{3} \\
\overline{7} \\
5 \\
11 \\
- \\
\overline{-} \\
26\end{array}$ & $\begin{array}{r}5 \\
3 \\
1 \\
7 \\
5 \\
11 \\
3 \\
3 \\
38 \\
\end{array}$ \\
\hline Use-wear & $\begin{array}{l}\text { Unifacial } \\
\text { Bifacial } \\
\text { Totals: }\end{array}$ & $\begin{array}{r}5 \\
\frac{7}{12} \\
\end{array}$ & $\begin{array}{l}15 \\
\frac{11}{26} \\
\end{array}$ & $\begin{array}{l}20 \\
18 \\
38 \\
\end{array}$ \\
\hline Pecking & $\begin{array}{l}\text { Unifacial } \\
\text { Bifacial } \\
\text { Absent } \\
\text { Indeterminate } \\
\text { Totals: } \\
\end{array}$ & $\begin{array}{l}2 \\
6 \\
- \\
\underline{4} \\
12\end{array}$ & $\begin{array}{r}14 \\
11 \\
1 \\
-\overline{26}\end{array}$ & $\begin{array}{r}16 \\
17 \\
1 \\
4 \\
38\end{array}$ \\
\hline Battering & $\begin{array}{l}\text { Moderate } \\
\text { Absent } \\
\text { Indeterminate } \\
\text { Totals: } \\
\end{array}$ & $\begin{array}{r}4 \\
4 \\
\underline{4} \\
12 \\
\end{array}$ & $\begin{array}{r}- \\
23 \\
\frac{3}{26} \\
\end{array}$ & $\begin{array}{r}4 \\
27 \\
7 \\
38 \\
\end{array}$ \\
\hline Reuse & $\begin{array}{l}\text { Present } \\
\text { Absent } \\
\text { Indeterminate } \\
\text { Totals: }\end{array}$ & $\begin{array}{r}7 \\
4 \\
1 \\
12\end{array}$ & $\begin{array}{r}17 \\
9 \\
- \\
26\end{array}$ & $\begin{array}{r}24 \\
13 \\
1 \\
38\end{array}$ \\
\hline
\end{tabular}

of sandstone. Bifacially distributed pecking occurs on six manos, three of fine-grained quartzite and three of sandstone. Pecking could not be determined on the remaining four manos, all made of fine-grained quartzite. A moderate degree of battering is present on four fine-grained quartzite manos. The battering noted on the complete specimen occurs on its margins, ends, and a small portion of one of its faces. Most of the margin and end battering may be from its use as a mano. The battering on the face may derive from the use of the tool as a hammerstone or chopper. The battering 


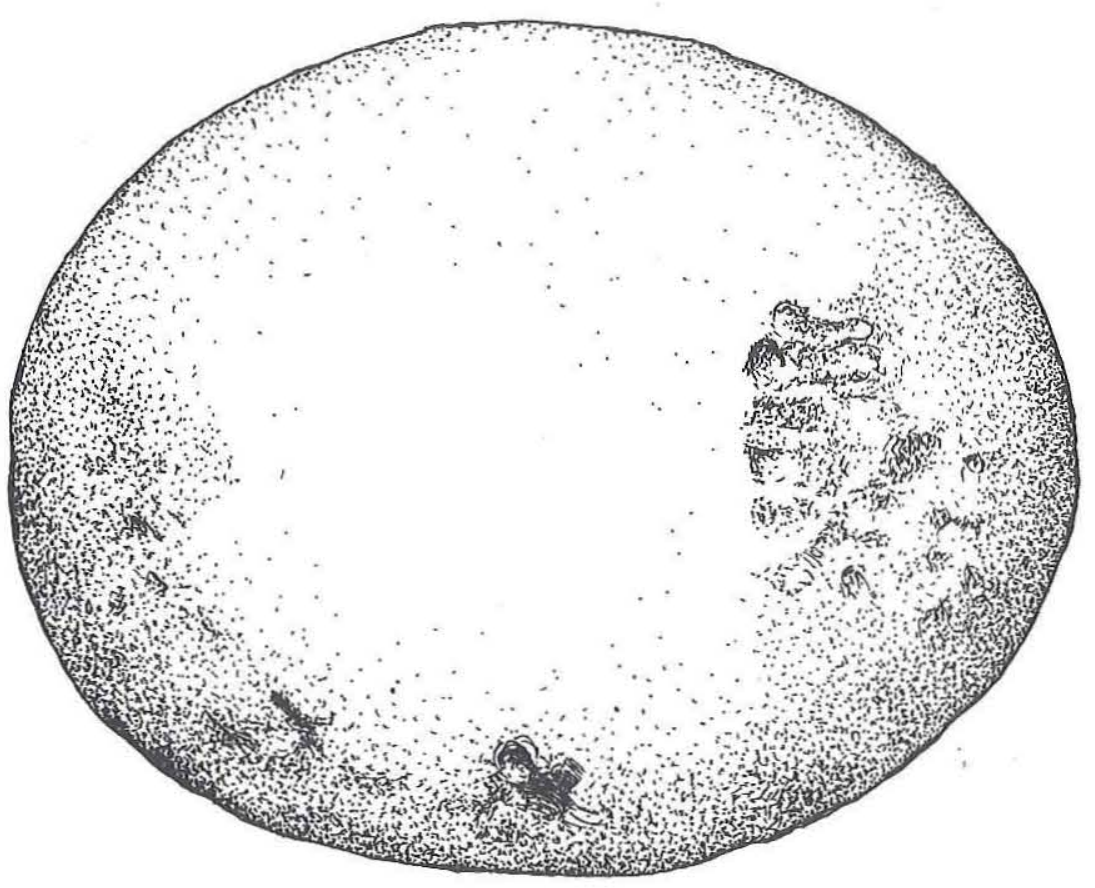

o

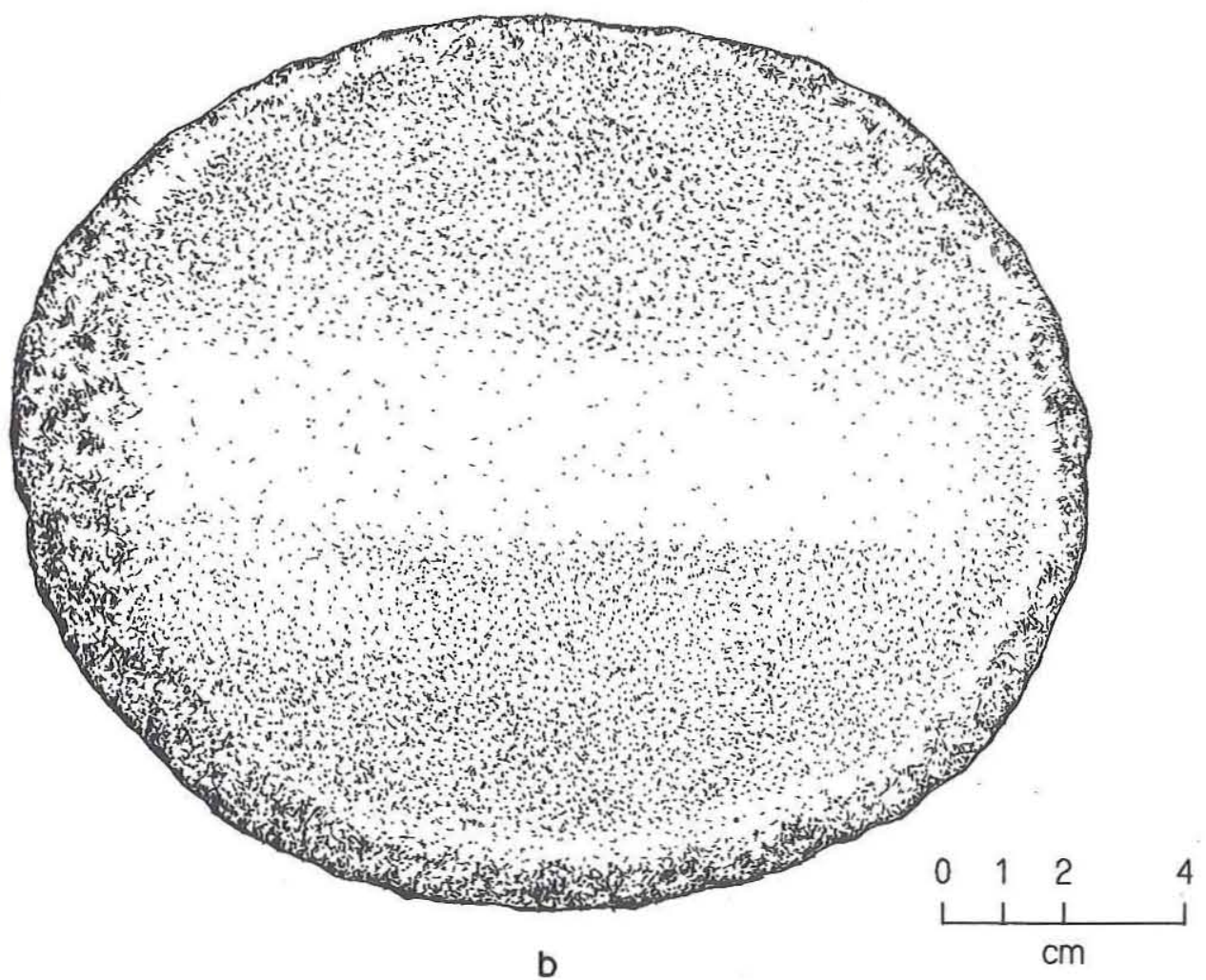

Figure 38. Manos, 41KT33. 
wear on the other three fine-grained quartzite fragments is distributed on acute edges formed by original unbroken and break faces. The battering consists of bifacial crushing and may be the result of reuse as hammerstones or choppers. Battering is indeterminate on four other small quartzite specimens and absent on the four sandstone mano fragments. In addition to the four reused fine-grained quartzite manos and fragments mentioned above, two other manos of the same material appear to have been reused as hearthstones. These fragments exhibit break morphologies characteristic of fire cracking. Reuse could not be determined on one small quartzite mano fragment, and evidence of reuse was absent on eight quartzite mano fragments. One of the four sandstone manos found in Feature 12 appears to have been reused as a hearthstone.

\section{METATES}

Twenty-six metates and fragments were recovered; 2 are associated with Feature 11, and 14 are from Feature 12. Metate fragments constitute $92 \%$ of the collection $(n=24)$, with only two complete specimens recovered. All 26 complete metates and fragments are made of sandstone.

The larger of the two complete specimens (Fig. 39) is a roughly rectangular, bifacially used metate recovered from surface. The specimen has a planoconcave transverse cross section. Both of its working surfaces exhibit pecking, but no battering is present. The specimen does not appear to have been reused. The metate is $590 \mathrm{~mm}$ long, $274 \mathrm{~mm}$ wide, and $86 \mathrm{~mm}$ thick. Its working surfaces measure $450 \times 210 \mathrm{~mm}$, and it weighs $15.8 \mathrm{~kg}$. The second complete specimen is a small metate recovered in two fragments. It is a rounded unifacially used specimen with a slightly planoconcave transverse cross section. Pecking is evident on the margins of the concave working surface, and battering is absent. The break faces on the two refitted fragments appear to represent fire cracking. Although the specimen was not recovered from a burned rock feature, the metate may have been reused as a hearthstone. It measures $90 \times 81 \times 40 \mathrm{~mm}$, with a small working surface that measures $77 \times 64 \mathrm{~mm}$. The specimen weighs $431 \mathrm{~g}$.

Of the 24 metate fragments, 14 are rectangular, 9 are angular, and a single specimen is oval. The majority $(n=11)$ are tabular fragments, followed by beveled $(n=5)$ and planoconcave $(n=5)$ specimens. The remaining three are biconcave. Use-wear is unifacial on 14 fragments and occurs on both faces of 10 specimens. Thirteen of the 14 metate fragments with unifacial use-wear also exhibit pecking. All 10 metate fragments with bifacial use-wear also exhibit bifacial pecking. Battering is absent on 21 specimens and could not be determined with certainty on three fragments. Signs of reuse are absent on nine metate fragments. One fragment is fire cracked, suggesting that it was reused as a hearthstone. All of the remaining 16 fragments were recovered from burned rock features, suggesting that they were reutilized for these features.

\section{HAMMERSTONES}

Of the four hammerstones recovered, two are complete and two are fragmentary. Both complete specimens exhibit only slight battering on their naturally rounded edges, and evidence of reuse is absent. The larger, a medium-sized hammerstone, measures $71 \times 67 \times 40 \mathrm{~mm}$ and weighs $267 \mathrm{~g}$. The smaller specimen, a small to medium-sized hammerstone, measures $57 \times 49 \times 36 \mathrm{~mm}$ and weighs $132 \mathrm{~g}$ (Fig. 40a). The two hammerstone fragments exhibit a different type of wear than that noted on the complete specimens. The larger of the fragments is the distal one-third of an oval to rounded quartzite pebble. Although it has slight battering on the distal end itself, much of the extensive battering is located away from the end, on the lateral margins, and on the broken edges of the fragment. The battering wear on the acute broken edges is highly similar to the wear noted on the working edges of chopping tools. The smaller of the fragments has two break edges with a moderate degree of battering (Fig. 40b). It is possible that this wear actually represents the reutilization of hammerstone fragments as choppers. However, Glen Goode (personal communication 1991) indicates that the acute edges noted on these fragments are the exact surfaces needed to strike isolated platforms because they provide a more-defined contact surface than the naturally rounded edges of unbroken nodules.

\section{Ceramics}

Six sherds of undecorated brownware were recovered from $41 \mathrm{KT} 33$, and all were found within the excavation block (Table 32). Based on identi- 


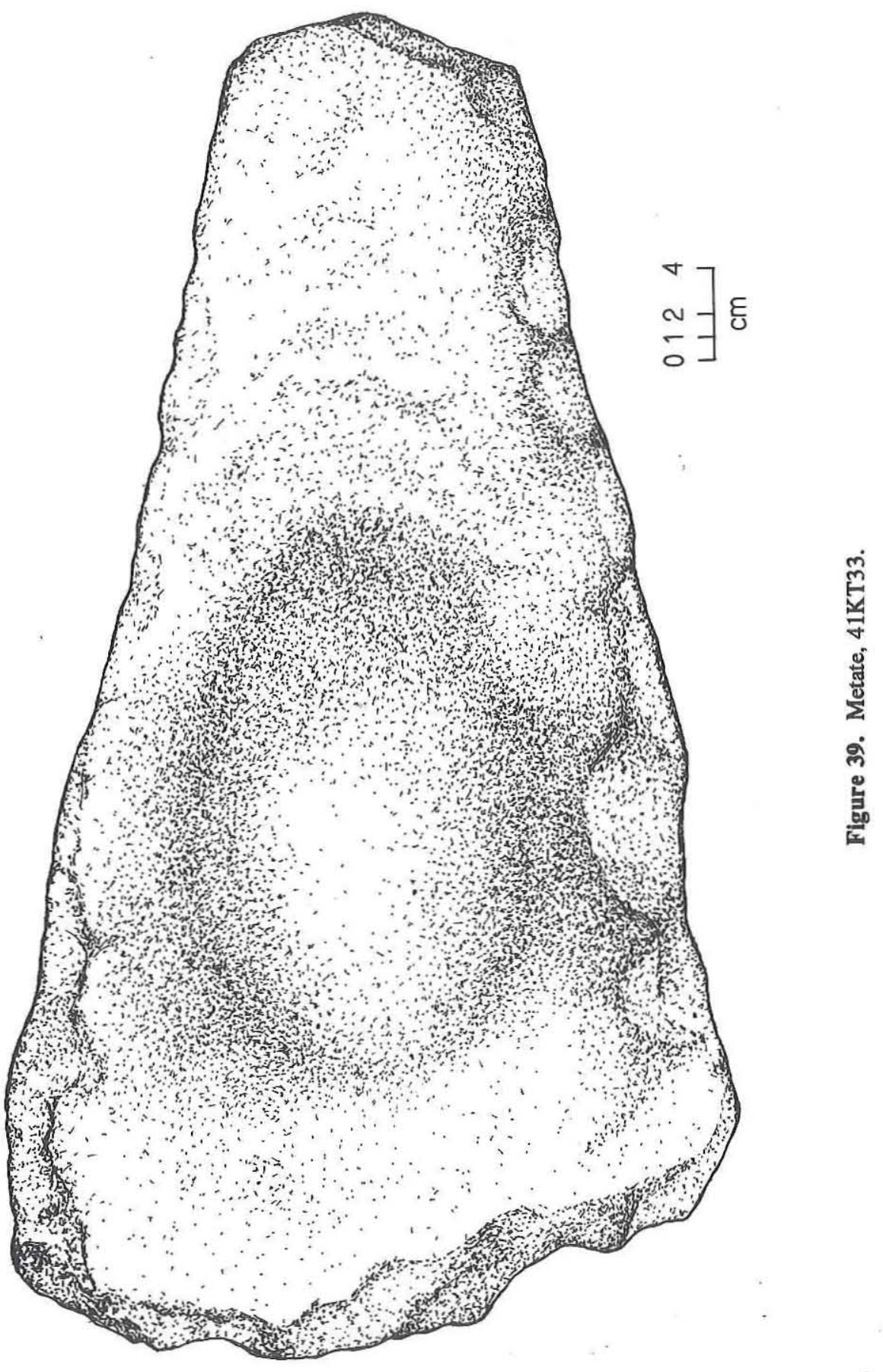



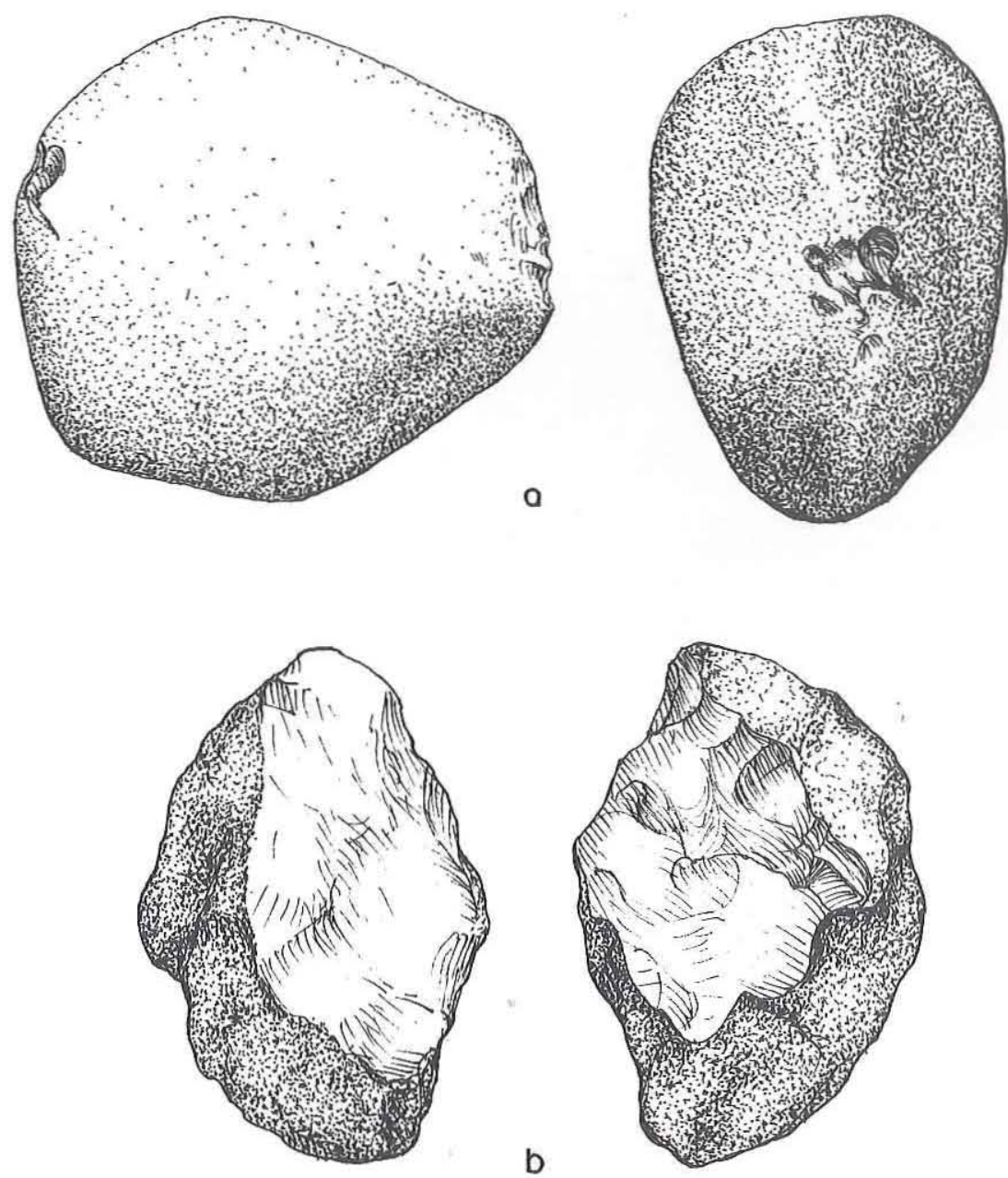

b

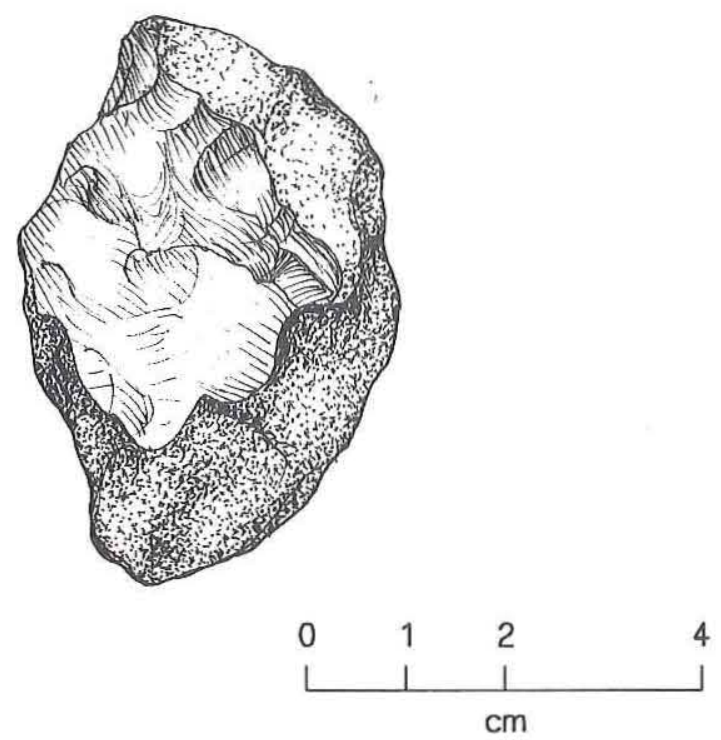

Figure 40. Hammerstones, 41KT33.

cal characteristics (i.e., color, finish, temper, and paste) and the fact that two of the sherds are refits, all are considered to be of the same type and possibly even from the same vessel. The sherds were visually examined, including low-power (10x to $40 x$ ) microscopic viewing, and described. They were then sent to two ceramic specialists, Regge Wiseman (Laboratory of Anthropology, Santa Fe, New Mexico) and Jack Hedrick (El Paso, Texas), who independently examined the sherds and provided additional descriptions and visual type identifications. The following description is largely derived from their observations.

The $41 \mathrm{KT} 33$ sherds are all very consistent and are described together. Interior and exterior colors are virtually the same, being reddish brown (5YR $4 / 3$ to 5 YR $5 / 3$ ). Sherd thicknesses range from 5-6 mm, and none of the sherds have any significant curvature so vessel form is indeterminate. Sherd breaks do not reveal manufacturing techniques, but coiling is the presumed method. Both surfaces have a smooth matte finish, probably the result of having been smoothed and floated (i.e., surface worked while wet).

The paste consists of ca. $50 \%$ clay matrix and ca. $50 \%$ crushed rock temper. The clay is very fine grained, rounded to subrounded particles, and the temper is rounded to subangular or platy, crushed and rolled rocks ranging in size from 0.25 to $1.5 \mathrm{~mm}$. The temper is dominated by white feld- 
TABLE 32

CERAMIC SHERDS FROM 41KT33

\begin{tabular}{|l|l|l|}
\hline & $\begin{array}{l}\text { Maximum } \\
\text { Dimensions } \\
(\mathrm{mm})\end{array}$ & $\begin{array}{l}\text { Thickness } \\
(\mathrm{mm})\end{array}$ \\
\hline EU 13, Level 2* & $21 \times 12$ & $5.0-5.5$ \\
EU 25, Level 3* & $11 \times 10$ & 5.0 \\
EU 30, Level 2 & $19 \times 11$ & 5.0 \\
EU 44, Level 2 & $24 \times 18$ & 5.0 \\
EU 47, Level 2 & $26 \times 18$ & $5.75-6.0$ \\
EU 59, Level 2 & $15 \times 8$ & 5.0 \\
\hline *These two sherds are from adjacent units and fit \\
together.
\end{tabular}

spar (50-60\%) which is rounded to subangular and ranges in size from 0.5 to $1.0 \mathrm{~mm}$. Some feldspar inclusions exhibit reddish (hematite) staining. Other temper components include black (ca. 20\%) and golden (ca. 20\%) mica or biotite (flat, platy fragments ranging from 0.25 to $0.5 \mathrm{~mm}$ ) and quartz (less than $10 \%$ rounded to subangular grains ranging from 0.5 to $1.5 \mathrm{~mm}$ ). In addition, hornblende/ amphibole crystal fragments and hematite were also identified as possible inclusions.

Both Wiseman and Hedrick agreed that these sherds are Mogollon brownwares. Hedrick specifically identified them as Jornada Brown and suggested that they are similar to the Jornada Brown found in the Hondo and Pecos river valleys between Lincoln and Roswell, New Mexico. Wiseman similarly identified them as a Pecos Valley variety of Jornada Brown and suggested that the high mica content is similar to Jelinek's (1967) Middle Pecos Micaceous Brown.

The petrographic analysis (see Appendix F) supported the visual identification of these sherds as Jomada Brown (with a relatively high mica content) or perhaps a Middle Pecos Micaceous Brown variety. The three analyzed sherds are characterized by a high degree of homogeneity with $60-65 \%$ temper composed mainly of volcanic feldspars, quartz, and biotite. The latter comprises $15-20 \%$ of the nonplastic inclusions in the sherds.

\section{Modified Shells}

Two freshwater mussel shells exhibit intentional modification as ornaments or tools. Specimen 1 is a small $(17 \times 22-\mathrm{mm})$, thin $(0.5-0.75-\mathrm{mm})$ shell fragment with seven or eight notches forming a serrated edge (Fig. 41a). The notches were cut into the interior of the shell (no modification is evident on the exterior) with the worked edge being the proximal end of a ventral margin fragment. It could have been modified to serve as a scraping or cutting tool, but three factors argue against this. The absence of visible use-wear suggests that it was not a tool, and the overall thinness of the fragment and the fact that the ventral margin fragment is very narrow and was worked along a proximal edge indicate that it was probably too weak to have been an effective tool. This specimen most likely was modified to serve as an ornament of some type.

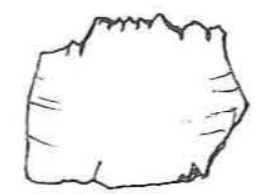

Q

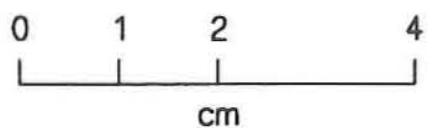

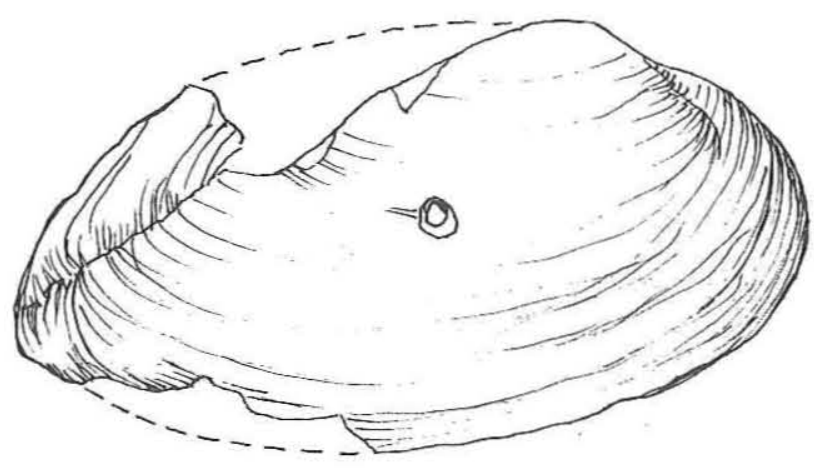

b

Figure 41. Modified shells, 41KT33. (a) Interior view of Specimen 1 from EU 57, Level 2; (b) exterior view of Specimen 2 from EU 18, Level 2. 
Specimen 2 is an almost complete, elliptical valve identified as Uniomerus declivus (see Appendix C) with a single drill hole in the approximate center of the shell (Fig. 41b). The valve is $80 \mathrm{~mm}$ long and, if complete, would have been ca. $45 \mathrm{~mm}$ wide, but it was damaged during excavation. It appears to have been a complete valve, but there is no apparent modification other than a 1-mmdiameter drill hole bored from the exterior that tapers inward toward the interior. No suspension wear, such as would be expected if the specimen was a pendant, is evident on the drill hole. It is likely that the specimen was discarded or abandoned during the early stage of manufacturing as an ornament. Perhaps the perforators recovered from the excavation block are related to the manufacture of shell ornaments.

\section{Burned Rocks}

Burned rocks at $41 \mathrm{KT} 33$ consist of burned sandstone and fire-cracked rocks. The burned sandstone was generally scattered throughout the excavation block but also was clustered into two distinct features which are interpreted as slightly disturbed hearths. A total of $133 \mathrm{~kg}$ of burned sandstone was encountered in the excavation block, accounting for $91 \%$ of all of the burned rocks. The majority of the burned sandstone was analyzed and discarded, but numerous ground stone fragments (recycled as hearthstones) were discovered and added to the ground stone assemblage. The sandstone is all local material dominated by Triassic grayish green, micaceous sandstones but also includes other varieties such as conglomerate sandstones (probably Triassic) and some red sandstones of probable Permian origin.

A total of $13 \mathrm{~kg}$ of fire-cracked rocks (ca. $9 \%$ of all burned rocks) was recovered; they were randomly scattered throughout the excavation block, and no feature clusters were observed. The majority $(80.5 \%)$ of the fire-cracked rocks are Potter chert, followed by $11.4 \%$ quartzite, $7.7 \%$ limestone, and $0.4 \%$ chert. All of these materials are of local origin. The few chert specimens may have been burned accidentally, and heat treating of lithic materials does not appear to have been intended.

\section{Faunal Remains}

The faunal remains recovered from 41KT33 include bones and shells which are identified and described in Appendix C. Vertebrate remains are represented by a single bone fragment identified as a tibia of a black-tailed prairie dog.

Invertebrate remains consist of 12 terrestrial snail shells and ca. $117 \mathrm{~g}$ of freshwater mussel shell fragments. The snails are interpreted as natural occurrences, but the mussels are thought to be cultural. Cultural evidence includes heat alteration and intentional modification. Two shell fragments exhibit thermal discoloration indicating the possible use of mussels as a food resource. These fragments appear to have been heated along the hinge, suggesting that this method may have been used to open the live mussel and obtain the meat. In addition, two specimens have been intentionally modified as ornaments or tools and are discussed previously (see Modified Shells).

\section{SUMMARY AND CONCLUSIONS}

The Phase III data recovery investigations at $41 \mathrm{KT} 33$ yielded evidence of a Late Prehistoric I cultural component. Two burned rock features were encountered, and 2,112 artifacts were recovered.

\section{Site Chronology and Definition of Component}

Analyses of sediments from the site demonstrate that a thin mantle of colluvial sediments covered an alluvial terrace, the Older Terrace, at 41KT33. This terrace was beveled by erosion during the middle Holocene, and the colluvial sediments that contain archeological materials appear to have accumulated during the later half of the Holocene. The radiocarbon date of $3370 \pm$ 205 B.P., cal. 3630 B.P., from the truncated soil in the Older Terrace at the site provides little useful data on an accurate chronological placement of the occupation at $41 \mathrm{KT} 33$ since the age of the occupation is expected to be much younger, but it does offer a minimum age for the erosion of the Older Terrace. Also, it provides a minimum estimate for the time span represented by the archeological materials, known to include the late Archaic, that have accumulated over the entire site. A single radiocarbon date of $1005 \pm 110$ B.P., cal. 933 B.P., from Feature 12 appears to be a reasonable age estimate for the site occupation.

The diagnostic artifacts that characterize this 
assemblage include Scallorn, Harrell, and untyped triangular arrow points and Jornada Brown pottery. These arrow points date to roughly the same time period in the Eastern Jornada region of southeastern New Mexico and western Texas (Leslie 1978). The co-occurrence of comer-notched Scallorn and side-notched Harrell points suggests that they were used contemporaneously or that occupation of the site spans the transitional period from corner- to side-notched arrow points. This transition apparently occurred ca. A.D. 1200 in the Eastern Jornada area (Leslie 1978:89-91) and at about the same time in the Texas South Plains (Hughes n.d.:67-69). The dating of this transition, however, is not well established, and the problem of the co-occurrence of corner- and side-notched arrow points has not been resolved.

In the 41KT33 assemblage, the Jornada Brown ceramics are indisputable evidence of a Late Prehistoric occupation but otherwise provide no greater temporal resolution. Jomada brownwares (and several related but virtually indistinguishable plainware types) were in use for a relatively long period of time. Runyan and Hedrick (1987:29) give dates of A.D. 900-1350 for Jornada Brown, but its prototype Alma Plain dates much earlier, perhaps to A.D. 300 (Smiley 1977:182) or even earlier. Ceramics identified as Jornada Brown have been dated to A.D. 700-1000 at sites in the Texas South Plains (Willey and Hughes 1978; Cruse 1989).

The cultural materials recovered from $41 \mathrm{KT} 33$ are interpreted as representing a single component but could, and probably do, result from multiple occupations. As used here, the term component simply refers to the most discrete and definable temporal unit within a site. While multiple occupations may be represented by the cultural remains at $41 \mathrm{KT} 33$, there is no practical way to separate them into more-discrete units.

An assessment of single componency is supported by the vertical distribution of artifacts, which are clustered in Level 2 and exhibit no natural or cultural stratigraphic separation (Table 33). Using the average number of artifacts per level, $85.6 \%$ were in the upper three levels. The average percentage of artifacts per level drops to $10.1 \%$ in Level 4, 4.3\% in Level 5, and $0 \%$ in Level 6. Level 6 was excavated into the buried soil that caps the Older Terrace, and Level 5 is at the contact between the overlying colluvium and the buried soil. Thus, the occurrence of artifacts in Level 5 is probably a result of bioturbation. Further support for an assessment of single componency is the fact that nine arrow points and six sherds were recovered but no dart points or other temporally incongruous artifacts were found in the excavation block. The arrow points and ceramics are very likely contemporaneous.

Although the cultural deposits are interpreted as representing a single component, there is evidence of multiple occupation. The 30-40-cm-thick cultural zone suggests that the materials were deposited over some length of time, but it is not clear how much time might be represented. Further evidence of repeated occupations includes burned rocks that appear to have been scattered by subsequent activities and ground stones recycled as hearthstones.

TABLE 33

VERTICAL DISTRIBUTION OF CHIPPED, GROUND, AND BATTERED STONES, 41KT33*

\begin{tabular}{|c|c|c|c|c|}
\hline Level & $\begin{array}{c}\text { No. of Units } \\
\text { Excavated }\end{array}$ & $\begin{array}{c}\text { No. of Artifacts } \\
\text { Recovered }\end{array}$ & $\begin{array}{c}\text { Average No. } \\
\text { of Artifacts }\end{array}$ & $\begin{array}{c}\% \text { of Average No. } \\
\text { of Artifacts }\end{array}$ \\
\hline 1 & 62 & 491 & 7.9 & 22.8 \\
2 & 62 & 860 & 13.9 & 40.2 \\
3 & 62 & 483 & 7.8 & 22.6 \\
4 & 57 & 198 & 3.5 & 4.3 \\
5 & 10 & 15 & 1.5 & 0.0 \\
6 & 1 & 0 & 0 & 34.6 \\
\hline \multicolumn{2}{|c}{} \\
Totals & 254 & 2,047 & \\
\hline
\end{tabular}




\section{Intrasite Patterning and Site Function}

The artifacts from $41 \mathrm{KT} 33$ are interpreted as representing a single component, and the distributions of features and artifacts were analyzed accordingly. It is acknowledged that the site is probably characterized by a small number of overlapping occupations which serve to obscure intrasite patterning; nevertheless, there is evidence that relatively distinct horizontal patterning of the material culture is present. The relatively small size of the excavation block is perhaps the greatest limitation to defining any meaningful activity patterning, but some inferences can be made. Even though some degree of disturbance by repeated occupations and bioturbation certainly has altered the distributions, these types of disturbances do not necessarily render the overall patterning useless (Gregg et al. 1991).

Burned sandstone is the most abundant cultural material, and the majority is distributed in one major cluster (Fig. 42a) that corresponds to the locations of two hearths near the center of the excavation block (Fig. 42b). Two other burned sandstone concentrations in the northwest quarter of the block (see Fig. 42a) were not recognized as features but may represent dispersed or disturbed hearths. The following discussion is predicated on the assumption that the burned rock features were hearths which served as the focal point for site activities (see 41GR383 discussion).

Compared to the burned sandstone, the fire-

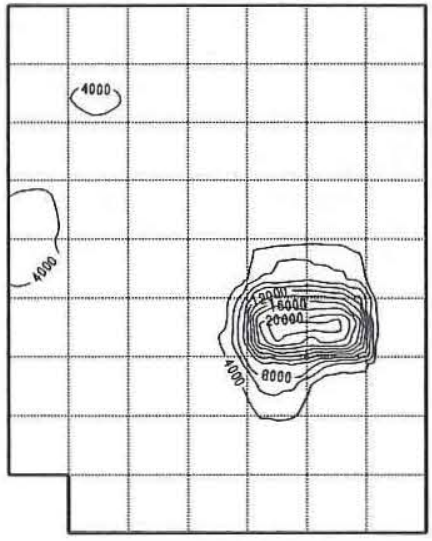

a) Burned Sandstone; Contour Interval=2000 grams

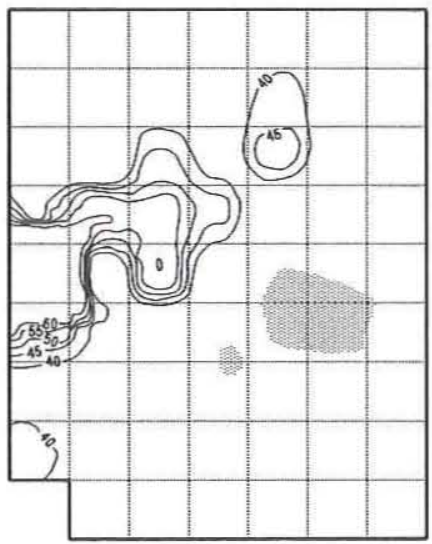

d) Unmodified Debitage; Contour Interval $=5$ artifacts

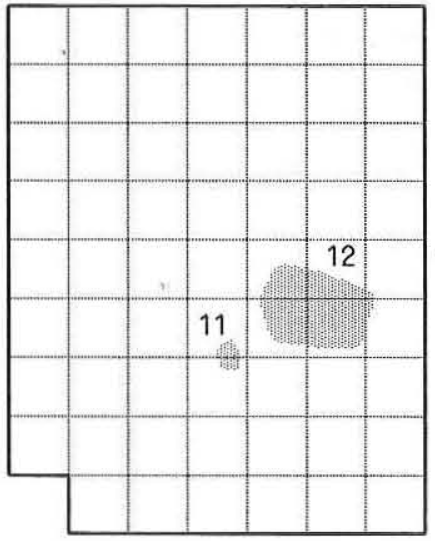

a) Features

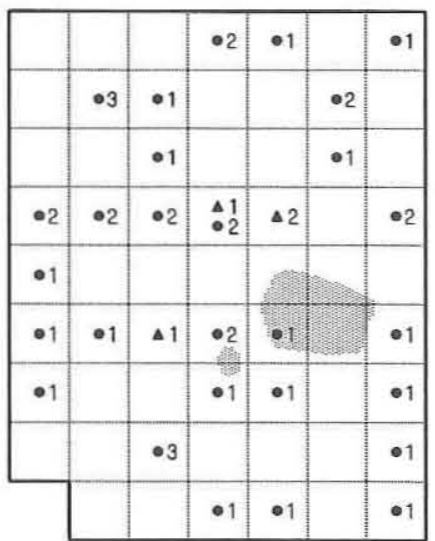

e) Hammerstones $=\mathbf{\Delta}$; Cores $=0$

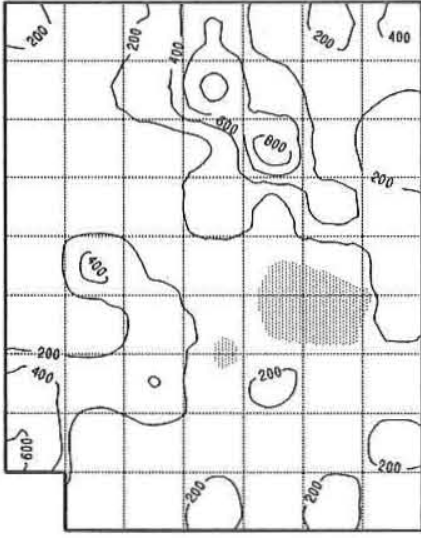

c) Fire-cracked Rocks; Contour Interval=200g

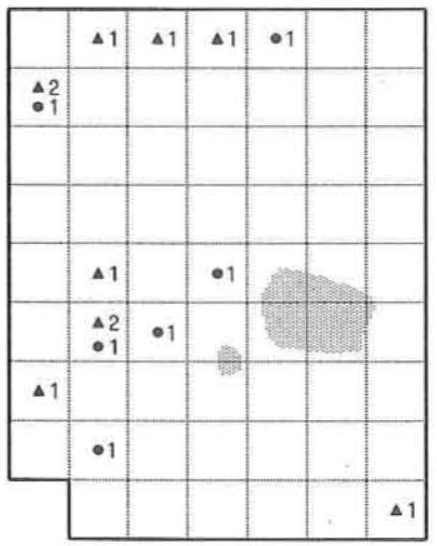

1) Arrow Points $=\Delta$; Ceramics $=0$

Figure 42. Distribution of artifacts and features in the excavation block, 41KT33; shaded areas denote burned rock features. 
cracked rocks (quartzite, limestone, and chert) have a different distribution (Fig. 42c), with the highest concentrations located adjacent to or offset from the high concentrations of burned sandstone. All of the burned rocks represent some type of heating (presumably cooking) activities, but it is likely that the burned sandstone represents in-place cooking features (e.g., rock-lined hearths or baking pits), while fire-cracked rocks were used as roasting or boiling stones and discarded or dumped nearby as secondary refuse.

Unmodified debitage, the largest single artifact category, is most dense in clusters north and west of the features in areas where firecracked rock densities are relatively low (Fig. 42d). Likewise, while core frequencies are low, they appear to be located mainly in and adjacent to the areas of high debitage frequency (Fig. 42e). Hammerstones occur between the hearths and high concentrations of unmodified debitage (see Fig. 42e). This suggests that lithic reduction occurred adjacent to the features, and their discard pattern is slightly offset from the unmodified debitage. Arrow points are scattered in units with low core and unmodified debitage frequencies, while ceramics seem to occur in units where fire-cracked rocks and burned sandstone are infrequent (Fig. 42f).

Most of the ground stone artifacts occur south of the burned sandstone features, areas where relatively low densities of other artifacts are observed (Fig. 43a). Seventeen ground stone fragments were incorporated into the features as hearthstones. These were not plotted but indicate considerable recycling of broken tools during lengthy or multiple occupations. The limited number of ground stone fragment refits suggests that they were discarded in the area of primary use (presumably south of the hearth) and tossed in refuse areas such as areas with high densities of lithic debitage.

The horizontal patterning of other artifact classes is less revealing. Edge-modified flakes are relatively abundant, and some concentrations are near hearths while others are near concentrations of unmodified debitage, suggesting use near the source or near high-use areas at the hearths (Fig. 43b). Cobble tools and perforators are infrequent, and their distributions are not particularly informative (Fig. 43c). Bifaces and unifaces appear to occur away from the greater concentration of fire-cracked rocks (Fig. 43d).
Mussel shells were ubiquitous and found in all but two units, but the most significant concentrations were adjacent to the burned rock features (Fig. 43e). Perhaps this can be explained in part by their use as a food resource, but heated shell fragments are too infrequent to provide clear hints (Fig. 43f). The two modified mussel shell specimens include one found inside the main concentration of shell fragments near the features and one found to the west (see Fig. 43f), and again occurrence is too sparse for firm interpretation.

Even though the horizontal patterning of the various artifact categories is somewhat hazy, some relatively clear patterns can be related to the distribution of burned rock features. Lithic reduction (manufacture and maintenance of tools) is most common to the west of the features, fire-cracked rocks commonly occur north and east of the features, and other limited forms of food-processing evidence (e.g., mussel shells and ground stone tools) are south of the hearths. These artifact distributions can be interpreted as a segregation of activities around hearths in a hunter-gatherer household camp. Obviously, exceptions to these simplifications occur; nevertheless, these recognizable distributions imply that domestic activities were positioned in relation to the fire hearths in a regular manner. If the portion of the site exposed in the excavation block represents multiple occupations, as the ground stone tools reused as hearthstones might imply, then the site may have been used in a similar manner through the various occupations. The visibility of the hearths and firecracked rocks may have allowed them to function as reference points for the repositioning of succeeding occupations. Cases of extreme continuity of site use and artifact distributions are known (Munday 1984), and it is not impossible to replicate a similar spatial use for a series of occupations at 41KT33. However, as multiple occupations extending from at least the late Archaic through the Late Prehistoric periods are present on the entire site, it is possible that the ground stones used as hearthstones could represent scavenging of existing suitable rocks off the surface of the site by a Late Prehistoric group during a single occupation concentrated in the eastern portion of the site (i.e., the excavation block area).

More-detailed synthetic analyses later in the project may offer additional interpretations, but some speculations can be offered at present. The 


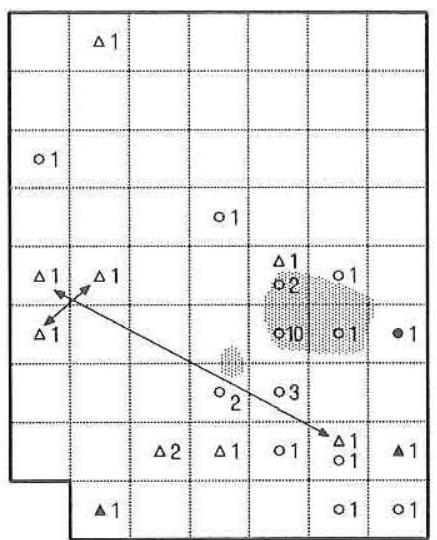

a) Mano $=\Delta ;$ Mano Fragment $=\Delta$; Metate $=\bullet$; Metate Fragment $=0$; Relit Fragments $=\leftrightarrow$

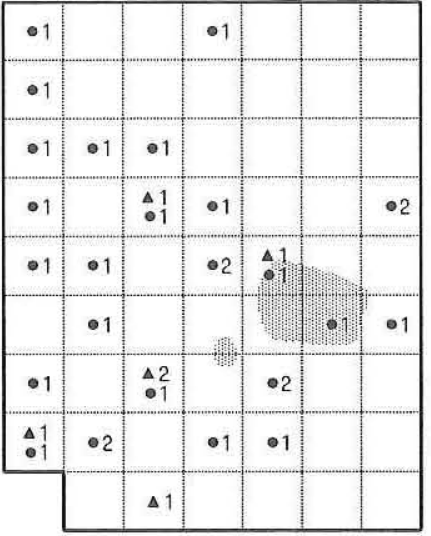

d) Bifaces $=\Delta ;$ Unifaces $=0$

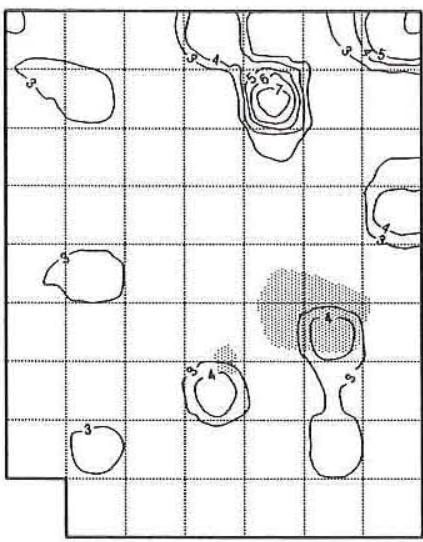

b) Edge-modified Flakes; Contour Interval= 1 flake

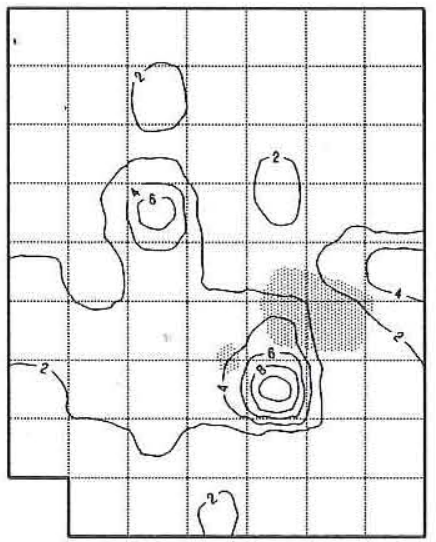

e) Mussel Shells: Contour Interval=2g

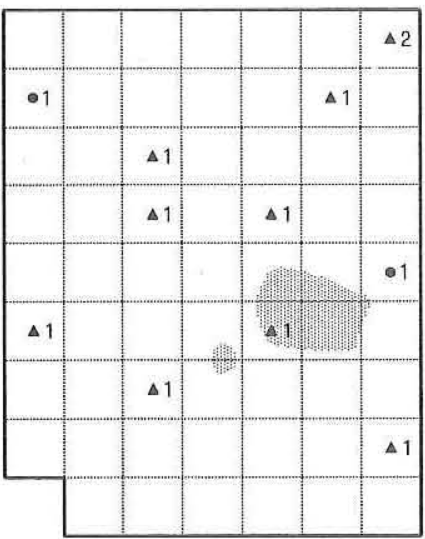

c) Cobbles $=\Delta ;$ Perforators $=0$

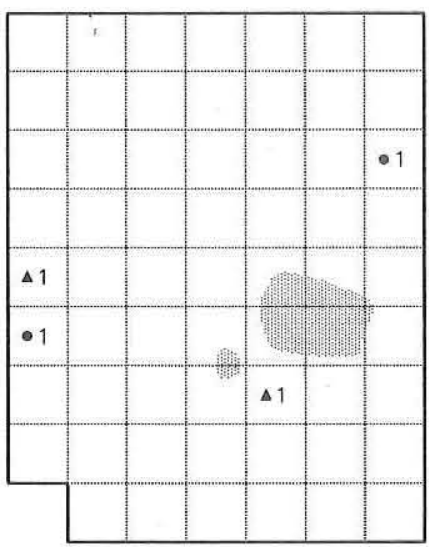

i) Modilied Shell= $\Delta$; Heated Shell $=0$

Figure 43. Distribution of artifacts in the excavation block, 41KT33; shaded areas denote bumed rock features.

occupation(s) may have been somewhat limited in terms of numbers of people and duration, generating only a moderate amount of cultural debris. The site location was probably selected because of its proximity to specific resources, but it is not clear what resources attracted the prehistoric peoples, although the materials recovered provide some hints. Apparently mussels were procured as a food resource, but the shell assemblage probably represents only limited use of mussels. The arrow points, scrapers, bifaces, and edge-modified flakes may indicate hunting and related processing (hide and meat) activities. The total absence of associated bones probably is due to poor preservation and does not necessarily reflect their actual absence.
The ground stone tools and perhaps the abundant burned rocks suggest that plant and food processing was important. The Jornada ceramics probably represent some form of storage or cooking vessel and could relate to plant or animal foods. The range of activities inferred from the artifacts lacks evidence suggesting a single overriding activity and suggests that $41 \mathrm{KT} 33$ probably served as a multifunctional temporary campsite for a hunter-forager group.

\section{Cultural Assessment of Component}

The diagnostic artifacts that provide some indication of the cultural affiliation of the inhabit- 
ants of $41 \mathrm{KT} 33$ are arrow points and ceramics. In the Texas Panhandle and Southern Plains, Plains Woodland occupations such as at the Lake Creek Site are known to include cordmarked ceramics as well as "Pecos Valley brown wares," while the projectile points from that site include triangular side-notched, triangular, and corner-notched arrow points as well as corner-notched dart points (Hughes 1962:82). Most of the artifacts at the Lake Creek Site were found on the surface, but limited vertical artifact distributions in a single test unit suggest that the brownwares might predate the cordmarked ceramics. Unfortunately, no further work has been done at the site, and no radiocarbon dates are available. This ceramic temporal pattern may be duplicated at the Tascosa Creek Site in Oldham County (Couzzourt 1985:94-98). The lack of cordmarked sherds in the excavation block at 41KT33 implies few similarities among these three sites.

All of the ceramics at $41 \mathrm{KT} 33$ were identified as Jomada brownwares, and because of this, they represent a link to the Jornada Mogollon area of southern and eastern New Mexico and western Texas. Lehmer (1948) first defined the Jornada Branch of the Mogollon with northern and southern variants in south-central New Mexico and TransPecos Texas. A poorly defined and still informal eastern variant was suggested by Corley (1965). This eastern variant extended into Texas and is divided into three phases-Querecho (1000850 B.P.), Maljamar (850-650 B.P.), and Ochoa (650-500 B.P.) - that roughly correspond to those defined for the northem and southern variants by Lehmer; however, these dates are based on ceramic cross-dating and require confirmation with absolute dating methods. In the eastern variant of the Jornada Branch of the Mogollon, an apparent widespread shift from corner-notched to sidenotched arrow points occurs at approximately 750 B.P. (Leslie 1978). The latest phase of Corley's eastern variant might be represented by sites with pithouse structures and Jornada brownware ceramics at sites near Andrews Lake in Andrews County, Texas (Collins 1968).

Investigations in the Middle Pecos region immediately south of Fort Sumner demonstrated the occurrence of pithouses and Jornada brownware ceramics in this region (Jelinek 1967). Eight phases were defined for the Middle Pecos region, and six of these are related to the Jornada Mogollon: Early
18 Mile (1150-1050 B.P.), Late 18 Mile (1050950 B.P.), Early Mesita Negra (950-850 B.P.), Late Mesita Negra (850-750 B.P.), Early MacKenzie (750-700 B.P.), and Late MacKenzie (700-600 B.P.). Brownware ceramics continue to the Late MacKenzie Phase when they are replaced by a variety of black-on-white ceramics. Also, corner-notched arrow points are replaced by sidenotched arrow points in the Early MacKenzie Phase, and shallow circular pithouses are replaced by surface rectangular structures in this same phase. It is unclear how far north this pattern extends, but it was not found as far north as Los Esteros Lake near Santa Rosa even though low frequencies of Jornada brownware ceramics are present (Mobley 1978). The eastem boundary of the Jornada Mogollon in the Southern Plains is poorly defined. In this area it is difficult to distinguish between sites that might represent actual Jornada Mogollon groups who were utilizing the Southern Plains on a temporary or perhaps seasonal basis and local Southern Plains groups who were strongly influenced by the Jornada Mogollon groups, possibly through trade or other forms of exchange.

Local Southern Plains interaction with the Jornada Mogollon is recognized informally as the Palo Duro Complex (Willey and Hughes 1978; Hughes 1991), which may, in fact, be related somehow to the Lake Creek Complex (Hughes 1962, 1991) defined in the Texas Panhandle. The Palo Duro Complex is known only through a handful of sites, but other than the presence of Jornada brownware ceramics, its relationship to the Jomada Mogollon is unclear. The Palo Duro Complex was defined originally at Deadman's Shelter in Swisher County (Willey and Hughes 1978), where occupations were radiocarbon dated between 1830-1140 B.P. Palo Duro Complex occupations contain distinctive arrow points with long basal barbs known as Deadman's arrow points, corner-notched Scallorn arrow points, and cornernotched dart points. A reduction through time in dart point frequencies was noted at Deadman's Shelter (Willey and Hughes 1978), but this pattern needs verification at other sites before its regional significance can be accepted and assessed (Larralde 1990). Recently at another Palo Duro Complex site, Cruse (1989) excavated Mogollon-like pithouses with ramped entryways at the Kent Creek Site in Hall County. Radiocarbon dates from this site are 1240 B.P., 1160 B.P., and 840 B.P., and it 
appears that the latter date may not be an accurate age estimate for the occupation. Ceramics from Deadman's Shelter include Jornada Brown or Alma Plain, and from the Kent Creek Site the ceramics are identified as Jornada Brown, Roswell Brown, and Middle Pecos Micaceous Brown. An unidentified sandy paste brownware sherd from the Kent Creek Site may represent a locally made ceramic type (Cruse 1989:105-106). Also, possible Deadman's arrow points are present in the Late 18 Mile Phase (1050-950 B.P.) in the Middle Pecos Valley (Jelinek 1967:104).

The absence of Deadman's arrow points at $41 \mathrm{KT} 33$ prohibits a firm assignment of its component to the Palo Duro Complex, even though the ceramics at $41 \mathrm{KT} 33$ are similar to Palo Duro Complex assemblages and Scallorn arrow points occur in both. The single radiocarbon date from Feature 12 is slightly younger than the available age estimates for the Palo Duro Complex, but considering the large standard deviation associated with the Feature 12 radiocarbon date, it is well within range of the upper age estimates of the Palo Duro Complex. Also, the Feature 12 radiocarbon date is within the temporal range of the Late 18 Mile Phase in the Middle Pecos Valley, and this is the phase that has possible Deadman's arrow points. The possibility of diagnostic artifact exclusion due to limited sample size from both the 41KT33 and the Middle Pecos Valley assemblages should be a serious concern when assessing these sites. If the 750 B.P. transition from corner-notched to sidenotched arrow points in the eastern Jornada and Middle Pecos areas can be extrapolated to the Southern Plains, then the presence of a side-notched (Harrell) and corner-notched (Scallorn) arrow points at 41KT33 are an indication that the component may postdate the Palo Duro Complex by a significant margin (unlikely considering the available radiocarbon dates), that both Late Prehistoric I and Late Prehistoric II occupations are present, or that a transitional component is present at 41KT33. Using 750 B.P. as a temporal marker for the transition from corner-notched to side-notched arrow points, this date is 2.3 standard deviations away from the Feature 12 radiocarbon date, and the probability of contemporaneity is less than $5 \%$ (Long and Rippeteau 1974). This suggests the likelihood of multiple Late Prehistoric I and II components at $41 \mathrm{KT} 33$ and that sample size and temporal integrity must be a concern. Conversely, the 750 B.P. date for the corner- to side-notched arrow point transition should be considered a crude approximation since it is based mainly on tenuous associations of points with typologically dated ceramics and is not supported by independent dating (Leslie 1978:88). Thus, it is possible that the 41KT33 excavation block represents a single transitional component or a mixture of two different components.

In an archeological overview of the Southern Great Plains, Hofman and Brooks (1989:70) state:

the occurrence of Jornada Brownware at sites throughout much of the Llano Estacado area indicates potentially very significant influences on the Southern High Plains groups as a result of interaction with groups living to the west and southwest. West of the Llano Estacado in the Pecos Valley, Jelinek (1967) has defined the 18 Mile Phase, dating prior to A.D. 1000, the early portion of which is characterized by Jornada Brownware (see Jelinek 1967: 47-49 for a description). Present evidence suggests that this early Southwestern influence "collided" on the eastern portion of the High Plains and western Prairie-Plains with eastern Plains Woodland influences, and these contacts resulted in a distinctive overlay of new technologies on an Archaic population which is assumed to have been present and well established in the region.

At present it appears that Jornada brownware ceramics in the Southern Plains were obtained by trade or other forms of exchange with groups in the Middle Pecos or the eastern variant of the Jornada Branch of the Mogollon. These Southern Plains groups, such as represented by the assemblage at $41 \mathrm{KT} 33$, do not appear to be agriculturalists but continued to employ hunting and gathering as their primary mode of subsistence. Nevertheless, more data, including subsistence information, with better chronological control are necessary before the interactions between Southern Plains hunter-gatherers and Jornada Mogollon agriculturists can be clarified. 


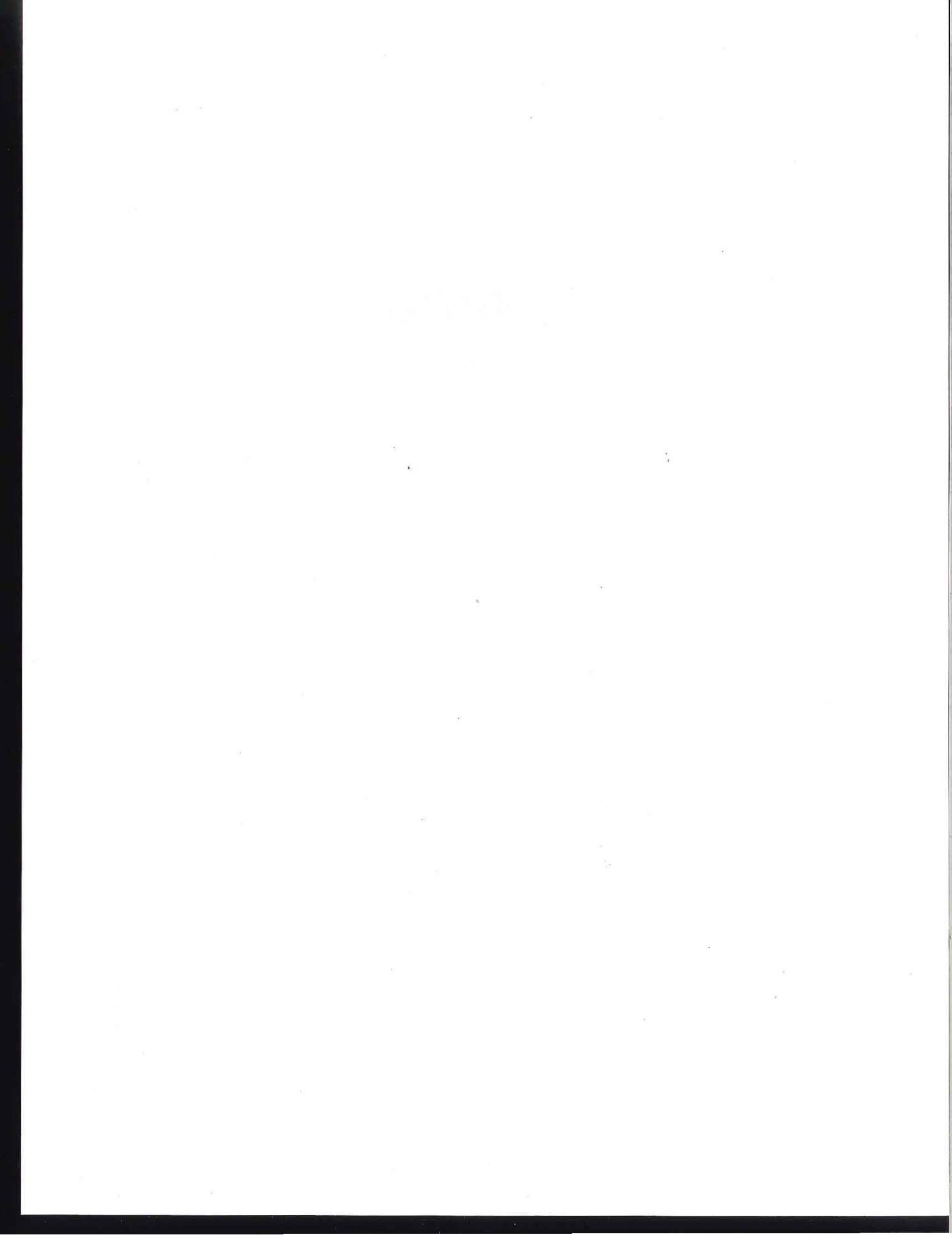




\section{OFF-SITE GEOLOGICAL INVESTIGATIONS}

C. Britt Bousman

Three areas near the dam site (the Double Mountain Fork valley floor, the Older Terrace, and the lower Grape Creek floodplain) were selected for additional off-site geological investigations during this first season of data recovery investigations (Fig. 44). In addition, geotechnical bore logs on the dam centerline and nearby borrows areas were inspected to provide information on areas, where off-site geological investigations were not undertaken or to supplement observations in investigated areas. These additional geological efforts were undertaken to provide more detail on the geological sequence developed by Blum (1989a) and Abbott (1990) as well as to identify additional geological events and processes that influence the archeological record.

\section{PIPELINE TRENCH}

An oil pipeline relocation trench immediately downstream of the dam site provided a transect south of the Double Mountain Fork channel across the entire floodplain, valley floor, valley wall, and overlying bluffs. In the pipeline trench, two profiles (PL 1 and PL 2) were recorded in the valley floor. A third profile (PL 3) was documented in a deep backhoe trench excavated some $20 \mathrm{~m}$ east of the pipeline trench in an intermediate position between the first two profiles, and a fourth undescribed profile (PL 4) was observed along the trench on the edge of the valley wall bluff some $20 \mathrm{~m}$ above the floodplain.

None of the floodplain profiles reached bedrock. All three, Profiles PL 1-3, have buried soils separated by fluvially deposited sand and gravel lenses. One extensive sand and gravel bed is the primary unit used for stratigraphic correlation (Fig. 45). In Profiles PL 2 and PL 3, and throughout most of the pipeline trench, trough crossstratified sand and gravel lenses in this marker bed provide clear evidence of their fluvial origin.

In PL 1, the upper five zones (C1 through C5 horizons) consist of very recent fluvial deposits that form a small inset fill adjacent to the bank of the Double Mountain Fork (see Fig. 45). These fluvial deposits sit on a weak soil (2Ab horizon) that is probably very young and is correlated here with the surface soil in PL 2. Below the $2 \mathrm{Ab}$ soil are two additional buried soils (3Abk1, 3ABk2, and 4Btb horizons) interstratified between and above fluvial deposits (2Ck, 3Ck, 4Ck1, and $4 \mathrm{Ck} 2$ horizons). The $3 \mathrm{Abk} 1$ horizon in PL 1 has a radiocarbon age estimate on bulk soil carbon of $1020 \pm 140$ B.P., cal. 938 B.P. (GX-16619). An age estimate of $1765 \pm 145$ B.P., cal. 1703 B.P. (GX-16620), was obtained on similar sediments from the $4 \mathrm{Btb}$ horizon.

In PL 2, charcoal from the upper portion of the first buried soil $(2 \mathrm{Ab})$ is dated to $620 \pm 115$ B.P., cal. 644-571 B.P. (GX-16621), and an age estimate of charcoal from the lower portion of this first buried soil is $825 \pm 75$ B.P., cal. 727 B.P. (GX-16622). This same soil can be traced stratigraphically to the $3 \mathrm{Abk} 1-2$ horizons in PL 1 with a radiocarbon date of $1020 \pm 140$ B.P., cal. 938 B.P. Also near PL 2 in the backdirt pile of the 
Figure 44. Map of geological trenches and profiles.

pipeline trench, a 6-7-year-old female bison mandible (Michael Quigg, personal communication 1991) was discovered. A gravelly sandy loam still adhered to it, and these are similar to sediments in the $2 \mathrm{Ab}$ horizon in PL 2 (see sediment data in Appendix I). The radiocarbon age of this bison mandible was estimated at $810 \pm 75$ B.P., cal. 720 B.P. (GX-16624-G), and this is in close agreement with the $825 \pm 75$ B.P. radiocarbon determination from the lower portion of the $2 \mathrm{Ab}$ soil horizon in PL 2.

In profile PL 2, the $2 \mathrm{Ab}$ soil grades down- ward into a $2 \mathrm{C}$ horizon composed of trough crossstratified sands and gravels (the marker bed), which themselves sit on a lower buried soil. This lower buried soil is undated in PL 2, but a bulk sediment sample in PL 3 was dated to $1330 \pm 130$ B.P., cal. 1281 B.P. (GX-16623). This radiocarbon assay is much younger than the age estimate from stratigraphically the same soil horizon (4Btb) in PL 1, but at this point these two dates are believed to bracket or occur within the true age of this soil. PL 3 provides the most complete view of sediments below the lower soil, and it indicates continued 


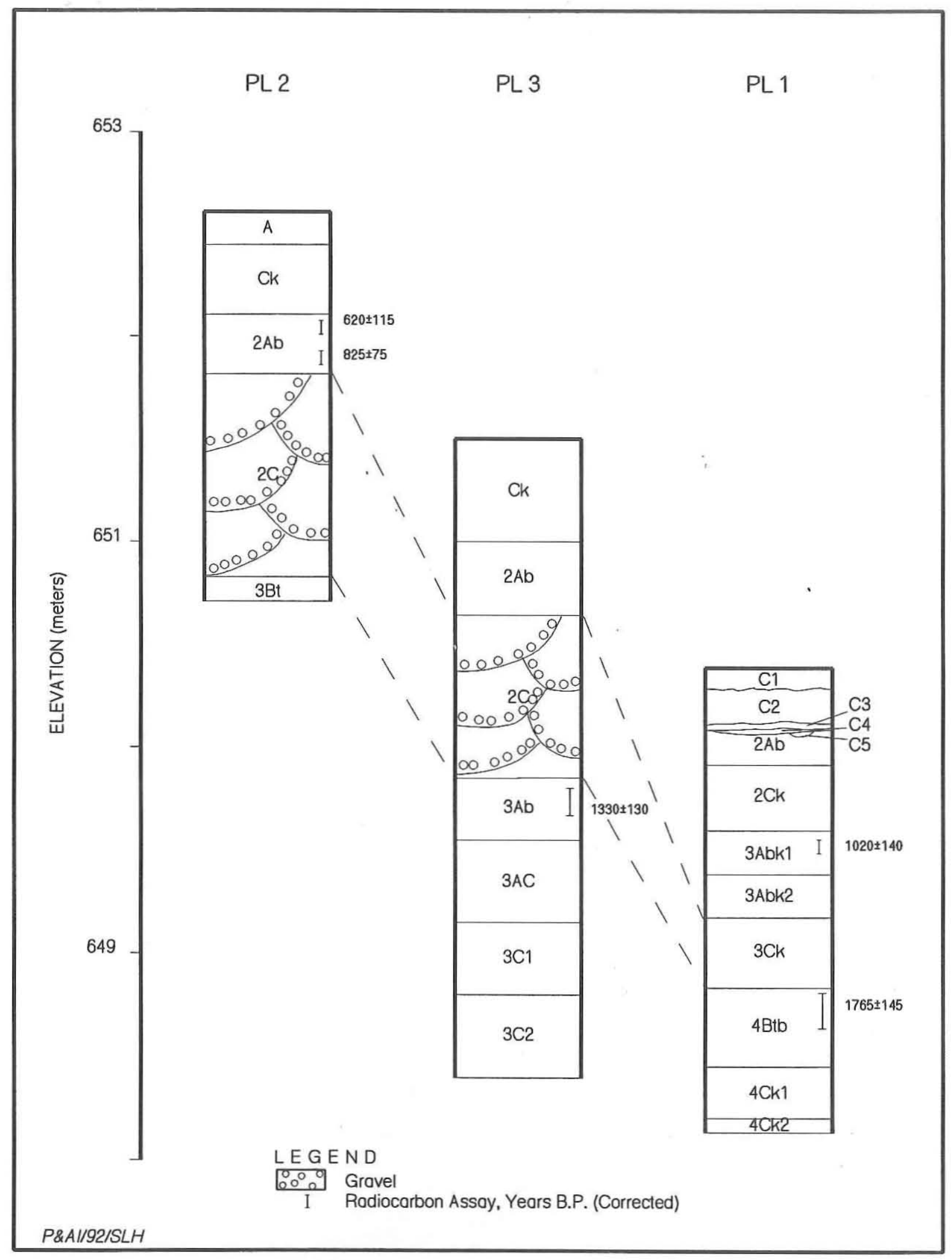

Figure 45. Pipeline (PL) trench profiles. 
fluvial construction of floodplain surfaces at that depth.

Additional evidence for floodplain construction can be supplemented by bore-hole logs from the geotechnical studies conducted for assessing dam construction (Mason Johnston and Associates, Inc. n.d.). In the middle of the valley immediately upstream of the dam site in Borrow Area D, these bore-hole logs demonstrate the existence of thick (18-19 m) fluvial deposits above bedrock in the valley floor. Gravel and sandy clay beds within sandy fluvial sediments can be constructed in three dimensions, and these plottings suggest the occurrence of a narrow and deeply buried, fine-grained paleochannel deposit stratified above a wider gravel channel deposit which itself sits directly on bedrock. These clay and gravel channel deposits have limited horizontal distributions which allow the demarcation of an infilled paleochannel. Unfortunately the age of this channel deposit is unknown, but a Holocene age cannot be dismissed.

A trough cross-stratified sand and gravel deposit was observed in the pipeline trench (PL 4) on a bluff that overlooks the valley. This channel deposit sits on a bench incised 5-6 $\mathrm{m}$ below the edge of the upland plains. Clearly this channel deposit represents an initial stage of valley incision. The age of this deposit is unknown, but it might be 150,000 to 100,000 years old. The entire region was covered by the Mio-Pliocene Ogallala Formation that now forms the Caprock Escarpment and still occurs as an isolated outlier southeast of the project area near Synder. Escarpment erosion of this and overlying sediments has slowly created the Rolling Plains in the Justiceburg region. Using estimates of Caprock Escarpment retreat ranging from $60 \mathrm{~m} / 1,000$ years to $180 \mathrm{~m} / 1,000$ years (Gustavson and Simpkins 1989:42) and measuring distances between the project area and the modern Caprock at $40-45 \mathrm{~km}$, the rough age for initial Caprock retreat can be estimated between 225,000735,000 years ago, i.e., the middle Pleistocene. It is unlikely that the PL 4 channel gravels are of this age because their occurrence on an incised platform below the edge of the modern valley suggests that a significant span of time separates the retreat of the Caprock from the deposition of these channel deposits. Throughout the uplands (and high above these channel deposits) are small gravel deposits scattered in primary and secondary contexts. These represent a series of ancient stream systems that transported sediments from the retreating Caprock, and they are similar to those described as the lower Lingos Formation by Caran and Baumgardner (1990). None of these upland gravel deposits can be related with confidence to modern channels. However, the perched channel deposit in the pipeline trench represents a phase of downcutting below the upland plain and as such probably represents the first stage of modern valley incision.

\section{OLDER TERRACE}

The Older Terrace was first recognized by Abbott (1990) in the area surrounding 41KT33, but no chronometric dates were obtained at that time for this alluvial deposit. A very dark sedimentary zone was observed in a roadcut at the southwestern edge of the Older Terrace near its abutment with the bedrock valley wall, and this indicated that some type of buried soil or rich organic zone was likely present. Three backhoe trenches (BHTs 1991-1, 1991-2 and 1991-2b) were excavated to investigate the nature of deposits in the Older Terrace (Fig. 46). Backhoe Trench 1991-2 was excavated at the highest point on the Older Terrace at the crest of a knoll in the southwest corner of the terrace, but the lower portion of the terrace was not visible in this trench. Backhoe Trench 1991-2b was excavated a few meters away on the slope of the knoll in order to investigate the lower portion of the terrace. Their combined sections demonstrate that the Older Terrace is approximately $4.5 \mathrm{~m}$ thick at its southwest edge where it is best protected by a bedrock outcrop. The third backhoe trench, BHT 1991-1, was dug adjacent to the 41KT33 excavation block, and bedrock was reached at $2.75 \mathrm{~m}$ below the surface. The differences in depth represent the amount of beveling due to subsequent erosion.

Colluvial deposits comprise the surface sediments in all three backhoe trenches. The colluvium in BHT 1991-2 (Ck1 horizon) and BHT 1991-2b (C horizon) has many pebbles derived from ancient in situ channel deposits (cf. Lingos Formation) directly upslope, and these are classified as gravelly loams. Because of greater distance from the source, the surface colluvial deposit at BHT 1991-1 (weak A horizon loam) has smaller and many fewer pebbles, and it probably contains an eolian contribution as well. Below the colluvial deposits are truncated 2B soil horizons in all three profiles, and these range from slightly gravelly loams to silt loams. In BHT 1991-2b, the 2B 


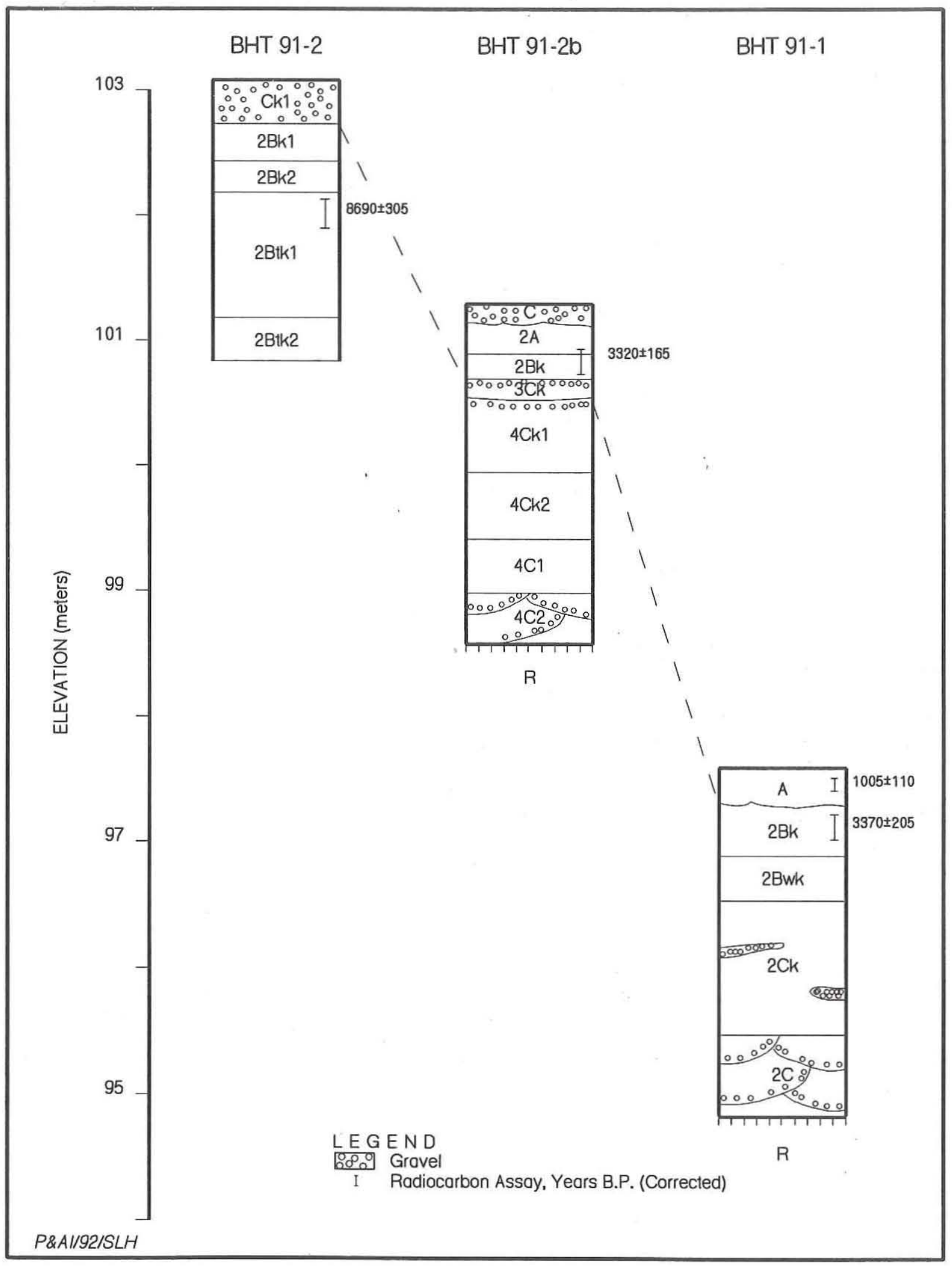

Figure 46. Older Terrace backhoe trench profiles. 
horizon sits on an erosional unconformity, and the underlying $3 \mathrm{Ck}$ horizon has a second erosional unconformity at its lower boundary. The erosional nature of these boundaries is clearly indicated by abrupt contacts and by lag calcium carbonate nodules on the boundaries. Backhoe Trench 1991-2 did not reach the underlying $\mathrm{C}$ horizons, but adjacent BHT 1991-2b shows their presence in the 3C and $4 \mathrm{C}$ horizons. Both the BHT 1991-1 and BHT 1991-2b profiles have well-bedded, trough crossstratified sands and gravel deposits sitting directly on bedrock, and these fluvial deposits grade up to unstratified sand and sandy loams that represent overbank alluvium.

Radiocarbon dates on bulk sediment samples from these deposits show that the age of fluvial deposition remains unknown. However, an assay from the 2Btk1 horizon in BHT 1991-2 suggests that a minimum age for the soil is $8690 \pm 305$ B.P., cal. 9595 B.P. (GX-16509). The radiocarbon date from BHT 1991-2b, $3320 \pm 165$ B.P., cal. 3570 B.P. (GX-16625), is stratigraphically separated from the much older BHT 1991-2 date by two erosional unconformities. The radiocarbon date from BHT 1991-1, $3370 \pm 205$ B.P., cal. 3630 B.P. (GX-16508), is close in age to the BHT 1991-2b date. It is suggested that the BHT 1991-1 radiocarbon sample has been contaminated by younger carbon leaching down-profile, but that the BHT 1991-2b sample, which comes from a much more organically rich sediment, represents a reasonable age estimate for a late Holocene soil. A single radiocarbon date is available from the surface colluvial/eolian unit near BHT 1991-1. This sample consists of charcoal from archeological site
$41 \mathrm{KT} 33$, and the resulting age estimate is $1005 \pm$ 110 B.P., cal. 933 B.P.

These radiocarbon dates can be used to suggest that the Older Terrace appears to have been eroded after 8690 B.P., and the radiocarbon date from BHT 1991-2b of 3320 B.P. might provide a younger limit for this erosional episode. Evidence is increasing for a major dry period during the middle Holocene in the Southern Plains (Meltzer and Collins 1987; Blum 1989a; Holliday 1989; Abbott 1990; Collins and Bousman 1990; Meltzer 1991), and a widespread erosional episode in the Double Mountain Fork valley may be evidence of the imbalance caused by such a dramatic climate change. The late Holocene date from the capping colluvial/eolian surface unit and the late Archaic and Late Prehistoric archeological remains at 41KT33 suggest this surface sedimentary unit is restricted to the late Holocene.

\section{GRAPE CREEK FLOODPLAIN}

Finally, a single long backhoe trench was excavated in the lower Grape Creek floodplain directly across from 41GR484 (see Fig. 44). Previously Blum (1989a) and Abbott (1990) had excavated a number of backhoe trenches in this floodplain, but an additional trench was justified in order to obtain chronometric information on the timing of the Grape Creek meandering that eroded the bedrock cutbank that forms the west side of 41GR484.

The BHT 1991-3 profile (Fig. 47) illustrates a series of tilting gravel, clay, and stratified sand beds that demonstrate an eastward migration of

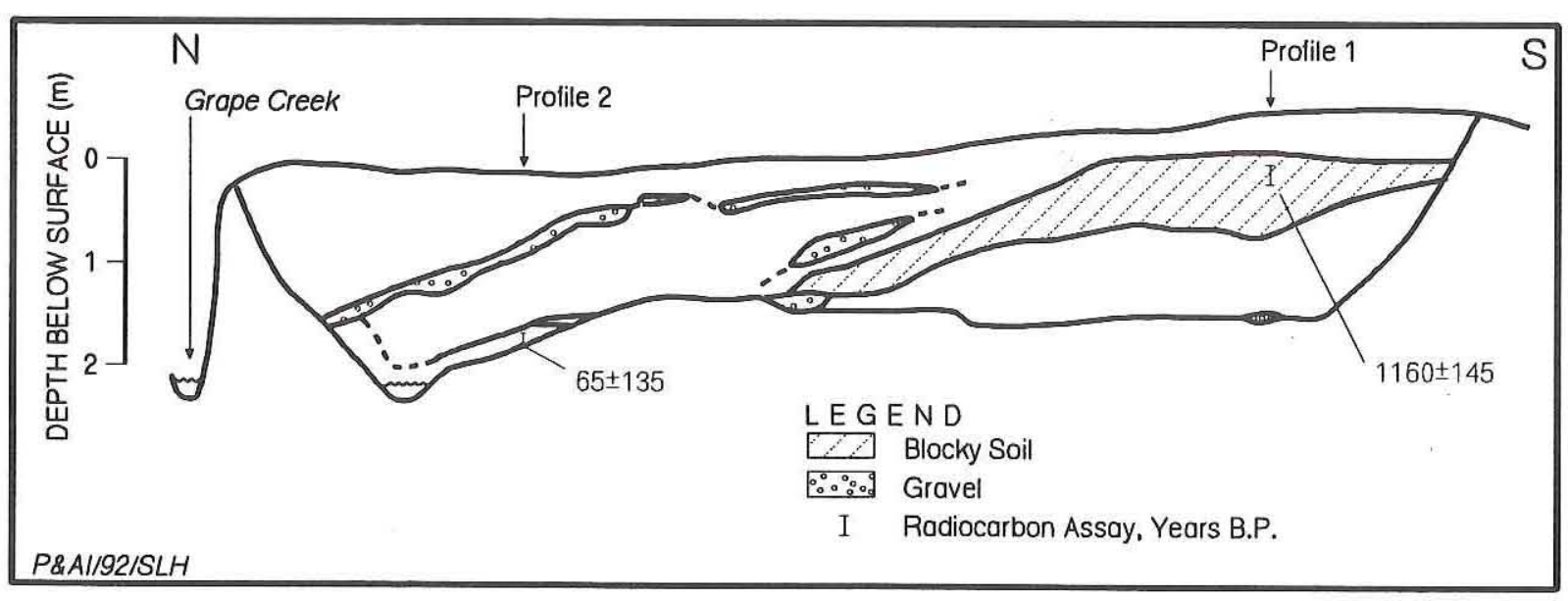

Figure 47. Grape Creek floodplain geological profiles, Backhoe Trench 1991-3. 
Grape Creek. A buried soil stratified above layers of sands and gravels, documented in Profile 2, indicates the infilling of an active stream channel and the development of a stable, nonaggrading surface on this channel fill. A radiocarbon date on total organic carbon from this soil suggests that this surface was extant at $1160 \pm 145$ B.P., cal. 1064 B.P. (GX-16511). A second radiocarbon assay on clays in the eastern portion of BHT 19913 indicates the presence of a low-energy channel at $65 \pm 135$ B.P., cal. $280-0$ B.P. Above this channel clay is a thin gravel layer that slopes toward the modern Grape Creek channel. The lower boundary of this gravel marks the initial erosion associated with the modern channel, and the well-bedded but thin sand and silt layers above this gravel are the lower portions of the modern and still-aggrading point bar. The thicker gravel deposit stratified above the eastern edge of the buried soil, identified in Profile 2, suggests that a second and older point bar associated with the channel clays is responsible for the accumulation of much of the sediment in this portion of the profile. However, the gradual buildup of sediments through point bar accretion was apparently interrupted by a small stream avulsion as indicated by the truncation of the channel clay by the youngest gravel layer. Total organic carbon from pedogenically altered floodplain sediments in Blum's (1989a) BHT 1987-5 (located ca. $250 \mathrm{~m}$ southwest of BHT 1991-3) were dated at $1750 \pm$ 60 B.P., and this demonstrates that the deposits in BHT 1991-3 are significantly younger and that Grape Creek has generally meandered from west to east in the late Holocene.

\section{CONCLUSIONS}

A number of amendments and refinements to the geological sequence established by Blum (1989a) and Abbott (1990) in the lower portion of the reservoir can be offered. These are illustrated in a schematic valley cross section (Fig. 48). First, the perched channel deposit on the upper valley margin at the inset cut bench represents the earliest

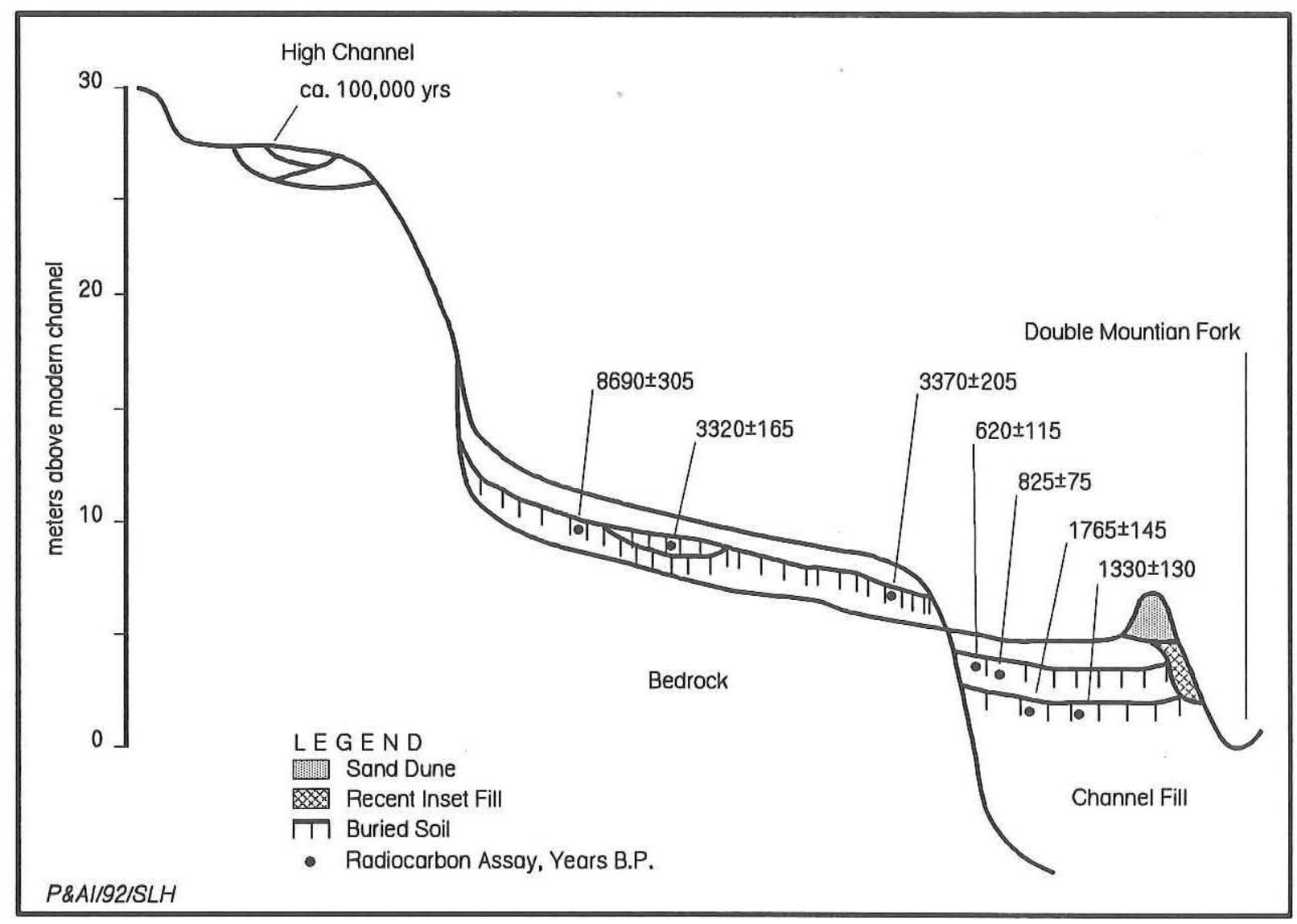

Figure 48. Schematic valley cross section. 
identified stage of valley incision. Unquestionably, this greatly predates the earliest human occupation anywhere in North America; however, if a chronometric age could be obtained, then it would provide a benchmark for rates of erosion and stream incision that could be useful in gauging Holocene geological processes.

The soil on the Older Terrace is at least 8,700 years in age; this demonstrates that the terrace is probably much older, and it is possible that the soil began to form in the late Pleistocene. These results suggest that sometime after 8700 B.P. the Older Terrace was eroded. It is possible that this erosional event is bracketed between the BHT 1991-2 soil date and the BHT 1991-2b sediment date, ca. 3300 B.P. This latter sample is stratified above two erosional unconformities capping the Older Terrace soil, so it clearly postdates an erosional event.

In the Double Mountain Fork floodplain, alternating surface stasis marked by soil development and floodplain construction is widely evident, with soils formed between $600-1000$ B.P. and between 1300-1800 B.P. Bore-hole logs of sediments in the remainder of the floodplain demonstrate the existence of alluvial deposits to a depth of $18-19 \mathrm{~m}$.

Analyses of sediments from the lower Grape Creek valley provide clear evidence of pedogenesis at approximately 1000 B.P., followed by stream meandering. This meandering of Grape Creek is not believed to be climate controlled, but it is clear that this process destroyed much of Late Prehistoric II archeological site 41GR484.

A general pattern is emerging from these limited geological investigations that is worth stating at this time. In the Double Mountain Fork valley, alluvial sediments are preserved best when immediately downstream of bedrock outcrops. The pipeline trench profiles are protected by the 41GR484 bedrock projection in the Double Mountain Fork floodplain, and the Older Terrace soil's most-complete occurrence is at BHT 1991-2 which is adjacent to a small bedrock outcrop that juts out slightly from the south valley wall. This pattern has not been recognized in the smaller drainage basins where good sediment preservation/storage often seems to occur upstream of bedrock constrictions in valley profiles. It appears that these protected downstream locales are most important for sediment preservation and temporary storage in the larger streams because of the erosion energy associated with the stream itself. In other words, the bedrock outcrops limit the amount of erosion caused by channel meandering of larger streams. Apparently, smaller streams do not contain enough energy to erode so effectively. 


\section{SUMMARY AND CONCLUSIONS}

Douglas K. Boyd, Steve A. Tomka, and C. Britt Bousman

This report documents the first of three separate field seasons of Phase III data recovery investigations at Justiceburg Reservoir. The Season 1 investigations included an archeological survey of 440 acres on South Sage Creek downstream from the reservoir's spillway, data recovery at one historic site (41KT42) and three prehistoric sites (41GR383, 41GR484, and 41KT33), and geoarcheological studies. The results of each of these investigations are summarized below. Since each of the sites provides relevant data, this chapter also evaluates the specific hypotheses and research questions proposed in the research design. The more comprehensive discussion of regional models and interregional interactions, such as presented in the research design (see Chapter 2), can be accomplished only through detailed intersite comparative studies on a broad scale. As a result, this portion of the discussion is deferred to the final synthetic report, by which time the analysis of data from all field seasons will have been completed.

\section{SOUTH SAGE CREEK SURVEY}

The archeological survey of the 440-acre tract on South Sage Creek (see Appendix A) discovered a total of nine new prehistoric sites. This investigation is the third archeological survey completed in conjunction with the City of Lubbock's Justiceburg Reservoir project. The total number of sites (excluding isolated finds) recorded in the project area is $377 ; 288$ sites have prehistoric components, historic components occur at 32 sites, and 74 sites contain Native American and/or Anglo rock art (Table 34). Thirteen of these sites have both prehistoric and historic components, while another four sites have prehistoric artifact components and rock art.

Four prehistoric sites in the South Sage Creek survey area $(41 \mathrm{KT} 153,41 \mathrm{KT} 155,41 \mathrm{KT} 159$, and $41 \mathrm{KT} 160$ ) could be eligible for listing on the National Register of Historic Places, but more information is needed before this assessment can be made. It is recommended that these sites not be impacted by reservoir activities, but if adverse effects cannot be avoided, then subsurface testing should be implemented for National Register assessments.

\section{DATA RECOVERY AT THE ARCHEOLOGICAL SITES}

Four archeological sites, one historic and three prehistoric, were excavated. These sites were selected for excavation to address specific issues, problems, and hypotheses identified and developed in the research design (see Chapter 2). Following are summaries of the data recovery investigations at each site and preliminary assessments of the applicability of the individual site data sets to the research design.

\section{Data Recovery at 41KT42}

A controlled surface collection of $1545 \times 5-m$ blocks constitutes the data recovery investigations 


\begin{tabular}{|l|l|l|l|c|}
\hline \multicolumn{5}{|c|}{ TUMMARY OF SITES AT JUSTICEBURG RESERVOIR* } \\
\hline & $\begin{array}{l}\text { Sites with } \\
\text { Prehistoric } \\
\text { (Native American) } \\
\text { Components }\end{array}$ & $\begin{array}{l}\text { Sites with } \\
\text { Historic } \\
\text { (Anglo) } \\
\text { Components }\end{array}$ & $\begin{array}{l}\text { Sites with Rock Art } \\
\text { (Native American } \\
\text { and Anglo) } \\
\text { Components }\end{array}$ & $\begin{array}{l}\text { Acres } \\
\text { Surveyed }\end{array}$ \\
\hline Survey & 243 & 30 & 74 & 8,600 \\
\hline 1987 Reservoir Survey & 5 & 1 & - & 0 \\
\hline $\begin{array}{l}1988 \text { Testing-Additional Sites } \\
\text { in Reservoir }\end{array}$ & 31 & 1 & - & 2,240 \\
\hline 1990 Wildlife Mitigation Survey & 9 & - & - & 440 \\
\hline 1990 South Sage Creek Survey & 288 & 32 & 74 & 11,280 \\
\hline Totals: & & & & \\
\hline *Excludes isolated finds & & & - & \\
\hline
\end{tabular}

at $41 \mathrm{KT} 42$ (see Chapter 4). A rock foundation and chimney excavated during the Phase II investigations are all that remain of a former structure, probably a wood-frame cabin, and two other rock features on the surface may have been smaller outbuildings. Cultural materials from the site consist of 634 artifacts recovered from all phases of work (see Table 9). The archeological assemblage complements the archival research, indicating that the site served as a ranching line camp prior to the turn of the century. The main structure may have been built as early as $1875-1885$ but more likely in the late 1880 s or 1890 s. Its construction cannot be definitely associated with any particular person, but it was associated with the OS Ranch during the early portion of its history. All evidence suggests that the site was occupied, perhaps at times even permanently, around the turn of the century from ca. 1880 to no later than 1920.

The paucity of nails in the artifact assemblage and the lack of charred wood in the foundation excavation suggest that the wood structure was scavenged rather than burned or rotted in place. It apparently was abandoned, or at least used very little, after ca. 1920, and the wooden superstructure may have been removed by this time.

The research design hypothesized that site $41 \mathrm{KT} 42$ is a unique example of a pre-1900, openrange line camp since it was a well-constructed wood-frame structure at a time when virtually all line camps were simple dugouts. Although this cannot be proven, the archival and archeological data suggest that this is indeed the case. Archival research indicates that the property was first purchased from the State of Texas between 1878 and 1882 at a time when most ranches only leased State-owned lands, thus making it one of the earliest land purchases in the project area. The line camp at $41 \mathrm{KT} 42$ was built during the open-range ranching period, which ended around the turn of the century when the 1895 Four-Section Act fragmented the large open-range ranches. The pre-1900 construction of the frame cabin at $41 \mathrm{KT} 42$ is thus explained in part by the fact that the ranchers actually owned the land, unlike most of their counterparts who only leased ranch land at that time.

\section{Data Recovery at $41 \mathrm{GR} 383$}

Data recovery excavations at $41 \mathrm{GR} 383$ consisted of fifty-three $1 \times 1-m$ excavation units which exposed three burned rock features and yielded 2,160 artifacts (see Chapter 5). Two of the excavation units were isolated from a contiguous block of 51 units. Combined with the artifacts from earlier investigations, the total artifact assemblage (Table 35) has few temporally diagnostic artifacts which include untypeable dart and arrow points (one possibly a Granbury arrow point) and bifaces that are probable dart or arrow point preforms. The most reliable radiocarbon dates $(1865 \pm 140$ B.P., 


\begin{tabular}{|c|c|c|c|c|c|}
\hline \multirow[b]{3}{*}{ Artifacts } & \multicolumn{4}{|c|}{$\begin{array}{c}\text { TABLE } 35 \\
\text { OF ARTIFACTS RECOVERED FROM 41GR383 }\end{array}$} & \multirow[b]{3}{*}{ Totals } \\
\hline & Phase I & \multicolumn{2}{|c|}{ Phase II } & \multirow{2}{*}{$\begin{array}{l}\text { Phase III } \\
\text { Excavation }\end{array}$} & \\
\hline & Surface & Surface & Excavation & & \\
\hline Arrow Points & - & 1 & - & 1 & 2 \\
\hline Dart Points & - & 4 & - & 1 & 5 \\
\hline Gouges & 1 & 6 & - & 2 & 9 \\
\hline Bifaces & - & 7 & 1 & 25 & 33 \\
\hline Cobble Tools & - & 5 & 4 & 10 & 19 \\
\hline Unifaces & & & & & \\
\hline End Scrapers & 1 & 14 & 1 & 4 & 20 \\
\hline Side Scrapers & - & 4 & - & 3 & 7 \\
\hline End/Side Scrapers & - & 3 & 1 & 2 & 6 \\
\hline Cutting Tool & - & 1 & - & - & 1 \\
\hline Indeterminate Edges & - & 1 & 1 & 2 & 4 \\
\hline Cores & - & 1 & 2 & 29 & 32 \\
\hline Edge-modified Flakes & . & & & & \\
\hline Saw/Cut & - & 4 & 10 & 4 & 18 \\
\hline Scrape & - & 4 & 3 & 45 & 52 \\
\hline Engrave & - & - & 1 & - & 1 \\
\hline Saw/Scrape & - & - & - & 6 & 6 \\
\hline Saw/Engrave & - & - & - & 1 & 1 \\
\hline Unmodified Debitage & - & 39 & 208 & 1,968 & 2,215 \\
\hline Ground Stones & & & & & \\
\hline Manos & - & 6 & - & 15 & 21 \\
\hline Metates & - & - & 1 & 35 & 36 \\
\hline Unknown Use & - & 4 & 3 & - & 7 \\
\hline Hammerstones & - & 1 & - & 5 & 6 \\
\hline Modified Shell & - & - & - & 1 & 1 \\
\hline Manuport & - & - & - & 1 & 1 \\
\hline Totals: & 2 & 105 & 236 & 2,160 & 2,503 \\
\hline
\end{tabular}

$1215 \pm 140$ B.P., and $1390 \pm 65$ B.P.) and geomorphic evidence suggest the site was occupied at the end of the Archaic period and the beginning of the Late Prehistoric period and that colluvial sedimentation buried the occupation in fine-grained sands and silts.

The vertical superposition of burned rocks in thicker portions of the site indicates multiple occupations, but the vertical distribution of diagnostic artifacts cannot be used to demonstrate the existence of distinct temporal components. A number of sites in the Southern Plains (e.g., Deadman's Shelter and Kent Creek Site) have dart points and arrow points in stratigraphic association (Willey and Hughes 1978; Cruse 1989). However, the stratigraphic associations are not well defined and could be due to mixing of late Archaic and
Late Prehistoric I occupations on these sites, could represent reuse and scavenging of abandoned dart points by more-recent Late Prehistoric I huntergatherers, or could represent a period of cultural transition when both dart points and arrow points were in use. Evidence from Central Texas and the Lower Pecos region suggests that the transitional period from dart points to arrow points was very short and that in most cases dart points and arrow points represent temporally distinct components (Dibble 1967; Prewitt 1981, 1985; Turpin 1982:2728). In southwestern Wyoming, Larralde (1990: 273-307) has argued that the wholesale replacement of darts points by arrow points did not occur because the two projectile armaments represent two distinct weapons systems - spears and bows and arrows - that were used for different purposes and 
thus complement each other. Bows and arrows bring down prey, and once disabled, spears tipped with dart points dispatch the prey. Larralde (1990) further argues that a gradual shift in hunting strategies resulted in the final replacement of dart points by arrow points. It is unfortunate that more unmixed assemblages from clear stratigraphic contexts are not available for this transitional period in the Southern Plains. The lack of stratigraphic resolution at 41GR383 will not allow this issue to be assessed and tested, and thus it remains unresolved.

The late Holocene human adaptation model mentioned in Chapter 2 and more fully discussed in the research design (Boyd and Tomka 1990) proposes that during times of bison abundance, such as proposed for the late Archaic period, human populations would have adopted a collector strategy for the procurement of bison, while during short (e.g., seasonal) periods of bison absence, human groups would have adopted a forager resource acquisition stance. The overall annual land-use pattern would have consisted of a seasonal shift between collector and forager strategies, the timing of the shifts being conditioned by bison availability.

To investigate this relationship between human adaptation and bison availability, the research design (see Chapter 2) presents a series of specific testable hypotheses grouped into four major research topics: (1) settlement patterns; (2) subsistence; (3) site structure; and (4) material culture. These research topics and the associated hypotheses serve to guide the discussion of the nature of the prehistoric occupations at 41GR383. Rather than beginning by addressing the reconstruction of settlement pattern, the broadest of the topics, the discussion commences at the more site-specific level (e.g., material culture, site structure, and subsistence).

Excluding cores, unknown-use ground stones, and unmodified debitage, the total artifact collection from 41GR383 contains 17 tool types. Four broad ranges of activities are represented in the collection but in considerably different proportions. The few projectile points are indicative of resource procurement activities. The bifaces, cobble tools, unifaces, edge-modified flakes, and various ground stone specimens indicate a heavy emphasis on resource processing. The gouges, cores, various manufacture-broken tools, and large quantity of unmodified debitage are indicative of tool manu- facture. Finally, a portion of the debitage in combination with the resharpening and reworking present on a number of tools is indicative of tool rejuvenation and reworking.

A number of the tool categories (e.g., edgemodified flakes) could have been and probably were used in more than one of these broad activity categories. Nonetheless, the range of activities indicated rules out the interpretation that this site was used as a specialized activity site for the bulk procurement of any particular subsistence resource. The fact that unmodified debitage and tools made on debitage (e.g, edge-modified flakes and a single unifacial cutting tool) outnumber chipped stone tools and cores 17 to 1 also suggests that the primary reason for the occupation of the site was not lithic procurement. The lack of an even greater disparity between manufacture refuse and chipped lithic tool and core counts, coupled with the probability that a good portion of the debitage results from tool rejuvenation and resharpening, suggests that a large portion of lithic tool manufacture activities occurred away from the site (e.g., procurement sites or staged manufacture of items at hunting camps).

Although it is likely that some procurement and processing activities do not involve chipped or ground stone tools, the ratio of chipped and ground stone tools to projectile points can be used as a rough indicator of the ratio of resource processing to resource procurement activities at the site. The ratio of 34:1 suggests that plant and animal resource processing activities were significantly more common at the site than resource procurement activities. Looking at faunal procurement and processing activities alone, the ratio of 25 chipped stone tools other than projectile points to 1 projectile point supports the same conclusion. Nonprojectile-point chipped stone tools outnumber ground stone tools 3:1. This suggests that faunal resource processing may have played a more significant role than plant processing among the activities at the site. However, the relatively high number of nonprojectile-point chipped stone tools may simply be due to the probability that a broader range of tool types is needed to process faunal resources compared to plant resources. The relatively large number of ground stone tools does suggest that wild plant food processing may have been an important activity. The presence of a possible pestle and bedrock mortars at the site is 
further evidence of plant processing. While the collection from 41GR383 probably represents multiple occupational episodes, not all of which were necessarily equivalent functionally, overall the artifact collection appears to be characteristic of a residential base camp.

Within a foraging land-use system, the full range of activities is carried out from and is represented at the residential base camps. The spatial segregation of activities into different specialized sites is a pattern characteristic of collector land-use systems. The seeming underrepresentation of faunal resource procurement and tool manufacture activities at 41GR383 suggests that perhaps these activities were carried out at other specialized sites. If this is correct, the existence of specialized activity sites in the settlement pattern points to a collector land-use system.

The ratio of highly expedient chipped lithic tools (i.e., edge-modified flakes) to formal nonprojectile-point chipped lithic tools is 0.8 to 1 . The facts that formal chipped lithic tools outnumber expedient tools and expedient tools tend to be more generalized than formally shaped items suggest that the chipped lithic tool assemblage consisted primarily of specialized tool kits. The fact that edgemodified flakes outnumber unifaces only 2 to 1 also indicates that formalized tools constituted a relatively significant proportion of the tool kits used at the site. In addition, the ratio of end scrapers to unifaces $(1.4: 1)$ suggests that hide processing was an important activity, assuming that end scrapers were hide-processing tools.

The proportion of formalized tools in the assemblage combined with the number of specialized hide-processing tools may be indicative of a tool assemblage that functioned within a collector system. It is assumed that the processing of bulk quantities of resources would necessitate a somewhat specialized tool assemblage. The presence of more-generalized tools may result from the functioning of the system within a foraging adaptive mode during a portion of the annual resource procurement cycle.

In summary, the material cultural evidence suggests that the site was a residential base camp where activities related to resource processing appear to have dominated those of resource procurement, with the exception perhaps of plant procurement. Plant processing activities appear to have played a significant role as may have been the case with hide processing. Lithic tool manufacture activities may have been less important compared to tool rejuvenation. These lines of evidence may be interpreted as indicating a land-use system that was collector oriented during part of the year, before and perhaps subsequent to the occupation of 41GR383, but that during the occupation of this site the system operated in a forager adaptive mode.

Site structural information indicates that some of the activities conducted at the site were centered around the hearths. There may have been some spatial separation between activity areas located adjacent to these features. It is impossible to determine whether these activity areas were single or multifunctional. Some general concem with activity area maintenance is indicated by clustering of unmodified debitage, fire-cracked rocks, and sandstone. This type of maintenance of generalized activity areas occurs among both foragers and collectors. However, the lack of specialized facilities or features used in the processing of bulk quantities of resources suggests that large quantities of any one resource, with the possible exception of stage-processed hides, were not introduced to the site. The lack of storage facilities also supports this interpretation. It is important to remember, however, that the block excavation unit represents only a small portion of the site and that specialized activity areas could have been missed by the block, especially given the possibility of well-segregated activity areas such as those expected among collectors.

The evidence regarding the subsistence of the occupants of the site is scarce. The possibility that cottontail and jack rabbit were culturally introduced, coupled with the presence of freshwater mussel shells and medium to large mammal remains, suggests a relatively broad diet. The absence of identifiable bison bones is intriguing, especially since the research design hypothesized that cultural groups utilizing the Southern Plains during the late Archaic bison-abundance period should have relied heavily on bison. If the absence of bison remains is not due to the poor preservation of bones in the site, the subsistence evidence may be interpreted at least three different ways: (1) the inhabitants of the site were not involved in bison procurement at all; (2) the site assemblage represents bison procurement of an extremely selective type; or (3) the site was occupied by bison-hunting groups during the off-season. The low number of 
projectile points, the large number of ground stone tools, and the possibility that the sparse faunal evidence is indicative of a broad diet suggest that the inhabitants of 41GR383 did not rely heavily on bison.

Alternatively, this same evidence may be interpreted as indicating that bison procurement was not staged directly from the site but that bison was an important part of the diet. The absence of bones may simply be due to the extremely selective transport of only meat and hides back to the residential camp. The processing of large quantities of meat for storage is expected to be manifested in drying facilities. These features were not recognized in the portion of the site encompassed by the excavation block. On the other hand, the presence of a large number of end scrapers may be indicative of the processing of fresh hides or the staged processing of hides obtained during the main hunting periods.

Finally, rather than assuming a highly selective transportation of bison meat, it is likely that the absence of bison skeletal elements may be a true indication that fresh bison meat was not introduced to this site on a regular basis. Rather, while the occupants of the site were bison hunters, the bison meat consumed at the site was introduced in the form of already processed pemmican or similar products. The site may have been occupied during the off-season when bison were not hunted, and hence the site could represent a late fall through early spring residential camp occupied by a group of people who were collectors during a part of the year but who operated in a foraging mode during the time of year that the site was occupied. The broad range of activities, diet, and reliance on plant resources supports this scenario, as does the apparent lack of evidence of faunal procurement activities at the site and the presence of a moderate number of end scrapers potentially used to finish processing bison hides acquired and partially processed during the actual hunting season.

Little can be said about the annual settlement pattern of any group based on a single site. As indicated above, the seeming underrepresentation of animal procurement activities among the site activities suggests the presence of a range of specialized activity sites as part of the land-use pattern. Another indication of the potential extent of the land-use system is gleaned from the chipped lithic raw material procurement practices. Although the possibility exists that some of the nonlocal raw materials present in the site were procured indirectly through trade, the fact that $37 \%(\mathrm{n}=900)$ of all the chipped lithic tools and debitage $(n=2,431)$ is from nonlocal sources suggests that the inhabitants of the site had access to the lithic resources of a relatively broad region. It is not known whether these nonlocal raw materials were procured through direct access, indirect access, or a combination of the two. However, the regional distribution of lithic resources suggests that artifacts made of Tecovas jasper and nonlocal Cretaceous cherts were most likely obtained through direct access and procurement. Artifacts of these two raw materials constitute $98.4 \%(n=886)$ of the nonlocal specimens. On the other hand, given the distance of available sources, artifacts made of Alibates agate were most likely obtained through trade or some other indirect means of procurement. Alibates agate specimens constitute $1.6 \%(n=14)$ of all the nonlocal specimens recovered from 41GR383. If these interpretations are correct, they indicate that the bulk of the nonlocal raw materials were obtained through direct procurement, while a small percentage may have been obtained through trade.

As indicated above, depending on how the artifactual, site structural, and subsistence data are interpreted, the site may be part of either a foraging resource acquisition system or a land-use system that combined foraging and collecting on a seasonal basis. If the assumptions underlying the research design are correct, and if the late Archaic period was a period of bison abundance, then it is likely that groups utilizing the Southern Plains and the project area would have exploited bison. The degree of reliance on bison would have depended on the season or seasons of bison availability. If the herds were present in the region on a seasonal basis rather than year-round, then a well-defined seasonal mix of foraging and collecting would be expected. However, even if bison herds were present year-round, the composition and structure of the herds may have varied sufficiently between the seasons to allow the procurement of large numbers of animals only during particular seasons. Smaller numbers of bison, coupled with the procurement of a broader range of animals, may have characterized other seasons of the year. During these seasons, the land-use system would have operated in a forager resource acquisition mode. The evidence from 41GR383 suggests that, as anticipated by the 
research design, the inhabitants of the site were involved in bison procurement only on a seasonal rather than year-round basis.

\section{Data Recovery at 41GR484}

Data recovery at $41 \mathrm{GR} 484$ consisted of surface collection of 2 artifacts and excavation of seventeen 1x1-m units that exposed two burned rock features but yielded only 27 artifacts (see Chapter 6). Wood charcoal from a hearth was identified as Carya sp., and it is probably pecan rather than hickory. Eight excavation units were isolated, while nine units were placed in a contiguous excavation block. This level of effort was substantially less than planned, but geoarcheological investigations demonstrated that recent meandering by Grape Creek has eroded the site by an unknown amount and a significant portion was destroyed. Since the artifact recovery was so low and much of the site was lost through erosion, the ability of the archeological component to allow reasonable interpretations was severely biased, and the archeological investigations were terminated. Combined with the artifacts from earlier phases (Table 36), the total assemblage consists of 94 artifacts.

The research design hypothesized that
41GR484 was a residential base camp generated by a bison-oriented collector system during the Late Prehistoric II period. Surface-collected arrow points and a 260 B.P. charcoal radiocarbon date associated with a hearth support this interpretation of a single Late Prehistoric II component. Due to the paucity of artifacts and the loss of an unknown portion of the site by erosion, additional interpretations are likely to be biased in indeterminable directions and degrees.

While the cultural materials do appear to represent a single component, multiple occupations are indicated by overlapping hearths and ground stones recycled as hearthstones. Lithic reduction, a common activity at campsites, is poorly represented by the cultural remains recovered, but ground stone tools are relatively abundant. In many ways, this site mimics other sites in the project area, such as the lower component at 41KT52 (and possibly the lower component at 41KT53), that have undoubtedly intact hearth features and ground stone tools but extremely low frequencies of chipped stone tools and debitage. Such sites could reflect specialized activities, perhaps related to procuring and/or processing some specific resource (e.g., plants or freshwater mussels). Low artifact densities at sites of this kind appear to be a very real

TABLE 36

SUMMARY OF ARTIFACTS RECOVERED FROM 41GR484

\begin{tabular}{|c|c|c|c|c|c|}
\hline \multirow[b]{2}{*}{ Artifacts } & \multicolumn{2}{|c|}{ Phase II } & \multicolumn{2}{|c|}{ Phase III } & \multirow[b]{2}{*}{ Totals } \\
\hline & Surface & Excavation & Surface & Excavation & \\
\hline Arrow Points & 1 & - & 1 & - & 2 \\
\hline Biface & - & 1 & - & - & 1 \\
\hline Cobble Tools & 2 & - & - & - & 2 \\
\hline Uniface (Cutting Tool) & - & 1 & - & - & 1 \\
\hline Cores & 2 & - & - & - & 2 \\
\hline Edge-modified Flakes & & & & & \\
\hline Saw/Cut & - & 1 & - & - & 1 \\
\hline Scrape & 1 & 1 & - & - & 2 \\
\hline Unmodified Debitage & 24 & 27 & - & 16 & 67 \\
\hline Ground Stones & & & & & \\
\hline Manos & 2 & - & 1 & 1 & 4 \\
\hline Metates & - & 1 & - & 5 & 6 \\
\hline Anvils & - & - & - & 2 & 2 \\
\hline Hammerstone & - & 1 & - & - & 1 \\
\hline Unmodified Pebbles (Manuports) & - & - & - & 3 & 3 \\
\hline Totals: & 32 & 33 & 2 & 27 & 94 \\
\hline
\end{tabular}


phenomenon at Justiceburg, and they probably represent a limited set of activities that might occur on sites occupied for very short periods of time (cf. Spurling and Hayden 1984). As they yield such sparse cultural evidence in the best of circumstances, these sites are difficult to interpret, and when significant portions are lost through natural processes such as erosion, the difficulties in interpretation are exponentially magnified.

Overall, the intensity of cultural activities, as reflected by artifact discard, is very low. The available evidence strongly suggests that 41GR484 (or at least the surviving portion) is a Late Prehistoric II special-activity area surrounding a hearth that may or may not have been attached to a residential camp. Because of the indeterminable nature of the component, its utility for addressing specific research design hypotheses is limited.

Nonetheless, the late Holocene human adaptation model mentioned with regard to 41GR383 also applies for 41GR484. It proposes that during times of bison abundance, such as the Late Prehistoric II period, human populations would have adopted an annual land-use pattern consisting of seasonal shifts between collector and forager strategies, the timing of the shifts being conditioned by bison availability. In addition to residential base camps occupied for some time, the settlement pattern would have consisted of a number of specialized site types. Subsistence activities would have focused on bison during seasons of availability and a broader range of resources during seasons of scarcity or when herd composition and structure did not allow the procurement of large numbers of animals. Site structure would be reasonably well developed on residential base camps and bulk resource procurement sites. The tool assemblage would consist of a mix of generalized tools in addition to some specialized items used in the procurement and processing of bulk resources.

The sample of artifacts recovered from 41GR484 is extremely small. The low mean frequency of artifacts per excavation unit (1.6) suggests either an ephemeral short occupation or a specilized activity site. Alternatively, it is possible that the 17 excavation units sampled a nonintensely used portion of the site. Given that an unknown portion of the site has been eroded by Grape Creek, it is possible that relatively little remains of the original site.

The small collection from 41GR484 contains artifacts indicative of four broad ranges of activities (i.e., resource procurement and processing and tool manufacture and rejuvenation). However, the 10 tool types recovered may or may not constitute a representative sample of the tool assemblage discarded on the site. If the percentages of the different tool types are considered representative of the proportions of activities, then the fact that ground stone tools outnumber chipped lithic tools 1.3 to 1 suggests that the site represents some type of specialized plant processing location. However, since a considerable number of the ground stone tools were surface finds and the majority of those recovered from the block excavation units are associated with burned rock features, it is also possible that the features, rather than the entire site, represent specialized activity areas associated with plant processing. It is impossible to conclude from the available data which of these interpretations is correct.

The evidence regarding subsistence practices and settlement patterns is equally sparse. The virtually total absence of faunal and floral evidence does not permit any speculation on the nature of the subsistence practices of the inhabitants of the site. Little can be said beyond the obvious observation that plant and animal resources were consumed. Given the small area excavated, there is a strong probability that, unlike 41GR383, the absence of identifiable bison bones at 41GR484 is due to incomplete site coverage. However, it is also possible, as mentioned above, that the site represents a specialized plant procurement and processing site. If the latter interpretation is correct, it would suggest that even during seasons when reliance on bison was low, the inhabitants of the region did maintain a collector resource procurement system by focusing on the bulk procurement of some type of plant resource. Unfortunately, however, the small area excavated and the small sample of artifacts do not provide sufficient evidence regarding the land-use system employed by the inhabitants of the site, and it cannot be established whether the site fits with either of the models developed in the research design or provides a hitherto unanticipated aspect of the Late Prehistoric II regional land-use systems.

\section{Data Recovery at 41KT33}

Data recovery at site $41 \mathrm{KT} 33$ consisted of 
excavation of 7 dispersed $1 \times 1-m$ sample units and 62 contiguous $1 \times 1-m$ units in an excavation block (see Chapter 7). Two burned rock features were encountered, and 2,113 artifacts were recovered (including 1 surface specimen). Combined with the artifacts recovered from previous investigations, the site assemblage includes 2,340 specimens (Table 37).

The total site assemblage appears to represent at least two components. The testing phase recovered dart points that led to an initial assessment of late Archaic age for the site. Data recovery excavations in the block, however, produced only Late Prehistoric artifacts, and a radiocarbon sample from Feature 12 yielded an age estimate of
1005 B.P. Ten arrow points and six ceramic sherds were recovered from the excavation block. The ceramics and most of the arrow points, as well as the radiocarbon date, suggest a Late Prehistoric I component; however, a single Harrell arrow point in the second level implies a Late Prehistoric II contribution to the artifact assemblage. Because of coarse stratigraphic resolution and the possibility of component mixing, the remainder of the artifacts, including those excavated from the widely scattered sample units, cannot be associated with the materials in the excavation block with any degree of confidence. Even though an arrow point was recovered from a sample unit, suggesting that some of these other materials are from the same time

TABLE 37

SUMMARY OF ARTIFACTS RECOVERED FROM 41KT33

\begin{tabular}{|c|c|c|c|c|c|c|c|c|}
\hline \multirow[b]{2}{*}{ Artifacts } & \multicolumn{2}{|c|}{ Phase I } & \multicolumn{2}{|c|}{ Phase II } & \multicolumn{3}{|c|}{ Phase III } & \multirow[b]{2}{*}{ Totals } \\
\hline & Surface & Excavation & Surface & Excavation & Surface & $\begin{array}{l}\text { Sample Unit } \\
\text { Excavation }\end{array}$ & $\begin{array}{l}\text { Excavation } \\
\text { Block }\end{array}$ & \\
\hline Arrow Points & - & - & - & - & - & 1 & 10 & 11 \\
\hline Dart Points & - & - & 1 & 1 & - & - & - & 2 \\
\hline Perforators & - & - & - & - & - & - & 2 & 2 \\
\hline Gouges & - & - & 1 & - & - & 1 & - & 2 \\
\hline Bifaces & - & - & 2 & - & - & - & 6 & 8 \\
\hline Cobble Tools & - & - & 4 & 3 & - & - & 10 & 17 \\
\hline \multicolumn{9}{|l|}{ Unifaces } \\
\hline End Scrapers & 1 & - & 3 & - & - & 1 & 5 & 10 \\
\hline Side Scrapers & - & - & 1 & - & - & - & 1 & 2 \\
\hline End/Side Scrapers & 1 & - & - & - & - & - & 6 & 7 \\
\hline End Scrapers/Gravers & - & - & - & - & - & - & 2 & 2 \\
\hline Indeterminate Edges & - & - & 1 & 1 & - & - & 13 & 15 \\
\hline Cores & - & - & - & 4 & - & - & 40 & 44 \\
\hline \multicolumn{9}{|l|}{ Edge-modified Flakes } \\
\hline Saw/Cut & - & - & - & - & - & - & 17 & 17 \\
\hline Scrape & - & - & 3 & 7 & - & 7 & 110 & 120 \\
\hline Engrave & - & - & - & 1 & - & 1 & 2 & 3 \\
\hline Saw/Scrape & - & - & - & - & - & - & 3 & 3 \\
\hline Saw/Engrave & - & - & - & - & - & - & 4 & 4 \\
\hline Saw/Scrape/Engrave & - & - & - & - & - & - & 1 & 1 \\
\hline Unmodified Debitage & - & 5 & 41 & 137 & - & 52 & 1,775 & 2,010 \\
\hline \multicolumn{9}{|l|}{ Ground Stones } \\
\hline Manos & 1 & - & 2 & - & - & 1 & 11 & 15 \\
\hline Metates & - & - & - & - & 1 & - & 25 & 26 \\
\hline Unknown Use & - & - & 2 & 1 & - & - & - & 3 \\
\hline Hammerstones & - & - & 4 & - & - & - & 4 & 8 \\
\hline Ceramics & - & - & - & - & - & - & 6 & 6 \\
\hline Modified Shells & - & - & - & - & - & - & 2 & 2 \\
\hline Totals: & 3 & 5 & 65 & 155 & 1 & 56 & 2,055 & 2,340 \\
\hline
\end{tabular}


period as those from the excavation block, the presence of dart points casts doubt on the association of the total site assemblage. Hence, only the materials recovered from the excavation block are considered when discussing the site's Late Prehistoric component.

The artifact assemblage is characterized by Scallom, Harrell, untyped, and untypable fragmentary arrow points and Jornada brownware ceramics. The component is considered to be related to the eastern extension of the Jornada Mogollon as proposed by Corley (1965) and possibly to the Palo Duro Complex as proposed by Willey and Hughes (1978) and summarized by Hughes (1991). In either case, influence from the Jornada region is implied.

The arrow points include unnotched (possible preforms), corner-notched, and side-notched varieties that are in many ways similar to specimens (types 1-3) illustrated by Leslie (1978) as being characteristic of the eastern Jornada area of southeastern New Mexico. The absence of Deadman's arrow points suggests that the $41 \mathrm{KT} 33$ occupations may not belong to the Palo Duro Complex. If the ca. 750 B.P. (A.D. 1200) transition from corner- to side-notched arrow points in the eastern Jornada area (which corresponds with the late Querecho into early Maljamar phases) can be extrapolated to the Lower Plains, then the presence of a side-notched (Harrell) arrow point at $41 \mathrm{KT} 33$ would be further indication that the assemblage may consist of Late Prehistoric I and Late Prehistoric II components. The 750 B.P. date for this transition, however, is speculative (based on ceramic typological dating and tenuous arrow point associations) and cannot be supported by independent chronological evidence.

The brownware ceramics recovered from $41 \mathrm{KT} 33$ certainly link the site to the Jornada area but not necessarily to the Palo Duro Complex. The petrographic analysis (see Appendix F) revealed that the 41KT33 sherds are somewhat different than those from ca. A.D. 200-700 at Deadman's Shelter but are most similar to some of the sherds from ca. A.D. $700-1000$ at the Kent Creek Site. Although the full implications of these ceramic data still require further investigation, one tentatively offered interpretation is that these ceramic differences reflect chronological variability (see discussion of the petrographic analysis later in this chapter).

The research design initially proposed that site $41 \mathrm{KT} 33$ fits into the late Archaic period, but the data recovery investigation revealed primarily a Late Prehistoric I component in the excavation block. After temporal reassignment, it was proposed that the site functioned as a residential base camp generated within a residentially mobile forager system. Initially, the Late Prehistoric I period was proposed to date from 2000-1000 B.P., but these dates were acknowledged as tentative. In reality, the timing of the transition from Late Prehistoric I to Late Prehistoric II, which generally correlates with the shift from corner- to sidenotched arrow points, is poorly documented although it is likely to be between $1000-700$ B.P. A single radiocarbon date places the age of the 41KT33 excavation block component at 1005 B.P. Thus, the radiocarbon date and the majority of the temporally diagnostic cultural materials fit well in the latter portion of the Late Prehistoric I period, but the presence of the side-notched Harrell point casts a shadow of doubt. The 41KT33 excavation block data can be interpreted as representing a relatively discrete component dating to the Late Prehistoric I/Late Prehistoric II transition period, or as a mix of very different components from both of these time periods. Unfortunately, the evidence from this site alone does not favor one interpretation over the other.

The late Holocene human adaptation model mentioned earlier in this chapter proposes that during times of bison scarcity, such as proposed for the Late Prehistoric I period, human populations would have adopted a generalized forager resource acquisition strategy by relying on a broad range of resources. The annual land-use pattern would have consisted of high residential mobility with the number of moves, the group size, and the length of stay in any one area being dependent on the productivity of the different resource patches. Most archeologically recognizable sites would be residential base camps with a broad but similar range of activities represented at each camp. The diet would have consisted of a broad range of resources with some constituents overrepresented at sites located in more-productive patches. Site structure would be poorly defined, and the tool assemblage would be generalized.

To investigate strategies of human adaptation during such bison-scarce periods, the research design (see Chapter 2) presents a series of specific testable hypotheses grouped into four major research topics: (1) settlement patterns; (2) subsis- 
tence; (3) site structure; and (4) material culture. As in the case of $41 \mathrm{GR} 383$, the discussion of the nature of the prehistoric occupations at $41 \mathrm{KT} 33$ is organized along these four research topics. The discussion commences with the consideration of the material culture and continues with site structure, subsistence practices, and settlement patterns.

Excluding cores, unknown-use ground stones, and unmodified debitage, the total artifact assemblage from $41 \mathrm{KT} 33$ contains 19 tool types. As in the case of $41 \mathrm{GR} 383$, four broad ranges of activities are represented, but in contrast to $41 \mathrm{GR} 383$ the activities appear to be represented in more-similar proportions. The moderately frequent projectile points are indicative of resource procurement activities. The bifaces, cobble tools, unifaces, edge-modified flakes, and various ground stone specimens indicate a heavy emphasis on resource processing. Gouges, cores, various manufacturebroken tools, and the large quantity of unmodified debitage are indicative of tool manufacture. Finally, a portion of the debitage in combination with the resharpening and reworking present on a number of tools is indicative of tool rejuvenation and reworking.

A number of the tool categories (e.g., edgemodified flakes) could have been and probably were used in more than one of these broad activity categories. Nonetheless, as in the case of $41 \mathrm{GR} 383$, the range of activities rules out the interpretation that $41 \mathrm{KT} 33$ was a specialized activity site used in the bulk procurement of any particular subsistence resource. The fact that unmodified debitage and tools made on debitage (e.g., edge-modified flakes and a single unifacial cutting tool) outnumber chipped stone tools and cores 20 to 1 suggests that lithic tool manufacture activities were a significant activity at the site. This pattern contrasts significantly with that observed at 41GR383. Overall, the artifact assemblage appears to be characteristic of a residential base camp, although, as in the case of 41GR383, it is important to remember that multiple, functionally varied occupational episodes are possible.

Although some procurement and processing activities may not be represented by chipped and/or ground stone tools, the ratio of chipped and ground stone tools to projectile points can be used as a rough indicator of the proportion of resource processing to resource procurement activities at the site. The ratio of 19:1 suggests that resource procurement activities in general were significantly more common at this site than at 41GR383. Looking at faunal procurement and processing activities alone, the ratio of 15 chipped stone tools other than projectile points to 1 projectile point supports the same conclusion. Nonprojectile-point chipped stone tools outnumber ground stone tools 5:1. This suggests that faunal resource processing may have played a more significant role than plant processing among the activities at the site. This pattern contrasts significantly with the relatively greater importance of plant processing activities at 41GR383.

Within a foraging land-use system, the full range of activities is carried out from and is represented at each of the residential base camps occupied through the annual cycle. The more balanced representation of faunal resource procurement and tool manufacture activities at $41 \mathrm{KT} 33$ suggests that these activities played a more equal role at this site compared to 41GR383. This pattern may also imply a narrow range of site types used during the year, a land-use pattern that is most characteristic of a foraging system.

The ratio of highly expedient chipped lithic tools (i.e., edge-modified flakes) to formal nonprojectile-point chipped lithic tools is 3 to 1 . The facts that expedient tools outnumber formal chipped lithic tools and that expedient tools tend to be more generalized than formally shaped items suggest that the chipped lithic tool assemblage from 41KT33 consisted primarily of functionally generalized tool kits. The fact that edge-modified flakes outnumber unifaces 7 to 1 , a much higher ratio than at 41GR383, also indicates that expedient tools constituted a relatively significant proportion of the tool kits used at the site. In addition, the ratio of end scrapers to other unifaces (0.9:1) suggests that hide processing was not as common as at 41GR383.

The proportion of expedient tools in the assemblage combined with the low number of specialized hide-processing tools may be indicative of a tool assemblage that functioned within a forager system. The overall lack of specialized tools may indicate that the human adaptive system had a foraging resource acquisition component throughout the annual resource procurement cycle.

In summary, the material cultural evidence suggests that the site was a residential base camp where activities related to both resource procurement and processing took place. Lithic tool manu- 
facture activities may have been as important as tool rejuvenation. These lines of evidence may be interpreted as indicating a land-use system that was forager oriented throughout the year. This interpretation contrasts significantly with that of 41GR383, where a resource acquisition mode that shifted seasonally between a collector and a forager stance has been proposed. Site structural information indicates that domestic activities were positioned in relation to the hearths in a regular manner. The distributions of lithic debitage, fire-cracked rocks, and ground stone tools suggest some spatial separation between activity areas located adjacent to these features. The areas surrounding the hearths appear to represent generalized activity areas. Although activities occurring at the same time may have been spatially segregated, with the exception of the hearth, no particular area appears to have been used for one activity alone. Although some clustering of unmodified debitage and fire-cracked rocks is apparent, it is difficult to say whether this represents less concern with activity area maintenance than noted at 41GR383. The lack of specialized facilities or features used in the processing of bulk quantities of resources suggests that large quantities of any one resource were not introduced to the site. The lack of storage facilities also supports this interpretation.

The evidence regarding the subsistence of the occupants of the site is poor. The presence of only freshwater mussel shells and the absence of identifiable bones allow no conclusions regarding the diet and subsistence of the inhabitants of the site. The generalized tool assemblage alluded to earlier suggests that subsistence consisted of a broad range of resources without the bulk procurement of any one resource. Such a subsistence pattern would be consistent with that employed by foragers. However, the near lack of data allows only speculations regarding subsistence practices.

As for 41GR383, little can be said about the annual settlement pattern of any group based on a single site. However, the balanced representation of animal procurement and animal and plant processing activities at the site suggests that the full range of activities carried out in forager residential camps is represented at $41 \mathrm{KT} 33$. This pattern is in significant contrast to that noted at 41GR383. Another potential indicator of the size of the region exploited by the site's inhabitants is provided by the chipped lithic raw material procurement practices. Although the mechanisms by which the nonlocal raw materials present in the site were obtained is not known, the fact that only $21 \%(n=489)$ of all the chipped lithic tools and debitage $(n=2,280)$ is from nonlocal sources suggests that the inhabitants of the site had more-limited access to nonlocal resources than the inhabitants of $41 \mathrm{GR} 383$. If, as noted for 41GR383, Tecovas jasper and Cretaceous cherts were obtained through direct procurement, the fact that $99.2 \%(n=485)$ of the nonlocal specimens consist of these two materials suggests that direct raw material procurement may have been more common at $41 \mathrm{KT} 33$ than at $41 \mathrm{GR} 383$. Only $0.8 \%$ $(n=4)$ of the nonlocal specimens consist of raw materials derived from more-distant sources (e.g., Alibates agate $[\mathrm{n}=3]$ and obsidian $[\mathrm{n}=1])$. The Alibates agate specimens, the obsidian flake, and the Jornada Brown pottery indicate that some extraregional contacts were maintained between groups inhabiting the project area and the surrounding regions. However, the sparse quantity of materials derived from distant sources suggests that these extraregional contacts may have been intermittent rather than part of a well-developed regional interaction sphere.

Overall, the composition of the tool assemblage, the range of activities performed at the site, and the minimal site structural evidence suggest that the site was occupied by foragers. Unlike 41GR383, no evidence exists at 41KT33 suggesting that the annual land-use pattern included specialized activity sites. This conclusion further implies that the inhabitants of the site practiced a forager resource procurement strategy throughout the year.

If the assumptions underlying the research design are correct and if the Late Prehistoric I period was a period of bison scarceness, then it is likely that groups utilizing the Southern Plains and the project area would have exploited a broad range of plant and animal resources. Lacking high-yield resources that could have provided surplus, food storage was probably minimal and stores may have lasted only short times. This subsistence pattern would have necessitated high residential mobility throughout the year to allow the tracking of the harvest schedules of different resources. The evidence from $41 \mathrm{KT} 33$ suggests that the inhabitants of the site were year-round foragers. 


\section{GEOARCHEOLOGICAL INVESTIGATIONS}

Off-site geological investigations were designed to assess and supplement the previous late Pleistocene and Holocene geological sequences developed for the project area by Blum (1989a) and Abbott (1990). Off-site geological investigations also were conducted in areas where the new information could be used to assess the geological histories of the investigated prehistoric archeological sites. These off-site studies supplemented the geological efforts conducted within archeological sites.

In the lower portion of the project area, Abbott (1990) identified an alluvial terrace known informally as the Older Terrace; however, no radiocarbon dates were assayed at that time. The occurrence of $41 \mathrm{KT} 33$ on the Older Terrace necessitated continued investigations in order to assess the stratigraphic integrity of the archeological assemblage. During these investigations, a wood charcoal sample from the sheet colluvial deposit at $41 \mathrm{KT} 33$ produced a radiocarbon age estimate of 1005 B.P., and geological investigations confirmed that the underlying Older Terrace has a truncated soil. Bulk carbon from this soil produced an age estimate of 3370 B.P. at $41 \mathrm{KT} 33$. At the southwestern end of 41KT33, two new backhoe trenches, BHTs 1991-2 and 1991-2b, excavated through a gravelly colluvial apron that flanks the steep valley wall, exposed a much more complete and less truncated profile of the Older Terrace. Radiocarbon assays on bulk carbon from this soil produced an age estimate of 8690 B.P., and an organic-rich deposit in a small channel fill produced an age estimate of 3320 B.P.

In the floodplain of the Double Mountain Fork of the Brazos River, a long pipeline trench exposed two buried soils. Charcoal from the uppermost soil was dated to $825-620$ B.P., and bulk sediments from the lower soil dated to 13301765 B.P. Geotechnical bore-hole logs demonstrated a total of $18 \mathrm{~m}$ of fluvial deposits in the floodplains, and it is suggested here that much of these deposits probably accumulated in the Holocene. Based on these results, it is likely that massive erosion removed much of the Older Terrace during the middle Holocene when drought conditions were severe in the Southern Plains (Meltzer and Collins 1987; Holliday 1989; Collins and Bousman 1990; Meltzer 1991). This erosional episode may be bracketed approximately by the radiocarbon dates from BHTs 1991-2 and 1991-2b, i.e., $8690-3320$ B.P., and it is possible that much of the buried floodplain deposits recorded by the bore-hole logs accumulated after this erosional episode.

Off-site geological investigations also focused on recent meandering of Grape Creek and demonstrated that the modern channel began to cut to the east some time after 280 B.P. This cutbank erosion destroyed much of archeological site 41GR484, which itself was occupied only a short time before.

Geoarcheological investigations on archeological sites focused on assessing the geological integrity of the prehistoric archeological materials. All three prehistoric sites occur in colluvial deposits. At 41GR383 and 41GR484, the colluvium rests directly on bedrock, while at $41 \mathrm{KT} 33$ the colluvial deposits sit on a truncated soil that caps the Older Terrace.

At 41GR383, colluvial deposition appears to be the primary agent of sedimentation. Bedrock is near the surface, but most deposits were in place by 2000-1000 B.P. At the northern edge of the site, adjacent to a county road and disturbed by its construction, was an infilled gully. Here, sediments accumulated more rapidly and to greater depths, and a weakly developed buried soil and superpositioning of buried rocks and artifacts within the gully suggest multiple occupations.

Sediment and chronological information at 41GR484 demonstrate a colluvial accumulation there in the late Holocene, and it appears that the Late Prehistoric II archeological occupation was buried by fairly low energy sedimentation on the slope and possibly truncated or interfingering with alluvial deposits near the river channel. As discussed above, Grape Creek meandering appears to have eroded a considerable portion of this site.

At 41KT33, the colluvial deposits could date to anytime within the last 3,000 years, and a radiocarbon date from the excavation block suggests it was accumulating there by 1,000 years ago. Prehistoric artifacts at $41 \mathrm{KT} 33$ along with the radiocarbon date from the underlying buried soil suggest that the surface of the Older Terrace was utilized for a longer period of time, however. Sediments on the site and surface grade can be used to suggest that low-energy colluvial accumulation 
with a likely eolian contribution are the processes responsible for burial.

\section{SUMMARY AND ASSESSMENT OF TECHNICAL STUDIES}

Five technical studies were incorporated with the first season of data recovery investigations at Justiceburg Reservoir. These are radiocarbon dating, macrobotanical and pollen analyses, faunal analysis, and petrographic analysis. These are discussed individually below.

\section{Chronometric Dating}

Sixteen radiocarbon dates were obtained from this season at Justiceburg Reservoir. Eleven samples are bulk sediments from geological and archeological sites, four are charcoal, and one is on the gelatin fraction of bone. All radiocarbon determinations were corrected for ${ }^{13} \mathrm{C} /{ }^{12} \mathrm{C}$ fractionation effects and tree-ring calibrated (see Appendix G). In most cases, charcoal is the preferred material for radiocarbon dating, but it is not well preserved at Justiceburg, even in prehistoric hearths. Because of the small sample sizes, two charcoal samples were combined in order to obtain a conventional assay, and one sample was dated by the AMS technique.

Bulk sediment radiocarbon dates can suffer from at least two problems. The first is the deposition of older carbon during the accumulation of the sediment, and the second is the introduction of younger carbon by materials leaching down-profile. In some depositional environments such as lacustrine deposits, neither process seems to have a significant effect (Hillaire-Marcel et al. 1989), but in other depositional environments, older or younger carbon can influence radiocarbon ages (Birkeland 1984; Haas et al. 1986). Identifying the actual occurrence of these contamination problems is not easy and requires matched charcoal and soil radiocarbon dates.

Charcoal and bulk sediment radiocarbon samples from the pipeline trench were submitted for dating, and the stratigraphic positions of these samples do not conflict with their radiocarbon assays; however, these are not matched samples, so a detailed assessment of the bulk sediment radiocarbon ages is not possible. At 41GR383, charcoal and bulk sediment samples were collected from below the rocks in Feature 13. The bulk sediment sample radiocarbon date is 1215 B.P., cal. 1163 B.P., and the charcoal radiocarbon determination is 1390 B.P., cal 1299 B.P. Clearly, the bulk sediment sample is contaminated slightly by younger carbon moving down-profile. The young age obtained on bulk sediment from a buried soil in EU 52 at the same site is believed to be contaminated by more-recent carbon as well. These sediments are very sandy, and in general it appears that the chance for young carbon contamination increases as the amount of leaching increases. As leaching occurs more easily in sandy sediments, the collection of bulk sediment radiocarbon samples from sandy deposits should be avoided when possible. The problem at Justiceburg is that sandy sediments are very common.

\section{Macrobotanical Analysis}

Six bulk sediment samples from buried features were processed by flotation, and three yielded no macrobotanical remains. The three samples that did contain macrobotanical remains were sent to the Archeobotanical Laboratory at Texas A\&M University for identification. One of these samples, fill from Feature 12 at $41 \mathrm{KT} 33$, contained no identifiable macrobotanical materials. The remaining two samples, both from Feature 1 at 41GR484, had Carya sp. charcoal. Juniperus sp. charcoal previously was identified from this feature, and within the entire project area, charcoal from hackberry, dogwood, juniper, mesquite, oak, sumac, and the rose and willow families have been identified.

The macrobotanical samples were extremely small due to poor recovery and possibly poor preservation, but they do provide limited information on possible resources and past environments. The presence of Carya approximately 300 years ago in the Justiceburg region may have important climatic implications because this taxa does not occur in the area today. It is too dry. These data, while limited, do provide important information on past resources and past environments in the Southern Plains.

\section{Pollen Analysis}

Twelve sediment samples were collected from feature and nonfeature contexts in archeological sites. Five pollen wash samples from stone arti- 
facts and burned rocks were processed, but these yielded a total of only four pollen grains.

Six of the sediment samples produced enough pollen for standard 200-grain counts, and counts in the remaining six samples ranged between 19-80 grains. Percentages of indeterminate pollen grains were high (11.4-40.9\%), and pollen concentration values were low $(146-1622$, average $=593$ grains/ $\mathrm{ml}$ of sediment). In addition, an average of only five taxa were identified in each sediment sample, and the identified taxa were very repetitive among samples. In general, as pollen concentration values decline the percent of indeterminate pollen grains increases and the number of identifiable taxa declines. These factors suggest that biases caused by poor pollen preservation are a serious problem, and interpretations based on these pollen data in most samples are unjustified. The high $\mathrm{pH}$ values from analyzed sediments (see Appendix I) 'suggest that well-preserved pollen will be difficult to locate. The vagaries of pollen preservation are well illustrated by Samples 5 and 6. Both were taken from the same feature. The concentration value in Sample 5 was 242 grains $/ \mathrm{ml}$, and the concentration in Sample 6 was 1,622 grains $/ \mathrm{ml}$. The total pollen count and number of identifiable taxa follow a similar pattern. At the present time, it is unclear which buried contexts contain acceptably preserved pollen.

\section{Faunal Analysis}

Limited faunal remains were recovered from the excavations at 41GR383, 41GR484, and $41 \mathrm{KT} 33$. Invertebrates comprise the most common group. Succinea luteola, a snail, was recovered in small numbers from 41GR383 and 41KT33. One species of freshwater mussel, Uniomerus declivus, was recovered from $75 \%$ of the excavation units at 41 GR 383 and $98 \%$ of the block excavation units at 41KT33. It was present in one excavation unit at 41GR484. Drilled mussel shells were recovered from 41GR383 and 41KT33, and some specimens from $41 \mathrm{KT} 33$ exhibit evidence of having been heated along the hinge. These data suggest that freshwater mussels were commonly utilized as food and their shells as manufacturing material at some sites. It is possible that shell ornaments were trade items in interregional exchange systems as apparently occurred during Late Prehistoric II and Protohistoric times (Habicht-Mauche 1988:144).
Mammal bones were virtually absent, and the ones that were present are believed to be introduced by modern bioturbation. While it is possible that the absence of bones is related to site function, it is more likely a factor of differential preservation. Soils are fairly alkaline (see $\mathrm{pH}$ values in Appendix I) but leaching is probably great, and this has stimulated the poor preservation of bones.

\section{Petrographic Analysis}

Robinson's petrographic analysis (Appendix F) is an important step toward accurately characterizing the nonlocal Mogollon brownwares and thus Jornada influence in the Southern Plains. It provides a useful comparison of Mogollon brownware sherds from the South Sage Creek Site (41KT33), the Deadman's Shelter (41SW23), and the Kent Creek Site (41HL66) (Willey and Hughes 1978; Cruse 1989). Ceramics from the latter two sites were selected for the analysis because their brownware sherds have been identified as Jornada Brown or variants of this type, and because they are from important dated archeological sites within the Lower Plains region. Additionally, many cultural similarities exist between these two sites and $41 \mathrm{KT} 33$ (see Chapter 7 discussion).

The sampled sherds from $41 \mathrm{KT} 33$ are all body sherds (possibly from the same vessel) that were independently identified by Jack Hedrick and Regge Wiseman as Jornada Brown. Both analysts noted the relatively high mica content, and Wiseman thought that they closely resembled the Middle Pecos Micaceous Brown variety (see Chapter 7).

The three sampled sherds from Deadman's Shelter are all from stratum $D$, radiocarbon dated to $1830-1740$ B.P., and include two body sherds and an olla rim sherd (illustrated in Willey and Hughes 1978:Fig. 64). Similar sherds were also recovered in stratum $B$, radiocarbon dated to $1485-$ 1240 B.P., and in undated strata $C$ and E, but these were not selected for petrographic analysis. All of the sherds were visually identified by Helene Warren as Jornada Brown, but she noted their similarity to Alma Plain. Warren considered most of the sherds to be tempered with crushed andesite from the Sierra Blanca region of New Mexico.

The six sherds from the Kent Creek Site were identified by Jack Hedrick and are classified as two each Jornada Brown, Roswell Brown, and Middle Pecos Micaceous Brown. These sherds are from a 
cultural occupation radiocarbon dated to 1240 840 B.P.

The petrographic analysis generally supported the visual identifications with a few exceptions. Based on the point-count data, all sherds were found to be tempered with crushed volcanic rock (predominantly feldspars), but two distinct groups were defined. Group 1 is characterized by $60-70 \%$ temper (nonplastic inclusions) of which $12-20 \%$ is biotite. Group 1 sherds consist of all sherds from 41KT33 (specimens 1-3) and three sherds from 41 HL66 (specimens 8, 10, and 12). Group 2 is characterized by $30-50 \%$ temper with less than $2 \%$ biotite. Group 2 sherds consist of all sherds from Deadman's Shelter (specimens 4-6) and three sherds from the Kent Creek Site (specimens 7, 9, and 11). Thus, the petrographic analysis suggests that the Group 1 sherds are similar to the Middle Pecos Micaceous Brown type, while the Group 2 sherds are most similar to the Jornada Brown type. According to the point-count data, only one sherd would be retyped (specimen 10 from 41HL66 is most similar to Middle Pecos Micaceous Brown), and there is no clear petrographic basis for separating the Roswell Brown from the Jornada Brown.
Because of these attributes and the frequency of volcanic rock, all of the sampled sherds are considered to be nonlocal ceramics manufactured in the Jornada Mogollon region of southeastern New Mexico. The angularity and size of the fragments suggest the use of crushed rock temper which was obtained at a primary or secondary igneous rock source. Thus, in summary, the earliest sherds from Deadman's Shelter are all Group 2 and date to approximately $1850-1250$ B.P. The sample from the Kent Creek Site dates to ca. 1240-840 B.P. and contains both Group 1 and Group 2 sherds that most likely were used contemporaneously. And finally, the sherds from $41 \mathrm{KT} 33$ are all Group 1 micaceous ceramics and date to ca. 1005 B.P. The temper variability observed in this sample might be fortuitous, but it could also signal meaningful temporal trends. Perhaps the variability indicates differences in source areas that are tied to local geological variability among manufacturing localities, thus indicating shifts in trade relations. Another possible explanation is that the Jornada potters selectively increased the amount of temper and mica content through time. Neither inference can be conclusively supported or refuted at this time. 


\section{REFERENCES CITED}

Abbott, James T.

1990 Geomorphic and Geoarcheological Investigations. Chapter 4 in Phase II Investigations at Prehistoric and Rock Art Sites, Justiceburg Reservoir, Garza and Kent Counties, Texas, by Douglas K. Boyd, James T. Abbott, William A. Bryan, Colin M. Garvey, Steve A. Tomka, and Ross C. Fields, pp. 23-62. Reports of Investigations No. 71, Volume I. Prewitt and Associates, Inc., Austin.

Alexander, Robert K.

1982 Archaeological Site Reconnaissance in the Proposed Justiceburg Reservoir Area, Garza County, Texas. Grand River Consultants, Inc., Grand Junction, Colorado.

Barnes, Frank C.

1989 Cartridges of the World. Sixth edition. D.B.I. Books, Inc., Northfield, Illinois.

Barnes, Virgil E. (project director)

1967 Geologic Atlas of Texas, Lubbock Sheet. Bureau of Economic Geology, The University of Texas at Austin.

Bartram, Laurence E., Ellen M. Kroll, and Henry T. Bunn 1991 Variability in Camp Structure and Bone Food Refuse Patteming at Kua San Hunter-Gatherer Camps. Chapter 4 in The Interpretation of Archaeological Spatial Patterning, edited by Ellen M. Kroll and T. Douglas Price, pp. 77148. Interdisciplinary Contributions to $\mathrm{Ar}-$ chaeology. Plenum Press, New York.

Bell, Robert E.

1958 Guide to the Identification of Certain American Indian Projectile Points. Special Bulletin No. 1. Oklahoma Anthropological Society, Norman.
Bell, Willis H., and Edward F. Castetter

1937 The Utilization of Mesquite and Screwbean by the Aborigines in the American Southwest. University of New Mexico Bulletin No. 314. Ethnobiological Studies in the American Southwest, Biology Series Vol. 5, No. 2. University of New Mexico Press, Albuquerque.

Binford, Lewis R.

1978 Dimensional Analysis of Behavior and Site Structure: Learning from an Eskimo Hunting Stand. American Antiquity 43(3):330-361.

1980 Willow Smoke and Dogs' Tails: HunterGatherer Settlement Systems and Archaeological Site Formation. American Antiquity 45(1):4-20.

Birkeland, Peter W.

1984 Soils and Geomorphology. Oxford University Press, Oxford, England.

Blair, W. Frank

1950 The Biotic Provinces of Texas. Texas Journal of Science 2(1):93-117.

Blum, Michael D.

1989a Geoarcheological Investigations. Chapter 7 in Phase I Cultural Resources Investigations at Justiceburg Reservoir on the Double Mountain Fork of the Brazos River, Garza and Kent Counties, Texas, by Douglas K. Boyd, Martha Doty Freeman, Michael D. Blum, Elton R. Prewitt, and J. Michael Quigg, pp. 81-106. Reports of Investigations No. 66, Volume I. Prewitt and Associates, Inc., Austin.

1989b Geoarcheological Trench Data. Appendix D in Phase I Cultural Resources Investigations at 
Justiceburg Reservoir on the Double Mountain Fork of the Brazos River, Garza and Kent Counties, Texas, by Douglas K. Boyd, Martha Doty Freeman, Michael D. Blum, Elton R. Prewitt, and J. Michael Quigg, pp. 389-395. Reports of Investigations No. 66, Volume I. Prewitt and Associates, Inc., Austin.

Boyd, Douglas K.

1989 Prehistoric Resources in Justiceburg Reservoir. Chapter 8 in Phase I Cultural Resources Investigations at Justiceburg Reservoir on the Double Mountain Fork of the Brazos River, Garza and Kent Counties, Texas, by Douglas K. Boyd, Martha Doty Freeman, Michael D. Blum, Elton R. Prewitt, and J. Michael Quigg, pp. 107-131. Reports of Investigations No. 66, Volume I. Prewitt and Associates, Inc., Austin.

Boyd, Douglas K., James T. Abbott, William A., Bryan, Colin M. Garvey, Steve A. Tomka, and Ross C. Fields

1990 Phase II Investigations at Prehistoric and Rock Art Sites, Justiceburg Reservoir, Garza and Kent Counties, Texas. Reports of Investigations No. 71.2 vols. Prewitt and Associates, Inc., Austin.

Boyd, Douglas K., C. Britt Bousman, and Martha Doty Freeman

1991 Archeological Survey of Wildlife Mitigation Lands, Justiceburg Reservoir, Garza County, Texas. Reports of Investigations No. 79. Prewitt and Associates, Inc., Austin.

Boyd, Douglas K., Martha Doty Freeman, Michael D. Blum, Elton R. Prewitt, and J. Michael Quigg

1989 Phase I Cultural Resources Investigations at Justiceburg Reservoir on the Double Mountain Fork of the Brazos River, Garza and Kent Counties, Texas. Reports of Investigations No. 66. 2 vols. Prewitt and Associates, Inc., Austin.

Boyd, Douglas K., and Steve A. Tomka

1990 A Model of Late Holocene Human Adaptation for Justiceburg Reservoir. In Chapter 8, Phase II Investigations at Prehistoric and Rock Art Sites, Justiceburg Reservoir, Garza and Kent Counties, Texas, by Douglas K. Boyd, James T. Abbott, William A. Bryan, Colin M. Garvey, Steve A. Tomka, and Ross C. Fields, pp. 261-273. Reports of Investigations No. 71, Volume II. Prewitt and Associates, Inc., Austin.
Bradley, Bruce

1975 Lithic Reduction Sequences: A Glossary and Discussion. In Lithic Technology: Making and Using Stone Tools, edited by E. Swanson, pp. 5-14. Mouton, The Hague.

Brown, Theodore M., Kay L. Killen, Helen Simons, and Virginia A. Wulfkuhle

1982 Resource Protection Planning Process for Texas. Texas Historical Commission, Austin.

Busch, Jane

1981 An Introduction to the Tin Can. Historical Archaeology 15(1):95-104.

Callahan, Everett

1979 The Basics of Biface Knapping in the Eastern Fluted Point Tradition: A Manual for Flintknappers and Lithic Analysts. Archaeology of Eastern North America 7:1-180.

Campbell, Robert G.

1975 Archaeological Reconnaissance of Portions of the South Plains Region. Texas Tech University, Lubbock.

1977 Archaeological Reconnaissance of Portions of the South Plains Planning Region. Report No. 2: Corrections and Additions. Texas Tech University, Lubbock.

Campbell, Robert G., and Sharon J. Judd

1977a Archaeological Reconnaissance of Portions of the South Plains Planning Region. Report No. 3: Tabulation of Archaeological Sites and Materials. Department of Anthropology, Texas Tech University, Lubbock.

1977b Archaeological Reconnaissance of Portions of the South Plains Planning Region. Report No. 4: Analysis of Archaeological Materials. Department of Anthropology, Texas Tech University, Lubbock.

Caran, S. C., and R. W. Baumgardner

1990 Quaternary Stratigraphy and Paleoenvironments of the Texas Rolling Plains. Geological Society of America Bulletin 102:768-785.

Clifton, Robert T.

1970 Barbs, Prongs, Points, Prickers, and Stickers: A Complete and Illustrated Catalogue of Antique Barbed Wire. University of Oklahoma Press, Norman. 
Collins, Michael Bruce

1968 The Andrews Lake Locality: New Archeological Data from the Southern Llano Estacado, Texas. Master's thesis, The University of Texas at Austin.

Collins, Michael B., and C. Britt Bousman

1990 Cultural Implications of Late Quatemary Environmental Change in Northeastem Texas. Ms. on file, Texas Historical Commission, Austin.

Corley, John A.

1965 Proposed Eastern Extension of the Jomada Branch of the Mogollon. Bulletin of the Lea County Archeological Society 1:30-36.

Couzzourt, Jim

1985 Preliminary Report: Testing at the Tascosa Creek Site, Oldham County, Texas. Transactions of the Twentieth Regional Archeological Symposium for Southeastern New Mexico and Western Texas:65-142.

Crabtree, Don E.

1972 An Introduction to Flintworking. Occasional Papers of the Idaho State Museum No. 28. Pocatello.

Cruse, J. Brett

1989 Archeological Investigations at the Kent Creek Site (41HL66): Evidence of Mogollon Influence on the Southern Plains. Unpublished Master's thesis, Department of Anthropology, Texas A\&M University, College Station.

Dibble, David S.

1967 Excavations at Arenosa Shelter, 1965-66. Texas Archeological Salvage Project, The University of Texas at Austin.

Etchieson, Gerald Meeks, Roberta D. Speer, and Jack T. Hughes

1979 Archeological Investigations in the Crowell Reservoir Area, Cottle, Foard, King and Knox Counties, Texas. Archeological Research Laboratory, Killgore Research Center, West Texas State University, Canyon.

Fike, Richard E.

1987 The Bottle Book: A Comprehensive Guide to Historic, Embossed Medicine Bottles. Peregrine Smith Books, Salt Lake City.

Flayderman, Norm 1980 Flayderman's Guide to Antique American
Firearms and their Values. 2nd edition. D.B.I. Books, Inc., Northfield, Illinois.

Freeman, Martha Doty

1990a Natural Resources Exploitation and Development: Buffalo Hunting on the Rolling Plains, 1874-1879. Chapter 2 in Phase II Historical Investigations at Justiceburg Reservoir, Garza and Kent Counties, Texas, by Martha Doty Freeman and Douglas K. Boyd, pp. 7-48. Reports of Investigations No. 72. Prewitt and Associates, Inc., Austin.

1990b Agriculture in Texas: Ranching on the Westem Rolling Plains, 1877-1945. Chapter 3 in Phase II Historical Investigations at Justiceburg Reservoir, Garza and Kent Counties, Texas, by Martha Doty Freeman and Douglas K. Boyd, pp. 51-97. Reports of Investigations No. 72. Prewitt and Associates, Inc., Austin.

Freeman, Martha Doty, and Douglas K. Boyd

1990 Phase II Historical Investigations at Justiceburg Reservoir, Garza and Kent Counties, Texas. Reports of Investigations No. 72. Prewitt and Associates, Inc., Austin.

Gargett, Rob, and Brian Hayden

1991 Site Structure, Kinship, and Sharing in Aboriginal Australia: Implications for Archaeology. Chapter 1 in The Interpretation of Archaeological Spatial Patterning, edited by Ellen M. Kroll and T. Douglas Price, pp. 1132. Interdisciplinary Contributions to Archaeology. Plenum Press, New York.

Greer, Georgeanna H.

1981 American Stonewares: The Art and Craft of Utilitarian Potters. Schiffer Publishing Limited, Exton, Pennsylvania.

Gregg, Susan A., Keith W. Kintigh, and Robert Whallon

1991 Linking Ethnoarchaeological Interpretation and Archaeological Data: The Sensitivity of Spatial Analytical Methods to Postdepositional Disturbance. Chapter 5 in The Interpretation of Archaeological Spatial Patterning, edited by Ellen M. Kroll and T. Douglas Price, pp. 149-196. Interdisciplinary Contributions to Archaeology. Plenum Press, New York.

Gustavson, Thomas C., and William W. Simpkins 1989 Geomorphic Processes and Rates of Retreat Affecting the Caprock Escarpment, Texas Panhandle. Reports of Investigations No. 180. Bureau of Economic Geology, The University of Texas at Austin. 
Haas, H., V. Holliday, and R. Stuckenrath

1986 Dating of Holocene Stratigraphy with Soluble and Insoluble Organic Fractions at the Lubbock Lake Archaeological Site, Texas: An Ideal Case Study. Radiocarbon 28(2A):473-485.

Habicht-Mauche, Judith Ann

1988 An Analysis of Southwestern-style Utility Ware Ceramics from the Southern Plains in the Context of Protohistoric Plains-Pueblo Interaction. University Microfilms International, Ann Arbor, Michigan.

Hackenberger, Steven, and Britt Bousman

1978 Resource Utilization and Hunter-Gatherer Demography: An Application of Jochim's Model. In An Archaeological Reconnaissance of Fort Sill, Oklahoma, assembled by C. Reid Ferring, pp. 212-234. Contributions of the Museum of the Great Plains, No. 6. Lawton, Oklahoma.

Hayden, Brian

1986 Resource Models of Inter-Assemblage Variability. Lithic Technology 15(3):82-89.

1987 Reply to Conaty. Lithic Technology 16(23):62.

Hendrix, John M.

1941 Texas Cow-Towns: Colorado City. The Cattleman 27(April):29-48, 53.

Herskovitz, Robert M.

1978 Fort Bowie Material Culture. University of Arizona Press, Tucson.

Hester, Thomas R., Delbert Gilbow, and Alan D. Albee

1973 A Functional Analysis of "Clear Fork" Artifacts from the Rio Grande Plain, Texas. American Antiquity 38(1):90-96.

Hillaire-Marcel, Claude, Anne-Marie Ancour, Raymonde Bonnelfille, Guy Riollet, Annie Vincens, and David Williamson

$1989{ }^{13} \mathrm{C} /$ Palynological Evidence of Differential Residence Times of Organic Carbon Prior to its Sedimentation in East African Rift Lakes and Peat Bogs. Quaternary Science Review 8: 207-212.

Hofman, Jack L., and Robert L. Brooks

1989 Prehistoric Culture History: Woodland Complexes in the Southern Great Plains. Chapter 5 in From Clovis to Comanchero: Archeological Overview of the Southern Great Plains, by Jack L. Hofman, Robert L. Brooks, Joe S.
Hays, Douglas H. Owsley, Richard L. Jantz, Murray X. Marks, and Mary H. Manhein, pp. 61-70. Research Series No. 35. Arkansas Archeological Survey, Fayetteville.

Holliday, V. T.

1989 Middle Holocene Drought on the Southern High Plains. Quaternary Research 31:74-82.

Hughes, Jack T.

1962 Lake Creek: A Woodland Site in the Texas Panhandle. Bulletin of the Texas Archeological Society 32(for 1961):65-84.

1991 Prehistoric Cultural Developments on the Texas High Plains. Bulletin of the Texas Archeological Society 60(for 1989):1-55.

Hughes, Jack T., and Patrick S. Willey

1978 Archeology at Mackenzie Reservoir. Archeological Survey Report 24. Office of the State Archeologist, Texas Historical Commission, Austin.

Hume, Ivor Noël

1969 A Guide to Artifacts of Colonial America. Alfred A. Knopf, New York.

Israel, Fred L.

19761897 Sears Roebuck Catalogue. Chelsea House Publishers, New York.

Jelinek, Arthur J.

1967 A Prehistoric Sequence in the Middle Pecos Valley, New Mexico. Anthropological Papers No. 31. Museum of Anthropology, University of Michigan, Ann Arbor.

Jelks, Edward B.

1962 The Kyle Site: A Stratified Central Texas Aspect Site in Hill County, Texas. Archaeology Series No. 5. Department of Anthropology, The University of Texas at Austin.

Johnson, Jay K.

1979 Archaic Biface Manufacture: Production Failures, a Chronicle of the Misbegotten. Lithic Technology 8(2):25-35.

1981 Further Additional Biface Production Failures. Lithic Technology 10(2-3):26-28.

Jones, Mrs. J. Lee, and O. W. Cline

1940 Frontier Days in Mitchell County and Colorado City. West Texas Historical Association Year Book 16(October):28-60. 
Jones, Mrs. J. Lee, and Rupert N. Richardson

1943 Colorado City, The Cattlemen's Capital. West Texas Historical Association Year Book 19 (October):36-63.

Judd, Sharon J.

1977 Prehistoric Cultural Resources in the Central Llano Estacado and Western Rolling Plains of Texas. Master's thesis, Department of Anthropology, Texas Tech University, Lubbock.

Kane, A. E., and C. K. Robinson

1988 Dolores Archeological Program: Anasazi Communities at Dolores: McPhee Village. U.S. Department of the Interior, Bureau of Reclamation, Engineering and Research Center, Denver.

Keeley, Lawrence $\mathrm{H}$.

1980 Experimental Determination of Stone Tool Use: A Microwear Analysis. The University of Chicago Press, Chicago.

Kelly, Robert L.

1980 Hunter-Gatherer Settlement Systems. Master's thesis, Department of Anthropology, University of New Mexico, Albuquerque.

1983 Hunter-Gatherer Mobility Strategies. Journal of Anthropological Research 39(3):277-306.

Kenmotsu, Ray D.

1981 An Assessment and Overview of the Flora of the Brazos Natural Salt Pollution Control Project Area. Appendix VII in A Preliminary Assessment of the Cultural Resources in the Brazos Natural Salt Pollution Control Project, Kent, King, and Stonewall Counties, Texas, by J. Peter Thurmond, Martha Doty Freeman, and Susan L. Andrews, pp. 339-351. Reports of Investigations No. 18. Prewitt and Associates, Inc., Austin.

Larralde, Signa Larue

1990 The Design of Hunting Weapons: Archaeological Evidence from Southwestern Wyoming . Unpublished Ph.D. dissertation, The University of New Mexico, Albuquerque.

Lehmer, Donald J.

1948 The Jornada Branch of the Mogollon. University of Arizona Bulletin 19(2); Social Science Bulletin 17. Tucson.

Leonhardy, Frank C.

1966 Test Excavations in the Mangum Reservoir
Area of Southwestern Oklahoma. Contributions of the Museum of the Great Plains, No. 2. Lawton, Oklahoma.

Leslie, Robert H.

1978 Projectile Point Types and Sequence of the Eastem Jomada-Mogollon, Extreme Southeastern New Mexico. Transactions of the 13th Regional Archeological Symposium for Southeastern New Mexico and Western Texas:81-157.

Lobeck, A. K.

1948 Physiographic Diagram of the United States. The Geographical Press, Maplewood, New Jersey.

Long, Austin, and Bruce Rippeteau

1974 Testing Contemporaneity and Averaging Radiocarbon Dates. American Antiquity 39(2, Part 1):205-215.

Longacre, William A., and James E. Ayres

1968 Archeological Lessons from an Apache Wickiup. In New Perspectives in Archeology, edited by Sally $\mathbf{R}$. Binford and Lewis $\mathbf{R}$. Binford, pp. 151-159. Aldine, Chicago.

Lorrain, Dessamae

1968 An Archeologist's Guide to Nineteenth Century American Glass. Historical Archeology 2:3544.

Mason Johnston and Associates, Inc.

n.d. Geotechnical Investigation, Justiceburg Dam, Kent/Garza Counties, Texas. 3 vols. Mason Johnston and Associates, Inc., Dallas.

Matthews, William H., III

1969 The Geologic Story of Palo Duro Canyon. Guidebook 8. Bureau of Economic Geology, The University of Texas at Austin.

McCallum, Henry D., and Frances T. McCallum

1965 The Wire that Fenced the West. University of Oklahoma Press, Norman.

Meltzer, David J.

1991 Altithermal Archaeology and Paleoecology at Mustang Springs on the Southern High Plains of Texas. American Antiquity 56(2):236-267.

Meltzer, David J., and Michael B. Collins

1987 Prehistoric Water Wells on the Southem High Plains: Clues to Altithermal Climate. Journal of Field Archaeology 14:9-28. 
Miller, George L.

1980 Classification and Economic Scaling of 19th Century Ceramics. Historical Archaeology 14: $1-40$.

Mobley, Charles M.

1978 Archaeological Research and Management at Los Esteros Reservoir, New Mexico. Archaeology Research Program, Department of Anthropology, Southern Methodist University, Dallas.

Moncure, Henry B.

1984 Historical Archeology at the Walling Cabin, 41RK104, Rusk County, Texas. Research Report No. 88. Texas Archeological Survey, The University of Texas at Austin.

Mueller, Chester, and John Olson

1968 Small Arms Lexicon and Concise Encyclopedia. 1st edition. Shooter's Bible, Inc., New Jersey.

Munday, Frederick C.

1984 Middle Paleolithic Intrasite Variability and its Relationship to Regional Patteming. In Intrasite Spatial Analysis in Archaeology, edited by Harold Hietala, pp. 32-43. Cambridge University Press, Cambridge, England.

Muto, Guy R.

1971 A Technological Analysis of the Early Stages in the Manufacture of Lithic Artifacts. Master's thesis, Idaho State University, Pocatello.

Nelson, Lee $\mathrm{H}$.

1968 Nail Chronology: An Aid to Dating Old Buildings. Technical Leaflet 48 of the American Association for the Advancement of State and Local History, Nashville (or) History News 24(11):detachable leaflet.

O'Connell, James F.

1987 Alyawara Site Structure and its Archaeological Implications. American Antiquity 52(1):74108.

O'Connell, James F., Kristen Hawkes, and Nicholas Blurton Jones

1991 Distribution of Refuse-producing Activities at Hadza Residential Base Camps: Implications for Analyses of Archaeological Site Structure. Chapter 3 in The Interpretation of Archaeological Spatial Patterning, edited by Ellen M. Kroll and T. Douglas Price, pp. 61-76. Interdisciplinary Contributions to Archaeology. Plenum Press, New York.
Odell, George H., and Frank Cowan

1986 Experiments with Spears and Arrows on Animal Targets. Journal of Field Archaeology 13(2):195-212.

Pass, Fred

1981 Texas Almanac and State Industrial Guide, 1982-1983. A. H. Belo, Dallas.

Peterson, John

1988 Prairie Hinterland: The Archaeology of Palo Duro Creek, A Cultural Resources Inventory. Archaeological Research, Inc., Austin.

Prewitt, Elton R.

1981 Cultural Chronology in Central Texas. Bulletin of the Texas Archeological Society 52:65-89.

1985 From Circleville to Toyah: Comments on Central Texas Chronology. Bulletin of the Texas Archeological Society 54(for 1983): 201-238.

Raisz, Erwin

1957 Landforms of the United States. Map, 6th revised edition, to accompany Atwood's "Physiographic Provinces of North America."

Rock, James T.

1984 Cans in the Countryside. Historical Archaeology 18(2):97-111.

Runkles, Frank A.

1964 The Garza Site: A Neo-American Campsite near Post, Texas. Bulletin of the Texas Archeological Society 35:101-125.

Runyan, John W., and John A. Hedrick

1987 Pottery Types of the Southwest Federation of Archaeological Societies (SWFAS) Area. The Artifact 25(4):23-59.

Schiffer, Michael B.

1987 Formation Processes of the Archaeological Record. University of New Mexico Press, Albuquerque.

Shiner, Joel L.

1975 The Clear Fork Gouge Revisited. Bulletin of the Texas Archeological Society 46:179-188.

Smiley, Nancy Kays

1977 Analysis of Ceramic Materials from McGregor Range. In A Cultural Resource Inventory and Assessment of McGregor Guided Missile Range, Otero County, New Mexico, Vol. 2: Special Archeological Studies, by Michael R. 
Beckes, Alan R. Dulaney, John D. Pigott, Robert F. Scott, IV, and Nancy Kays Smiley, pp. 129-261. Research Report No. 65, Part II. Texas Archeological Survey, The University of Texas at Austin.

Soil Survey Staff

1975 Soil Taxonomy: A Basic System of Soil Classification for Making and Interpreting Soil Surveys. Soil Conservation Service, U.S. Department of Agriculture, Washington, D.C.

South, Stanley

1977 Method and Theory in Historical Archeology. Academic Press, New York.

Spurling, Brian, and Brian Hayden

1984 Ethnoarchaeology and Intrasite Spatial Analysis: A Case Study from the Australian Western Desert. In Intrasite Spatial Analysis in Archaeology, edited by Harold Hietala, pp. 224-241. Cambridge University Press, Cambridge, England.

Tomka, Steve A.

1986 Biface Manufacture Failures. In Intensive Excavations of the State Highway 71 Rightof-Way, 41BP19, Bastrop County, Texas, by Leland C. Bement, pp. 110-129. Ms. on file, Texas Archeological Research Laboratory, The University of Texas at Austin.

Tomka, Steve A., and Ross C. Fields

1990 Chipped Stone Artifacts, 41LN29A and 41LN106. Chapter 9 in Excavations at the Charles Cox, Lambs Creek Knoll, and Buffalo Branch Sites, Jewett Mine Project, Leon and Freestone Counties, Texas, edited by Ross C. Fields, pp. 141-287. Reports of Investigations No. 70, Volume I. Prewitt and Associates, Inc., Austin.

Tringham, R., G. Cooper, G. Odell, B. Voytek, and A. Whitman

1974 Experimentation in the Formation of Edge Damage: A New Approach to Lithic Analysis. Journal of Field Archaeology 1:171-196.
Turpin, Solveig A.

1982 Seminole Canyon: The Art and the Archeology, Val Verde County, Texas. Research Report No. 83. Texas Archeological Survey, The University of Texas at Austin.

Wallace, Ernest, and E. Adamson Hoebel

1952 The Comanches, Lords of the South Plains. University of Oklahoma Press, Norman.

Wetherbee, Joan

1985 A Second Look at White Ironstone. WallaceHomestead Book Co., Lombard, Illinois.

White, Henry P., and Burton D. Munhall

1977 Cartridge Headstamp Guide. H. A. White Laboratory, Belair, Maryland. Originally published in 1963, First Revision by R. T. Huntington and D. R. Dunn.

Willey, Patrick S., and Jack T. Hughes

1978 The Deadman's Shelter Site. In Archeology at Mackenzie Reservoir, edited by Jack T. Hughes and Patrick S. Willey, pp. 149-190. Archeological Survey Report No. 24. Texas Historical Commission, Austin.

Wilson, Rex L.

1981 Bottles on the Western Frontier. University of Arizona Press, Tucson.

Wulfkuhle, Virginia A.

1986 Investigations into the Prehistory of the Upper Clear Fork of the Brazos River, Fisher and Jones Counties, Texas. Master's thesis, The University of Texas at Austin.

Yellen, John E.

1977 Archaeological Approaches to the Present: Models for Reconstructing the Past. Academic Press, New York.

Yerkes, Richard W.

1987 Prehistoric Life on the Mississippi Floodplain: Stone Tool Use, Settlement Organization, and Subsistence Practices at the Labras Lake Site, Illinois. University of Chicago Press, Chicago. 

APPENDIX A: Archeological Survey of South Sage Creek, Kent County, Texas

\author{
Douglas K. Boyd
}





\section{INTRODUCTION}

As part of it's Justiceburg Reservoir project, the City of Lubbock is acquiring an additional ca. 360 acres of land along the lower east side of South Sage Creek, beginning at the point where the proposed emergency spillway enters the creek and extending downstream to its confluence with the Double Mountain Fork of the Brazos River. This tract of land will not be subject to any direct impacts associated with the construction of the reservoir; however, it could be subject to secondary impacts from accelerated erosion as a result of emergency spillway overflow, or it could be developed after Lake Alan Henry is completed. At the request of the City, an archeological survey was conducted to provide a cultural resources inventory for future planning and use. The survey was conducted during the Season I data recovery investigations.

The project area specified by the City of Lubbock prior to the survey consisted of ca. 440 acres. Negotiations for the land purchases were under way at that time, but the final agreements were not made until after the fieldwork was completed. As a result of these negotiations, the City will purchase 360 acres, a tract that is ca. 80 acres smaller than the survey area. Thus, all references herein to the South Sage Creek survey area (Fig. 49) denote the 440-acre tract that was actually surveyed.

The survey area (see Fig. 49) is located along the east side of South Sage Creek, from its mouth upstream for $3.5 \mathrm{~km}$. The creek valley is wide at its mouth and then constricts upstream until it splits into two branches, one that continues southward and one that turns eastward. The northern half of the survey area is dominated by the South Sage alluvial valley but also includes some bedrock (sandstones and mudstones which are dominantly Triassic but may include some Permian deposits) hills and ridges along its eastern edge. These landforms are erosional remnants that extend north and west from the upland flat. Sporadic colluvial gravel concentrations are found on the bedrock remnants, having been redeposited from ancient upland channel deposits (cf. Lingos Formation). The southern half of the survey area is primarily a narrow alluvial valley confined within a steepwalled canyon but also includes ca. 70 acres of upland flats. In some areas, the upland ends abruptly at the canyon rim, with a nearly vertical $30-\mathrm{m}$ dropoff into the valley. In other places, the canyon edge is not as clearly defined, and differential erosion of the bedrock has created moderate to gently sloping valley walls, stair-stepped benches, and isolated ridges and knolls. Sporadic outcrops of channel gravels are found along the upland margin and have been redeposited onto lower bedrock benches. The total relief in the survey area is ca. $50 \mathrm{~m}$, and elevations range from 2120 to $2280 \mathrm{ft}$ above mean sea level (msl).

\section{METHODS}

Prior to the field survey, a review of the archeological records at the Texas Archeological Research Laboratory at The University of Texas at Austin revealed that no previously recorded sites were located within the survey area. Previously compiled historical documentation was also reviewed to identify potential historic sites, but none were located. In addition, aerial photographs and topographic data were reviewed to identify high and low site probability areas and the extent of modern ground disturbance within the survey tract.

The field investigation consisted of a $100 \%$ pedestrian reconnaissance of the survey area by a crew of five archeologists. Transects spaced at 20$30-\mathrm{m}$ intervals were used to cover all flat or gently sloping areas, but survey transects following landform topography have been demonstrated to be very effective and were used in the canyon-confined, narrow-valley portions of the survey area. All survey and recording methods employed in the South Sage Creek survey are consistent with those used during the 1987 reservoir survey (Boyd et al. 1989: 76-79) and the 1990 wildlife mitigation lands survey (Boyd et al. 1991). The site types discussed in this report include open campsites, lithic procurement areas, and lithic scatters, and follow the site type definitions presented in Boyd et al. (1989:108-109).

Off-site shovel testing was conducted in a few locations to inspect the buried sediments but was not utilized systematically as a means of discovering buried sites. The exception, however, is that shovel probes (sediment not screened) and shovel tests (sediment screened) were used systematically along the bluff edge to test for cultural deposits in overhangs and shelters. Past survey work has shown that shovel testing is not an effective method for discovering open sites in any setting within the project area (Boyd et al. 1989:196-197). Thus, the survey concentrated on examining all areas where sediments were exposed by erosion or artificial means. 


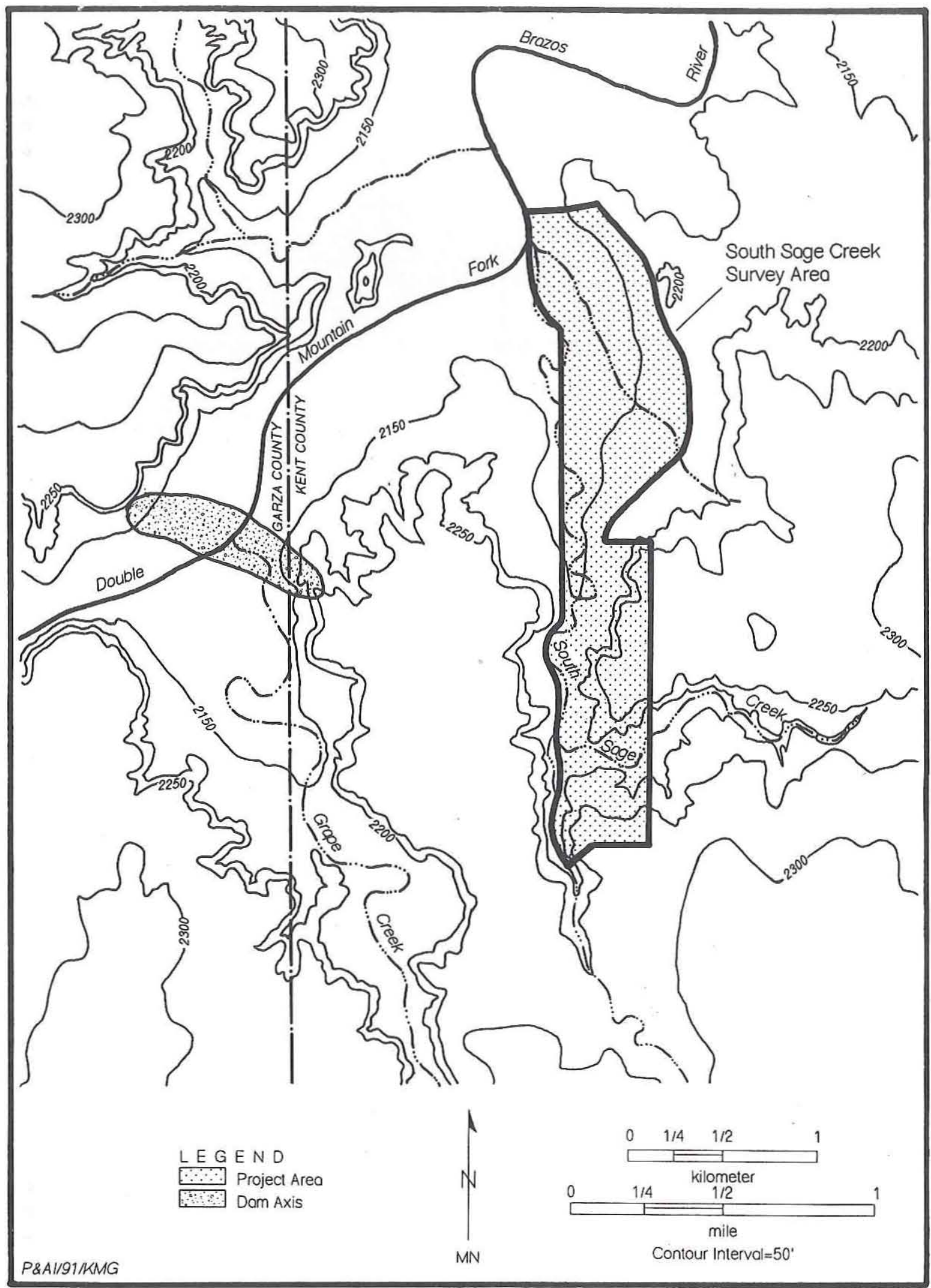

Figure 49. General location map, South Sage Creek survey area. 
When archeological materials were discovered, a reconnaissance of the area was made and, if necessary, shovel probes or shovel tests were excavated. Materials were then recorded as either archeological sites or isolated finds. Isolated finds are defined as a single artifact or feature with no other cultural associations or as surface sites with a density of cultural materials of less than one item in $20 \mathrm{~m}^{2}$; once it was established that there was no potential for association with any buried cultural deposits, isolated finds were described and the topographic setting, elevation, and location were recorded.

All archeological sites were recorded on State of Texas Site Data Forms and assigned a temporary field number. Each site was plotted on a USGS 7.5' topographic map, a paced sketch map was made, and at least one black-and-white photograph and one color slide were taken. On-site shovel tests were excavated if the site lacked natural or artificial exposures and there was potential for buried archeological deposits. All cultural materials recovered from the shovel tests were collected and bagged by provenience. Artifacts that were surface collected were plotted on the site sketch map and bagged by provenience. For specimens thought to be in a relatively undisturbed context, nails were placed in the ground at the location where they were surface collected so that the exact provenience could be relocated.

\section{RESULTS}

The archeological survey of the ca. 440-acre tract of land along South Sage Creek documented nine prehistoric archeological sites and one isolated find. No historic sites were discovered. The isolated find consists of a tertiary flake of Potter chert and a utilized flake (possibly a drill base fragment) of Cretaceous chert found on the alluvial terrace east of South Sage Creek, ca. $100 \mathrm{~m}$ northwest of site 41KT152. The ground surface in the vicinity of the isolated find was covered with colluvial gravels that have washed off the valley talus slope to the east. Two shovel tests excavated nearby produced no cultural evidence, and it was determined that these artifacts most likely were redeposited in colluvial slopewash.

Extensive root plow and blading disturbance of portions of the alluvial terraces and upland flats was observed. Aerial photographs indicate that this occurred after 1941. The uplands in the southern portion of the survey area had been disturbed by
1968 , and the terraces in the northern portion were disturbed sometime between 1968 and 1986. It appears that the project area has never been cultivated but that vegetation clearing has occurred. The recognition of these widespread disturbances is crucial for evaluating the significance and research potentials of shallowly buried and surficial sites.

The nine sites recorded consist of two lithic scatters, one lithic procurement area, five open campsites, and one combination campsite/lithic procurement area. The temporal affiliation of five of these sites is undefined, but time-diagnostic artifacts were recovered at four open campsites, allowing for a tentative assessment of site chronology. Two sites produced Archaic dart points, one Late Prehistoric site yielded ceramic sherds, and a fourth site yielded a probable Late Prehistoric II Plains end scraper. Each site is described below.

\section{Site Descriptions}

\section{$41 K T 152$}

Site $41 \mathrm{KT} 152$ is an open campsite located on the alluvial terrace east of South Sage Creek, ca. $1.6 \mathrm{~km}$ upstream from its confluence with the Double Mountain Fork of the Brazos River. It is situated immediately adjacent to the creek along the outside of a meander bend at an elevation of $2140-2160 \mathrm{ft}$ msl. The South Sage cutbank on the west side of the site exposes 1-2 $\mathrm{m}$ of alluvial sediment overlying bedrock (probably Triassic). Gully and sheet erosion have cut into the terrace along the creekbank, providing excellent ground exposure. Siliceous gravels, redeposited from upland channel deposits (cf. Lingos Formation), are present in the terrace sediment and fill the shallow gullies. Two gravel knolls near the creek suggest that extensive colluvial slopewash has occurred. Vegetation consists of a sparse growth of grasses, broomweed, Mormon tea, mesquite, prickly pear, and cholla on the terrace, with some hackberry along the creek.

The site is bisected by a fenceline and parallel two-track road. The barbed wire fence marks a property boundary that extends east-west across the South Sage Creek valley. The southern half of the site appears to be undisturbed, but the area north of the fenceline has been extensively disturbed, likely to at least $30 \mathrm{~cm}$, by vegetation clearing (probably root plowing).

Cultural evidence at $41 \mathrm{KT} 152$ is limited to 
surface artifacts exposed mainly along the eroding terrace edge. No features were observed, and no in situ artifacts were found in the cutbank and gully exposures. The cultural component that appears to cover a ca. 150-m-diameter area is surficial to shallowly buried, perhaps to 20 or $30 \mathrm{~cm}$ depth. Two shovel tests in the undisturbed southern portion of the site were negative.

Surface artifacts observed include burned sandstone fragments, fire-cracked Potter chert and quartzite fragments, a quartzite hammerstone, lithic debitage, a gray Cretaceous chert biface fragment, and a sandstone metate fragment. The cultural materials occur in very low density and are likely to have been disturbed by the extensive colluvial slopewash (and root plow activity in the northern half of the site). It is unlikely that any primary cultural deposits are present, and $41 \mathrm{KT} 152$ is assessed as having a low research potential.

\section{$41 K T 153$}

Site $41 \mathrm{KT} 153$ is an open campsite/lithic procurement area located on the bedrock ridge west of the confluence of South Sage Creek and the Double Mountain Fork of the Brazos River. This large site, ca. $400 \mathrm{~m}$ east-west by $800 \mathrm{~m}$ north-south, covers the northwest-southeast-oriented, gravel-covered bedrock ridge and extends down onto the east alluvial terrace of South Sage Creek at an elevation of 2120$2180 \mathrm{ft}$ msl. Ground exposure along the bedrock ridge and colluvial slope is excellent, with only a sparse vegetation cover consisting mainly of grasses and an occasional juniper, mesquite, prickly pear, or cholla. Vegetation is very dense in the lower portion of the site (i.e., the alluvial terrace) and consists mainly of grasses and sunflowers with some prickly pear and cholla. The lower terrace has been root plowed, resulting in sporadic surface undulations. The dense vegetation cover is a result of revegetation after this disturbance.

This site is divided into two areas for discussion purposes. The upper portion of the site is along the bedrock ridge and colluvial slope and consists of evidence of lithic procurement and possible campsite activities. The siliceous gravels occur as sporadic and low-density outcrops with limited evidence of utilization as a lithic source area (i.e., cores, tested cobbles, flakes, and hammerstones). A few fragments of fire-cracked rocks and possible burned sandstone fragments suggest camping activities. One feature, a ca. 1-m-diameter cluster of fire-cracked Potter chert fragments, was observed, and a unifacial planoconvex scraper of gray Cretaceous chert was collected. This scraper is similar to the Late Prehistoric type often referred to as a "turtleback," "snubnosed," or Plains end scraper.

The lower portion of the site contains an occasional isolated flake or fire-cracked rock and a concentration of lithic materials exposed in the northern portion of the site close to the river confluence. These materials are exposed within a ca. $50-\mathrm{m}$-diameter area by natural gully and sheet erosion and root-plow disturbances along the lower edge of the terrace. In a gully along the lower edge of the terrace, numerous tertiary flakes (including unmodified and utilized flakes) of gray nonlocal Cretaceous (i.e., Edwards) chert were found, along with fire-cracked and burned rocks, a uniface fragment, and flakes of Tecovas jasper. A second concentration of gray Cretaceous chert tertiary flakes was found about $20 \mathrm{~m}$ back from this gully and appears to have been dug up by the root plow. The terrace surface undulates considerably, and these flakes were scattered within an 8-m-diameter disturbed area. A shovel test in this concentration recovered five small tertiary flakes in the upper $10 \mathrm{~cm}$ and revealed disturbed sediment to a depth of ca. $35 \mathrm{~cm}$.

It is impossible to assess the potential for intact buried cultural materials at this site since intensive shovel testing or backhoe trenching was beyond the scope of this survey. The cultural materials in the upper portion of the site are limited to surficial or shallowly buried materials. Cultural materials could be buried near the lower edge of the bedrock ridge where the colluvial slope and alluvial terrace transition occurs. It is even more speculative to address the problem of buried cultural deposits in the lower portion (alluvial terrace) of the site. Heavy vegetation cover obscures the ground surface over most of this area. The concentration of materials along the eroded terrace edge indicates that buried deposits are present, and there are likely to be some areas which have not been disturbed by root plowing; however, the potential for deeply buried cultural deposits or paleosols cannot be assessed without extensive backhoe testing. Site 41KT153 is assessed as having an unknown research potential. At least one component appears to date to the Late Prehistoric II period, but this age cannot be extrapolated to all areas of this large site. 
$41 K T 154$

Site 41KT154 is an open campsite on an alluvial terrace immediately adjacent to South Sage Creek. It covers an estimated $150 \mathrm{~m}$ east-west by $250 \mathrm{~m}$ north-south and is bordered by South Sage Creek on the west and a smaller unnamed tributary on the east. The north and south site boundaries are poorly defined since they are based solely on the extent of surface artifacts. The terrace is very flat, at elevation 2120-2130 ft msl, with sheet and cutbank erosion along the creeks. Vegetation, consisting of grasses, small mesquite, cholla, yucca, and sunflowers, is moderate to heavy on the terrace but is very sparse in the eroded areas along the creekbanks. The entire area appears to have been disturbed by root plowing.

The cultural materials observed consist of chert flakes, fire-cracked Potter chert fragments, a chert pebble core, and a battered quartzite cobble. No features were observed, and less than 20 artifacts were noted throughout the entire site area. In spite of the excellent erosional exposure along the creekbank, it appears that this site has a very low artifact density. This assessment is supported by four shovel tests in the central portion of the site, all of which were negative. All cultural materials are thought to be surficial or shallowly buried. Due to the probability of disturbance and the paucity of cultural evidence, this component is considered to have a low research potential. There is a potential, however, for a deeply buried component in the vicinity, but this potential cannot be determined without backhoe testing.

\section{$41 K T 155$}

Site $41 \mathrm{KT} 155$ is an open campsite situated on an alluvial terrace on the east side of South Sage Creek near its mouth and the confluence of a smaller unnamed drainage. The area is generally flat, at elevation 2110 to $2120 \mathrm{ft} \mathrm{msl}$, but slopes gradually to the north and west. Active erosion along the west edge of the site provides good surface exposure. A sparse to moderate vegetation cover consists of small mesquite, short grasses, cholla, prickly pear, and sunflowers. Some areas appear to have been disturbed by root plowing.

Cultural evidence consists of a $75 \times 100-\mathrm{m}$ surface scatter of chipped stone debitage; a few cores of local quartzite, Potter chert, and silicified wood; a few fragments of ground sandstone and quartzite; and burned sandstone and fire-cracked Potter chert. A flake of probable nonlocal Tecovas jasper also was observed, and a dart point fragment was collected. The cultural materials are exposed along the sloping margins, but no features were observed. Two shovel tests were excavated near the exposed artifacts to test for buried archeological materials, but none were recovered. An unimproved road crosses the site, and it appears that some vegetation clearing has occurred in the vicinity; the extent of disturbance, however, is not clear.

The single diagnostic artifact is a stemmed dart point that is missing the distal tip. It is made of a $\tan$ Cretaceous chert that is most likely from the local gravels. The specimen is untyped but indicates that $41 \mathrm{KT} 155$ has one component that dates to the Archaic period. This site is considered to have an unknown research potential due to the limited nature of the survey data. Additional subsurface testing is needed to determine if intact cultural deposits exist and the extent of disturbance to the sediments.

\section{$41 K T 156$}

Site 41KT156 is an upland margin lithic procurement area located along the east canyon rim overlooking the point where the South Sage Creek valley begins to constrict, ca. $2 \mathrm{~km}$ upstream from its mouth. The 20x50-m site area is deflated to bedrock in some places and has only a thin veneer of sandy sediment in others. A sparse gravel (cf. Lingos Formation) outcrop is exposed along the eroding canyon edge at elevation $2160-2170 \mathrm{ft} \mathrm{msl}$. The vegetation cover, consisting of juniper, cholla, yucca, prickly pear, grasses, and various shrubs, is moderate to sparse. Large vertical slabs of sandstone in the vicinity indicate that vegetation clearing (blading and/or root plowing) has occurred.

The cultural evidence observed consists of less than 25 artifacts, indicating minimal utilization of the sparse gravel outcrop. Materials observed include flakes, cores, tested cobbles, a crude unifacial pebble tool made of chert, and two quartzite hammerstones. All materials are surficial, and there is little or no potential for buried deposits. This lithic procurement site is considered to have a very low research potential due to the paucity of cultural materials and the extent of disturbance. 


\section{$41 K T 157$}

Site $41 \mathrm{KT} 157$ is a lithic scatter located on the upland margin along the east canyon rim overlooking a very narrow segment of the South Sage Creek valley, ca. $3.5 \mathrm{~km}$ upstream from its mouth. This small site, ca. $75 \times 75 \mathrm{~m}$, is relatively flat at elevation 2160-2170 ft msl. Sandy sediment covers the area except along the eroding canyon edge where sandstone bedrock is exposed. Vegetation consists of a moderate growth of mesquite, grasses, cholla, prickly pear, juniper, and yucca. A buried petroleum pipeline crosses the site, but no other disturbances are evident.

Cultural materials consist of sparse lithic debitage and one possible quartzite hammerstone; less than 20 artifacts were observed. No gravels crop out in the site area, and the lack of tested cobbles and cores indicates that this locality is not a lithic procurement area. No features or burned rocks were observed. A shovel test in the central portion of the site produced no cultural evidence. In addition, the pipeline cut does not expose any cultural materials, which would be expected if significant buried deposits were present.

Site $41 \mathrm{KT} 157$ is considered to be a very low density, surficial lithic scatter with little or no potential for intact buried deposits: hence, it is assessed as having a low research potential.

\section{$41 K T 158$}

Site $41 \mathrm{KT} 158$ is a lithic scatter located on a bedrock bench overlooking the west-flowing branch of South Sage Creek. This $75 \times 75-\mathrm{m}$ site occupies a bench at elevation $2220-2250 \mathrm{ft}$ msl, approximately midway on the valley wall ( 40 vertical feet below the canyon rim and 40 vertical feet above the creek). The surface undulates considerably, with outcrops of bedrock (sandstones and mudstones) interspersed with pockets of thin sandy sediment. The vegetation cover is sparse and consists of juniper, catclaw acacia, yucca, and mesquite. Artificial disturbance is confined to a small area where vertical sandstone slabs and rock piles indicate that blading has occurred. The disburbed area is relatively flat, and it is likely that this disturbance is related to oilfield activities (e.g., seismic exploration). In addition, the site area is heavily eroded.

Cultural materials observed consist of a few flakes, two tested cobbles, and two crude unifacial tools (less than 20 artifacts total), and no features or burned rocks were observed. No significant concentrations of gravels occur in the site area, but a nearby gravel-covered bedrock knoll could have served as a lithic source area. It appears that $41 \mathrm{KT} 158$ is a very low density lithic scatter with no potential for intact buried deposits; hence, it is assessed as having a low research potential.

\section{$41 K T 159$}

Site $41 \mathrm{KT} 159$ is an open campsite located on an alluvial terrace along the west-flowing branch of South Sage Creek, near its confluence with the main branch. It covers the entire terrace, ca. 150x150 m, and slopes southward from the base of the talus slope at elevation $2190 \mathrm{ft} \mathrm{msl}$ to the creek edge at $2160 \mathrm{ft}$ msl. A prominent bedrock peninsula (an erosional remnant bench) projects southward into the valley, partially enclosing the terrace on the west side. A deep gully cuts down into the terrace all along the talus slope of this bench and forms the western edge of the site. The eastern edge of the site is also dissected by headward gully erosion, although it is not as deeply incised as the western edge. The gullies provide excellent exposure of the alluvial terrace sediments. Vegetation cover on the terrace consists of a sparse growth of mesquite, grasses, cholla, prickly pear, yucca, and a few small junipers near the valley wall. There are no apparent artificial disturbances to the site, and the terrace surface is very flat.

Cultural evidence consists of a low-density scatter of artifacts and three distinct features. The features are ca. 1-m-diameter clusters of burned sandstone that are probably in situ hearths exposed by sheet erosion. No artifacts were observed in direct association with the features, and very few artifacts (less than 20) were found over the entire site. Chert flakes and a unifacial chert tool were observed, and four artifacts - a sandstone mano, a quartzite mano, and two dart points - were surface collected.

The dart points are both corner-notched basal fragments. One specimen is classified as a Castroville, and the other is a Marshall. These dart points suggest a late Archaic occupation. Similar point types have been found at late Archaic bison-kill sites in the Lower Plains (Hughes 1977).

Two bison ribs were found at $35-40 \mathrm{~cm}$ below the ground surface in the western gully cutbank, but these bones are not necessarily associated with the occupation of the site. The cultural component 
appears to be surficial or shallowly buried (i.e., in the upper $20 \mathrm{~cm}$ ), and no artifacts were found in the gullies. Four shovel tests excavated in the area where the features and cultural materials are concentrated yielded no cultural evidence.

Site 41KT159 cannot be fully evaluated at this time, but the evidence suggests a single-component late Archaic occupation. It is possible that the occupation is completely surficial and very ephemeral, in which case the site has a low research potential. Conversely, it is also possible that the site contains a discrete, low-density component and that much of it remains shallowly buried and intact. In that case, the site would have a much greater research potential. Additional testing is needed before such determinations can be made, and the site is considered to have an unknown research potential.

\section{$41 K T 160$}

Site $41 \mathrm{KT} 160$ is an open campsite located on the east alluvial terrace in a narrow-valley segment of South Sage Creek, ca. $2.7 \mathrm{~km}$ upstream from its mouth. It covers a ca. 80-m-diameter area immediately adjacent to the creek and is at an elevation of 2160-2180 ft msl. A bladed north-south road crosses the terrace, and much of the vicinity has been disturbed by blading, apparently to construct an earthen berm or levee to slow down the gully erosion cutting into the terrace just north of the site. It appears that a ditch (ca. 50-100 cm deep and 3-6 m wide) was excavated parallel to the creek channel and that the fill was used to form the berm between the ditch and the creek. Aerial photographs indicate that the road was put in between 1941 and 1968 but that the extensive blading occurred after 1968 . Vegetation cover is sparse and consists of small mesquites and junipers, yucca, cholla, prickly pear, and short grasses.

Bone fragments, Cretaceous chert debitage (high-quality gray chert of probable nonlocal origin), and ceramic sherds are exposed along the lower edge of the site as a result of sheet erosion and/or blading activities. In addition, a few flakes and a unifacial scraper (also of gray Cretaceous chert) were observed away from the terrace edge. No features or burned rocks were observed. Two shovel tests were excavated. One was located near the exposed bones and recovered nine additional bone fragments, indicating that more materials probably are buried in the terrace. The second shovel test was located near a flake concentration, but it yielded no cultural evidence.

The ceramic sherds were collected but could not be positively identified. They indicate that occupation of the site dates to Late Prehistoric times, but this assessment cannot be further refined. The sherds could be some variant of Mogollon brownware from the Southwest or they could be a locally made Panhandle-Plains ware.

It is not clear how many components may be represented; however, three possibilities are offered here to explain the cultural evidence at $41 \mathrm{KT} 160$. First, it is possible that the cultural materials represent a shallowly buried or surficial component, a significant portion of which has been destroyed by extensive blading. If this is the case, then the component is quite ephemeral and the site has a very low research potential. The second scenario is that the materials represent a more deeply buried component, exposed mainly along the lower edge of the terrace by natural erosion, and that the cultural deposits extend below the blading disturbance. If this is correct, then much of the component could remain intact and the site would have a much greater research potential. The third possibility is that multiple components are present, with the upper components being badly disturbed and the lower components being more intact. Backhoe testing is needed to determine the nature of the component, its geomorphic setting, and the extent of disturbance at this site.

\section{Artifact Descriptions}

Twenty-five artifacts were collected from four sites in the South Sage Creek survey area (Table 38). As in the previous surveys at Justiceburg Reservoir, only a minimum quantity of artifacts, those considered necessary to support site interpretations and assessments, were collected. Artifact collection during this survey was limited to materials recovered in shovel tests and surface collection of temporally diagnostic specimens, unique materials, or other formal tools of special interest.

Cultural materials recovered in shovel tests consist of flakes and bone fragments. Surfacecollected temporally diagnostic specimens consist of three dart points, five ceramic sherds, and one unifacial scraper. Formal tools of special interest are two manos, which are considered to be from the same component as the two dart points. 


\begin{tabular}{|l|l|l|c|}
\hline \multicolumn{5}{|c|}{ TABLE 38 } \\
ARTIFACTS RECOVERED DURING SOUTH SAGE CREEK SURVEY \\
\hline Site No. & Surface Collection & Shovel Tests & Totals \\
\hline 41 KT153 & Unifacial scraper & 5 tertiary flakes & 6 \\
\hline 41 KT155 & Untyped dart point & - & 1 \\
\hline 41 KT159 & $\begin{array}{l}\text { Castroville dart point } \\
\text { Marshall dart point } \\
\text { 2 manos }\end{array}$ & - & \\
\hline 41 KT160 & 5 ceramic sherds & 9 bone fragments & 4 \\
\hline TOTAL: & & & 25 \\
\hline
\end{tabular}

\section{Chipped Stones}

Three dart points (Table 39) were'surface collected from two sites. Specimen 1 is an untyped, stemmed dart point from 41KT155 (Fig. 50a). The distal tip is missing, but it is otherwise complete. The blade exhibits a slight alternate right bevel. One shoulder is rounded, while the other is very weak and may indicate resharpening of one blade edge. The point is made of light grayish brown Cretaceous chert that may be of local origin.

Specimen 2 is a Castroville dart point (Suhm and Jelks 1962:173-174) from 41KT159 (Fig. 50b). It is a corner-notched, expanding-stem basal fragment missing all of one barb and part of the other. The point is made of light gray Cretaceous (Edwards) chert of probable nonlocal origin. One side is very lightly patinated, and the other side is much more heavily patinated.

Specimen 3 is a Marshall dart point (Suhm and Jelks 1962:211-212) from 41KT159 (Fig. 50c). It is a basal fragment that is missing the tip of one barb. The specimen is corner notched with an expanding stem and slightly concave base and is made of light gray to white Cretaceous chert of probable nonlocal origin. One side is heavily patinated, while the other exhibits only moderate patina. Slight discoloration (i.e., reddening) and a glossy sheen on the lesspatinated face suggest that the specimen was heat treated.

A unifacial scraper (Fig. 50d) was surface collected from 41KT153. It is a tertiary flake of gray Cretaceous (Edwards) chert. The proximal end is a striking platform, and the concave ventral flake surface retains a prominent bulb of percussion. The dorsal surface is convex and has been primarily trimmed on the lateral edges. The convex bit on the distal end has been primarily trimmed and resharpened and exhibits evidence of use-wear (i.e., undercutting of the bit and slight polish). It is $53 \mathrm{~mm}$ long, $35 \mathrm{~mm}$ wide, $15 \mathrm{~mm}$ thick, and has a bit angle of 60 $70^{\circ}$. This specimen is typical of the planoconvex

\begin{tabular}{|l|l|l|l|l|l|l|l|l|}
\hline \multicolumn{10}{|c|}{ TABLE 39} \\
\hline & METRIC DATA FOR DART POINTS, SOUTH SAGE CREEK SURVEY* \\
\hline Type & Site No. & Thickness & $\begin{array}{l}\text { Total } \\
\text { Length }\end{array}$ & $\begin{array}{l}\text { Maximum } \\
\text { Blade Width }\end{array}$ & $\begin{array}{l}\text { Base } \\
\text { Width }\end{array}$ & $\begin{array}{l}\text { Haft } \\
\text { Length }\end{array}$ & $\begin{array}{l}\text { Neck } \\
\text { Width }\end{array}$ & $\begin{array}{l}\text { Base } \\
\text { Depth }\end{array}$ \\
\hline Mastroville & 41 KT159 & 5 & $69 *$ & $40^{*}$ & 27 & 14 & 21 & +1 \\
Untyped & 41 KT159 & 6 & $67 *$ & 38 & 20 & 11 & 17 & +3 \\
\hline *All measurements are in millimeters; base depth (+ = concave; - = convex). An asterisk (*) indicates an \\
estimated measurement based on reconstruction of a fragmentary specimen. \\
\hline
\end{tabular}




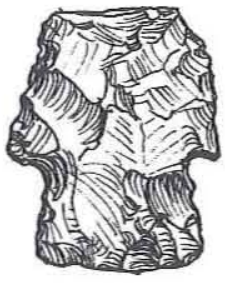

o

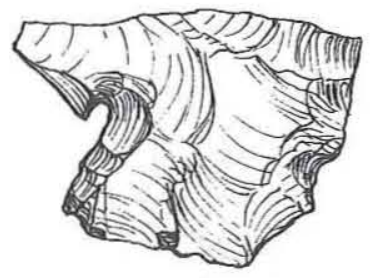

b
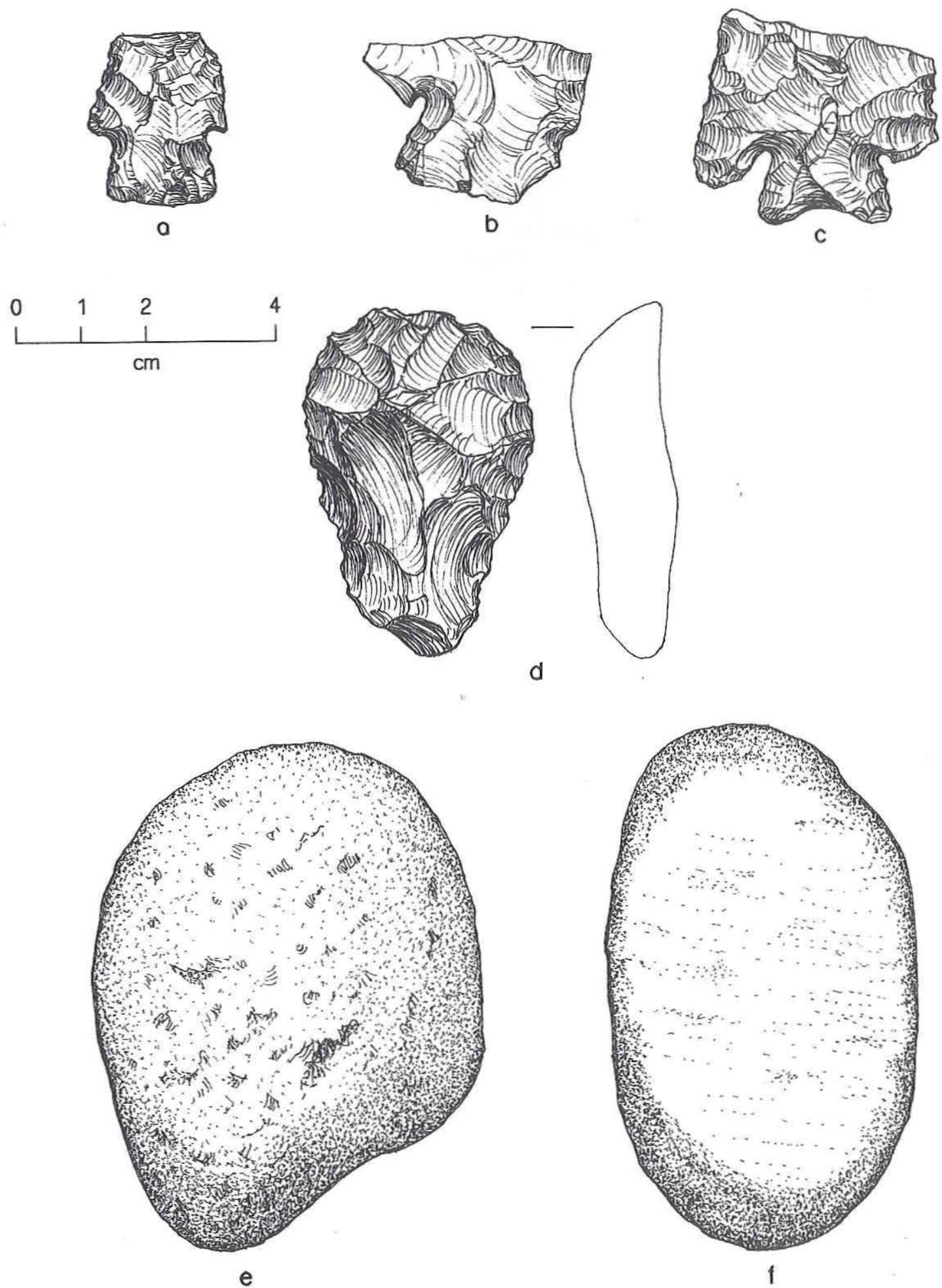

Figure 50. Artifacts from South Sage Creek survey. (a) Untyped dart point, 41KT155; (b) Castroville dart point, 41KT159; (c) Marshall dart point, 41KT159; (d) snub-nosed end scraper, 41KT153; (e) quartzite mano, 41KT159; (f) sandstone mano, $41 \mathrm{KT} 159$. 
snub-nosed end scrapers (also called keeled or Plains end scrapers) that are diagnostic Late Prehistoric hide-scraping tools (Wedel 1970).

\section{Lithic Debitage}

Five tertiary chert flakes were recovered from $0-10 \mathrm{~cm}$ below the surface at $41 \mathrm{KT} 153$. They are all small, late-reduction-stage flakes ranging in size from $8-17 \mathrm{~mm}$ in maximum dimension. One is a bifacial thinning flake, while two appear to be uniface rejuvenation flakes. The raw material is a gray Cretaceous chert of probable nonlocal origin and is similar to the material of the unifacial scraper recovered from the same site (see above).

\section{Ground Stones}

Two ground stone artifacts were recovered from 41KT159. Specimen 1 is a bifacial mano (Fig. 50e) made from a natural stream cobble of red or maroon Ogallala quartzite that is ubiquitous in the local upland gravel deposits. It is roughly oval in outline, transverse in cross section, and has been worked on both faces. One face has been pecked, presumably to roughen the surface. Battering is evident along the edges, indicating that it also served as a hammerstone. This specimen is $124 \mathrm{~mm}$ long, $95 \mathrm{~mm}$ wide, and $55 \mathrm{~mm}$ thick.

Specimen 2 is a bifacial mano (Fig. 50f) made from local Triassic micaceous sandstone. It is oval in outline, and the edges are shaped by pecking and/or battering. One face is very flat, while the opposite face is beveled toward the lateral edges, with a central longitudinal ridge. It is $125 \mathrm{~mm}$ long, $73 \mathrm{~mm}$ wide, and 35-36 mm thick along the longitudinal ridge.

\section{Ceramics}

Five ceramic sherds were surface collected from 41KT160. These sherds were independently inspected by Regge Wiseman (Labortory of Anthropology, Santa Fe, New Mexico) and Jack Hedrick (El Paso, Texas). Much of the following description is derived from their observations.

Four of the five sherds fit together into a large (maximum length $59 \mathrm{~mm}$, width $40 \mathrm{~mm}$ ) fragment. The fifth sherd is very small (maximum length $14 \mathrm{~mm}$ ); this sherd is similar to the others and may be from the same vessel. The reconstructed fragment varies from 4.5 to $6 \mathrm{~mm}$ thick and is strongly curved. It appears to be a body sherd from the neck portion of an inverted-rim vessel, but since the rim itself is missing, the vessel form cannot be determined. The sherd color varies from dark brown (7.5YR 4/2) to very dark gray (7.5YR 3/0), and it has a solid black (7.5YR 2/0) core which leaves a black streak. It is heavily oxidized (carbonized) and was probably fired at relatively low temperatures. The surface finish is smooth and floated. The exterior appears to have been scraped, the interior was wiped, and both surfaces are eroded. The surface appears to be more heavily polished toward the rim. The paste texture is fine with a crumbly fracture. The temper appears to consist of variable-sized (fine to coarse), wellrounded and rolled quartz (i.e., sand) grains.

Neither Wiseman nor Hedrick would classify these sherds by type. Wiseman felt that they could represent some variety of Mogollon brownware, while Hedrick thought they are most likely a locally made Panhandle variety. At present, they cannot be classified with any degree of confidence.

\section{Bones}

Nine bone fragments were recovered from 20-30 $\mathrm{cm}$ below the surface at $41 \mathrm{KT} 160$. All are small (largest is $38 \mathrm{~mm}$ in maximum dimension) fragments of medium to large mammal bones.

\section{SUMMARY, ASSESSMENTS, AND RECOMMENDATIONS}

The archeological survey of the 440-acre South Sage Creek area resulted in the documentation of nine prehistoric sites (Table 40). This brings the total number of acres surveyed at Justiceburg Reservoir to 11,280 and the total number of sites with prehistoric components to 288 (see Table 34).

The sites on South Sage Creek are typical of those elsewhere in the Justiceburg area. The lithic procurement areas and lithic scatters provide evidence of prehistoric utilization of the upland gravel deposits. The open campsites provide evidence of prehistoric habitation with more-diverse activities and possible interregional exchange. The relatively low artifact density at most of the campsites suggests an ephemeral use of the region by highly mobile groups. Three of the South Sage Creek campsites yielded artifacts that date to the late Holocene (i.e., late Archaic and Late Prehistoric periods). The domi- 
TABLE 40

SITES IN THE SOUTH SAGE CREEK SURVEY AREA

\begin{tabular}{|c|c|c|c|c|}
\hline Site No. & Topographic Setting & Site Type & Temporal Affiliation & $\begin{array}{l}\text { National Register } \\
\text { Assessment }\end{array}$ \\
\hline 41KT152 & Alluvial terrace & Open campsite & Undefined Prehistoric & Not eligible \\
\hline $41 \mathrm{KT} 153$ & $\begin{array}{l}\text { Alluvial/bedrock } \\
\text { terrace }\end{array}$ & $\begin{array}{l}\text { Open campsite/lithic } \\
\text { procurement area }\end{array}$ & Late Prehistoric II & Potentially eligible \\
\hline 41KT154 & Alluvial terrace & Open campsite & Undefined Prehistoric & Not eligible \\
\hline $41 \mathrm{KT} 155$ & Alluvial terrace & Open campsite & Undefined Archaic & Potentially eligible \\
\hline $41 \mathrm{KT} 156$ & Upland margin & Lithic procurement area & Undefined Prehistoric & Not eligible \\
\hline $41 \mathrm{KT} 157$ & Upland margin & Lithic scatter & Undefined Prehistoric & Not eligible \\
\hline $41 \mathrm{KT} 158$ & Bedrock bench & Lithic scatter & Undefined Prehistoric & Not eligible \\
\hline $41 \mathrm{KT} 159$ & Alluvial terrace & Open campsite & $\begin{array}{l}\text { Late Archaic, probably } \\
\text { single component }\end{array}$ & Potentially eligible \\
\hline $41 \mathrm{KT} 160$ & Alluvial terrace & Open campsite & Late Prehistoric & Potentially eligible \\
\hline
\end{tabular}

nance of late Holocene archeological deposits in the Justiceburg area is a phenomenon that can be explained in part by fluctuating paleoenvironmental conditions and geological processes. Previous geoarcheological studies suggest that sediments and sites dating to the mid Holocene or earlier have been largely removed (i.e., eroded away) or effectively obscured (e.g., deeply buried) from archeological view (Blum 1989; Abbott 1990; Bousman 1991), and this is substantiated by the geoarcheological investigations reported here (see Chapter 3).

Only one of the South Sage Creek sites, $41 \mathrm{KT} 159$, is interpreted as a relatively discrete, single-component site. This apparently short-term occupation can be linked by diagnostic dart point types (Castroville and Marshall) to the late Archaic bison hunters in the Lower Plains (Hughes 1977). Thus, 41KT159 is one of the few campsites in the region that can be associated with these peoples.

Prehistoric site density in the South Sage Creek survey area is one site per 49 acres, a figure that is somewhat lower than the average density of one site per 35 acres in the reservoir and wildlife mitigation surveys (Boyd et al. 1989:107, 1991:85). One factor that may contribute to this discrepancy is the absence of freshwater springs in the South Sage Creek survey tract. The absence of springs today does not necessarily mean they were absent throughout prehistoric times, but well-developed seep springs, such as those in the wildlife mitigation area, appear to have been attractive resources throughout the late Holocene. The lower site density along South Sage Creek is perhaps a realistic cultural phenomenon reflecting somewhat less favorable conditions (i.e., lessdependable water sources) due to localized geological characteristics.

Cultural resources must be evaluated relative to the criteria for listing on the National Register of Historic Places (U.S. Department of the Interior, National Park Service, National Register Division 1982:1). The significance of individual prehistoric sites at Justiceburg Reservoir is determined by the potential that each site has to contribute information relative to the "Model of Late Holocene Human Adaptation" (Boyd and Tomka 1990). In order for a site to be considered significant, and thus be eligible for listing on the National Register, it must (1) meet the minimum integrity criteria, and (2) be demonstrated that it can contribute information to the specific research questions and the broad theoretical orientation put forth in the model.

Of the nine prehistoric sites, five (41KT152, 41KT154, 41KT156, 41KT157, and 41KT158) lack sufficient integrity to meet the minimum criteria for listing on the National Register of Historic Places. The minimum criteria for a National Register-eligible 
prehistoric site is that the cultural materials can be isolated into components or reasonably discrete periods of use and must exhibit little or no disturbance of those deposits (Boyd et al. 1990:276, 1991: 96-97). It has been demonstrated that these five sites, for various reasons, are of dubious integrity and fail to meet these criteria. It is recommended that they be considered not eligible for listing on the National Register, and no further work is recommended for these sites.

Four sites (41KT153, 41KT155, 41KT159, and $41 \mathrm{KT} 160$ ) could potentially meet the minimum criteria for listing on the National Register of Historic Places. The current level of information, however, is not sufficient to fully evaluate the nature and integrity of any of these sites. Lacking any firm data on the basic integrity of these occupations, the potential for contributing significant information relative to the model cannot be demonstrated. Thus, these four sites are considered to be potentially eligibile for listing on the National Register. For each of these sites, it is recommended that (1) any impacts to the site be avoided if at all possible, and (2) if impacts cannot be avoided, then subsurface hand and/or mechanical testing should be done in order to evalute the integrity of the site.

In addition, this survey did not adequately address the potential for deeply buried sites in the South Sage Creek alluvial terraces. This is particularly true of the wide valley segment in the northern half of the survey area where the potential for deeply buried sites is greatest. Thus, it is generally recommended that subsurface backhoe testing be done prior to any land-altering disturbances in the South Sage Creek valley. The specific objective of such testing should be to locate buried archeological sites, but the testing program should also incorporate a geomorphic study to be integrated with the previous geoarcheological investigations in the Justiceburg Reservoir area. 


\section{REFERENCES CITED}

Abbott, James T.

1990 Geomorphic and Geoarcheological Investigations. Chapter 4 in Phase II Investigations at Prehistoric and Rock Art Sites, Justiceburg Reservoir, Garza and Kent Counties, Texas, by Douglas K. Boyd, James T. Abbott, William A. Bryan, Colin M. Garvey, Steve A. Tomka, and Ross C. Fields, pp. 23-62. Reports of Investigations No. 71, Volume I. Prewitt and Associates, Inc., Austin.

Blum, Michael D.

1989 Geoarcheological Investigations. Chapter 7 in Phase I Cultural Resources Investigations at Justiceburg Reservoir on the Double Mountain Fork of the Brazos River, Garza and Kent Counties, Texas, by Douglas K. Boyd, Martha Doty Freeman, Michael D. Blum, Elton R. Prewitt, and J. Michael Quigg, pp. 81-106. Reports of Investigations No. 66, Volume I. Prewitt and Associates, Inc., Austin.

Bousman, C. Britt

1991 Geoarcheological Investigations. Chapter 4 in Archeological Survey of Wildlife Mitigation Lands, Justiceburg Reservoir, Garza County, Texas, by Douglas K. Boyd, C. Britt Bousman, and Martha Doty Freeman, pp. 45-49. Reports of Investigations No. 79. Prewitt and Associates, Inc., Austin.

Boyd, Douglas K., James T. Abbott, William A. Bryan, Colin M. Garvey, Steve A. Tomka, and Ross C. Fields

1990 Phase II Investigations at Prehistoric and Rock Art Sites, Justiceburg Reservoir, Garza and Kent Counties, Texas. Reports of Investigations No. 71. 2 vols. Prewitt and Associates, Inc., Austin.

Boyd, Douglas K., C. Britt Bousman, and Martha Doty Freeman

1991 Archeological Survey of Wildlife Mitigation Lands, Justiceburg Reservoir, Garza County,
Texas. Reports of Investigations No. 79. Prewitt and Associates, Inc., Austin.

Boyd, Douglas K., Martha Doty Freeman, Michael D. Blum, Elton R. Prewitt, and J. Michael Quigg

1989 Phase I Cultural Resources Investigations at Justiceburg Reservoir on the Double Mountain Fork of the Brazos River, Garza and Kent Counties, Texas. Reports of Investigations No. 66. 2 vols. Prewitt and Associates, Inc., Austin.

Boyd, Douglas K., and Steve A. Tomka

1990 A Model of Late Holocene Human Adaptation for Justiceburg Reservoir. In Chapter 8, Phase II Investigations at Prehistoric and Rock Art Sites, Justiceburg Reservoir, Garza and Kent Counties, Texas, by Douglas K. Boyd, James T. Abbott, William A. Bryan, Colin M. Garvey, Steve A. Tomka, and Ross C. Fields, pp. 261-273. Reports of Investigations No. 71, Volume II. Prewitt and Associates, Inc., Austin.

Hughes, David T.

1977 Analysis of Certain Prehistoric Bison Kills in the Texas Panhandle and Adjacent Areas. Master's thesis, University of Arkansas, Fayetteville.

Suhm, Dee Ann, and Edward B. Jelks

1962 Handbook of Texas Archeology: Type Descriptions. Texas Archeological Society Special Publication No. 1 and Texas Memorial Museum Bulletin No. 4. Austin.

U.S. Department of the Interior, National Park Service, National Register Division

1982 How to Apply the National Register Criteria for Evaluation. National Park Service, Department of the Interior, Washington, D.C.

Wedel, Waldo R.

1970 Antler Tine Scraper Handles in the Central Plains. Plains Anthropologist 15(47):36-45. 


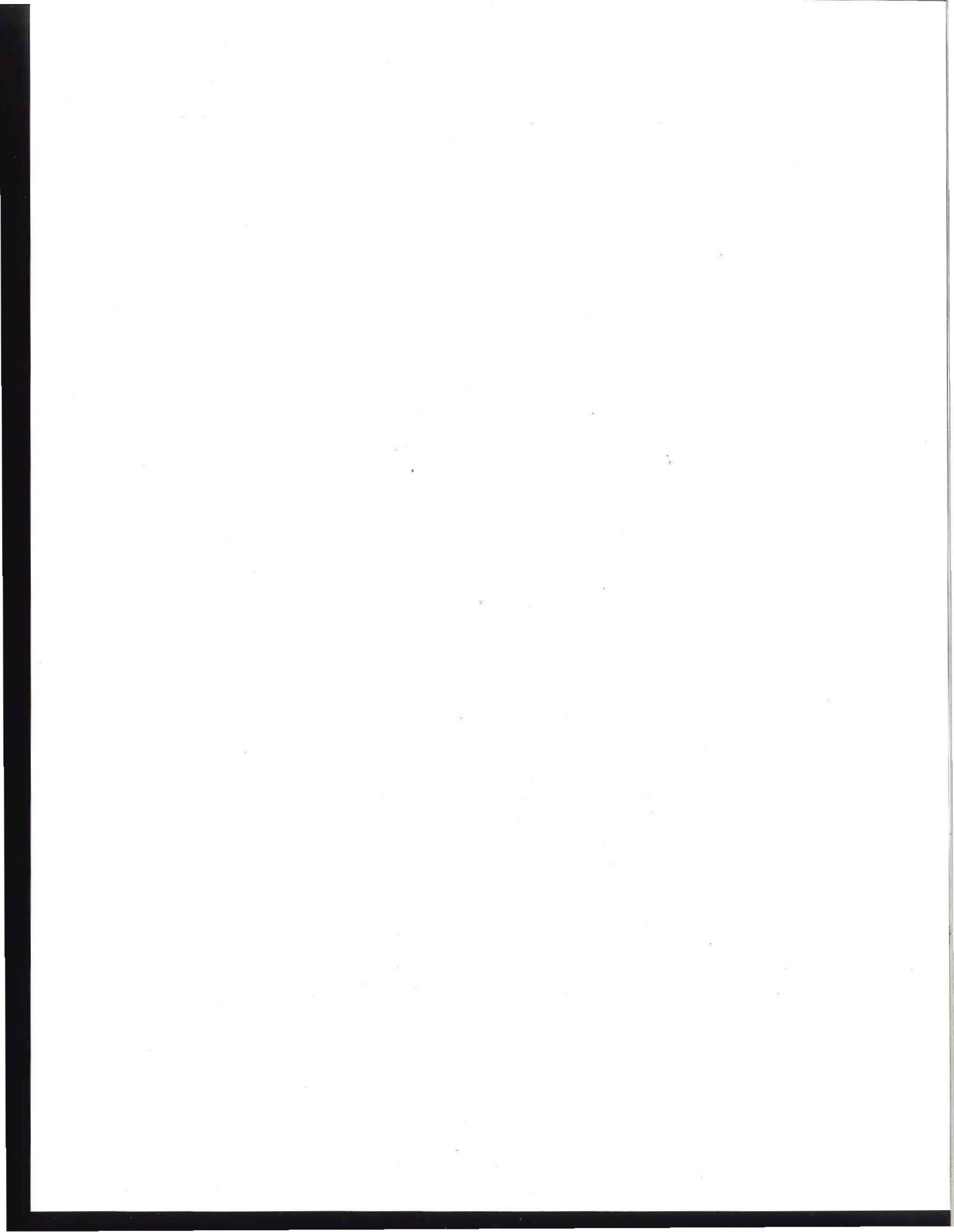


APPENDIX B: Artifact Provenience, Prehistoric Sites 



\begin{tabular}{|c|c|c|c|c|c|c|c|c|c|c|c|c|c|c|c|c|}
\hline $\begin{array}{l}\text { Excavarion Unit } \\
\text { and Level }\end{array}$ & \begin{tabular}{|l} 
Arrow \\
Points
\end{tabular} & $\begin{array}{l}\text { Dart } \\
\text { Points }\end{array}$ & Pefforators & Gouges & Bifaces & $\begin{array}{l}\text { Cobble } \\
\text { Tools }\end{array}$ & Unifaces & Cores & 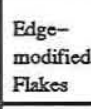 & $\begin{array}{l}\text { Unmodificed } \\
\text { Debiage }\end{array}$ & $\begin{array}{l}\text { Ground } \\
\text { Strone } \\
\text { Tools }\end{array}$ & Hammerstones & Manports & Ceramics & \begin{tabular}{|l} 
Modified \\
Shells
\end{tabular} & Toals \\
\hline $\begin{array}{l}\text { 41GR383 } \\
\text { EU1 } 1 \\
\text { Level 1 } \\
\text { LLvel 2 } \\
\text { Level 3 }\end{array}$ & $\bar{z}$ & $\bar{z}$ & $\bar{z}$ & $\bar{z}$ & $\bar{z}$ & $\bar{~}$ & $\bar{z}$ & $\bar{z}$ & $\begin{array}{l}\overline{1} \\
1 \\
\end{array}$ & $\begin{array}{r}13 \\
18 \\
4 \\
\end{array}$ & $\overline{-}$ & $\bar{z}$ & $\bar{z}$ & E & $\bar{z}$ & $\begin{array}{r}13 \\
19 \\
7 \\
\end{array}$ \\
\hline $\begin{array}{l}\text { EU2 } 2 \\
\text { Level1 } \\
\text { Levev12 } \\
\text { Level } 3\end{array}$ & z & $\bar{z}$ & $\overline{-}$ & $\bar{z}$ & $\overline{1}$ & $\overline{1}$ & $\bar{z}$ & $\bar{z}$ & $\frac{1}{1}$ & $\begin{array}{l}9 \\
7 \\
7 \\
\end{array}$ & $\begin{array}{l}- \\
1 \\
1\end{array}$ & $\overline{-}$ & $\bar{z}$ & $\overline{-}$ & $\overline{-}$ & $\begin{array}{r}10 \\
8 \\
11 \\
\end{array}$ \\
\hline $\begin{array}{l}\text { EU 3 } \\
\text { L Lovel 1 } \\
\text { Level 2 } \\
\text { Level 3 } \\
\end{array}$ & $\overline{-}$ & $\bar{z}$ & $\bar{~}$ & z & $\overline{1}$ & $\bar{z}$ & छ & z & $\begin{array}{c}1 \\
3 \\
1 \\
\end{array}$ & $\begin{array}{r}13 \\
16 \\
1 \\
\end{array}$ & $\frac{-}{1}$ & $\Xi$ & z & 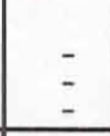 & - & $\begin{array}{r}14 \\
20 \\
3 \\
\end{array}$ \\
\hline 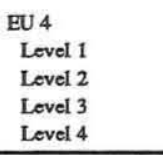 & $\bar{z}$ & $\bar{z}$ & $\bar{z}$ & $\bar{z}$ & $\begin{array}{l}\bar{z} \\
\bar{z}\end{array}$ & $\begin{array}{l}\bar{z} \\
1 \\
\end{array}$ & $\begin{array}{l}\bar{z} \\
\overline{-}\end{array}$ & $\begin{array}{l}\overline{1} \\
\overline{-} \\
\end{array}$ & $\overline{1}$ & $\begin{array}{l}7 \\
9 \\
9 \\
\end{array}$ & $\bar{z}$ & $\bar{z}$ & $\bar{z}$ & $\bar{~}$ & $\bar{z}$ & $\begin{array}{r}7 \\
10 \\
11 \\
1 \\
\end{array}$ \\
\hline $\begin{array}{l}\text { EUS } 5 \\
\text { Lovel 1 } \\
\text { LLvel } 2 \\
\text { Level } 3 \\
\text { Lovel } 4 \\
\end{array}$ & $\begin{array}{l}\bar{z} \\
\bar{z}\end{array}$ & $\bar{z}$ & $\bar{z}$ & $\begin{array}{l}\bar{z} \\
\bar{z}\end{array}$ & 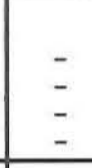 & ¿ & छ & $\begin{array}{l}\bar{z} \\
\bar{z} \\
\end{array}$ & $\begin{array}{l}\bar{z} \\
\overline{-} \\
\end{array}$ & $\begin{array}{c}1 \\
12 \\
5 \\
7 \\
\end{array}$ & $\begin{array}{l}- \\
\overline{4} \\
- \\
\end{array}$ & $\begin{array}{l}\bar{z} \\
\bar{z}\end{array}$ & $\begin{array}{l}- \\
\bar{z} \\
\end{array}$ & $\begin{array}{l}\bar{z} \\
\bar{z}\end{array}$ & $\begin{array}{l}\bar{y} \\
\bar{z} \\
\end{array}$ & $\begin{array}{r}1 \\
12 \\
9 \\
7 \\
\end{array}$ \\
\hline $\begin{array}{l}\text { HU6 } \\
\text { Lovel 1 } \\
\text { Level } 2 \\
\text { Lovel } 3 \\
\end{array}$ & $\overline{-}$ & $\bar{z}$ & $\overline{-}$ & $\bar{z}$ & $\bar{z}$ & $\overline{-}$ & E & $\frac{1}{-}$ & $\begin{array}{r}1 \\
2 \\
-\end{array}$ & $\begin{array}{r}12 \\
12 \\
7 \\
\end{array}$ & $\overline{-}$ & $\bar{z}$ & $\overline{-}$ & $\bar{z}$ & $\overline{-}$ & $\begin{array}{r}14 \\
14 \\
7 \\
\end{array}$ \\
\hline $\begin{array}{l}\text { EU 7 } \\
\text { Level 1 } \\
\text { Level 2 } \\
\text { Level 3 } \\
\end{array}$ & $\overline{-}$ & $\overline{-}$ & $\overline{-}$ & 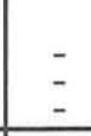 & z & $\bar{z}$ & $\overline{-}$ & $\bar{z}$ & $\begin{array}{l}- \\
1 \\
1 \\
\end{array}$ & $\begin{array}{r}7 \\
25 \\
9 \\
\end{array}$ & $\overline{-}$ & $\bar{~}$ & ¿ & $\overline{-}$ & $\overline{-}$ & $\begin{array}{l}7 \\
26 \\
10 \\
\end{array}$ \\
\hline $\begin{array}{l}\text { Lus } \\
\text { Lovel 1 } \\
\text { Level } 2\end{array}$ & - & $\Xi$ & - & - & - & - & - & - & $\overline{1}$ & $\begin{array}{r}8 \\
28 \\
\end{array}$ & E & - & 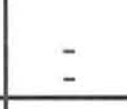 & - & - & $\begin{array}{r}8 \\
29 \\
\end{array}$ \\
\hline $\begin{array}{l}\text { EU9 } 9 \\
\text { Lovel 1 } \\
\text { Lovel 2 } \\
\text { Level 3 } \\
\end{array}$ & $\overline{-}$ & $\overline{-}$ & $\overline{-}$ & $\bar{z}$ & $\begin{array}{l}- \\
1 \\
\end{array}$ & $\overline{-}$ & $\overline{1}$ & $\bar{z}$ & $\begin{array}{l}\overline{1} \\
- \\
\end{array}$ & $\begin{array}{r}2 \\
18 \\
8 \\
\end{array}$ & $\frac{-}{1}$ & z & 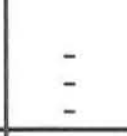 & $\bar{z}$ & $\bar{z}$ & $\begin{array}{r}2 \\
21 \\
9 \\
\end{array}$ \\
\hline $\begin{array}{c}\text { Ev } 10 \\
\text { Level 1 } \\
\text { Lovel 2 }\end{array}$ & - & 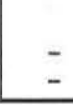 & E & $=$ & - & $=$ & - & $\overline{1}$ & $\bar{i}$ & $\begin{array}{r}8 \\
12 \\
\end{array}$ & - & $\overline{-}$ & 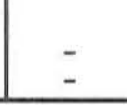 & - & - & $\begin{array}{c}8 \\
14 \\
14 \\
\end{array}$ \\
\hline
\end{tabular}




\begin{tabular}{|c|c|c|c|c|c|c|c|c|c|c|c|c|c|c|c|c|}
\hline $\begin{array}{l}\text { Excavarion Unit } \\
\text { and Level }\end{array}$ & \begin{tabular}{|l} 
Arrow \\
Points
\end{tabular} & $\begin{array}{l}\text { Dart } \\
\text { Points }\end{array}$ & Perforators & Gouges & Bifaces & \begin{tabular}{|l} 
Cobble \\
Tools
\end{tabular} & \begin{tabular}{|l|} 
Uniffaces \\
\end{tabular} & Cores & 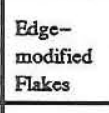 & \begin{tabular}{|l} 
Unmodificed \\
Desiage
\end{tabular} & \begin{tabular}{|l} 
Ground \\
Strone \\
Tools \\
\end{tabular} & Hammerstones & \begin{tabular}{|l} 
Manuports \\
\end{tabular} & Ceramics & \begin{tabular}{|l} 
Modifinod \\
Shcls
\end{tabular} & Touls \\
\hline $\begin{array}{l}\text { 41GR383, continuec } \\
\text { EU 11 } \\
\text { Level 2 } \\
\text { Level 3 } \\
\text { Level 4 }\end{array}$ & $\bar{z}$ & $\bar{z}$ & $\bar{z}$ & $\bar{z}$ & $\bar{z}$ & $\bar{z}$ & $\overline{2}$ & $\bar{z}$ & $\begin{array}{l}- \\
1 \\
\end{array}$ & $\begin{array}{r}7 \\
20 \\
4 \\
\end{array}$ & $\bar{z}$ & $\Xi$ & $\Xi$ & $\bar{z}$ & $\bar{z}$ & $\begin{array}{r}7 \\
23 \\
5 \\
\end{array}$ \\
\hline $\begin{array}{l}\text { EU } 12 \\
\text { Level 1 } \\
\text { Level } 2 \\
\text { Level } \\
\text { Level } 4 \\
\end{array}$ & $\bar{z}$ & $\begin{array}{l}- \\
z \\
\end{array}$ & $\bar{\Sigma}$ & $\begin{array}{l}\bar{z} \\
\bar{z}\end{array}$ & $\begin{array}{l}\overline{-} \\
\bar{z}\end{array}$ & $\bar{z}$ & $\begin{array}{l}\overline{-} \\
\bar{z}\end{array}$ & $\begin{array}{l}\bar{z} \\
1 \\
\end{array}$ & $\begin{array}{r}- \\
1 \\
-1 \\
\end{array}$ & $\begin{array}{r}10 \\
26 \\
3 \\
15 \\
\end{array}$ & $\begin{array}{l}\overline{2} \\
\overline{-} \\
\end{array}$ & $\bar{~}$ & $\begin{array}{l}\bar{z} \\
\bar{z}\end{array}$ & छ & $\bar{z}$ & $\begin{array}{l}10 \\
29 \\
5 \\
15 \\
\end{array}$ \\
\hline $\begin{array}{l}\mathrm{EU} 13 \\
\text { Level 1 } \\
\text { LLvel } 2 \\
\text { Level } \\
\text { Level } 4 \\
\end{array}$ & $\begin{array}{l}\bar{z} \\
\bar{z}\end{array}$ & $\begin{array}{l}\bar{z} \\
\bar{z}\end{array}$ & $\bar{z}$ & $\begin{array}{l}\bar{z} \\
\bar{z}\end{array}$ & $\begin{array}{l}\overline{-} \\
\overline{-}\end{array}$ & $\bar{z}$ & z & $\begin{array}{l}\overline{1} \\
\overline{-} \\
\end{array}$ & z & $\begin{array}{c}10 \\
16 \\
3 \\
1 \\
1\end{array}$ & $\begin{array}{l}\bar{z} \\
\bar{z}\end{array}$ & $\bar{z}$ & $\bar{z}$ & $\bar{z}$ & $\bar{z}$ & $\begin{array}{c}10 \\
17 \\
3 \\
1\end{array}$ \\
\hline $\begin{array}{l}\text { EU } 14 \\
\text { Level } 2 \\
\text { Level } \\
\text { Level }\end{array}$ & $\bar{z}$ & $\bar{z}$ & $\bar{z}$ & $\bar{z}$ & 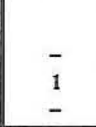 & $\bar{z}$ & $\bar{z}$ & $\bar{z}$ & $\begin{array}{l}1 \\
2 \\
-\end{array}$ & $\begin{array}{r}52 \\
22 \\
10\end{array}$ & $\bar{z}$ & $\bar{z}$ & $\bar{z}$ & $\bar{z}$ & $\overline{-}$ & $\begin{array}{l}6 \\
25 \\
10\end{array}$ \\
\hline $\begin{array}{l}\text { EUIS } \\
\text { Level 1 } \\
\text { LLvel } 2 \\
\text { Level } 3 \\
\text { Lovel 4 } \\
\end{array}$ & $\begin{array}{l}\bar{z} \\
\bar{z}\end{array}$ & $\begin{array}{l}\bar{z} \\
\bar{z} \\
\end{array}$ & $\bar{z}$ & $\begin{array}{l}\bar{z} \\
\bar{z}\end{array}$ & $\bar{z}$ & $\begin{array}{l}\bar{z} \\
\bar{z}\end{array}$ & $\bar{z}$ & $\begin{array}{l}1 \\
- \\
\end{array}$ & $\bar{z}$ & $\begin{array}{c}9 \\
19 \\
12 \\
6 \\
6\end{array}$ & $\begin{array}{l}\overline{2} \\
\overline{-}\end{array}$ & $\bar{z}$ & $\begin{array}{l}\bar{z} \\
\bar{z}\end{array}$ & $\bar{z}$ & $\bar{z}$ & $\begin{array}{l}10 \\
21 \\
12 \\
6\end{array}$ \\
\hline $\begin{array}{l}\text { EU16 } 1 \\
\text { Level } 1 \\
\text { Level } 2 \\
\text { LLvel } 3 \\
\text { Level 4 } \\
\end{array}$ & $\bar{z}$ & $\begin{array}{l}\bar{z} \\
\bar{z} \\
\end{array}$ & $\begin{array}{l}\overline{-} \\
\bar{z}\end{array}$ & $\bar{z}$ & $\begin{array}{l}1 \\
- \\
\end{array}$ & 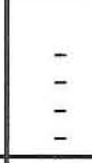 & $\begin{array}{l}\bar{z} \\
\bar{z}\end{array}$ & $\begin{array}{l}1 \\
\vdots \\
\end{array}$ & $\begin{array}{l}- \\
1 \\
3 \\
1 \\
\end{array}$ & $\begin{array}{r}2 \\
11 \\
14 \\
2 \\
\end{array}$ & $\bar{z}$ & $\bar{z}$ & $\begin{array}{l}\bar{z} \\
\bar{z}\end{array}$ & $\bar{z}$ & $\bar{z}$ & $\begin{array}{c}4 \\
12 \\
17 \\
4 \\
\end{array}$ \\
\hline 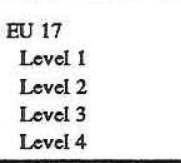 & $\begin{array}{l}\bar{z} \\
\bar{z}\end{array}$ & $\begin{array}{l}\bar{z} \\
\bar{z}\end{array}$ & $\bar{z}$ & $\begin{array}{l}\bar{z} \\
\bar{z}\end{array}$ & $\begin{array}{l}\bar{z} \\
\bar{z}\end{array}$ & $\begin{array}{l}\vdots \\
\vdots\end{array}$ & $\bar{z}$ & $\begin{array}{l}\bar{z} \\
\bar{z}\end{array}$ & $\bar{z}$ & $\begin{array}{l}1 \\
11 \\
16 \\
10\end{array}$ & $\begin{array}{l}\bar{z} \\
- \\
\end{array}$ & $\bar{z}$ & $\begin{array}{l}\bar{z} \\
\bar{z}\end{array}$ & $\bar{z}$ & $\bar{~}$ & $\begin{array}{l}1 \\
11 \\
16 \\
10 \\
10\end{array}$ \\
\hline $\begin{array}{l}\text { EU } 18 \\
\text { Level } 1 \\
\text { LLvel } \\
\text { Level } \\
\text { Level } \\
\end{array}$ & $\bar{z}$ & $\begin{array}{l}z \\
z \\
\end{array}$ & $\bar{z}$ & $\begin{array}{l}\bar{z} \\
\overline{-}\end{array}$ & $\bar{z}$ & $\bar{z}$ & $\bar{~}$ & $\begin{array}{l}\bar{z} \\
\bar{z}\end{array}$ & $\bar{z}$ & $\begin{array}{l}1 \\
9 \\
3 \\
1 \\
\end{array}$ & $\begin{array}{l}5 \\
\bar{z}\end{array}$ & $\bar{z}$ & $\bar{z}$ & $\begin{array}{l}\bar{z} \\
\bar{z}\end{array}$ & $\bar{z}$ & $\begin{array}{l}1 \\
9 \\
3 \\
1\end{array}$ \\
\hline $\begin{array}{l}\text { EU 19 } \\
\text { Level 1 } \\
\text { Level } 2 \\
\text { LLvel } \\
\text { Level } 4 \\
\end{array}$ & $\begin{array}{l}\bar{z} \\
\bar{z}\end{array}$ & $\begin{array}{l}5 \\
z \\
\end{array}$ & $\bar{z}$ & $\begin{array}{l}\bar{z} \\
\bar{z}\end{array}$ & $\begin{array}{l}\bar{z} \\
\bar{z}\end{array}$ & $\begin{array}{l}\bar{\Sigma} \\
\overline{-} \\
\end{array}$ & $\begin{array}{l}\bar{z} \\
\bar{z} \\
\end{array}$ & $\begin{array}{l}\bar{z} \\
\bar{z}\end{array}$ & $\begin{array}{l}\bar{z} \\
\overline{-}\end{array}$ & $\begin{array}{r}7 \\
21 \\
7 \\
2 \\
\end{array}$ & $\begin{array}{l}- \\
\overline{1} \\
- \\
\end{array}$ & $\bar{z}$ & $\begin{array}{l}\bar{z} \\
\bar{z}\end{array}$ & $\begin{array}{l}\bar{z} \\
\bar{z}\end{array}$ & $\begin{array}{l}\bar{z} \\
\bar{z}\end{array}$ & $\begin{array}{r}7 \\
21 \\
8 \\
2\end{array}$ \\
\hline
\end{tabular}




\begin{tabular}{|c|c|c|c|c|c|c|c|c|c|c|c|c|c|c|c|c|}
\hline $\begin{array}{l}\text { Excavation Unit } \\
\text { and Level }\end{array}$ & $\begin{array}{l}\text { Arrow } \\
\text { Poinits }\end{array}$ & $\begin{array}{l}\text { Dart } \\
\text { Points }\end{array}$ & \begin{tabular}{|l} 
Perforators \\
\end{tabular} & Gouges & Bifaces & $\begin{array}{l}\text { Cobble } \\
\text { Tools }\end{array}$ & Unifaces & Cores & 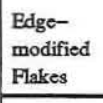 & \begin{tabular}{|l} 
Unmodified \\
Debitago
\end{tabular} & \begin{tabular}{|l} 
Ground \\
Stone \\
Tools \\
\end{tabular} & Hammerstones & Manuports & Ceramics & $\begin{array}{l}\text { Modified } \\
\text { Shells }\end{array}$ & Totals \\
\hline $\begin{array}{l}\text { 41GR383, continue } \\
\text { EU 20 } \\
\text { Level 1 } \\
\text { Lovel 2 } \\
\text { Level 3 } \\
\text { Level 4 } \\
\text { Level } 5 \\
\end{array}$ & $\begin{array}{l}- \\
\bar{z} \\
\overline{-} \\
\end{array}$ & $\begin{array}{l}- \\
\bar{z} \\
- \\
-\end{array}$ & $\begin{array}{l}- \\
\bar{z} \\
- \\
-\end{array}$ & $\begin{array}{l}- \\
- \\
- \\
-\end{array}$ & $\begin{array}{l}- \\
- \\
\overline{1} \\
- \\
\end{array}$ & $\begin{array}{l}- \\
- \\
- \\
- \\
\end{array}$ & $\begin{array}{l}- \\
\overline{1} \\
- \\
- \\
\end{array}$ & $\begin{array}{l}- \\
\overline{2} \\
- \\
- \\
\end{array}$ & $\begin{array}{l}- \\
1 \\
1 \\
- \\
-\end{array}$ & $\begin{array}{r}4 \\
16 \\
3 \\
4 \\
1 \\
\end{array}$ & $\begin{array}{l}z \\
1 \\
- \\
-\end{array}$ & $\begin{array}{l}- \\
- \\
- \\
-\end{array}$ & $\begin{array}{l}- \\
\bar{z} \\
- \\
-\end{array}$ & $\begin{array}{l}z \\
\bar{z} \\
-\end{array}$ & $\begin{array}{l}- \\
\bar{z} \\
- \\
-\end{array}$ & $\begin{array}{r}4 \\
17 \\
8 \\
5 \\
1 \\
\end{array}$ \\
\hline $\begin{array}{l}\text { EU } 21 \\
\text { Level } 1 \\
\text { Level } 2 \\
\text { Level } 3 \\
\text { Level } 4 \\
\end{array}$ & $\begin{array}{l}- \\
\overline{-} \\
-\end{array}$ & $\begin{array}{l}- \\
\bar{z} \\
-\end{array}$ & $\begin{array}{l}- \\
\bar{z} \\
\end{array}$ & $\begin{array}{l}z \\
z \\
z\end{array}$ & $\begin{array}{l}- \\
\bar{y} \\
1 \\
\end{array}$ & $\begin{array}{l}- \\
z \\
-\end{array}$ & $\begin{array}{l}- \\
\bar{z} \\
- \\
\end{array}$ & $\begin{array}{l}- \\
\overline{-} \\
- \\
\end{array}$ & $\begin{array}{l}- \\
\overline{1} \\
- \\
\end{array}$ & $\begin{array}{r}6 \\
11 \\
6 \\
5 \\
\end{array}$ & $\begin{array}{l}- \\
\overline{-} \\
-\end{array}$ & $\begin{array}{l}\bar{z} \\
\overline{-}\end{array}$ & $\begin{array}{l}z \\
z \\
-\end{array}$ & $\begin{array}{l}z \\
z \\
-\end{array}$ & $\begin{array}{l}z \\
z \\
-\end{array}$ & $\begin{array}{r}6 \\
11 \\
7 \\
6 \\
\end{array}$ \\
\hline $\begin{array}{l}\text { EU } 22 \\
\text { Lovel } 1 \\
\text { Lovel } 2 \\
\text { Lovel } 3 \\
\text { Lovel } 4 \\
\end{array}$ & $\begin{array}{l}- \\
\bar{z} \\
-\end{array}$ & $\begin{array}{l}- \\
\bar{z} \\
-\end{array}$ & $\begin{array}{l}- \\
\bar{z} \\
-\end{array}$ & $\begin{array}{l}z \\
z \\
z\end{array}$ & $\begin{array}{l}- \\
1 \\
- \\
-\end{array}$ & $\begin{array}{l}- \\
\bar{z} \\
- \\
\end{array}$ & $\begin{array}{l}- \\
\bar{z} \\
- \\
\end{array}$ & $\begin{array}{l}- \\
\overline{-} \\
-\end{array}$ & $\begin{array}{l}- \\
\overline{1} \\
-\end{array}$ & $\begin{array}{r}3 \\
8 \\
13 \\
1 \\
\end{array}$ & $\begin{array}{l}- \\
\overline{-} \\
-\end{array}$ & $\begin{array}{l}- \\
\overline{1} \\
1 \\
\end{array}$ & $\begin{array}{l}- \\
\bar{z} \\
-\end{array}$ & $\begin{array}{l}\overline{-} \\
\overline{-} \\
\end{array}$ & $\begin{array}{l}- \\
\overline{-} \\
\end{array}$ & $\begin{array}{r}3 \\
9 \\
15 \\
2 \\
\end{array}$ \\
\hline $\begin{array}{l}\text { EU } 23 \\
\text { Lovel } 1 \\
\text { Lovel } 2 \\
\text { Lovel } 3 \\
\text { Level } 4 \\
\end{array}$ & $\begin{array}{l}- \\
\bar{z} \\
-\end{array}$ & $\begin{array}{l}- \\
\bar{z} \\
-\end{array}$ & $\begin{array}{l}- \\
\bar{z} \\
-\end{array}$ & $\begin{array}{l}z \\
z \\
z\end{array}$ & $\begin{array}{l}- \\
\bar{z} \\
- \\
\end{array}$ & $\begin{array}{l}- \\
z \\
- \\
\end{array}$ & $\begin{array}{l}- \\
- \\
- \\
\end{array}$ & $\begin{array}{l}- \\
\bar{z} \\
-\end{array}$ & $\begin{array}{l}- \\
\bar{z} \\
-\end{array}$ & $\begin{array}{l}1 \\
9 \\
3 \\
5 \\
\end{array}$ & $\begin{array}{l}z \\
\bar{z} \\
\end{array}$ & $\begin{array}{l}\bar{z} \\
\bar{z} \\
-\end{array}$ & $\begin{array}{l}\bar{z} \\
\bar{z} \\
-\end{array}$ & $\begin{array}{l}\bar{z} \\
\overline{-} \\
\end{array}$ & $\begin{array}{l}- \\
\bar{z} \\
-\end{array}$ & $\begin{array}{l}1 \\
9 \\
3 \\
5 \\
\end{array}$ \\
\hline $\begin{array}{l}\text { EU } 24 \\
\text { Level } 2 \\
\text { Level } 13 \\
\text { Lovel } 4 \\
\end{array}$ & $\begin{array}{l}- \\
\overline{-}\end{array}$ & $\begin{array}{l}\overline{-} \\
-\end{array}$ & $\begin{array}{l}\bar{z} \\
\overline{-}\end{array}$ & $\begin{array}{l}1 \\
- \\
\end{array}$ & $\begin{array}{l}- \\
- \\
\end{array}$ & $\begin{array}{l}- \\
-\end{array}$ & $\begin{array}{l}\bar{z} \\
\overline{-}\end{array}$ & $\begin{array}{l}\bar{z} \\
2 \\
\end{array}$ & $\begin{array}{l}- \\
-\end{array}$ & $\begin{array}{r}24 \\
10 \\
5 \\
\end{array}$ & $\begin{array}{l}\overline{1} \\
-\end{array}$ & $\begin{array}{l}\bar{z} \\
\overline{-}\end{array}$ & $\begin{array}{l}- \\
\overline{-}\end{array}$ & $\begin{array}{l}\bar{z} \\
\overline{-}\end{array}$ & $\begin{array}{l}\overline{-} \\
-\end{array}$ & $\begin{array}{c}25 \\
12 \\
7 \\
\end{array}$ \\
\hline $\begin{array}{l}\text { EU 25 } \\
\text { Lovel 1 } \\
\text { Level } 2 \\
\text { Lovel } 3 \\
\end{array}$ & $\begin{array}{l}- \\
\overline{-}\end{array}$ & $\begin{array}{l}- \\
-\end{array}$ & $\begin{array}{l}\bar{z} \\
-\end{array}$ & $\begin{array}{l}- \\
\overline{-} \\
\end{array}$ & $\begin{array}{l}- \\
- \\
\end{array}$ & $\begin{array}{l}- \\
- \\
\end{array}$ & $\begin{array}{l}- \\
- \\
\end{array}$ & $\begin{array}{l}- \\
-\end{array}$ & $\begin{array}{l}- \\
\overline{-}\end{array}$ & $\begin{array}{r}10 \\
21 \\
7 \\
\end{array}$ & $\begin{array}{l}- \\
-\end{array}$ & $\begin{array}{l}\overline{-} \\
-\end{array}$ & $\begin{array}{l}\bar{z} \\
\overline{-}\end{array}$ & $\begin{array}{l}\bar{z} \\
\overline{-}\end{array}$ & $\begin{array}{l}\bar{z} \\
-\end{array}$ & $\begin{array}{r}10 \\
21 \\
7 \\
\end{array}$ \\
\hline $\begin{array}{l}\text { EU } 26 \\
\text { Lovel } 1 \\
\text { Lovel } 2 \\
\text { Lovel } 3 \\
\text { Level } 4 \\
\end{array}$ & $\begin{array}{l}- \\
\overline{-} \\
-\end{array}$ & $\begin{array}{l}- \\
\bar{z} \\
-\end{array}$ & $\begin{array}{l}- \\
\bar{z} \\
-\end{array}$ & $\begin{array}{l}z \\
z \\
-\end{array}$ & $\begin{array}{l}- \\
\overline{-} \\
- \\
\end{array}$ & $\begin{array}{l}- \\
- \\
- \\
\end{array}$ & $\begin{array}{l}- \\
- \\
- \\
\end{array}$ & $\begin{array}{l}- \\
\bar{z} \\
-\end{array}$ & $\begin{array}{l}- \\
\bar{z} \\
\end{array}$ & $\begin{array}{r}1 \\
14 \\
6 \\
9 \\
\end{array}$ & $\begin{array}{l}\overline{-} \\
\overline{-}\end{array}$ & $\begin{array}{l}- \\
\overline{-} \\
-\end{array}$ & $\begin{array}{l}- \\
\overline{-} \\
-\end{array}$ & $\begin{array}{l}\bar{z} \\
\bar{z}\end{array}$ & $\begin{array}{l}- \\
- \\
-\end{array}$ & $\begin{array}{r}1 \\
14 \\
6 \\
9\end{array}$ \\
\hline $\begin{array}{l}\text { EU } 27 \\
\text { Level 1 } \\
\text { Lovel 2 } \\
\end{array}$ & - & - & - & - & $\begin{array}{l}- \\
-\end{array}$ & - & - & - & $\overline{1}$ & $\begin{array}{r}5 \\
22 \\
\end{array}$ & - & - & - & - & - & $\begin{array}{r}5 \\
23 \\
\end{array}$ \\
\hline $\begin{array}{l}\text { EU } 28 \\
\text { Level } 1 \\
\text { Lovel } 2 \\
\text { Level } 3\end{array}$ & $\bar{z}$ & $\bar{z}$ & $\bar{z}$ & $\begin{array}{l}- \\
-\end{array}$ & $\begin{array}{l}- \\
-\end{array}$ & $\begin{array}{l}- \\
-\end{array}$ & $\begin{array}{l}- \\
-\end{array}$ & $\bar{z}$ & $\begin{array}{l}\overline{1} \\
-\end{array}$ & $\begin{array}{r}11 \\
12 \\
2\end{array}$ & $\bar{z}$ & $\begin{array}{l}\overline{-} \\
\overline{-}\end{array}$ & $\bar{z}$ & $\bar{z}$ & $\bar{z}$ & $\begin{array}{c}11 \\
13 \\
2\end{array}$ \\
\hline
\end{tabular}




\begin{tabular}{|c|c|c|c|c|c|c|c|c|c|c|c|c|c|c|c|c|}
\hline $\begin{array}{l}\text { Excavation Unit } \\
\text { and Lovel }\end{array}$ & \begin{tabular}{|l} 
Arrow \\
Points
\end{tabular} & $\begin{array}{l}\text { Dart } \\
\text { Points } \\
\end{array}$ & Pefforators & Gouges & Bifaces & $\begin{array}{l}\text { Cobble } \\
\text { Tools }\end{array}$ & Unifaces & Cores & \begin{tabular}{|l}
$\begin{array}{l}\text { Edgo- } \\
\text { modified } \\
\text { Flakes }\end{array}$ \\
\end{tabular} & \begin{tabular}{|l} 
Unmodified \\
Debiage
\end{tabular} & \begin{tabular}{|l} 
Ground \\
Stone \\
Tools \\
\end{tabular} & Hammerstones & Manuports & Ceramics & $\begin{array}{l}\text { Modified } \\
\text { Shells }\end{array}$ & Totals \\
\hline $\begin{array}{l}\text { 41GR383, continued } \\
\text { EU 29 } \\
\text { Lovel } 1 \\
\text { Lovel 2 } \\
\end{array}$ & - & $\overline{-}$ & $\bar{z}$ & $\overline{-}$ & $\begin{array}{l}1 \\
- \\
\end{array}$ & $\overline{-}$ & $\begin{array}{l}- \\
-\end{array}$ & $\overline{1}$ & $\overline{1}$ & $\begin{array}{r}3 \\
11 \\
\end{array}$ & - & - & $\bar{z}$ & $\overline{-}$ & $\bar{z}$ & $\begin{array}{r}4 \\
13\end{array}$ \\
\hline $\begin{array}{l}\text { EU } 30 \\
\text { Level } 1 \\
\text { Lovel } 2 \\
\text { Level } 3 \\
\end{array}$ & $\begin{array}{l}- \\
- \\
\end{array}$ & $\begin{array}{l}\bar{z} \\
\overline{-}\end{array}$ & $\begin{array}{l}\bar{z} \\
\overline{-}\end{array}$ & $\begin{array}{l}- \\
\overline{-}\end{array}$ & $\begin{array}{l}\bar{z} \\
\overline{-}\end{array}$ & $\begin{array}{l}- \\
\overline{-}\end{array}$ & $\begin{array}{l}- \\
- \\
\end{array}$ & $\begin{array}{l}- \\
- \\
\end{array}$ & $\begin{array}{l}\overline{1} \\
-\end{array}$ & $\begin{array}{r}3 \\
19 \\
20 \\
\end{array}$ & $\begin{array}{l}1 \\
1 \\
1 \\
\end{array}$ & $\begin{array}{l}\bar{z} \\
\overline{-}\end{array}$ & $\begin{array}{l}\bar{z} \\
\overline{-}\end{array}$ & $\begin{array}{l}- \\
-\end{array}$ & $\begin{array}{l}\bar{z} \\
\overline{-}\end{array}$ & $\begin{array}{r}4 \\
21 \\
21 \\
\end{array}$ \\
\hline $\begin{array}{l}\text { EU } 31 \\
\text { Lovel 1 } \\
\text { Lovel } 2 \\
\text { Lovel } 3 \\
\end{array}$ & $\begin{array}{l}- \\
-\end{array}$ & $\begin{array}{l}\bar{z} \\
\overline{-}\end{array}$ & $\begin{array}{l}\bar{z} \\
-\end{array}$ & $\begin{array}{l}\bar{z} \\
\overline{-}\end{array}$ & $\begin{array}{l}\overline{1} \\
-\end{array}$ & $\begin{array}{l}\overline{2} \\
\overline{-}\end{array}$ & $\begin{array}{l}- \\
-\end{array}$ & $\begin{array}{l}- \\
\overline{-}\end{array}$ & $\begin{array}{l}\overline{-} \\
-\end{array}$ & $\begin{array}{r}11 \\
29 \\
8 \\
\end{array}$ & $\begin{array}{l}- \\
1 \\
-\end{array}$ & $\begin{array}{l}\bar{z} \\
\overline{-}\end{array}$ & $\begin{array}{l}\bar{z} \\
\overline{-}\end{array}$ & $\begin{array}{l}\bar{z} \\
-\end{array}$ & $\begin{array}{l}- \\
-\end{array}$ & $\begin{array}{r}11 \\
33 \\
8 \\
\end{array}$ \\
\hline $\begin{array}{l}\text { EU } 32 \\
\text { Lovel } 1 \\
\text { Lovel } 2 \\
\text { Lovel } 3 \\
\end{array}$ & $\begin{array}{l}- \\
- \\
\end{array}$ & $\begin{array}{l}- \\
\overline{-}\end{array}$ & $\begin{array}{l}\bar{z} \\
\overline{-}\end{array}$ & $\begin{array}{l}- \\
\overline{-}\end{array}$ & $\begin{array}{l}- \\
\bar{z}\end{array}$ & $\begin{array}{l}- \\
\overline{-}\end{array}$ & $\begin{array}{l}- \\
- \\
\end{array}$ & $\begin{array}{l}- \\
\overline{-}\end{array}$ & $\begin{array}{l}\bar{z} \\
\overline{-}\end{array}$ & $\begin{array}{r}3 \\
20 \\
7 \\
\end{array}$ & $\frac{-}{1}$ & $\begin{array}{l}\overline{1} \\
-\end{array}$ & $\begin{array}{l}\bar{z} \\
-\end{array}$ & $\begin{array}{l}\overline{-} \\
\overline{-}\end{array}$ & $\begin{array}{l}- \\
-\end{array}$ & $\begin{array}{r}3 \\
22 \\
7 \\
\end{array}$ \\
\hline $\begin{array}{l}\text { EU } 33 \\
\text { Lovol } 1 \\
\text { Lovel } 2 \\
\text { Lovel } 3 \\
\end{array}$ & $\begin{array}{l}- \\
- \\
\end{array}$ & $\begin{array}{l}\bar{z} \\
\overline{-}\end{array}$ & $\begin{array}{l}\bar{z} \\
\overline{-}\end{array}$ & $\begin{array}{l}\overline{-} \\
\overline{-}\end{array}$ & $\begin{array}{l}- \\
- \\
\end{array}$ & $\begin{array}{l}- \\
1 \\
\end{array}$ & $\begin{array}{l}\overline{1} \\
- \\
\end{array}$ & $\begin{array}{l}- \\
\overline{-}\end{array}$ & $\overline{-}$ & $\begin{array}{r}2 \\
29 \\
15 \\
\end{array}$ & $\begin{array}{l}- \\
- \\
\end{array}$ & $\begin{array}{l}\overline{-} \\
-\end{array}$ & $\begin{array}{l}\bar{z} \\
\overline{-}\end{array}$ & $\begin{array}{l}\overline{-} \\
-\end{array}$ & $\begin{array}{l}\bar{z} \\
\overline{-}\end{array}$ & $\begin{array}{r}2 \\
30 \\
17 \\
\end{array}$ \\
\hline $\begin{array}{l}\text { EU } 34 \\
\text { Lovel } 1 \\
\text { Lovel } 2 \\
\text { Level } 3 \\
\text { Lovel } 4 \\
\end{array}$ & $\begin{array}{l}- \\
\bar{z} \\
- \\
\end{array}$ & $\begin{array}{l}- \\
\bar{z} \\
-\end{array}$ & $\begin{array}{l}z \\
z \\
z\end{array}$ & $\begin{array}{l}- \\
\bar{z} \\
-\end{array}$ & $\begin{array}{l}1 \\
- \\
- \\
-\end{array}$ & $\begin{array}{l}- \\
\bar{z} \\
-\end{array}$ & $\begin{array}{l}- \\
\overline{-} \\
\end{array}$ & $\begin{array}{l}\bar{z} \\
\bar{z} \\
\end{array}$ & $\begin{array}{l}- \\
\bar{z} \\
\overline{-}\end{array}$ & $\begin{array}{r}2 \\
14 \\
18 \\
3 \\
\end{array}$ & $\begin{array}{l}- \\
2 \\
- \\
\end{array}$ & $\begin{array}{l}- \\
\bar{z} \\
\overline{-}\end{array}$ & $\begin{array}{l}- \\
\bar{z} \\
\end{array}$ & $\begin{array}{l}- \\
\bar{z} \\
\end{array}$ & $\begin{array}{l}- \\
\bar{z} \\
\overline{-}\end{array}$ & $\begin{array}{r}3 \\
15 \\
20 \\
3 \\
\end{array}$ \\
\hline $\begin{array}{l}\text { EU 35 } \\
\text { Lovel } 1 \\
\text { Lovel } 2 \\
\text { Lovel } 3 \\
\text { Lovel } 4 \\
\end{array}$ & $\begin{array}{l}- \\
\overline{-} \\
- \\
\end{array}$ & $\begin{array}{l}\bar{z} \\
\bar{z} \\
\end{array}$ & $\begin{array}{l}z \\
\bar{z}\end{array}$ & $\begin{array}{l}- \\
\bar{z} \\
- \\
\end{array}$ & $\begin{array}{l}1 \\
1 \\
- \\
- \\
\end{array}$ & $\begin{array}{l}- \\
\bar{z} \\
- \\
\end{array}$ & $\begin{array}{l}- \\
\bar{z} \\
- \\
\end{array}$ & $\begin{array}{l}\bar{z} \\
\overline{-} \\
\end{array}$ & $\begin{array}{l}- \\
\overline{-} \\
-\end{array}$ & $\begin{array}{r}- \\
12 \\
3 \\
6 \\
\end{array}$ & $\begin{array}{l}- \\
1 \\
- \\
-\end{array}$ & $\begin{array}{l}- \\
\bar{z} \\
-\end{array}$ & $\begin{array}{l}\bar{z} \\
\overline{-}\end{array}$ & $\begin{array}{l}- \\
\bar{z} \\
-\end{array}$ & $\begin{array}{l}- \\
\bar{z} \\
-\end{array}$ & $\begin{array}{r}1 \\
14 \\
3 \\
6 \\
\end{array}$ \\
\hline $\begin{array}{l}\text { EU 36 } \\
\text { Lovel } 1 \\
\text { Lovel } 2 \\
\text { Lovel } 3 \\
\text { Lovel } 4 \\
\text { Lovel } 5 \\
\end{array}$ & $\begin{array}{l}- \\
- \\
- \\
- \\
\end{array}$ & $\begin{array}{l}\bar{z} \\
\bar{z} \\
-\end{array}$ & $\begin{array}{l}- \\
\bar{z} \\
z \\
-\end{array}$ & $\begin{array}{l}- \\
- \\
- \\
- \\
\end{array}$ & $\begin{array}{l}\overline{1} \\
- \\
- \\
- \\
\end{array}$ & $\begin{array}{l}- \\
- \\
- \\
-\end{array}$ & $\begin{array}{l}- \\
- \\
- \\
- \\
\end{array}$ & $\begin{array}{l}- \\
\overline{1} \\
- \\
-\end{array}$ & $\begin{array}{l}- \\
\bar{z} \\
\overline{1} \\
1\end{array}$ & $\begin{array}{r}5 \\
12 \\
15 \\
7 \\
1 \\
\end{array}$ & $\begin{array}{l}5 \\
1 \\
- \\
\end{array}$ & $\begin{array}{l}z \\
z \\
z \\
-\end{array}$ & $\begin{array}{l}- \\
- \\
- \\
-\end{array}$ & $\begin{array}{l}- \\
- \\
- \\
-\end{array}$ & $\begin{array}{l}\overline{-} \\
\overline{-} \\
- \\
\end{array}$ & $\begin{array}{r}5 \\
13 \\
17 \\
7 \\
2 \\
\end{array}$ \\
\hline $\begin{array}{l}\text { EU } 37 \\
\text { Level } 1 \\
\text { Lovel } 2 \\
\text { Level } 3 \\
\text { Lovel } 4 \\
\end{array}$ & $\begin{array}{l}- \\
\overline{-} \\
-\end{array}$ & $\begin{array}{l}\bar{z} \\
\bar{z} \\
\end{array}$ & $\begin{array}{l}\bar{z} \\
\overline{-} \\
-\end{array}$ & $\begin{array}{l}\bar{z} \\
\bar{z} \\
-\end{array}$ & $\begin{array}{l}\overline{1} \\
\overline{-} \\
-\end{array}$ & $\begin{array}{l}- \\
\overline{-} \\
-\end{array}$ & $\begin{array}{l}- \\
\overline{-} \\
1 \\
\end{array}$ & $\begin{array}{l}\bar{z} \\
\bar{z} \\
\end{array}$ & $\begin{array}{l}1 \\
- \\
- \\
-\end{array}$ & $\begin{array}{r}11 \\
23 \\
4 \\
3 \\
\end{array}$ & $\begin{array}{l}- \\
3 \\
- \\
-\end{array}$ & $\begin{array}{l}\overline{-} \\
\overline{-} \\
-\end{array}$ & $\begin{array}{l}- \\
\bar{z} \\
\overline{-}\end{array}$ & $\begin{array}{l}z \\
z \\
z\end{array}$ & $\begin{array}{l}- \\
\overline{-} \\
-\end{array}$ & $\begin{array}{r}12 \\
27 \\
4 \\
4\end{array}$ \\
\hline
\end{tabular}




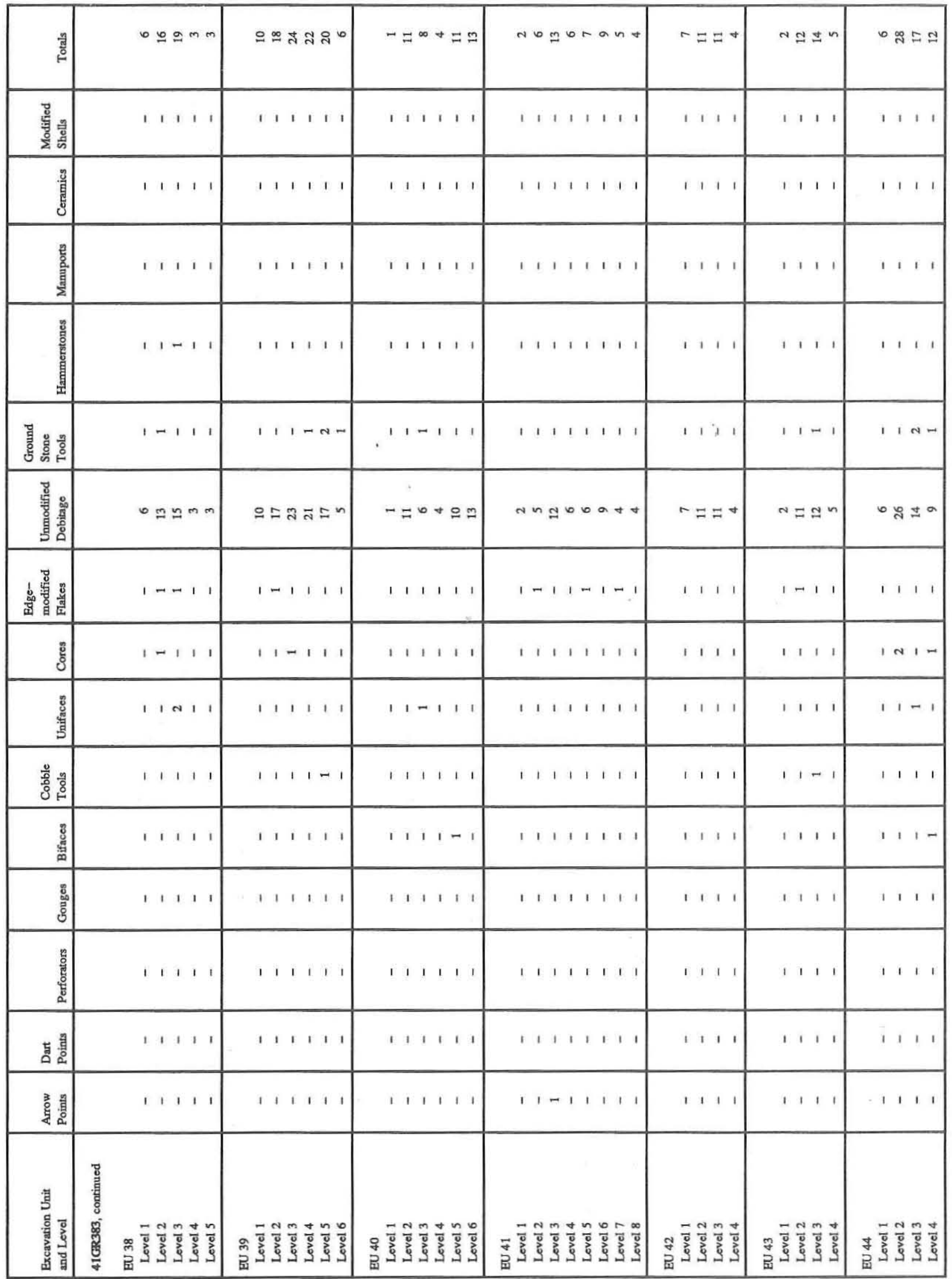




\begin{tabular}{|c|c|c|c|c|c|c|c|c|c|c|c|c|c|c|c|c|}
\hline $\begin{array}{l}\text { Excevvition Unit } \\
\text { and Level }\end{array}$ & \begin{tabular}{|l}
$\begin{array}{l}\text { Arrow } \\
\text { Poins }\end{array}$ \\
\end{tabular} & \begin{tabular}{|l} 
Dart \\
Points
\end{tabular} & Pefforators & Gouges & Bifaces & \begin{tabular}{|l} 
Cobble \\
Tools
\end{tabular} & Unificces & Cores & 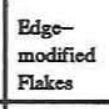 & \begin{tabular}{|l} 
Unmodififed \\
Debiiage
\end{tabular} & \begin{tabular}{|l} 
Groond \\
rstoge \\
Tools \\
\end{tabular} & Hammerstones & Manpoorts & Cermices & \begin{tabular}{|l} 
Modified \\
Sholls
\end{tabular} & Toats \\
\hline 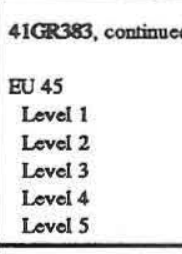 & $\begin{array}{l}\bar{z} \\
\bar{z} \\
\end{array}$ & $\begin{array}{l}\vdots \\
\vdots \\
\end{array}$ & $\begin{array}{l}\overline{-} \\
\bar{z} \\
\end{array}$ & $\begin{array}{l}\bar{z} \\
\bar{z}\end{array}$ & $\begin{array}{l}\bar{z} \\
\bar{z} \\
\end{array}$ & $\begin{array}{l}\vdots \\
\vdots \\
\end{array}$ & $\begin{array}{l}\bar{z} \\
\bar{z} \\
\end{array}$ & $\begin{array}{l}\bar{z} \\
\bar{z} \\
\bar{y}\end{array}$ & $\begin{array}{l}- \\
\overline{1} \\
1 \\
-\end{array}$ & $\begin{array}{c}3 \\
10 \\
18 \\
10 \\
8 \\
\end{array}$ & $\begin{array}{l}z \\
z \\
z\end{array}$ & $\begin{array}{l}\bar{z} \\
\bar{z}\end{array}$ & $\begin{array}{l}\overline{-} \\
\bar{z} \\
\end{array}$ & $\begin{array}{l}\overline{-} \\
\bar{z} \\
\end{array}$ & $\begin{array}{l}\bar{z} \\
\bar{z} \\
\end{array}$ & $\begin{array}{r}3 \\
10 \\
19 \\
11 \\
8 \\
\end{array}$ \\
\hline $\begin{array}{l}\text { EU } 46 \\
\text { Level } 1 \\
\text { Lovel } 2 \\
\text { Level } 3 \\
\text { Lovel } 4 \\
\text { Level } 5 \\
\end{array}$ & $\begin{array}{l}\bar{z} \\
\bar{z} \\
-\end{array}$ & $\begin{array}{l}- \\
\bar{z} \\
-\end{array}$ & $\begin{array}{l}\bar{z} \\
\bar{z}\end{array}$ & $\begin{array}{l}\bar{z} \\
\bar{z} \\
\end{array}$ & $\begin{array}{l}\bar{z} \\
1 \\
- \\
\end{array}$ & $\begin{array}{l}\bar{z} \\
\bar{z} \\
\bar{z}\end{array}$ & $\begin{array}{l}\bar{z} \\
\bar{z} \\
\overline{-}\end{array}$ & $\begin{array}{l}- \\
\bar{z} \\
- \\
-\end{array}$ & $\begin{array}{l}- \\
1 \\
- \\
-\end{array}$ & $\begin{array}{r}1 \\
10 \\
20 \\
- \\
2\end{array}$ & $\begin{array}{l}- \\
\overline{2} \\
-\end{array}$ & $\begin{array}{l}z \\
z\end{array}$ & $\begin{array}{l}\bar{z} \\
1 \\
\overline{-}\end{array}$ & $\begin{array}{l}\bar{z} \\
\bar{z}\end{array}$ & $\begin{array}{l}\bar{z} \\
\bar{z}\end{array}$ & $\begin{array}{r}1 \\
10 \\
23 \\
4 \\
2\end{array}$ \\
\hline $\begin{array}{l}\text { EU } 47 \\
\text { Level 1 } \\
\text { L Level } 2 \\
\text { Level } 3 \\
\text { L Lovel } 4 \\
\text { Level } 5 \\
\text { Level } 6 \\
\text { Level } 7 \\
\text { Level } 8 \\
\end{array}$ & $\begin{array}{l}\bar{z} \\
\vdots \\
\vdots \\
\vdots \\
-\end{array}$ & $\begin{array}{l}\vdots \\
\vdots \\
\vdots \\
\vdots \\
\end{array}$ & $\begin{array}{l}\bar{z} \\
\bar{z} \\
\bar{y} \\
\bar{y}\end{array}$ & $\begin{array}{l}\bar{z} \\
\vdots \\
\vdots \\
\vdots \\
\end{array}$ & $\begin{array}{l}- \\
\vdots \\
3 \\
\vdots \\
\vdots \\
-\end{array}$ & $\begin{array}{l}\vdots \\
\vdots \\
\vdots \\
\vdots \\
\vdots\end{array}$ & $\begin{array}{l}\bar{z} \\
\vdots \\
\vdots \\
\vdots \\
-\end{array}$ & $\begin{array}{l}- \\
\overline{2} \\
\vdots \\
1 \\
\vdots \\
\end{array}$ & $\begin{array}{l}- \\
\overline{1} \\
1 \\
\bar{y} \\
\bar{y}\end{array}$ & $\begin{array}{r}3 \\
13 \\
25 \\
12 \\
15 \\
7 \\
5 \\
2 \\
\end{array}$ & $\begin{array}{l}- \\
- \\
\vdots \\
\vdots \\
\vdots\end{array}$ & $\begin{array}{l}\bar{z} \\
\vdots \\
\vdots \\
\vdots \\
\end{array}$ & $\begin{array}{l}\bar{z} \\
\bar{z} \\
\bar{z} \\
\bar{y}\end{array}$ & $\begin{array}{l}- \\
\vdots \\
\vdots \\
\vdots \\
-\end{array}$ & $\begin{array}{l}z \\
\vdots \\
z \\
z \\
\end{array}$ & $\begin{array}{r}3 \\
15 \\
27 \\
18 \\
15 \\
8 \\
5 \\
2 \\
\end{array}$ \\
\hline $\begin{array}{l}\text { EU 48 } \\
\text { Level 1 } \\
\text { Level 2 } \\
\text { Level 3 } \\
\text { Lovel 4 } \\
\text { Level } 5 \\
\text { Level 6 } 6 \\
\end{array}$ & $\begin{array}{l}z \\
\bar{z} \\
\vdots \\
-\end{array}$ & $\begin{array}{l}- \\
\vdots \\
\overline{1} \\
- \\
\end{array}$ & $\begin{array}{l}\overline{-} \\
\bar{z} \\
\bar{z} \\
\end{array}$ & $\begin{array}{l}- \\
\vdots \\
z \\
\end{array}$ & $\begin{array}{l}z \\
z \\
z \\
-\end{array}$ & $\begin{array}{l}\vdots \\
\vdots \\
\vdots \\
\end{array}$ & $\begin{array}{l}z \\
z \\
z \\
z \\
\end{array}$ & $\begin{array}{l}\bar{z} \\
\bar{z} \\
\bar{y} \\
-\end{array}$ & $\begin{array}{l}\overline{1} \\
\bar{z} \\
\overline{-}\end{array}$ & $\begin{array}{c}11 \\
17 \\
15 \\
22 \\
10 \\
7 \\
\end{array}$ & $\begin{array}{l}z \\
\bar{z} \\
z \\
z\end{array}$ & $\begin{array}{l}z \\
z \\
z \\
z\end{array}$ & $\begin{array}{l}z \\
z \\
z \\
z\end{array}$ & $\begin{array}{l}- \\
\bar{z} \\
\bar{z} \\
\overline{-}\end{array}$ & $\begin{array}{l}z \\
z \\
z \\
z\end{array}$ & $\begin{array}{r}11 \\
11 \\
15 \\
22 \\
11 \\
7 \\
7\end{array}$ \\
\hline $\begin{array}{l}\text { Eu } 49 \\
\text { Level } 1 \\
\text { Level } 2 \\
\text { Lovel } 3 \\
\text { Lovel } 4 \\
\end{array}$ & $\begin{array}{l}\bar{z} \\
\overline{-} \\
\end{array}$ & $\begin{array}{l}\bar{z} \\
\overline{-} \\
\end{array}$ & 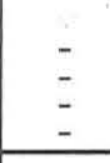 & $\bar{z}$ & $\begin{array}{l}\bar{z} \\
\overline{1} \\
\end{array}$ & $\begin{array}{l}\bar{z} \\
\bar{z} \\
\end{array}$ & $\bar{z}$ & $\begin{array}{l}\overline{1} \\
\overline{1}\end{array}$ & $\bar{\vdots}$ & $\begin{array}{r}14 \\
20 \\
6 \\
5 \\
\end{array}$ & $\begin{array}{l}- \\
\overline{2} \\
- \\
\end{array}$ & $\bar{z}$ & $\bar{~}$ & $\vdots$ & $\bar{\vdots}$ & $\begin{array}{r}14 \\
20 \\
8 \\
7 \\
\end{array}$ \\
\hline $\begin{array}{l}\text { EU So } \\
\text { Lovel } 1 \\
\text { Level } 2 \\
\text { Level } 3\end{array}$ & $\bar{z}$ & $\bar{z}$ & $\overline{-}$ & $\overline{-}$ & $\bar{z}$ & $\bar{z}$ & $\bar{z}$ & $i$ & $\overline{-}$ & $\begin{array}{r}27 \\
6 \\
3\end{array}$ & $\bar{z}$ & i & $\overline{-}$ & $\vdots$ & $\overline{-}$ & $\begin{array}{r}27 \\
8 \\
3\end{array}$ \\
\hline $\begin{array}{l}\text { Eu 51 } \\
\text { Level 1 } \\
\text { Levol } 2 \\
\text { Lovel } 3 \\
\text { Lovel } 4 \\
\text { Lovel } 5\end{array}$ & $\begin{array}{l}z \\
\bar{z} \\
z\end{array}$ & $\begin{array}{l}\bar{z} \\
\bar{z} \\
-\end{array}$ & $\begin{array}{l}\bar{z} \\
\bar{z} \\
\overline{-}\end{array}$ & $\begin{array}{l}\bar{z} \\
\bar{z}\end{array}$ & $\begin{array}{l}\overline{1} \\
\overline{-} \\
-\end{array}$ & $\begin{array}{l}\bar{z} \\
\bar{z}\end{array}$ & $\begin{array}{l}\bar{z} \\
1 \\
\overline{-}\end{array}$ & $\begin{array}{l}\bar{z} \\
\bar{z}\end{array}$ & $\begin{array}{l}1 \\
1 \\
- \\
- \\
-\end{array}$ & $\begin{array}{c}12 \\
16 \\
15 \\
4 \\
4\end{array}$ & $\begin{array}{l}z \\
4 \\
-\end{array}$ & $\begin{array}{l}\bar{z} \\
\bar{z}\end{array}$ & $\begin{array}{l}\bar{z} \\
\bar{y}\end{array}$ & $\begin{array}{l}\bar{z} \\
\vdots\end{array}$ & $\begin{array}{l}\bar{z} \\
\bar{z}\end{array}$ & $\begin{array}{r}13 \\
18 \\
20 \\
4 \\
4\end{array}$ \\
\hline
\end{tabular}




\begin{tabular}{|c|c|c|c|c|c|c|c|c|c|c|c|c|c|c|c|c|}
\hline $\begin{array}{l}\text { Excavastion Unit } \\
\text { and Level }\end{array}$ & \begin{tabular}{|l} 
Arrow \\
Points
\end{tabular} & $\begin{array}{l}\text { Dart } \\
\text { Poins }\end{array}$ & \begin{tabular}{|l|l} 
Pefforations \\
\end{tabular} & \begin{tabular}{|l|l|} 
Gougess \\
\end{tabular} & Bifaces & $\begin{array}{l}\text { Cobble } \\
\text { Tools } \\
\end{array}$ & \begin{tabular}{|l} 
Unifaces \\
\end{tabular} & Cores & $\begin{array}{l}\text { Edge- } \\
\text { modificed } \\
\text { Flakes }\end{array}$ & \begin{tabular}{|l} 
Unmmodificed \\
Debitiage
\end{tabular} & $\begin{array}{l}\text { Ground } \\
\text { Strone } \\
\text { Trols }\end{array}$ & Hammerstones & \begin{tabular}{|l} 
Manports \\
\end{tabular} & Ceramics & \begin{tabular}{|l} 
Modified \\
Shells
\end{tabular} & Touls \\
\hline $\begin{array}{l}\text { 41GR383, continuec } \\
\text { EU 52 } \\
\text { Lovel } 2 \\
\text { Level } 3 \\
\text { Level } 4 \\
\text { Level } 5 \\
\text { Lovel } 6 \\
\text { Level } 7 \\
\text { Level } 8 \\
\text { Lovel } 9 \\
\end{array}$ & $\begin{array}{l}\bar{z} \\
\bar{z} \\
\bar{z} \\
\bar{z} \\
\end{array}$ & $\begin{array}{l}- \\
\bar{z} \\
= \\
\overline{-} \\
- \\
\end{array}$ & $\begin{array}{l}\bar{z} \\
\bar{z} \\
\bar{z} \\
\bar{z} \\
\overline{-}\end{array}$ & $\begin{array}{l}\bar{z} \\
\bar{z} \\
\bar{z} \\
\bar{z} \\
\end{array}$ & $\begin{array}{l}1 \\
\overline{1} \\
\bar{z} \\
\bar{z} \\
\overline{-}\end{array}$ & $\begin{array}{l}- \\
\overline{1} \\
- \\
- \\
-\end{array}$ & $\begin{array}{l}\bar{z} \\
\bar{z} \\
\bar{z} \\
\bar{z}\end{array}$ & $\begin{array}{l}- \\
- \\
\overline{1} \\
- \\
- \\
\end{array}$ & $\begin{array}{l}\bar{z} \\
\bar{z} \\
1 \\
\bar{z} \\
\bar{z} \\
\end{array}$ & $\begin{array}{r}2 \\
5 \\
4 \\
4 \\
11 \\
9 \\
4 \\
2 \\
\end{array}$ & $\begin{array}{l}\bar{z} \\
\overline{1} \\
1 \\
\vdots \\
- \\
\end{array}$ & $\begin{array}{l}\bar{z} \\
\bar{z} \\
\bar{z} \\
\bar{z}\end{array}$ & $\begin{array}{l}\bar{z} \\
\bar{z} \\
\bar{z} \\
\bar{z}\end{array}$ & $\begin{array}{l}\bar{z} \\
\bar{z} \\
\bar{z} \\
\bar{z} \\
\end{array}$ & $\begin{array}{l}\bar{z} \\
\bar{z} \\
\bar{z} \\
\bar{z} \\
\end{array}$ & $\begin{array}{r}2 \\
6 \\
4 \\
6 \\
13 \\
9 \\
4 \\
2 \\
\end{array}$ \\
\hline 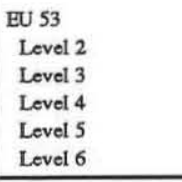 & $\begin{array}{l}\bar{z} \\
\bar{z} \\
\bar{z}\end{array}$ & $\begin{array}{l}\bar{z} \\
z \\
\end{array}$ & $\begin{array}{l}\bar{y} \\
\bar{z} \\
\bar{z}\end{array}$ & $\begin{array}{l}\bar{z} \\
\bar{z} \\
\bar{z}\end{array}$ & $\begin{array}{l}\bar{z} \\
\bar{z} \\
\overline{-}\end{array}$ & $\begin{array}{l}\bar{z} \\
\bar{z} \\
\end{array}$ & $\begin{array}{l}\bar{z} \\
\bar{z} \\
\end{array}$ & $\begin{array}{l}\bar{z} \\
\overline{1} \\
- \\
\end{array}$ & $\begin{array}{l}\bar{z} \\
\bar{z} \\
\overline{-}\end{array}$ & $\begin{array}{l}4 \\
6 \\
4 \\
1 \\
2 \\
\end{array}$ & $\begin{array}{l}\bar{z} \\
\overline{1} \\
-1\end{array}$ & $\begin{array}{l}\bar{z} \\
\bar{z} \\
\end{array}$ & $\begin{array}{l}- \\
\bar{z} \\
\bar{z}\end{array}$ & $\begin{array}{l}\bar{z} \\
\bar{z} \\
\end{array}$ & $\begin{array}{l}\overline{1} \\
\overline{-} \\
\overline{-}\end{array}$ & $\begin{array}{l}4 \\
7 \\
4 \\
3 \\
2 \\
\end{array}$ \\
\hline $\begin{array}{l}\text { 41CReA44 } \\
\text { Surface }\end{array}$ & 1 & - & - & - & - & - & - & - & - & 16 & 1 & - & - & - & - & 18 \\
\hline $\begin{array}{l}\text { EU6 } \\
\text { Level1 }\end{array}$ & - & - & - & - & - & - & - & - & - & - & 1 & - & - & - & - & 1 \\
\hline 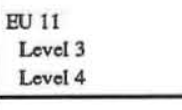 & - & 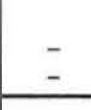 & E & $\overline{-}$ & - & - & 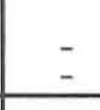 & $\overline{-}$ & - & $z$ & $\begin{array}{l}1 \\
2 \\
\end{array}$ & - & $\overline{3}$ & - & - & $\begin{array}{l}1 \\
5 \\
\end{array}$ \\
\hline $\begin{array}{l}\text { IU } 12 \\
\text { Level } 2 \\
\text { Level } 13\end{array}$ & - & $\overline{-}$ & $\overline{-}$ & - & - & 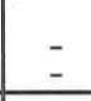 & $\overline{-}$ & - & - & 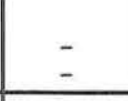 & $\begin{array}{l}1 \\
2 \\
\end{array}$ & - & - & $\overline{-}$ & $\overline{-}$ & $\begin{array}{l}1 \\
2 \\
2\end{array}$ \\
\hline $\begin{array}{l}\text { EU } 14 \\
\text { Levol } 2 \\
\end{array}$ & - & - & - & - & - & - & - & - & - & - & 1 & - & - & - & - & 1 \\
\hline $\begin{array}{l}4 \mathrm{HKT} 33 \\
\text { Surface } \\
\end{array}$ & - & - & - & - & - & - & - & - & - & - & 1 & - & - & - & - & 1 \\
\hline 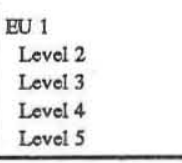 & $\bar{z}$ & $\begin{array}{l}z \\
z \\
\end{array}$ & $\bar{z}$ & $\bar{z}$ & $\bar{z}$ & $\bar{z}$ & z & $\begin{array}{l}\overline{1} \\
1 \\
\end{array}$ & $\bar{z}$ & $\begin{array}{r}7 \\
4 \\
5 \\
3 \\
\end{array}$ & $\bar{z}$ & $\bar{z}$ & $\bar{z}$ & $\bar{z}$ & $\bar{\Sigma}$ & $\begin{array}{l}7 \\
5 \\
6 \\
3 \\
\end{array}$ \\
\hline 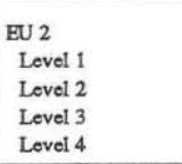 & $\bar{z}$ & $\bar{z}$ & $\bar{z}$ & $\bar{z}$ & $\bar{z}$ & $\bar{z}$ & $\bar{z}$ & $\begin{array}{l}1 \\
- \\
-\end{array}$ & $\begin{array}{l}1 \\
-\end{array}$ & $\begin{array}{l}2 \\
7 \\
2 \\
1\end{array}$ & $\begin{array}{l}\overline{1} \\
\overline{-}\end{array}$ & $\bar{z}$ & $\bar{z}$ & $\bar{z}$ & $\bar{z}$ & $\begin{array}{l}4 \\
8 \\
2 \\
1\end{array}$ \\
\hline
\end{tabular}




\begin{tabular}{|c|c|c|c|c|c|c|c|c|c|c|c|c|c|c|c|c|}
\hline $\begin{array}{l}\text { Excavasion Unit } \\
\text { and Level }\end{array}$ & $\begin{array}{l}\text { Arrow } \\
\text { Points }\end{array}$ & \begin{tabular}{|l} 
Dart \\
Points
\end{tabular} & Perforators & Gouges & Biffaces & \begin{tabular}{|l} 
Cobble \\
Trools
\end{tabular} & Unifaces & Cores & 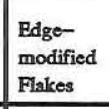 & \begin{tabular}{|l|} 
Unmodifified \\
Debitage
\end{tabular} & $\begin{array}{l}\text { Ground } \\
\text { Strone } \\
\text { Tools }\end{array}$ & Hammerszones & Manuports & Coramics & $\begin{array}{l}\text { Moditiced } \\
\text { Shells }\end{array}$ & Tousts \\
\hline $\begin{array}{l}\text { 4LKT 33, continued } \\
\text { EU 3 } \\
\text { Level 1 } \\
\text { Level 2 } \\
\text { Level 3 } \\
\text { Level 5 }\end{array}$ & $\begin{array}{l}\bar{z} \\
\bar{z}\end{array}$ & $\bar{z}$ & $\bar{z}$ & $\bar{z}$ & $\bar{z}$ & $\bar{z}$ & $\bar{z}$ & $\begin{array}{l}\overline{1} \\
1 \\
\end{array}$ & $\begin{array}{l}1 \\
2 \\
- \\
\end{array}$ & $\begin{array}{r}6 \\
10 \\
3 \\
2 \\
\end{array}$ & $\bar{z}$ & $\bar{z}$ & $\bar{z}$ & $\bar{~}$ & $\bar{z}$ & $\begin{array}{r}7 \\
12 \\
4 \\
\end{array}$ \\
\hline $\begin{array}{l}\text { EU 4 } \\
\text { Level 1 } \\
\text { LLvel 2 } \\
\text { Level 3 } \\
\text { Level 4 }\end{array}$ & $\begin{array}{l}\bar{z} \\
\bar{z}\end{array}$ & $\begin{array}{l}\bar{z} \\
\bar{z}\end{array}$ & $\begin{array}{l}\bar{z} \\
\bar{z}\end{array}$ & $\begin{array}{l}\bar{z} \\
\bar{z}\end{array}$ & $\bar{z}$ & $\begin{array}{l}\bar{z} \\
\overline{1}\end{array}$ & $\begin{array}{l}\bar{z} \\
\bar{z}\end{array}$ & $\begin{array}{l}\bar{i} \\
\overline{-} \\
\end{array}$ & $\begin{array}{l}\overline{2} \\
\overline{-} \\
\end{array}$ & $\begin{array}{l}2 \\
7 \\
\frac{7}{3}\end{array}$ & $\begin{array}{l}\bar{z} \\
\overline{1} \\
-\end{array}$ & $\bar{z}$ & $\begin{array}{l}\bar{z} \\
\bar{z}\end{array}$ & $\bar{z}$ & $\bar{z}$ & $\begin{array}{r}2 \\
10 \\
1 \\
4\end{array}$ \\
\hline $\begin{array}{l}\text { EU S } \\
\text { Lovel 1 } \\
\text { LLvel } 2 \\
\text { Level } 3 \\
\text { Level 4 } \\
\end{array}$ & $\begin{array}{l}\bar{z} \\
\bar{z}\end{array}$ & $\begin{array}{l}\bar{z} \\
\bar{z}\end{array}$ & $\begin{array}{l}\bar{Z} \\
\overline{-}\end{array}$ & $\begin{array}{l}\bar{z} \\
\overline{-}\end{array}$ & $\begin{array}{l}\bar{z} \\
\bar{z}\end{array}$ & $\begin{array}{l}1 \\
- \\
\end{array}$ & $\begin{array}{l}\bar{z} \\
\bar{z}\end{array}$ & $\begin{array}{l}\bar{i} \\
\overline{1} \\
\end{array}$ & $\begin{array}{l}\overline{2} \\
\overline{-} \\
\end{array}$ & $\begin{array}{l}- \\
6 \\
3 \\
1 \\
\end{array}$ & $\begin{array}{c}\overline{-} \\
10 \\
\end{array}$ & $\begin{array}{l}\bar{z} \\
\bar{z}\end{array}$ & $\begin{array}{l}\bar{z} \\
\overline{-}\end{array}$ & $\bar{z}$ & $\bar{z}$ & $\begin{array}{r}1 \\
8 \\
14 \\
1 \\
1\end{array}$ \\
\hline 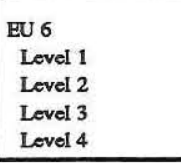 & $\begin{array}{l}1 \\
\overline{-} \\
\end{array}$ & $\begin{array}{l}\bar{z} \\
\bar{z}\end{array}$ & $\begin{array}{l}\bar{Z} \\
\overline{-}\end{array}$ & $\begin{array}{l}\bar{z} \\
\bar{z}\end{array}$ & $\bar{z}$ & $\bar{z}$ & $\begin{array}{l}\bar{z} \\
\bar{z}\end{array}$ & $\begin{array}{l}\bar{z} \\
\overline{1} \\
\end{array}$ & $\begin{array}{l}1 \\
\vdots \\
\end{array}$ & $\begin{array}{l}7 \\
7 \\
6 \\
4 \\
\end{array}$ & $\begin{array}{l}- \\
\overline{-} \\
\end{array}$ & $\bar{z}$ & $\begin{array}{l}\bar{z} \\
\bar{z}\end{array}$ & $\begin{array}{l}\overline{-} \\
\bar{z}\end{array}$ & $\bar{z}$ & $\begin{array}{l}8 \\
9 \\
7 \\
4\end{array}$ \\
\hline $\begin{array}{l}\text { EU 7 } \\
\text { Lovel 1 } \\
\text { LLvel 2 } \\
\text { Level 3 } \\
\text { Level 4 }\end{array}$ & $\bar{z}$ & $\begin{array}{l}\bar{z} \\
\bar{z}\end{array}$ & $\begin{array}{l}\overline{-} \\
\overline{-}\end{array}$ & $\begin{array}{l}\bar{z} \\
\bar{z}\end{array}$ & $\bar{z}$ & $\begin{array}{l}\bar{z} \\
\bar{z}\end{array}$ & $\begin{array}{l}\bar{z} \\
\bar{z}\end{array}$ & $\begin{array}{l}\bar{y} \\
\overline{1} \\
\end{array}$ & $\begin{array}{l}\overline{1} \\
\overline{1} \\
\end{array}$ & $\begin{array}{l}5 \\
5 \\
3 \\
2 \\
\end{array}$ & $\begin{array}{l}\bar{z} \\
\bar{z}\end{array}$ & $\begin{array}{l}\bar{z} \\
\bar{z}\end{array}$ & $\bar{z}$ & $\bar{z}$ & $\bar{z}$ & $\begin{array}{l}5 \\
6 \\
3 \\
4 \\
4\end{array}$ \\
\hline $\begin{array}{l}\text { EU 8 } \\
\text { Lovel 1 } 1 \\
\text { Level } \\
\text { Lovel 3 }\end{array}$ & $\bar{z}$ & $\bar{z}$ & $\bar{z}$ & $\bar{z}$ & $\bar{z}$ & $\bar{z}$ & $\begin{array}{l}\overline{1} \\
\overline{-}\end{array}$ & $\bar{\Sigma}$ & $\begin{array}{l}- \\
1 \\
1\end{array}$ & $\begin{array}{c}3 \\
11 \\
5\end{array}$ & $\overline{-}$ & $\bar{z}$ & $\bar{z}$ & $\bar{\Sigma}$ & $\bar{\Sigma}$ & $\begin{array}{r}3 \\
13 \\
7\end{array}$ \\
\hline $\begin{array}{l}\text { Eu9 } 9 \\
\text { Lovel 1 } \\
\text { Lovel } 2 \\
\text { Level } 3 \\
\text { Level 4 }\end{array}$ & $\bar{z}$ & $\begin{array}{l}\bar{z} \\
\bar{z}\end{array}$ & $\bar{z}$ & $\bar{z}$ & $\begin{array}{l}\bar{z} \\
\bar{z}\end{array}$ & $\bar{z}$ & $\bar{\vdots}$ & $\begin{array}{l}\bar{z} \\
\bar{z} \\
\end{array}$ & $\begin{array}{l}2 \\
1 \\
1 \\
1 \\
\end{array}$ & $\begin{array}{l}9 \\
5 \\
5 \\
7 \\
\end{array}$ & $\begin{array}{l}\overline{1} \\
\end{array}$ & $\begin{array}{l}\bar{z} \\
\bar{z}\end{array}$ & $\begin{array}{l}\bar{z} \\
\bar{z}\end{array}$ & $\bar{z}$ & $\bar{z}$ & $\begin{array}{r}11 \\
6 \\
7 \\
9 \\
\end{array}$ \\
\hline $\begin{array}{l}\text { Eu 10 } \\
\text { Level 1 } \\
\text { LLvel } 2 \\
\text { Level } 3 \\
\text { Level } 4\end{array}$ & $\bar{z}$ & $\bar{z}$ & $\bar{z}$ & $\begin{array}{l}\bar{z} \\
\bar{z}\end{array}$ & $\begin{array}{l}\bar{z} \\
\bar{z}\end{array}$ & $\bar{z}$ & $\bar{z}$ & $\begin{array}{l}1 \\
- \\
-\end{array}$ & $\begin{array}{l}\frac{1}{1} \\
\frac{1}{3}\end{array}$ & $\begin{array}{l}5 \\
8 \\
9 \\
-\end{array}$ & $\bar{z}$ & $\bar{z}$ & $\bar{z}$ & $\bar{z}$ & $\bar{z}$ & $\begin{array}{r}7 \\
8 \\
12 \\
3\end{array}$ \\
\hline 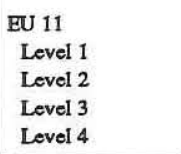 & $\bar{z}$ & $\bar{z}$ & $\bar{z}$ & $\begin{array}{l}\bar{z} \\
\bar{z}\end{array}$ & $\bar{z}$ & $\begin{array}{l}\bar{z} \\
\bar{z}\end{array}$ & $\begin{array}{l}\bar{z} \\
\bar{z}\end{array}$ & $\bar{z}$ & $\begin{array}{l}1 \\
\vdots \\
1\end{array}$ & $\begin{array}{l}5 \\
9 \\
7 \\
5\end{array}$ & $\begin{array}{l}\bar{z} \\
\bar{z}\end{array}$ & $\bar{z}$ & $\bar{z}$ & $\bar{z}$ & $\bar{z}$ & $\begin{array}{l}6 \\
9 \\
7 \\
6\end{array}$ \\
\hline
\end{tabular}




\begin{tabular}{|c|c|c|c|c|c|c|c|c|c|c|c|c|c|c|c|c|}
\hline $\begin{array}{l}\text { Excavation Unit } \\
\text { and Level }\end{array}$ & \begin{tabular}{|l} 
Arrow \\
Points
\end{tabular} & $\begin{array}{l}\text { Dart } \\
\text { Points }\end{array}$ & \begin{tabular}{|l} 
Perforators \\
\end{tabular} & Gouges & Bifaces & $\begin{array}{l}\text { Cobble } \\
\text { Tools }\end{array}$ & \begin{tabular}{|l} 
Unifaces \\
\end{tabular} & Cores & \begin{tabular}{|l}
$\begin{array}{l}\text { Edge- } \\
\text { modified } \\
\text { Falases }\end{array}$ \\
\end{tabular} & $\begin{array}{l}\text { Unmodified } \\
\text { Debitage }\end{array}$ & \begin{tabular}{|l|l} 
Ground \\
Stone \\
Tools \\
\end{tabular} & Hammerstones & \begin{tabular}{|l} 
Manuports \\
\end{tabular} & Ceramics & \begin{tabular}{|l}
$\begin{array}{l}\text { Modified } \\
\text { Shells }\end{array}$ \\
\end{tabular} & Totals \\
\hline $\begin{array}{l}\text { 41KT33, continimed } \\
\text { EU 12 } \\
\text { Level 1 } \\
\text { Level 2 } \\
\text { Level 3 } \\
\text { Level 4 }\end{array}$ & $\begin{array}{l}- \\
\bar{z} \\
- \\
\end{array}$ & $\begin{array}{l}- \\
\bar{z} \\
-\end{array}$ & $\begin{array}{l}- \\
\bar{z} \\
\overline{-} \\
\end{array}$ & $\begin{array}{l}- \\
\bar{z} \\
- \\
\end{array}$ & $\begin{array}{l}- \\
- \\
- \\
-\end{array}$ & $\begin{array}{l}- \\
\overline{-} \\
- \\
\end{array}$ & $\begin{array}{l}- \\
\bar{z} \\
- \\
\end{array}$ & $\begin{array}{l}- \\
\overline{1} \\
- \\
\end{array}$ & $\begin{array}{l}\overline{-} \\
\overline{-} \\
1 \\
\end{array}$ & $\begin{array}{l}8 \\
2 \\
2 \\
5 \\
\end{array}$ & $\begin{array}{l}- \\
- \\
- \\
\end{array}$ & $\begin{array}{l}\bar{z} \\
\bar{z} \\
-\end{array}$ & $\begin{array}{l}- \\
\bar{z} \\
-\end{array}$ & $\begin{array}{l}\overline{-} \\
\overline{-} \\
-\end{array}$ & $\begin{array}{l}\overline{-} \\
\bar{z} \\
\end{array}$ & $\begin{array}{l}8 \\
2 \\
3 \\
6 \\
\end{array}$ \\
\hline $\begin{array}{l}\text { EU } 13 \\
\text { Level 1 } \\
\text { Level 2 } \\
\text { Level 3 } \\
\end{array}$ & $\begin{array}{l}- \\
- \\
\end{array}$ & $\begin{array}{l}\bar{z} \\
\overline{-}\end{array}$ & $\begin{array}{l}\bar{z} \\
\overline{-}\end{array}$ & $\begin{array}{l}\overline{-} \\
\overline{-}\end{array}$ & $\begin{array}{l}- \\
- \\
\end{array}$ & $\begin{array}{l}- \\
- \\
\end{array}$ & $\begin{array}{l}\overline{1} \\
1 \\
\end{array}$ & $\begin{array}{l}\overline{-} \\
\overline{-}\end{array}$ & $\begin{array}{l}\overline{1} \\
2\end{array}$ & $\begin{array}{r}3 \\
24 \\
3\end{array}$ & $\begin{array}{l}- \\
\overline{-}\end{array}$ & $\overline{-}$ & $\begin{array}{l}- \\
\overline{-}\end{array}$ & $\begin{array}{l}\overline{1} \\
-\end{array}$ & $\bar{z}$ & $\begin{array}{r}3 \\
27 \\
6\end{array}$ \\
\hline $\begin{array}{l}\text { EU } 14 \\
\text { Level 1 } \\
\text { Level } 2 \\
\text { Level } 3 \\
\text { Level } 4 \\
\end{array}$ & $\begin{array}{l}z \\
= \\
-\end{array}$ & $\begin{array}{l}\overline{-} \\
\overline{-} \\
-\end{array}$ & $\begin{array}{l}\bar{z} \\
\bar{z} \\
\end{array}$ & $\begin{array}{l}- \\
\overline{-} \\
- \\
\end{array}$ & $\begin{array}{l}- \\
- \\
- \\
\end{array}$ & $\begin{array}{l}- \\
\overline{-} \\
-\end{array}$ & $\begin{array}{l}- \\
- \\
- \\
-\end{array}$ & $\begin{array}{l}- \\
\overline{-} \\
- \\
\end{array}$ & $\begin{array}{l}- \\
3 \\
1 \\
- \\
\end{array}$ & $\begin{array}{l}5 \\
4 \\
2 \\
1 \\
\end{array}$ & $\begin{array}{l}\overline{1} \\
1 \\
- \\
\end{array}$ & $\begin{array}{l}- \\
\bar{z} \\
- \\
\end{array}$ & $\begin{array}{l}- \\
\bar{z} \\
-\end{array}$ & $\begin{array}{l}\bar{z} \\
\bar{z} \\
\end{array}$ & $\begin{array}{l}- \\
\bar{z} \\
-\end{array}$ & $\begin{array}{l}5 \\
8 \\
4 \\
1 \\
\end{array}$ \\
\hline $\begin{array}{l}\text { EU } 15 \\
\text { Level 1 } \\
\text { Level 2 } \\
\text { Level } 3 \\
\text { Level } 4\end{array}$ & $\begin{array}{l}- \\
\bar{z} \\
-\end{array}$ & $\begin{array}{l}\bar{z} \\
\bar{z} \\
-\end{array}$ & $\begin{array}{l}\overline{1} \\
- \\
-\end{array}$ & $\begin{array}{l}- \\
\bar{z} \\
-\end{array}$ & $\begin{array}{l}- \\
\bar{z} \\
-\end{array}$ & $\begin{array}{l}- \\
\overline{-} \\
-\end{array}$ & $\begin{array}{l}- \\
\overline{-} \\
-\end{array}$ & $\begin{array}{l}- \\
\bar{z} \\
-\end{array}$ & $\begin{array}{l}\overline{1} \\
\overline{-} \\
-\end{array}$ & $\begin{array}{l}2 \\
5 \\
9 \\
3 \\
3\end{array}$ & $\begin{array}{l}- \\
- \\
-\end{array}$ & $\begin{array}{l}\bar{z} \\
\overline{-} \\
-\end{array}$ & $\begin{array}{l}- \\
\overline{-} \\
-\end{array}$ & $\begin{array}{l}\bar{z} \\
\overline{-}\end{array}$ & $\begin{array}{l}- \\
\bar{z} \\
-\end{array}$ & $\begin{array}{l}2 \\
7 \\
9 \\
3\end{array}$ \\
\hline $\begin{array}{l}\text { EU } 16 \\
\text { Level } 1 \\
\text { Level } 2 \\
\text { Level } 3 \\
\end{array}$ & $\begin{array}{l}- \\
- \\
\end{array}$ & $\begin{array}{l}\overline{-} \\
\overline{-}\end{array}$ & $\begin{array}{l}\overline{-} \\
-\end{array}$ & $\begin{array}{l}\overline{-} \\
-\end{array}$ & $\begin{array}{l}- \\
- \\
-\end{array}$ & $\begin{array}{l}- \\
- \\
-\end{array}$ & $\begin{array}{l}\overline{1} \\
- \\
\end{array}$ & $\begin{array}{l}\overline{-} \\
-\end{array}$ & $\begin{array}{l}\overline{-} \\
\overline{1}\end{array}$ & $\begin{array}{l}2 \\
6 \\
2 \\
\end{array}$ & $\begin{array}{l}- \\
\overline{1} \\
\end{array}$ & $\begin{array}{l}\overline{-} \\
\overline{-}\end{array}$ & $\begin{array}{l}- \\
-\end{array}$ & $\begin{array}{l}\overline{-} \\
- \\
\end{array}$ & $\begin{array}{l}\overline{-} \\
-\end{array}$ & $\begin{array}{l}2 \\
7 \\
4 \\
\end{array}$ \\
\hline $\begin{array}{l}\text { EU } 17 \\
\text { Level 1 } \\
\text { Level } 2 \\
\text { Level } 3 \\
\text { Level } 4 \\
\end{array}$ & $\begin{array}{l}- \\
\bar{z} \\
- \\
\end{array}$ & $\begin{array}{l}\bar{z} \\
\bar{z} \\
\overline{-}\end{array}$ & $\begin{array}{l}\bar{z} \\
\overline{-} \\
\end{array}$ & $\begin{array}{l}- \\
\bar{z} \\
-\end{array}$ & $\begin{array}{l}- \\
\bar{z} \\
- \\
\end{array}$ & $\begin{array}{l}- \\
\overline{-} \\
- \\
\end{array}$ & $\begin{array}{l}- \\
\overline{-} \\
-\end{array}$ & $\begin{array}{l}- \\
\bar{z} \\
- \\
\end{array}$ & $\begin{array}{l}- \\
1 \\
2 \\
-\end{array}$ & $\begin{array}{l}4 \\
3 \\
3 \\
4 \\
\end{array}$ & $\begin{array}{l}- \\
\bar{z} \\
- \\
\end{array}$ & $\begin{array}{l}- \\
\bar{z} \\
-\end{array}$ & $\begin{array}{l}- \\
\bar{z} \\
-\end{array}$ & $\begin{array}{l}\bar{z} \\
\overline{-} \\
\overline{-}\end{array}$ & $\begin{array}{l}\bar{z} \\
\overline{-} \\
-\end{array}$ & $\begin{array}{l}4 \\
4 \\
5 \\
4 \\
\end{array}$ \\
\hline $\begin{array}{l}\text { EU } 18 \\
\text { Levol } 2 \\
\text { Level } 3 \\
\text { Level } 4 \\
\end{array}$ & $\begin{array}{l}- \\
\overline{-}\end{array}$ & $\begin{array}{l}\bar{z} \\
\overline{-}\end{array}$ & $\begin{array}{l}\bar{z} \\
\overline{-}\end{array}$ & $\begin{array}{l}- \\
- \\
\end{array}$ & $\begin{array}{l}- \\
- \\
\end{array}$ & $\begin{array}{l}- \\
\overline{-}\end{array}$ & $\begin{array}{l}1 \\
- \\
\end{array}$ & $\begin{array}{l}- \\
\overline{1}\end{array}$ & $\begin{array}{l}\bar{z} \\
\overline{2}\end{array}$ & $\begin{array}{r}3 \\
11 \\
7 \\
\end{array}$ & $\begin{array}{l}1 \\
-2 \\
- \\
\end{array}$ & $\begin{array}{l}- \\
\overline{-}\end{array}$ & $\begin{array}{l}\overline{-} \\
\overline{-}\end{array}$ & $\begin{array}{l}\bar{z} \\
\overline{-}\end{array}$ & $\begin{array}{l}1 \\
- \\
\end{array}$ & $\begin{array}{r}6 \\
13 \\
11 \\
\end{array}$ \\
\hline $\begin{array}{l}\text { EU } 19 \\
\text { Level 1 } \\
\text { Level } 2 \\
\text { Level } 3 \\
\text { Level } 4 \\
\end{array}$ & $\begin{array}{l}- \\
\bar{z} \\
- \\
\end{array}$ & $\begin{array}{l}- \\
\bar{z} \\
-\end{array}$ & $\begin{array}{l}- \\
\bar{z} \\
\overline{-}\end{array}$ & $\begin{array}{l}- \\
\bar{z} \\
- \\
\end{array}$ & $\begin{array}{l}- \\
z \\
- \\
\end{array}$ & $\begin{array}{l}- \\
\overline{-} \\
- \\
\end{array}$ & $\begin{array}{l}1 \\
- \\
- \\
\end{array}$ & $\begin{array}{l}\overline{1} \\
\overline{1} \\
\end{array}$ & $\begin{array}{l}\overline{2} \\
\overline{1} \\
\end{array}$ & $\begin{array}{l}11 \\
13 \\
13 \\
10 \\
\end{array}$ & $\begin{array}{l}- \\
1 \\
- \\
\end{array}$ & $\begin{array}{l}\overline{1} \\
\overline{-} \\
\end{array}$ & $\begin{array}{l}- \\
\overline{-} \\
-\end{array}$ & $\begin{array}{l}\overline{-} \\
\overline{-} \\
\overline{-}\end{array}$ & $\begin{array}{l}\overline{-} \\
\overline{-} \\
\overline{-}\end{array}$ & $\begin{array}{l}12 \\
17 \\
14 \\
12 \\
\end{array}$ \\
\hline $\begin{array}{l}\text { EU } 20 \\
\text { Level 1 } \\
\text { Level } 2 \\
\text { Level } 3 \\
\text { Level } 4 \\
\end{array}$ & $\begin{array}{l}- \\
\overline{-} \\
- \\
\end{array}$ & $\begin{array}{l}\overline{-} \\
\overline{-} \\
\end{array}$ & $\begin{array}{l}- \\
\bar{z} \\
-\end{array}$ & $\begin{array}{l}- \\
\bar{z} \\
- \\
\end{array}$ & $\begin{array}{l}- \\
\bar{z} \\
- \\
\end{array}$ & $\begin{array}{l}- \\
\bar{z} \\
- \\
\end{array}$ & $\begin{array}{l}- \\
- \\
- \\
\end{array}$ & $\begin{array}{l}- \\
\bar{z} \\
-\end{array}$ & $\begin{array}{l}\bar{y} \\
\bar{z} \\
-\end{array}$ & $\begin{array}{r}13 \\
13 \\
5 \\
1 \\
\end{array}$ & $\begin{array}{l}- \\
\overline{1} \\
- \\
\end{array}$ & $\begin{array}{l}- \\
\bar{z} \\
-\end{array}$ & $\begin{array}{l}- \\
\bar{z} \\
\overline{-}\end{array}$ & $\begin{array}{l}- \\
\bar{z} \\
-\end{array}$ & $\begin{array}{l}- \\
- \\
- \\
\end{array}$ & $\begin{array}{r}13 \\
13 \\
6 \\
1 \\
\end{array}$ \\
\hline
\end{tabular}


Phase III Data Recovery, Season 1, Justiceburg Reservoir

\begin{tabular}{|c|c|c|c|c|c|c|c|c|c|c|}
\hline 咅 & & $-0 \bumpeq m$ & $\because \pm 一$ & $\simeq \mathrm{m} \mathrm{mm}$ & $0 m a n$ & $\forall \cong 0 \mathrm{~m}$ & 오으 & 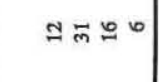 & $0 \cong n+$ & $=0 \infty \mathrm{N}$ \\
\hline 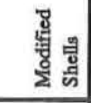 & & $\begin{array}{llll}1 & 1 & 1 & 1\end{array}$ & $\begin{array}{lll}1 & 1 & 1\end{array}$ & $\begin{array}{llll}1 & 1 & 1 & 1\end{array}$ & $\begin{array}{llll}1 & 1 & 1 & 1\end{array}$ & $\begin{array}{llll}1 & 1 & 1 & 1\end{array}$ & $\begin{array}{llll}1 & 1 & 1 & 1\end{array}$ & $\begin{array}{llll}1 & 1 & 1 & 1\end{array}$ & $\begin{array}{llll}1 & 1 & 1 & 1\end{array}$ & $\begin{array}{llll}1 & 1 & 1 & 1\end{array}$ \\
\hline 㝰 & & $\begin{array}{llll}1 & 1 & 1 & 1\end{array}$ & $\begin{array}{lll}1 & 1 & 1\end{array}$ & $\begin{array}{llll}1 & 1 & 1 & 1\end{array}$ & $\begin{array}{llll}1 & 1 & 1 & 1\end{array}$ & $11-1$ & $\begin{array}{llll}1 & 1 & 1 & 1\end{array}$ & $\begin{array}{llll}1 & 1 & 1 & 1\end{array}$ & $\begin{array}{llll}1 & 1 & 1 & 1\end{array}$ & 1111 \\
\hline $\begin{array}{l}\text { 总 } \\
\text { 章 } \\
\end{array}$ & & $\begin{array}{llll}1 & 1 & 1 & 1\end{array}$ & $\begin{array}{lll}1 & 1 & 1\end{array}$ & $\begin{array}{llll}1 & 1 & 1 & 1\end{array}$ & $\begin{array}{llll}1 & 1 & 1 & 1\end{array}$ & $\begin{array}{llll}1 & 1 & 1 & 1\end{array}$ & $\begin{array}{llll}1 & 1 & 1 & 1\end{array}$ & $\begin{array}{llll}1 & 1 & 1 & 1\end{array}$ & $\begin{array}{llll}1 & 1 & 1 & 1\end{array}$ & 1111 \\
\hline 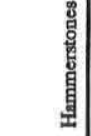 & & $\begin{array}{llll}1 & 1 & 1\end{array}$ & $\begin{array}{lll}1 & 1 & 1\end{array}$ & $\begin{array}{llll}1 & 1 & 1 & 1\end{array}$ & $\begin{array}{llll}1 & 1 & 1 & 1\end{array}$ & $1-1 \quad 1$ & $\begin{array}{llll}1 & 1 & 1 & 1\end{array}$ & $\begin{array}{llll}1 & 1 & 1 & 1\end{array}$ & $\begin{array}{llll}1 & 1 & 1 & 1\end{array}$ & $\begin{array}{llll}1 & 1 & 1 & 1\end{array}$ \\
\hline 둥 융 & & $11 \mathrm{ml}$ & 111 & $1--1$ & 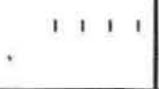 & $\begin{array}{llll}1 & 1 & 1 & 1\end{array}$ & $\begin{array}{llll}1 & 1 & 1 & 1\end{array}$ & $\begin{array}{llll}1 & 1 & 1 & 1\end{array}$ & $\begin{array}{llll}1 & 1 & 1 & 1\end{array}$ & 1111 \\
\hline 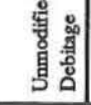 & & - & 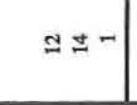 & $\pm 2 \mathrm{Nm}$ & $+9 N \backsim$ & $m \dddot{n n m}$ & $\stackrel{2}{2} \approx=$ & $\approx \pi \pm n$ & $0 \cong \cong+$ & $a \overbrace{}^{\infty} \mathrm{N}$ \\
\hline 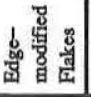 & & $1 / N 1$ & 111 & --11 & $1-1+1$ & $-7-11$ & $1+-1$ & 101011 & $\begin{array}{llll}1 & 1 & 1 & 1\end{array}$ & 1011 \\
\hline ở & & $\begin{array}{llll}1 & 1 & 1 & 1\end{array}$ & 111 & $-N \mid 1$ & $\begin{array}{llll}1 & 1 & 1 & 1\end{array}$ & $\begin{array}{llll}1 & 1 & 1 & 1\end{array}$ & $\begin{array}{llll}1 & 1 & 1 & 1\end{array}$ & $1--1$ & 1111 & $1-11$ \\
\hline $\begin{array}{l}\text { : } \\
\text { : } \\
\text { : }\end{array}$ & & $11-1$ & 111 & 111 & $1-11$ & $\begin{array}{llll}1 & 1 & 1 & 1\end{array}$ & 1111 & $111-$ & $\begin{array}{llll}1 & 1 & 1 & 1\end{array}$ & -111 \\
\hline 总 & & 1111 & 111 & $\begin{array}{llll}1 & 1 & 1\end{array}$ & $1-1.1$ & $\begin{array}{llll}1 & 1 & 1 & 1\end{array}$ & $\begin{array}{llll}1 & 1 & 1 & 1\end{array}$ & $11-1$ & $\begin{array}{llll}1 & 1 & 1 & 1\end{array}$ & -111 \\
\hline 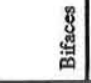 & & $\begin{array}{llll}1 & 1 & 1 & -1\end{array}$ & -11 & $\begin{array}{llll}1 & 1 & 1\end{array}$ & $\begin{array}{lllll}N & 1 & 1 & 1\end{array}$ & $\begin{array}{llll}1 & 1 & 1 & 1\end{array}$ & $\begin{array}{llll}1 & 1 & 1 & 1\end{array}$ & $1-1 \quad 1$ & $\begin{array}{llll}1 & 1 & 1 & 1\end{array}$ & 1111 \\
\hline $\begin{array}{l}: \\
. \\
5 \\
\end{array}$ & & 1111 & 111 & 1111 & $\begin{array}{llll}1 & 1 & 1 & 1\end{array}$ & $\begin{array}{llll}1 & 1 & 1 & 1\end{array}$ & $\begin{array}{llll}1 & 1 & 1 & 1\end{array}$ & $\begin{array}{llll}1 & 1 & 1 & 1\end{array}$ & $\begin{array}{llll}1 & 1 & 1 & 1\end{array}$ & 1111 \\
\hline 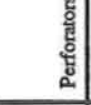 & & 1111 & 111 & $\begin{array}{llll}1 & 1 & 1 & 1\end{array}$ & $\begin{array}{llll}1 & 1 & 1 & 1\end{array}$ & $\begin{array}{llll}1 & 1 & 1 & 1\end{array}$ & $\begin{array}{llll}1 & 1 & 1 & 1\end{array}$ & $\begin{array}{llll}1 & 1 & 1 & 1\end{array}$ & $\begin{array}{llll}1 & 1 & 1 & 1\end{array}$ & $\begin{array}{llll}1 & 1 & 1 & 1\end{array}$ \\
\hline 臬惫 & & 1111 & 111 & 1111 & $\begin{array}{llll}1 & 1 & 1 & 1\end{array}$ & $\begin{array}{llll}1 & 1 & 1 & 1\end{array}$ & $\begin{array}{llll}1 & 1 & 1 & 1\end{array}$ & $\begin{array}{llll}1 & 1 & 1 & 1\end{array}$ & $\begin{array}{llll}1 & 1 & 1 & 1\end{array}$ & 1111 \\
\hline 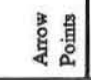 & & 1111 & $1 \quad 1 \quad 1$ & $\begin{array}{llll}1 & 1 & 1 & 1\end{array}$ & $\begin{array}{llll}1 & 1 & 1 & 1\end{array}$ & $\begin{array}{llll}1 & 1 & 1 & 1\end{array}$ & $\begin{array}{llll}1 & 1 & 1 & 1\end{array}$ & $\begin{array}{llll}1 & 1 & 1 & 1\end{array}$ & $\begin{array}{llll}1 & 1 & 1 & 1\end{array}$ & 1111 \\
\hline 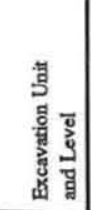 & 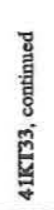 & 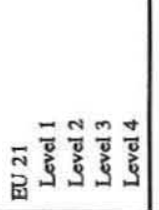 & 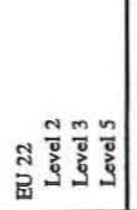 & 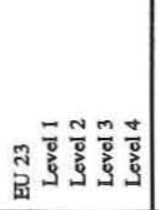 & 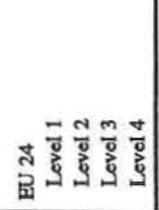 & 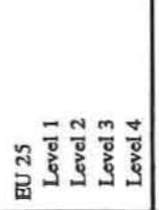 & 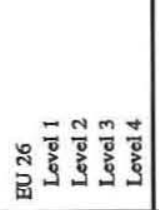 & 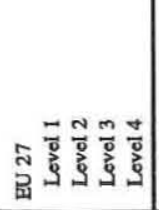 & 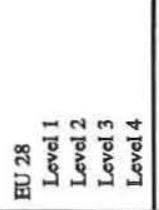 & 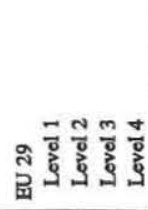 \\
\hline
\end{tabular}




\begin{tabular}{|c|c|c|c|c|c|c|c|c|c|c|c|c|c|c|c|c|}
\hline $\begin{array}{l}\text { Excavation Unit } \\
\text { and Level }\end{array}$ & \begin{tabular}{|l} 
Arrow \\
Points
\end{tabular} & $\begin{array}{l}\text { Dart } \\
\text { Points }\end{array}$ & Pefforators & Gouges & Bifaces & \begin{tabular}{|l} 
Cobble \\
Tools \\
\end{tabular} & Unifaces & Cores & \begin{tabular}{|l|}
$\begin{array}{l}\text { Edgo- } \\
\text { modificd } \\
\text { Flales }\end{array}$ \\
\end{tabular} & \begin{tabular}{|l} 
Unmodified \\
Debitage
\end{tabular} & \begin{tabular}{|l} 
Ground \\
Stone \\
Tools \\
\end{tabular} & \begin{tabular}{|l} 
Hammerstones \\
\end{tabular} & \begin{tabular}{|l} 
Manuports \\
\end{tabular} & Ceramics & \begin{tabular}{|l}
$\begin{array}{l}\text { Modified } \\
\text { Shells }\end{array}$ \\
\end{tabular} & Totals \\
\hline $\begin{array}{l}\text { 41KT33, continue } \\
\text { EU 30 } \\
\text { Level 1 } \\
\text { Level 2 } \\
\text { Level 3 } \\
\text { Level 4 } \\
\end{array}$ & $\begin{array}{l}\overline{1} \\
\overline{1} \\
\end{array}$ & $\begin{array}{l}\bar{z} \\
\overline{-} \\
-\end{array}$ & $\begin{array}{l}\bar{z} \\
\bar{z}\end{array}$ & $\begin{array}{l}\bar{z} \\
\bar{z} \\
\end{array}$ & $\begin{array}{l}- \\
z \\
- \\
\end{array}$ & $\begin{array}{l}- \\
z \\
- \\
\end{array}$ & $\begin{array}{l}- \\
\overline{1} \\
- \\
\end{array}$ & $\begin{array}{l}\overline{1} \\
\overline{-} \\
\end{array}$ & $\begin{array}{l}1 \\
1 \\
- \\
- \\
\end{array}$ & $\begin{array}{r}7 \\
25 \\
4 \\
3 \\
\end{array}$ & $\begin{array}{l}\bar{z} \\
\bar{z} \\
\end{array}$ & $\begin{array}{l}\bar{z} \\
\bar{z} \\
\end{array}$ & $\begin{array}{l}\bar{z} \\
\bar{z} \\
\end{array}$ & $\begin{array}{l}\overline{1} \\
\overline{-} \\
\end{array}$ & $\begin{array}{l}- \\
\bar{z} \\
-\end{array}$ & $\begin{array}{r}8 \\
29 \\
5 \\
4 \\
\end{array}$ \\
\hline $\begin{array}{l}\text { EU } 31 \\
\text { Levol 2 } \\
\text { Level } 3 \\
\text { Level } 4 \\
\end{array}$ & $\begin{array}{l}1 \\
- \\
\end{array}$ & $\begin{array}{l}- \\
\bar{z}\end{array}$ & $\begin{array}{l}- \\
\overline{-}\end{array}$ & $\begin{array}{l}- \\
\overline{-}\end{array}$ & $\begin{array}{l}\overline{-} \\
\overline{-}\end{array}$ & $\begin{array}{l}- \\
- \\
\end{array}$ & $\begin{array}{l}1 \\
- \\
\end{array}$ & $\begin{array}{l}- \\
- \\
\end{array}$ & $\begin{array}{l}1 \\
2 \\
1 \\
\end{array}$ & $\begin{array}{r}16 \\
4 \\
1 \\
\end{array}$ & $\begin{array}{l}1 \\
- \\
\end{array}$ & $\begin{array}{l}\bar{z} \\
\bar{z}\end{array}$ & $\begin{array}{l}\bar{z} \\
\overline{-}\end{array}$ & $\begin{array}{l}\bar{z} \\
\overline{-}\end{array}$ & $\begin{array}{l}- \\
- \\
\end{array}$ & $\begin{array}{r}20 \\
6 \\
2 \\
\end{array}$ \\
\hline $\begin{array}{l}\text { Eu } 32 \\
\text { Lovel } 1 \\
\text { Lovel } 2 \\
\text { Lovel } 3 \\
\text { Level } 4 \\
\end{array}$ & $\begin{array}{l}- \\
\bar{z} \\
-\end{array}$ & $\begin{array}{l}\bar{z} \\
\bar{z}\end{array}$ & $\begin{array}{l}\bar{z} \\
\overline{-} \\
\end{array}$ & $\begin{array}{l}z \\
z \\
-\end{array}$ & $\begin{array}{l}- \\
z \\
z\end{array}$ & $\begin{array}{l}- \\
z \\
z\end{array}$ & $\begin{array}{l}\bar{z} \\
\bar{z}\end{array}$ & $\begin{array}{l}\overline{2} \\
\overline{-} \\
\end{array}$ & $\begin{array}{l}1 \\
- \\
-\end{array}$ & $\begin{array}{r}14 \\
35 \\
7 \\
5 \\
\end{array}$ & $\begin{array}{l}z \\
\bar{z} \\
\end{array}$ & $\begin{array}{l}\bar{z} \\
\overline{-}\end{array}$ & $\begin{array}{l}z \\
\bar{z} \\
\end{array}$ & $\begin{array}{l}\bar{z} \\
\bar{z}\end{array}$ & $\begin{array}{l}z \\
z \\
-\end{array}$ & $\begin{array}{r}15 \\
37 \\
7 \\
5 \\
\end{array}$ \\
\hline $\begin{array}{l}\text { Eu } 33 \\
\text { Level } 1 \\
\text { Level 2 } \\
\text { Level } 3 \\
\text { Level } 4 \\
\end{array}$ & $\begin{array}{l}- \\
\bar{z} \\
-\end{array}$ & $\begin{array}{l}\bar{z} \\
\bar{z}\end{array}$ & $\begin{array}{l}\bar{z} \\
\bar{z} \\
-\end{array}$ & $\begin{array}{l}- \\
\bar{z} \\
\bar{z}\end{array}$ & $\begin{array}{l}\bar{z} \\
\bar{z} \\
\end{array}$ & $\begin{array}{l}\overline{-} \\
\bar{z} \\
\bar{y}\end{array}$ & $\begin{array}{l}\overline{-} \\
\overline{-} \\
\end{array}$ & $\begin{array}{l}- \\
\bar{z} \\
-\end{array}$ & $\begin{array}{l}\bar{z} \\
\bar{z} \\
-\end{array}$ & $\begin{array}{r}4 \\
14 \\
6 \\
1 \\
\end{array}$ & $\begin{array}{l}\bar{z} \\
\bar{z} \\
\end{array}$ & $\begin{array}{l}\bar{z} \\
\bar{z} \\
\end{array}$ & $\begin{array}{l}\bar{z} \\
\bar{z} \\
-\end{array}$ & $\begin{array}{l}\bar{z} \\
\overline{-}\end{array}$ & $\begin{array}{l}- \\
\bar{z} \\
-\end{array}$ & $\begin{array}{r}4 \\
15 \\
6 \\
1 \\
\end{array}$ \\
\hline $\begin{array}{c}\text { EU } 34 \\
\text { Level } 1 \\
\text { Level 2 } \\
\text { Level } 3 \\
\text { Level } 4\end{array}$ & $\begin{array}{l}- \\
\bar{z} \\
-\end{array}$ & $\begin{array}{l}\bar{z} \\
\bar{z}\end{array}$ & $\begin{array}{l}\bar{z} \\
\bar{z} \\
\end{array}$ & $\begin{array}{l}z \\
z \\
-\end{array}$ & $\begin{array}{l}- \\
\bar{z} \\
- \\
\end{array}$ & $\begin{array}{l}- \\
\overline{1} \\
- \\
\end{array}$ & $\begin{array}{l}- \\
\overline{-} \\
- \\
\end{array}$ & $\begin{array}{l}- \\
- \\
-\end{array}$ & $\begin{array}{l}- \\
1 \\
1 \\
-\end{array}$ & $\begin{array}{l}5 \\
4 \\
3 \\
2 \\
\end{array}$ & $\begin{array}{l}z \\
z \\
-\end{array}$ & $\begin{array}{r}\overline{1} \\
1 \\
-\end{array}$ & $\begin{array}{l}\bar{z} \\
\bar{z}\end{array}$ & $\begin{array}{l}\bar{z} \\
\bar{z}\end{array}$ & $\begin{array}{l}z \\
z \\
z\end{array}$ & $\begin{array}{l}5 \\
6 \\
6 \\
2\end{array}$ \\
\hline $\begin{array}{l}\text { EU } 35 \\
\text { Level 2 } \\
\text { Level } 3 \\
\text { Level } 4\end{array}$ & $\begin{array}{l}- \\
-\end{array}$ & $\begin{array}{l}\bar{z} \\
-\end{array}$ & $\begin{array}{l}\overline{-} \\
-\end{array}$ & $\overline{-}$ & $\begin{array}{l}- \\
- \\
\end{array}$ & $\begin{array}{l}- \\
- \\
\end{array}$ & $\begin{array}{l}- \\
\overline{-}\end{array}$ & $\begin{array}{l}- \\
-\end{array}$ & $\begin{array}{l}1 \\
- \\
-\end{array}$ & $\begin{array}{r}12 \\
9 \\
4 \\
\end{array}$ & $\overline{-}$ & $\begin{array}{l}\bar{z} \\
\bar{z}\end{array}$ & $\overline{-}$ & $\bar{z}$ & $\begin{array}{l}\overline{-} \\
\end{array}$ & $\begin{array}{r}13 \\
9 \\
4\end{array}$ \\
\hline $\begin{array}{c}\text { EU } 36 \\
\text { Level 1 } \\
\text { Level 2 } \\
\text { Level } 3 \\
\end{array}$ & $\begin{array}{l}- \\
- \\
\end{array}$ & $\begin{array}{l}- \\
-\end{array}$ & $\begin{array}{l}- \\
- \\
\end{array}$ & $\overline{-}$ & $\begin{array}{l}- \\
- \\
\end{array}$ & $\begin{array}{l}- \\
z \\
\end{array}$ & $\begin{array}{l}- \\
\overline{-}\end{array}$ & $\begin{array}{l}- \\
- \\
\end{array}$ & $\begin{array}{l}- \\
\overline{-}\end{array}$ & $\begin{array}{r}3 \\
22 \\
7 \\
\end{array}$ & $\begin{array}{l}- \\
-\end{array}$ & $\bar{z}$ & $\begin{array}{l}- \\
\end{array}$ & $\begin{array}{l}- \\
\end{array}$ & $\bar{z}$ & $\begin{array}{r}3 \\
23 \\
7 \\
\end{array}$ \\
\hline $\begin{array}{l}\text { EU } 37 \\
\text { Level 1 } \\
\text { Level } 2 \\
\text { Level } 3 \\
\text { Level } 4\end{array}$ & $\begin{array}{l}\overline{-} \\
\overline{-} \\
-\end{array}$ & $\begin{array}{l}\bar{z} \\
\bar{z}\end{array}$ & $\begin{array}{l}- \\
\bar{z} \\
-\end{array}$ & $\begin{array}{l}- \\
- \\
- \\
\end{array}$ & $\begin{array}{l}- \\
- \\
- \\
\end{array}$ & $\begin{array}{l}- \\
\overline{-} \\
- \\
\end{array}$ & $\begin{array}{l}\bar{z} \\
\bar{z}\end{array}$ & $\begin{array}{l}\bar{z} \\
\bar{z} \\
\end{array}$ & $\begin{array}{l}1 \\
- \\
2 \\
-\end{array}$ & $\begin{array}{r}3 \\
12 \\
24 \\
9 \\
\end{array}$ & $\begin{array}{l}- \\
\bar{z} \\
\end{array}$ & $\begin{array}{l}- \\
\bar{z} \\
\end{array}$ & $\begin{array}{l}- \\
\bar{z} \\
\end{array}$ & $\begin{array}{l}- \\
\bar{z} \\
-\end{array}$ & $\begin{array}{l}- \\
\bar{z} \\
-\end{array}$ & $\begin{array}{r}4 \\
12 \\
26 \\
9\end{array}$ \\
\hline $\begin{array}{l}\text { EU } 38 \\
\text { Level 1 } \\
\text { Level 2 } \\
\text { Level } 13\end{array}$ & $\overline{1}$ & $\bar{z}$ & $\bar{z}$ & $\bar{z}$ & $\bar{z}$ & $\bar{z}$ & $\frac{1}{-}$ & $\frac{2}{-}$ & $\begin{array}{l}2 \\
1 \\
2\end{array}$ & $\begin{array}{r}7 \\
13 \\
5\end{array}$ & $\overline{-}$ & $\overline{-}$ & $\bar{z}$ & $\overline{-}$ & $\overline{-}$ & $\begin{array}{r}12 \\
15 \\
7\end{array}$ \\
\hline
\end{tabular}




\begin{tabular}{|c|c|c|c|c|c|c|c|c|c|c|c|c|c|c|c|c|}
\hline $\begin{array}{l}\text { Excavarion Unit } \\
\text { and Level }\end{array}$ & \begin{tabular}{|l} 
Arrow \\
Points
\end{tabular} & \begin{tabular}{|l} 
Dart \\
Points
\end{tabular} & Perfortors & Gouges & Bifaces & $\begin{array}{l}\text { Cobble } \\
\text { Trools }\end{array}$ & Unifaces & Cores & 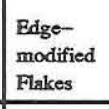 & 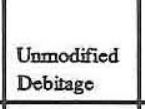 & $\begin{array}{l}\text { Ground } \\
\text { Strono } \\
\text { Trols }\end{array}$ & Hammerstones & Manuports & Ceramics & $\begin{array}{l}\text { Modififed } \\
\text { Shells }\end{array}$ & Totals \\
\hline $\begin{array}{l}\text { 41KT33, continued } \\
\text { EU } 39 \\
\text { Level 1 } \\
\text { Level 2 } \\
\text { Level 3 } \\
\end{array}$ & $\begin{array}{l}1 \\
- \\
\end{array}$ & $\bar{z}$ & $\bar{z}$ & $\bar{z}$ & $\bar{z}$ & $\bar{z}$ & $\bar{z}$ & $\bar{z}$ & $\frac{2}{-}$ & $\begin{array}{c}12 \\
6 \\
6 \\
\end{array}$ & $\bar{z}$ & $\bar{z}$ & $\bar{z}$ & $\bar{~}$ & $\bar{~}$ & $\begin{array}{r}14 \\
7 \\
6 \\
\end{array}$ \\
\hline $\begin{array}{l}\mathrm{EU} 40 \\
\text { Level } 1 \\
\text { Level } 2 \\
\text { Level } 3 \\
\text { Level } 4 \\
\end{array}$ & $\begin{array}{l}\bar{z} \\
\bar{z} \\
\end{array}$ & $\begin{array}{l}\bar{z} \\
\bar{z}\end{array}$ & $\begin{array}{l}\overline{-} \\
\bar{z}\end{array}$ & $\begin{array}{l}\bar{z} \\
\bar{z}\end{array}$ & $\begin{array}{l}\bar{z} \\
\bar{z}\end{array}$ & $\begin{array}{l}\bar{y} \\
\overline{-} \\
\end{array}$ & $\begin{array}{l}- \\
2 \\
- \\
\end{array}$ & $\begin{array}{l}1 \\
1 \\
- \\
\end{array}$ & $\begin{array}{l}2 \\
3 \\
- \\
\end{array}$ & $\begin{array}{r}4 \\
17 \\
3 \\
3 \\
\end{array}$ & $\begin{array}{l}\bar{z} \\
\bar{z}\end{array}$ & $\begin{array}{l}\bar{z} \\
\bar{z}\end{array}$ & $\bar{z}$ & $\begin{array}{l}\overline{1} \\
\bar{z}\end{array}$ & $\bar{z}$ & $\begin{array}{r}7 \\
23 \\
3 \\
3 \\
\end{array}$ \\
\hline 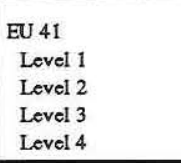 & $\bar{z}$ & $\bar{z}$ & $\begin{array}{l}\bar{z} \\
\overline{-}\end{array}$ & $\begin{array}{l}\bar{z} \\
\bar{z}\end{array}$ & $\begin{array}{l}\bar{z} \\
\bar{z} \\
\end{array}$ & $\begin{array}{l}\bar{y} \\
\overline{-}\end{array}$ & $\begin{array}{l}\bar{z} \\
\bar{z} \\
\end{array}$ & $\begin{array}{l}\bar{z} \\
\bar{z}\end{array}$ & $\begin{array}{l}\bar{z} \\
\bar{z}\end{array}$ & $\begin{array}{r}9 \\
10 \\
5 \\
3 \\
\end{array}$ & $\begin{array}{l}\bar{z} \\
\bar{z} \\
\end{array}$ & $\begin{array}{l}\bar{z} \\
\bar{z}\end{array}$ & $\bar{z}$ & $\bar{\Sigma}$ & $\begin{array}{l}\bar{z} \\
\bar{z}\end{array}$ & $\begin{array}{r}9 \\
10 \\
5 \\
3\end{array}$ \\
\hline $\begin{array}{l}\text { EU } 42 \\
\text { Level } 1 \\
\text { Lovel } 2 \\
\text { Lovel } \\
\text { Level14 }\end{array}$ & $\begin{array}{l}\bar{z} \\
\bar{z}\end{array}$ & $\begin{array}{l}\bar{z} \\
\bar{z}\end{array}$ & $\bar{z}$ & $\begin{array}{l}\bar{z} \\
\bar{z}\end{array}$ & $\begin{array}{l}\bar{z} \\
\bar{z}\end{array}$ & $\bar{z}$ & $\begin{array}{l}\bar{z} \\
\bar{z}\end{array}$ & $\begin{array}{l}1 \\
- \\
\end{array}$ & $\begin{array}{l}\overline{2} \\
\overline{-} \\
\end{array}$ & $\begin{array}{r}10 \\
20 \\
3 \\
1 \\
\end{array}$ & $\begin{array}{l}\bar{z} \\
\bar{z}\end{array}$ & $\begin{array}{l}\bar{z} \\
\bar{z}\end{array}$ & $\begin{array}{l}\bar{z} \\
\bar{z}\end{array}$ & $\begin{array}{l}\bar{z} \\
\bar{z}\end{array}$ & $\bar{z}$ & $\begin{array}{r}11 \\
22 \\
3 \\
1\end{array}$ \\
\hline 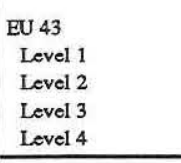 & $\begin{array}{l}\bar{z} \\
\bar{z}\end{array}$ & $\begin{array}{l}\bar{z} \\
\bar{z}\end{array}$ & $\bar{z}$ & $\begin{array}{l}\bar{z} \\
\bar{z}\end{array}$ & $\bar{z}$ & $\begin{array}{l}\bar{z} \\
\bar{z}\end{array}$ & $\begin{array}{l}\bar{z} \\
\bar{z}\end{array}$ & $\begin{array}{l}\bar{z} \\
\bar{z}\end{array}$ & $\begin{array}{l}\bar{z} \\
1 \\
\end{array}$ & $\begin{array}{l}2 \\
9 \\
6 \\
5 \\
\end{array}$ & $\begin{array}{l}\bar{z} \\
1 \\
\end{array}$ & $\begin{array}{l}\bar{z} \\
\bar{z}\end{array}$ & $\begin{array}{l}\bar{z} \\
\bar{z}\end{array}$ & $\bar{z}$ & $\bar{z}$ & $\begin{array}{l}2 \\
9 \\
8 \\
5 \\
\end{array}$ \\
\hline $\begin{array}{l}\text { EU } 44 \\
\text { Level 1 } \\
\text { Level 2 } \\
\text { Level 3 } \\
\text { Level } 4 \\
\text { Level 5 } \\
\end{array}$ & $\begin{array}{l}\bar{z} \\
\bar{z} \\
- \\
\end{array}$ & $\begin{array}{l}\bar{z} \\
\bar{z} \\
\bar{z}\end{array}$ & $\begin{array}{l}\bar{z} \\
\bar{z} \\
\bar{z}\end{array}$ & $\begin{array}{l}\bar{z} \\
\bar{z} \\
\end{array}$ & $\begin{array}{l}\bar{z} \\
\bar{z} \\
\end{array}$ & $\begin{array}{l}\bar{z} \\
\bar{z} \\
\overline{-}\end{array}$ & $\begin{array}{l} \\
1 \\
1 \\
- \\
\end{array}$ & $\begin{array}{l}\bar{z} \\
\bar{z} \\
\overline{-}\end{array}$ & $\begin{array}{l}- \\
2 \\
1 \\
1 \\
- \\
\end{array}$ & $\begin{array}{l}3 \\
2 \\
9 \\
4 \\
2 \\
\end{array}$ & $\begin{array}{l}\bar{z} \\
\bar{z} \\
- \\
\end{array}$ & $\begin{array}{l}\bar{z} \\
\bar{z} \\
\overline{-}\end{array}$ & $\begin{array}{l}\bar{z} \\
\bar{z} \\
\overline{-}\end{array}$ & $\begin{array}{l}\overline{1} \\
\overline{-} \\
\overline{-} \\
\end{array}$ & $\begin{array}{l}\bar{z} \\
\bar{z} \\
-\end{array}$ & $\begin{array}{r}3 \\
6 \\
11 \\
5 \\
2 \\
\end{array}$ \\
\hline 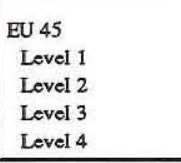 & $\begin{array}{l}\bar{z} \\
\bar{z}\end{array}$ & $\begin{array}{l}\bar{z} \\
\bar{z}\end{array}$ & $\bar{z}$ & $\bar{z}$ & $\bar{z}$ & $\bar{z}$ & $\bar{z}$ & $\begin{array}{l}\bar{z} \\
\bar{z}\end{array}$ & $\begin{array}{l}\overline{1} \\
\overline{-} \\
\end{array}$ & $\begin{array}{r}8 \\
6 \\
15 \\
2 \\
\end{array}$ & $\bar{z}$ & $\bar{z}$ & $\bar{z}$ & $\begin{array}{l}\bar{z} \\
\bar{z}\end{array}$ & $\bar{z}$ & $\begin{array}{r}8 \\
7 \\
15 \\
2 \\
\end{array}$ \\
\hline 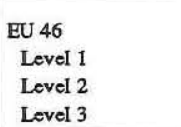 & $\bar{z}$ & $\bar{z}$ & $\bar{z}$ & $\bar{z}$ & $\bar{z}$ & $\bar{z}$ & $\bar{z}$ & $\bar{z}$ & $\begin{array}{l}4 \\
4 \\
-\end{array}$ & $\begin{array}{c}24 \\
17 \\
3\end{array}$ & $\bar{z}$ & $\bar{z}$ & $\bar{z}$ & $\bar{z}$ & $\bar{z}$ & $\begin{array}{r}28 \\
21 \\
3\end{array}$ \\
\hline 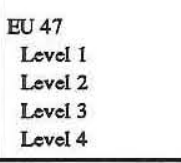 & $\begin{array}{l}\bar{z} \\
\bar{z}\end{array}$ & $\bar{z}$ & $\bar{z}$ & $\bar{z}$ & $\bar{z}$ & $\begin{array}{l}\bar{z} \\
\bar{z}\end{array}$ & $\begin{array}{l}\bar{z} \\
\bar{z}\end{array}$ & $\bar{z}$ & $\frac{2}{5}$ & $\begin{array}{r}24 \\
8 \\
2 \\
- \\
\end{array}$ & $\bar{z}$ & $\bar{z}$ & $\bar{z}$ & $\begin{array}{l}\overline{1} \\
\overline{-} \\
\end{array}$ & $\begin{array}{l}\bar{z} \\
\overline{-}\end{array}$ & $\begin{array}{r}26 \\
9 \\
2 \\
1\end{array}$ \\
\hline
\end{tabular}




\begin{tabular}{|c|c|c|c|c|c|c|c|c|c|}
\hline : & $\stackrel{a}{a}=-$ & $\infty=n$ & $N \cong 0$ & $\pm \infty \infty$ & $\cong \simeq 0-$ & $\sigma$ 里 & $-\overline{4} a \mathrm{n}$ & $\sim \cong \cong=+$ & $-=9 \infty \mathrm{N}$ \\
\hline 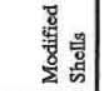 & $\begin{array}{lll}1 & 1 & 1\end{array}$ & $\begin{array}{lll}1 & 1 & 1\end{array}$ & $\begin{array}{lll}1 & 1 & 1\end{array}$ & $\begin{array}{lll}1 & 1 & 1\end{array}$ & $\begin{array}{llll}1 & 1 & 1 & 1\end{array}$ & 1111 & 1111 & $\begin{array}{lllll}1 & 1 & 1 & 1 & 1\end{array}$ & $\begin{array}{lllll}1 & 1 & 1 & 1 & 1\end{array}$ \\
\hline 息 & $\begin{array}{lll}1 & 1 & 1\end{array}$ & $\begin{array}{lll}1 & 1 & 1\end{array}$ & $\begin{array}{lll}1 & 1 & 1\end{array}$ & $\begin{array}{lll}1 & 1 & 1\end{array}$ & $\begin{array}{llll}1 & 1 & 1 & 1\end{array}$ & $\begin{array}{llll}1 & 1 & 1 & 1\end{array}$ & $\begin{array}{llll}1 & 1 & 1 & 1\end{array}$ & $\begin{array}{lllll}1 & 1 & 1 & 1 & 1\end{array}$ & $\begin{array}{lllll}1 & 1 & 1 & 1 & 1\end{array}$ \\
\hline 夏 & $\begin{array}{lll}1 & 1 & 1\end{array}$ & $\begin{array}{lll}1 & 1 & 1\end{array}$ & $\begin{array}{lll}1 & 1 & 1\end{array}$ & $\begin{array}{lll}1 & 1 & 1\end{array}$ & $\begin{array}{llll}1 & 1 & 1 & 1\end{array}$ & 1111 & 1111 & $\begin{array}{lllll}1 & 1 & 1 & 1 & 1\end{array}$ & $\begin{array}{lllll}1 & 1 & 1 & 1 & 1\end{array}$ \\
\hline 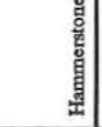 & $\begin{array}{lll}1 & 1 & 1\end{array}$ & 111 & $\begin{array}{lll}1 & 1 & 1\end{array}$ & $\begin{array}{lll}1 & 1 & 1\end{array}$ & 1111 & 1111 & 1111 & $\begin{array}{lllll}1 & 1 & 1 & 1 & 1\end{array}$ & 1111 \\
\hline 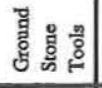 & $\begin{array}{lll}1 & 1 & 1\end{array}$ & $\begin{array}{ll}-1 & 1\end{array}$ & $\begin{array}{lll}1 & 1 & 1\end{array}$ &, $\begin{array}{lll}1 & 1 & 1\end{array}$ & $\begin{array}{llll}1 & 1 & 1 & 1\end{array}$ & $1-1$ & $1-1 ; 1$ & $\begin{array}{lllll}1 & 1 & 1 & 1 & 1\end{array}$ & $\begin{array}{lllll}1 & 1 & 1 & 1 & 1\end{array}$ \\
\hline 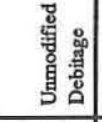 & $y^{\infty} \infty 1$ & $\pm \approx N$ & $N \circ \circ$ & $\approx=-$ & $\simeq \cong 0-$ & $a \tilde{\sim}$ & $-\infty a N$ & 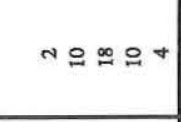 & $-0=-1$ \\
\hline 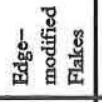 & $-n-1$ & $\begin{array}{lll}N & 1 & 1\end{array}$ & $1 \mathrm{ml} 1$ & $\begin{array}{lll}-1 & 1\end{array}$ & $m \quad 1 \quad 1 \quad 1$ & $|N| 1$ & $1-11$ & $1-1-1 \quad 1 \quad 1$ & $1-11 N$ \\
\hline 。ํ. & $N-1$ & $\begin{array}{lll}1 & 1 & 1\end{array}$ & $\begin{array}{lll}1 & 1 & 1\end{array}$ & $-1-$ & $\begin{array}{llll}1 & 1 & 1 & 1\end{array}$ & $1-1$ & 1111 & $\begin{array}{lllll}1 & 1 & 1 & 1 & 1\end{array}$ & $11-1$ \\
\hline 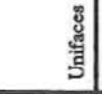 & $\begin{array}{lll}1 & 1 & 1\end{array}$ & 111 & $\begin{array}{lll}1 & 1 & 1\end{array}$ & $\begin{array}{lll}1 & 1 & 1\end{array}$ & $\begin{array}{llll}1 & 1 & 1 & 1\end{array}$ & $\begin{array}{llll}1 & 1 & 1 & 1\end{array}$ & $1-11$ & $\begin{array}{llll}1 & -1 & 1 & 1\end{array}$ & $111-1$ \\
\hline 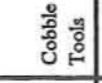 & $\begin{array}{lll}1 & 1 & 1\end{array}$ & 111 & $\begin{array}{lll}1 & 1 & 1\end{array}$ & $1-1$ & $\begin{array}{llll}1 & 1 & 1 & 1\end{array}$ & $1-11$ & 1111 & $\begin{array}{lllll}1 & 1 & 1 & 1 & 1\end{array}$ & 11111 \\
\hline 㤐 & $\begin{array}{lll}1 & 1 & 1\end{array}$ & $\begin{array}{lll}1 & 1 & 1\end{array}$ & $\begin{array}{lll}1 & 1 & 1\end{array}$ & $\begin{array}{lll}1 & 1 & 1\end{array}$ & $\begin{array}{llll}1 & 1 & 1 & 1\end{array}$ & 1111 & 1111 & $111-1$ & $\begin{array}{lllll}1 & 1 & 1 & 1 & 1\end{array}$ \\
\hline 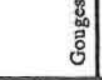 & $1 \quad 1 \quad 1$ & $\begin{array}{lll}1 & 1 & 1\end{array}$ & $\begin{array}{lll}1 & 1 & 1\end{array}$ & $\begin{array}{lll}1 & 1 & 1\end{array}$ & $\begin{array}{llll}1 & 1 & 1 & 1\end{array}$ & $\begin{array}{llll}1 & 1 & 1 & 1\end{array}$ & 1111 & $\begin{array}{lllll}1 & 1 & 1 & 1 & 1\end{array}$ & 11111 \\
\hline 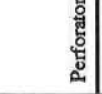 & 111 & 111 & $\begin{array}{lll}1 & 1 & 1\end{array}$ & $\begin{array}{lll}1 & 1 & 1\end{array}$ & $\begin{array}{llll}1 & 1 & 1 & 1\end{array}$ & 1111 & $\begin{array}{llll}1 & 1 & 1 & 1\end{array}$ & $\begin{array}{lllll}1 & 1 & 1 & 1 & 1\end{array}$ & $\begin{array}{lllll}1 & 1 & 1 & 1 & 1\end{array}$ \\
\hline 莫軎 & $\begin{array}{lll}1 & 1 & 1\end{array}$ & $\begin{array}{lll}1 & 1 & 1\end{array}$ & $\begin{array}{lll}1 & 1 & 1\end{array}$ & $\begin{array}{lll}1 & 1 & 1\end{array}$ & 1111 & $\begin{array}{llll}1 & 1 & 1 & 1\end{array}$ & 1111 & $\begin{array}{lllll}1 & 1 & 1 & 1 & 1\end{array}$ & $\begin{array}{lllll}1 & 1 & 1 & 1 & 1\end{array}$ \\
\hline 量责 & $\begin{array}{lll}1 & 1 & 1\end{array}$ & -11 & $\begin{array}{lll}1 & 1 & 1\end{array}$ & $\begin{array}{lll}1 & 1 & 1\end{array}$ & $\begin{array}{llll}1 & 1 & 1 & 1\end{array}$ & 1111 & 1111 & $\begin{array}{lllll}1 & 1 & 1 & 1 & 1\end{array}$ & $11-1$ \\
\hline 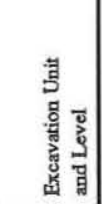 & 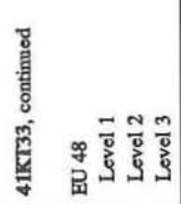 & 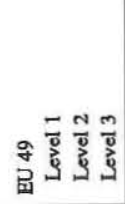 & 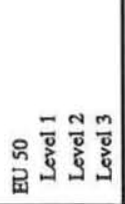 & 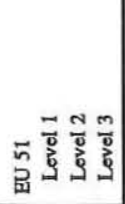 & 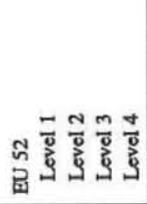 & 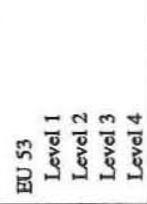 & 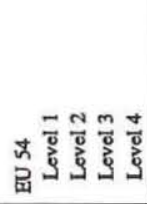 & 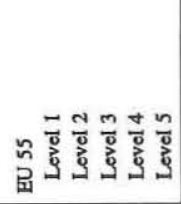 & 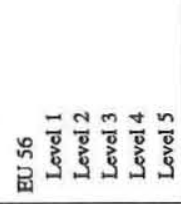 \\
\hline
\end{tabular}




\begin{tabular}{|c|c|c|c|c|c|c|c|c|c|c|}
\hline 형 & & உニ - & 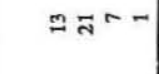 & $m=\infty$ & $\bar{N}=m-$ & $-\underline{\infty}+N$ & $2 m-$ & $-2-n m$ & $m m-$ & -- \\
\hline 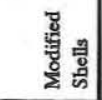 & & $1-11$ & $\begin{array}{llll}1 & 1 & 1 & 1\end{array}$ & $\begin{array}{llll}1 & 1 & 1 & 1\end{array}$ & $\begin{array}{llll}1 & 1 & 1 & 1\end{array}$ & $\begin{array}{llll}1 & 1 & 1 & 1\end{array}$ & 111 & $\begin{array}{lllll}1 & 1 & 1 & 1 & 1\end{array}$ & $\begin{array}{lll}1 & 1 & 1\end{array}$ & 11 \\
\hline 息 & & $\begin{array}{llll}1 & 1 & 1 & 1\end{array}$ & $\begin{array}{llll}1 & 1 & 1 & 1\end{array}$ & $1-1 \quad 1$ & $\begin{array}{llll}1 & 1 & 1 & 1\end{array}$ & $\begin{array}{llll}1 & 1 & 1 & 1\end{array}$ & 111 & $\begin{array}{lllll}1 & 1 & 1 & 1 & 1\end{array}$ & $\begin{array}{lll}1 & 1 & 1\end{array}$ & 11 \\
\hline 总 & & $\begin{array}{llll}1 & 1 & 1 & 1\end{array}$ & 1111 & $\begin{array}{llll}1 & 1 & 1 & 1\end{array}$ & $\begin{array}{llll}1 & 1 & 1 & 1\end{array}$ & $\begin{array}{llll}1 & 1 & 1 & 1\end{array}$ & $\begin{array}{lll}1 & 1 & 1\end{array}$ & $\begin{array}{lllll}1 & 1 & 1 & 1 & 1\end{array}$ & $\begin{array}{lll}1 & 1 & 1\end{array}$ & 11 \\
\hline $\begin{array}{l}\text { : } \\
\text { : } \\
\text { 兽 } \\
\text { 尊 }\end{array}$ & & $\begin{array}{llll}1 & 1 & 1 & 1\end{array}$ & $\begin{array}{llll}1 & 1 & 1 & 1\end{array}$ & $\begin{array}{llll}1 & 1 & 1 & 1\end{array}$ & $\begin{array}{llll}1 & 1 & 1 & 1\end{array}$ & $\begin{array}{llll}1 & 1 & 1 & 1\end{array}$ & $\begin{array}{lll}1 & 1 & 1\end{array}$ & $\begin{array}{lllll}1 & 1 & 1 & 1 & 1\end{array}$ & $\begin{array}{lll}1 & 1 & 1\end{array}$ & 11 \\
\hline 구유. & & $\begin{array}{llll}-1 & 1 & 1\end{array}$ & $\begin{array}{llll}1 & 1 & 1 & 1\end{array}$ & $\begin{array}{llll}1 & 1 & 1 & 1\end{array}$ & $\begin{array}{llll}1 & 1 & 1 & 1\end{array}$ & $\begin{array}{llll}1 & 1 & 1 & 1\end{array}$ & $\begin{array}{lll}1 & 1 & 1\end{array}$ & $1:-11$ & $\begin{array}{lll}1 & 1 & 1\end{array}$ & 11 \\
\hline 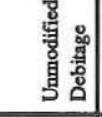 & & $a \simeq a-$ & $\approx \cong ⿻ 上 丨$ & $m a \pm 0$ & $\stackrel{\infty}{=} \mathrm{m}-$ & $m=\forall n$ & $\pm a-$ & - $2 n n m$ & $m m-$ & \\
\hline 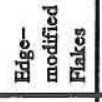 & & $1 n-1$ & $-1-1$ & $1-7-$ & $\begin{array}{llll}m & 1 & 1 & 1\end{array}$ & $1-1 \quad 1$ & $\nabla N 1$ & $\begin{array}{lllll}1 & 1 & 1 & 1 & 1\end{array}$ & $\begin{array}{lll}1 & 1 & 1\end{array}$ & 11 \\
\hline 8 & & $1-11$ & $\begin{array}{llll}1 & n & 1 & 1\end{array} \mid$ & $\begin{array}{llll}1 & 1 & 1 & 1\end{array}$ & $\begin{array}{llll}1 & 1 & 1 & 1\end{array}$ & $\begin{array}{llll}1 & 1 & 1 & 1\end{array}$ & $1-1$ & $\begin{array}{lllll}1 & 1 & 1 & 1 & 1\end{array}$ & $\begin{array}{lll}1 & 1 & 1\end{array}$ & 11 \\
\hline 递 & & $11-1$ & $1-1 \quad 1$ & $1-1 \quad 1$ & $1-1-1$ & $\begin{array}{llll}1 & 1 & 1 & 1\end{array}$ & $\begin{array}{lll}1 & 1 & 1\end{array}$ & $1-1 \quad 1 \quad 1$ & $\begin{array}{lll}1 & 1 & 1\end{array}$ & 11 \\
\hline ) & & $1 \quad 1 \quad 1$ & $\begin{array}{llll}1 & 1 & 1 & 1\end{array}$ & $\begin{array}{llll}1 & 1 & 1 & 1\end{array}$ & $\begin{array}{llll}1 & 1 & 1 & 1\end{array}$ & $\begin{array}{llll}1 & 1 & 1 & 1\end{array}$ & --1 & $\begin{array}{lllll}1 & 1 & 1 & 1 & 1\end{array}$ & $\begin{array}{lll}1 & 1 & 1\end{array}$ & 11 \\
\hline : & & $\begin{array}{llll}1 & 1 & 1 & 1\end{array}$ & $\begin{array}{llll}1 & 1 & 1 & 1\end{array}$ & $\begin{array}{llll}1 & 1 & 1 & 1\end{array}$ & $\begin{array}{llll}1 & 1 & 1 & 1\end{array}$ & $\begin{array}{llll}1 & 1 & 1 & 1\end{array}$ & $1 \quad 1 \quad 1$ & $\begin{array}{lllll}1 & 1 & 1 & 1 & 1\end{array}$ & $\begin{array}{lll}1 & 1 & 1\end{array}$ & 11 \\
\hline $\begin{array}{l}\text { : } \\
\text { है } \\
\end{array}$ & & $\begin{array}{llll}1 & 1 & 1 & 1\end{array}$ & $\begin{array}{llll}1 & 1 & 1 & 1\end{array}$ & $\begin{array}{llll}1 & 1 & 1 & 1\end{array}$ & $\begin{array}{llll}1 & 1 & 1 & 1\end{array}$ & $\begin{array}{llll}1 & 1 & 1 & 1\end{array}$ & $\begin{array}{lll}1 & 1 & 1\end{array}$ & $11-11$ & $\begin{array}{lll}1 & 1 & 1\end{array}$ & 11 \\
\hline $\begin{array}{l}0 \\
\text { : } \\
\text { : } \\
\text { : } \\
\end{array}$ & & $\begin{array}{llll}1 & 1 & 1 & 1\end{array}$ & $\begin{array}{llll}1 & 1 & 1 & 1\end{array}$ & $111-$ & $\begin{array}{llll}1 & 1 & 1 & 1\end{array}$ & $\begin{array}{llll}1 & 1 & 1 & 1\end{array}$ & 111 & $\begin{array}{lllll}1 & 1 & 1 & 1 & 1\end{array}$ & $\begin{array}{lll}1 & 1 & 1\end{array}$ & 11 \\
\hline 青貝 & & $\begin{array}{llll}1 & 1 & 1 & 1\end{array}$ & $\begin{array}{llll}1 & 1 & 1 & 1\end{array}$ & $\begin{array}{llll}1 & 1 & 1 & 1\end{array}$ & $\begin{array}{llll}1 & 1 & 1 & 1\end{array}$ & $\begin{array}{llll}1 & 1 & 1 & 1\end{array}$ & $\begin{array}{lll}1 & 1 & 1\end{array}$ & 11111 & 111 & 11 \\
\hline 高是是 & & $\begin{array}{llll}1 & 1 & 1 & 1\end{array}$ & $\begin{array}{llll}1 & 1 & 1 & 1\end{array}$ & $1--1$ & $\begin{array}{llll}1 & 1 & 1 & 1\end{array}$ & $\begin{array}{llll}1 & 1 & 1 & 1\end{array}$ & 111 & $1-1 \quad 1$ & 111 & 11 \\
\hline 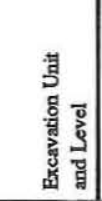 & 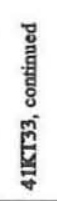 & 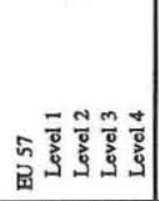 & 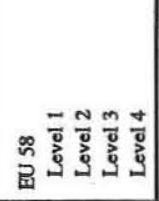 & 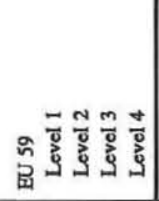 & 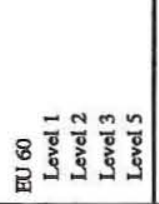 & 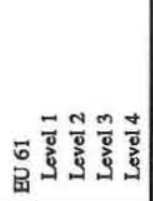 & 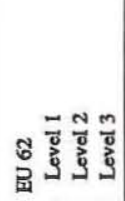 & 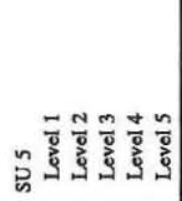 & 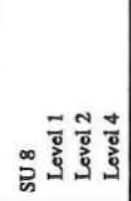 & 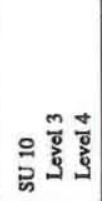 \\
\hline
\end{tabular}




\begin{tabular}{|c|c|c|c|c|c|}
\hline : & & $-m+N$ & $n-D$ & N- & - \\
\hline 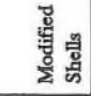 & & $\begin{array}{llll}1 & 1 & 1 & 1\end{array}$ & 1111 & $\begin{array}{lll}1 & 1 & 1\end{array}$ & ' \\
\hline 尊 & & 1111 & 111 & $\begin{array}{lll}1 & 1 & 1\end{array}$ & I \\
\hline 总 & & $\begin{array}{llll}1 & 1 & 1\end{array}$ & 111 & $\begin{array}{lll}1 & 1 & 1\end{array}$ & I \\
\hline $\begin{array}{l}\text { : } \\
\text { : } \\
\text { : } \\
\text { 首 } \\
\text { 基 }\end{array}$ & & $\begin{array}{llll}1 & 1 & 1 & 1\end{array}$ & 111 & $\begin{array}{lll}1 & 1 & 1\end{array}$ & I \\
\hline 鄫 & & $\begin{array}{llll}1 & 1 & 1 & 1\end{array}$ & $\begin{array}{lll}1 & 1 & 1\end{array}$ & $\begin{array}{lll}1 & 1 & 1\end{array}$ & 1 \\
\hline 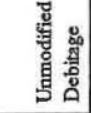 & & $-m+n$ & $n \rightarrow-$ & $n=-$ & - \\
\hline 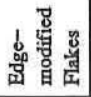 & & $\begin{array}{llll}1 & 1 & 1 & 1\end{array}$ & 111 & $\begin{array}{lll}1 & 1 & 1\end{array}$ & 1 \\
\hline 8. & & $\begin{array}{llll}1 & 1 & 1 & 1\end{array}$ & $\begin{array}{lll}1 & 1 & 1\end{array}$ & $\begin{array}{lll}1 & 1 & 1\end{array}$ & I \\
\hline 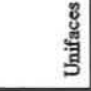 & & $\begin{array}{llll}1 & 1 & 1\end{array}$ & 111 & $\begin{array}{lll}1 & 1 & 1\end{array}$ & 1 \\
\hline 융 & & $\begin{array}{llll}1 & 1 & 1 & 1\end{array}$ & 111 & $\begin{array}{lll}1 & 1 & 1\end{array}$ & I \\
\hline 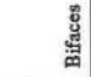 & & $\begin{array}{llll}1 & 1 & 1 & 1\end{array}$ & 111 & $\begin{array}{lll}1 & 1 & 1\end{array}$ & I \\
\hline $\begin{array}{l}\text { है } \\
\text { है } \\
\text { है }\end{array}$ & & $\begin{array}{llll}1 & 1 & 1 & 1\end{array}$ & 111 & $\begin{array}{lll}1 & 1 & 1\end{array}$ & 1 \\
\hline $\begin{array}{l}\text { : } \\
\text { : } \\
\text { : } \\
\text { : }\end{array}$ & & 1111 & 111 & 111 & ' \\
\hline 点軎 & & $\begin{array}{llll}1 & 1 & 1 & 1\end{array}$ & $\begin{array}{lll}1 & 1 & 1\end{array}$ & $1 \quad 11$ & ' \\
\hline 量高 & & 1111 & 111 & 111 & ' \\
\hline 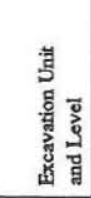 & 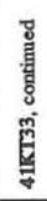 & 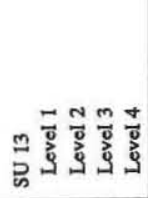 & 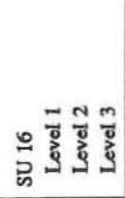 & 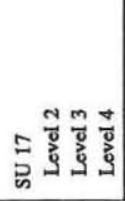 & ${ }_{\mathrm{B}}^{\infty}$ \\
\hline
\end{tabular}




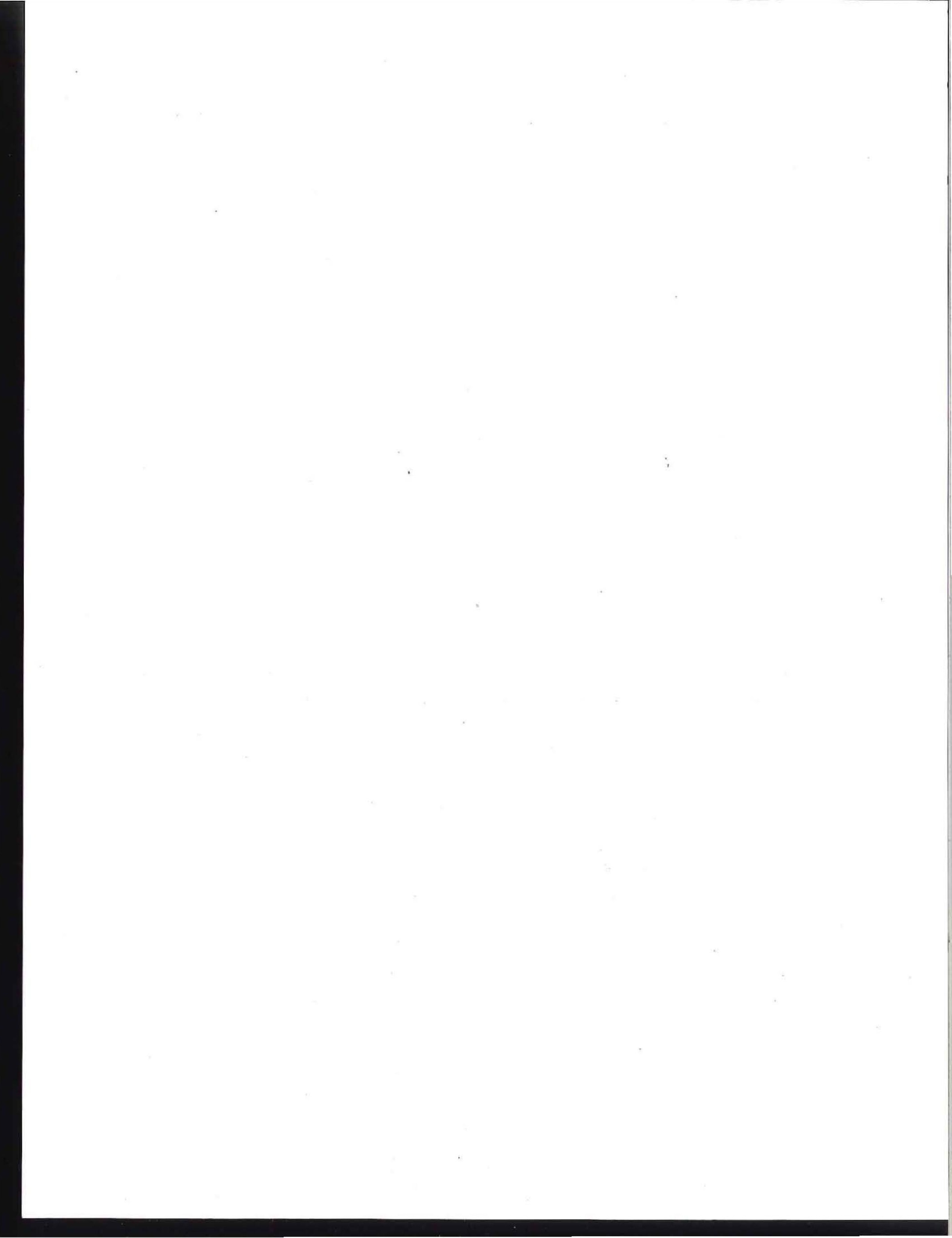


APPENDIX C: Faunal Remains from the Prehistoric Sites

\author{
Raymond W. Neck \\ and \\ Douglas K. Boyd
}




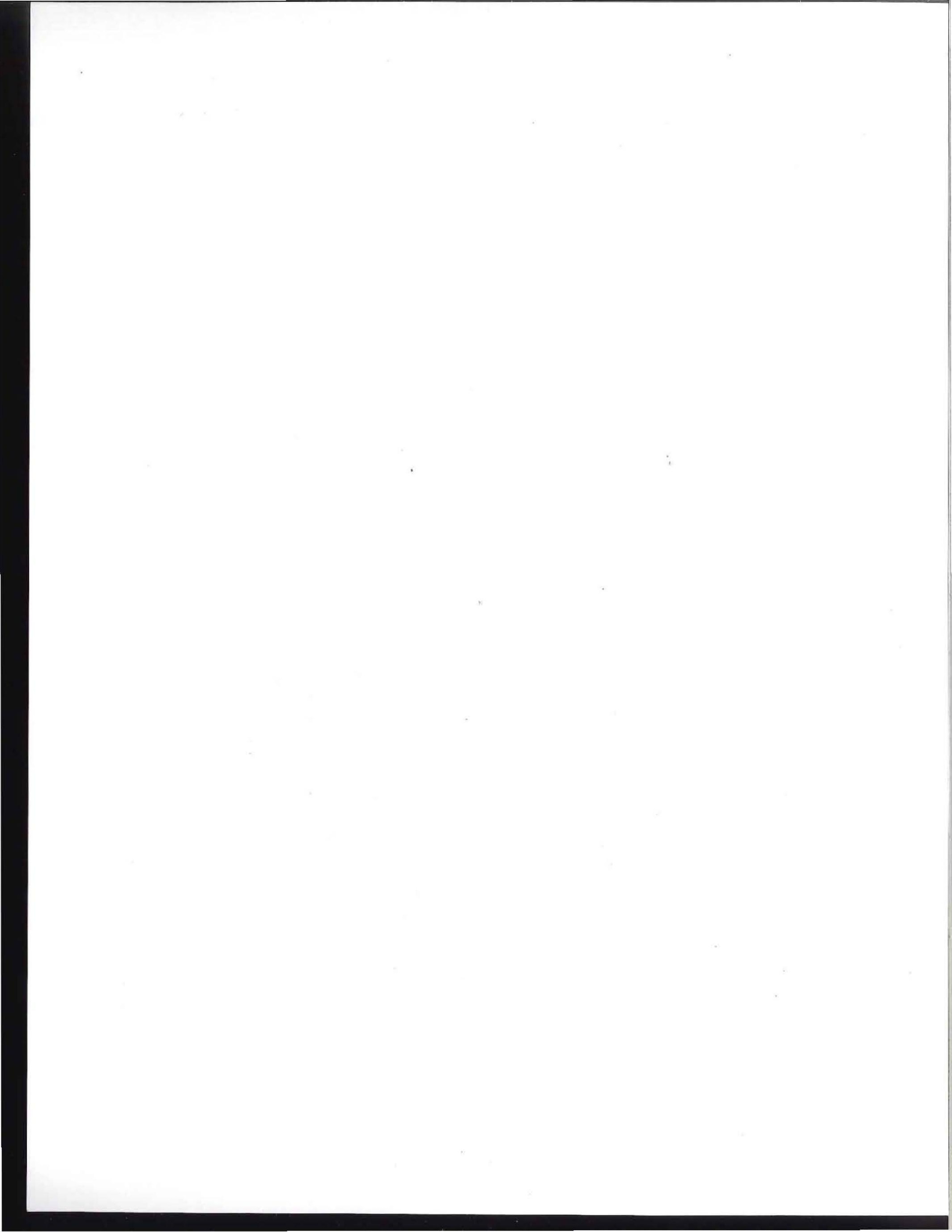




\section{INTRODUCTION}

The faunal remains recovered from the prehistoric sites during the Season 1 investigation include a small sample of vertebrate bones and a comparatively large sample of invertebrate remains. The vertebrate remains are identified by J. Michael Quigg (Mariah Associates, Inc., Austin, Texas) and are described by Boyd; the invertebrate remains are identified and discussed by Dr. Raymond W. Neck (Texas Parks and Wildlife Department, Austin).

\section{VERTEBRATE REMAINS}

The vertebrate faunal materials recovered from prehistoric sites during the Season 1 investigation constitute a very meager sample. Only six bone fragments were recovered from two of the prehistoric sites, and they are all most likely of modern, noncultural origin (Table 41). All of the specimens are unmodified except for root etching/weathering deterioration. While they would be of cultural origin, the only identifiable remains are of burrowing animals. Species represented by the faunal remains include cottontail and jack rabbit at 41GR383 and blacktailed prairie dog at $41 \mathrm{KT} 33$. In addition, one medium to large mammal bone fragment was recovered from 41GR383.

The scarcity of bones at the two oldest prehistoric sites, 41GR383 and 41KT33, is thought to be a factor of preservation. The recent age and better preservation at 41GR484, however, suggest that the absence of bones is a real cultural phenomenon; the fact that bone fragments were recovered in a 1988 backhoe trench at 41GR484 further supports the interpretation that the paucity of bones at the site is not due to poor preservation.

\section{INVERTEBRATE REMAINS}

The invertebrate remains consist of molluscan shells from three sites (Table 42). Only two species, one terrestrial gastropod and one freshwater mussel, were identified from these samples. Despite the limited species representation, some environmental and cultural information can be deduced from these samples.

Succinea luteola is a terrestrial gastropod that is known from a variety of habitats. Many populations occur in dry silty or sandy clay flats with clumps of short grass sparsely distributed between small trees or shrubs, e.g., junipers or prickly pear. Other populations are found along shore margins of ponds, creeks, and rivers. Occasionally, populations of this species are associated with seeps. The $S$. luteola from $41 \mathrm{KT} 33$ are the typical moderately narrow shape with thick shells, indicating xeric conditions. The S. luteola from 41GR383 are somewhat atypical with large apertures and reduced shell thickness. Those shells probably indicate a seasonally wet area, possibly a seep. An alternative interpretation, due to the greater age of this site, would be increased overall moisture availability.

Most of the mussel shell fragments from these sites are nondiagnostic, but all of these fragments probably represent shells of Uniomerus declivus, the only species of freshwater mussel that could be recognized from these samples. Uniomerus declivus

\begin{tabular}{|c|c|c|}
\hline \multicolumn{3}{|r|}{ TABLE 41} \\
\hline \multicolumn{3}{|c|}{ DISTRIBUTION OF VERTEBRATE FAUNAL REMAINS AT PREHISTORIC SITES } \\
\hline Site & Provenience & Description \\
\hline \multirow[t]{4}{*}{$41 \mathrm{GR} 383$} & EU 23 & 1 distal humerus, jack rabbit (Lepus californicus) \\
\hline & EU 26 & $\begin{array}{l}1 \text { unidentifiable fragment, small mammal; } \\
1 \text { distal humerus, cottontail rabbit (Sylvilagus sp.) }\end{array}$ \\
\hline & EU 36 & 1 tooth enamel fragment, medium to large mammal \\
\hline & EU 41 & 1 unidentifiable fragment, medium mammal \\
\hline $41 \mathrm{KT} 33$ & EU 15 & $\begin{array}{l}1 \text { tibia (minus both articular ends), probably black-tailed prairie dog (Cynomys } \\
\text { ludevicianus) }\end{array}$ \\
\hline
\end{tabular}


Phase III Data Recovery, Season 1, Justiceburg Reservoir

TABLE 42

MOLLUSCAN REMAINS RECOVERED FROM PREHISTORIC SITES

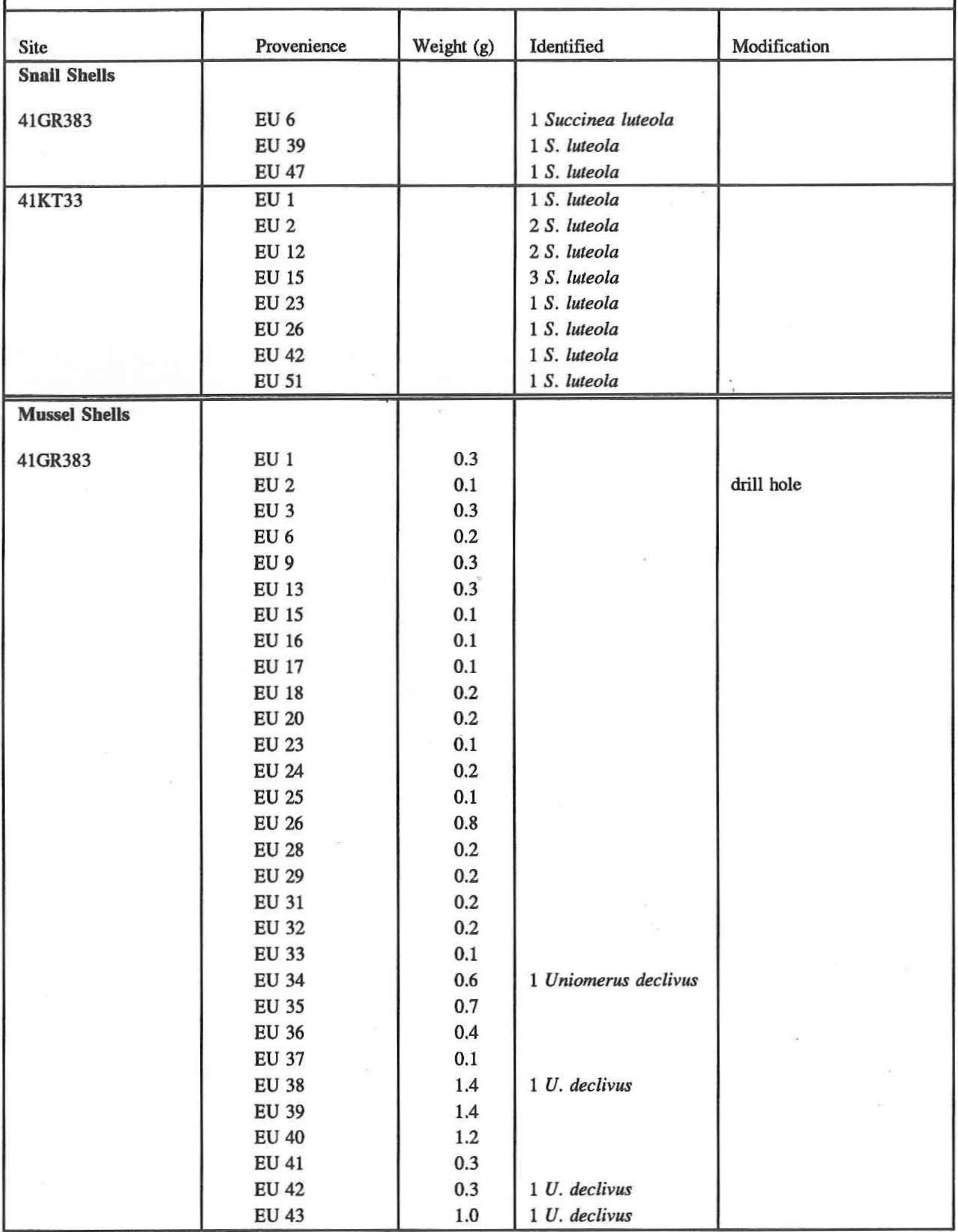




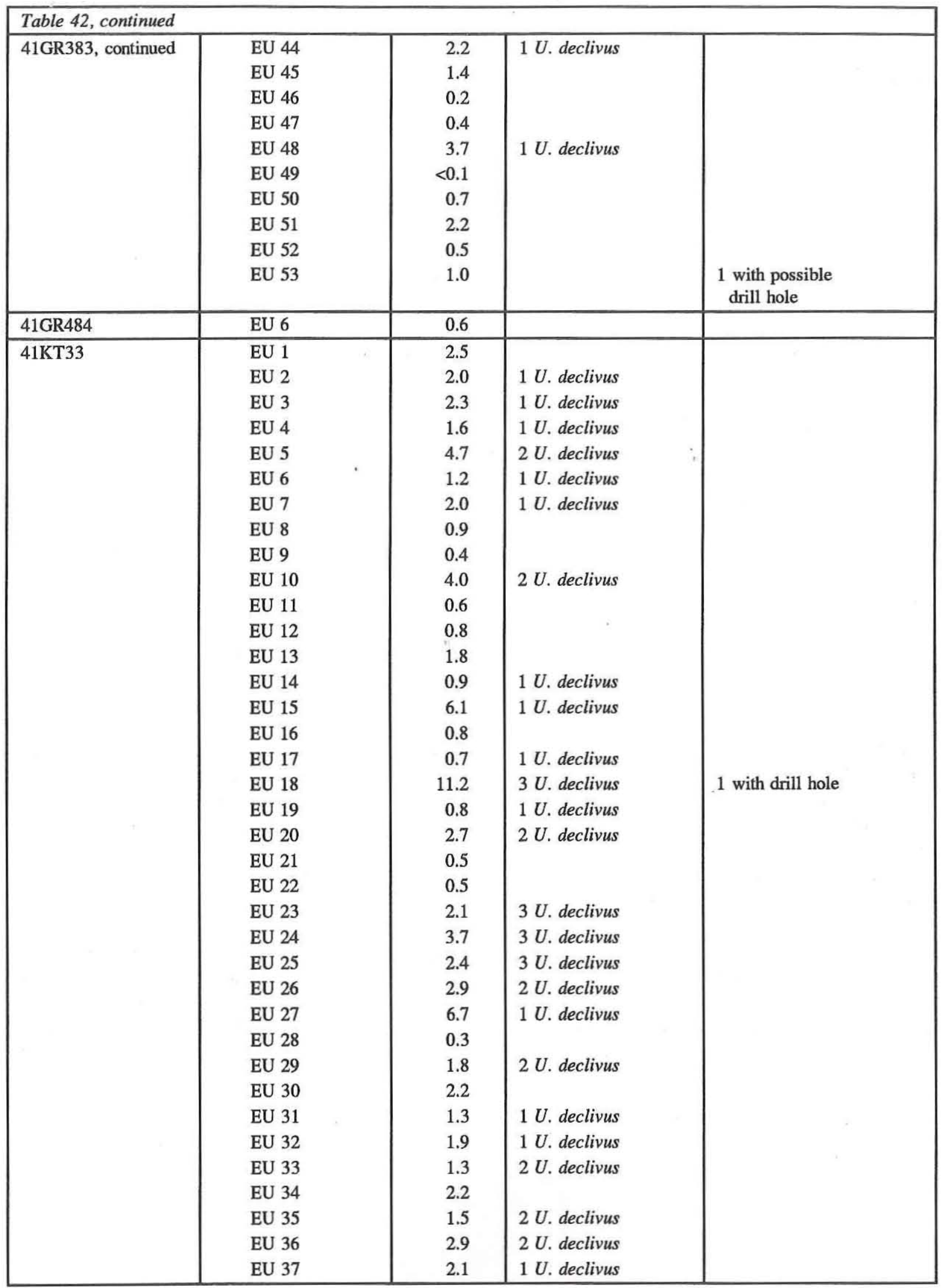




\begin{tabular}{|c|c|c|c|c|}
\hline Site & Provenience & Weight (g) & Identified & Modification \\
\hline $41 \mathrm{KT} 33$, continued & $\begin{array}{l}\text { EU } 38 \\
\text { EU } 39 \\
\text { EU } 40 \\
\text { EU } 41 \\
\text { EU } 42 \\
\text { EU } 43 \\
\text { EU } 44 \\
\text { EU } 45 \\
\text { EU } 46 \\
\text { EU } 47 \\
\text { EU } 48 \\
\text { EU } 49 \\
\text { EU 50 } \\
\text { EU 51 } \\
\text { EU 53 } \\
\text { EU 54 } \\
\text { EU 55 } \\
\text { EU } 56 \\
\text { EU } 57 \\
\text { EU } 58 \\
\text { EU 59 } \\
\text { EU } 60 \\
\text { EU } 61 \\
\text { SU } 5\end{array}$ & $\begin{array}{r}0.6 \\
1.4 \\
0.5 \\
1.8 \\
<0.1 \\
1.7 \\
1.2 \\
3.0 \\
0.9 \\
1.0 \\
0.7 \\
1.5 \\
1.8 \\
0.4 \\
2.6 \\
1.6 \\
1.9 \\
1.4 \\
2.3 \\
0.3 \\
1.9 \\
1.7 \\
1.2 \\
1.3\end{array}$ & $\begin{array}{l}2 U . \text { declivus } \\
1 U . \text { declivus } \\
2 U . \text { declivus } \\
2 U . \text { declivus } \\
3 U . \text { declivus } \\
2 U . \text { declivus } \\
2 U . \text { declivus } \\
3 U . \text { declivus } \\
1 U . \text { declivus } \\
\\
2 U . \text { declivus } \\
1 U . \text { declivus }\end{array}$ & $\begin{array}{l}1 \text { heated } \\
1 \text { heated } \\
1 \text { with serrated edge }\end{array}$ \\
\hline
\end{tabular}

declivus lives in slow-moving streams, sloughs, and ponds. This species has the ability to survive for several months in the dried substrate of a pond or stream after all of the free water evaporates. Most fragments of $U$. declivus from these samples came from moderate-sized shells -55 to $80 \mathrm{~mm}$ in shell length. A few fragments indicate large shells with original shell lengths as large as 100 to $110 \mathrm{~mm}$.

The shell fragments of Uniomerus declivus indicate at least two cultural uses of this species. Two charred or heat-altered pieces indicate utilization of this freshwater mussel as food by the prehistoric human inhabitants of site 41KT33. Live mussels were probably placed dorsal surface (hinge line) down on a hot rock or log.

Other shells of Uniomerus declivus indicate use as ornaments or tools. Two specimens (one from 41GR383 and one from 41KT33) exhibit drilled holes. These shells may have functioned as rattles, clinkers, or pendants attached to clothing. One shell fragment from 41KT33 exhibits several small teeth that have been carved along an edge of a piece of shell. The small size of these teeth indicates that the piece may be a remnant of a scraping tool (such as a ceramic design tool?). These artifacts are described in more detail in the respective site chapters. 


\section{APPENDIX D: Macrobotanical Analysis of Three Flotation Samples from Justiceburg Reservoir}

Phil Dering

Palynology Laboratory

Texas A\&M University

College Station, Texas 



\section{INTRODUCTION}

Three flotation samples from two archeological sites at Justiceburg Reservoir were examined for archeobotanical remains. Even though the study involved a very small sample size, it constitutes an important contribution to a slowly growing data base. Because of the paucity of paleoenvironmental information available from the area, even the smallest studies can at least contribute to the data base.

\section{METHODS}

The three samples were weighed and then sieved through a 1/8-inch screen. Both fractions were then examined for botanical remains. The only charred material was dicotyledonous wood. The wood charcoal was examined by the snap technique (Leney and Casteel 1975) and examined under a low-power stereomicroscope at magnifications of $5 \mathrm{x}$ to $35 \mathrm{x}$. The identifications were confirmed by reference material in the Archeobotanical Laboratory at Texas A\&M University.

\section{RESULTS AND DISCUSSION}

The results of the investigation are presented in Table 43. Only two samples yielded identifiable charcoal, and both came from Feature 1, 41GR484. The charcoal was Carya spp. which is either pecan or hickory. Based on the distribution of these two trees, it most likely represents pecan.

This constitutes the first report of pecan, a distinctly lowland riparian resource, from the reservoir area. Previously, John Jones of Texas A\&M University had examined a total of 29 samples from 16 sites in the reservoir (Jones 1990). He identified the charcoal of hackberry, dogwood, juniper, mesquite, oak, sumac, and the rose and willow families. Prior to this study, Jones had identified Juniperus charcoal from Feature 1 of 41GR484.

The small size of the sample precludes the reconstruction of paleoenvironment or subsistence patterns. However, the presence of Carya sp. is an indication of the presence and utilization of an important riparian resource in the region.

TABLE 43

MACROBOTANICAL MATERIAL FROM FLOTATION SAMPLES

\begin{tabular}{|l|c|c|c|}
\hline Provenience & Total Sample Weight & Charcoal Type & Weight of Charcoal \\
\hline $\begin{array}{l}\text { 41KT33, EU 5, Feature 12 } \\
\text { Below burned rocks }\end{array}$ & $16.8 \mathrm{~g}$ & - & - \\
\hline $\begin{array}{l}\text { 41GR484, Feature 1 } \\
\text { Fill from west half of feature }\end{array}$ & $18.3 \mathrm{~g}$ & Carya sp. & $4.2 \mathrm{~g}$ \\
\hline $\begin{array}{l}\text { 41GR484, Feature 1, } \\
\text { From bumed sediment layer } \\
\text { below feature rocks }\end{array}$ & $16.8 \mathrm{~g}$ & Carya sp. & $1.2 \mathrm{~g}$ \\
\hline
\end{tabular}

\section{REFERENCES CITED}

Jones, John

1990 Assessment of Pollen Preservation and Macrobotanical Analysis. Appendix H in Phase II Investigations at Prehistoric and Rock Art Sites, Justiceburg Reservoir, Garza and Kent Counties, Texas, by D. Boyd, J. Abbott, W. Bryan, C. Garvey, S. Tomka, and R. Fields, pp.
522-525. Reports of Investigations No. 71, Volume II. Prewitt and Associates, Inc., Austin.

Leney, L., and R. Casteel

1975 Simplified Procedure for Examining Charcoal Specimens for Identification. Journal of Archaeological Science 29:109-144. 



\section{APPENDIX E: Pollen Analysis of Archeological Sediments from Justiceburg Reservoir}

Phil Dering

and

Vaughn M. Bryant, Jr.

Palynology Laboratory

Texas A\&M University

College Station, Texas 



\section{INTRODUCTION}

Pollen analyses form the data base for many types of interpretations ranging from sequential changes in past environments to information about the lifestyles and diets of prehistoric human populations. In each of these studies, the eventual interpretation of pollen data must account for all factors that may have influenced the composition of the original pollen rain, and later for the factors that may have altered the composition of the buried pollen assemblage.

During the last 50 years, palynologists have learned that there are many complex factors that determine the original composition of the pollen rain in a region. These include factors such as type of pollination, differences in pollen production, differential dispersion patterns, and the size, weight, and aerodynamic ability of pollen types to remain airborne. Once deposited, other factors influence eventual loss or recovery of specific pollen types. These factors include pollen recycling, the chemical composition of a pollen grain's exine, its morphological shape and surface ornamentation type, and its susceptibility to various types of degradation processes including those from mechanical, chemical, or biological agents (Bryant 1978, 1988; Bryant and Holloway 1983; Bryant and Jones 1989; Holloway 1989; O'Rourke 1990). It is this last category, postdepositional degradation processes, that is the focus of this report.

One of the first agents that can affect pollen grains is mechanical degradation. After pollen is released from its source, it can become abraded or broken during the transportation phase. These alterations can result from impact or from changes in the natural environment. Studies by Duhoux (1982), for example, have shown that changes in atmospheric moisture levels can result in high numbers of exine ruptures in closely related, thin-walled pollen taxa such as Taxodium, Juniperus, and Thuja. Later, after being deposited, these thin-walled pollen types as well as other types of grains can become further abraded by the cultural activities of humans such as burning, land-surface modifications, construction activities, and agricultural practices. Abrasion of pollen can also occur from various causes in the natural environment such as impact against objects, water and wind erosion, changes in temperature, changes in atmospheric or soil moisture contents, volcanic eruptions, and soil movement.

The morphological structure and omamentation of pollen walls seem to be important factors in determining their potential susceptibility to mechanical degradation. For example, pollen grains having protruding structures, like the bladders of many conifer species or the spines of some Malvaceae grains, have a tendency for their projections to break off or erode through a variety of mechanical processes. In some cases, the actual appearance of a pollen grain may become so altered after the loss of an appended structure or structures that accurate identification is no longer possible. In addition, structural alteration by mechanical processes can also cause severe exine weakening, thereby hastening the eventual destruction of the entire grain through other processes.

Soil chemistry, acting on the natural chemical composition of a pollen grain's exine, is another factor that seems to play an important role in pollen preservation. Although the exine is mostly composed of a highly durable material called sporopollenin, certain environmental factors can adversely affect it. Brooks and Shaw (1968), Shaw (1971), Rowley and Prijanto (1977), and Rowley (1990) found that differences in sporopollenin composition and molecular structure can make pollen grains either more or less resistant to chemical deterioration.

Using the effects of $\mathrm{pH}$ as an example, Dimbleby (1957) was one of the first to chart differences in pollen preservation caused by soil chemistry. His research revealed that soils with a low acidic $\mathrm{pH}$ are ideal deposits for pollen preservation, while sediments with a $\mathrm{pH}$ above 6.0 often result in the destruction of fossil pollen. Since Dimbleby's original study in the late 1950s, other studies conducted in the arid regions of the American Southwest by Martin (1963), Bryant (1969), and Hall (1981) have demonstrated that fossil pollen can be recovered from alkaline soils with a $\mathrm{pH}$ as high as 8.9. Even when this is possible, however, the recovered pollen has often deteriorated, a fact that makes accurate pollen analyses difficult and in some cases nearly impossible.

Related to Dimbleby's (1957) original work on $\mathrm{pH}$ is Tschudy's (1969) research on the Eh (oxidation potential) of sediments. Tschudy (1969) asserts that Eh actually may be a more important guide to the eventual preservation or destruction of palynomorphs than is pH. Low Eh reflects a reducing, anaerobic environment where carbon dioxide and hydrogen sulfide are the by-products of microbe respiration and combine to decrease the $\mathrm{pH}$ values. Thus, in 
some sediments the creation of a negative Eh potential results in the formation of a strongly reducing environment (Tschudy 1969). Because a reducing environment retards oxygen retention, the resulting low Eh environment becomes an ideal environment for pollen preservation. Likewise, an oxiding sediment with a high Eh speeds the destruction of pollen.

The chemical composition of pollen walls and pollen wall structural morphology also play important roles in determining whether or not pollen grains will remain preserved in various sediments. In a 20 -year study beginning in 1964 and ending in 1984, Havinga $(1964,1984)$ reported that the relationship between the percentage of sporopollenin to cellulose in the wall of pollen grains seems to affect their susceptibility to eventual destruction through oxidation. He found, for example, that pollen grains having high percentages of sporopollenin in their walls tend to remain preserved longer, even in soils with high $\mathrm{pH}$ and Eh values, than do pollen grains with walls composed mostly of cellulose. Recently, Rowley et al. (1990) have conducted detailed SEM studies of the processes of pollen destruction in various soil types and report these results through the presentation of detailed photomicrographs.

Biological agents, such as fungi and bacteria, can cause pollen grain destruction. Recent studies (Holloway 1981) show that some taxa of Phycomycete fungi seek out and feed on the nutrient materials in the cytoplasm of pollen grains. His experimental studies show that the filamentous threads of fungi, called hyphae, often enter a pollen grain through natural aperture openings; yet at other times, they dissolve areas of the exine in order to enter the grain. Both types of attack contribute to the eventual destruction of pollen grains by creating new holes in the exine or enlarging tiny cracks in the exine, thus weakening the overall grain and making it more susceptible to other forms of degradation.

Some years earlier, Phycomycete fungi were investigated by Goldstein (1960), who found they were a causative factor in the destruction of pollen. Data from his initial study showed that some taxa of Phycomycetes are selective in their preference for pollen types and will infect certain pollen taxa at a much faster rate than others. For example, he found pollen grains from certain species of coniferous trees, especially Pseudotsuga, were attacked much more frequently by Phycomycetes than were types of angiosperm pollen. Unlike Holloway's (1981) study, Goldstein did not focus on how fungi actually damage pollen grains. Instead, his data concluded only that pollen from many conifer taxa are the most susceptible types to fungi infection and thus, by inference, eventual destruction.

Elsik (1966) noted that bacterial degradation of pollen grains also occurs. He found that certain bacteria, especially types of Actinomycetes, degrade pollen walls in a definite pattern. He found that in some cases this type of bacterial destruction can continue to occur long after pollen grains have lost their cytoplasm and have become preserved in sediments for thousands, or even millions, of years (Elsik 1966).

\section{DATA BASE}

The first fossil pollen studies of sediments from the Justiceburg region were conducted by Cummings (1990) and Jones (1990). Dr. Cummings reported a wide variety of pollen types present in the samples she examined, while Jones reported poorly preserved pollen.

The current study focuses on 12 additional pollen samples from three archeological sites located in the Justiceburg Reservoir area (Table 44). In addition, five pollen washes were also collected from artifacts recovered during the Justiceburg archeological studies, and they were included in the samples we were asked to analyze.

\section{METHODS}

All fossil pollen soil samples were processed in the same manner so that their data would be comparable. Each processed sample consisted of $20 \mathrm{ml}$ of soil. Added to each sample was a spike of $22,600 \pm 800$ spores of the cryptogram Lycopodium. These spores were added so we could determine the pollen concentration values of each fossil sample. Lycopodium spores were selected as our "exotic" because Lycopodium is a plant rarely found in the natural environment of arid regions in the Justiceburg part of North Texas. Likewise, previous paleoenvironmental studies listed by Hall (1985) for Southwestern regions of North America show no evidence that Lycopodium ever grew in these arid regions during the last 5,000 years.

When conducting pollen concentration values for fossil or modern soil samples, one much select a unit of measure against which concentration values can be calculated. Convenient measuring units 


\begin{tabular}{|c|l|}
\hline \multicolumn{2}{|c|}{ TABLE 44 } \\
\multicolumn{2}{|c|}{ POLLEN SAMPLES FROM JUSTICEBURG } \\
\multicolumn{1}{|c|}{ RESERVOIR } \\
\hline Sample Number & Provenience \\
\hline Soil Samples & \\
1 & 41GR383, EU 15, Feature 13 \\
2 & 41GR383, EU 5, Feature 14 \\
3 & 41GR383, EU 52, 37-42 cm bgs \\
4 & 41GR383, EU 52, 85-90 cm bgs \\
5 & 41KT33, EU 5, Feature 12 \\
6 & 41KT33, Feature 12 \\
7 & 41KT33, EU 60, 10-15 cm bgs \\
8 & 41GR484, EU 12, Feature 1 \\
10 & 41GR484, EU 11, Feature 1 \\
11 & 41GR484, EU 14, Feature 3 \\
12 & 41GR483, EU 34, Feature 15 $14,28-38 \mathrm{~cm}$ bgs \\
\hline Pollen Washes & \\
13 & 41KT33, EU 4, mano \\
14 & 41GR383, EU 39, burned rock \\
15 & 41GR383, EU 46, sandstone* \\
16 & 41GR484, EU 11, manuport \\
17 & 41GR484, EU 11, manuport \\
\hline *Originally thought to be a pestle \\
\hline \multicolumn{2}{|c|}{}
\end{tabular}

include grams, ounces, and cubic centimeters (milliliters). Because different types of sediments tend to weigh different amounts depending on whether they are wet or dry, palynologists often prefer to use milliliters as their standard unit of measure for calculating pollen concentration values. Milliliters are often selected rather than ounces because they are units in a metric system.

The sediments in the Justiceburg region were from environments having a $\mathrm{pH}$ value higher than 6.0 (see Appendix I). Thus, anhydrous carbonates were one of the common compounds found in these samples. During the first step of processing, carbonates were removed by using concentrated hydrochloric acid. The second step focused on removing small rocks and coarse-grained silicates by decanting. Each sample was placed in a large beaker, filled with distilled water, and then stirred in all directions to enable pollen to remain suspended. The liquid fraction was then quickly poured into another beaker and saved. This process was repeated several times for each sample and discarded. Fine-grained sili- cates not removed by decanting were dissolved in $70 \%$ hydrofluoric acid for at least 15 hours.

After the carbonates and silicates were removed, each sample was deflocculated in a Darvan dispersing solution, then sonicated for 1 minute in a Delta D-5 sonicator. This was followed by heavy density separation with zinc bromide, a process that removed much of the remaining detritus from the pollen. Because most of these soils had a high Eh potential, little organic debris was present. However, to make certain, we processed each sample using the acetolysis method (Erdtman 1960).

When the laboratory procedures were completed, samples were stained with saffranin-0 and mounted in glycerin for examination. Identification and counting were performed using a JENA binocular microscope. Identifications of pollen and spore types in each sample were checked against reference materials on file in the Texas A\&M Palynology Laboratory. These include the Texas A\&M Modern Pollen Reference Collection and the Mobil Oil Modern Pollen Reference Collection. Whenever possible, we attempted to count at least 200 fossil grains from each sample (excluding fungal spores and Lycopodium exotic spores).

The pollen washes were processed by a much simpler method. Each liquid sample was placed in a beaker, and then one tablet of Lycopodium exotic spores was added. The sample was then dehydrated and acetylated. The remaining material was then transferred into glycerine for storage.

\section{RESULTS}

Of the 12 sediment samples examined, only 6 (50\%) contained sufficient pollen to conduct statistically valid counts in excess of 200 grains as recommended by Barkley (1934), Martin (1963), and others (Table 45). We believe the remaining group of six samples $(50 \%)$ was almost entirely void of fossil pollen because the pollen had been destroyed shortly after deposition or during the years between the time of deposition and the time the sediments were excavated and sampled. The most significant points were that the small amounts of pollen found in all 12 samples represented (1) taxa known to be highly resistant to various agents of destruction, (2) types that could still be recognized even though they were severely degraded, (3) indeterminable pollen grains that were badly degraded, or (4) types that are overrepresented in the pollen rain because they are 


\begin{tabular}{|c|c|c|c|c|c|c|c|c|c|c|c|c|}
\hline \multicolumn{13}{|c|}{$\begin{array}{c}\text { TABLE } 45 \\
\text { RELATIVE POLLEN COUNTS }\end{array}$} \\
\hline \multirow[b]{2}{*}{ Taxa } & \multicolumn{12}{|c|}{ Sample Number } \\
\hline & 1 & 2 & 3 & 4 & 5 & 6 & 7 & 8 & 9 & 10 & 11 & 12 \\
\hline Asteraceae low spine & 88 & 78 & 14 & 12 & 36 & 83 & 75 & 68 & 7 & 5 & 59 & 14 \\
\hline Asteraceae high spine & 21 & 28 & - & - & 3 & 5 & - & 11 & 1 & - & 14 & - \\
\hline Artemisia & - & 3 & - & - & - & - & 5 & - & - & - & - & - \\
\hline Ephedra & 3 & - & - & 5 & - & 7 & 7 & 19 & 3 & 2 & 8 & - \\
\hline Poaceae & 36 & 36 & 6 & 13 & - & 15 & 9 & 6 & - & 3 & 8 & 2 \\
\hline Cheno-am & 20 & 16 & - & 21 & 24 & 69 & 62 & 49 & 28 & 7 & 67 & 8 \\
\hline Onagraceae & - & 2 & - & - & - & - & - & - & - & - & - & - \\
\hline Polygonum & - & - & - & - & - & 1 & - & - & $;-$ & - & - & - \\
\hline Pinus & - & - & - & - & 5 & 3 & 9 & 6 & - & - & 11 & 3 \\
\hline Salix & - & 1 & - & - & - & - & - & - & - & - & - & - \\
\hline Quercus & 3 & 4 & - & - & - & 4 & 1 & 3 & - & - & - & - \\
\hline Indeterminate & 36 & 32 & 12 & 25 & 12 & 24 & 36 & 45 & 27 & 2 & 33 & 4 \\
\hline Total Pollen & 207 & 200 & 32 & 76 & 80 & 211 & 204 & 207 & 66 & 19 & 200 & 31 \\
\hline Lycopodium & 278 & 340 & 248 & 310 & 264 & 147 & 394 & 291 & 317 & 49 & 290 & 75 \\
\hline CONC/ML & 841 & 665 & 146 & 277 & 242 & 1622 & 585 & 804 & 256 & 438 & 779 & 467 \\
\hline
\end{tabular}

produced in vast numbers. This type of limited pollen recovery phenomenon is common in many Southwestern and Texas soils and has been previously noted by palynologists, including Hall (1981), Holloway (1981), and Bryant and Schoenwetter (1987).

Even though 11 different pollen types were found in the 12 fossil pollen samples we examined, the average number of pollen taxa per fossil sample was only five. One of the 12 samples contained only two identifiable pollen types, and several other samples had only four pollen taxa represented. In the 12 fossil pollen samples used in this study, the five most common taxa in almost every sample were (1) Pinus, (2) Cheno-am (a combined term used to represent pollen taxa in both the family Chenopodiaceae and the genus Amaranthus), (3) genera of the Asteraceae family, (4) Ephedra, and (5) genera of Poaceae. Although these five pollen types represent plants common in the floral communities of the
Justiceburg region, they also represent distinctive pollen types that can be recognized easily even after becoming severely degraded.

Pollen concentration values for each of the 12 fossil pollen samples were generally low. Eleven of the samples $(92 \%)$ contained fossil pollen concentrations of less than 1,000 grains $/ \mathrm{ml}$ of sediment. At the low end of the scale, $50 \%$ of the 12 samples had pollen concentrations under 500 grains $/ \mathrm{ml}$ of sediment. For all 12 fossil samples, the average concentration value was only 593.5 grains $/ \mathrm{ml}$ of sediment.

The amount of indeterminable pollen grains averaged $20.8 \%$ in each of the 12 fossil samples. Percentages of indeterminable pollen in samples ranged from a low of $10.5 \%$ to a high of $40.9 \%$. Pollen grains listed in the indeterminable category included grains that were broken, corroded, or degraded in ways that made their identification impossible. If pollen grains were broken, corroded, or degraded, but still identifiable, they were counted and 
included in the taxa to which they belonged and were not counted in the indeterminable category.

The pollen wash samples were devoid of pollen except for one modern grass pollen grain contaminant in Sample No. 13 and three high-spine Asteraceae in Sample No. 15.

\section{DISCUSSION}

For more than three decades, palynologists have been searching Texas sediments for pollen clues about the lifeways and cultures of prehistoric Indians who once lived in the region. Unfortunately, except in a few successful cases, most of the attempts to recover fossil pollen from archeological sediments in Texas have ended in frustration. The primary causes of these frustrations have been the inability to recover fossil pollen. The pollen loss, as we now know, is caused by a wide variety of destructive agents, each of which causes some degree of pollen degradation.

Even after all of the palynology research advances made during this 50-year period, our knowledge of pollen wall morphology and chemical composition is still being debated. We still do not fully understand the elements that determine pollen destruction or preservation in different environmental settings. Our present study is a case in point. We suspect many factors (i.e., pH, Eh, bacteria, fungi, soil chemistry, mechanical agents, soil moisture, temperature, etc.) may have contributed to the destruction of fossil pollen in the samples we examined for this study.

In different geographical regions and in specific environmental settings, different agents of pollen destruction may play more- or less-important roles than others. Yet, in the sediments of the Justiceburg region, we suspect that soil chemistry and mechanical degradation are two factors causing the greatest amount of pollen loss.

As noted in the Results section, the fossil pollen recovered from these 12 sediment samples was disappointing. Very little pollen was present in any of the samples, and when present, only the most durable types remained preserved. More than anything else, these sediments reflect a fossil record containing a wide variety of fungal spores, a common characteristic of sediments where high levels of pollen destruction have occurred. Some of the many varieties of fungal spores we found seem to mimic pollen grains. We found three different fungal spore types that were echinate and looked very similar to the pollen of high- and low-spine Asteraceae types. Other fungal spores in these sediments looked very similar to the pollen from plants such as larch, poppy, grass, and juniper. Still other fungal spores are present in polyads and at first glance might be mistaken for the polyad pollen grains of various acacia species. Finally, there are other fungal spores that look like monoporate cattail pollen grains.

Another aspect of our study that confirmed the high level of fossil pollen destruction was the low number of pollen taxa we encountered in each of the samples. This type of phenomenon is common in regions where pollen degradation has been severe. In his study, Havinga (1984) reported that one of the characteristics of sediments where differential pollen preservation has occurred is that they no longer contain many of the pollen taxa that were initially deposited. As the more fragile pollen types become destroyed, only those few taxa with the most resistant pollen will remain preserved.

We believe one of the primary factors that caused pollen loss in the Justiceburg samples is the frequency of soil hydration-dehydration. Various forms of fossil pollen destruction and deterioration are linked to phenomena associated with the evaporative process of changing a liquid to a gas (Holloway 1989). Experiments conducted by Burstyn and Bartlett (1975) showed that several tons of pressure per unit area can be exerted on a curved surface of a hollow sphere at the instant when water is transformed, by evaporation, from a liquid to a gas. This pressure phenomenon would be especially critical for water-filled, tiny, spherical structures like pollen grains. As such, we believe that over a period of time these forces could cause major structural damage to the exine of pollen grains. Each time the soil hydration-dehydration process occurs, the pollen trapped in the soil is subjected to two potentially destructive processes: (1) the expansion-contraction process caused by being wetted and dried; and (2) the pressure phenomenon described by Burstyn and Bartlett (1975). The more frequently this cycle occurs in a soil, the greater the potential for fossil pollen to be destroyed or deteriorated, first by developing stress cracks in the exine, and next by further breakdown of the pollen wall by mechanical processes.

In an effort to test the destructive effects of the hydration-dehydration cycle on pollen grains, Holloway (1989) examined this phenomenon in a closely supervised laboratory setting. In his experi- 
ment, Holloway noticed that after as few as 25 cycles of wetting and drying, there were significant changes and noticeable amounts of pollen wall deterioration in many of the 14 pollen taxa he selected for testing. He found that $76 \%$ of the fresh pollen tested and $86 \%$ of the acetylated pollen tested showed exine degradation at the end of only 25 cycles of wetting and drying. Holloway's experiments also indicated how differential pollen preservation can occur as a result of the hydration-dehydration process. Of the 14 pollen taxa he tested, those showing the greatest degree of degradation and those that were nearly impossible to recognize by the end of the 25 cycles included Carya, Juniperus, Populus, Pseudotsuga, Salix, Typha, and Zea. Types of deterioration included categories Holloway called (1) broken grains, (2) corroded grains, and (3) degraded grains. Other pollen taxa included in the same experiment, such as Iva and Amaranthus, also showed some signs of degradation but were still recognizable even when badly degraded.

After looking at our current samples from the Justiceburg deposits and after conducting pollen concentration tests on each sample, we do not believe there is enough fossil pollen preserved in any of the samples to warrant the formation of valid pollen interpretations of either a cultural or paleoenvironmental nature. Even in those few samples where we were able to identify over 200 pollen grains, the pollen data recovered is of little value. The limited number of pollen taxa present in each sample, the record of only the most durable pollen taxa remaining preserved, and the high degree of pollen degradation, as indicated by the number and variety of fungal spores and the percentages of indeterminate pollen, suggest that significant portions of the pollen record have been lost. 


\section{REFERENCES CITED}

Barkley, F. A.

1934 The Statistical Theory of Pollen Analysis. Ecology 47:439-447.

Brooks, J., and G. Shaw

1968 Chemical Structure of the Exine of Pollen Walls and a New Function for Carotenoids in Nature. Nature 219:523-524.

Bryant, V. M., Jr.

1969 Late Full-glacial and Post-glacial Pollen Analysis of Texas Sediments. Ph.D. dissertation, Department of Botany, The University of Texas at Austin.

1978 Palynology: A Useful Method for Determining Paleoenvironments. Texas Journal of Science 45:1-45.

1988 Preservation of Biological Remains from Archaeological Sites. In Interdisciplinary Workshop on the Physical-Chemical-Biological Processes Affecting Archaeological Sites, edited by C. Mathewson, pp. 85-115. U.S. Army Corps of Engineers Waterways Experiment Station, Vicksburg.

Bryant, V. M., Jr., and R. G. Holloway

1983 The Role of Palynology in Archaeology. In Advances in Archaeological Method and Theory \#6, edited by M. Schiffer, pp. 191-224. Academic Press, New York.

Bryant, V. M., Jr., and J. G. Jones

1989 Pollen Analysis of Samples Collected from Archaeological Sites along the Route of the All American Pipeline. In Cultural Resources Report for the All American Pipeline Project, edited by All American Pipeline Company, pp. 316-365. New Mexico State University, Las Cruces.

Bryant, V. M., Jr., and J. Schoenwetter

1987 Pollen Records from Lubbock Lake. In Lubbock Lake Late Quaternary Studies on the Southern High Plains, edited by E. Johnson, pp. 36-40. Texas A\&M University Press, College Station.

Burstyn, H. P., and A. A. Bartlett

1975 Critical Point Drying: Application of the Physics of the PVT Surface to Electron Microscopy. American Journal of Physics 43:414-419.
Cummings, Linda Scott

1990 Phytoliths and Pollen Analyses: A Feasibility Study. Appendix I in Phase II Investigations at Prehistoric and Rock Art Sites, Justiceburg Reservoir, Garza and Kent Counties, Texas, by D. Boyd, J. Abbott, W. Bryant, C. Garvey, S. Tomka, and R. Fields, pp. 534-549. Reports of Investigations No. 71, Vol. II. Prewitt and Associates, Inc., Austin.

Dimbleby, G. W.

1957 Pollen Analysis of Terrestrial Soils. New Phytologist 56:12-28.

Duhoux, E.

1982 Mechanism of Exine Rupture in Hydrated Taxoid Type of Pollen.' Grana 21:1-7.

Elsik, W. K.

1966 Biologic Degradation of Fossil Pollen Grains and Spores. Micropaleontology 12:515-518.

Erdtman, G.

1960 The Acetolysis Method: A Revised Description. Svensky Botanisk Tidskrift 54:561-564.

Goldstein, S.

1960 Destruction of Pollen by Phycomycetes. Ecology 41:543-545.

Hall, S. A.

1981 Deteriorated Pollen Grains and the Interpretation of Quaternary Pollen Diagrams. Review of Paleobotany and Palynology 32:193-206.

1985 Quaternary Pollen Analysis and Vegetational History of the Southwest. In Pollen Records of Late-Quaternary North American Sediments, edited by V. M. Bryant, Jr., and R. G. Holloway, pp. 95-125. American Association of Stratigraphic Palynologists Foundation, Dallas.

Havinga, A. J.

1964 Investigations into the Differential Corrosion Susceptibility of Pollen and Spores. Pollen et Spores 6:621-635.

1984 A 20-Year Experimental Investigation into the Differential Corrosion Susceptibility of Pollen and Spores in Various Soil Types. Pollen et Spores 26:541-558. 
Holloway, R. G.

1981 Preservation and Experimental Diagenesis of the Pollen Exine. Ph.D. dissertation, Department of Botany, Texas A\&M University, College Station.

1989 Experimental Mechanical Pollen Degradation and its Application to Quaternary Age Deposits. Texas Journal of Science 41:131-145.

Jones, J.

1990 Assessment of Pollen Preservation and Macrobotanical Analysis. Appendix $\mathrm{H}$ in Phase II Investigations at Prehistoric and Rock Art Sites, Justiceburg Reservoir, Garza and Kent Counties, Texas, by D. Boyd, J. Abbott, W. Bryan, C. Garvey, S. Tomka, and R. Fields, pp. 522-525. Reports of Investigations No. 71, Vol. II. Prewitt and Associates, Inc., Austin.

Martin, Paul S.

1963 The Last 10,000 Years: A Fossil Pollen Record of the American Southwest. University of Arizona Press, Tucson.

O'Rourke, M. K.

1990 Pollen Reentrainment: Contributions to the Pollen
Rain in an Arid Environment. Grana 29:147152.

Rowley, J. R.

1990 The Fundamental Structure of the Pollen Exine. Plant Systematic Evolution [suppl. 5]:13-19.

Rowley, J. R., and B. Prijanto

1977 Selective Destruction of the Exine of Pollen Grains. Geophytology 7:1-23.

Rowley, J. R., J. S. Rowley, and J. Skvarla

1990 Corroded Exines from Havinga's Leaf Mold Experiment. Palynology 14:53-80.

Shaw, G.

1971 The Chemistry of Sporopollenin. In Sporopollenin, edited by J. Brooks, P. Grant, M. Muir, P. van Gijzel, and G. Shaw, pp. 305-350. Academic Press, New York.

Tschudy, R. H.

1969 Relationship of Palynomorphs to Sedimentation. In Aspects of Palynology, edited by R. Tschudy and R. Scott, pp. 79-96. Wiley \& Sons, New York. 
APPENDIX F: Petrographic Analysis of Nonlocal Plainwares

David G. Robinson

Texas Archeological Research Laboratory

The University of Texas at Austin 


\section{INTRODUCTION}

In April 1991, a petrographic analysis was performed on 12 ceramic potsherds recovered from sites in the proposed Justiceburg Reservoir and from the Texas South Plains region. The study sherds are all identified as nonlocal pottery native to regions outside the Texas South Plains; the specimens are plainwares, i.e., pottery without ornamentation in the form of painting or surface modification. The collection was drawn from three sites, 41KT33, 41SW23, and 41HL66. The petrographic analysis was conducted to aid in answering three questions about the ceramics: (1) Does the petrography of the ceramics confirm or contradict their typological classification? (2) Do the petrographic data suggest anything about the actual origin of the Texas South Plains brownwares? (3) Do the petrographic data suggest or support a chronology of the cerramics?

Among the 12 sherds, three types were identified by various typologists: Jornada Brown, Middle Pecos Micaceous Brown, and Roswell Brown. All these types have regions of distribution to the west in New Mexico, in the Pecos River drainage, or farther southwest in the Sacramento Mountains and the Southern Basin and Range. The mineral constituents should reflect the published descriptions of the types. Furthermore, if the sherds are indeed nonlocal, their mineralogies should reflect the environment of these western regions rather than the Texas South Plains. Determination of the petrography and mineralogy is by thin section analysis, pioneered in archeology by Shepard $(1942,1954)$. Comparisons of the determined mineralogy with ceramics from New Mexico were made by reference to petrographic studies of New Mexican ceramics (Rugge 1985; Garrett 1988).

\section{METHODOLOGY}

Thin sections were prepared for the study at the Bureau of Economic Geology, The University of Texas at Austin, Balcones Research Center. Cross sections of the sherds were cut with a lapidary saw and impregnated with a setting resin. This measure strengthened the relatively soft ceramic material against crumbling and plucking-out during the grinding process. The prepared sections were then fastened to microscope slides with more setting resin and ground to a standard light-transmitting thinness of 30 microns.

Identification and point-counting were conduct- ed on a Zeiss stereo petrographic microscope with a rotating and mechanical stage at the Bureau of Economic Geology. After the various minerals, rocks, and other materials in the collection were identified with confidence, a point-count was made of each thin section. The slide was traversed with the mechanical stage at consistent 1-mm intervals, and every species or body falling directly under the cross hairs was counted; traverses continued until a count of 200 was achieved. The procedure follows the method of Chayes (1949). The clay body, all solid inclusions and pore spaces, or voids, were included in the counts as they all pattern the ceramics. In all mechanically consistent processes such as pointcounting, rare and unrepresentative (but potentially signal) phenomena may fail to enter the sample. When rare minerals were observed but did not enter the point-count, they were entered on the tabulation chart as "trace." In this way, their presence and contribution were noted without violating the consistency of the point-count.

As a result of the procedure, information on 20 attributes was recorded. These attributes are proportions of matrix, temper, and voids; maximum grain size; average particle shape; particle size distribution; 13 minerals; and unidentified rock categories which consist of multiple igneous minerals. The outcome of the point-count is a quantified assessment of the attributes, a body of data amenable to comparisons with other similarly gained data, and manipulation by a variety of statistical measures.

\section{RESULTS}

The finished point-counts are tabulated on Tables 46 and 47 in order to observe the patterning in the overall assemblage. The analysis in general confirmed the typological attributions of the sherds. Furthermore, the identified minerals are predominantly volcanic. Particle and crystal sizes as well as the specific mineral types suggest origins in granites. The prevailing subangular particle shape suggests manufacture where granitic rocks were available for crushing as temper. Rounded particles or other features suggestive of stream-transported constituents of the ceramics are notably rare.

Specimen 1: The sherd, an example of Group 1 (see below), has a high proportion of particles versus matrix but little variety: plagioclase, biotite, a nonferrous opaque, and Rock A. Rock A is 


\begin{tabular}{|c|c|c|c|c|c|c|c|c|}
\hline \multirow[b]{3}{*}{ Specimen No. } & \multicolumn{7}{|c|}{$\begin{array}{c}\text { TABLE } 46 \\
\text { CERAMIC ATTRIBUTES BASED ON POINT-COUNT DATA }\end{array}$} & \multirow{3}{*}{$\begin{array}{l}\text { Particle } \\
\text { Size } \\
\text { Distribution }\end{array}$} \\
\hline & \multirow[b]{2}{*}{ Site No. } & \multirow[b]{2}{*}{ Ceramic Type } & \multicolumn{3}{|c|}{$\begin{array}{l}\text { Estimated Volume \% } \\
\text { from Point Count }\end{array}$} & \multirow{2}{*}{$\begin{array}{l}\text { Maximum } \\
\text { Grain } \\
\text { Size (mm) }\end{array}$} & \multirow{2}{*}{$\begin{array}{l}\text { Average } \\
\text { Particle } \\
\text { Shape/ } \\
\text { Angularity }\end{array}$} & \\
\hline & & & Matrix & Temper & Voids & & & \\
\hline 1 & $41 \mathrm{KT} 33$ & $\begin{array}{l}\text { Jornada Brown or } \\
\text { Middle Pecos Micaceous Brown }\end{array}$ & 34.5 & 65.0 & 0.5 & 2.0 & subangular & seriate \\
\hline 2 & $41 \mathrm{KT} 33$ & $\begin{array}{l}\text { Jomada Brown or } \\
\text { Middle Pecos Micaceous Brown }\end{array}$ & 36.5 & 61.0 & 2.5 & 2.0 & subangular & seriate \\
\hline 3 & $41 \mathrm{KT} 33$ & $\begin{array}{l}\text { Jomada Brown or } \\
\text { Middle Pecos Micaceous Brown }\end{array}$ & 38.0 & 61.5 & 0.5 & 2.0 & subangular & seriate \\
\hline 4 & $41 \mathrm{SW} 23$ & Jomada Brown & 46.0 & 48.5 & 4.5 & 1.8 & subangular & bimodal \\
\hline 5 & $41 \mathrm{SW} 23$ & Jornada Brown & 64.5 & 31.0 & 4.5 & 1.0 & subrounded & unimodal \\
\hline 6 & $41 \mathrm{SW} 23$ & Jornada Brown & 52.5 & 47.0 & 0.5 & 1.5 & subangular & seriate \\
\hline 7 & $41 \mathrm{HL} 66$ & Roswell Brown & 46.5 & 46.0 & 7.5 & 1.5 & subangular & seriate \\
\hline 8 & 41HL66 & Middle Pecos Micaceous Brown & 37.5 & 60.0 & 2.5 & 2.0 & subangular & seriate \\
\hline 9 & 41HL66 & Jomada Brown & 52.0 & 43.0 & 5.0 & 2.5 & subrounded & seriate \\
\hline 10 & 41HL66 & Jornada Brown & 28.0 & 66.5 & 5.5 & 2.0 & subangular & seriate \\
\hline 11 & 41HL66 & Roswell Brown & 44.0 & 50.0 & 6.0 & 2.0 & subrounded & bimodal \\
\hline 12 & 41HL66 & Middle Pecos Micaceous Brown & 28.0 & 70.0 & 2.0 & 2.0 & subangular & bimodal \\
\hline
\end{tabular}




\begin{tabular}{|c|c|c|c|c|c|c|c|c|c|c|c|c|c|c|c|}
\hline \multirow[b]{3}{*}{$\begin{array}{l}\text { Specimen } \\
\text { No. }\end{array}$} & \multirow[b]{3}{*}{\begin{tabular}{|l} 
Plutonic \\
Quartz
\end{tabular}} & \multirow[b]{3}{*}{$\begin{array}{l}\text { Composite } \\
\text { Quartz }\end{array}$} & \multirow[b]{3}{*}{$\begin{array}{l}\text { Plagio- } \\
\text { clase }\end{array}$} & \multicolumn{8}{|c|}{ TABLE 47} & & & & \\
\hline & & & & Alk & ali Felds & & & & \multirow[b]{2}{*}{$\begin{array}{l}\text { Horn- } \\
\text { blende }\end{array}$} & \multirow[b]{2}{*}{\begin{tabular}{|l|}
$\begin{array}{l}\text { Ortho- } \\
\text { pyroxene }\end{array}$ \\
\end{tabular}} & \multirow[b]{2}{*}{$\begin{array}{l}\text { Clino- } \\
\text { pyroxene }\end{array}$} & \multirow[b]{2}{*}{ Opaques } & \multirow[b]{2}{*}{$\begin{array}{l}\text { Specular } \\
\text { Hematite } \\
\end{array}$} & \multirow[b]{2}{*}{\begin{tabular}{|l} 
Iron \\
Stain \\
\end{tabular}} & \multirow[b]{2}{*}{$\begin{array}{l}\text { UID } \\
\text { Rocks }\end{array}$} \\
\hline & & & & Sanidine & $\begin{array}{l}\text { Ortho- } \\
\text { clase }\end{array}$ & $\begin{array}{l}\text { Micro- } \\
\text { perthite }\end{array}$ & Biotite & Chlorite & & & & & & & \\
\hline 1 & - & - & 15.5 & - & - & - & 20.5 & trace & - & - & - & 7.0 & - & - & $22.0 \mathrm{~A}$ \\
\hline 2 & 24.0 & - & - & trace & 1.0 & - & 20.0 & trace & - & - & trace & - & 4.5 & - & $11.5 \mathrm{~A}$ \\
\hline 3 & 8.0 & - & 9.5 & - & - & - & 15.0 & trace & - & - & - & 12.0 & - & - & $17.0 \mathrm{~A}$ \\
\hline 4 & 4.5 & - & 13.0 & 1.5 & - & - & 1.5 & - & - & - & 0.5 & - & 1.5 & 19.5 & $8.0 \mathrm{~B}$ \\
\hline 5 & 10.0 & - & 17.0 & - & - & - & 2.0 & - & - & trace & - & - & 2.0 & - & - \\
\hline 6 & 31.5 & 0.5 & 8.5 & - & 1.0 & - & 1.0 & - & 0.5 & - & - & - & 2.5 & 1.5 & - \\
\hline 7 & 16.0 & 9.5 & trace & 17.5 & 3.0 & - & 0.5 & - & trace & - & - & - & trace & - & - \\
\hline 8 & 12.5 & 2.5 & 9.5 & 18.0 & - & - & 13.0 & - & - & - & - & - & 5.0 & - & - \\
\hline 9 & 10.5 & - & - & 14.5 & 10.5 & - & - & - & - & - & - & - & 0.5 & - & $7.0 \mathrm{C}$ \\
\hline 10 & 12.0 & - & 0.5 & 7.0 & 6.5 & - & 15.0 & - & - & - & 5.0 & - & 5.0 & - & $16.0 \mathrm{~A}$ \\
\hline 11 & 22.0 & - & - & 9.0 & 6.0 & 1.0 & 1.0 & - & - & - & 0.5 & 2.0 & - & - & $9.0 \mathrm{D}$ \\
\hline 12 & 24.5 & 0.5 & 0.5 & 4.0 & 3.5 & - & 12.5 & trace & - & - & 9.5 & - & 5.5 & - & $6.5 \mathrm{E}$ \\
\hline
\end{tabular}


plagioclase and possibly other feldspars. The rock is commonly clouded with opaque masses.

Specimen 2: Much plutonic quartz, biotite, some specular hematite, minor alkali feldspars (sanidine, orthoclase), and Rock A characterize the section. Rock $\mathrm{A}$ includes plagioclase and biotite and is the same unidentified rock as in Specimen 1.

Specimen 3: The section contains plutonic quartz, biotite, plagioclase, nonferrous opaque, and Rock A. Rock A is the same unidentified rock as in Specimen 1.

Specimen 4: An exemplar of Group 2 (see below), the sherd has a large amount of plagioclase, and the matrix is heavily iron stained. Small amounts of plutonic quartz, sanidine, biotite, pyroxene, specular hematite, and Rock B are also found. Rock B is mostly plagioclase with some quartz and biotite.

Specimen 5: Much plagioclase and quartz, little biotite, pyroxene, and specular hematite. The section varies from Specimen 4 only in lacking any unidentifiable rock type.

Specimen 6: Also rich in plagioclase, this sherd has abundant plutonic quartz and a minor fraction of composite quartz. Minor constituents are orthoclase, biotite, hornblende, specular hematite, and iron staining.

Specimen 7: This sherd has abundant alkali feldspar-sanidine and orthoclase-and only a trace of plagioclase. Plentiful plutonic and composite quartz and traces of biotite, homblende, and specular hematite complete the constituent inventory.

Specimen 8: Large amounts of biotite, sanidine, plutonic quartz, and plagioclase characterize the section. Minor composite quartz and specular hematite also were observed.

Specimen 9: Notably high in sanidine and orthoclase, the section also has plutonic quartz and traces of specular hematite. Unidentified Rock C, comprised of quartz, sanidine, and orthoclase, also was observed.

Specimen 10: Biotite, quartz, and unidentified rock are the principal constituents, with some sanidine, orthoclase, and specular hematite. A trace of plagioclase, some pyroxene, and Rock A complete the inventory. Rock A is comprised of quartz, plagioclase, and possibly some orthoclase.

Specimen 11: The section is dominated by plutonic quartz, sanidine, orthoclase, and Rock D. Minor amounts of biotite, microperthite, pyroxene, and an opaque mineral complete the inventory. Rock
D has quartz, sanidine, and possibly microperthite and plagioclase.

Specimen 12: The sherd is characterized by abundant plutonic quartz, biotite, pyroxene, and a mixture of small amounts of plagioclase and alkali feldspars. There is also specular hematite, a trace of composite quartz, and Rock E. Rock E contains quartz, clinopyroxene, plagioclase, biotite, and sanidine.

Two general groups are observed within the collection. The first has a low proportion of clay matrix to solid temper or other particles, a large proportion of biotite, significant amounts of plagioclase feldspars, and variable amounts of plutonic quartz. Sherds included in this group are Specimens $1,2,3,8,10$, and 12 . With one exception, this group corresponds to the identified Middle Pecos Micaceous Brown sherds from 41KT33 and 41HL66. The exception is Specimen 10, a Jornada Brown sherd from 41HL66. The second group has a matrix to temper ratio averaging 1:1, abundant alkali or plagioclase feldspars, abundant plutonic quartz, minor biotite, minor hornblende or pyroxenes, and iron in the form of specular hematite or iron staining of the matrix. This group includes the Jornada Brown sherds from 41SW23 and 41HL66 (except Specimen 10) and the Roswell Brown sherds from 41HL66. The latter specimens (Nos. 7 and 11) have slight variations from the larger group but vary more from each other than from it.

The typology and volcanic character of the collection strongly suggest nonlocal sources for all the sherds. In the Texas South Plains region of the three study sites, the surface geology apart from Quaternary deposits is comprised of sedimentary rocks and deposits of the Permian Quartermaster Formation and Triassic Dockum Group. Minor fractions of streamrolled volcanic sands are found, however, in modern stream deposits throughout the Panhandle-Plains area. These small-sized, rounded fractions cannot account for the subangular and angular, coarse sandsized volcanics in the study collection. The nearest region where fresh igneous rocks are abundant is the Middle Pecos River Valley of Eastern New Mexico. The river receives sediments from numerous mountain ranges which expose volcanic and metamorphic rocks. Pleistocene terraces in the Middle Pecos valley contain granite and metamorphic gravels in abundance (Jelinek 1967). The Pecos may be considered the nearest possible source for the ceramics, but specific source areas cannot be specified without accurate 
petrographic characterizations of large areas of New Mexico. The Wichita Mountains of southwestern Oklahoma also expose igneous rocks and must remain an outside possibility as a source area (Christopher Henry, Petroleum Geologist, Bureau of Economic Geology, The University of Texas at Austin, personal communication 1991). Three brownware sherds analyzed by Garrett (1988) from eastern New Mexico were heavily volcanic but dissimilar to the study sherds. They varied in having significant amounts of monzonite, syenite, homblende, and few free crystals of quartz or feldspars. Rugge's (1985) study of plainwares in the Southern Basin and Range southwest of the Sacramento Mountains showed that his ceramics likewise reflected the volcanic nature of the region, but they are also dissimilar in their specific minerals from the Justiceburg study sherds. The contrast is seen in a virtual lack of biotite in the southern New Mexico thin sections and low proportions of plagioclase and other feldspars with the exception of large amounts of microperthite, rare in the Justiceburg thin sections. The New Mexico sherds also have minerals such as epidote, allanite, sphene, and muscovite, also lacking in the Texas South Plains collection.

The petrographic analysis does not provide any evidence useful for independent chronological assessment. Although two groups of sherds were noted in the study sample, it is not known whether they represent variability within one ceramic type, two distinct variations from different source areas in contemporaneous use, or two chronologically distinct varieties. Lacking a substantial comparative sample of petrographic point-count data, no chronological inferences can be made at this time.

\section{REFERENCES CITED}

Chayes, $\mathrm{F}$.

1949 A Simple Point-Counter for Thin Section Analysis. American Mineralogist 34:1-11.

Garrett, Elizabeth M.

1988 Petrographic Analysis of Prehistoric Ceramics from the Melrose Range Project, ACOE, 1987. Appendix $\mathrm{H}$ in Class II Survey and Testing of Cultural Resources at the Melrose Air Force Range, Curry and Roosevelt Counties, New Mexico. Mariah Associates, Inc., Albuquerque.

Jelinek, Arthur J.

1967 A Prehistoric Sequence in the Middle Pecos Valley, New Mexico. Anthropological Papers 31. Museum of Anthropology, University of Michigan, Ann Arbor.
Rugge, Dale R.

1985 Petrographic Analysis of Ceramic Technology. In Archeological Testing at the Fairchild Site (LA45732), Otero County, New Mexico, edited by Roger Anyon. Office of Contract Archeology, University of New Mexico, Albuquerque.

Shepard, A. O.

1942 Rio Grande Glaze Paint Ware: A Study Illustrating the Place of Ceramic Technological Analysis in Archaeological Research. Contributions to American Anthropology and History 7(39):entire volume. Camegie Institution of Washington, Washington, D.C.

1954 Ceramics for the Archaeologist. Publication 609. Carnegie Institution of Washington, Washington, D.C. 


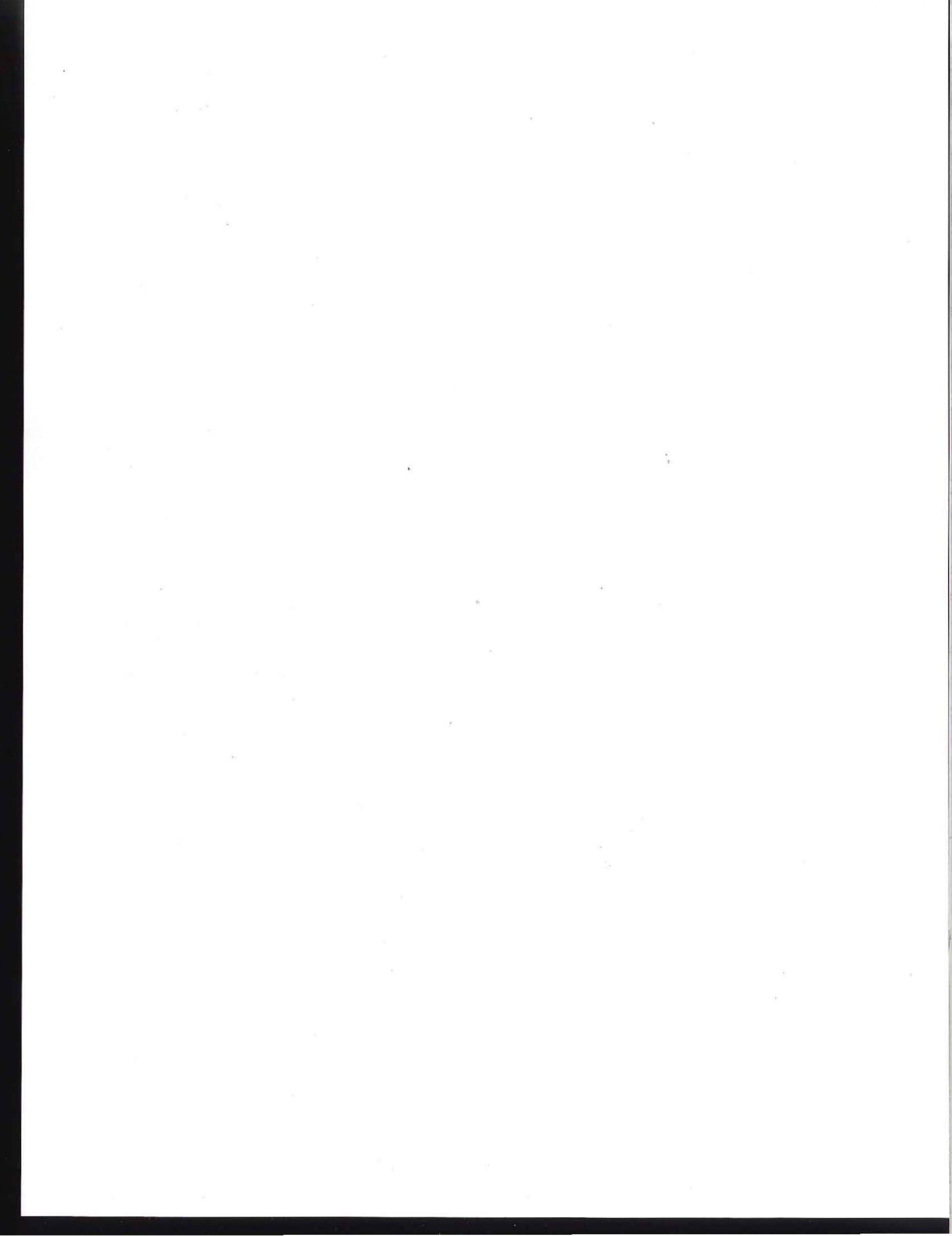


APPENDIX G: Absolute Chronology Results

\author{
C. Britt Bousman
}




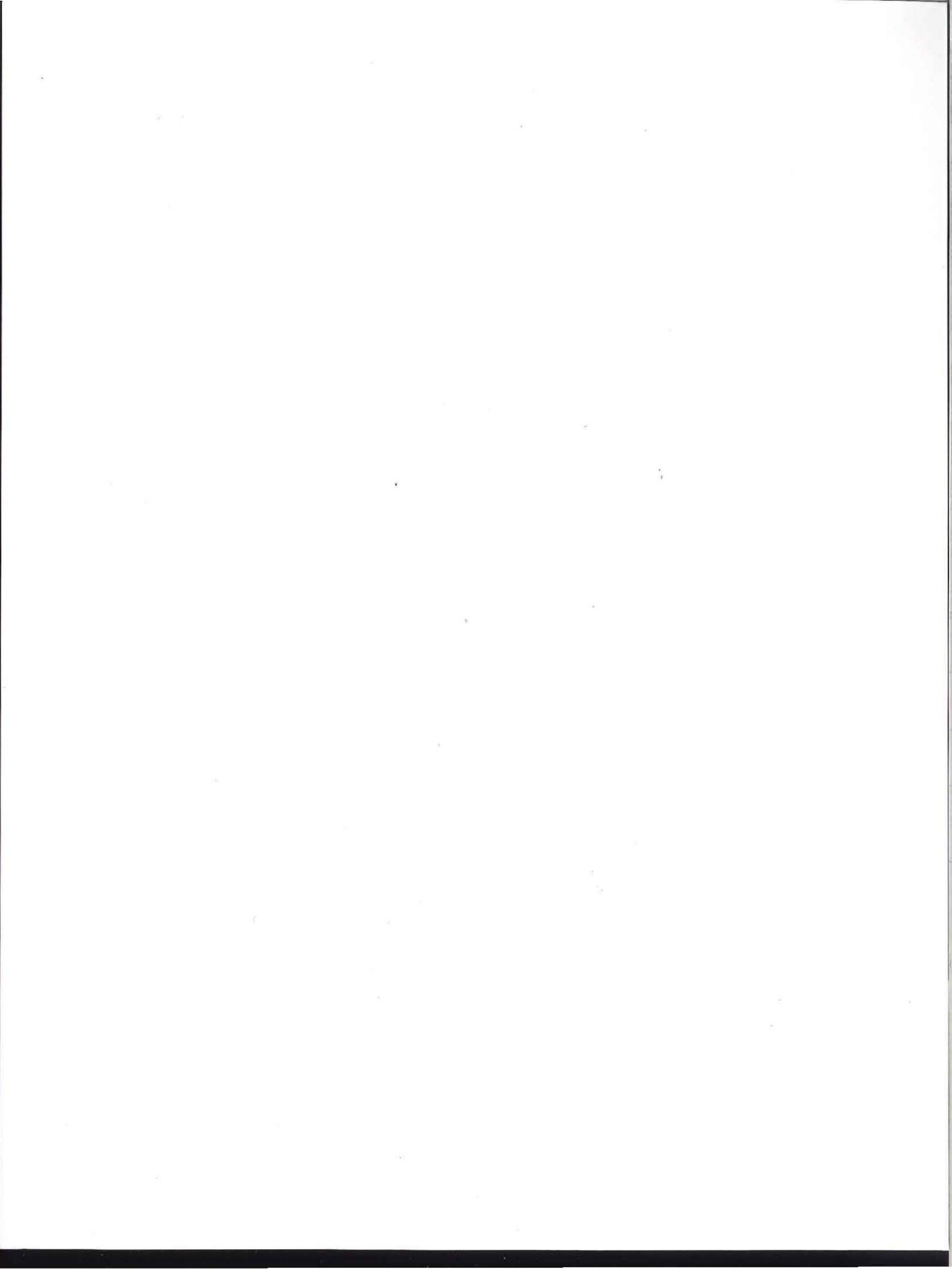


Sixteen new radiocarbon determinations from archeological and geological sites in Justiceburg Reservoir are presented here in Table 48. Eleven assays on bulk carbon from sediment samples, four on charcoal, and one on the gelatin fraction of bone were provided by Geochron Laboratories in Cambridge, Massachusetts. One of the charcoal samples utilized the AMS (accelerator mass spectrometer) technique, and these measurements were conducted by the Institute of Nuclear Research, D.S.I.R., in New Zealand. The remaining samples are conventional beta-count measurements. All dates younger than 8100 B.P. were tree-ring calibrated using the 20 -year atmospheric record in the PC computer calibration program CALIB Rev 2.0 (Stuiver and Reimer 1986) and corrected for $\delta^{13} \mathrm{C}$ fractionation effects as required by the tree-ring calibration procedure. A single radiocarbon determination (GX-16509) was older than 8100 B.P., and the date and its associated single standard deviation range were calibrated using the formula from Stuiver et al. (1986: 971):

$$
\text { Calibrated age }=\mathbf{1 . 0 5}(\text { corrected age })+450
$$

In Table 48, the one standard deviation range brackets the single, or in one case multiple, intercepts of the tree-ring calibrations within parentheses. A single determination (GX-16510) falls within the nonlinear portion of the calibration curve, and an accurate calibration is not possible. The calibrated ages are as much as 905 years older $(10.4 \%$ of GX$16509)$ and as much as 98 years younger $(11.9 \%$ of $\mathrm{GX}-16622)$ than their matching ${ }^{14} \mathrm{C}$ ages. When constructing detailed chronologies, especially in the late Holocene, calibration potentially can provide much improved results. For the last 200 years or so during the Protohistoric period, calibration unfortunately does not produce reliable age estimates and other absolute dating procedures must be sought. 


\begin{tabular}{|c|c|c|c|c|c|}
\hline \multicolumn{6}{|c|}{$\begin{array}{c}\text { TABLE } 48 \\
\text { RADIOCARBON ASSAYS }\end{array}$} \\
\hline Lab Number & Provenience & Material & $\begin{array}{l}\text { Corrected Age } \\
\text { Years B.P. }\end{array}$ & $\begin{array}{l}\text { Tree-ring Calibrated } \\
\text { Age B.P. }\end{array}$ & $\delta^{13} \mathrm{C}(\%)$ \\
\hline$G X-16508$ & $\begin{array}{l}\text { BHT 1991-1, Zone } 2 \\
32-65 \mathrm{~cm} \text { bs }\end{array}$ & bulk sediment & $3370 \pm 205$ & 3879 (3630) 3389 & -17.9 \\
\hline GX-16509 & $\begin{array}{l}\text { BHT } 1991-2 \text {, Zone } 4 \\
90-120 \mathrm{~cm} \text { bs }\end{array}$ & bulk sediment & $8690 \pm 305$ & 9900 (9595) 9290 & -18.1 \\
\hline GX-16510 & $\begin{array}{l}\text { BHT 1991-3 } \\
\text { Profile } 1 \text {, Zone } 3 \\
60-80 \mathrm{~cm} \text { bs }\end{array}$ & bulk sediment & $65 \pm 135$ & $280(0) 0$ & -19.9 \\
\hline GX-16511 & $\begin{array}{l}\text { BHT 1991-3 } \\
\text { Profile 2, Zone } 3 \\
148-158 \mathrm{~cm} \text { bs }\end{array}$ & bulk sediment & $1160 \pm 145$ & 1270 (1064) 940 & -17.3 \\
\hline GX-16512 & $\begin{array}{l}41 \mathrm{GR} 383 \text {, EU } 52 \\
35-45 \mathrm{~cm} \text { bs }\end{array}$ & bulk sediment & $450 \pm 125$ & $550(510) 324$ & -17.1 \\
\hline $\begin{array}{l}\text { GX-16513/ } \\
16514\end{array}$ & $\begin{array}{l}41 \mathrm{KT} 33 \text {, EU } 5 \\
\text { Feature } 12 \\
17-27 \mathrm{~cm} \text { bs }\end{array}$ & charcoal & $1005 \pm 110$ & 1052 (933) 790 & -26.0 \\
\hline GX-16515 & $\begin{array}{l}\text { 41GR } 383, \text { EU } 48 \\
35-45 \mathrm{~cm} \text { bs }\end{array}$ & bulk sediment & $1865 \pm 140$ & 1959 (1824) 1619 & -15.7 \\
\hline GX-16619 & $\begin{array}{l}\text { PL } 1 \text {, Zone } 8 \\
82-86 \mathrm{~cm} \text { bs }\end{array}$ & bulk sediment & $1020 \pm 140$ & 1060 (938) 780 & -17.5 \\
\hline GX-16620 & $\begin{array}{l}\text { PL } 1, \text { Zone } 11 \\
155-170 \mathrm{~cm} \text { bs }\end{array}$ & bulk sediment & $1765 \pm 145$ & $1870(1703) 1530$ & -20.9 \\
\hline GX-16621 & $\begin{array}{l}\text { PL 2, Zone } 3 \\
54-61 \mathrm{~cm} \mathrm{bs}\end{array}$ & charcoal & $620 \pm 115$ & $\begin{array}{l}680(644,591,571) \\
530\end{array}$ & -23.1 \\
\hline GX-16622 & $\begin{array}{l}\text { PL 2, Zone } 3 \\
74-80 \mathrm{~cm} \text { bs }\end{array}$ & charcoal & $825 \pm 75$ & 791 (727) 683 & -23.1 \\
\hline GX-16623 & $\begin{array}{l}\text { PL 3, Zone } 4 \\
164-185 \mathrm{~cm} \text { bs }\end{array}$ & bulk sediment & $1330 \pm 130$ & 1350 (1281) 1098 & -17.2 \\
\hline GX-16624-G & Near pipeline, Zone 4 & bison mandible & $810 \pm 75$ & $(720)$ & -9.5 \\
\hline$G X-16625$ & $\begin{array}{l}\text { BHT 1991-2b } \\
\text { Zone } 2 \\
35-50 \mathrm{~cm}\end{array}$ & bulk sediment & $3320 \pm 165$ & (1281) & -15.8 \\
\hline GX-16626 & $\begin{array}{l}\text { 41GR383, EU } 15 \\
\text { Feature } 13 \\
\text { Below burned rocks } \\
32-38 \mathrm{~cm} \text { bs }\end{array}$ & bulk sediment & $1215 \pm 140$ & (1163) & -15.0 \\
\hline $\begin{array}{l}\text { GX-16627- } \\
\text { AMS }\end{array}$ & $\begin{array}{l}\text { 41GR } 383, \text { EU } 12 \\
\text { Feature } 13 \\
\text { ca. } 25 \mathrm{~cm} \text { bs }\end{array}$ & charcoal & $1390 \pm 65$ & 1344 (1299) 1279 & -25.5 \\
\hline
\end{tabular}


Appendix G: Absolute Chronology Results

\section{REFERENCES CITED}

Stuiver, Minze, Bernd Kramer, Bernd Becker, and C. W. Ferguson

1989 Radiocarbon Age Calibration Back to 13,300 years B.P. and the ${ }^{14} \mathrm{C}$ Age Matching of the German Oak and U.S. Bristlecone Pine Chronologies. Radio- carbon 28(2B):969-979.

Stuiver, Minze, and P. J. Reimer

1986 A Computer Program for Radiocarbon Age Calibration. Radiocarbon 28(2B):1022-1030. 


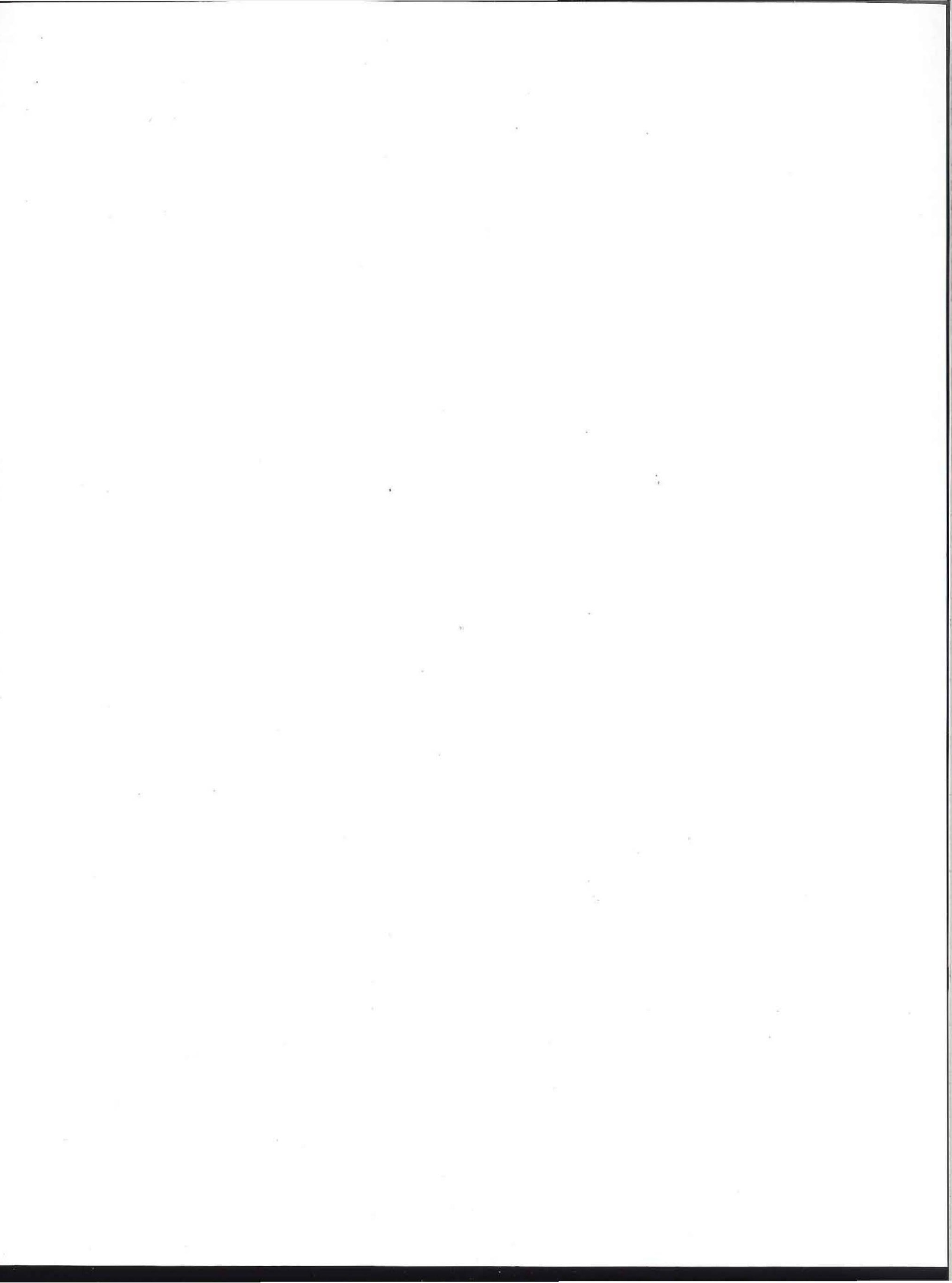


APPENDIX H: Geomorphic Profile Descriptions

C. Britt Bousman 

The sediments are described according to procedures presented by Soil Survey Staff (1975:459-477) and Birkeland (1984). Soil horizons are classified by combining the procedures of Soil Survey Staff (1975) and Folk (1980). Soil scientists and geologists have developed their own separate texture classifications. The soil classifications focus on variations of sand, silt, and clay fractions, while the geological classification lumps silts and clays together as muds and places greater emphasis on gravels. These differences between the two systems occur because of the interest soil scientists have with pedogenic processes and the focus of geologists on sedimentary processes, especially fluvial processes. In terms of Quaternary stratigraphy, both processes must be a serious concern. By calculating the percentages of sand, silt, and clay independent of gravels and then calculating the percentage of gravels in relation to the remaining finer textures (see Appendix I), this allows each sample to be classified by both the soil (Soil Survey Staff 1975:459-477) and geological (Folk 1980:26) classifications.

Color (Munsell Soil Color Chart) and consistency (loose, friable, or firm) were recorded moist. Final soil horizon classifications were made with quantified texture analyses of samples when available (see Appendix I); otherwise, field sediment texture definitions were used. Field definitions of texture consist of the following: (1) sand (loose, single grained, moist cast will crumble); (2) sandy loam (mostly sand with silt and clay, individual sand grains visible, moist cast bears careful handling); (3) loam (even mixture of sand, silt, and clay; gritty but smooth; slightly plastic; moist cast handles freely); (4) silt loam (fine sands; little clay; mostly silt; dry clods break easily; soft, smooth, and floury if dry; moist casts do not break; will not ribbon); (5) clay loam (hard dry clods, moist ribbon breaks easily, moist cast bears heavy handling, kneaded heavy compact mass that will not crumble); and (6) clay (very hard clods, very plastic and sticky when wet, flexible ribbon). The structure of the sediments is described by grade, size, and type. The grade is shown as weak, moderate, or strong; the size is shown as fine $(<2 \mathrm{~cm})$, medium $(2-5 \mathrm{~cm})$, or coarse $(>5 \mathrm{~cm})$; and the type is identified as blocky (angular or subangular), platy, or crumb. Mottles are described by color, abundance, contrast, and size. Abundance is shown as few $(<2 \%)$, common (2$20 \%$ ), and many $(>20 \%)$, while contrast is described as faint, distinct, or prominent. Size ranges are given as fine $(<0.5 \mathrm{~cm})$, medium $(0.5-1.5 \mathrm{~cm})$, and coarse $(>1.5 \mathrm{~cm})$. The lower boundary of each zone is described in terms of distinctiveness, i.e., very abrupt $(<0.1 \mathrm{~cm})$, abrupt $(0.1-2.5 \mathrm{~cm})$, clear $(2.5-6.0 \mathrm{~cm})$, gradual $(6.0-12.5 \mathrm{~cm})$, and diffuse $(>12.5)$, and topography, i.e., smooth, wavy, irregular, broken, sloping, or horizontal. 
Zone Depth $(\mathrm{cm}) \quad$ Description

\section{GR383}

Unit 12, North Wall

$1 \quad 0-2$

Dark yellowish brown (10YR 4/4) friable sandy loam with weak fine platy structure, common rootlets, abrupt smooth lower boundary, Ap horizon.

$2 \quad 2-9$

Strong brown to dark yellowish brown (7.5YR 4/6 to 10YR 4/6) sandy loam, common rootlets and insect burrows, rare decomposed sandstone pebbles, abrupt wavy to irregular lower boundary, $\mathrm{C}$ horizon.

$39-30$

Dark yellowish brown (10YR 4/4) sandy loam to silty gravelly loamy sand, few rootlets, rare roots, burned sandstone rocks at $22 \mathrm{~cm}$ (Feature 13), rare decomposed sandstone pebbles, clear wavy lower boundary, $2 \mathrm{Ab}$ horizon.

$4 \quad 30-39$

Yellowish brown (10YR 5/4) slightly gravelly loamy, sand, few rootlets, few decomposing sandstone pebbles, common rodent burrows, represents bioturbated zone of decomposing sandstone and overlying sediment, clear wavy lower boundary, $\mathrm{Cr}$ horizon.

$539+$

Sandstone bedrock, $\mathrm{R}$ horizon.

Unit 22, East Wall

$1 \quad 0-4$

$2 \quad 4-10$

$3 \quad 10-37$

4

Dark brown (7.5YR 3/4) friable sandy loam, common roots, abrupt smooth lower boundary, Ap horizon.

Dark brown (7.5YR 3/4) slightly firm sandy loam, common rootlets, abrupt smooth lower boundary, A1 horizon.

Brown (10YR 4/3) gravelly to slightly gravelly loamy sand, common rootlets, very abrupt lower boundary, A2 horizon.

Sandstone bedrock, R horizon.

Unit 25, East Wall

$1 \quad 0-31$

Brown (10YR 4/3) friable loamy sand, rare small decomposed sandstone pebbles, rare small subrounded to subangular quartzite pebbles, very abrupt irregular lower boundary, A horizon.

2

$31+$

Sandstone bedrock, $\mathrm{R}$ horizon.

Unit 33. West Wall

$1 \quad 0-12$

Brown (7.5YR 4.5/4) sandy loam, common rootlets, Potter chert flake at $8 \mathrm{~cm}$, clear smooth lower boundary, A horizon. 


\section{Zone Depth $(\mathrm{cm}) \quad$ Description}

$2 \quad 12-25$

Dark yellowish brown (10YR 4/4) gravelly loamy sand, common rootlets, few decomposing sandstone pebbles that increase down profile, burned rock features in lower portion of zone, rare subrounded siliceous pebbles, clear smooth lower boundary, AC horizon.

$3 \quad 25-46$

Yellowish brown (10YR 5/4) loamy sand, few rootlets, common decomposing sandstone pebbles, chert flake at $32 \mathrm{~cm}$, abrupt irregular lower boundary, $\mathrm{Cr}$ horizon.

4

$46+$

Unit 52. West Wall

1

$0-8$

2

8-32

3

$32-55$

4

$55-74$

5

74-94

6

$94+$

$\underline{\text { Road Cut, North of Unit } 41}$

$1 \quad 0-25$

2

25-93
Strong brown (7.5YR 4/6) loamy sand, common rootlets, clear slightly wavy lower boundary, A horizon.

Brown/strong brown (7.5YR 4/5) slightly gravelly sandy loam to sandy loam with extremely weak medium subangular blocky structure, rare subrounded to subangular sandstone and siliceous pebbles, common rootlets, gradual smooth lower boundary, $\mathrm{AB}$ horizon.

Brown (7.5YR 4/4) slightly gravelly sandy loam with very weak medium subangular blocky structure, common rootlets, few roots, rare subangular to subrounded sandstone and siliceous pebbles, few faint $\mathrm{CaCO}^{3}$ filaments, burned sandstone features near upper boundary, clear smooth lower boundary, 2Abk horizon.

Strong brown (7.5YR 5/6) gravelly sandy loam to sandy loam with very weak coarse subangular blocky structure, common $\mathrm{CaCO}^{3}$ filaments on ped faces, clear smooth sloping lower boundary, 2ACk horizon.

Brown (7.5YR 5/4) slightly gravelly sandy loam, common small sandstone slabs and subrounded pebbles, few subrounded quartzite pebbles, few $\mathrm{CaCO}^{3}$ nodules, very abrupt and irregularly sloping lower boundary, $2 \mathrm{Crk}$ horizon.

Sandstone bedrock, $\mathrm{R}$ horizon.

Strong brown (7.5YR 4/6) slightly gravelly sandy loam, common rootlets, few roots, few medium-sized sandstone burned slabs, few small sandstone pebbles, gradual smooth lower boundary, $\mathrm{C}$ horizon.

Brown (7.5YR 4/4) slightly gravelly loamy sand to sandy loam, few subrounded quartzite pebbles in upper portion of zone, burned sandstone at $53 \mathrm{~cm}$, common rootlets, few roots, gradual smooth lower boundary, $2 \mathrm{Ab}$ horizon. 
Zone Depth (cm) Description

$3 \quad 93-114$

$4 \quad 114-136$

5

$136+$
Reddish yellow (7.5YR 6/6) sandy loam, common rootlets, few subrounded to subangular quartzite pebbles, chert flake at $103 \mathrm{~cm}$, few $\mathrm{CaCO}^{3}$ filaments, gradual smooth lower boundary, 2Ck1 horizon.

Reddish yellow (7.5YR 6/6) firm to friable fine sand, common subrounded to subangular pebbles, few $\mathrm{CaCO}^{3}$ filaments, few rootlets and roots, very abrupt irregular lower boundary, $2 \mathrm{Ck} 2$ horizon.

Sandstone bedrock, $\mathrm{R}$ horizon.

\section{Geomorphic Cut 1}

1

2

3

$65-100+$
Reddish brown (5YR 4/4) friable sandy loam, common rootlets, few insect burrows, gradual smooth lower boundary, $\mathrm{C} 1$ horizon.

Yellowish red' (5YR 5/8) sandy loam, few rootlets, rare small decomposed sandstone pebbles, gradual smooth lower boundary, C2 horizon.

Reddish brown (5YR 5/6) firm sandy loam, rare rootlets, common $\mathrm{CaCO}^{3}$ filaments, few insect burrows, rare decomposed sandstone pebbles, lower boundary not observed, Ck horizon.

\section{GR484}

\section{Profile 1, Unit 16, West Wall}

$1 \quad 0-4$

2

3

$11-27$

4

$27-38+$
Dark reddish brown (5YR 3/4) slightly gravelly sandy loam, common rootlets, small subrounded to subangular chert pebbles common on surface and few in matrix, common insect burrows, abrupt wavy lower boundary, A horizon.

Reddish brown (5YR 4/4) sandy loam, zone forms thin lenticular wedge that pinches out to the north, clear smooth lower boundary, possible rodent burrow, C1 horizon.

Dark reddish brown (5YR 3/3) slightly gravelly loam, common rootlets, few small subangular to subrounded chert pebbles, few insect burrows - some filled with dark gray (10YR 4/1) sandy loam, others filled with light gray (10YR 7/1) loam, rare large pebbles, clear smooth lower boundary, C2 horizon.

Reddish brown (5YR 4/4) slightly gravelly loam to loam, few roots, few small subrounded to subangular chert pebbles, common insect burrows, lower boundary not observed, C3 horizon.

Profile 2, Unit 8, South Wall

$1 \quad 0-43$

Reddish brown (5YR 4/4) sandy loam to loam, common rootlets decrease in frequency down profile, few subrounded to subangular small chert pebbles, few insect burrows, clear smooth lower boundary, Ap horizon. 
Zone Depth (cm) Description

2

3

4

$77-90+$
Dark red (2.5YR 3/6) slightly gravelly loam, few roots and insect burrows, few small subrounded to subangular chert pebbles, abrupt smooth lower boundary, C1 horizon.

Reddish brown (5YR 4/4) slightly gravelly loam to loam, weak coarse subangular blocky structure, few rootlets and insect burrows, few small subrounded to subangular chert pebbles, gradual smooth lower boundary, 2B horizon.

Yellowish red (5YR 4/6) loam to silt loam, few small subrounded to subangular pebbles, few insect burrows and rootlets, lower boundary not observed, $2 \mathrm{C}$ horizon.

Profile 3, Unit 3, South Wall

$1 \quad 0-5$

2

$5-58+$

$41 \mathrm{KT} 33$

Profile 1, EU 6, South Wall

1

0-11

2

$11-25$

3

4
$25-40$

$40-60+$

$11-25$

(2)
Strong brown (7.5YR 5/8) gravelly sandy loam with hard surface crust, common rootlets, very small subrounded chert pebbles, clear wavy lower boundary, Ap horizon.

Reddish brown to yellowish red (5YR $4 / 4$ to 4/6) slightly gravelly loam, many rootlets, few small subrounded to subangular chert pebbles, common insect burrows, few charcoal flecks, lower boundary not observed, $\mathrm{C}$ horizon.
Dark reddish brown (5YR 3/4) friable sandy loam, common rootlets, few charcoal flecks, few subangular small chert pebbles, clear smooth to wavy lower boundary, A horizon.

Reddish brown (5YR 4/4) friable sandy loam, common rootlets, small pink (5YR $7 / 4$ ) very soft bone at $22 \mathrm{~cm}$, few small subangular to subrounded chert pebbles, few charcoal flecks, few insect burrows filled with dark yellowish brown (10YR 4/6) sand, clear smooth to wavy lower boundary, AC horizon.

Reddish brown (5YR 4/4) firm sandy loam, common rootlets, common $\mathrm{CaCO}^{3}$ films, few small subangular and subrounded chert pebbles, pink (5YR 7/4) small soft subrounded nodules that may be bone, few insect burrows filled with dark reddish brown (5YR 3/2) clay, gradual smooth lower boundary, 2Bk1 horizon.

Yellowish red (5YR 4/6) firm sandy loam, few rootlets, common small subangular to subrounded chert pebbles, common insect burrows-some filled with dark reddish brown (5YR 3/2) clay, few $\mathrm{CaCO}^{3}$ films, lower boundary not observed, 2Bk2 horizon.

\section{Profile 2, EU 60, North Wall}

$1 \quad 0-10$

Reddish brown (5YR 4/4) friable slightly gravelly sandy loam to sandy loam, many rootlets, common subangular to subrounded small chert pebbles, rare charcoal flecks, clear smooth lower boundary, A horizon. 


\begin{abstract}
Zone Depth $(\mathrm{cm}) \quad$ Description
$2 \quad 10-23$

Dark reddish brown (5YR 3/4) friable sandy loam, common subrounded to subangular small chert pebbles, common rootlets, common insect burrows, single large rodent burrow filled with yellowish red (5YR 4/6) sandy loam, clear smooth lower boundary, AC horizon.

$3 \quad 23-35$

Reddish brown (5YR 4/4) firm slightly gravelly sandy loam, common rootlets, common thin $\mathrm{CaCO}^{3}$ films, common small subangular to subrounded chert pebbles, few small pink (5YR 7/4) soft nodules, clear smooth lower boundary, 2Bk1 horizon.

$4 \quad 35-50+$

Reddish brown (5YR 4/4) firm sandy loam, common rootlets, common subangular to subrounded small chert pebbles, few insect burrows-some filled with black (N 2/0) clay, few $\mathrm{CaCO}^{3}$ nodules and films, lower boundary not observed, 2Bk2 horizon.
\end{abstract}

Backhoe Trench 1991-1

$1 \quad 0-32$

2

$32-70$

3

70-105

4

$105-210$

5

$210-265$

6

$265-275+$

Yellowish red (5YR 4/6) friable loam with very weak medium subangular blocky structure, common rootlets, rare small subrounded pebbles, quartzite and large sandstone burned rocks, abrupt irregular to wavy lower boundary, A horizon.

Reddish brown (5YR 4/4) firm sandy loam with fine to medium subangular blocky structure, common $\mathrm{CaCO}^{3}$ nodules and filaments, common insect burrows, few rootlets, gradual smooth lower boundary, $2 \mathrm{Bk}$ horizon.

Red (2.5YR 5/6) firm loam with moderate medium blocky structure, common $\mathrm{CaCO}^{3}$ nodules and filaments, common insect burrows, gradual smooth lower boundary, $2 \mathrm{Bwk}$ horizon.

Yellowish red (5YR 5/6) firm to friable gravelly sandy loam to sandy loam, few $\mathrm{CaCO}^{3}$ nodules, few small subrounded to subangular pebble lenses, gradual wavy lower boundary, $2 \mathrm{Ck}$ horizon.

Well-bedded pebble and gravel lenses, $2 \mathrm{C}$ horizon.

Reddish yellow to gray (5YR 6/8 to 8/1) decomposed sandstone and shale bedrock, $\mathrm{R}$ horizon.

Backhoe Trench 1991-2

$1 \quad 0-35$

Reddish brown (5YR 4/4) gravelly loam, common subrounded to subangular pebbles, few $\mathrm{CaCO}^{3}$ nodules, gradual smooth lower boundary, $\mathrm{Ck}$ horizon.

$2 \quad 35-65$

Yellowish red (5YR 4/6) friable to firm slightly gravelly loam, common $\mathrm{CaCO}^{3}$ filaments and a few $\mathrm{CaCO}^{3}$ nodules, few subrounded pebbles and insect burrows, gradual smooth lower boundary, 2Bk1 horizon. 
Zone Depth $(\mathrm{cm}) \quad$ Description

$3 \quad 65-90$

Dark reddish brown (5YR 3/4) slightly gravelly loam with medium to fine moderate subangular blocky structure, common $\mathrm{CaCO}^{3}$ filaments and nodules, rare subangular pebbles, diffuse lower boundary, 2Bk2 horizon.

$4 \quad 90-190$

Reddish brown (5YR 4/3) very firm loam to slightly gravelly loam with strong fine to medium subangular to angular blocky structure, common $\mathrm{CaCO}^{3}$ filaments and nodules, few insect burrows, rare subangular to subrounded pebbles, gradual smooth lower boundary, 2Btk1 horizon.

$5 \quad 190-225+$

Yellowish red (5YR 4/6) very firm sandy loam with strong medium to fine subangular blocky structure, some ped faces have pressure surfaces, common $\mathrm{CaCO}^{3}$ filaments and nodules, common manganese nodules that increase in frequency down profile, lower boundary not observed, 2Btk2 horizon.

\section{Backhoe Trench 1991-2b}

$1 \quad 0-15$

Brown (10YR 4/3) gravelly loam, common rootlets and quartzite pebbles, clear irregular lower boundary, $\mathrm{C}$ horizon.

Dark brown (10YR 3/3) silt loam with weak medium subangular blocky structure, common rootlets, few quartzite pebble lenses, few $\mathrm{CaCO}^{3}$ filaments some along rootlets, few insect burrows, gradual smooth lower boundary, 2A horizon.

Strong brown (7.5YR 4/6) loam with moderate to strong medium subangular to angular blocky structure, common $\mathrm{CaCO}^{3}$ filaments, few $\mathrm{CaCO}^{3}$ nodules, few manganese concretions, thin quartzite pebble stringer at lower boundary, clear wavy lower boundary, $2 \mathrm{Bk}$ horizon.

Yellowish red (5YR 4/6) firm sandy loam with moderate medium subangular to angular blocky structure, common $\mathrm{CaCO}^{3}$ filaments on well-developed ped faces, few $\mathrm{CaCO}^{3}$ nodules, common manganese concretions, clear to abrupt wavy lower boundary, 3Ck horizon.

Reddish yellow (5YR 6/8) firm sandy loam, many $\mathrm{CaCO}^{3}$ nodules particularly on upper boundary, few manganese concretions, gradual smooth lower boundary, 4Ck1 horizon.

Strong brown (7.5YR 5/8) friable sand, common $\mathrm{CaCO}^{3}$ cementing grains, few $\mathrm{CaCO}^{3}$ filaments, few rodent burrows, gradual smooth lower boundary except for thin $\mathrm{CaCO}^{3}$ crust in southwest corner of profile, $4 \mathrm{Ck} 2$ horizon.

Reddish yellow (7.5YR 6/6) friable sand with few distinct medium strong brown (7.5YR 5/8) mottles, abrupt wavy lower boundary, 4C1 horizon.

White (10YR 8/2) trough cross stratified sands and gravel beds, gravels are mostly small to medium quartzite pebbles, very abrupt smooth to irregular lower boundary, $4 \mathrm{C} 2$ horizon. 
Zone Depth (cm) Description

9

$272+$

Pipeline Trench

PL 1

$1 \quad 0-10$

2

$10-26$

3

$26-28$

4

$28-32$

5

$32-32.5$

6

$32.5-47$

7

47-79

8

$79-100$

9

$100-121$

10

$121-155$

11

$155-193$
Dark reddish brown (2.5YR 3/4) friable slightly gravelly loam, common rootlets and insect burrows, abrupt irregular lower boundary that interfingers with Zone 2, C1 horizon.

Dark red to yellowish red (2.5YR $3 / 6$ to 5 YR $5 / 6$ ) friable slightly gravelly loam sand, some horizonal bedding visible, common rootlets, very abrupt wavy lower boundary, $\mathrm{C} 2$ horizon.

Dark red (2.5YR 3/6) loose loamy sand, few rootlets and insect burrows, abrupt smooth lower boundary, C3 horizon.

Reddish yellow (7.5YR 6/6) friable fine sandy loam lens with weak platy structure, few rootlets, few small insect burrows filled with red (2.5YR 5/8) sand, very abrupt wavy lower boundary, $\mathrm{C} 4$ horizon.

Yellowish red (5YR 5/6) friable very fine sand and silt, occurs in low spots between Zones 4 and 6, very abrupt wavy lower boundary, C5 horizon.

Dark reddish brown (2.5YR 3/4) friable sandy loam with weak medium subangular blocky structure, few roots and rootlets, few insect burrows, few $\mathrm{CaCO}^{3}$ filaments, few small pebbles, rare charcoal flecks, gradual smooth lower boundary, $2 \mathrm{Ab}$ horizon.

Reddish brown (5YR 4/4) slightly gravelly sandy loam, common $\mathrm{CaCO}^{3}$ filaments, heavily bioturbated, clear smooth to wavy lower boundary, $2 \mathrm{Ck}$ horizon.

Dark reddish brown (5YR 3/3) firm loam with medium coarse subangular blocky structure, common insect burrows, common $\mathrm{CaCO}^{3}$ filaments, rare charcoal flecks, few rootlets, gradual smooth lower boundary, 3Abk1 horizon.

Dark reddish brown (5YR 3/3) firm sandy loam with very weak coarse subangular blocky structure, few $\mathrm{CaCO}^{3}$ filaments, few insect burrows and rootlets, gradual smooth lower boundary, $3 \mathrm{Abk} 2$ horizon.

Dark red (2.5YR 3/6) friable sandy loam, common $\mathrm{CaCO}^{3}$ flecks, few rootlets, few rodent and insect burrows, gradual smooth lower boundary, $3 \mathrm{Ck}$ horizon.

Dark reddish brown (2.5YR 3/4) firm loam with weak coarse subangular blocky structure, common $\mathrm{CaCO}^{3}$ flecks, few rootlets and insect burrows, clear smooth lower boundary, $4 \mathrm{Btb}$ horizon. 
Zone

12

13

PL 2

1

2

3

4

5

178-190+

1

$0-165$

2

165-195

3

$195-235$

4

235-270

5

$270-310+$

\section{Description}

Yellowish red (5YR 5/6) friable slightly gravelly loamy sand, common $\mathrm{CaCO}^{3}$ flecks, clear wavy lower boundary, 4Ck1 horizon.

Red (2.5YR 4/6) friable slightly gravelly sandy loam, common $\mathrm{CaCO}^{3}$ flecks, lower boundary not observed, $4 \mathrm{Ck} 2$ horizon.

Dusty red (2.5YR $3 / 2)$ friable slightly gravelly sandy loam with very weak coarse subangular blocky structure, common roots and rootlets, few subangular to rounded pebbles, clear smooth lower boundary, A horizon.

Yellowish red (5YR 4/6) friable slightly gravelly sandy loam, common subrounded to subangular pebbles, common rootlets and insect burrows, few $\mathrm{CaCO}^{3}$ flecks, gradual smooth lower boundary, Ck horizon.

Yellowish red (5YR 4/6) firm slightly gravelly sandy loam with weak coarse subangular blocky structure, few rootlets, charcoal fragments at $58 \mathrm{~cm}$ and $76 \mathrm{~cm}$, upper charcoal fragment represents in situ burning, gradual smooth lower boundary, $2 \mathrm{Ab}$ horizon.

Yellowish red (5YR 5/6 to 4/6) trough cross bedded sand and gravel lenses, few roots, abrupt smooth lower boundary, $2 \mathrm{C}$ horizon.

Dark reddish brown (5YR 3/3) firm silt loam with moderate medium subangular blocky structure, common $\mathrm{CaCO}^{3}$ filaments, lower boundary not observed, 3Bt horizon.

Similar to PL 2 Zones 2-5 (16-190 cm), Ck, 2Ab, 2C, and 3Bt horizons.

Dark reddish brown (5YR 3/4) loam with weak fine crumb structure, few charcoal flecks, rare sand filled rodent burrow, few rootlets, gradual smooth lower boundary, 3Ab horizon.

Red (2.5YR 4/6) sandy loam with very weak fine crumb structure, clear wavy lower boundary, $3 \mathrm{AC}$ horizon.

Red (2.5YR 4/6) loose sandy loam gravel, with many small-medium pebble lenses, clear wavy lower boundary, $3 \mathrm{C} 1$ horizon.

Alternating lenses of red (2.5YR 5/6) friable to loose sandy loam, lower boundary not observed, $3 \mathrm{C} 2$ horizon. 
Zone Depth (cm) Description

Grape Creek Floodplain

Backhoe Trench 1991-3, Profile 1

$1 \quad 0-35$

Brown, reddish brown and dark reddish brown (7.5YR 5/4, 5YR 4/4, 5YR 3/4) alternating lenses of sand, silt and gravel, common rootlets and insect burrows, common charcoal flecks, very abrupt smooth to wavy lower boundary, $\mathrm{C}$ horizon.

2

35-50 Dark reddish brown (5YR 3/4) silt loam with weak medium subangular blocky structure, common rootlets and insect burrows, few thin sand lenses, common charcoal flecks, thin zone $(48-50 \mathrm{~cm})$ of carbonized plant partings, clear wavy lower boundary, $2 \mathrm{Ab}$ horizon.

$3 \quad 50-95$

Reddish brown (5YR 4/4) firm silt loam with moderate medium subangular blocky structure, few roots and insect burrows, few charcoal flecks, rare $\mathrm{CaCO}^{3}$ filaments and flecks, grädual smooth lower boundary, 2AC1 horizon.

$4 \quad 95-125$

Yellowish red (5YR 4/6) firm silt loam with weak coarse subangular blocky structure, few rootlets and insect burrows, few $\mathrm{CaCO}^{3}$ filaments, clear smooth lower boundary, 2AC2 horizon.

$5 \quad 125-195$

Yellowish red (5YR 5/6) friable sand, abrupt wavy lower boundary, 2C1 horizon.

6 195-200+ Gravels, lower boundary not observed, 2C2 horizon.

\section{Backhoe Trench 1991-3, Profile 2}

$1 \quad 0-67$

Strong brown to reddish brown (7.5YR 5/6 to 5YR 4/4) alternating sand and silty sand lenses, common rootlets and insect burrows, rare rodent burrows and charcoal flecks, few subrounded to subangular pebbles, abrupt wavy lower boundary, C1 horizon.

$2 \quad 67-75$

Very small to small subrounded to subangular pebble layer, loose, very abrupt wavy to irregular lower boundary, C2 horizon.

$3 \quad 75-136$

Yellowish red (5YR 4/6) sandy silt to sand, rare rootlets and charcoal flecks, few thin discontinuous gravel lenses, clear irregular lower boundary, C3 horizon.

$4 \quad 136-171+$

Reddish brown (5YR 4/4) sandy clay, rare charcoal flecks, lower boundary not observed, C4 horizon. 


\section{REFERENCES CITED}

Birkeland, Peter W.

1984 Soils and Geomorphology. Oxford University Press, Oxford.

Folk, Robert L.

1980 Petrology of Sedimentary Rocks. Hemphill
Publishing Company, Austin, Texas.

Soil Survey Staff

1975 Soil Taxonomy: A Basic System of Soil Classification for Making and Interpreting Soil Surveys. Soil Conservation Service, U.S. Department of Agriculture, Washington, D.C. 
Appendix I: Textural and Chemical Analysis of Sediment Samples

\author{
C. Britt Bousman
}



One hundred eighteen sediment samples were analyzed by the Physical Geography Laboratory, Department of Geography, University of WisconsinMilwaukee. Textures were measured by the hydrometer method and sieve screens. In the late nineteenth century, Udden (1898) proposed using a size classification of clastic sediments based on a ratio scale of two. That is, each next largest class is twice as large as its adjacent smaller size class. Wentworth (1922) later modified this scale and its terminology, and it is his divisions and terminology that are used most commonly today. The scale uses millimeters; for example, the lower size limit for sand is $0.0625 \mathrm{~mm}$, while the upper size limit is $2 \mathrm{~mm}$ (Blatt et al. 1980). Krumbein (1934) suggested that the millimeter sizes could be converted to a logarithmic scale which is known as the phi $(\phi)$ scale. The formula for this measure is

$$
\Phi=-\log _{2} \mathrm{~mm} .
$$

Thus, a phi value of zero equals a sieve size of
$1 \mathrm{~mm},-1$ phi equals $2 \mathrm{~mm}, 1$ phi equals $0.5 \mathrm{~mm}$, 4 phi equals $0.063 \mathrm{~mm}$, and so on. As phi values decrease particle sizes increase. The use of logarithmic ratio scales for grain sizes results in morenormally distributed sediment populations. Soil scientists use a slightly different texture size between silt and clays, 9.0 phi versus 8.0 phi used by geologists.

The texture boundaries utilized in this analysis in terms of phi values are as follows: gravel $\leq 1.0$, sand $>-1.0$ to $\leq 4.0$, silt $>4.0$ to $\leq 9.0$, and clay $\geq 9.0$. The texture values are percentages based on weight. Percentages of sand, silt, and clay were calculated in relation to each other, while the percentage of gravel was calculated in relation to the remainder of the sample. In addition, the percent of organic matter, the percent of total carbonate, and sample $\mathrm{pH}$ values are presented when possible (McLean 1982; Nelson 1982; Nelson and Sommers 1982). In some rare cases, usually due to small sample size, not all measurements could be obtained, e.g., the gravels in BHT 1991-1, $270 \mathrm{~cm}$. 
Phase III Data Recovery, Season 1, Justiceburg Reservoir

Sample

41GR383, EU 12

$0.5 \mathrm{~cm}$
$7.5 \mathrm{~cm}$
$14.5 \mathrm{~cm}$
$22.5 \mathrm{~cm}$
$33.5 \mathrm{~cm}$
$42.0 \mathrm{~cm}$

$\begin{array}{ll}70.0 & 30.0 \\ 70.0 & 30.0 \\ 72.0 & 24.0 \\ 74.0 & 24.0 \\ 75.0 & 23.0 \\ 81.0 & 19.0\end{array}$

0.0
0.0
4.0
2.0
2.0
0.0

0.1
0.0
0.2
1.4
2.2
0.4

12.4
7.6
7.1
8.2
10.7
5.0

41GR383, EU 22

$2.5 \mathrm{~cm}$
$9.0 \mathrm{~cm}$
$15.0 \mathrm{~cm}$
$30.0 \mathrm{~cm}$
$39.0 \mathrm{~cm}$

67.0

69.0

74.0

71.0

80.0

32.0
30.0
25.0
27.0
20.0

1.0

1.0

1.0

2.0

0.0

0.1

0.1

5.4

1.9

0.0

41GR383, EU 25

$10.0 \mathrm{~cm}$

$25.0 \mathrm{~cm}$

$35.0 \mathrm{~cm}$

76.0

74.0

73.8

24.0
26.0
26.2

0.0

0.0

0.4

0.3

0.0

7.9

6.0

8.9

6.2

6.7

8.8

6.5

0.0

70.0

73.0

72.2

$18.5 \mathrm{~cm}$

$41.5 \mathrm{~cm}$

$46.0 \mathrm{~cm}$

65.5

30.0

27.0

26.7

7.1

71.0

68.0

70.0

70.0

70.0

72.0

70.0

69.0

$71.0 \mathrm{~cm}$

$90.0 \mathrm{~cm}$
29.0

29.0

27.0

27.0

26.0

24.0

26.0

28.0

0.0
0.0
1.1
1.9

0.9

5.0

0.1

8.4

4.3

7.8

11.1

6.0
7.9
6.0


4.3
7.8
1.1

0.0

3.0

0.1

1.4

10.0

10.8

11.0

12.3

13.7

13.7

13.4

13.7

$4.0 \quad 1.3$

$4.0 \quad 5.3$

$\begin{array}{ll}4.0 & 0.8\end{array}$

$3.0 \quad 3.4$

3.4

41GR383, Geologic Profile

$\begin{array}{crrrrrrr}13.0 \mathrm{~cm} & 72.0 & 22.0 & 6.0 & 0.4 & 6.4 & 2.7 & 7.5 \\ 40.0 \mathrm{~cm} & 74.0 & 18.0 & 8.0 & 0.0 & 5.6 & 2.4 & 8.1 \\ 80.0 \mathrm{~cm} & 62.5 & 32.5 & 5.0 & 0.0 & 6.0 & 2.3 & 8.2 \\ \text { unconsolidated } & 81.0 & 18.0 & 1.0 & 0.8 & 11.2 & 2.2 & 8.8\end{array}$

sandstone bedrock

41GR383, Roadcut Profile

$\begin{array}{rrrrrrrr}9.5 \mathrm{~cm} & 72.0 & 25.0 & 3.0 & 2.1 & 10.6 & 2.9 & 8.5 \\ 34.5 \mathrm{~cm} & 70.0 & 28.0 & 2.0 & 0.7 & 7.4 & 2.5 & 8.4 \\ 53.0 \mathrm{~cm} & 73.0 & 24.0 & 3.0 & 2.5 & 9.0 & 2.6 & 8.5\end{array}$


$\%$

Carbonate
\% Organic Matter
pH

41GR383, Roadcut Profile, continued

$\begin{array}{rrrrrrrr}71.5 \mathrm{~cm} & 75.0 & 21.0 & 4.0 & 0.7 & 9.8 & 2.9 & 8.4 \\ 90.5 \mathrm{~cm} & 73.0 & 21.0 & 6.0 & 1.6 & 10.7 & 2.6 & 8.6 \\ 107.5 \mathrm{~cm} & 72.0 & 22.0 & 6.0 & 1.8 & 11.2 & 2.6 & 8.5 \\ 132.5 \mathrm{~cm} & 71.0 & 23.0 & 6.0 & 1.7 & 11.1 & 2.5 & 8.6\end{array}$

41GR484, EU 3

$$
\begin{array}{r}
1.0 \mathrm{~cm} \\
9.0 \mathrm{~cm} \\
19.0 \mathrm{~cm} \\
29.0 \mathrm{~cm} \\
39.0 \mathrm{~cm} \\
49.0 \mathrm{~cm}
\end{array}
$$

41GR484, EU 8

54.0
44.0
39.0
38.0
34.0
34.0

43.0

42.0

46.0

42.0

45.0

46.0

3.0
14.0
15.0
20.0
21.0
20.0

5.2
1.2
3.8
9.0
2.5
2.1

$1.0 \mathrm{~cm}$

$9.0 \mathrm{~cm}$

$19.0 \mathrm{~cm}$

$29.0 \mathrm{~cm}$

$39.0 \mathrm{~cm}$

$49.0 \mathrm{~cm}$

$59.0 \mathrm{~cm}$

$69.0 \mathrm{~cm}$

$79.0 \mathrm{~cm}$

$89.0 \mathrm{~cm}$

41GR484, EU 16

48.0
47.0
42.5
40.0
38.0
37.0
37.5
50.0
38.9
35.0

$\begin{array}{lr}49.0 & 3.0 \\ 47.0 & 6.0 \\ 46.2 & 11.2 \\ 46.0 & 14.0 \\ 46.0 & 16.0 \\ 48.0 & 15.0 \\ 48.8 & 13.8 \\ 39.0 & 11.0 \\ 47.8 & 13.3 \\ 50.0 & 15.0\end{array}$

0.0

0.9

0.8

0.5

0.2

1.0

1.4

0.7

0.2

0.2

19.3

14.5

13.0

14.6

16.0

16.7

3.7
2.9
3.5
3.2
5.7
2.9
2.8
3.1
3.6
3.9

7.8

8.2

8.4

8.3

$$
8.3
$$

8.6

8.5

8.2

8.0

$1.0 \mathrm{~cm}$

$8.0 \mathrm{~cm}$

$19.0 \mathrm{~cm}$

$28.0 \mathrm{~cm}$

$37.0 \mathrm{~cm}$

41KT33, Profile 1
51.0

55.6

48.8

44.0

44.3

$\begin{array}{rr}41.0 & 8.0 \\ 42.2 & 2.2 \\ 41.2 & 10.0 \\ 46.0 & 10.0 \\ 41.2 & 14.3\end{array}$

4.0
0.1
2.3
1.2
0.9

11.5
8.3
12.7
15.7
16.0

$2.0 \mathrm{~cm}$

$9.0 \mathrm{~cm}$

$19.0 \mathrm{~cm}$

$29.0 \mathrm{~cm}$

$39.0 \mathrm{~cm}$

$49.0 \mathrm{~cm}$

$59.0 \mathrm{~cm}$

$\begin{array}{rrr}68.0 & 32.0 & 0.0 \\ 64.0 & 33.0 & 3.0 \\ 61.0 & 32.0 & 7.0 \\ 60.0 & 31.0 & 9.0 \\ 59.0 & 31.0 & 10.0 \\ 60.0 & 30.0 & 10.0 \\ 61.1 & 30.0 & 8.9\end{array}$

0.0

0.2

0.3

0.4

0.1

0.5

0.2

11.8
9.8
12.6
12.9
13.4
14.0
13.0

41KT33, Profile 2

$$
\begin{array}{r}
2.0 \mathrm{~cm} \\
9.0 \mathrm{~cm} \\
19.0 \mathrm{~cm} \\
29.0 \mathrm{~cm} \\
39.0 \mathrm{~cm}
\end{array}
$$

$\begin{array}{rrr}63.0 & 33.0 & 4.0 \\ 66.0 & 28.0 & 6.0 \\ 62.0 & 27.0 & 11.0 \\ 57.0 & 29.0 & 14.0 \\ 58.0 & 28.0 & 14.0\end{array}$

4.5
0.8
0.2
1.4
0.3

9.1

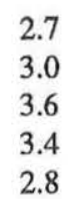

8.1

8.3

8.1

8.1

8.4 
Phase III Data Recovery, Season 1, Justiceburg Reservoir

Sample $\%$ Sand $\%$ Silt $\%$ Clay $\%$ Gravel Carbonate

\% Organic Matter

pH

41KT33, Profile 2, continued
$49.0 \mathrm{~cm}$
64.0
24.0
12.0
0.2
8.1
2.3
8.3

BHT 1991-1

$15.0 \mathrm{~cm}$
$55.0 \mathrm{~cm}$
$78.0 \mathrm{~cm}$
$132.0 \mathrm{~cm}$
$220.0 \mathrm{~cm}$
$270.0 \mathrm{~cm}$

43.0

53.0

50.0

60.0

63.0

96.3

37.0
33.0
35.0
25.0
30.0
15.1

20.0

14.0

15.0

15.0

7.0

2.3

BHT 1991-2

$$
\begin{array}{r}
23.0 \mathrm{~cm} \\
45.0 \mathrm{~cm} \\
75.0 \mathrm{~cm} \\
107.0 \mathrm{~cm} \\
160.0 \mathrm{~cm} \\
207.0 \mathrm{~cm}
\end{array}
$$

$\begin{array}{ll}48.0 & 37.0 \\ 51.0 & 36.0 \\ 48.0 & 32.0 \\ 43.0 & 37.0 \\ 45.0 & 45.0 \\ 53.0 & 37.0\end{array}$

17.0

13.0

20.0

20.0

10.0

10.0

19.4
2.0
2.1
0.3
10.2
0.8

0.6
0.6
0.4
14.0
0.0

11.2

15.6

9.6

18.1

17.0

$\begin{array}{cc}3.2 & 8.2 \\ 4.2 & 8.4 \\ 3.3 & 8.4 \\ 0.2 & 9.2 \\ 2.3 & 9.0 \\ - & -\end{array}$

BHT 1991-3, Profille 1

$$
\begin{array}{r}
22.0 \mathrm{~cm} \\
26.0 \mathrm{~cm} \\
31.0 \mathrm{~cm} \\
47.0 \mathrm{~cm} \\
65.0 \mathrm{~cm} \\
120.0 \mathrm{~cm} \\
170.0 \mathrm{~cm} \\
195.0 \mathrm{~cm}
\end{array}
$$

86.7

61.2

90.0

41.3

30.0

31.0

69.0

81.0

13.3

38.8

10.0

48.7

57.0

59.0

28.0

18.0

$\begin{array}{rrr}51.0 & 40.0 & 9.0 \\ 74.6 & 31.4 & 1.5 \\ 53.0 & 37.0 & 10.0 \\ 16.0 & 60.0 & 24.0\end{array}$

0.0

0.0

0.0

10.0

13.0

10.0

3.0

1.0

0.9

0.0

0.0

0.1

0.1

0.0

0.4

19.5

8.3

12.9

12.4

9.0

8.8

23.7

21.6

13.1

9.0

19.3

17.6

17.3

12.9

24.4

0.4

16.6

$-$

15.6

20.5

0.0

$147.0 \mathrm{~cm}$

Pipeline Profile 1

$$
\begin{array}{r}
5.0 \mathrm{~cm} \\
15.0 \mathrm{~cm} \\
27.0 \mathrm{~cm} \\
30.0 \mathrm{~cm} \\
32.0 \mathrm{~cm} \\
38.0 \mathrm{~cm} \\
60.0 \mathrm{~cm} \\
83.0 \mathrm{~cm} \\
110.0 \mathrm{~cm} \\
140.0 \mathrm{~cm} \\
170.0 \mathrm{~cm} \\
210.0 \mathrm{~cm}
\end{array}
$$

$\begin{array}{rrr}44.0 & 46.0 & 10.0 \\ 84.0 & 16.0 & 0.0 \\ 78.8 & 21.2 & 0.0 \\ 56.0 & 42.0 & 2.0 \\ 10.0 & 2.5 & 8.2 \\ 55.0 & 38.0 & 7.0 \\ 54.0 & 34.0 & 12.0 \\ 38.0 & 42.0 & 20.0 \\ 60.0 & 28.0 & 12.0 \\ 74.0 & 20.0 & 6.0 \\ 45.0 & 41.0 & 14.0 \\ 86.0 & 14.0 & 0.0\end{array}$

3.0

3.6

0.3

0.6

$-$

0.6

2.4

0.0

0.0

0.0

0.0

1.4

22.4

50.1

5.9

7.1

$-$

13.4

31.2

13.7

12.5

15.2

31.9

17.0

$\begin{array}{ll}3.1 & 8.4 \\ - & - \\ 2.6 & 8.3 \\ 4.0 & 9.1\end{array}$

$\begin{array}{ll}2.9 & 8.2\end{array}$

$3.1 \quad 8.4$

$1.9 \quad 8.6$

$\begin{array}{ll}5.8 & 8.3\end{array}$

$\begin{array}{ll}4.9 & 8.2\end{array}$

$\begin{array}{ll}4.0 & 8.2\end{array}$

$1.7 \quad 8.6$

$\begin{array}{ll}1.6 & 9.2\end{array}$ 
Appendix I: Textural and Chemical Analysis of Sediment Samples

$\begin{array}{lllllccc} & & & \% & \% \text { Organic } & \\ \text { Sample } & \% \text { Sand } & \% \text { Silt } & \% \text { Clay } & \% \text { Gravel } & \text { Carbonate } & \text { Matter } & \text { pH }\end{array}$

Pipeline Profile 1, continued

$227.0 \mathrm{~cm}$

67.0

28.0

62.5

$10.0 \mathrm{~cm}$

$40.0 \mathrm{~cm}$

$60.0 \mathrm{~cm}$

$140.0 \mathrm{~cm}$

$185.0 \mathrm{~cm}$

43.0

53.0

87.0

27.0

32.0

57.0

81.0

61.0

$260.0 \mathrm{~cm}$

$300.0 \mathrm{~cm}$

$175.0 \mathrm{~cm}$

45.0

25.0

13.0

30.0
5.0

13.0

11.0

0.0

15.0

23.0

18.0

6.0

9.0
3.4

4.5

2.4

3.0

0.1

0.1

0.1
0.7
67.6
0.4

0.1
0.7
67.6
0.4

14.6

17.1

15.1

8.2
1.0

4.8

4.1

1.7

5.0

8.3

8.3

8.4

8.9

8.5

$\begin{array}{lll}4.9 & 5.0 & 8.5\end{array}$




\section{REFERENCES CITED}

Blatt, Harvey, Gerard Middleton, and Raymond Murray 1980 Origin of Sedimentary Rocks. 2nd edition. Prentice-Hall, Inc., Englewood Cliffs, New Jersey.

Krumbein, W. C.

1934 Size Frequency Distributions of Sediments. Journal of Sedimentary Petrology 4:65-77.

McLean, E. D.

1982 Soil pH and Lime Requirement. In Methods of Soil Analysis, Part 2: Chemical and Microbiological Properties, 2nd edition, edited by $\mathrm{A}$. L. Page, R. H. Miller, and D. R. Keeney, pp. 199-224. American Society of Agronomy, Inc., Soil Science Society of America, Inc., Madison, Wisconsin.

Nelson, R. E.

1982 Carbonate and Gypsum. In Methods of Soil Analysis, Part 2: Chemical and Microbiological Properties, 2nd edition, edited by A. L. Page, R.
H. Miller, and D. R. Keeney, pp. 181-197. American Society of Agronomy, Inc., Soil Science Society of America, Inc., Madison, Wisconsin.

Nelson, D. W., and L. E. Sommers

1982 Total Carbon, Organic Carbon, and Organic Matter. In Methods of Soil Analysis, Part 2: Chemical and Microbiological Properties, 2nd edition, edited by A. L. Page, R. H. Miller, and D. R. Keeney, pp. 539-579. American Society of Agronomy, Inc., Soil Science Society of America, Inc., Madison, Wisconsin.

Udden, J. A.

1898 Mechanical Composition of Wind Deposits. Augustane Library Publication No. 1.

Wentworth, C. K.

1922 A Scale of Grade and Class Terms for Clastic Sediments. Journal of Geology 30:377-392. 